Historic, Archive Document

Do not assume content reflects current scientific knowledge, policies, or practices. 



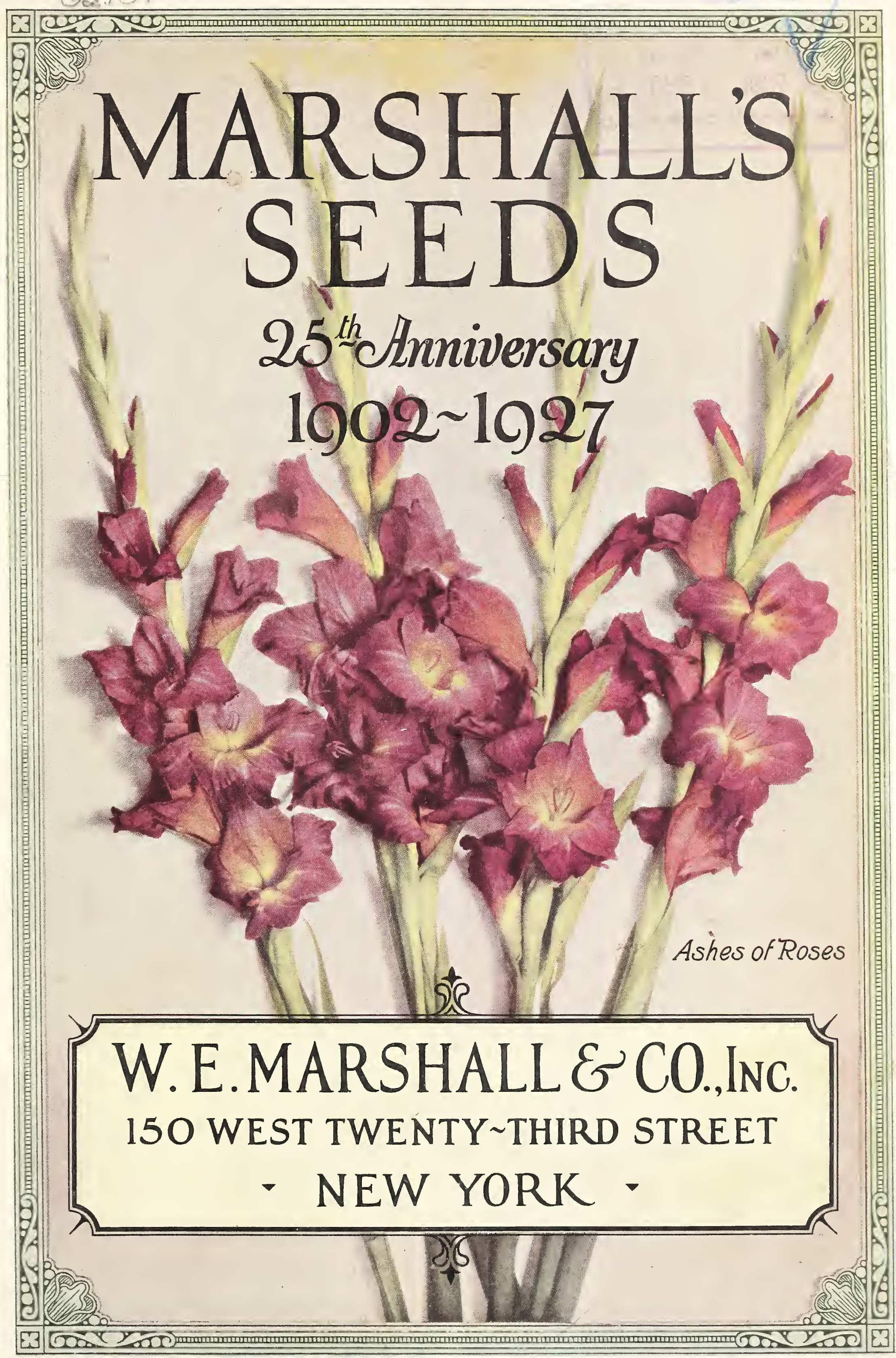




\section{Our Twenty-fifth Anniversary}

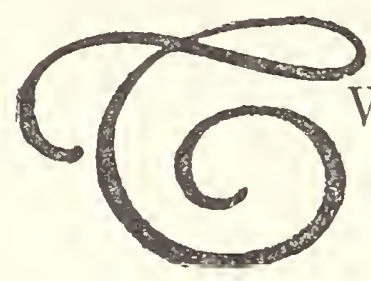

WENTY-FIVE YEARS AGO, the founder, W. E. Marshall, started business alone in a small way, using deskroom in an architect's office at 41 West 24th St. and at the same time conducting his packing and shipping from a cellar in Dey St. 'Two years later a co-partnership was formed with Alfred E. Wheeler under the name of W. E. Marshall \& Co., when a store was opened at 146 West 23rd St. A few years later we moved to more commodious quarters at 166 West $23 \mathrm{rd} \mathrm{St}$. in order to fully take care of the rapidly expanding business. There we remained for fifteen years, during which period we incorporated in the year 1916, but were, during these later years, obliged to rent space in nearby buildings to carry on efficiently.

Again we were forced to obtain a larger store and in February, 1925, we moved into our present quarters. On entering this place we dispensed with all our old fixtures, and installed every new necessary device to aid us in facilitating the execution of our ever-increasing business, and make it what we believe is one of the best organized institutions of its kind in the country.

Each department has a separate staff, enabling them to concentrate in their particular branch and to exercise the care and promptitude which has proven a most valuable asset to our business.

We invite our patrons to visit our store, where they may be assured courteous treatment and advice from our fellow workers who have so materially aided us in the growth of our business.

\section{The Lily}

One of our specialties is the Lily, which we have selected on account of its grandeur, stature and gracefulness in the American garden. We believe the Lilium family offers to the amateur, as well as the professional gardener, a most interesting study because of its individual habits and many other remarkable traits.

We have done all in our power to popularize this hardy garden favorite in importing different varieties from different parts of the world, experimenting with so-called sub-tropical varieties and finally obtaining a number of these that we find to be hardy here although not so in England.

We are going still further in the matter of Lilies in presenting to the public the most comprehensive catalogue of Lilies ever published, and wherein all details of planting and culture will be found, including colored plates of most of the varieties in commerce with full description and treatise of same. See page 4.

W. E. Marshall \& Co., INC.

Fanuary $I, I 927$. 


\section{Views of Store}

These photographs of the interior of store and office show the spacious, well lighted quarters we have for the prompt filling of orders.

The basement covering the same floor space as the store is used for stock and shipping. dow.

Right-hand upper circle, show win-

Center, interior view of store.

Right-hand lower circle, implement and garden tool display.

Left-hand lower circle, office in rear of store.

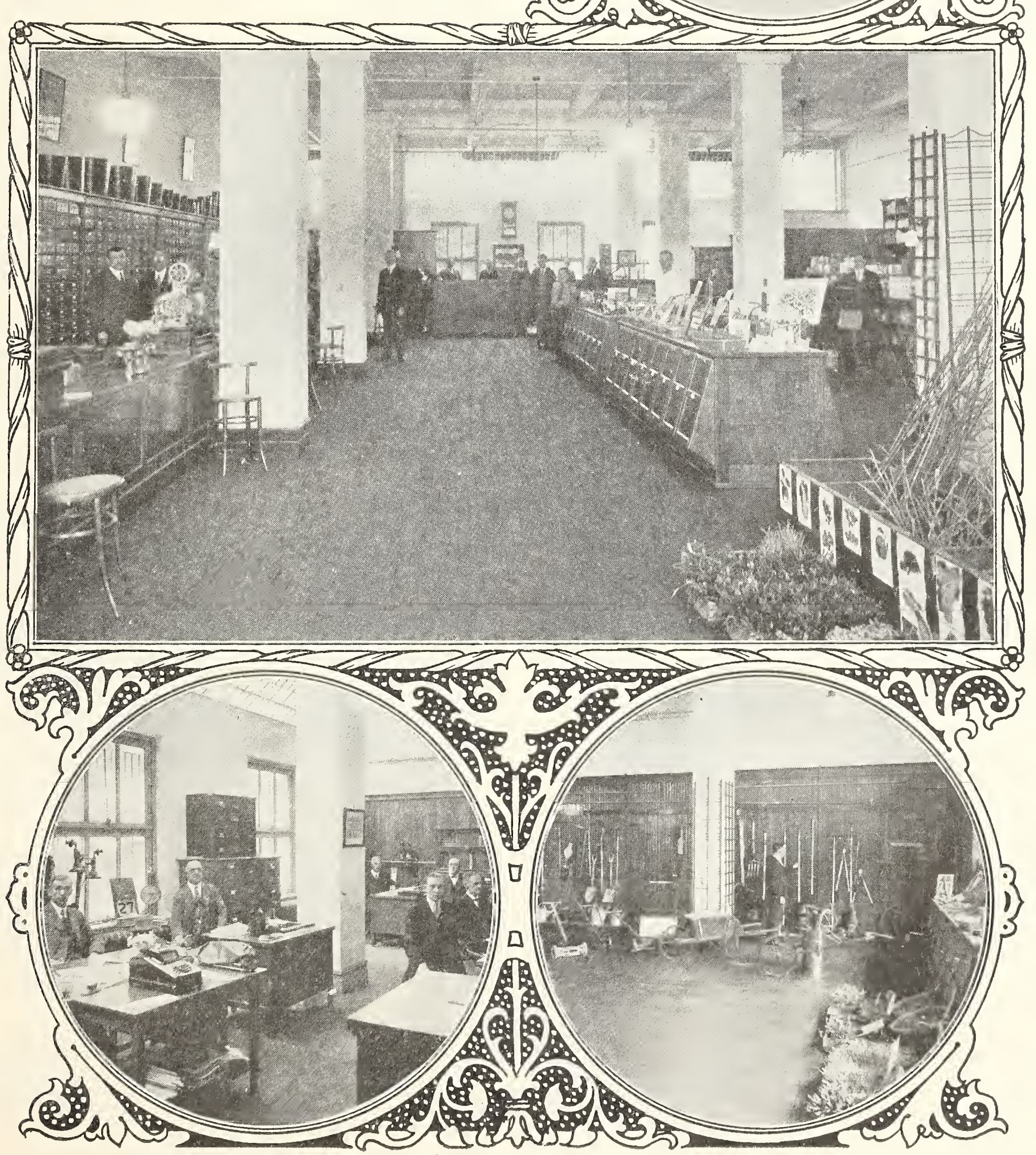




\section{WHO'S WHO}

Through the following method we have endeavored to give you a biography of each of the directors and employees holding important positions in our establishment, many of whom are stockholders in the corporation as an award for Iong and faithfuI services. Our object is to place our patrons in personal touch with our employees.

WILLIAM EMERSON MARSHALL, our president, was born in Edinburgh, Scotland, where he received his education at George Watson's College for Boys. Although it was expected that he should follow the path of his elder brothers, one of whom was Dr. John Marshall, rector of the Royal High School, Edinburgh, and the other, Dr. Tom Marshall of London, he decided to stick closer to the soil, and became apprenticed to the seed and nursery establishment of John Downie in Edinburgh. Four years' training equipped him for the position as manager of the agricultural seed business of John Maclure of the same city. In $1891, \mathrm{Mr}$. Marshall emigrated to this country, where for the first year he received an intensive training in the greenhouses of the W. B. Dinsmore estate at Staatsburg, N. Y., under the tutelage of his uncle, that well-known gardener, Thos. Emerson. For the following nine years he was employed in the seed establishments of Peter Henderson \& Co., J. M. Thorburn \& Co., and Weeber \& Don, during which period he did considerable traveling among the large estates until he started the present business twenty-five years ago.

Mr. Marshall's sole hobby is gardening, and he spends his spare time in his garden at Bayville, Long Island.

$\triangle$ LFRED E. WHEELER was born near Worcester, England, A his father being a successful agriculturist in Worcestershire. $\mathrm{He}$ received his education in the Cheltenham and Handley Grammar Schools. At the age of 16, he was apprenticed to Jos. H. White, seedsman, florist and nurseryman, for five years, At the expiration of the term he took a position in a seed store in Chesterfield, remaining for four years. In 1896 he emigrated to the United States, and soon after arrival found employment with $\mathrm{P}$. Henderson \& Co. for the season, leaving them to take up gardening on private estates for a year to learn more of American floriculture, returning to the seed trade for two years with J. M. Thorburn \& Co., and four years with Weeber \& Don of New York. He joined W. E. Marshall in partnership in 1903 and was made vice-president and treasurer upon their incorporation.

For the past 13 years he has resided in Floral Park, L. I., where he maintains an extensive garden for pleasure and personal knowledge of horticulture.

TARRY J. RUTE. Born in New York City. Came to us 1 twenty years ago when the firm was in its infancy. He knew little of gardening, but was confident he would be interested. He afterward proved that by his never failing efforts to learn, and through his close connections with some of the large private estates in the vicinity of New York, he has gained a knowledge of gardening and farming which is really surprising because of the fact that he has never been actively engaged in their pursuits. Mr. Rute has served in all departments of the business and has gradually worked his way up to his present position as one of the directors.

WILLIAM ALEXANDER. Born in Glasgow, Scotland, and educated in the public schools in Rothesay. He commenced his apprenticeship in the seed business of Dobbie \& Co., Rothesay, in 1900. After serving in every department, including the nursery, he became manager of the stock room. In 1910, Dobbie \& Co. moved their establishment to Edinburgh, where he made his home. In the Fall of 1911 he accepted a position as general manager of the firm of A. S. Ritchie \& Co., seedsmen and florists, Belfast, Ireland, and remained there till 1913, when he returned to Edinburgh as manager of Dickson \& Co., seedsmen. In March, 1914, he arrived in New York and immediately secured a position with Peter Henderson \& Co., and in a short time after, he accepted a call from this firm as manager of the flower seed department, and after three years in that capacity he became traveling salesman, in which position his thorough knowledge of the various branches has become a valuable asset to our business.

PHILIP WILLIAM POPP. Widely known in horticultural circles as a first-class gardener and a successful exhibitor. Born in Wappingers Falls, N. Y, and at the age of 14, he entered, as apprentice, the gardens of "Netherwood," the country estate of Mr. Irving Grinnell at New Hamburg. A wide variety of stock was grown there, and the experience gained after ten years' service laid the foundation for a successful career. During the following ten years he held many important gardening positions in various parts of the country, and finally entered the employ of Mrs. Harry Darlington as superintendent of her handsome estate at Mamaroneck, N. Y., where he remained for thirteen years. He afterwards attached himself to the commercial field, representing various firms, until his employment by our firm, over five years ago, in the capacity of traveling salesman.
DONALD EMERSON MARSHALL, son of the president, is graduate of Cornell University, having taking the agricultural course, where he specialized in rural engineering, which specially fitted him for golf course construction. He spent three years in this work, assisting in the construction of two courses, and having entire charge of construction of three others. After two years' sojourn in the Island of Crete, Greece, as partner in the Anglo-American Hellenic Co., Importers of Agricultural Machinery, he returned to take active part in the agricultural and golf departments of our business. He also acts in the capacity of traveling salesman.

FDWARD BENSON was born on a farm near Ossining, N. Y. and was employed by us fourteen years ago in the packing and shipping department, where he spent three years. He was then transferred to the implement department, where he was in charge for five years. He was received in the vegetable seed department six years ago, and is now in full charge. His early training on the farm has greatly aided him in attaining his present position.

SYDNEY WHITEMAN was born in Northampton, England, educated at University School, Hastings, apprenticed for four years to Thos. W. Edmunds, Ltd., Westerham, Kent, who had 300 acres of nurseries and greenhouses. Then for several years each with Barr \& Sons, bulb and plant growers; R. Wallace \& Co. Hardy Lily and plant growers, both of England; from there to Dobbie \& Co., seedsmen and plantsmen, Edinburgh. 'Fifteen years ago, he came to the United States and was engaged in landscape gardening for the Sage Foundation Homes Co., at Forest Hills, L. I. for five years. In all he spent four years in the flower seed department of Peter Henderson \& Co., and came to firm seven years ago to take charge of the flower seed department. Although he is actively engaged in attending to the nursery part of the business, he still keeps a watchful eye on the flower seed department.

PAUL LONGART was born in Stuttgart, Germany. He was employed by us eleven years ago to take charge of the packing and shipping departments. Five years ago he was placed in charge of the implement department and afterward the Lily business was added. This latter department has developed to such an extent that he is obliged to relinquish the implement department and devote all his energies to Lilies, which is now a very important part of our business.

GRNEST LUMLEY was born in Brooklyn and started with us seven years ago as assistant in the packing department. His fitness for better work was soon manifest in the flower seed department and through valuable knowledge gained under the tutelage of Mr. Whiteman who still has a watchful eye on this department, he has now been placed in actual charge.

GEORGE ROBERT FISHER. Native of Boston, England. Educated at a private boarding school, Dibbens Academy, Sleaford, Lincolnshire, graduating from Boston Grammar School, one of Britain's notable educational establishments. Early commercial experience gained in the counting-houses of old established City of London firms, including that of Hitchcock Williams \& Co., of St. Paul's Churchyard, Mr. Williams (later Sir George Williams) being the founder of The Young Men's Christian Association. For the past 25 years he has been en. gaged in the bookkeeping departments of several New York business houses of high standing, including Hickson Inc., Lucile, Ltd., and Vaughan's Seed Store.

R ALPH PAGE BRAMMAN was born in Chicago, educated in the Massachusetts grammar schools, the New Jersey high schools, and the Richmond Academy. Since that time he has been engaged in clerical work and later as corporation assistant in the Electric Bond and Share Co., New York. Five years ago he was engaged by us as assistant bookkeeper, during which time he instituted modern methods in office efficiency, and has just organized a system which will insure still more promptitude in the execution of orders.

I OUIS GRENIS, another product of Brooklyn, came to us five years ago to take charge of the packing and shipping departments which position he has held until recently when he was brought upstairs to take charge of the implement department. $\mathrm{He}$ is known in the trade as the star pitcher of Marshall's baseball team. 


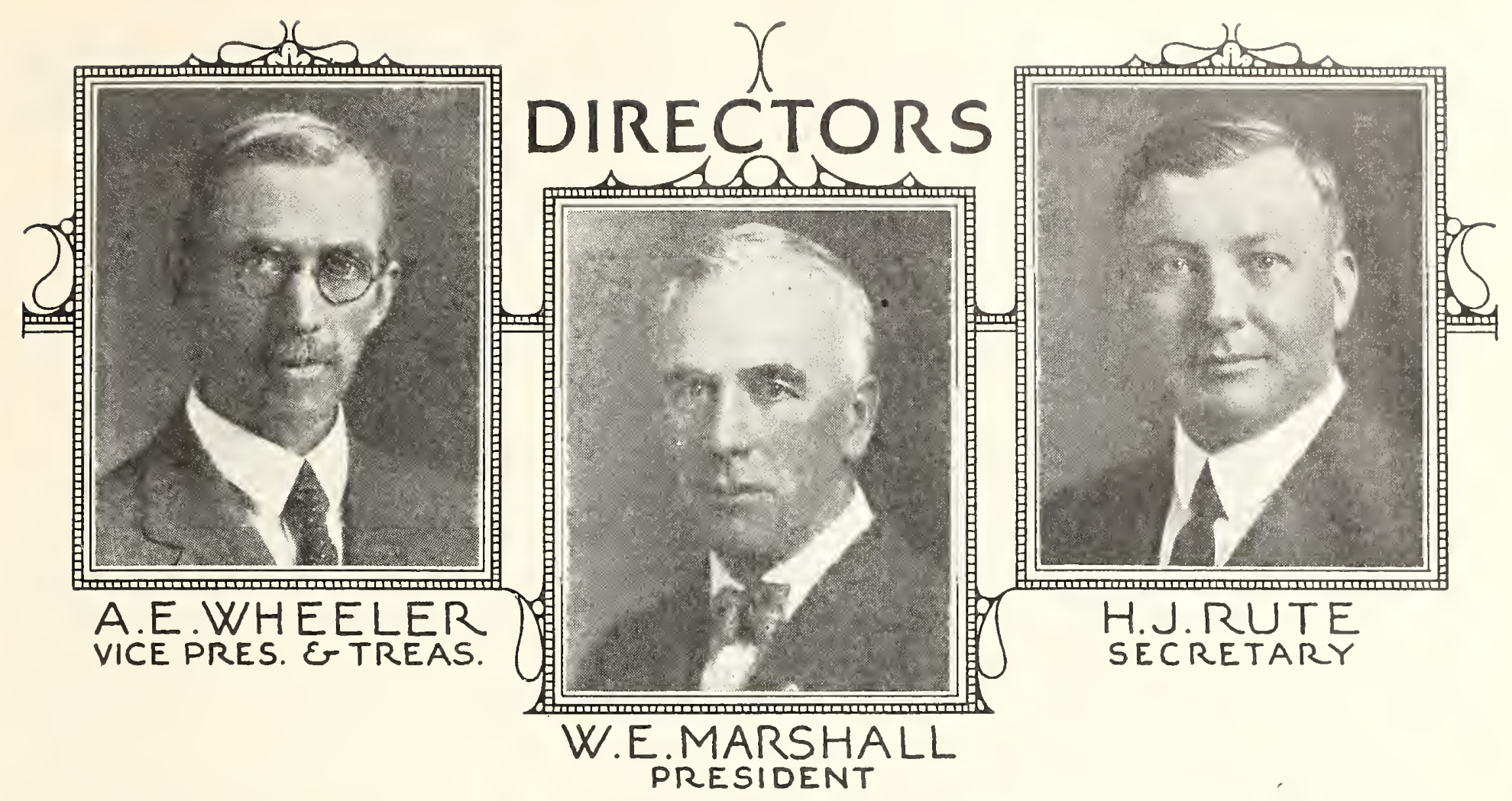

TRAVELING SALESMEN

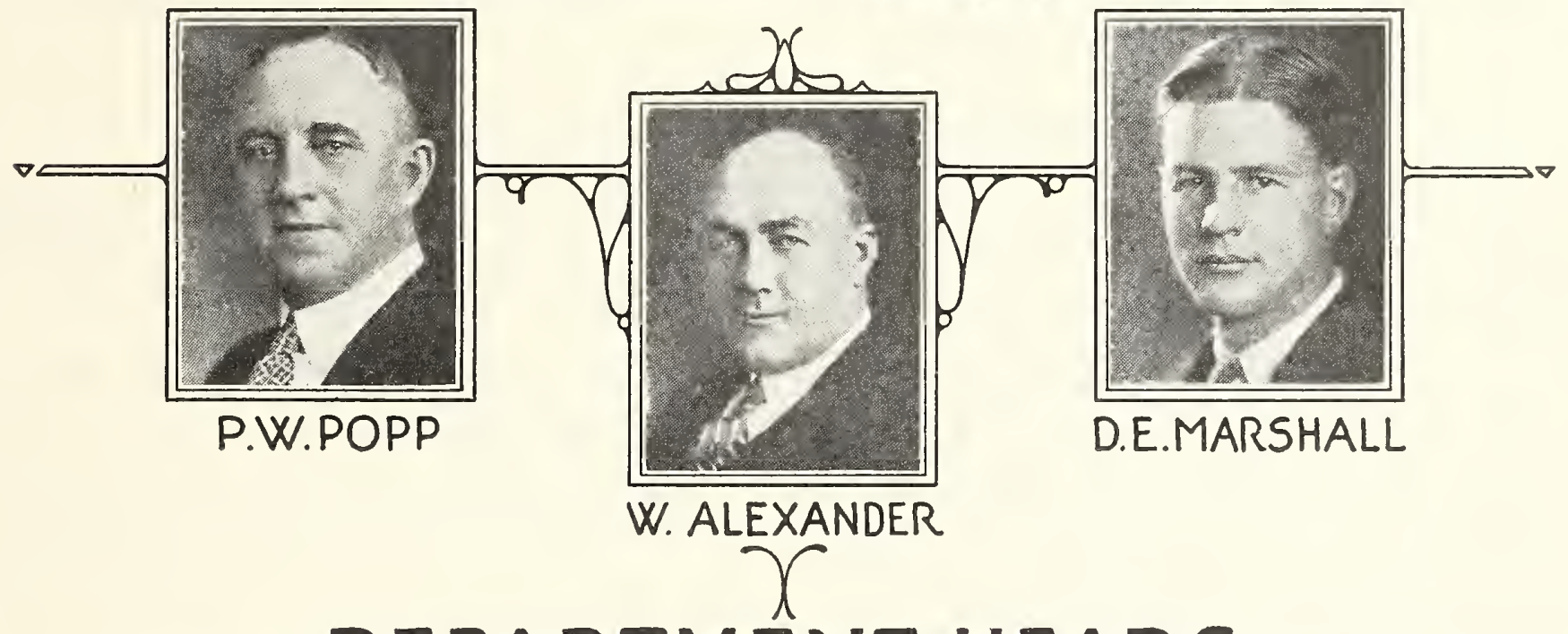

DEPARTMENT HEADS

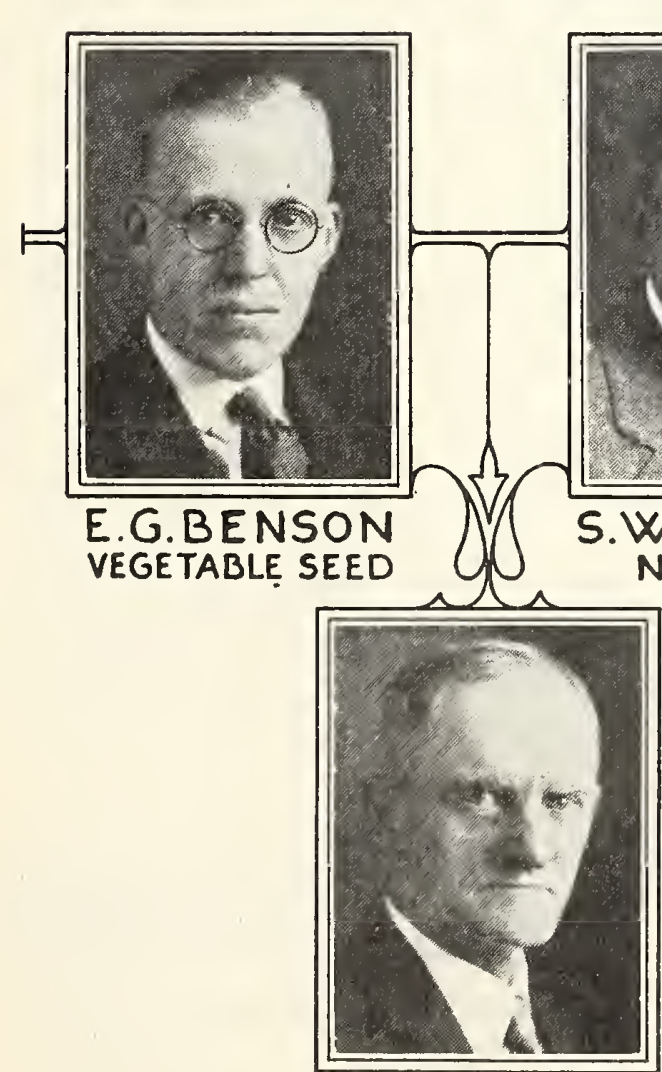

G.R.FISHER BOOKKEEPING

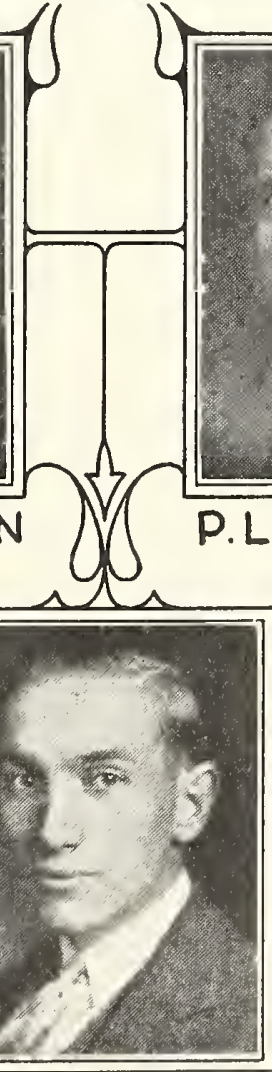

R.P.BRAMMAN GENERAL OFFICE
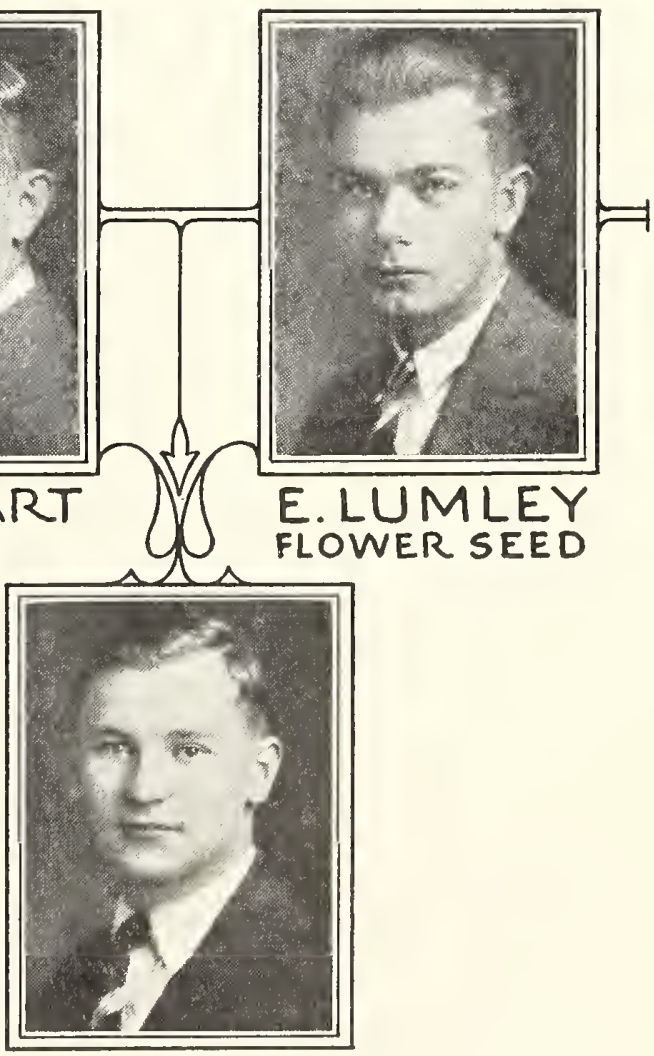

L.G. GRENIS IMPLEMENT 


\section{General Directions to Customers}

\section{ORDER EARLY}

We request our customers to order as early as possible on receipt of catalogue. We endeavor to ship all orders immediately on receipt, but during the busy season it is almost impossible; hence, the importance of ordering early.

\section{PARCELS POST}

We deliver free by Parcels Post all seeds, except Beans, Corn, Peas, Farm Seeds or Clovers. If these are wanted by mail, please add the cost of postage at zone rates. delivery.

Fertilizers, insecticides, sundries, trees and plants are at all times excluded from free

No charge for delivery to railroad station, steamer or express office.

Owing to the scarcity of all bags, we are compelled to charge them at cost and credit will be given when returned, charges prepaid, if in good condition.

\section{EXHIBITIONS}

At different periods, we expect to make displays of our Rock Garden Plants, Lilacs, lris, Peonies, Gladiolus, Hardy Lilies, Hardy Herbaceous Flowers, Vegetable, Garden and Farm Produce. We invite our patrons to visit our store, where courteous treatment will be accorded by our fellow workers who have aided us in the expansion of our business, and who share with us its prosperity.

\section{GARDENERS AND FARMERS}

Parties requiring the services of reliable men, married or single, should consult with us, as we have the names of a number on our register, thoroughly experienced in every branch of the business. We have a large acquaintance among gardeners in this vicinity, and it is seldom that anyone who applies to us fails of getting the right party. No fee.

\section{SPEGIAL NOTICE: PRIGES}

The prices published in this Catalogue are subject to market changes without notice.

Owing to the fluctuating market in prices of all materials, we cannot bind ourselves on prices of any articles.

\section{WE ISSUE THE FOLLOWING CATALOGUES AND SPECIAL LISTS}

AGRICULTURAL IMPLEMENTS, MACHINERY, ETC. A complete list of farm tools.

BULB CATALOGUE. Ready about July 1st, containing a complete list of all bulbs for Fall planting and'greenhouse forcing.

LILACS. A list of 100 of the best varieties.

LILIES. A complete list of 80 varieties described and illustrated. (See below):

ROCK GARDEN. Illustrated list containing over 300 varieties of plants and evergreen shrubs.

\section{HARDY GARDEN LILIES}

One of our specialties is "The Lily," and on that most interesting subject we have compiled the most comprehensive catalogue ever published and wherein all details of planting and culture will be found, including colored plates of nearly all the varieties in commerce. Owing to the great expense incurred in producing this valuable Lily book we are obliged to charge one dollar for same, which will be credited to the purchase of the first order for Lilies to the amount of three dollars or over. This means that credit slip for one dollar received with book should be sent with your first order for three dollars or over.

TELEPHONE CHELSEA 3288

\section{W. E. MARSHALL \& CO. Inc.} 150 WEST 23d STREET, NEW YORK

LOCATION OF OUR STORE-Our store, No. 150 West $23 \mathrm{~d}$ Street, is situated between Sixth and Seventh Avenues. 


\section{Novelties and Specialties in Flower Seeds}

\section{MY GARDEN}

A garden is a lovesome thing, God wot? Rose plot,

Fringed pool,

Ferned grot-

The veriest school

Of peacc: and yet the fool

Contends that God is not-

Not God? in gardens! when the evc is cool?

Nay, but I have a sign:

"Tis very sure God walks in mine.

-Thomas Eidward Brown.

ALYSSUM saxatile, "Silver Queen." An early of palest lemon flowers. Height 6 in. Pkt. 25c.

ALONSOA warscewiczi compacta. A charming growing about 15 in. high. Foliage dark green with racemes of bright scarlet flowers. Pkt. $25 \mathrm{c}$.

ANTIRRHINUM Dwarf Silver Queen. A disA beautiful color under artificial light. Adapted for bedding or pot culture. Pkt. 25c.

AOUILEGIA Marshall's Rose Queen. A beauQULU1A tiful selection of long-spurred rose shades of this popular hardy perennial. Pkt. $25 \mathrm{c}$.

ASPERULA azurea setosa. ' A very effective with numerous sweet-scented pale blue ftowers. Remains in bloom for a long period. Pkt. $25 \mathrm{c}$.

ASTER Everlasting Flesh. This curious Aster A IR resembles a large Helichrysum or Strawflower; when cut and dried it retains its color and shape as an everlasting flower. Pkt. 25c.

Farreri. A very interesting perennial commencing to bloom in. May. The flowers are single with violet mauve petals and a large golden orange disc, often over $21 / 2$ in. in diameter produced on long, stiff naked stems. Pkt. 50c.

BEGONIA semperflorens, Marshall's Crimson. The habit is similar to the Begonia Gloire de Lorraine, with light green leaves and blooms continuously on flower stalks crowned with crimson fiery-red blossoms about $11 / 2$ in. in diameter. A valuable acquisition as a pot plant or for Summer bedding. Pkt. $50 \mathrm{c}$.

BROWALLIA viscosa. A very useful, free or indoor culture. The salver-shaped flowers are of a bright violet-blue. Pkt. 50c.

CALLIOPSIS Dwarf Dazzler. A beautiful plant CALLIOPSN of easy culture growing about 12 in. high with large flowers with a rich maroon red center and broad golden yellow border. Valuable for bedding or cutting. Pkt. 35c.

CHEIRANTHUS linifolius. This charming liCHEIRANIHUS lac Wallflower is seldom out of flower and grows about 12 in. in height. Valuable for hardy borders and rock gardens. Pkt. 35c.

CYCLAMEN giganteum. The following English tion novelties we offer as the best selection from the largest grower of Cyclamen in England.

Bush Hill Pink. Color a bright rosy-pink, foliagc beautifully marbled. Pkt. $\$ 1.00$.

Fragrance. Color rose and beautifully fragrant. Pkt. $\$ 1.00$.

Fragrant Gem. Flowers white with rose eye. Pkt. $\$ 1.00$.

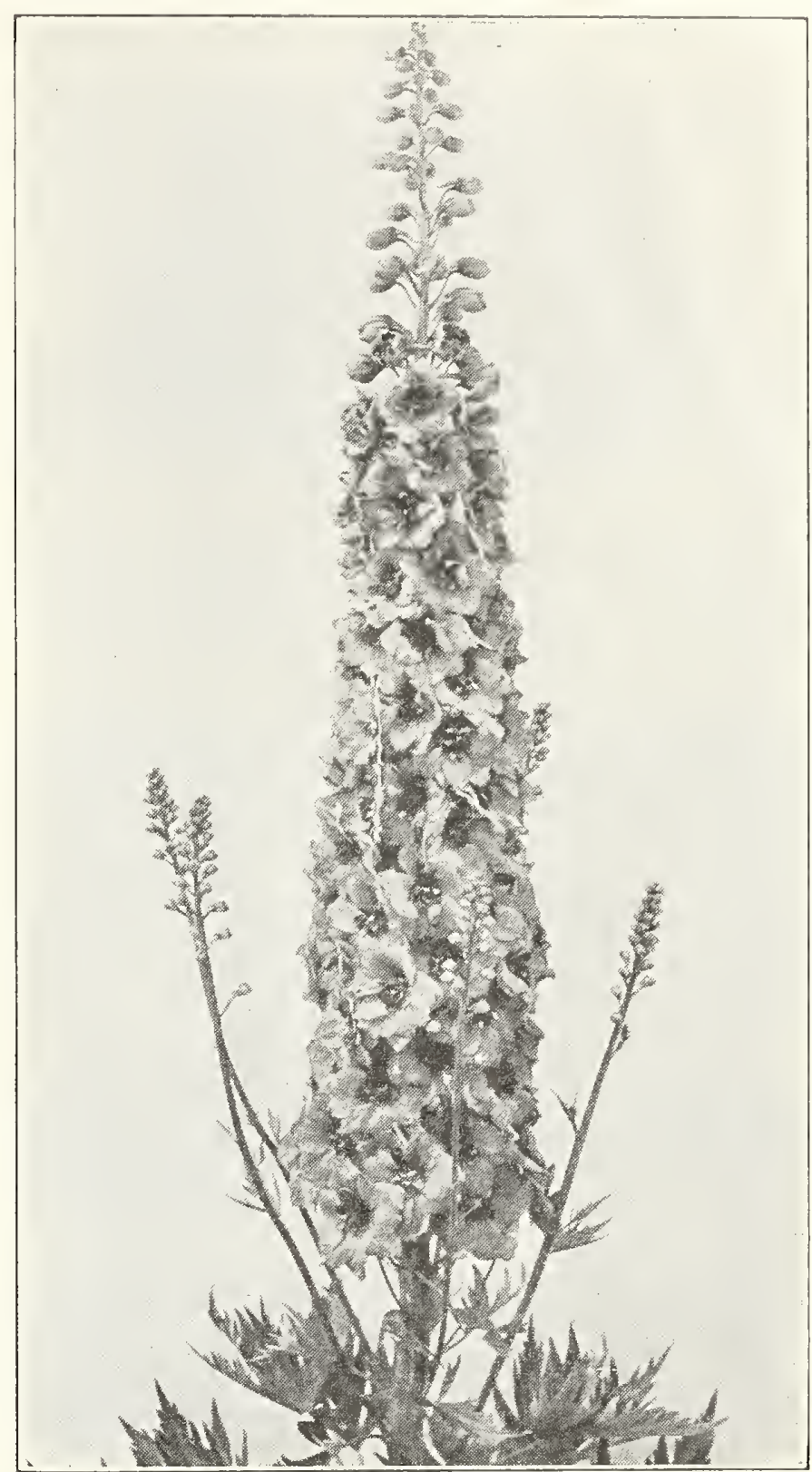

Delphinium, Wrexham Hybrids

DELPHINIUM Wrexham or Hollyhock Hybrids. This wonderful strain is conspicuous for its broad-based tall spikes, carrying large individual flowers that run largely in dcep shades, much prized by experienced growers. Even the young plants blooming for the first time are a revelation to Delphinium growers, and their massive character in fuller maturity is cause for fresh amazement. Pkt. $\$ 2.00$.

DIASCIA barberae. Pretty pink, coral-like flowers whoduced on slender stems during the pot plant for grcenhouse decoration. Height 9 in. Half-hardy annual. Pkt. 25c.

DIANTHUS Pink Beauty (Heddewigi). A beauIANIHUS tiful double pale pink annual variety. An ideal plant for borders or bedding. Plst. $35 \mathrm{c}$.

DIGITALIS Giant Shirley Hybrids. These vigor, growing from 5 to $6 \mathrm{ft}$. in height. Flower heads are $3 \mathrm{ft}$. long, crowded with bell-shaped flowers. Colors range from white, shcll pink and deep rose, many dotted with crimson. Pkt. 25c., 1/8 oz. $\$ 1.00$. 
DIGITALIS Isabellina. A distinct break; the purpurea. Pkt. $35 \mathrm{c}$.

ESCHSCHOLTZIA californica, Double ToreUSCHSCHOLILA ador. In color and form this new variety has to be seen to be fully appreciated. The petals of golden bronze are artistically arranged and the reverse flower is a rich orange crimson. Pkt. 50c.

GEUM Orange Queen. We are pleased to be able to offer a Geum of a shade intermediate between Mrs. Bradshaw and Lady Stratheden. The plants are of similar habit to both and quite as large and free blooming, in a beautiful orange color. Pkt. $50 \mathrm{c}$.

LARKSPUR Emperor, Pink Delight. A fine or pots, of compact growth. A charming soft pink color. Pkt. 50c.

LUPINES Marshall's Matchless. An entirely new UUPLN strain, comprising a wonderful range of previously unknown colors among perennial Lupines. Matchless. Apricot shades. Pkt. 50c

Matchless. Bronze and copper shades. Pkt. 50c.

Matchless. Creamy pink shades. Pkt. 50c.

Matchless. Light yellow shades. Pkt. 50c.

Matchless. Red and mahogany shades. Pkt. 50c.

Matchless. Yellow shades. Pkt. 50c.

Matchless. Mixed shades. Pkt. 50c.

Collection, 1 pkt. each, six shades, $\$ 2.50$

MYOSOTIS Marshall's Blue Bird. A very MUSO11S fine dark blue variety with long stems for Winter blooming. Sow seed in June outside and transplant in the Fall in greenhouse for inside culture. Pkt. $\$ 1.00$.

NICOTIANA Dwarf white. A delightful, hardy NGO11ANA annual adapted for pot work or borders, the sweet-scented flowers remain open all day. Height 18 in. Pkt. 25c.

RANUNCULUS Giant-flowered Florentine. A culus which will flower from seed if sown in early Spring. They have a strong and vigorous habit with flower stems, $2 \mathrm{ft}$. high and individual flowers 4 to 5 in. in diameter. Protect from severe frost in Winter and they will be at their best the following year. Mixed colors. Pkt. 50c.

SCABIOSA Peach Blossom. A beautiful shade SCABLNA of peach blossom pink, of large size and long stems. An excellent cut flower. Pkt. 25c.

Shasta. A pure white of enormous size. The flowers measure 3 in. across with extremely long stems. Pkt. 25c.

SIDALCEA Stark's Hybrids. A real good, hardy border plant, easily raised from seed. The colors embrace all shades from blush, pink, rose, carmine and crimson. The height varies from 2 to $4 \mathrm{ft}$. and it flowers from June to Sept. Pkt. 50c

SWEET PEA Silver Blue. Early flowering. The spray and are a pleasing delicate shade of lavender blue. Pkt. $25 \mathrm{c} ., 1 / 4$ oz. $75 \mathrm{c}$., oz. $\$ 2.00$.

Snowball. A beautiful late Spencer with snow-white flowers. A vigorous grower, with long, sturdy stems supporting four frilled and well spaced flowers. Pkt. $50 \mathrm{c} ., 1 / 4$ Oz. $\$ 1.25$.

Early Flowering Superior Pink. This wonderful variety was awarded a Silver Medal at the New York Flower Show in 1926. The color is a beautiful

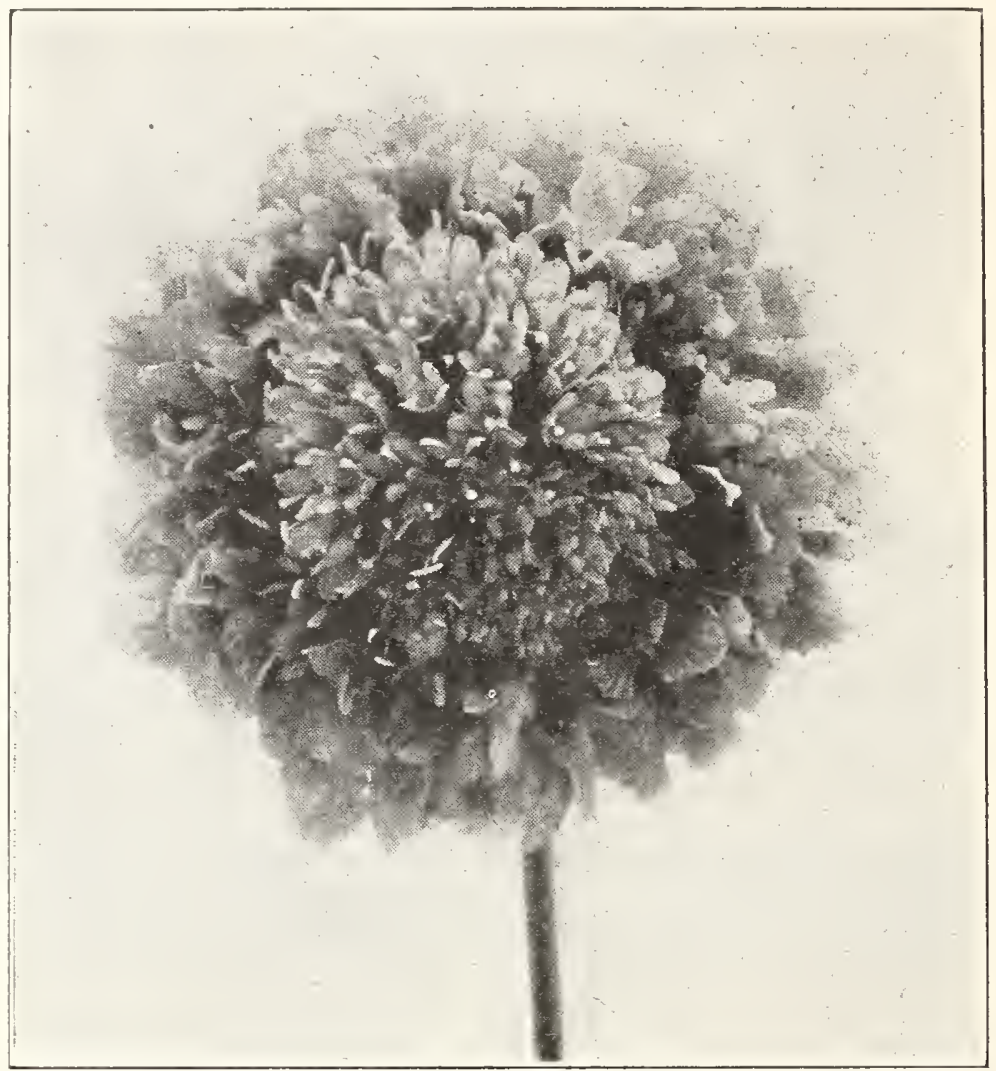

Scabiosa, Peach Blossom

rose-pink, very slightly shaded with salmon. A good grower with long stems, 16 to $18 \mathrm{in.} \mathrm{long,} \mathrm{carry-}$ ing four flowers to a spray. Pkt. 50c., 1/4 oz. $\$ 1.50$, oz. $\$ 5.00$.

Vulcan, Early -flowering. The color is the most vivid scarlet seen in Sweet Peas; it never burns in the hottest sun, stems are strong with 3 or 4 flowers on each. Pkt. 25c., 1/4 oz. 75c., oz. $\$ 2.00$.

VERBASCUM Miss Willmott. A lovely hardy perennial with large, ivory-white spikes of flowers, $5 \mathrm{ft}$. high. Pkt. $50 \mathrm{c}$.

VERBENA Grandiflora erecta Royal Bouquet. A valuable decorative plant for bedding or growing in pots. It forms a plant 15 to 18 in. high and 10 in. across. The distinct feature is its compact, erect habit. Mixed colors. Pkt. 25c.

Luminosa. A new color added to the mammoth Verbenas. Large blooms of luminous flame-pink toning to softer shades of salmon, flesh and coral, giving the whole a most beautiful color that must be seen to be appreciated. Pkt. 50c.

VIOLA Haslemere. A distinct variety with rosylilac flowers. The habit of the plant is erect, flowers of medium size and produced in great profusion for a long period. Valuable for borders and rock gardens. Pkt. $35 \mathrm{c}$.

Cornuta, "Jersey Gem." The flowers are a pleasing shade of deep violet-blue and may be relied on to come about 70 per cent true from seed. It forms a large compact plant, producing a continuous profusion of bloom throughout the Summer. Pkt. 50c.

WALLFOWER Early Wonder. A new double WALLFLWER annual-flowering Wallflower which will bloom in five months from seed. It grows about $21 / 2 \mathrm{ft}$. high with many lateral branches and is specially adapted for cutting purposes. It was given an Award of Merit at the R. H. S. in June, 1926. Mixed colors. Pkt. 50c.

FOR OTHER FLOWER SEEDS, SEE PAGES 28 to 49 


\section{SPECIALTIES IN VEGETABLES}

\section{BROCGOLI. Marshall's Green Heading}

A distinct type of Broccoli with a delicious flavor, without the strong Cauliflower taste. It forms a small head with a branching habit, which are a dark green color from September until severe weather in December. Pkt. 25c., $1 / 2$ oz. $\$ 1.00$, oz. $\$ 2.00$.

\section{CABBAGE. Marshall's Baby Head}

Small, perfectly round, solid heads, few outer leaves, adapted for forcing in hotbeds or for early use in the garden. The small heads mature in six to seven weeks after planting. Pkt. $15 \mathrm{c} ., 1 / 2$ oz. $60 \mathrm{c} ., \mathrm{oz} . \$ 1.00$.

\section{CARROT. Long Red Surrey}

A fine exhibition variety, with long, tapering root, smooth skin of orange-red color. A good keeper and suitable for deep soils. Pkt. 10c., oz. 30c., 1/4 lb. $\$ 1.00$.

\section{LETTUCE. Wheeler's Tom Thumb}

A splendid forcing variety, small head, dark green, crumpled leaves, forming into a small butter head. Pkt. 10c., 0z. 75c.

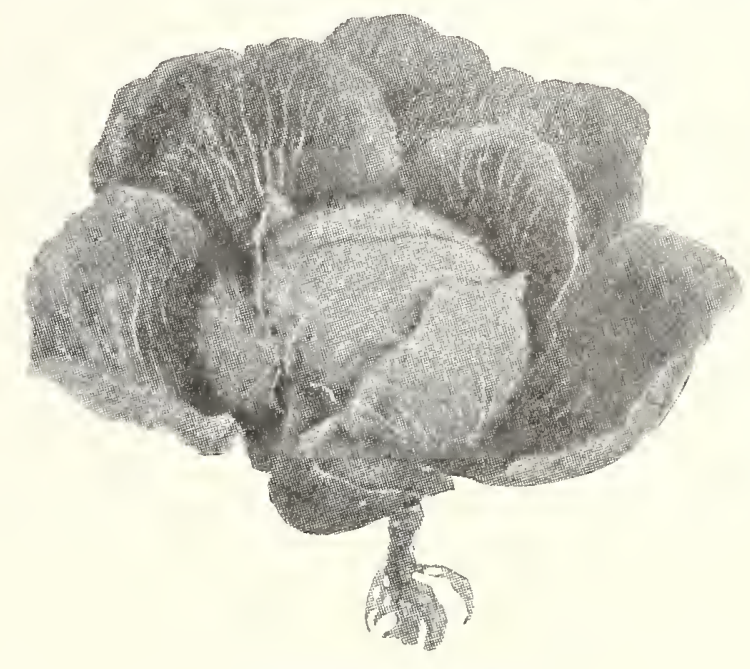

Cabbage, Baby Head

PEPPER. Marshall's Early Giant

A very large variety adapted for growing in the Northern states, early and prolific. Color deep green turning to brilliant red when ripe. Flesh very thick and sweet. Pkt. 25c., $1 / 2$ oz. $\$ 1.00$.

\section{NEW AND RARE PLANTS}

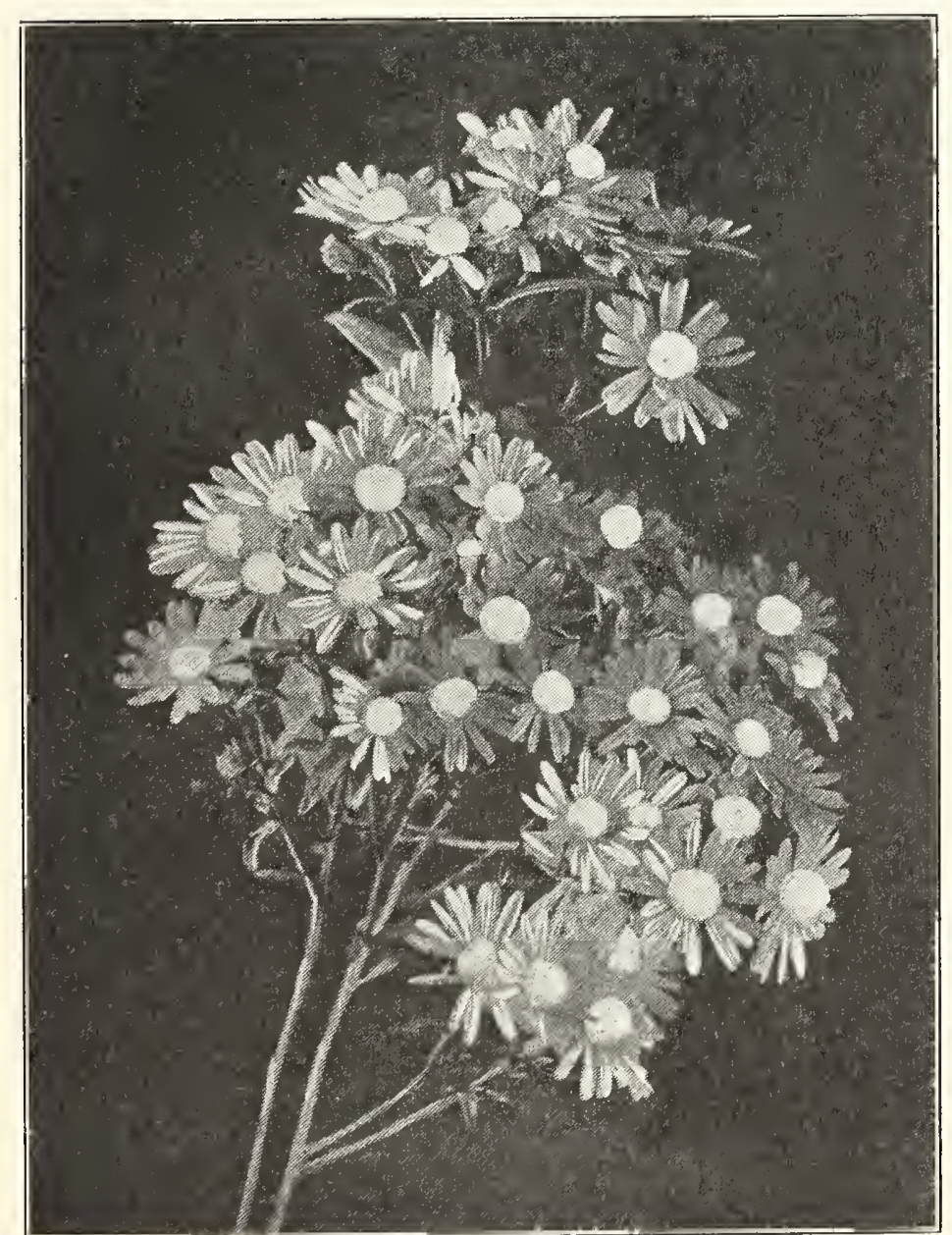

Aster, Michaelmas Daisy

\section{NEW ANTIRRHINUMS}

Judd's New Early Dark Pink. A beautiful rosepink, similar to the Premier Rose.

Judd's New Early Light Pink. A magnificent pink, similar to the Columbia Rose.

The two above varieties will bloom about eight weeks earlier than all other varieties.

Plants from 21/4-in. pots, doz. $\$ 2.50,100 \$ 15.00$.

\section{ASTER. Michaelmas Daisy}

Of late years a great improvement has been shown in these Hardy Asters and from the newer varieties we have selected the following which, in our estimation are the best of the group.

Blue Gem. A rich true blue, flowers double; $5 \mathrm{ft}$.

Grey Lady. A soft shade of opal grey, large, semidouble flowers, with long ray florets; $4 \mathrm{ft}$.

Heather Glow. Large rose-colored flowers; robust habit; $4 \frac{1}{2} \mathrm{ft}$.

Queen of Colwall. Large, stout-branching stems covered with pale mauve flowers; $4 \mathrm{ft}$.

Wonder of Colwall. Very large flowers of a beautiful pale blue. Handsome, pyramidal spikes; $4 \mathrm{ft}$. Plants of the above, 35c. each, 10 for $\$ 3.00$.

Countess. Beautiful rose color, lovely in artificial light and a free bloomer; $3 \mathrm{ft}$.

Mother of Pearl. Immense pale, mauve-colored flowers with a conspicuous green center; $4 \mathrm{ft}$.

October Dawn. A pretty shade of bright lilac and mauve; 18 to 24 in.

Snowdrift. Branching pyramids of large, snow white, semi-double flowers. The finest white of all; $4 \mathrm{ft}$. Plants of the above, 50c. each, 10 for $\$ 4.50$.

\section{BARBERRY. New Red-Leaved Japanese}

This new Barberry is similar in all respects to the green-leaved Japanese Barberry, except the foliage, which is of a rich, lustrous, bronzy-red, similar to the red-leaved Maples. It retains its color throughout the Summer and in the Fall, its foliage is a vivid red shade. The scarlet berries remain on the plant the entire Winter.

One-year-old plants, each 75c., 10 for $\$ 7.00$; two-yearold plants, each $\$ 1.25,10$ for $\$ 11.00$; three-year-old specimen plants, each $\$ 2.50,10$ for $\$ 20.00$. 


\section{ANEMONE. Windflower}

(See cover of catalogue)

Valuable plants for Autumn-flowering in masses or single plants. The blooming period extends from August until November, the large, open flowers are fine for cutting or decorative purposes. Plants should be well protected in Winter. The roots we offer are two-year-old, extra strong, field-grown.

Alice. Large flowers of rose, carmine, lilac center Each 50c., 10 for $\$ 4.50$.

Hupehensis. A pleasing mauve rose colored flower. Plants grow about $1 \mathrm{ft}$. high. Each 35c., 10 for $\$ 3.00$. Max Vogel. Large, semi-double, light rose flowers. Each 50c., 10 for $\$ 4.50$.

Prince Henry. Double red flowers, dwarf habit. Each 60c., 10 for $\$ 5.50$.

Whirlwind. An excellent double white; height 2 to $3 \mathrm{ft}$. Each 30c., 10 for $\$ 2.50$.

All the above are extra strong, two-year-old, fieldgrown roots.

\section{NEW GARNATIONS}

Sceptre. The best new Carnation sent out in recent years. A seedling of Pink Delight; flowers as large as Surprise; color salmon-pink and wonderful keeper and good grower.

Boston Ward. A fine dark pink of improved Wartype.

North Star. An extra fine yellow, size good and excellent quality.

Radiolete. A new brilliant scarlet, the winner of the Dorner Memorial Medal.

Rooted cuttings of the above, doz. $\$ 3.50,100 \$ 25.00$.

For other Carnations, see page 58 .

\section{NEW FUCHSIA. Giant Pink}

Exceptionally large pink and white flowers; habit half-dwarf, making a wonderful pot plant, very free flowering and the finest Fuchsia ever offered. Rooted cuttings, doz. \$1.50, $100 \$ 10.00$.

Plants from 21/4-in. pots, doz. $\$ 3.00,100 \$ 20.00$.

\section{MYOSOTIS. Alpestris Pink}

The Pink Forget-me-not which has been under process of selection for several years and is now 97 per cent true to color. A most striking companion to the blue variety. Plants in 3, in paper pots, each 3ãc., 10 for $\$ 3.00$.

\section{NEW GREENHOUSE ROSE FLOREX}

We believe Florex to be one of the best all-round commercial Roses ever offered to the trade. Habit of growth, freedom of bloom, color, keeping and shipping qualities are superior to any of our standard commercial varieties grown today. Color, bright coral salmon absolutely distinct from any other Rose, therefore difficult to describe and must be seen to be appreciated It has proven to be a good Summer Rose as well as a Winter Rose.

Own root stock, 21/4-in. pots, doz. $\$ 9.00,100 \$ 65.00$.

Grafted stock, 21/4-in. pots, doz. $\$ 10.00,100 \$ 75.00$.

For other Greenhouse Roses, see page 68.

\section{SIDALCEA. Lowfield Pink}

A great improvement over Rose Queen, producing extra large flowers of a beautiful satiny pink shade. Each 50c., 10 for $\$ 4.50$.

\section{VIOLA Jersey Gem}

The most valuable bedding Viola suited to our climatic conditions. They will bloom continuously from May until the Fall. The plant is of compact, sturdy habit and produces a pure violet flower with stems 6 inches long in great profusion.

Plants, each 35̌c., doz. \$4.00, $100 \$ 30.00$.

\section{COLD STORAGE LILY BULBS}

We are prepared to ship the following in 25,50 or 100 lots at any time; 50 bulbs supplied at 100 rate. LILIUM formosum (Erabu black stem). Bulbs 11 to 13 in. 25 for $\$ 18.00,100$ for $\$ i 0.00$.

LILIUM giganteum. Bulbs 9 to $10 \mathrm{in.} 25$ for $\$ 15.00,100$ for $\$ 55.00$.

LILIUM auratum. Bulbs 11 to $13 \mathrm{in.} 25$ for $\$ 18.00,100$ for $\$ 70.00$.

LIIIUM speciosum album. Bulbs 8 to 9 in. 25 for $\$ 15.00,100$ for $\$ 55.00$.

LIIIUM speciosum album. Bulbs 9 to 11 in. 25 for $\$ 18.00,100$ for $\$ 70.00$.

LILIUM speciosum Melpomene, or rubrum. Bulbs 11 to 13 in. 25 for $\$ 17.50,100$ for $\$ 65.00$.

LILIUM speci osum Melpomene, or rubrum. Bulbs 13 to 15 in. 25 for $\$ 27.50,100$ for $\$ 105.00$.

\section{LILY OF THE VALLEY PIPS FROM COLD STORAGE}

We have in storage a large quantity of Dresden Pips for forcing at any season of the year.

Lily of the Valley can be forced in about four weeks from cold storage pips. We cannot supply less than 250 pips.

Marshall's Matchless Pips. 250 for $\$ 16.00,500$ for $\$ 30.00,1000$ for $\$ 60.00$.

Note.-To obtain best results with Cold Storage Lily of the Valley, the pips should be plunged into cold water on arrival for at least 12 hours before placing them in heat. 


150 WEST 23rd ST., NEW YORK 5

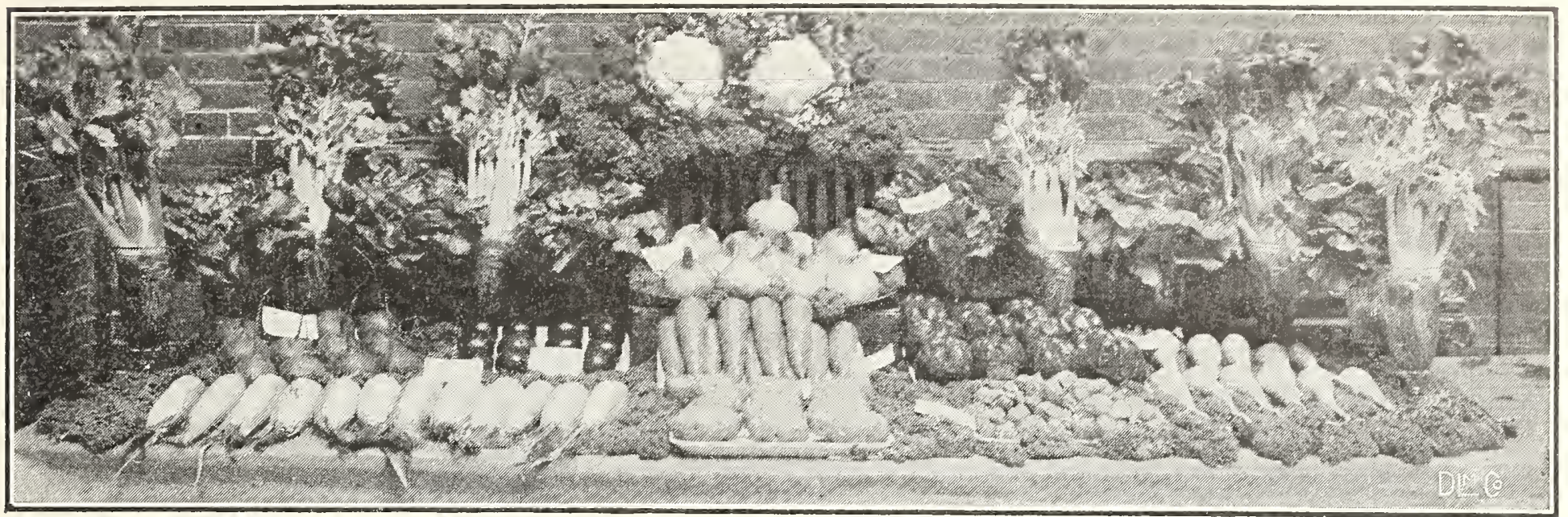

\section{MARSHALL'S VEGETABLE SEEDS}

\section{WITH GENERAL DIRECTIONS FOR CULTIVATION}

We give no warranty, express or implied, as to description, purity, productiveness, or any other matter of any seeds, plants or bulbs we sell, and we will not be in any way responsible for them. If the purchaser does not accept the goods on these terms, they are at once to be returned.

W. E. MARSHALL \& CO., Inc.

\section{ARTICHOKE}

One ounce will sow 100 feet of row, and produce about 500 plants.

A rich, sandy loam is best adapted for this plant. The seed should be sown in drills $11 / 2$ inches deep and 1 foot apart. Transplant to rows 3 feet apart. They reach maturity the second year. Protect in Winter by a covering of leaves or coarse manure.

Large French Globe. Heads large, fleshy and of rich flavor. Plit. 25c., 1/2 oz. 60c., oz. \$1.00.

\section{ARTICHOKE PLANTS}

Large French Globe. Plants ready for shipment after April 1st. Doz. \$2.50, $100 \$ 20.00$.

Jerusalem. Grown for the tubers, which resemble Potatoes, and are cultivated in a similar manner, but the rows should be at least 4 feet apart. Qt. 30c., pk. $\$ 1.75$.

\section{ASPARAGUS One ounce will produce}

Sow in Autumn or in Spring as soon as the soil is in good working condition. At one or two years transplant to permanent beds.

Conover's Colossal. Very prolific and tender

Palmetto. A fine variety, producing large, green Asparagus.

Pkt. Oz. $1 / 4 \mathrm{lb}$

Washington. A rust resistant variety, with long, dark green stalks

$\$ 0.10 \$ 0.20 \$ 0.45$

$\begin{array}{lrr}.10 & .20 & .45\end{array}$

\section{ASPARAGUS ROOTS}

\section{It requires 100 plants for a single row of 150 feet.}

Culture.-The permanent bed should be trenched or ploughed very deeply, and well manured with rich, thoroughly decayed manure. Set the plants 18 inches apart in rows, carefully spreading out and separating the roots, and deep enough to admit of the top of the plants being covered 6 inches. In November the plants should have their annual top-dressing of manure after the stalks have been cleared away.

\begin{tabular}{|c|c|c|c|c|c|c|}
\hline ONE-YEAR-OLD ROOTS & 100 & 1000 & TWO-YEAR-OLD RC & 25 & 100 & 1000 \\
\hline Palmetto. Large, bright green &.$\$ 1.25$ & $\$ 10.00$ & Palmetto. &.$\$ 0.60$ & $\$ 2.00$ & $\$ 15.00$ \\
\hline Conover's Colossal. Deep gre & 1,25 & 10.00 & Conover's Col & .60 & 2.00 & 15.00 \\
\hline mbian Mammoth. & 1.25 & 10.00 & Washington & 1.25 & 4.50 & 40.00 \\
\hline Vashington. & 3 & 30.00 & Forcing Clumps & 3.00 & 10.00 & \\
\hline
\end{tabular}

\section{BEANS}

Beans like a well drained, rich and light loam. Plant about the middle of April when warm and favorable, and at intervals throughout the season for a succession, until the latter part of August. Bush varieties should be planted in drills 2 feet apart, and from two to six plants to the foot in a row. Keep them well cultivated and draw the earth up to the stem. For String Beans gather the pods clean as soon as fit for use. The plants will remain all the longer in bearing.

\section{DWARF SHELL BEANS}

Sow in drills 2 feet apart as soon as walm weather has set in; soil should be light and rich; covering about 2 inches.

Boston Pea or Navy. Used when dry for cooking purposes. . . . . . . . . . . . . \$0.20 $\$ 0.30 \quad \$ 0.60 \quad \$ 2.00$

$\begin{array}{llll}1 / 2 \text { pt. } & \text { Pt. } & \text { Qt. } & 4 \mathrm{qts} .\end{array}$

White Kidney. Excellent Shell, or String Bean.

White Marrow. For use in a dry state in Winter, or as a String Bean

English Green Windsor. A nutritious, large Bean growing 3 feet high on stiff stems. Should be planted very early...

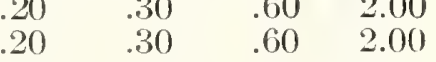

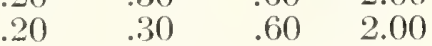

Add postage at Zone rates if Beans are to be mailed. One pint is erquivalent to one pound. 


\section{DWARF GREEN-PODDED SNAP BEANS}

One quart will plant 150 feet of drill.

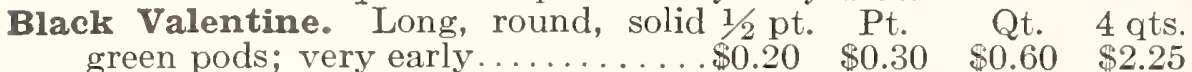

Bountiful. Early, very prolific and long

bearing; flat, green pods, tender and stringless. .

Canadian Wonder. Large, green pods. Fine for table or exhibition........

Early Mohawk. Long, straight, flat

Extra Early Refugee. Two weeks earlier than the Late Refugee; very prolific, long, round pods.

Extra Early Red Valentine. One of the earliest. Round, thick, solid pods.

Full Measure. A fine stringless bean with round, straight, green pods. . .

Giant Stringless Green Pod. This Bean is absolutely stringless. The pods are round and full

Longfellow. Long, straight, round, solid green pods; very early.......

Masterpiece. A beautiful round, greenpodded variety, long, straight, stringless pods; fine for forcing and exhibition

Refugee Late, or 1000 to 1 . Medium to late; very productive and tender. Largely grown for main crop; round pod. .

Stringless Green Pod (Burpee's) Ä Ä early, round, green-podded Bean; stringless, remains tender and crisp

\begin{tabular}{rrrr}
.20 & .30 & .60 & 2.25 \\
.25 & .50 & 1.00 & 3.50 \\
.20 & .30 & .60 & 2.25 \\
.20 & .30 & .60 & 2.25 \\
.20 & .30 & .60 & 2.25 \\
.20 & .35 & .70 & 2.50 \\
.20 & .40 & .70 & 2.50 \\
.20 & .30 & .60 & 2.25 \\
& & & \\
.40 & .75 & 1.50 & 5.00 \\
& & & \\
.20 & .30 & .60 & 2.25 \\
.20 & .35 & .70 & 2.50 \\
BDANS & & \\
\hline
\end{tabular}

\section{DWARF WAX-PODDED BEANS}

$\begin{array}{ccccc}\text { Black Wax, Currie's Rust-Proof. } 1 / 2 \text { pt. } & \text { Pt. } & \text { Qt. } & 4 \text { qts. } \\ \text { Large, flat pods; early........... } \$ 0.20 & \$ 0.30 & \$ 0.60 & \$ 2.25\end{array}$ Davis' White Kidney Wax. Long, waxy white; flat pods...............

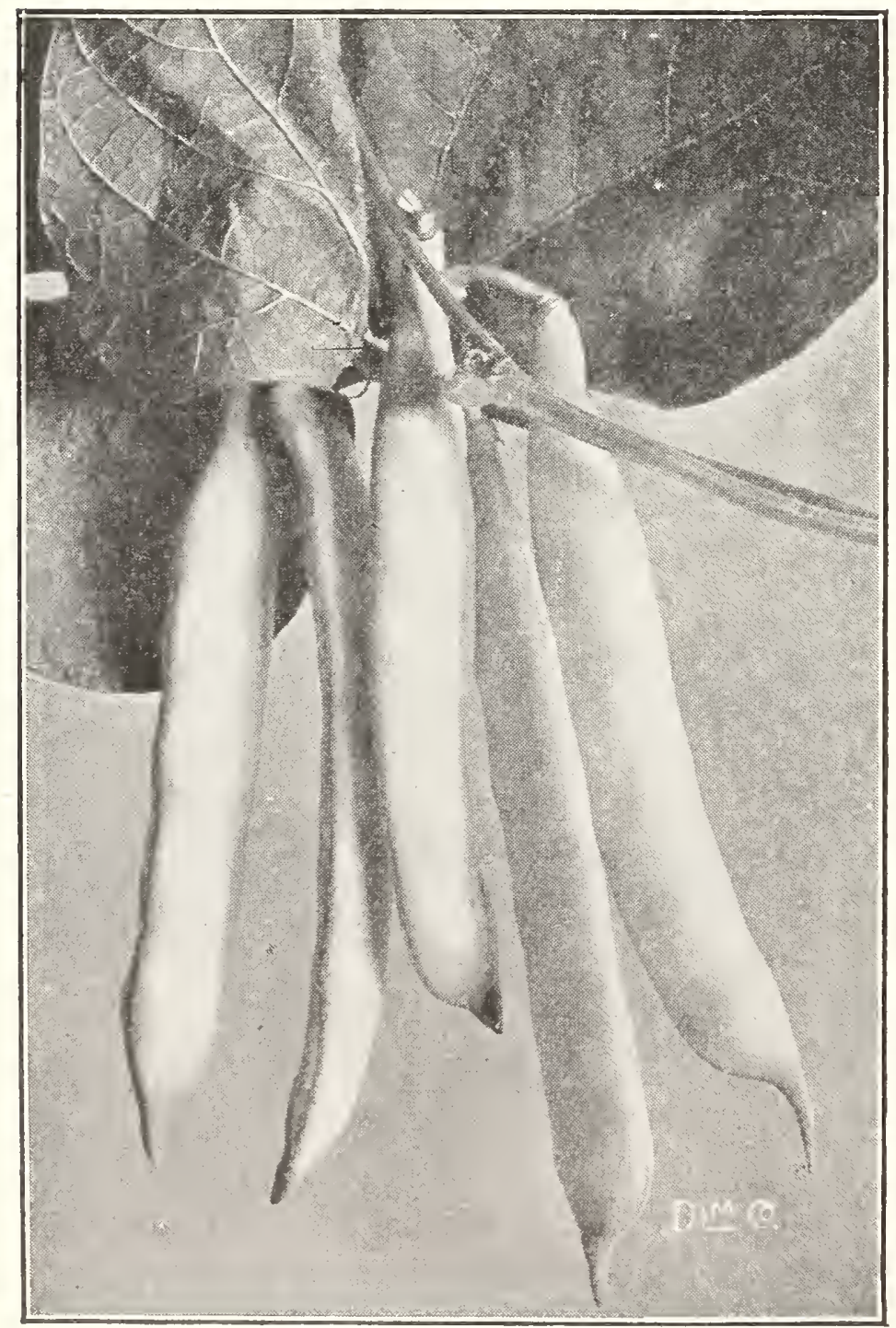

Beans, Golden Wax

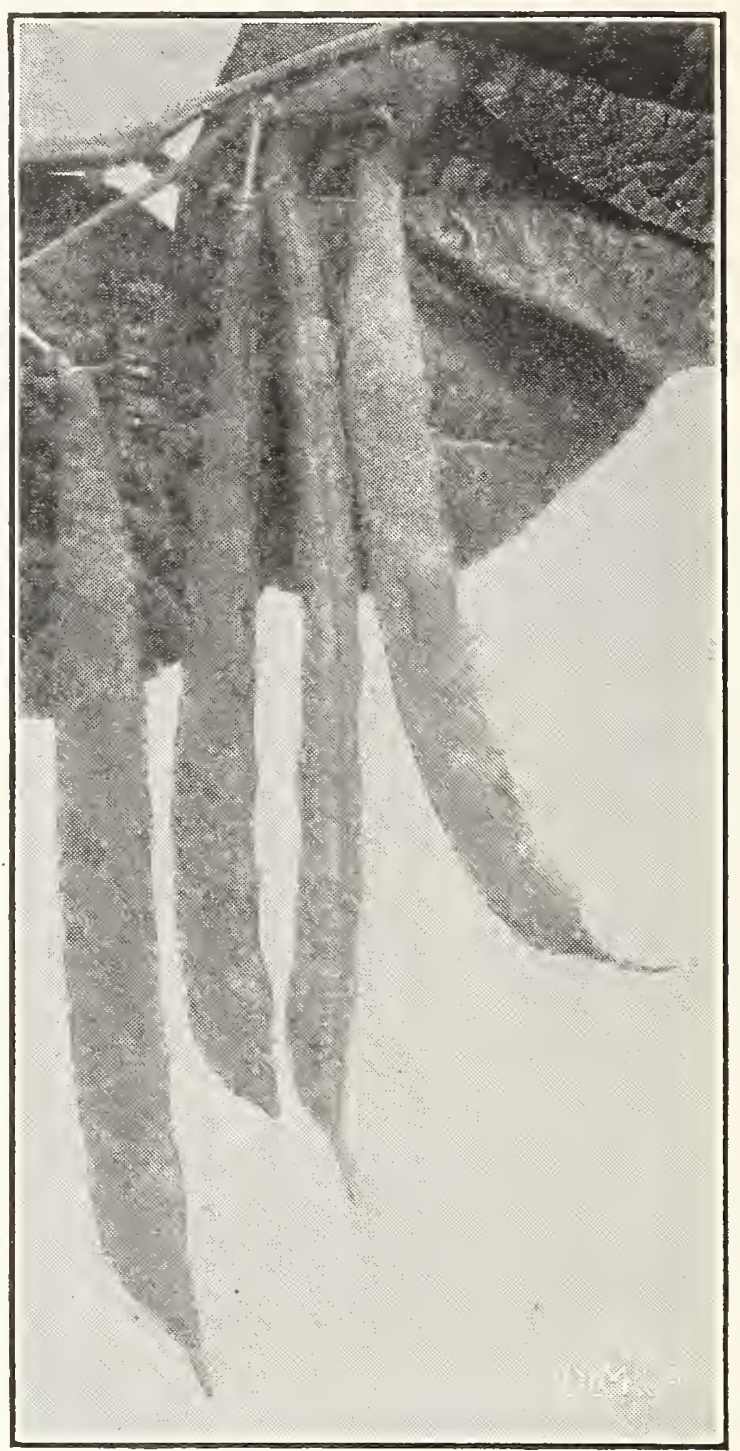

Beans, Bountiful

Golden Wax, Improved. 1/2 pt. Pt. Qt. 4 qts. Very early; flat pods,

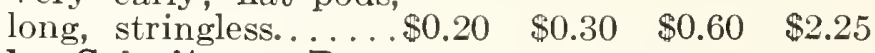

Golden Scimitar, or Pencil-Pod Black Wax. Long, round, yellow, stringless pods........

Hodson Wax. (Valentine Wax). H a nd some, thick, flat, yellow pods. Free from blight and rust. Heavy bearer. .

Refugee Wax. A Refugee with long, round, wax pods; stringless.

Wardwell's Kidney Wax. Early; long, straight, flat, wax stringless pods

$.20 \quad .35 \quad .65$

2.25

$\begin{array}{llll}.20 & .35 & .70 & 2.50\end{array}$

$\begin{array}{llll}.20 & .35 & .70 \quad 2.50\end{array}$

$\begin{array}{llll}.20 & .30 & .60 & 2.25\end{array}$

\section{DWARF, OR BUSH LIMA BEANS}

Burpee's Improved Bush Lima. A bush form of the large, flat Pole Lima..................

Dreer's Bush Lima. Round, thick Beans; very prolific.........

$\$ 0.30 \quad \$ 0.50 \quad \$ 1.00 \quad \$ 3.75$

$\begin{array}{llll}.30 & .50 & 1.00 & 3.75\end{array}$ It is of erect habit: Beans very large and heavy cropper

derson's Bush Lima, early small type with pods about 3 in. long. .

Wilson's Improved Bush Lima. A week to ten days earlier than Burpee's, more productive but not quite so large. 


\section{POLE, OR RUNNING BEANS}

Sow from the 1st of May (for all except Limas) to the latter part of May, in hills 4 feet each way. Limas should not be planted until warm weather has fairly set in. One quart of Limas will plant about 100 hills, allowing four or five beans to a hill, and of the smaller sorts about 200 hills. Poles 8 to 10 feet long should be firmly set in the hills before planting seed. Set poles 4 feet apart each way, and plant 4 to 6 beans about 1 inch deep around each pole. Thin out to three plants to a pole if the soil is rich; pinch off the ends of plants when they overrun the top of the poles, to effect more perfect growth below.

Carpenteria Lima. The beans have a greenish tint; vines vigorous and very pro- 1/2 pt. Pt. Qt. 4 qts.

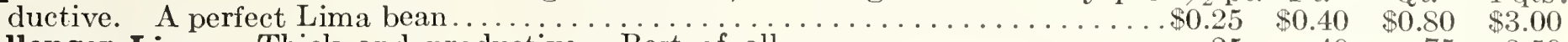

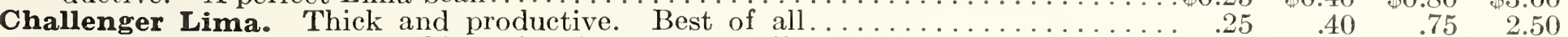

Extra Early Jersey Lima. This variety is ten days earlier than the ordinary variety,

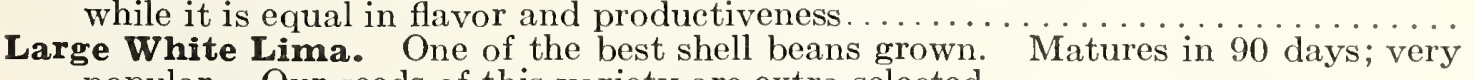

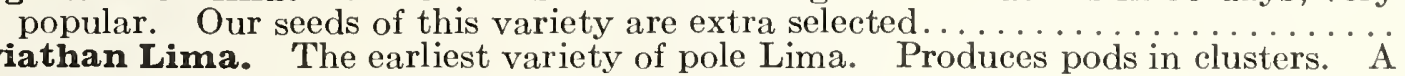

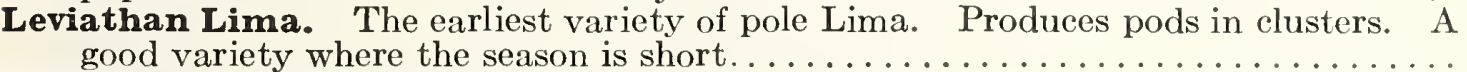

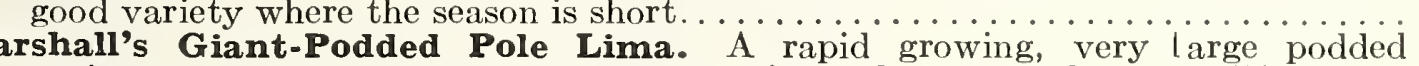
variety. The beans are extra large and thicker than any other pole Lima....

Small Sieva, or Carolina Lima. Small size; early and prolific . . . . . . . . . . . .

Golden Cluster Wax. Long, golden yellow pods in clusters. . .

Horticultural Pole. Good as a snap or shelled Bean.

Kentucky Wonder (Old Homestead). Pods green, very long and flat.

Scarlet Runner. A popular English pole bean; very ornamental.

Tender and True (Sutton's). Long, straight green pods, excellent for culture under glass. A great yielder...

$\begin{array}{rrrr}.25 & .40 & .75 & 2.50 \\ .25 & .40 & .75 & 2.50 \\ .25 & .40 & .80 & 3.00 \\ .30 & .50 & 1.00 & 3.50 \\ .25 & .40 & .80 & 3.00 \\ .30 & .40 & .75 & 2.50 \\ .25 & .40 & .75 & 2.50 \\ .25 & .40 & .80 & 3.00 \\ .25 & .40 & .80 & 3.00 \\ & & & \end{array}$

"MULFORD CULTURES." The use of Mulford Cultures when planting Beans will increase your yields. Small size, 35c. Garden size, 75c. State if wanted for String or Lima Beans when ordering.

\section{BEET}

One ounce will sow 150 feet of drill.

For early supply sow as soon as the ground is in working order, in drills 1 foot apart and 2 inches deep. For main crop sow the second week in May, and for Winter use sow in June. When the plants are well forward thin out to about 9 inches apart. The young Beets, with their tops, pulled out of the row, are excellent used as Spinach.

Early Blood Turnip. The

$$
\text { Pkt. }
$$

leading early sort; also

fine for late use..... \$0.05

Oz. $1 / 4 \mathrm{lb}$.

Lb.

Early Eclipse. Very early; dark blood color; small

Extra Early Egyptian. .10

$0.20 \$ 0.60$

$\$ 1.75$

The best for first crop out of doors. The root is very dark red, flat.

Crosby's Egyptian. Extra early, round, dark red.

Crimson Globe. Fine globular shape; flesh deep purple; fine quality....

20

$.60 \quad 1.75$

$\begin{array}{llll}.10 & .20 & .60 & 1.75 \\ .10 & .20 & .60 & 2.00\end{array}$

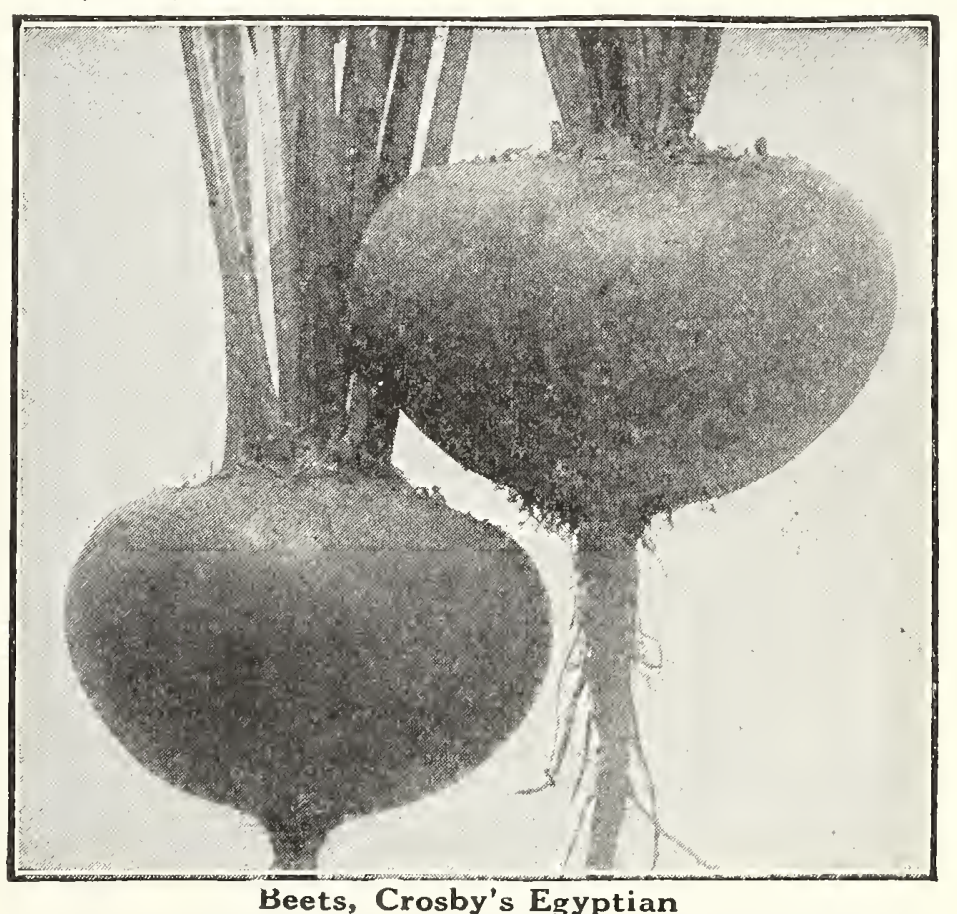

Detroit Dark Red Turnip. Round; skin dark blood red; flesh bright red. Pkt.

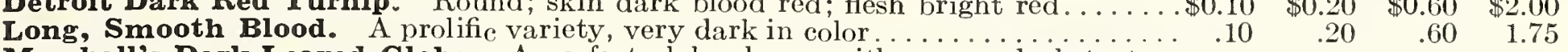

Marshall's Dark Leaved Globe. A perfect globe-shape, with a very dark texture and leaf.

Marshall's Exhibition Globe. Very carefully selected stock. Dark red and the

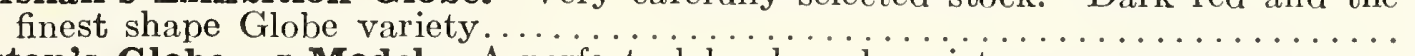

Sutton's Globe, or Model. A perfect globe-shaped variety . . . . . . . . . . . .

Swiss Chard. The roots of this variety are of no value, but the leaves are superior

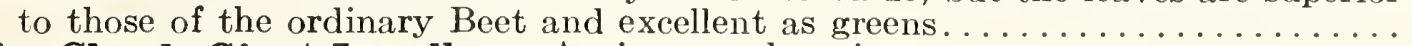

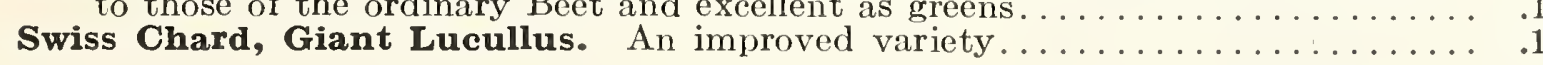

$\begin{array}{rrrr}.10 & .30 & .75 & 2.50 \\ & & & \\ .10 & .30 & .75 & 2.50 \\ .10 & .30 & .75 & 2.50 \\ & & & \\ .10 & .20 & .50 & 1.50 \\ .10 & .20 & .60 & 2.00\end{array}$

\section{MANGEL-WURZEL AND SUGAR BEET}

Sow 6 to 8 pounds per acre.

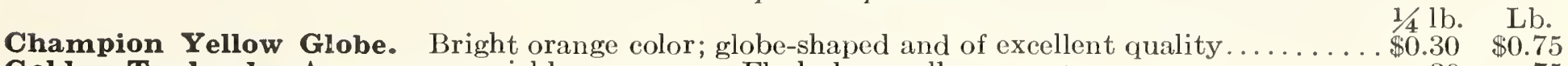

Golden Tankard. An enormous yielder per acre. Flesh deep yellow ................. $\quad .30 \quad .75$

Mammoth Long Red. The largest and heaviest cropper of all the Mangels.......................75 


\section{BROCCOLI}

(For Cultural Directions, see Cauliflower). White Cape. Heads compact Pkt. Oz. 1/4 lb. and of a creamy white color.. $\$ 0.10 \quad \$ 0.75 \quad \$ 2.50$

\section{BRUSSELS SPROUTS}

One ounce will produce about 2000 plants.

Sow in May in shallow drills 1 inch deep and 12 inches apart; transplant in July. A very hardy, delicious vegetable which should find a place in every garden; greatly improved by hard frosts.

Marshall's Exhibition. Pkt. $1 / 2 \mathrm{oz} . \mathrm{Oz} \quad 1 / 4 \mathrm{lb}$. The finest variety of all

of all the Brussel's

Sprouts. Very large

and of supcrior quality.\$0.10 $\$ 0.50 \quad \$ 1.00 \quad \$ 3.00$

Long Island Improved. Solid, round sprouts of the best quality..... $\quad .10 \quad .30 \quad .60 \quad 2.00$

Improved Dwarf. A dwarf variety, producing numerous heads...

$.10 \quad .30 \quad .60 \quad 2.00$

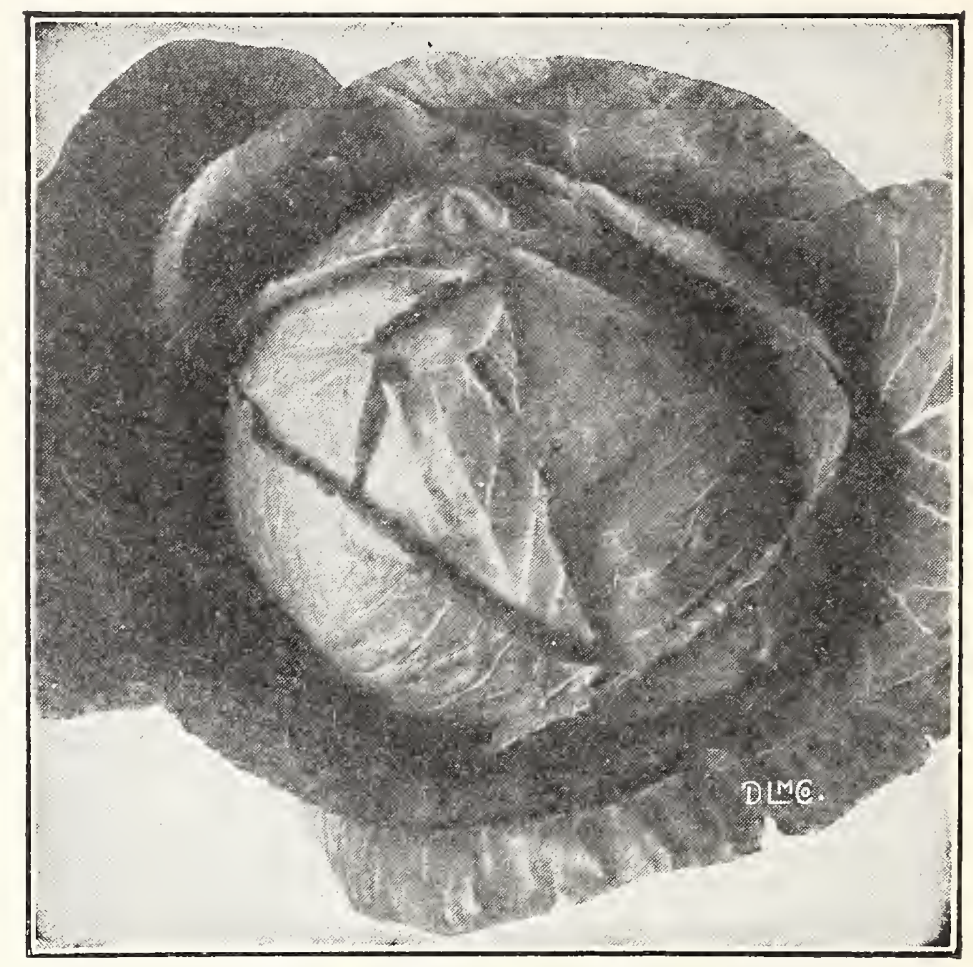

Cabbage, Copenhagen Market

\section{CABBAGE}

One ounce will produce 3000 plants.

For early use sow the seeds in hotbeds in February or March. Transplant as soon as the ground can be worked, in rows 2 feet apart, and the plants 18 inches apart in the rows. For late or Winter use sow the seed in May.

Marshall's Baby Head. Small, perfectly round, solid heads; fine for forcing or

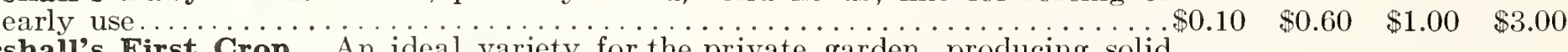

Marshall's First Crop. An ideal variety for the private garden, producing solid pointed heads earlier than any other variety..........

Autumn King. One of the finest late varieties....... Chinese, or Celery (Pe Tsai). Resembling a Cos Lettuce; the outer leaves are $\begin{array}{rrr}.5 \\ \text { used as a salad or cooked.... }\end{array}$

Copenhagen Market. Very early, round head; short stemmed.............10

Danish Ball Head. Very round; solid Winter sort. A fine shipper..............

Early Flat Dutch. A second early Cabbage; large, solid heads .............. 10

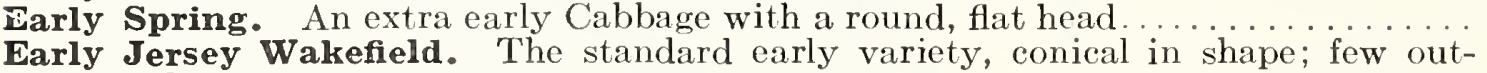

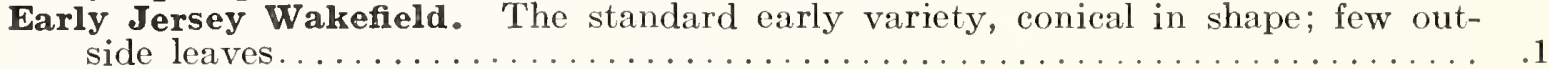

Early Winnigstadt. Conical shape; quality very good.

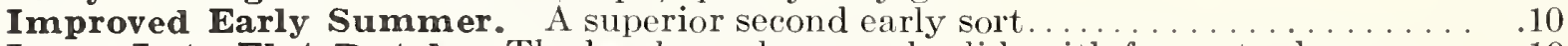

Large Late Flat Dutch. The heads are large and solid, with few outer leaves.... $\quad .10$

Large Early York. A fine early sort; solid heads and of good size .............. $\quad .10$

Late American Drumhead. One of the largest and best keeping varieties. Fine keeper $\quad .10$

Succession. A week later than Early Summer. Large, solid heads.

\section{SAVOY CABBAGE}

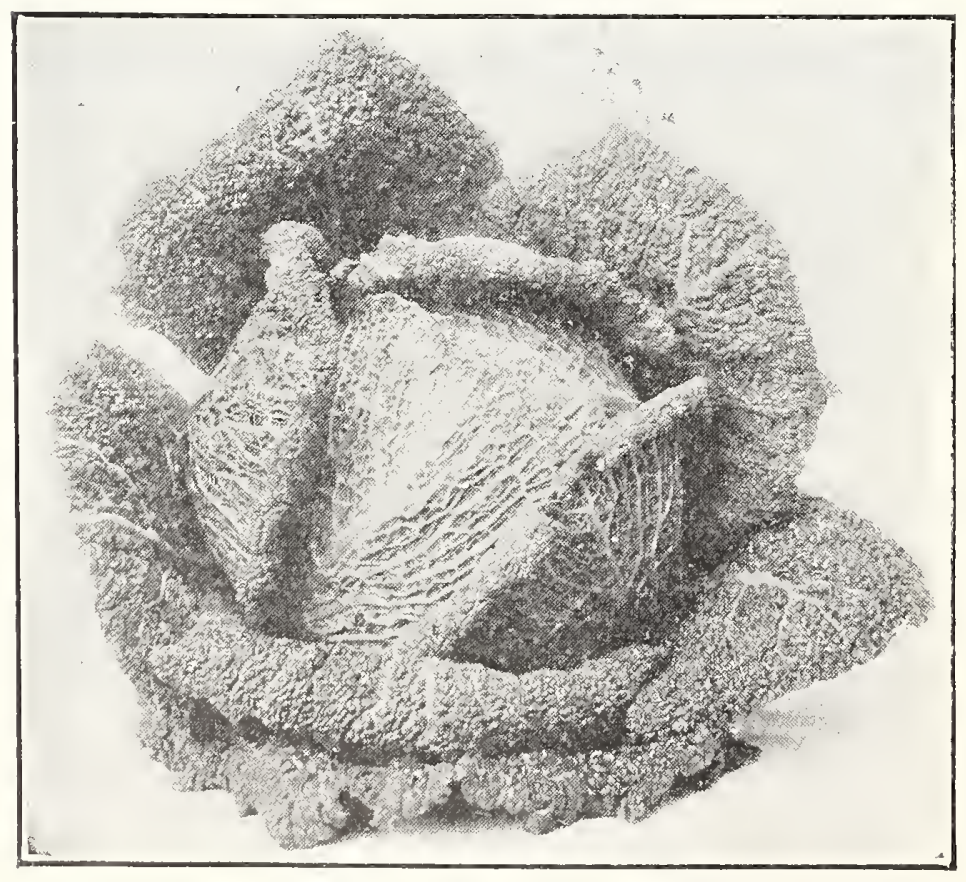

Cabbage, Exhibition Savoy
Marshall's Exhibition. Pkt. 1/2 oz. Oz. 1/4 lb. The heads are of medium size and mature early, the leaves deeply embossed and distinctly ornamental. The best variety for private use............ A

$\$ 0.10 \quad \$ 0.40 \quad \$ 0.75 \quad \$ 2.50$

Perfection Drumhead. A
large, improved strain. Strong and vigorous grower........... . . 10

$10 \quad .25$

\section{RED CABBAGE}

Red Haco. The earliest of all red cabbages. Round, solid uniform heads.

Mammoth Rock Red. The largest red Cab-

Red Stonehead. Medium size, but very solicl 


\section{CARDOON}

Large Solid. Grows about 4 feet high; leaves nearly free from spines. Pkt. 10c., oz. 35c.

\section{CARROTS}

One ounce will sow 200 feet of row

For early crops sow as soon as the ground can be worked, and for later crops from the beginning until the end of May, in rows 15 inches apart and $1 / 2$ inch deep. Thin out the young plants to 5 inches and keep the surface open by frequent use of the hoe.

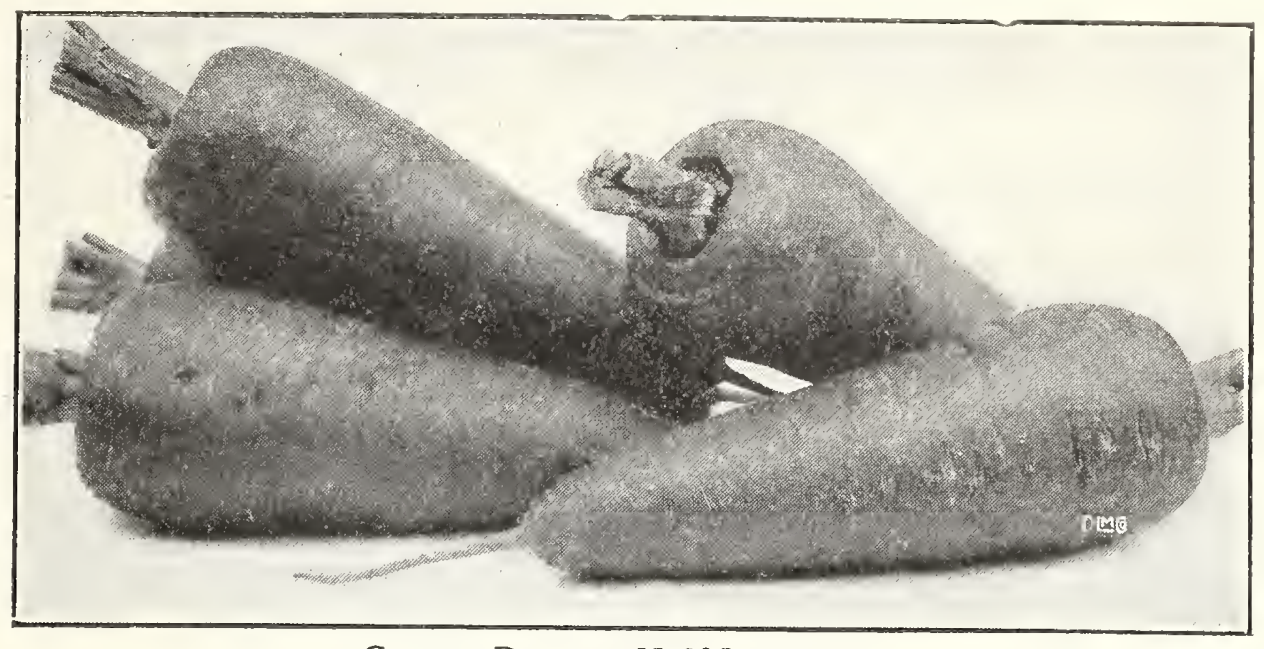

Carrot, Danvers Half Long

Early French Forcing. Tender and fine, best for early crops and frames.

Early Scarlet Horn. Very thick roots; fine for frames

Chantenay Half Long Stump. Style of Nantes, broader shoulder

Danvers Half Long. Large; of good quality and productive. One of the most popular sorts...

Half Long Stump-rooted, Nantes strain. Very popular.

Long Orange. For garden and field crops this is the best variety.

Marshall's Exhibition. A superb intermediate variety; skin clear, bright red color. $\quad .10$

Marshall's Intermediate. Fine exhibition variety

Oxheart (Guerande). Very thick and short, very sweet.

White Belgium. Very large; for stock.

$\begin{array}{rrrrr} & \text { Pkt. } & \text { Oz. } & \text { 1/4 Ib. } & \text { Lb. } \\ . \$ 0.10 & \$ 0.50 & \$ 1.50 & \$ 4.00 \\ .10 & .25 & .75 & 2.50 \\ .10 & .25 & .70 & 2.25 \\ . & & & & \\ . & .10 & .25 & .70 & 2.25 \\ .10 & .25 & .70 & 2.25 \\ . & .10 & .25 & .70 & 2.25 \\ . & .10 & .30 & 1.00 & 3.00 \\ . & .10 & .30 & 1.00 & 3.00 \\ . & .10 & .25 & .70 & 2.25 \\ .10 & .20 & .60 & 2.00\end{array}$

\section{CAULIFLOWER}

One ounce of seed produces about 3000 plants

By sowing the early varieties in a hotbed in February or March, or later in a coldframe, fine heads can be obtained quite early. When large enough transplant, making the rows about $21 / 2$ feet apart and 18 inches between the plants. Transplanting should be done in moist weather.

Marshall's First and Best. Produces large and fine grained heads of snowy whiteness. It Pkt. 1/4 oz. Oz.

is the earliest and most solid heading variety grown $\ldots \ldots \ldots \ldots \ldots \ldots \ldots \ldots$

Earliest Dwarf Erfurt. The best and earliest for forcing under glass; very dwarf and com-

pact, with short stem and small leaves.

Marshall's Extra Early Snowball. One of the best for forcing or open ground

Dry Weather. This variety is especially adapted for long, dry seasons.

Extra Early Paris. Heads of medium size; first-class.

$0.50 \$ 3.00 \$ 10.00$

Autumn Giant. Vigorous in growth and very large: late...

Algiers. An extra fine, late variety; suitable for market and sure to head. .

Market Garden. A large variety of the Erfurt type, solid white heads. A popular late sort.

$\begin{array}{rrr}.50 & 2.50 & 8.00 \\ .25 & 1.50 & 5.00 \\ .25 & 1.50 & 5.50 \\ .10 & .60 & 2.00 \\ .20 & .75 & 2.50 \\ .10 & .60 & 2.00 \\ .10 & .75 & 2.50\end{array}$

\section{GELERY}

One ounce will sow about 300 feet of row and produce about 5000 plants.

Sow in the open border early in April, in rich ground. When the plants are 3 inches high transplant 4 inches apart into temporary beds of soft, rich soil until they acquire sufficient strength for planting out. Plant in rows 3 feet apart and set 8 inches apart in the rows. About the middle of August earthing up is necessary for blanching and whitening of that which is wanted for early use.

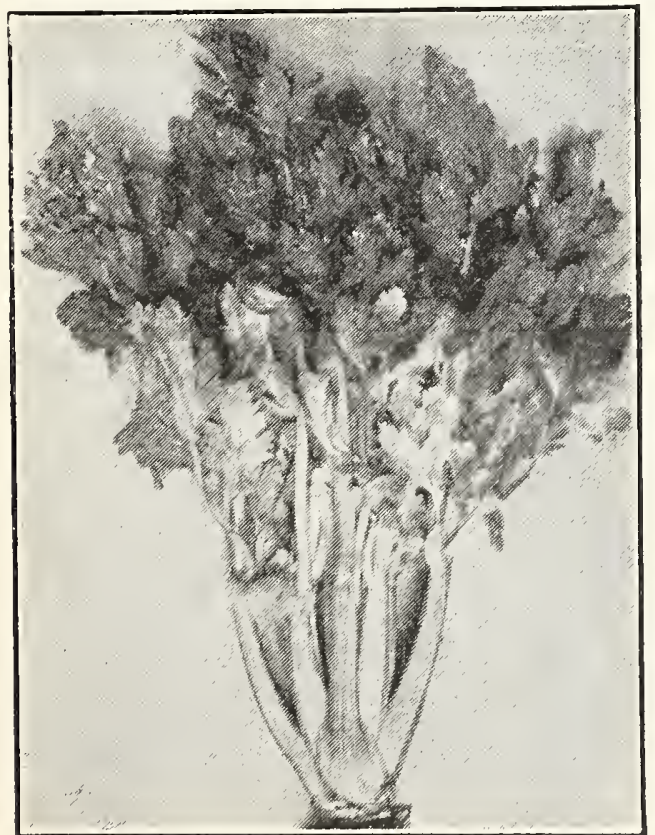

Celery, Golden Dwarf
Easy Blanching. Blanches very easily, medium dwarf, good flavor and a fine keeper..............

Emperor or Fordhook. A dwarf and stocky variety with large, light yellow heart; very crisp and

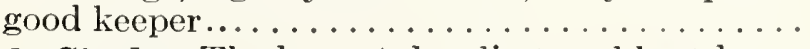

Fin de Siecle. The largest, hardiest and best keep-

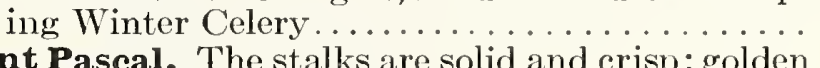

Giant Pascal. The stalks are solid and crisp; golden yellow heart. . ............. . . . . . . riety; crisp, solid; fine flavor. . .............

Golden Self-Blanching. French grown; crisp, tender and of fine flavor.

Market Red. Large and very solid. A fine table variety.

Marshall's Golden Plume. Two to three weeks earlier than any other variety. Blanches easily, solid, rapid growing heart; sweet, crisp and tender.

Marshall's White Plume. A valuable early variety. Requires very little blanching. ........

Winter Queen or Schumacher. Very large; solid green, Winter variety; blanches well.

Celery Seed. Used in kitchens for flavoring soups.
Pkt. 1/2 oz Oz.

$0.15 \$ 0.60 \$ 1.00$

$\begin{array}{lll}.15 & .60 & 1.00\end{array}$

$\begin{array}{lll}.10 & .25 & .40\end{array}$

$\begin{array}{lll}.10 & .25 & .40\end{array}$

$\begin{array}{lll}10 & .25 & .40\end{array}$

$\begin{array}{lll}.25 & .60 \quad 1.00\end{array}$

$\begin{array}{lll}.10 & .35 & .60\end{array}$

$\begin{array}{lll}.25 & 3.00 & 5.50\end{array}$

$\begin{array}{lll}.10 & .35 & .60\end{array}$

$\begin{array}{lll}.10 & .30 & .50\end{array}$

20 


\section{CELERIAC, or TURNIP-ROOTED}

Grown mostly for its bulbous roots, which may be stored like Beets for Winter use.

Giant Prague. The finest variety. Very large roots Pkt. 1/2 oz. Oz. which are almost round..................\$0.10 $\$ \$ 0.25 \quad \$ 0.40$

\section{CHER VIL}

The Curled Chervil is cultivated like Parsley and used for garnishing and flavoring soups and salads.

Curled Chervil. The young leaves are used for flavoring

soups and salads.

\section{GHICORY}

Large-Rooted Magdeburg. Used to mix with or as a

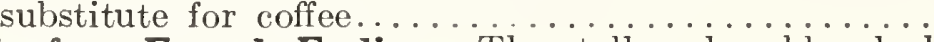

Witloof, or French Endive. The stalks when blanched are used for salad.....

\section{COLLARDS}

Sow Seeds, as for Cabbage, in June, July and August, for succession. Transplant when a month old in rows a foot apart each way, and hoe often. Georgia. Cabbage greens used as a substitute for Cabbage. Pkt. 10c. oz. $20 \mathrm{c} ., 1 / 4$ lb. $45 \mathrm{c}$.

\section{CORN SALAD, OR FETTICUS}

\section{One ounce will sow 150 feet of drill.}

Sow in September in drills 8 inches apart, covering the seeds lightly, and protect from frost by light covering of hay and litter. The seed may be sown in Spring.

Large-Seeded. The most popular variety grown. Pkt. 10c., oz. 25c., 1/4 lb. $75 \mathrm{c} .$, lb. $\$ 2.00$.

\section{CORN, SWEET}

One quart will plant 200 hills.

Plant in hills 3 feet apart each way, dropping five or six kernels in each hill, or in rows 3 feet apart, and the plants thinned out to 8 or 9 inches in the row. From May until the middle of July a succession planting can be made every two or three weeks, and a continued supply can be had until frost kills the plants.

\section{EXTRA EARLY}

Marshall's Earliest of All. One of the earliest Sweet Corns. Ears 6 to 7 inches

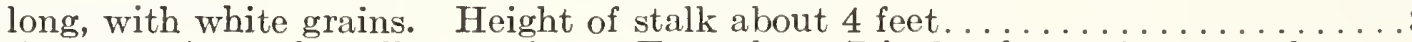

Charlevoix. An early yellow variety. Ears about 7 inches long, eight-rowed; very

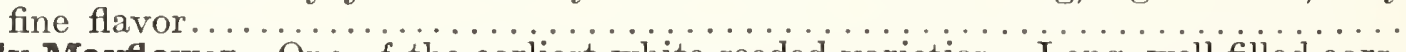

Early Mayflower. One of the earliest white-seeded varieties. Long, well filled ears. .15

Early Minnesota. One of the earliest varieties grown. Dwarf; ears small......... .15

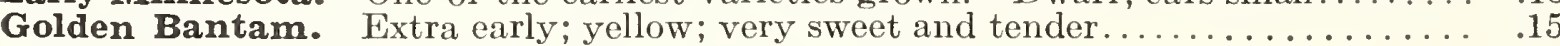

Golden Rod. Very early, golden grains and sweet flavor. . . . . . . . . . . . . .15

Howling Mob. An early variety of large size ears: white, sweet grains......... .15

Mammoth White Cory. Ears double the size of the old Cory.

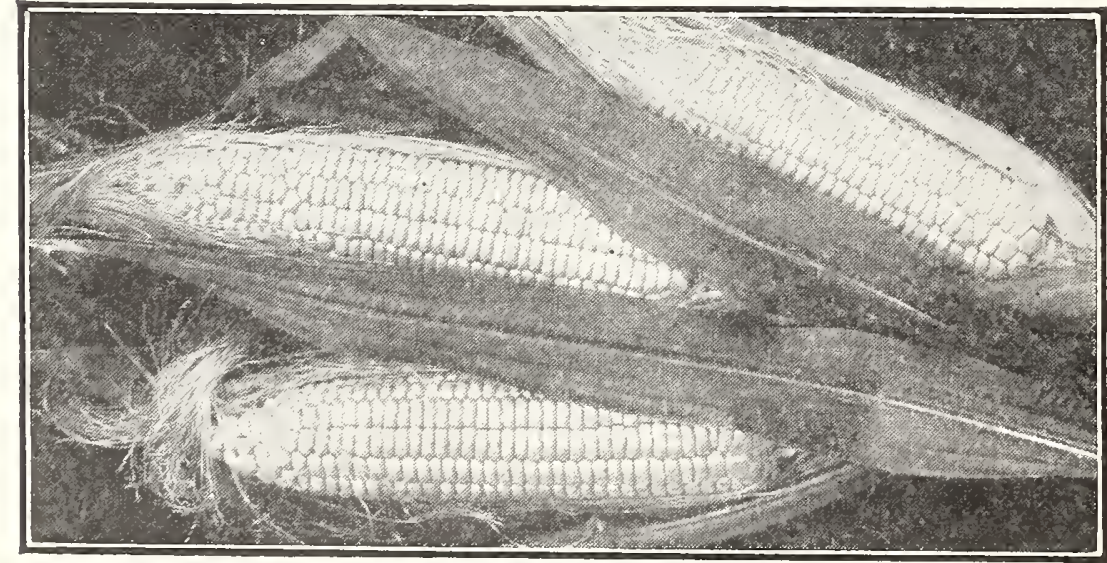

Corn, Golden Bantam
SECOND EARLY

Crosby's Early. One of the standard early sorts....

Qt. 4 qts.

$\$ 0.30$

$\$ 0.60 \$ 2.00$

\section{.30}

.25

.25

.30

.30
.30

.30
.25

$.60 \quad 2.00$

$.50 \quad 1.75$

$.50 \quad 1.75$

$60 \quad 2.00$

$60 \quad 2.00$

$60 \quad 2.00$

$.50 \quad 1.75$

Early Champion. Large; white cob; very sweet.

Early Evergreen. Ripens about 10 days earlier than Stowell's Evergreen .........

Early Mammoth. Ten days earlier than Mammoth Metropolitan. Large, handsome ears of fine quality.......

\section{GENERAL AND LATE}

Black Mexican. The sweetest and most delicious variety grown ..............

Country. Gentleman. Ears medium size; deep grains in irregular rows on cob and deliciously sweet.

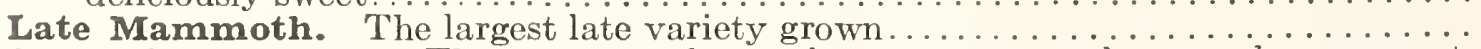

Stowell's Evergreen. The most popular variety grown; ears large and very sweet.

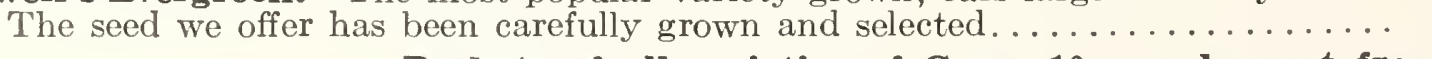

Packets of all varieties of Corn, 10c. each, post free. 


\section{CRESS, OR PEPPERGRASS}

One ounce will sow 150 fect of drill.

A popular salad which should be sown early in the Spring very thickly in shallow drills and at short intervals for succession, as it soon runs to seed.

Extra Curled. The best variety grown; leaves are beautifully cut and curled; highly Pkt. Oz. 1/4 lb. Lb.

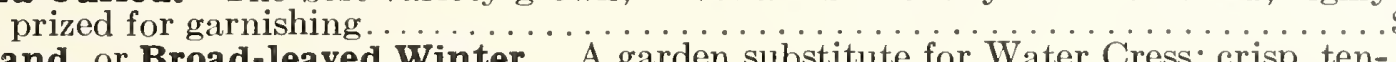

Upland, or Broad-leaved Winter. A garden substitute for Water Cress; crisp, tender and perfectly hardy.

True Water Cress. Water Cress requires a stream of running water, ditch or pond, in whych it will grow without care, except at first keeping weeds from interfering with it.

$\$ 0.05 \$ 0.15 \quad \$ 0.50 \quad \$ 1.50$

$.10 \quad .15 \quad .50 \quad 1.50$

\section{CUCUMBERS}

One ounce to 60 hills, 2 to 3 pounds to one acre.

For very early use seed may be started in heat and the plants set out in May. Pieces of inverted sod are an excellent medium for starting and growing early $\mathrm{Cu}$ cumber plants, as they can readily be lifted from the hotbed to the garden without disturbing the young plants growing upon them. For main crop plant in hills 4 feet apart at the end of May. Keep the young plants safe from the striped bug by dusting with dry plaster or powdered Hellebore. Leave four strong plants to each hill.

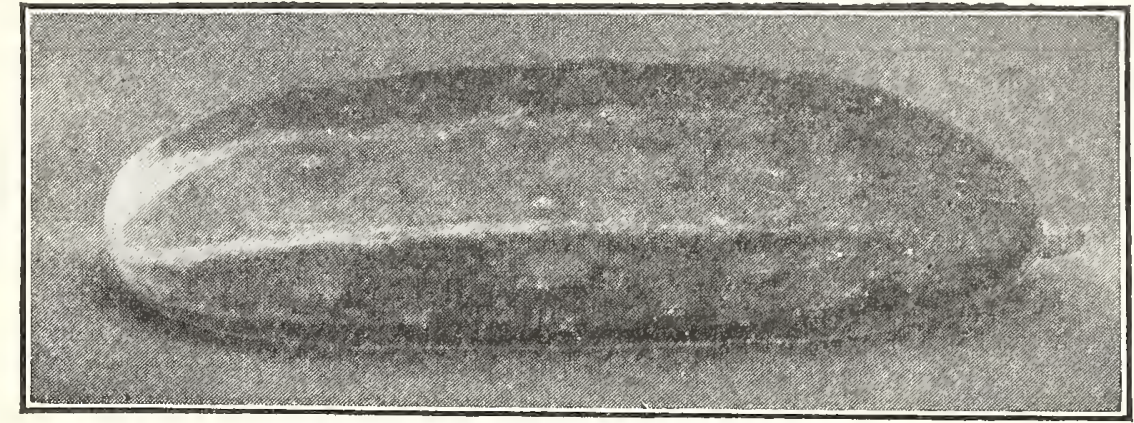

Cucumber, Improved White Spine

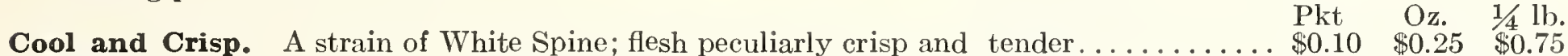

Davis' Perfect. An excellent variety both for outdoors and foreing purposes.

Early Fortune. Very dark green skin, flesh thick, seed cavity small and excellent quality; for table use or pickles.

Everbearing. Valauable as a green pickler.

Extra Long White Spine. Much longer than ordinary White Spine; very prolific........

Fordhook Famous. The largest and most handsome garden variety. The skin is a bright green.

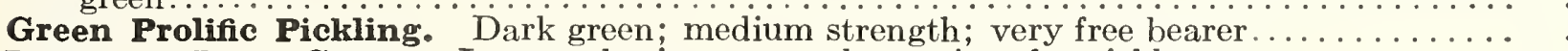

Improved Long Green. Long and crisp; a popular variety for pickles................. dark green color and flesh crisp and excellent.

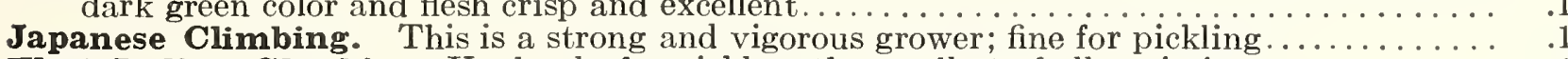

West Indian Gherkin. Used only for pickles; the smallest of all varieties.

$.10 \quad .25 \quad .70$

$.10 \quad .25 \quad .75$

$.10 \quad .25 \quad .70$

$.10 \quad .25 \quad .70$

$\begin{array}{lll}.10 \quad .25 & .75\end{array}$

$\begin{array}{lll}10 & .25 & .75\end{array}$

$\begin{array}{lll}.10 & .25 & .70\end{array}$

$\begin{array}{lll}.10 & .25 & .70\end{array}$

$\begin{array}{lll}10 & .25 & .75\end{array}$

ENGLiSh Foraing GUGUMbers

Covent Garden Favorite . . . . . . . . . . . . Pkt. $\$ 0.50$

Lockie's Perfection, . . . . . . . . . . . Pkt. .50

Sutton's Matchless, ................. Pkt. $\quad .50$

Telegraph Improved................. $\quad .50$

\section{EGG PLANT}

One ounce will produce about 2000 plants.

The Egg Plant will thrive well in good garden soil. The seed should be sown in hotbed or warm greenhouse in March or April, and when about an inch high put in 2-inch pots. Plant about June 1 st, $21 / 2$ feet apart. If no hotbed is at hand they can be grown in any light room when the temperature will average 75 degrees.

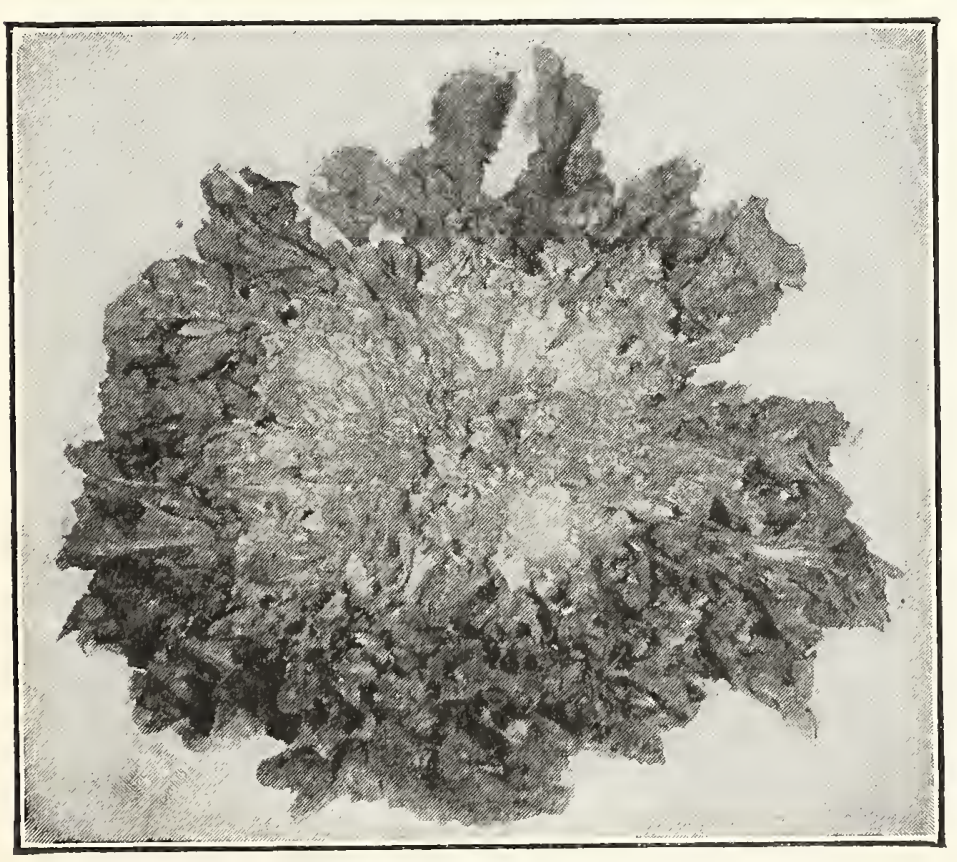

Endive, Broad-leaved
Black Beauty. As large as Pkt. 1/2 oz. Oz. 1/4 lb. New York Improved

but ten days earlier. . $\$ 0.10 \quad \$ 0.40 \quad \$ 0.80 \quad \$ 2.50$

Long Purple. Fruit longer and smaller than the

above sort; hardy; pro-

New York Improved.

$\begin{array}{llll}.10 \quad .40 & .75 & 2.50\end{array}$ Purple; the best variety; very large, oval,

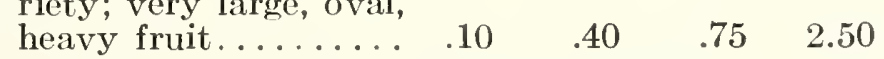

ENDIVE One ounce of seed for

One of our best salad plants. For a first crop sow about the middle of April; for succession small sowings may be made every month till August, when the main planting is made. Set out the plants 1 foot apart in rows and when well grown blanch by folding the leaves. Broad-leaved (Escarolle). Leaves Pkt. Oz. 1/4 lb. long and broad; thick and suc-

Green Curled... Härdy, finely

$\$ 0.10 \$ 0.35 \$ 1.00$

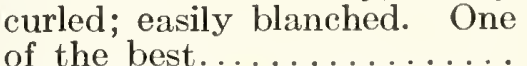
of the best. Bianches rapidly: $\begin{array}{llll}\text { excellent and very tender.... } & .10 & .35 & 1.00\end{array}$ 


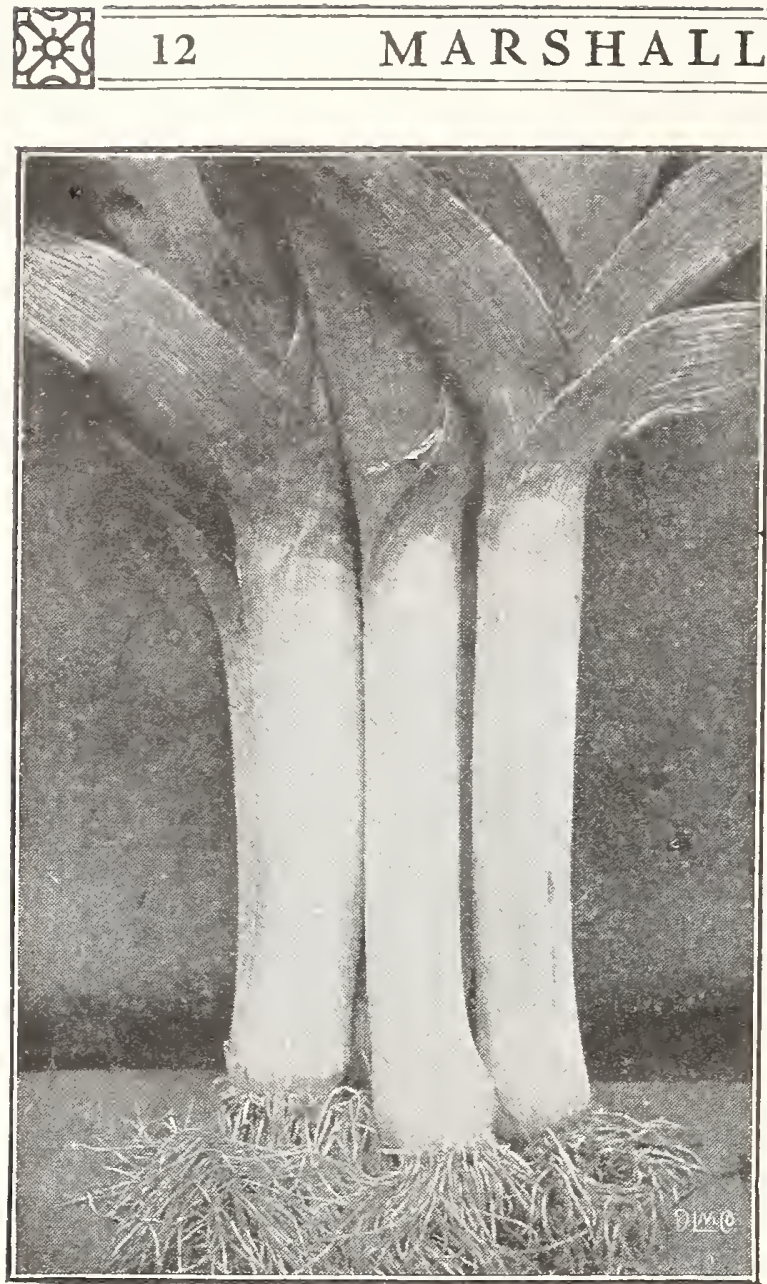

Leek, Marshall's Giant

\section{KALE, OR BORECOLE}

Sow about the middle of April in prepared beds, covering thinly and evenly; plant out in June, following the directions recommended for cultivating Caḅbage.

Curled Dwarf Green Scotch. Very dwarf and spreading; best strain .......... \$0.10 $\$ 0.30 \quad \$ 1.00$ Marshall's Exhibition Curled. Closely

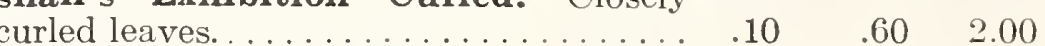

Curled Siberian Improved. Uniformly dwarf; green curled; hardy .......... $\quad .10 \quad .30 \quad 1.00$

\section{KOHL-RABI}

One ounce will sow 300 feet of row.

Cultivate the same as the Cabbage, but in hoeing be careful not to throw earth into the heart of the plant or the bulb cannot be formed.

Early White Vienna. Very early Pkt. 1/2 oz. Oz. 1/4 lb. and should be used before being fully grown. Flesh white with

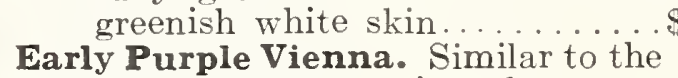
$\$ 0.10 \quad \$ 0.25 \quad \$ 0.50 \quad \$ 1.50$ preceding, except in color... . $\begin{array}{llll}.10 & .25 & .50 & 1.50\end{array}$

\section{LEEK}

One ounce will sow 200 feet of drill.

The leak is very hardy and easily cultivated; it succeeds best in light but well enriched soil. Sow as early in the Spring as practicable, in drills 1 inch deep and 1 foot apart. When 6 to 8 inches high transplant in rows 10 inches apart each way, as deep as possible, that the neck, being covered, may be blanched.

Marshall's Giant. The largest and best Leek for exhibition. Highly recommended as the Pkt. Oz. 1/4 lb. choicest variety in cultivation, of a mild and delicious flavor. . . . . . . . . . . . \$0.10 $\$ \$ \$ 0.80 \quad \$ 2.50$ Large American Flag. The most desirable for market or family use . . . . . . . . . . . . $\quad .10 \quad .30 \quad 1.00$ Musselburgh, or Carentan. A very large variety of superior quality . . . . . . . . . . . . $\quad .10 \quad .30 \quad 1.00$

\section{LETTUCE $\begin{gathered}\text { One ounce will sow } \\ \text { and }\end{gathered}$}

Sow in the open ground as early as possible, barely covering the seed. If the hotbed is used let it be started quite early. Give but little heat and plenty of water and air on fine days. Let plants in the beds be about 4 inches apart. As they increase in size thin them out or they will become weak. Plant for late use in a cool, partially shaded place in rich soil.

\section{CURLED, or LOOSE-LEAVED VARIETIES}

Plkt. Oz. $1 / 4 \mathrm{lb}$.

Black-Seeded Simpson. Nearly double the size of Curled Simpson . . . . . . . . . $\$ 0.10 \quad \$ 0.30 \quad \$ 1.00$

Early Curled Simpson. One of the earliest and best for market. . . . . . . . . . . . . . . . . $\quad .10 \quad \begin{array}{lll} & .30 & 1.00\end{array}$

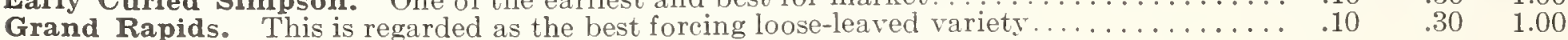

\section{CABBAGE, or HEADING VARIETIES}

All Heart. A beautiful yellowish green head Lettuce. Withstands intense heat. . . . . $\quad .10 \quad .35 \quad 1.00$ All Seasons. Large, handsome, extremely solid head; color a light grayish green....... $\quad .10 \quad .30 \quad 1.00$

Boston Market (White Seed Pkt. Oz. 1/4 lb. Tennisball). Solid, crisp and compact. One of the best for forcing............\$ \$0.10 \$0.40\$1.50

Big Boston. Fine for forcing in coldframes or for open ground

$.10 \quad .40 \quad 1.50$

Deacon. A splendid variety for standing the Summer heat; large, solid head... .

Giant Crystal Head, or Iceberg. Large, solid; outside leaves bright green, inside white.

Golden Queen. A good forcing variety of a golden yellow color; heads solid.

Hanson Improved. Heads large, hearts quickly, and stands the Summer well...

Marshall's Royal Summer. A large butter head, with thick leaves, dark green tinged and spotted brown. The inside of head is a rich yellow.................

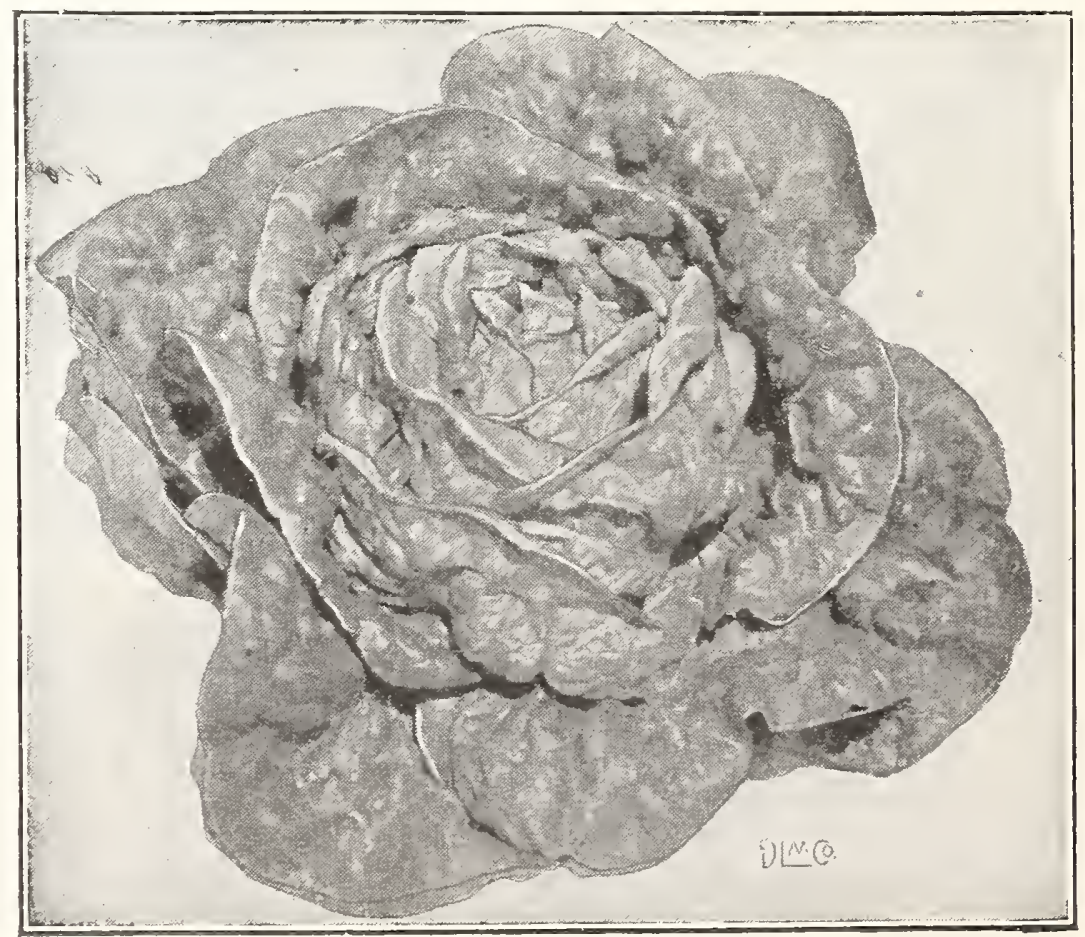

Lettuce, Marshall's Royal Summer 
LETTUCE-Continued. Pkt. Oz. $1 / 4 \mathrm{lb}$.

Marshall's Matchless. A cross between a head variety and the Cos type; it has numerous loose leaves which form into a long, loose head. Very sweet and tender, a fine variety for Summer use and early frames.............\$0.10

May King. Extra large, solid heads; light green outside, with clear yellow heart; very tender and of fine flavor; splendid forcer............

Mignonette. Distinct russet colored; very solid and compact.

$.35 \quad 1.00$

$.10 \quad .35 \quad 1.00$

New York, or Wonderful. Large solid heads; inside very white......

Tennis Ball Black Seeded) or Salamander. A very distinct compact head with few outer leaves...........

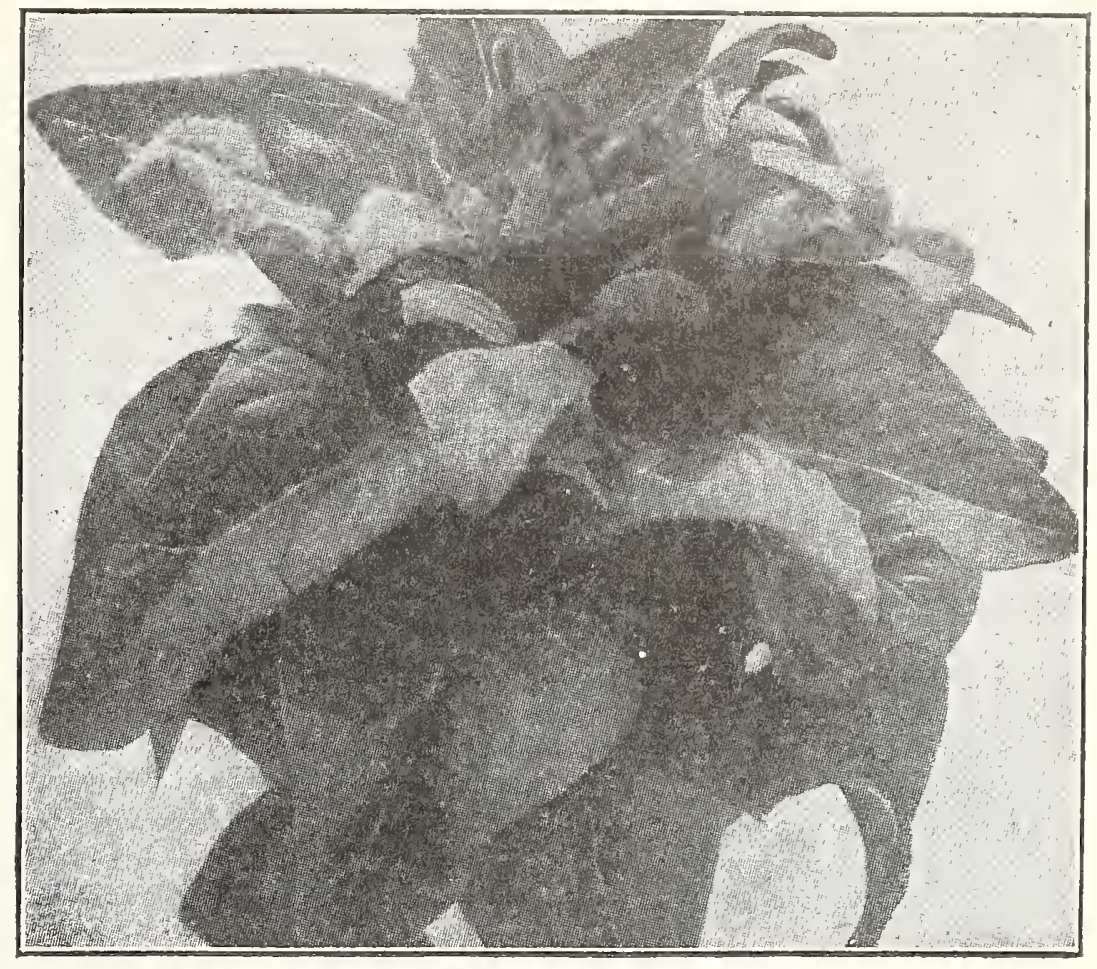

Lettuce, Marshall's Matchless

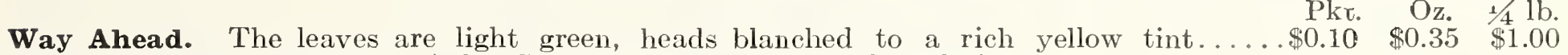
White Summer Cabbage. A fine Summer variety; heads of good size . . . . . . . . . . . . . $\quad .10 \quad \begin{array}{ll}.35 & 1.00\end{array}$

\section{ROMAINE, or COS VARIETIES}

These are distinct from the ordinary Lettuce, and much liked on account of their crisp, tender quality. They produce long, narrow leaves, blanched by drawing in the outer leaves and tying. $\quad \mathrm{Pkt}$. Oz. 1/4 lb. Eclipse Cos. A perfectly distinct variety. It is the dwarfest Cos Lettuce... . . . . . . . $\$ 0.10 \quad \$ 0.60 \quad \$ 2.00$ Paris White, or Trianon Cos, Romaine. One of the finest varieties for Summer use.... $\quad .10 \quad .35 \quad 1.00$

\section{MELON, MUSK One ounce will plant}

After all danger of frost is over and the ground has become warm and dry, plant in hills 4 to 6 feet apart each way, 6 to 12 seeds to a hill. When up and all danger of insects has passed, pull out all but three plants. Cultivate until the vines cover the ground.

Emerald Gem. Small, early; dark green skin, orange flesh; very sweet.

Field's Daisy. Rich orange flesh resembling Emerald Gem but is larger, with thicker flesh and better flavor

Fordhook. The flesh is very thick, of a deep salmon color.

Hackensack. Large, round and good quality.

Harute. Very large, beautifully netted. Flesh solid and pale yellow when ripe

Honey Dew. Large, round to oval in shape, skin smooth, hard and nearly white, flesh light green. Excellent flavor.

Jenny Lind. Small, green fleshed; very early; good quality.

Long Island Beauty. The earliest and finest in quality; green flesh.

Marshall's Surprise. A very delicious, large salmon fleshed Melon. Shape oblong and rounded at the ends.

Marshall's Matchless. A large luscious Melon. Flesh orange scarlet color, very thick.

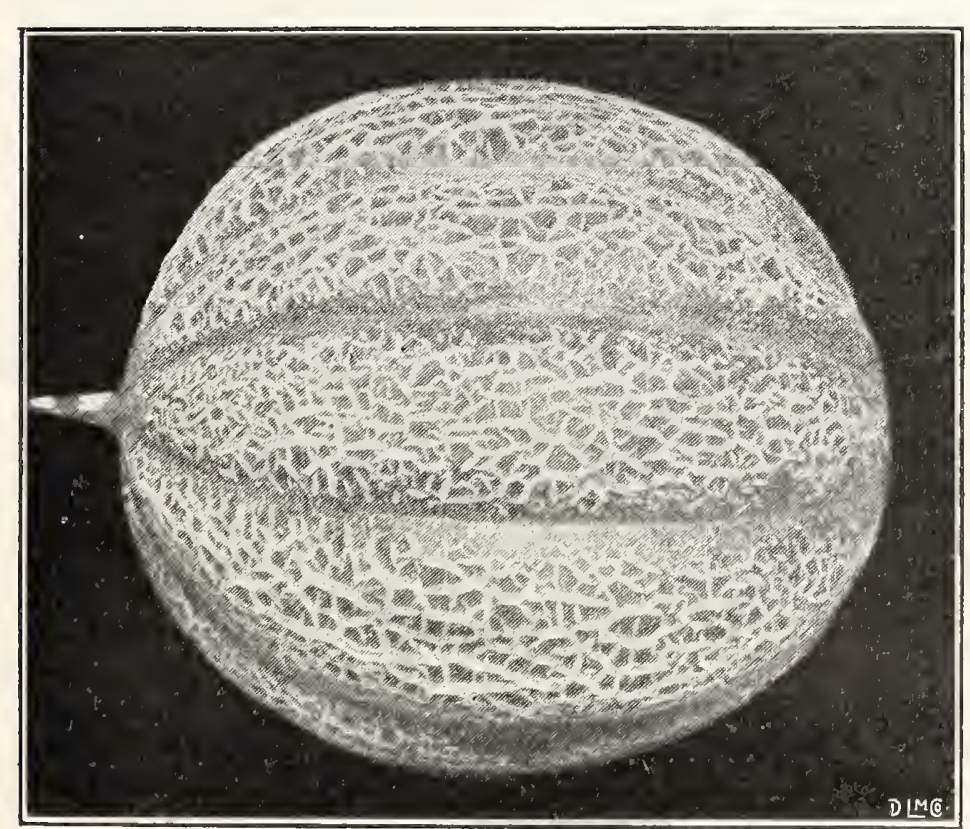

Muskmelon, Osage
Montreal Market. Large, round

Pkt. Oz. 1/4 lb.

$\$ 0.10 \$ 0.30 \$ \$ 1.00$

$\begin{array}{lll}.10 & .40 & 1.25\end{array}$

$\begin{array}{lll}.10 & .30 & 1.00 \\ .10 & .30 & 1.00\end{array}$

$\begin{array}{lll}.10 & .30 & 1.00\end{array}$

$\begin{array}{lll}.25 & .75 & 2.50\end{array}$

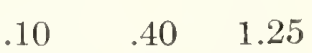

$\begin{array}{lll}.10 & .30 & 1.00\end{array}$

$.10 \quad .30 \quad 1.00$

$\begin{array}{lll}.10 & .40 \quad 1.25\end{array}$

$25-2.00$

$\begin{array}{lll}10 & .30 & 1.00\end{array}$ green; late.

Osage, or Miller's Cream. A large oval, orange-salmon flesh Melon of superior quality

Paul Rose. Oval; rich orange flesh; very sweet.

Rocky Ford. Very sweet and fine flavored; oblong; light green flesh.

Tip Top. A slightly oval shape and yellow-flesh variety; fine flavor.

\section{ENGLISH FORCING MELONS}

Blenheim Orange. Scarlet flesh..........\$0.50

Diamond Jubilee. Greenish white flesh..... . .50

King George. Scarlet flesh . . . . . . . . . .50

Royal Sovereign. Golden skin, white flesh .... . .50

Sutton's A1. Scarlet flesh ............ . .50

Superlative. Scarlet flesh...........,, 50 
MELON, WATER

One ounce will plant about 30 hills.

Plant in hills as directed for Musk Melons, and treat in all respects the same, except that the hills should be 8 to 10 feet apart.

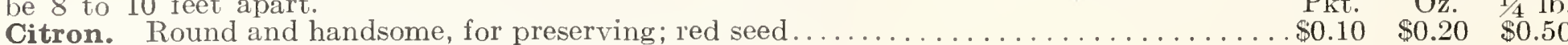

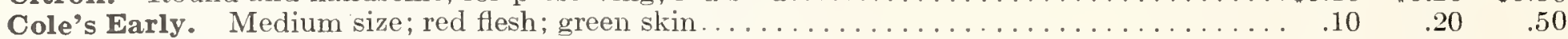

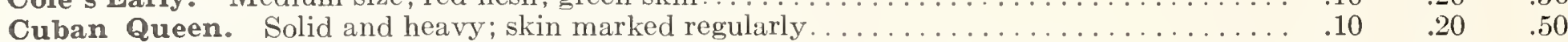

Fordhook, Early. Flesh bright red; very sweet . . . . . . . . . . . . . . . . . . . . . . . . .10 .20 .60

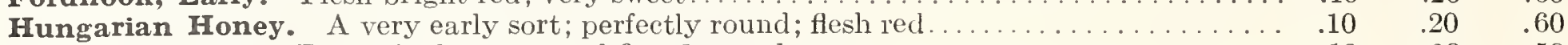

Kleckley Sweets. Exceedingly sweet and fine flavored . . . . . . . . . . . . . . . . . . . . .10 .20 .50

Mountain Sweet. Early, large, oblong, skin dark green, flesh red and sweet. A good $\begin{array}{rr}.10 & .20 \quad .50\end{array}$

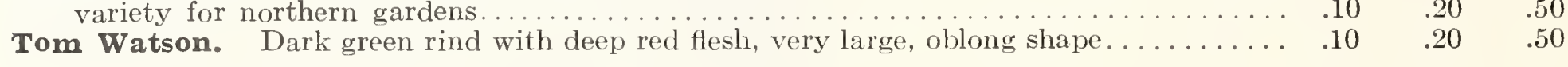

\section{MUSHROOM SPAWN}

Ten pounds will spawn about 10 feet square.

Mushroom beds may be made in a warm, dry cellar, or in any building where the frost does not penetrate, and in the open air during the Summer and Fall months. Having procured the spawn, the next thing to be attended to is to make preparation for the beds. About two or three weeks before the beds are to be made collect a quantity of fresh horse manure without the straw; place it in a heap under cover, and as it heats keep turning it over once or twice a week, until the fiery heat has become exhausted, which will require from ten to fourteen days' time. When the manure is in a condition to be made up lay out your bed, according to your requirements, say 3 feet wide, 10 feet long and from 2 to 3 feet deep; beat it down well with the back of the spade as the process of building goes on. When the

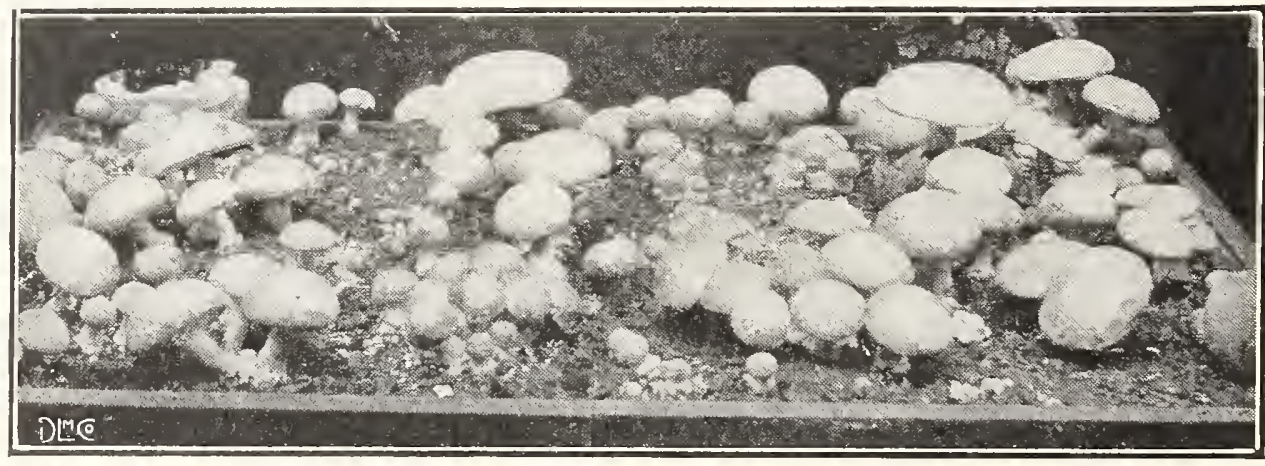

Pure Culture Mushrooms

bed has been made some time, say a week or thereabouts, and the heat sufficiently declined to a temperature of 65 or 75 degrees, the spawn may be put in to it. Break the spawn in pieces 2 inches square, and put them 6 inches apart, all over the bed; then cover the bed with 2 inches of rich soil. If everything goes on well, you may expect Mushrooms in about five or six weeks. When the soil looks dry give a gentle watering with tepid water, using a rose on the watering pot. Good crops of Mushrooms can be obtained by spawning the hotbeds in Spring.

Pure Culture Prolific Direct Bricks. An American-made spawn which produces large crops of large size, deep cream, and excellent quality Mushrooms. Per brick 40c., 10 bricks for $\$ 3.50,50$ bricks $\$ 15.00$.

Bottle Spawn. This spawn is very perishable and can only be kept in cold storage. Orders filled from the factory. Per quart bottle $\$ 1.25,12$ quarts for $\$ 12.00$.

\section{MUSTARD}

One ounce will sow 100 feet of drill.

For early crops the seed may be sown in a hotbed in March, and for general crop at frequent intervals through the Spring, in drills from 8 to 12 inches apart. Pkt. Oz. 1/4 lb. Lb. White London. The best variety for salad . . . . . . . . . . . . . . . . . . . . \$ \$0.10 $\$ 0.20 \quad \$ 0.40 \quad \$ 1.25$

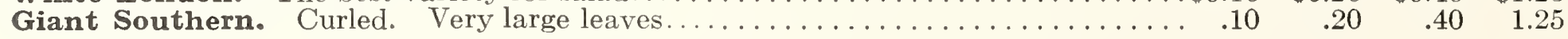

\section{OKRA, OK GUMBO}

One ounce will plant 100 hills

This plant is extensively cultivated for its green pods, which are used in soups and stews, and are very wholesome and nutritious. Sow about the middle of May in drills 3 feet apart and thin out the plants to 1 foot apart.

Plit. Oz. 1/4lb. Lb.

Dwarf Green. Very early; smooth pods..........................\$0.10 $\$ 0.25 \quad \$ 0.50 \quad \$ 1.25$

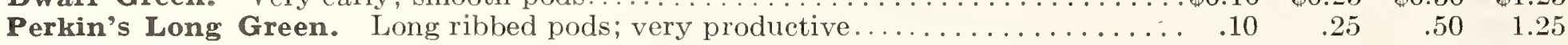

White Velvet. Tender white pods; smooth and velvety in appearance......... $.10 \quad \begin{array}{llll}.25 & .50 & 1.25\end{array}$

\section{ONION SETS}

Three quarts will plant 100 yards of row.

Onion Sets should be planted early in the Spring in rows 12 inches apart, placing the sets 4 inches apart in the row. When raised from sets the Onion can be used in the green state in June, or they will be matured by July.

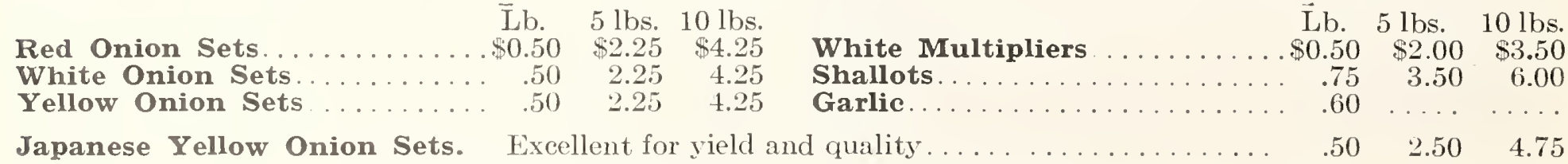




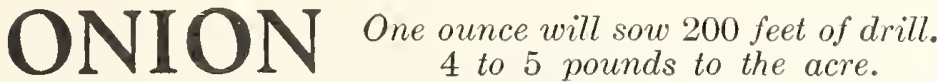

Sow in drills 1 foot apart and cover about one-third of an inch, treading or rolling after sowing so that the hot, dry atmosphere may not destroy the sprouting seed. When 3 inches high thin to 2 inches apart. Stir the ground freely without disturbing the young plants and keep free from weeds.

\section{RED VARIETIES}

Large Red Wethersfield. Pkt. 1/2 oz. Oz. 1/4 lb. Half early and a good keep-

er; large size...........\$0.10\$0.30\$0.60\$2.00

Large Red Globe (Southport Strain). The finest large red sort.................... $10 \quad .40 \quad .70 \quad 2.25$ WHITE VARIETIES

\section{Early White Barletta, or} White Queen. A small $\begin{array}{lllll}\text { white Italian sort; very early } & .10 & .20 & .40 & 1.25\end{array}$ Large White Portugal. The large, flat sort of the New York markets......... White Marshall's Large White Globe (Southport Strain)

Mammoth White Garganus or Silver King. Large, silvery white.............

White Bermuda. A very

White Tripoli. Large, white

Italian variety .......... $\quad .10 \quad .30 \quad .60 \quad 2.00$

\section{YELLOW VARIETIES}

Marshall's Ailsa Craig. The skin is a pale straw color and oval in shape; excellent

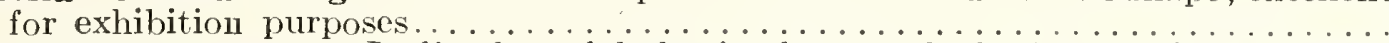

Cranston's Excelsior. Inclined to globular in shape and of a beautiful straw color.

Danvers Yellow. A round, flat, standard sort; early and a good keeper.

Marshall's Giant Gibraltar. Fine exhibition variety.

Marshall's Invincible Giant. An improved type of Ailsa Craig. Pale yellow color. Fine for exhibition purposes.

Yellow Globe Danvers (Southport Strain). Of more globular shape; keeps well.

Yellow Prizetaker. Immense size globe-shaped,

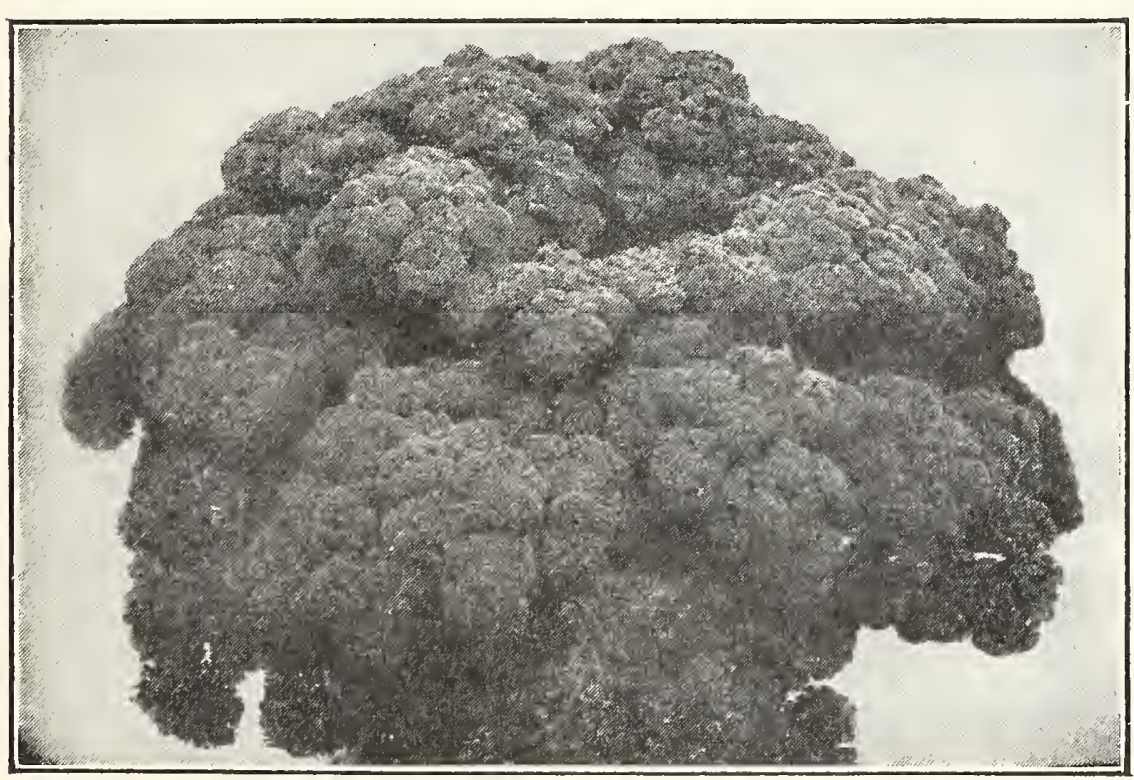

Marshall's Dwarf Perfection Parsley

\section{PARSLEY}

One ounce will sow 200 feet of row.

Sow as early as possible in Spring, first soaking the seed three hours in water; cover lightly, raking the soil fine and level on top. The drills should be about 15 inches apart. The plants appear in two to four weeks. Thir: to 3 inches apart.

\section{Marshall's Dwarf Per-}

fection. A dwarf

and compact Parsley

of bright green color, Pkt. Oz. $\quad 1 / 4 \mathrm{Ib}$. exquisitely curled. . \$0.10 $\$ 0.35 \quad \$ 1.00$

\section{Marshall's Crested}

Gem. Fine closely

cut foliage with dwarf

compact habit.

$.50 \quad 1.50$

Extra Double, or Moss Curled. A beautiful

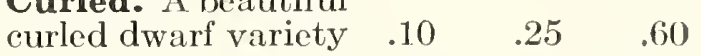

Tuxnip Rooted. Grown for its roots which are used in flavoring soups . . . . . . . . . . $\quad .10 \quad .25 \quad .60$ Plain. A plain-leaved variety; fine for flavoring.

\section{PARSNIP One ounce will sow}

Sow Parsnip seed as early in the Spring as the weather will permit, in drills from 15 to 18 inches apart, covering with fine soil to the depth of half an inch. The soil should be rich and deep; manured if possible, the previous Autumn. Thin out the young plants to about 6 inches apart and keep the surface of the ground open and free from weeds. It is perfectly hardy and may remain in the ground through the Winter. Indeed, the fine sugary flavor is only perfected by a severe frost.

Marshall's Marrow. A grand selection, clean white, long roots; fine for exhibition Pkt. Oz. 1/4lb. Lb.

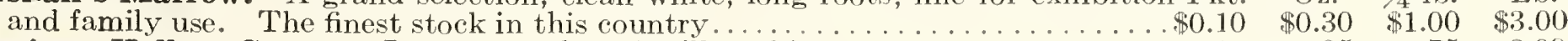

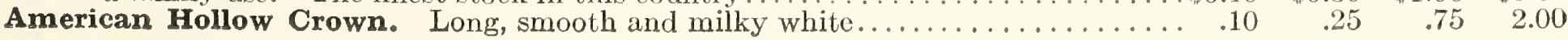




16 MARSHALL'S MATCHLESS SEEDS

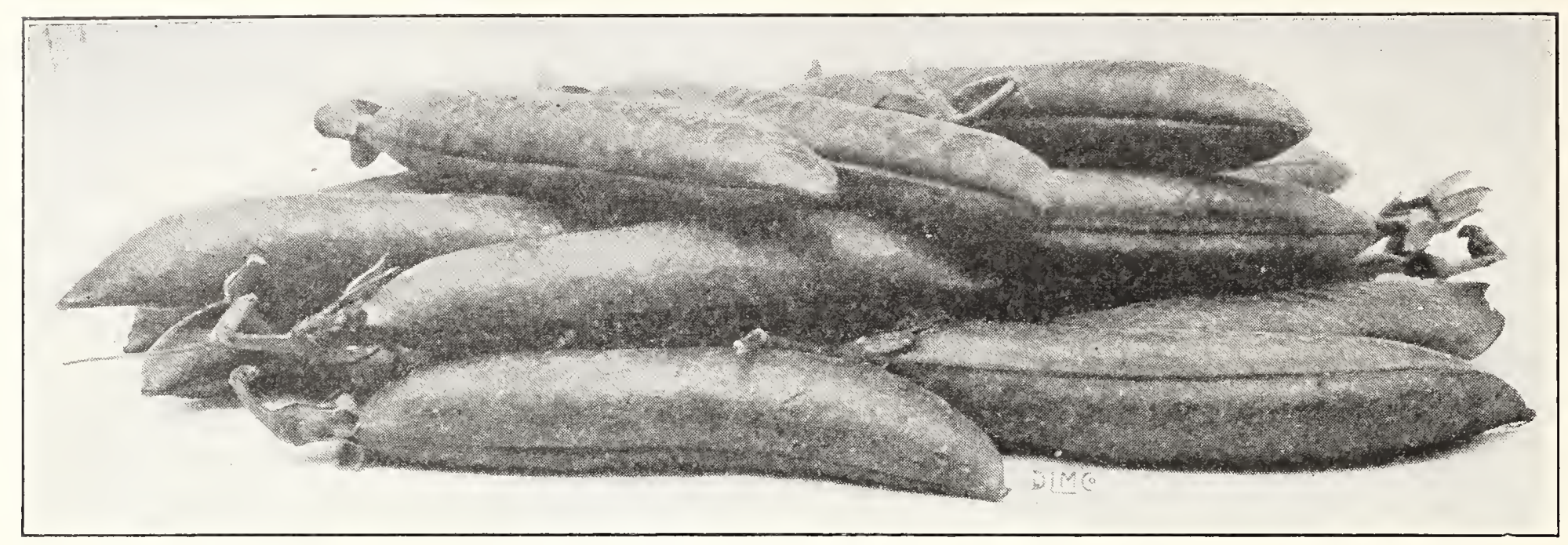

Peas, Little Marvel

\section{PEAS}

One quart will plant about 150 feet of drill

Peas mature earliest in a light, rich soil; for general crop a rich loam is the best. When grown in gardens sow in double rows 6 to 8 inches apart, the rows 2 to 4 feet apart, the tall ones requiring brush. Commence sowing the extra early varieties as early as the ground can be worked in February or March and continue for a succession every two weeks until July.

\section{EXTRA EARLY PEAS Height $1 \frac{1 / 2}{\text { in feet }}$ Pint Quart 4 Qts}

Alaska. One of the very earliest blue Peas; quite productive............. $21 / 2 \quad \begin{array}{lllll}\$ 0.20 & \$ 0.40 & \$ 0.80 & \$ 2.75\end{array}$

Blue Bantam. A fine extra early wrinkled Pea. Large pods well filled with

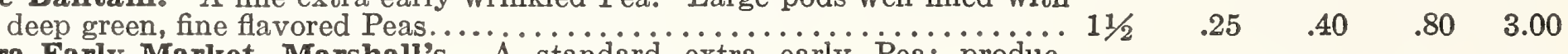

Extra Early Market, Marshall's. A standard extra early Pea; produc-

tive and profitable to grow............................

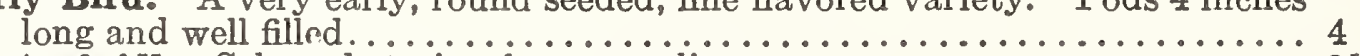

First of All. Selected strain of extra earlies....................... $21 / 2$

Gradus, or Prosperity. The finest extra early Pea. The pods are very

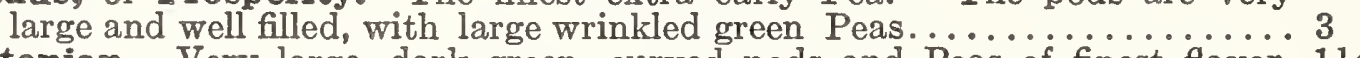

Laxtonian. Very large, dark green, curved pods and Peas of finest flavor. $11 / 2$

Laxton's Progress. An English wrinkled variety. A great bearer.......... 2

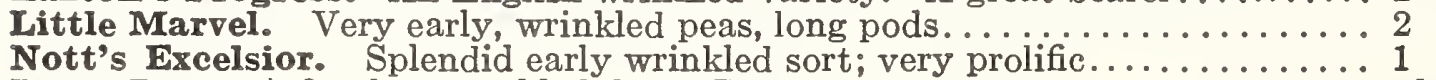

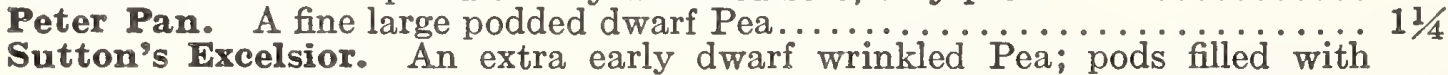

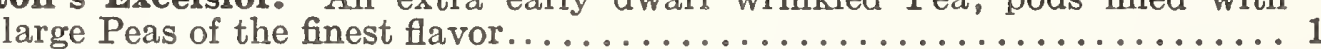

Thomas Laxton. Very productive. The pods are large and contain seven or eight large wrinkled Peas of the finest flavor $\ldots \ldots \ldots \ldots \ldots \ldots \ldots$

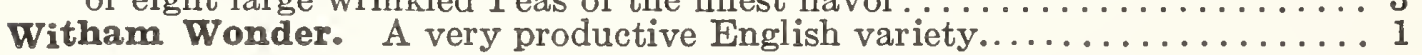

\section{MEDIUM GROP PEAS}

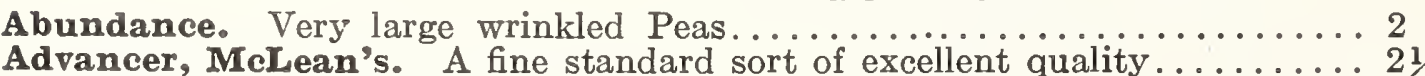

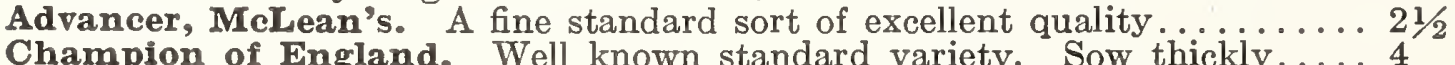

Dwarf Champion, or Juno. Dwarf form of Champion of England........

Duke of Albany (American Champion). Immense pods.............. 4

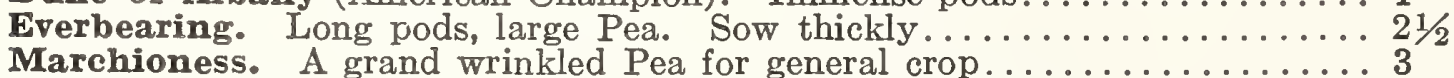

Market Garden. On the style of Advancer; very prolific................ $21 / 2$

Perfect. An English mid-season variety, with handsome long pods produced

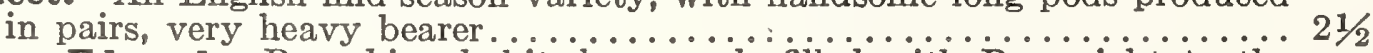

Prince Edward. Branching habit, large pods filled with Peas right to the

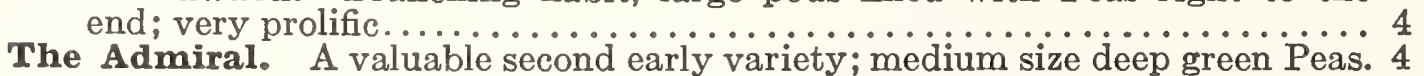

The Lion. A wonderfully productive English early variety............ 3

$\begin{array}{rrrr}.25 & .40 & .80 & 2.75 \\ .35 & .60 & 1.20 & 4.50 \\ .20 & .35 & .70 & 2.50 \\ & & & \\ .25 & .45 & .90 & 3.25 \\ .25 & .40 & .80 & 3.00 \\ .30 & .50 & 1.00 & 3.50 \\ .20 & .35 & .70 & 2.50 \\ .20 & .35 & .70 & 2.50 \\ .25 & .40 & .75 & 2.50 \\ .25 & .40 & .80 & 2.75 \\ & & & \\ .25 & .45 & .90 & 3.25 \\ .30 & .50 & 1.00 & 3.50\end{array}$

$\begin{array}{rrrr}.20 & .35 & .70 & 2.50 \\ .20 & .35 & .70 & 2.50 \\ .20 & .35 & .70 & 2.50 \\ .20 & .35 & .70 & 2.50 \\ .25 & .45 & .90 & 3.25 \\ .20 & .35 & .70 & 2.50 \\ .25 & .40 & .80 & 3.00 \\ .20 & .35 & .70 & 2.50 \\ .25 & .50 & 1.00 & 3.50 \\ & & & \\ .25 & .35 & .70 & 2.50 \\ .20 & .35 & .70 & 2.50 \\ .25 & .50 & 1.00 & 3.50\end{array}$

\section{MAIN GROP PEAS}

Alderman. One of the finest of the large podded main crop varieties. Pods measure nearly 6 inches, well filled....................... 4

Quite Content. A giant podded variety; very prolific............... 5

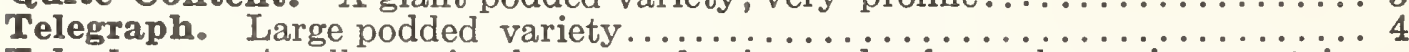

Telephone. A tall growing late sort, having pods of very large size, contain-

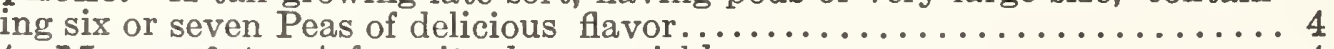

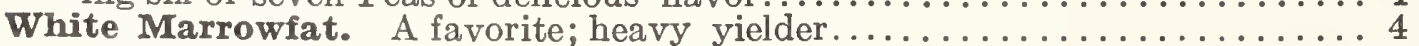

Black-Eyed Marrowfat. Very hardy and prolific; for market...........

$\begin{array}{llll}.25 & .40 & .80 & 3.00 \\ .25 & .45 & .90 & 3.25 \\ .20 & .35 & .70 & 2.50 \\ & & & \\ .20 & .35 & .70 & 2.50 \\ .25 & .40 & .70 & 2.50 \\ .25 & .40 & .70 & 2.50\end{array}$

"Mulford Cultures." Peas yield earlier, longer and better crops when treated with Mulford Cultures. Garden size, $35 \mathrm{c}$. ; bushel size $60 \mathrm{c}$. 
PEAS-Continued

\section{SUGAR PEAS (Edible Pods)}

In Sugar Peas the pods are gathered, broken and cooked like string beans when the Peas start to develop in the pod or have reached about half their full size. $1 / 2 \mathrm{pt}$. Pt. Qt. $4 \mathrm{qts}$. Gray-Seeded Sugar. Large edible pods.

Height 3 feet...................... $\$ 0.20 \quad \$ 0.35 \quad \$ 0.70 \quad \$ 2.50$

Tall, Melting Sugar. One of the best

$\begin{array}{llllll}\text { edible pod sorts. Height } 5 \text { feet...... } & .20 & .40 & .80 & 2.75\end{array}$

\section{PEPPER One ounce will produce}

Sow in hotbeds in March, and when the soil has become warm, set in rows 2 feet apart and 18 inches in the rows; hoe frequently. Plants may also be forwarded in small pots. Pkt. 1/2 oz. Oz, 1/4 lb. Cayenne, Long Red. Bright red, slender pods; 3 inches long............... \$0.10 $\$ 0.40 \quad \$ 0.75 \quad \$ 2.00$ $\begin{array}{lllll}\text { Chinese Giant. Very large, bright scarlet. } & .10 & .40 & .75 & 2.50\end{array}$ Large Bell or Bull Nose. Large, bright red largely used for pickling, mild flavor.:
Magnum Dulce. Very large; flesh mild and sweet...................... mo mild sweet, similar to Bull Nose. Plant dwarf, compact and very productive. The earliest variety grown............
arshall's Early Giant. A very large Marshall's Early Giant. A very large red variety...................... V

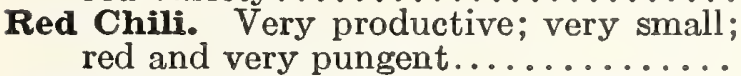
red and very pungent...............

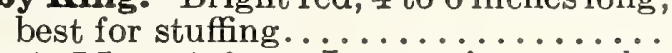

Sweet Mountain. Large size, regular handsome shape, mild flavor.........

$\begin{array}{rrrr}.10 & .40 & .75 & 2.00 \\ .10 & .40 & .75 & 2.50 \\ & & & \\ .10 & .50 & 1.00 & 3.50 \\ .25 & 1.00 & 2.00 & 6.00 \\ .10 & .40 & .75 & 2.00 \\ .10 & .40 & .75 & 2.00 \\ .10 & .40 & .75 & 2.00\end{array}$

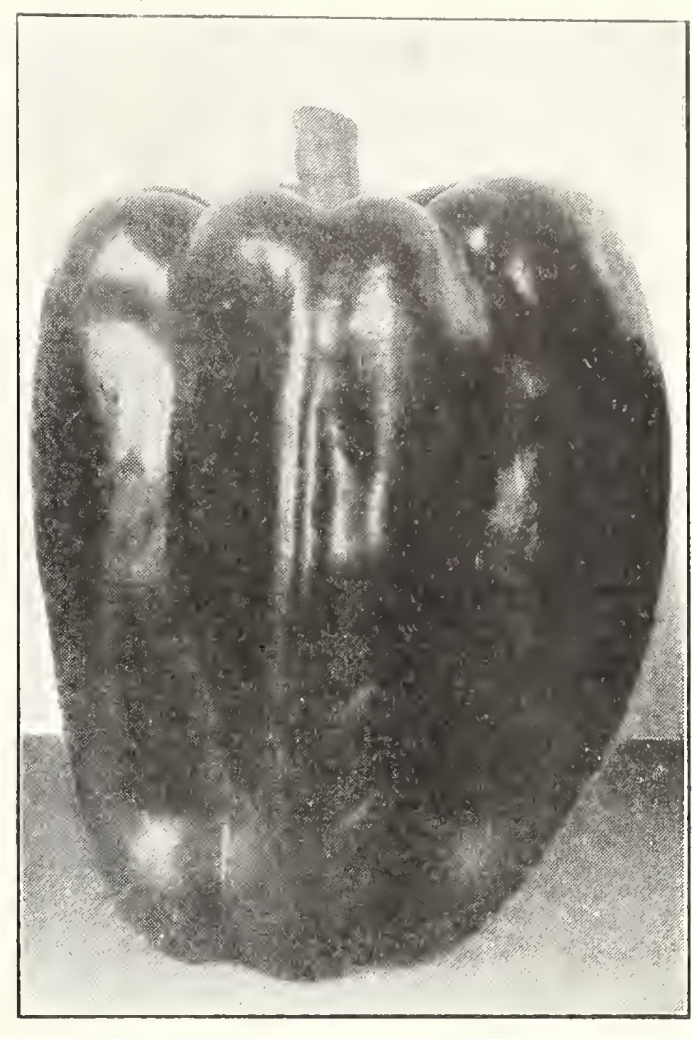

Pepper, Ruby King

\section{POTA ATOHS GROWN EXPRESSLY FOR}

Peck will plant 100 foot row. Ten bushels cut tubers will plant 1 acre.

The Potato, like the robust-growing vegetable, can be grown with, varying success on soils of all kinds and in all conditions of fertility, but the soil best suited to it is a sandy loam. Manure is applied either in rows or hills or broadcast over the hills and ploughed in - the latter in most cases being preferable. In highly enriched soils the plants are more liable to disease than when grown in soil that is naturally good. Plant as early in Spring as the ground can be had in fair working order, in hills or ridges, about 3 feet apart, cover lightly with soil about 4 inches deep.

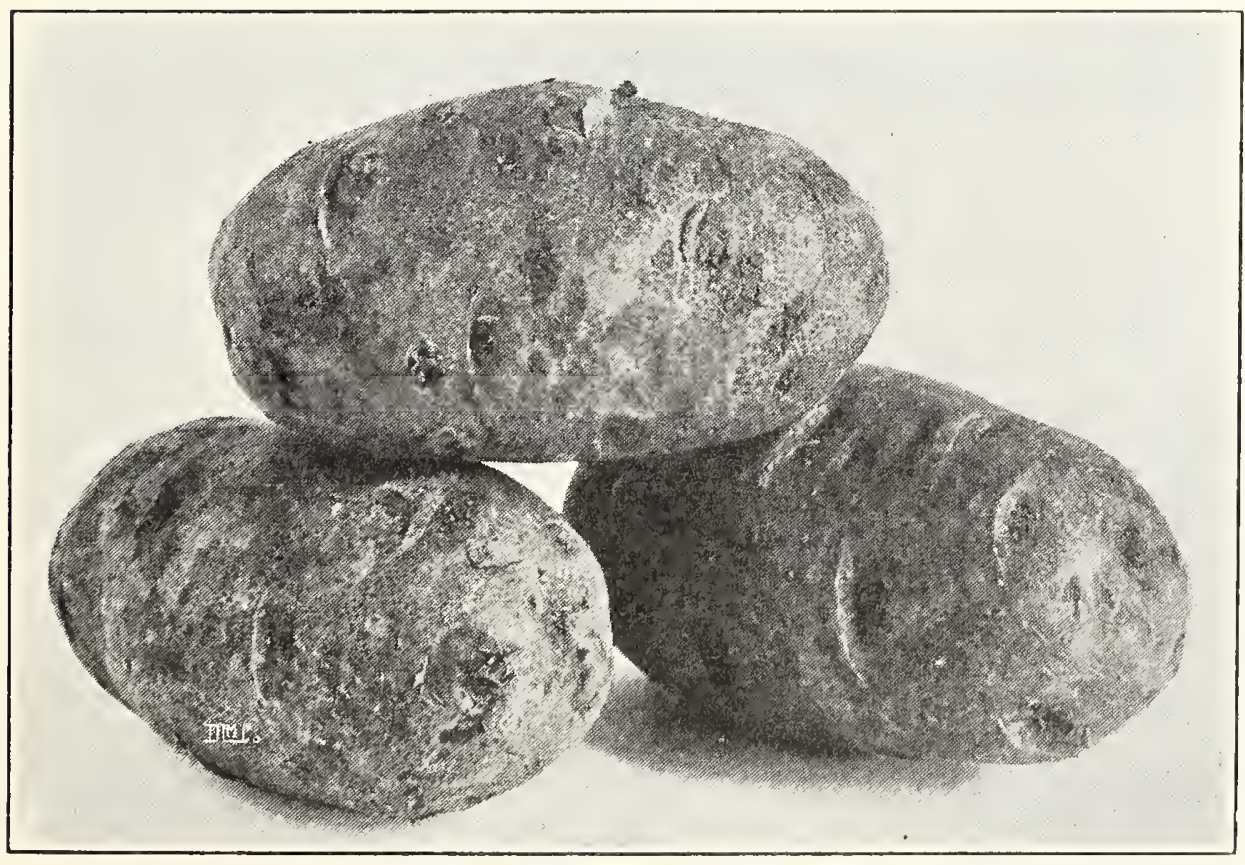

Green Mountain Potatoes

Beauty of Hebron. Slightly flesh colored skin, with pure white flesh; very productive and of the finest quality.

Bovee. Extra early; fine quality; flesh white.

Dibble's Russet. This is the best main crop Potato in cultivation. The tubers are round to oblong in shape, good size, white flesh and covered with a russet skin. The quality when cooked cannot be excelled. It also has great diseaseresistant and blightproof properties.

Early Rose ("Spaulding's"). Very early; fine quality; very productive, skin shaded rose color.

Gold Coin. Very productive, fine table quality; flesh pure white and cooks very dry.

Green Mountain. Oval shape; white skin and flesh; heavy yielder; good for Winter use.

Irish Cobbler. One of the best extra early varieties.

At the time of going to press with this catalogue the Potato market is so unsettled that prices are subject to change.

We request those desiring Seed Potatoes to write for prices on the quantities wanted and we will give quotations by mail.

Unpriced orders will be filled at the prevailing market prices at time of shipment. Potatoes are forwarded by express or freight as directed, purchaser paying charges.

Du Pont Semesan. Potatoes treated with Semesan will be freer from disease and yield much larger crops. See page 98 . 


\section{PUMPKIN}

One ounce will plant 50 hills.

The common practice is to drop two or three seeds in every second or third hill in the Cornfield, but if cultivated on a large scale the seed may be sown in hills 8 feet apart each way, four plants to each hill, and otherwise treated in the same manner as Melons or Cucumbers. Connecticut Field. Grown in Corn fields for stock Cushaw Striped. A splendid striped crook-neck variety .. Early Sugar. Fine grained; small; yellow . Large Cheese. Flat; the best variety for small family use. Pkt. Oz, 1/4 lb. Lb. $\$ 0.10 \quad \$ 0.20 \quad \$ 0.60 \quad \$ 1.50$ Mammoth King. Grows to an enormous size.

Mammoth Tours. A very large French variety. . Quaker Pie. Very prolific and a good keeper; fine for pies.

\section{RADISH}

One ounce of seed will sow 150 feet of drill.

Radishes require a light, loamy soil, moderately fertile, which should be deeply dug and well pulverized. The situation should be warm and sheltered. For an early supply sow in January or February in hotbeds, keeping well ventilated. In May they may be sown out-of-doors. Successive sowings should be made every two weeks. Radishes to be crisp and tender should make a rapid growth.

Winter varieties should be sown in July and August.

\section{FORCING VARIETIES}

\section{Early Scarlet Turnip}

Forcing. Crisp; very Pkt. Oz. 1/4 lb. Lb. early ............. \$0.10 $\$ 0.25 \quad \$ 0.75 \quad \$ 2.00$

Deep Scarlet Turnip Forcing or Non Plus Ultra. Round, short leaved, crisp; very early........... $10 \quad .25 \quad .75 \quad 2.00$

Scarlet Turnip White-Tipped Forcing. Round, very early Early Scarlet Globe. Fine for forcing or open ground

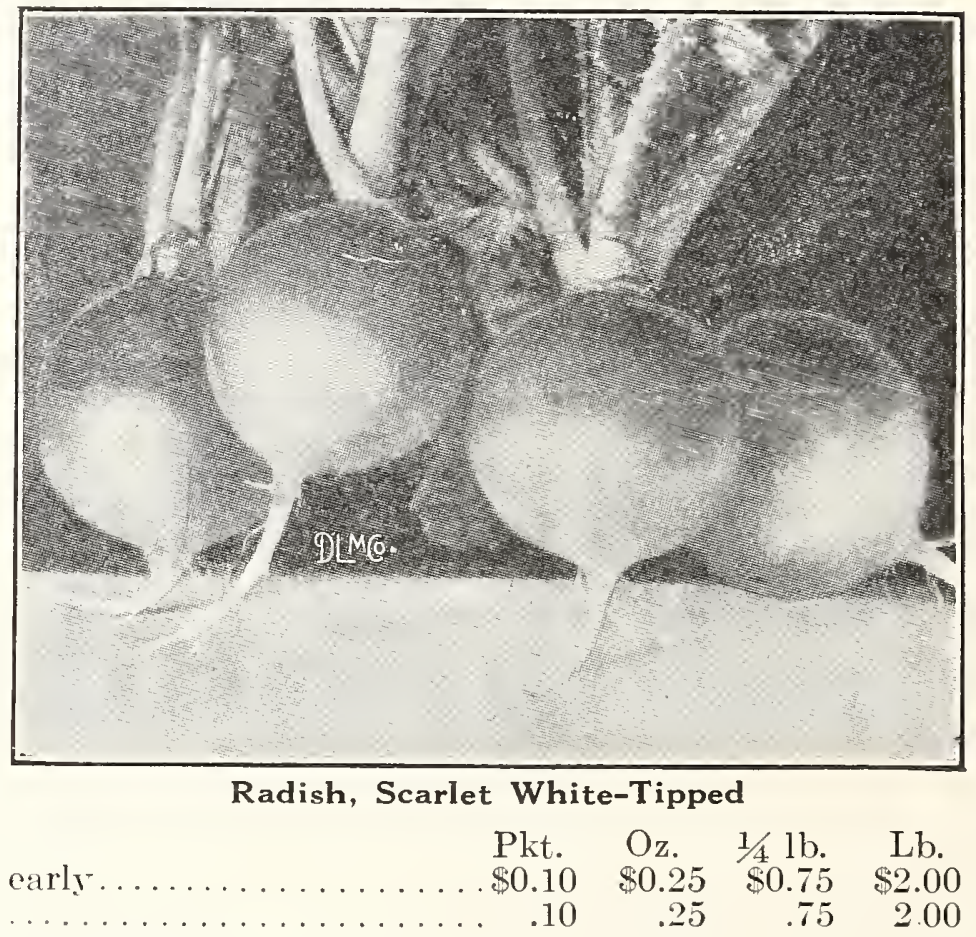

\section{OUTDOOR VARIETIES}

Turnip, Marshall's Perfection. Brilliant red with white tip extending nearly half way up the root...

Turnip, Early Scarlet. Very early. The French favorite

Turnip, Scarlet White-Tipped. Very early for frames or outdoors

Turnip, Early White, or Box. Flesh pure white and sweet.

Turnip, Crimson Giant. Suitable for forcing or outdoors; flesh very tender and crisp.

Turnip, Triumph (Speckled Beauty). Very prettily striped or mottled scarlet or or white; fine forcer

Turnip, Large White Summer. Of large size; roundish shape.

Olive-Shaped French Breakfast. Pink and white; early

Olive-Shaped Deep Scarlet. Crisp; very early

Olive-Shaped White. Mild and fine for Summer

Long Scarlet Short Top. Very long; for frames or outdoors.

Long White Vienna, or Lady Finger. Crisp and tender in Summer.

Long Icicle. Pure white; of fine flavor; suitable for forcing.........

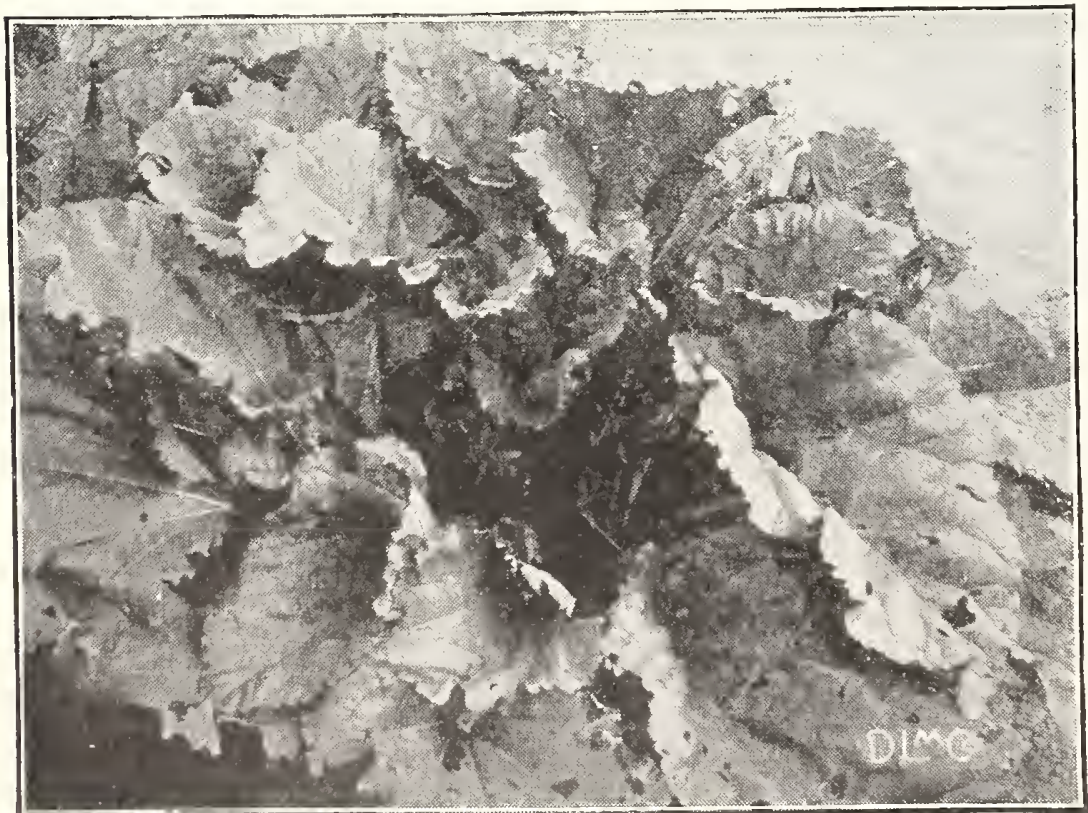

Rhubarb, Victoria
Long Black Span-

$\begin{array}{llll}.10 & .25 & .75 & 2.00 \\ .10 & .20 & .50 & 1.50 \\ .10 & .20 & .50 & 1.50 \\ .10 & .25 & .60 & 2.00 \\ .10 & .25 & .60 & 2.00 \\ & & & \\ .10 & .25 & .75 & 2.50 \\ .10 & .20 & .50 & 1.50 \\ .10 & .20 & .50 & 1.50 \\ .10 & .20 & .60 & 1.75 \\ .10 & .20 & .60 & 1.75 \\ .10 & .20 & .60 & 1.75 \\ .10 & .20 & .60 & 1.75 \\ .10 & .20 & .60 & 1.75\end{array}$

\section{WINTER VARIETIES} ish. The popular Winter sort..

Round Black Spanish. Fine for Winter.

California White Mammoth. A very large Winter variety

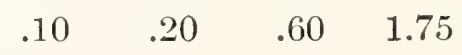

Sakurajima (Mam-

\section{RHUBARB}

One ounce will produce 1000 plants. Sow in drills 18 inches apart. When the plants are strong enough, thin out to 6 inches. in the Fall or following Spring, transplant the roots into deep, rich soil, 3 feet apart each way. Victoria. Tery large; later than the Linnaeus. Pkt. 10c., oz. 35c., 1/4 lb. $\$ 1.00$, lb. $\$ 3.00$.

Rhubarb Roots. Extra strong. Each 25c., doz. $\$ 2.50,100 \$ 20.00$.

Rhubarb Roots. For forcing. Each 35c., doz. $\$ 3.50,100 \$ 25.00$. 


\section{SALSIFY, OR OYSTER PLANT}

One ounce will sow 150 feet

A most delicious vegetable. It is used stewed, boiled, or fried, and sometimes as a salad. When cooked it has an oyster flavor. Sow seed from April to May in drills 18 inches apart. Cultivate the same as for Carrots or Parsnips:

Mammoth Sandwich Is-

land. True. Large and

superior; very fine flavor $\$ 0.10 \quad \$ 0.40 \quad \$ 1.25$

Long Black, or Scorzonera.

Resembles long white,

but black........ $\quad .10 \quad .50 \quad 1.50$
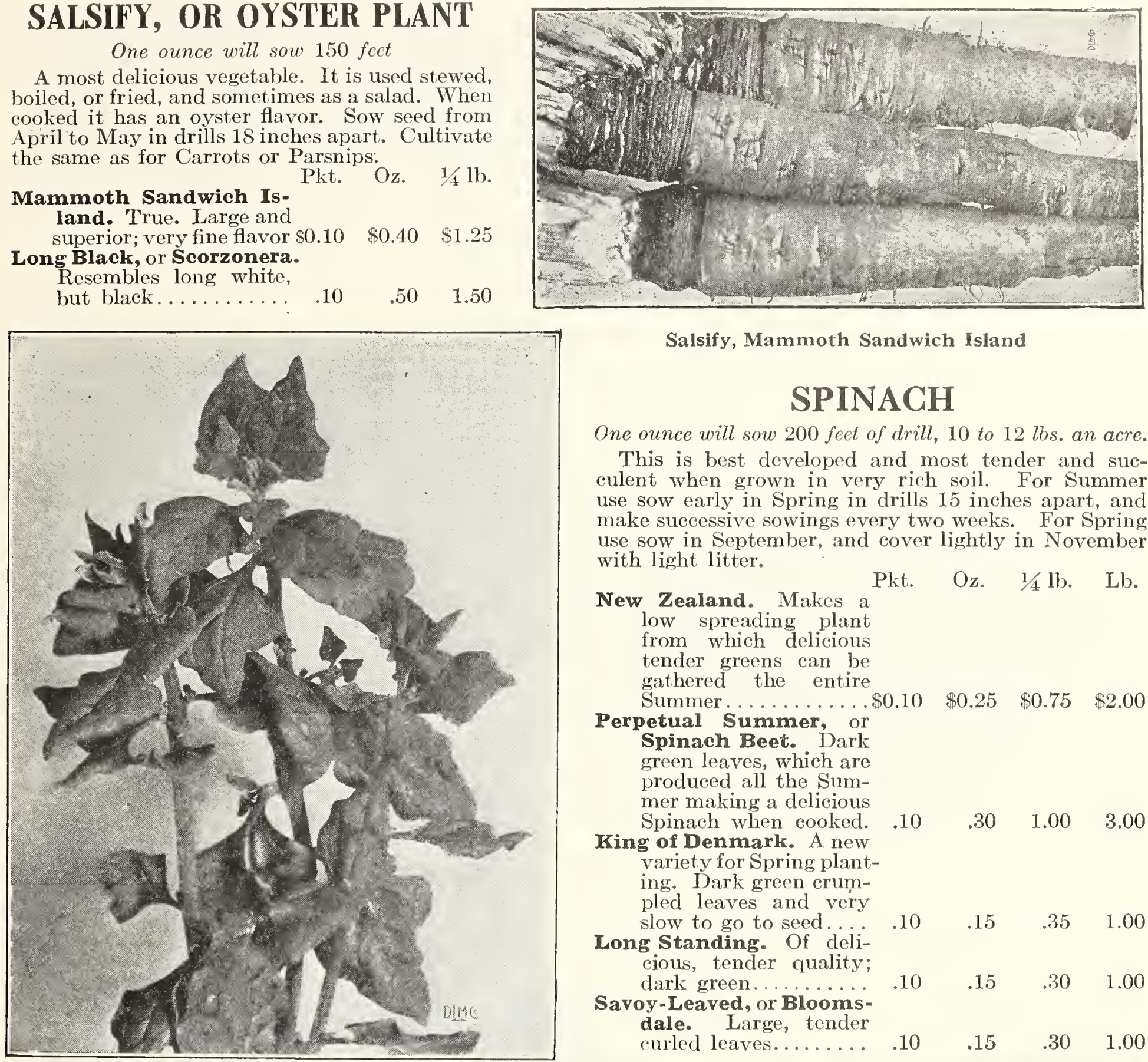

Salsify, Mammoth Sandwich Island

\section{SPINACH}

One ounce will sow 200 feet of drill, 10 to 12 lbs. an acre.

This is best developed and most tender and succulent when grown in very rich soil. For Summer use sow early in Spring in drills 15 inches apart, and make successive sowings every two weeks. For Spring use sow in September, and cover lightly in November with light litter.

New Zealand. Makes a

$$
\text { Pkt. Oz. 1/4 lb. Lb. }
$$

low spreading plant

from which delicious

tender greens can be

gathered the entire

Summer .............

Perpetual Summer, or
Spinach Beet. Dark Spinach Beet. Dark produced all the Summer making a delicious Spinach when cooked.

Kring of Denmark. A new variety for Spring planting. Dark green crumpled leaves and very slow to go to seed...

Long Standing. Of delicious, tender quality; dark green.

oy-Leaved, or Bloomsdale. Large, tender curled leaves........ $\quad .10 \quad .15 \quad .30 \quad 1.00$

\section{Spinach, New Zealand}

Victoria. A variety with Pkt. Oz. 1/4 lb. Lb. thick dark-green leaves. Best long standing

Spinach............ \$0.10 $\$ 0.15 \quad \$ 0.30 \quad \$ 0.75$

Viroflay Thick-Leaved. A standard sort, equally good for early Spring or Fall sowing......

Prickly, or Winter. Vigorous and hardy, recommended for Fall sowing

$\begin{array}{llll}.10 \quad .15 & .30 \quad .75\end{array}$

\section{SORREL}

One ounce will sow 150 feet of drill.

Used cooked as Spinach or to mix with salads. Sow in shallow drills 12 inches apart, and thin out the young plants to 6 inches.

Large-Leaved French. Pkt. 10c., oz. 25c., 1/4 1b. 75c., lb. $\$ 2.50$.

\section{SWISS CHARD}

This beet produces leaves only; excellent as greens. Cultivate same as Spinach, sowing the seed in early Spring, in drills $1 \frac{1}{2}$ feet apart. Good cultivation will increase the delicacy and tenderness of the leaves.

Swiss Chard. Pkt. 10c., oz. 20c., 1/4 lb. 50c., lb. $\$ 1.50$ Giant Lucullus. Pkt. 10c., oz. 20c., 1/4 lb. 60c., lb. $\$ 2.00$.

5

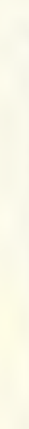

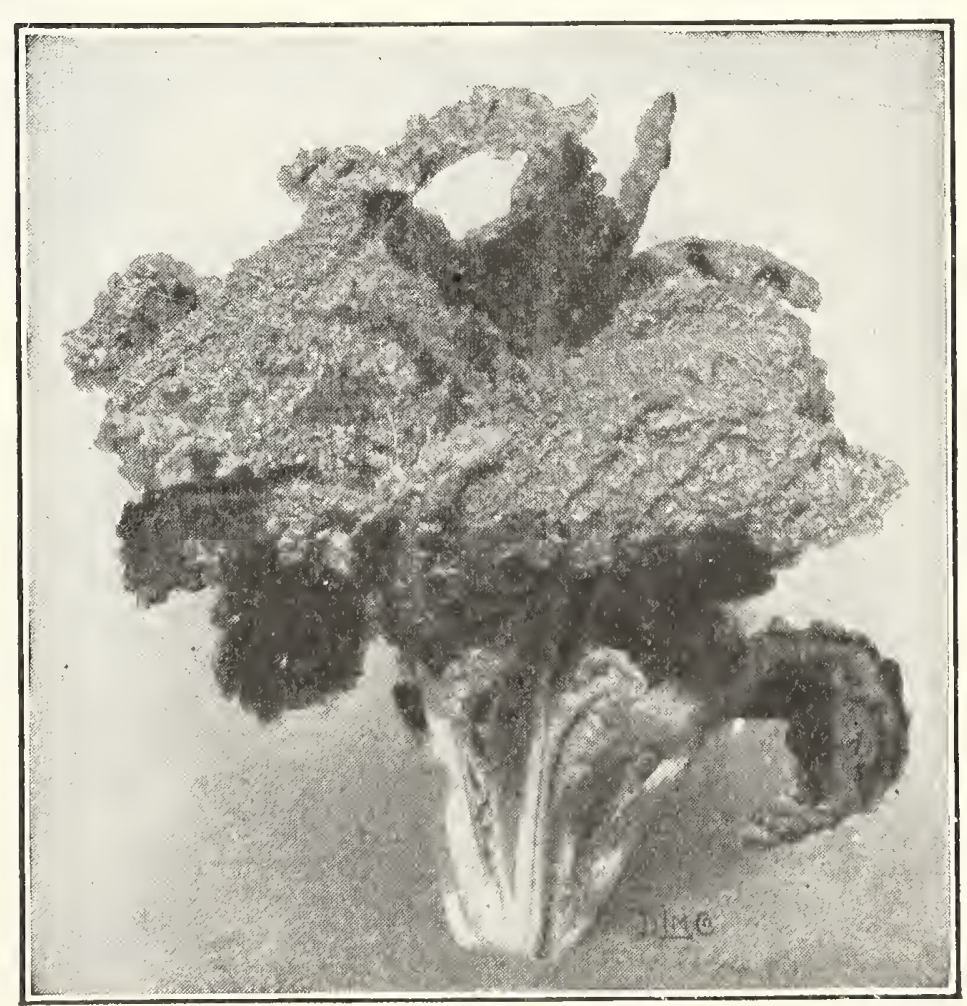

Swiss Chard 


\section{SQUASH}

One ounce Early Squash will plant about 50 hills. One ounce Marrow Squash will plant about 25 hills.

The Squash succeeds best in good rich soil. It is not advisable to plant before May 15th. Sow in hills in the same manner as Cucumbers and Melons. Use seed freely, 8 to 12 seeds to the hill, to provide for losses by insects.

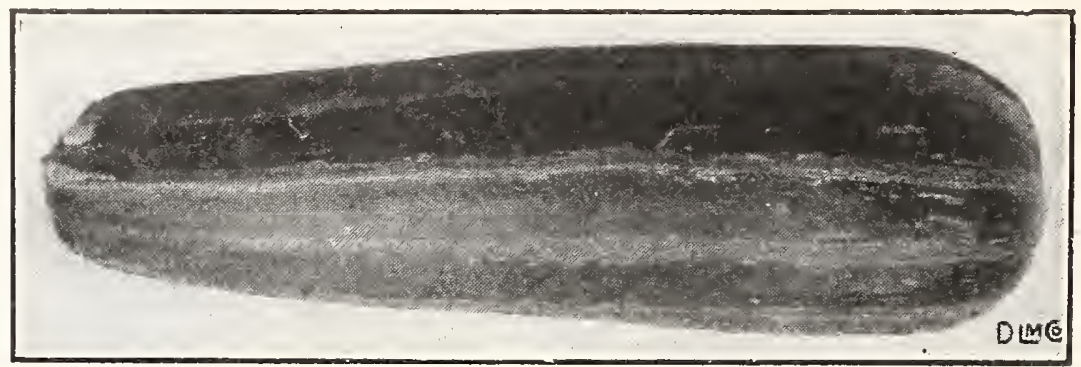

Squash, Cocozelle Bush

\section{BUSH VARIETIES}

Cocozelle Bush. A fine variety; oblong shape; skin smooth, dark green, marbled yellow Pkt.

or pale green.................................. \$ 0.10

Improved Early White Bush Scallop. A good early shipping variety. . . . . . . . . . . . 10

Giant Summer Crookneck. Double the size of Summer Crookneck. . . . . . . . . . . . . . 10

Golden Custard. Fine quality and cooks tender. . . . . . . . . . . . . . . . . . . . . . .

Golden Summer Crookneck. Yellow fruit; distinct; best for Summer.

Yellow Bush Scallop. The popular yellow variety.

RUNNING VARIETIES

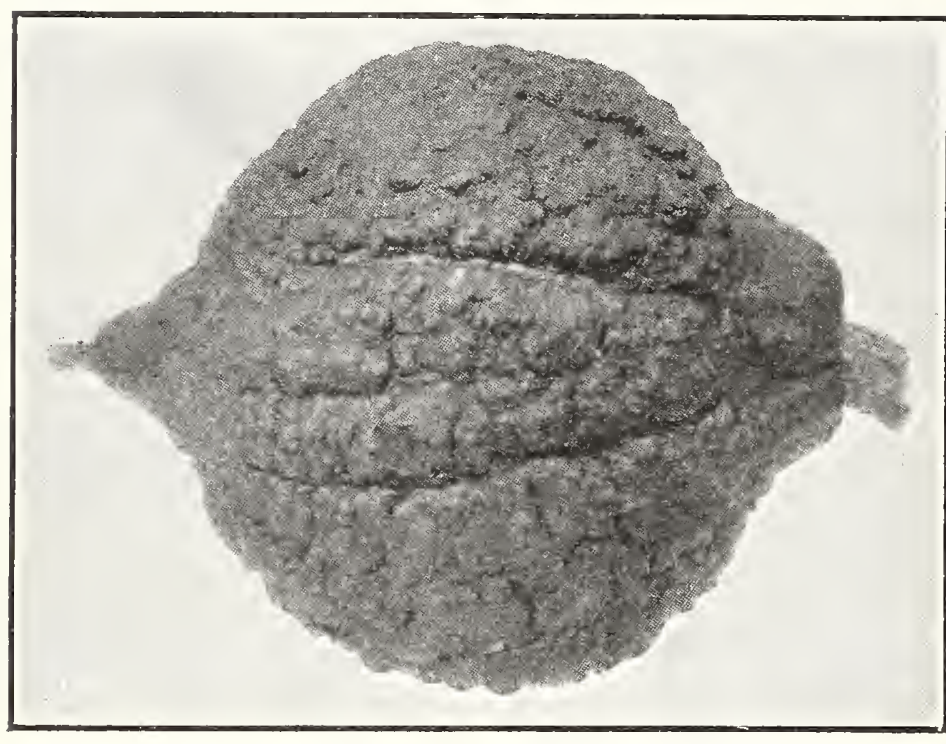

Squash, Mammoth Warted Hubbard

Boston Marrow. Oval; bright orange; flesh yellow and fine.

Delicious. Green skin; orange flesh; fine grained; sweet and dry.... \# desirable variety for Summer and Winter use; fruit oblong in shape, smooth yellow skin, flesh light yellow.......

Golden, or Red Hubbard. Flesh deep golden yellow; fine for private use ................

Improved Hubbard. Well known and liked for late use.......

Mammoth Warted Hubbard. Very large, covered with warts.

Fine keeper.............. flesh; grows to an enormous size

Vegetable Marrow. A favorite English sort; skin greenish yel-

.10
.10
.10
.10
.10
.10

\section{ENGLISH VEGETABLE MARROWS}

The following varieties are well adapted for growing in this climate. Pkt. $\mathrm{Oz}$. Long Green Bush. Fruits long pale green; rich flavor.........

very prolific........ Very long,

pale cream color; trailing sort.

\section{TOBACGO SEED}

One ounce will produce plants for one acre.

Connecticut Seed Leaf. Suitable for growing in these latitudes; used for cigar wrappers. Pkt. 10c., oz. 30c., $1 / 4$ lb. $\$ 1.50$. low; flesh white............. .10

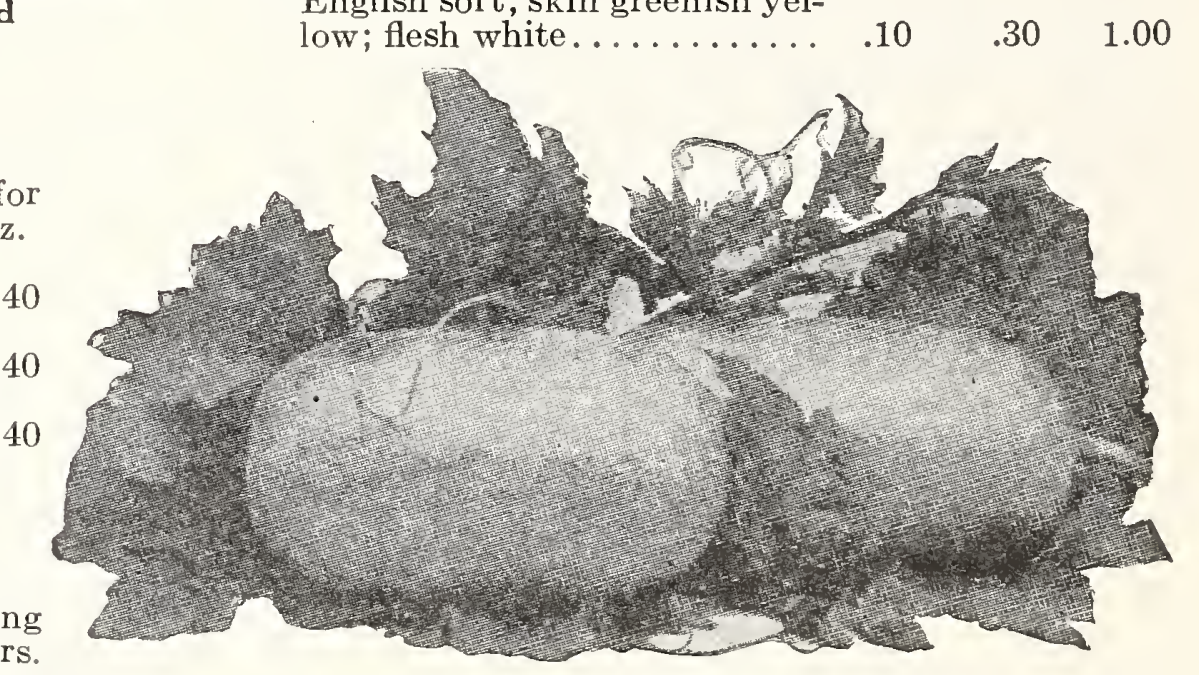

Vegetable Marrow, Long White Bush

TOMATO

Sow thinly about the first week in March in a hotbed, greenhouse, window or sitting room, where the temperature is never below 60 degrees. When 2 inches high, set out the plants in boxes about 4 inches apart, or pot singly. About the first of June they may be transferred to the open ground. Set them deeply 4 feet apart.

\section{FORCING VARIETIES}

Marshall's Prolific. The finest medium-sized Tomato for forcing or outdoor planting. It Pkt. $1 / 2 \mathrm{oz} . \quad$ Oz.

is an enormous cropper, producing large clusters of bright scarlet fruit. . . . . . . . . . $\$ 0.25 \quad \$ 2.00 \quad \$ 4.00$

Comet. Beautiful, smooth, round fruit in great abundance. Color a rich scarlet red...... $\quad \begin{array}{llll} & .25 & 1.00 & 2.00\end{array}$

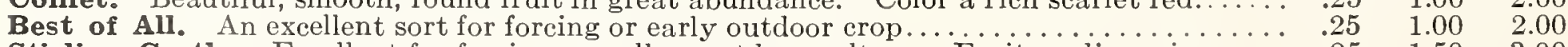

Stirling Castle. Excellent for forcing as well as outdoor culture. Fruit medium size..... $\quad .25 \quad 1.50 \quad 3.00$

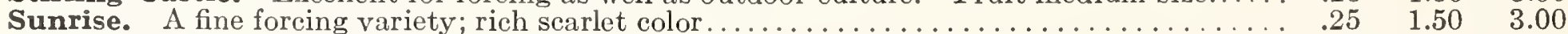

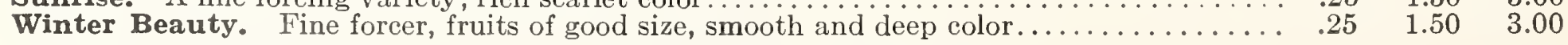

\section{OUTDOOR VARIETIES}

Bonny Best. A very early bright red variety. Smooth, solid and uniform. . . . . . . . . $\quad .10 \quad .25 \quad .50$

Chalk's Jewel. An exceptionally fine early variety. Color crimson............. $\quad .10 \quad .25 \quad .50$ 


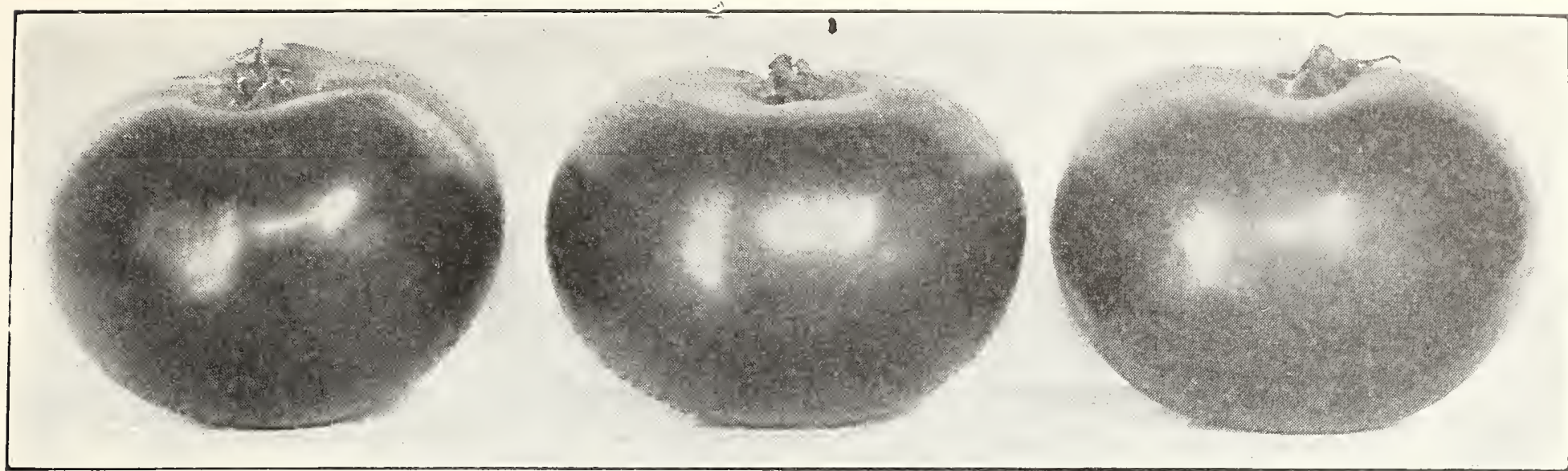

TOMATO-OUTDOOR VARIETIES-Continued

Pkt. $1 / 2$ oz. Oz,

Crimson Cushion. Extra large, handsome, bright crimson.

$\$ 0.10 \$ 0.30 \quad \$ 0.60$

Dwarf Champion. The plant is of dwarf and compact growth

Dwarf Stone. Color bright scarlet, perfect shape; resembles Dwarf Champion, but with larger fruit.

Earliana. Extra early; bright red; smooth ...................... A good yellow sort; first-class quality; large and solid
Goolden Queen. A

John Baer. A beautiful, brilliant red variety; perfect, solid, high crown fruits.

Marshall's National. A very early, bright red, coreless variety.

Matchless. Extra large, smooth and handsome; bright red; very solid

Perfection. Early, regular and productive; reddish scarlet.

Ponderosa. The largest variety in cultivation; very solid and meaty

Stone. Very large, perfectly smooth; fine, bright scarlet...

\section{SMALL FRUITED TOMATOES}

Red Cherry. Small fruits; used for pickles; very handsome..................... . 10

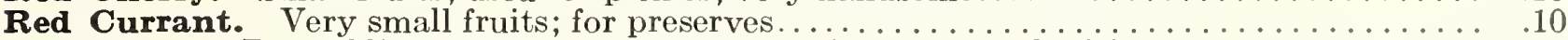

Red Peach. Resembling a Peach; for preserves, pickles and exhibition............... 10

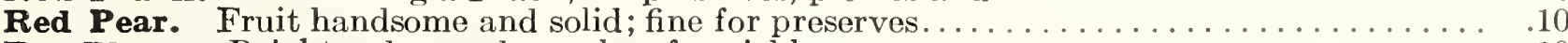

Red Plum. Bright red, round, regular; for pickles. ..................... 10

Strawberry (Winter Cherry, or Husk Tomato). Makes fine sauce.............. $\quad .10$

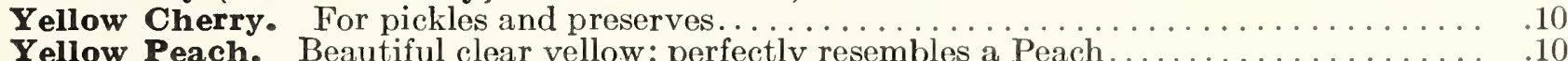

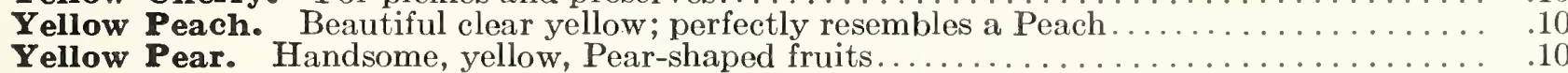

Yellow Plum. Round and regular; bright yellow..

\section{TURDVIP One ounce will sow 200}

Turnips do best on highly enriched, light sandy or gravelly soil. Commence sowing the earliest varieties in April, in drills, from 12 to 15 inches apart, and thin out early to 6 or 9 inches in the rows. For a succession, sow at intervals of two weeks, until the middle of August. $\quad$ Pkt. Oz. 1/4 lb. Lb.

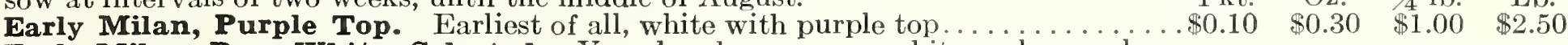

Early Milan, Pure White, Selected. Very handsome, pure white and as early as the above; flesh very sweet and tender.

Early Snowball. Small, and rapid growth; pure white...

Golden Ball. Very handsome; keeps fairly well...........

Quicksilver. A perfect shaped, round, white skinned, solid white flesh variety. Very quick growing and fine for exhibition. ...

Red Top, Strap Leaf. The popular Fall flat sort

Red Top, Globe-shaped. A standard sort in the New York market

Seven Top. Grown exclusively for the tops, which are used for greens.

White Egg. Oval, handsome and sweet.

White Strap Leaf Flat. Pkt. Oz. 1/4 lb. Lb. A good early white

flat sort..........\$0.10 $\$ 0.20 \quad \$ 0.50 \quad \$ 1.50$

Yellow Aberdeen. A hardy and productive variety $\begin{array}{lllll}\text { of excellent quality... } & .10 & .20 & .50 & 1.50\end{array}$

\section{RUTA-BAGA}

Seed should be sown the end of June or July. Desirable for table use and feeding stock.

Marshall's Matchless. A Pkt. Oz. 1/4 lb. Lb. purplish bronze variety, with single tap root and small top. Excellent quality......... \$0.10 $\$ 0.25 \quad \$ 0.75 \quad \$ 2.50$ American Purple Top. A strain of Purple top yellow.

Champion Purple Top. Very large...........

White-Fleshed. Large and productive..........

$\begin{array}{rrrr}.10 & .20 & .50 & 1.50 \\ .10 & .20 & .50 & 1.50 \\ .10 & .25 & .75 & 2.00\end{array}$

$\begin{array}{rrrr}.10 & .30 & 1.00 & 2.50 \\ .10 & .20 & .50 & 1.50 \\ .10 & .20 & .50 & 1.50 \\ & & & \\ .10 & .35 & 1.00 & 3.00 \\ 10 & .20 & .50 & 1.50 \\ .10 & .20 & .50 & 1.50 \\ .10 & .20 & .50 & 1.50 \\ .10 & .20 & .50 & 1.50\end{array}$

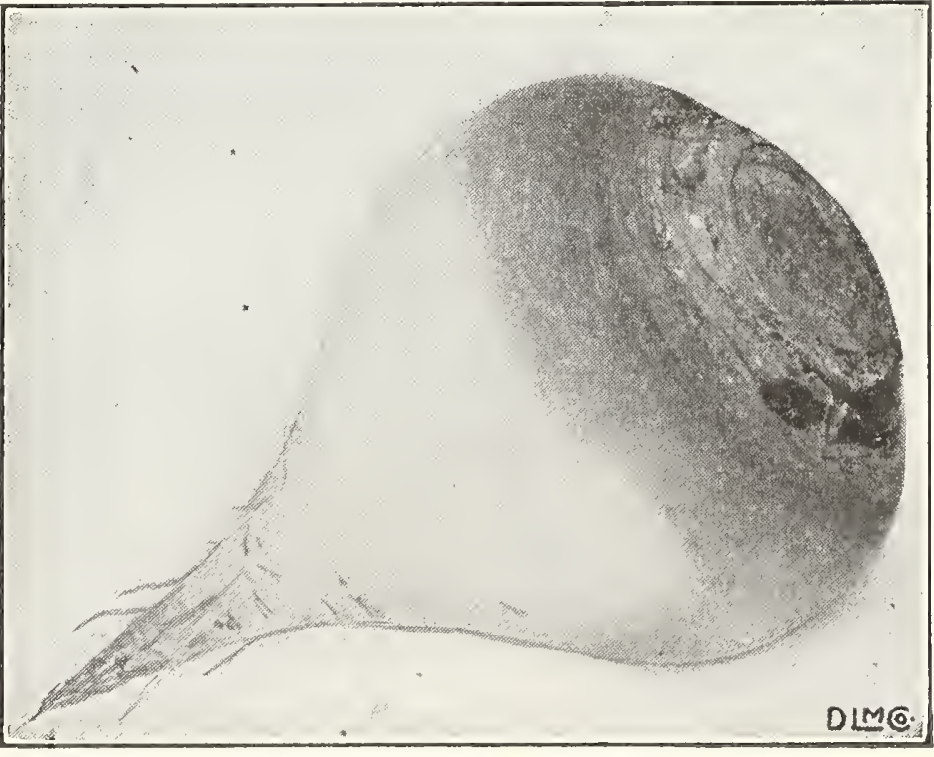

Ruta-Baga, Matchless 


\section{HERBS-SWEET AND MEDICINAL}

Plant in the Spring, when the ground is warm, in drills, covering lightly. When the plants are well up, thin out or transplant to about 4 inches apart. They should be harvested on a dry day just before the blossom develops, dried quickly and bottled, or closely packed in dry boxes with the air entirely excluded.

Anise. Annual. Used for flavoring and garnishing........................ . .

Balm. Perennial. Leaves have a fra grant odor and are used medicinally. ing soups, stews, etc.

Borage. Annual. Leaves are used for flavoring, and bees are attracted by the flowers.

Caraway. Perennial. Used for flavoring confectionery, bread, etc.

Catnip. Perennial. Sometimes used in medicine.

Coriander. Annual. Used in the manufacture of confectionery.

Dill. Biennial. The seeds are aromatic and pungent. Used in pickling $\mathrm{Cu}$ cumbers.

Fennel, Sweet. Perennial Leaves when boiled are used in sauces...........

Fennel, Florence. The roots are boiled,

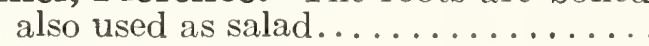

Pkt. Oz.

$0.10 \$ 0.30$

$.10 \quad .40$

$.10 \quad .30$

$.10 \quad .75$

$.10 \quad .40$

$.10 \quad .30$

$10 \quad .30$

$10 \quad .30$
Horehound. Perennial. Used medicinally, also for seasoning........\$0.10 \$0.50

Hyssop. Perennial. Used medicinally. The leaves have a pungent taste... $\quad .10 \quad .50$

Lavender. Perennial. Yields an oil used in medicine and perfumery........ $\quad .10 \quad .50$

Marigold, Pot. For medicinal purposes. $\quad .10 \quad .40$

Marjoram, Sweet. Annual. Aromatic and fragrant. Much used in flavoring $\quad .10 \quad .50$

Mint. Plants only.

Rosemary. Perennial. Leaves fragrant, with warm, pungent, bitterish taste..

Sage. Perennial. More used than any other herb for dressings and seasoning.

Summer Savory. Annual. Used for fiavoring soups and dressings...........

Tarragon, or Estragon ...............
Thyme. Perennial. Used for seasoning. Also used medicinally.

Wormwood. Perennial. Used medicinally and is beneficial for poultry.....
Pkt. $\mathrm{Oz}$

$.10 \quad .60$

$.10 \quad .50$

$.10 \quad .50$

$.10 \quad 1.00$

$10 \quad 1.00$

$.10 \quad .50$

\section{PLANTS OF HERBS}

To meet the increasing demand for plants of the most popular herbs, we can supply the following:

\begin{tabular}{|c|c|c|c|c|}
\hline & Each & Doz. & Each & Doz. \\
\hline Balm. &.$\$ 0.25$ & $\$ 2.50$ & Mint (Peppermint). & $\$ 2.50$ \\
\hline Chives. & .25 & 2.50 & Rosemary........ & 2.50 \\
\hline Horehound . . . . . . . . . . . . . . & .25 & 2.50 & Sage, Common... & 2.50 \\
\hline Hyssop $\ldots \ldots \ldots \ldots \ldots \ldots \ldots \ldots$ & .25 & 2.50 & Savory, Winter................. & 2.50 \\
\hline Lavender, True $\ldots \ldots \ldots \ldots \ldots \ldots$ & .25 & 2.50 & Thyme, French $\ldots \ldots \ldots \ldots \ldots$ & 2.50 \\
\hline Marjoram, Pot....... & .25 & 2.50 & Tarragon, or Estragon. & 3.50 \\
\hline
\end{tabular}

\section{VEGETABLE PLANTS AND ROOTS}

Prices of Vegetable Plants are subject to change at time shipments are made.

Artichoke Plants, Globe, Selected Large Green. Ready April 1st. Doz. \$2.50, $100 \$ 20.00$.

Asparagus Roots. See page 5 .

Cabbage Plants. For April and May delivery. Doz. 30c., $100 \$ 1.75$. Delivery June, July and August. $100 \$ 1.50,1000 \$ 7.00$.

Cauliflower Plants. Snowball. Ready April, May and June. Doz. 60c., $100 \$ 3.00$.

Celery. Golden Self-Blanching, White Plume, Winter Queen, or Giant Pascal. Extra strong, transplanted plants. Delivery July and August. 100 $\$ 1.50,1000 \$ 10.00$.

Chicory Roots. Strong for forcing. Doz. $\$ 1.00,100$ $\$ 7.00$.

Egg Plants. Ready in May and June. Grown in pots. Doz. $\$ 1.00,100 \$ 7.00$.
Horse Radish Sets, New Bohemian. A new variety which produces roots of enormous size and succeeds in every soil. Doz. 20c., $100 \$ 1.00$.

Kohl-Rabi (White Vienna). Doz. 30c., $100 \$ 3.00$.

Lettuce. Ready in April and May. Boston Market, Paris Cos. Doz. 30c., $100 \$ 2.00$.

Parsley (Double Curled). Doz. 30c., $100 \$ 2.00$.

Peppers. Ready in May and June. (Bell or Bull Nose). Long Red Cayenne. Doz. 50c.

Rhubarb Roots, Victoria. Strong roots. Each 25c., doz. $\$ 2.50,100 \$ 20.00$.

Sweet Potato Plants. Ready in June. $100 \$ 1.00$, $1000 \$ 7.00$.

Tomato Plants. Ready in May and June. Dwarf Champion, Perfection, Ponderosa, Stone, etc. Doz. 40c., $100 \$ 3.00$. Small Fruit Varieties. Doz. 75c. Pot-grown plants. Doz. 60c.

Vegetable Plants will be shipped by express in 'lue time for planting at purchaser's risk only.

We carry a supply at our store in their resrestive planting seasons.

\section{BIRD SEEDS, ETC.}

Per lb.

CANARY. Best Sicily recleaned..........\$0.15

CANARY SEED, Mixed.

FISH FOOD.

GRAVEL FOR CAGES . . . .

HEMP . . . . . . . . . . . . . . . . . 12

LETTUCE SEED ....................
MILLET, AMERICAN............ 4 lbs. $50 \mathrm{c} . \$ 0.15$ RAPE...................... 2 lbs. 25c. .15 SUNFLOWER SEED. For parrots, 2 lbs. 25c. .15

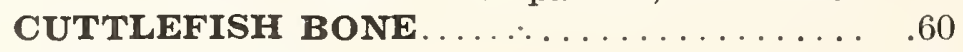

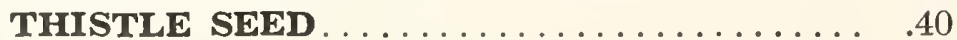




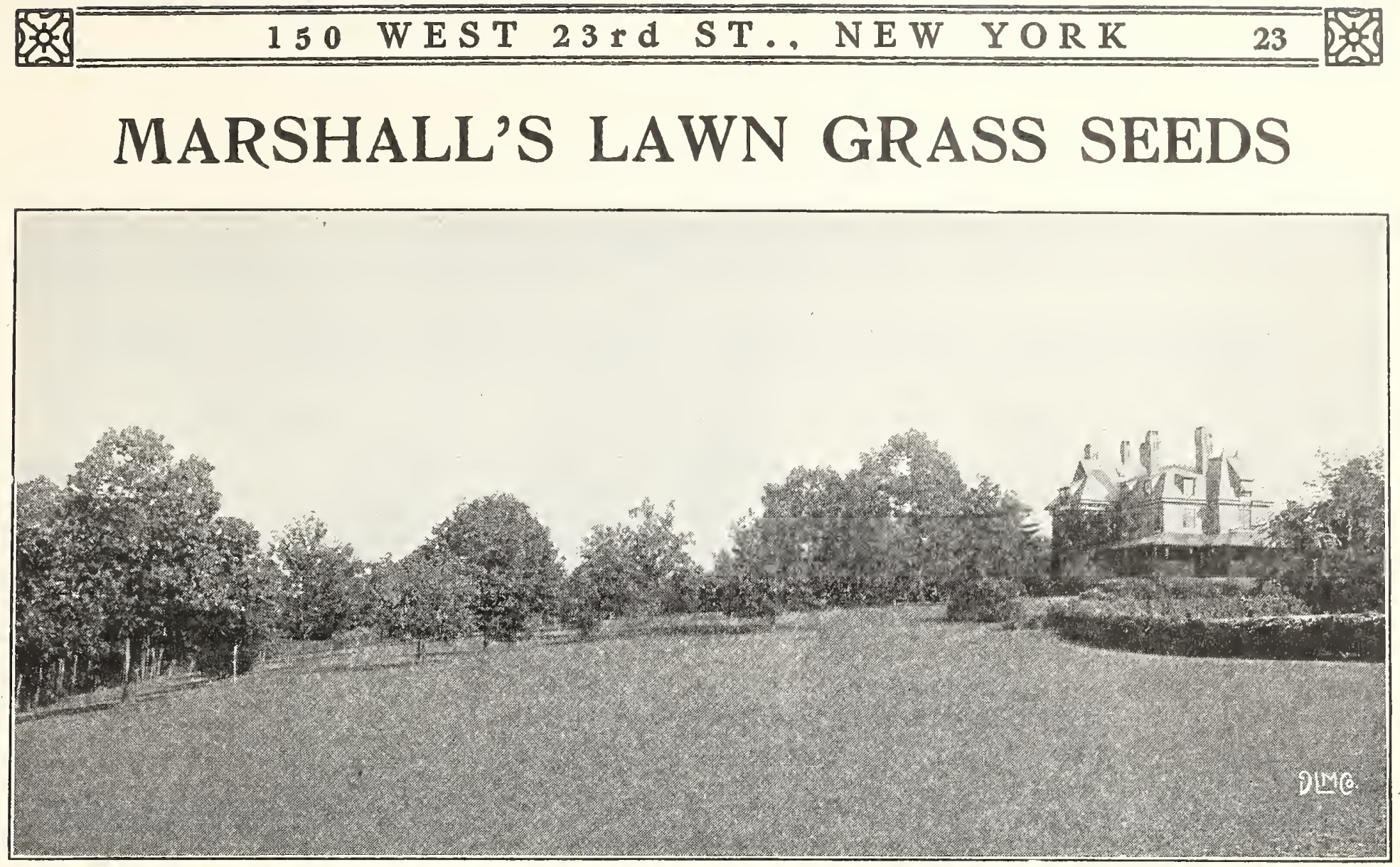

\section{MARSHALL'S "SPEGIAL" LAWN GRASS MIXTURE}

Marshall's Special Lawn Grass Seed produces a perfect and enduring lawn of luxuriant richness with closely interwoven, firm and elastic turf, and it is usually ready for cutting in six weeks from time of sowing. This Lawn Grass is composed of a combination of various fine-leaved, deep-rooting grasses of interweaving habit, that flourish under our varied conditions, soils and climates, growing during different seasons of the year, so that a deep green, smooth and velvety sward, free from clumps, is maintained without burning brown in Summer.

This mixture contains highest grade recleaned seeds of Red Top, Kentucky Blue, Chewing's Fescue, and Perennial Rye Grasses, blended in suitable quantities.

Price: Lb. 70c., 5 lbs. $\$ 3.25,20$ lbs. $\$ 12.00,100$ lbs. $\$ 60.00$.

\section{MARSHALL'S "CENTRAL PARK" LAWN GRASS}

Marshall's Central Park Lawn Grass will produce an even, dense growth of permanent sward as early in the season as it is possible to do. This mixture contains no annual grasses for making quick show to the detriment of a good lawn, but only those of lasting value and hardiness, which, when once established, need no reseeding for years. Our seed, which we know to be as pure as can be found anywhere, is of the best varieties, best suited for even and permanent growth; it is carefully cleaned and free as it is possible to make it from foreign matter.

1 lb. will sow $25 \times 25$ feet ( 625 square feet); 5 lbs., $50 \times 50$ feet (2500 square feet); 20 lbs. $100 \times 100$ feet (10,000 square feet); 100 lbs., one acre.

Price: Lb. 50c., 5 lbs. $\$ 2.10,20$ lbs. $\$ 8.00,100$ lbs. $\$ 40.00$.

\section{MARSHALL'S "SHADY PLAGE" LAWN GRASS}

Usually it is quite difficult to obtain a satisfactory growth of grass under trees and in shady places; for sowing in such places we recommend the use of this special mixture. It will quickly produce an abundant and even growth of beautiful green grass. The grasses used in making this special mixture are only those adapted for growing in shade. It has been successfully used on some large operations where a green sward was desired on land partially shaded by old trees.

Price: Lb. 70c., 5 lbs. $\$ 3.25$, bu. 20 1bs., $\$ 12.00,100$ lbs. $\$ 60.00$.

\section{SPEGIAL LAWN GRASS MIXTURE FOR SEASIDE LAWNS}

A mixture of fine grasses peculiarly suited to seaside lawns and very sandy soils.

Price: Lb. 60c., 5 1bs. $\$ 2.75,20$ 1bs. $\$ 10.00$. 


\section{MARSHALL'S TERRAGE MIXTURE LAWN GRASS}

A special mixture of grasses for sowing on terraces and side hills-grasses that produce strong, spreading roots, thus preventing heavy rain from washing them out; that will withstand drought and exposure, thrive on shallow soils and produce a rich, green turf throughout the season.

Price: Lb. 70c., 5 1bs. $\$ 3.25$, bu. 20 lbs. $\$ 12.00$.

\section{PERMANENT GRASS MIXTURES FOR GOLF LINKS}

\section{MARSHALL'S PUTTING GREEN, or TENNIS GOURT MIXTURE}

A very carefully prepared mixture for use on putting greens, croquet lawns, tennis courts, bowling greens and lawns. This mixture produces a very thick, soft growth, when sown on a well-prepared ground, and mowed short will allow a ball to roll in almost a direct line. We especially recommend this mixture to those who are particular to obtain the very best. Our mixture contains only the very fine-bladed species of grasses without Rye Grass. $25 \mathrm{lbs}$. will seed a putting green 75 feet square.

Price: 5 lbs. $\$ 4.00,25$ 1bs. $\$ 17.50,100$ lbs. $\$ 70.00$.

\section{MARSHALL'S FAIR GREEN MIXTURE}

Marshall's Fair Green Mixture is composed mainly of perennial native grasses and two very important European grasses which have proven of great value for Fair Green use. They are all of dwarf spreading growth, forming a close velvety surface which improves from year to year if given proper care.

This mixture contains no Clover but will be added if desired in quantity of one-half pound per bushel of grass seed. Sow $100 \mathrm{lbs}$. per acre.

Price: 20 lbs. $\$ 10.00,100$ lbs. $\$ 48.00$.

\section{GRASS FOR HAY CROPS AND PASTURES}

\section{MIXTURES FOR HAY AND PERMANENT PASTURES}

The results obtained from our special Grass Seed mixtures are well known by the constantly increasing demand for them. Fall seeding is preferable, but Spring sowing will be successful if done early, while the land is cool and moist. In addition to the Grasses, we advise sowing $10 \mathrm{lbs}$. of Mixed Clover Seed per acre.

We recommend sowing 50 lbs. to the acre.

PERMANENT PASTURE MIXTURE NO. 1. For cool and light soils. Bus. (15 lbs.)

PERMANENT PASTURE MIXTURE NO. 2. For medium soils. Bus. (15 lbs.)

PERMANENT PASTURE MIXTURE NO. 3. For heavy soils. Bus. (15 lbs.)

Prices of any of the above Mixtures, $10 \mathrm{lbs}$ \$5.25, $50 \mathrm{lbs}$. $\$ 25.50,1001 \mathrm{bs}$. $\$ 50.00$.

\section{GLOVERS}

Prices subject to market changes.

Alfalfa, or Lucerne (Medicago sativa). Northwestern Pine Tree. One of for acre Per lb. bushel $100 \mathrm{lb}$ the most valuable forage plants....................... 20 lbs. $\$ 0.45 \$ 21.00 \$ 35.00$

Alfalfa, Grimm. Certified. Much hardier than any other variety . . . . . 20 20 lbs. $\quad .75 \quad 36.00 \quad 60.00$

Alsike (Trifolium hybridum). The hardiest of all Clovers, can be cut several times in one season. Grows well on low, wet land................ 10 lbs. $\quad .60 \quad 30.00 \quad 50.00$

Crimson, or Scarlet Clover (Trifoliuin incarnatum). Pine Tree. An annual variety producing large crops of green foliage. . . . . . . . . . . . . . . . . 20 lbs. $\quad .30 \quad 12.00 \quad 20.00$

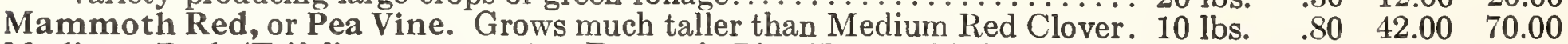

Medium Red (Trifolium pratense). Domestic Pine Tree. This is the common Red Clover so largely grown throughout the country............ 15 lbs. $\quad .80 \quad 42.0070 .00$

Medium Red. Imported seed. Ten per cent stained seed. . . . . . . . . . . . 15 lbs. $\quad .60 \quad 30.00 \quad 50.00$

Sweet Clover, Bokhara (Melilotus alba). Pine Tree. Will grow on very poor soils; usefu! for ensilage and plowing under. Grows from 3 to $4 \mathrm{ft}$.

high. Hulled seed.............................. 15 lbs. $\quad .35 \quad 15.00 \quad 25.00$

White Clover (Trifolium repens). The best variety for lawns; valuable in

INOCULATE THIS SEED WITH

MULFORD CULTURE

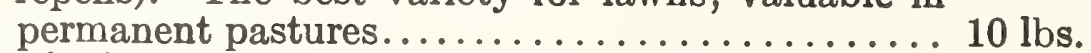

$\begin{array}{lll}.80 & 42.00 \quad 70.00\end{array}$

$\begin{array}{lll}.65 & 36.00 \quad 60.00\end{array}$

For Clovers, bushel size $\$ 1.00,21 / 2$ bushels $\$ 2.25,10$ bushels $\$ 8.00$. State which variety of Clover wanted for. 


\section{GRASS SEEDS \\ For Pasture, Mowing and Lawn}

Prices subject to market changes.

Bermuda Grass. Used in the southern states for Lawns.

Canadian Blue Grass (Poa compressa). A more rapid grower than Kentucky Blue Grass and equally good for pasture, but not as suitable for lawns. This is an excellent pasture grass for poor, dry land and should be more largely used for this purpose.......................................

Greeping Bent Grass Mixed (Agrostis species). Desirable for mixing with other lawn or pasture grasses........................................... Roots fibrous and tufted This is a most valuable permanent pasture grass. For parks this grass is

well suited because of its fine, close growth and pleasant green color......
English Rye Grass (Lolium perenne). Produces a strong growth in four or five weeks after sowing. It cures into a hay that is rather hard, but having a sweet flavor and much relished by cattle and horses. Sow $60 \mathrm{lbs}$. to acre.

English Rye Grass (Pacey's). A carefully selected, short-seeded, dwarf-

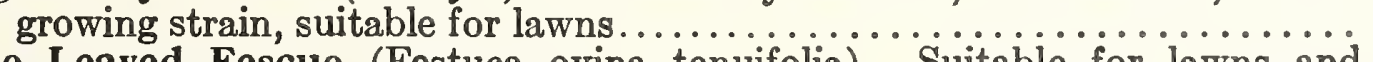

Fine Leaved Fescue (Festuca ovina tenuifolia). Suitable for lawns and

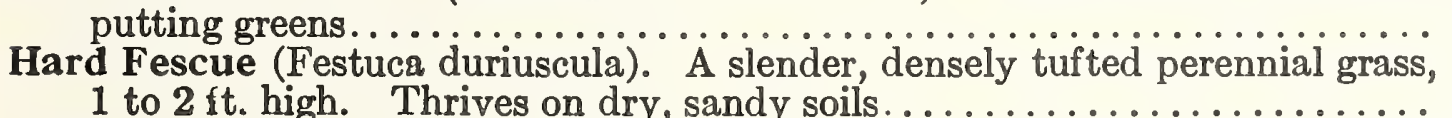

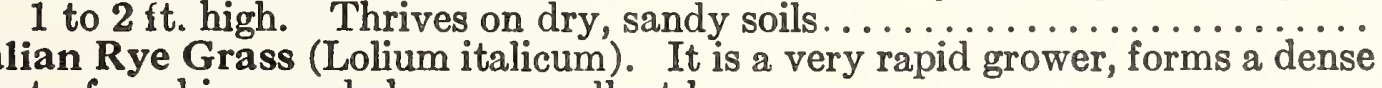

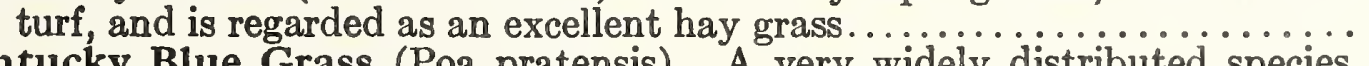

Kentucky Blue Grass (Poa pratensis). A very widely distributed species, and without a rival as a pasture grass. Being of perennial habit, it will, when established, last indefinitely. One of the finest varieties of grasses

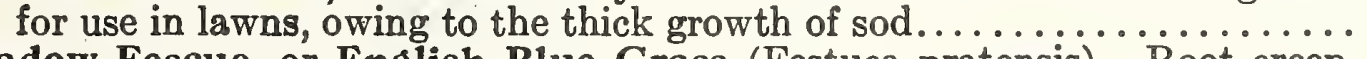

Meadow Fescue, or English Blue Grass (Festuca pratensis). Root creeping; perennial; flowers in July; one of the most valuable of the Fescue grasses. This grass is well adapted for permanent pastures. It grows rapidly in rich and rather moist soils and makes an excellent pasture grass, its long, tender leaves being much relished by cattle. It should be always

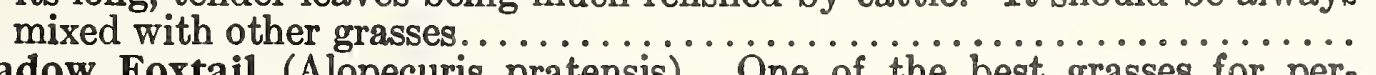
manent pasture, and should always form a fair proportion of the mixtures for that purpose. Thrives best on a rich, strong soil......................... 10 lbs.

5 lbs. $\quad .55 \quad 7.00 \quad 4500$ thrives on inferior soils, gravelly banks and exposed hills. $25 \mathrm{lbs}$. to acre. $14 \mathrm{lbs}$.

Orchard Grass. A good grass for hay crop, yielding nearly the same amount as Timothy and almost equal in feeding value. Orchard Grass will grow on almost every soil. It prefers a moderately dry soil with considerable sandy material. One of the best grasses for sowing in shady places and

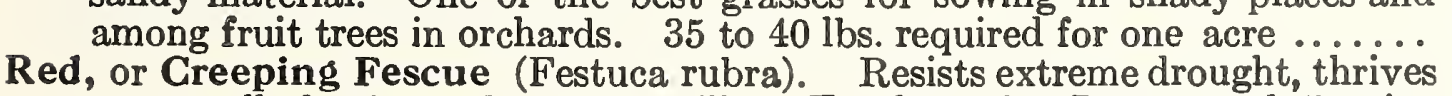
on gravelly banks and exposed hills. Excellent for Lawns and Putting Greens, 25 lbs. per acre ................. for permanent pasture and as meadow grass for hay. Red Top is especially valuable for sour and acid soils, and meadow lands. Red Top makes one of the best grasses for lawn use, either sown alone or in connection with White Clover, or in a mixture with other grasses. Use 14 to $16 \mathrm{lbs}$.

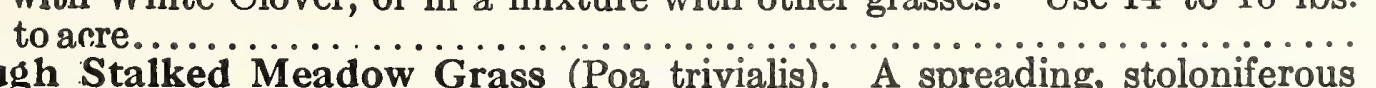

Rough Stalked Meadow Grass (Poa trivialis). A spreading, stoloniferous

rooted grass. Adapted for shady lawns and pasture mixtures..............
Sheep Fescue (Festuca ovina). A small tufted, hardy grass, of value in mix-

ture for lawns or dry soil..................................................................
Tall Meadow Oat Grass (Avena elatior).
in July; of luxuriant growth, and valuable in permanent pasture on account

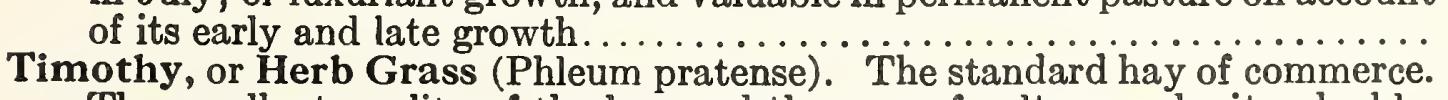
The excellent quality of the hay and the ease of culture make it valuable. It is adapted to most soils, but succeeds best on moist loam and clay. Timothy sown alone requires about 20 lbs. per acre; when sown with Red

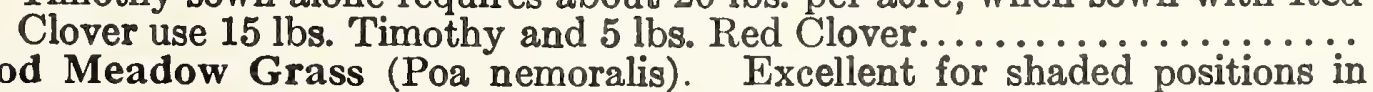
lawns and woodland parks. Very hardy, resisting extremes of heat and cold. $14 \mathrm{lbs} . \quad 1.00 \quad 12.00 \quad 85.00$ 


\section{FARM AND FIELD SEEDS}

\section{BARLEY}

$48 \mathrm{lbs}$. to the bushel, 2 bushels to the acre.

Peck Bush.

Beardless Spring. This variety is free from beards................. \$1.25 \$4.00

\section{BEANS}

Sow $1 / 2$ to $3 / 4$ bushels to the acre. Soja Bean, Mammoth Yellow. Valuable as a forage crop and for fertilizing the soil. Thrives well in hot and dry weather. Sow broadcast $1 / 2$ bushel to acre, or plant in drills $3 \mathrm{ft}$. apart and $1 \mathrm{ft}$. between plants......... 1.25

4.50

\section{BROOM CORN Lb. 100 lbs.}

Evergreen. Succeeds in a good, deep soil; it is very sensitive to cold. Sow

$10 \mathrm{lbs}$. to acre............. \$0.20 \$15.00

\section{BEET, MANGEL-WURZEL}

Sow 6 to 8 pounds to acre.

Lb.

Champion Yellow Globe. Bright orange color; globe-shaped and of excellent quality......\$0.75

Danish Sludstrup. A long, reddish yellow va-

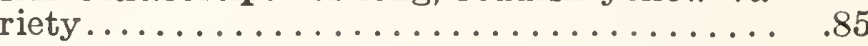

Golden Tankard. An enormous yielder per acre. Flesh deep yellow................ .75

Mammoth Long Red. The largest and heaviest cropper of all the Mangels.............

\section{BUCKWHEAT}

48 pounds to the bushel. Sow 1 bushel to the acre.

Japanese. Earliest and most productive Peck Bush. of the Buckwheats.............. \$1.25 \$4.00

\section{FIELD CORN}

8 quarts will plant 1 acre in hills, 3 bushels will sow 1 acre broadcast

\section{FLINT VARIETIES}

Peck Bush.

Early Yellow Canada. A very desirable variety. Ears rather small, 8-rowed and deep grained. The earliest Flint Corn, usually ripening in August and producing a

Golden Nugget. Very early, large ears, which a werage from 12 to 15 in. long................... 1.50

Longfellow. A very large-eared Flint variety, grown very extensively in this vicinity for its productiveness. Ears 8-rowed, often 14 to 15 in. long, with small cob and deep kernels.......................... 1.25

Luce's Favorite. $\ddot{A}$ hybrid between the Yellow Flint and Golden Dent. Ears large and abundant foliage. Valuable for ensilage or as a shell corn .............. 1.50

Sanford White Flint. Of spreading habit, long ears and very tall. Valuable for fodder................... 1.25

$\$ 4.50$

5.00

\section{DENT VARIETIES}

Improved Leaming. Large, handsome ears, deep-grained and of a deep orange color. An early maturing variety, distinctly Dent, and a great yielder.................. 1.25

Lancaster County Sure Crop. A good variety for crib or silo. Long ears with deep yellow grains............ 1.50

Mastodon Improved. A very early large-eared sort. A

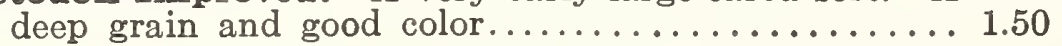

\section{FODDER AND ENSILAGE VARIETIES}

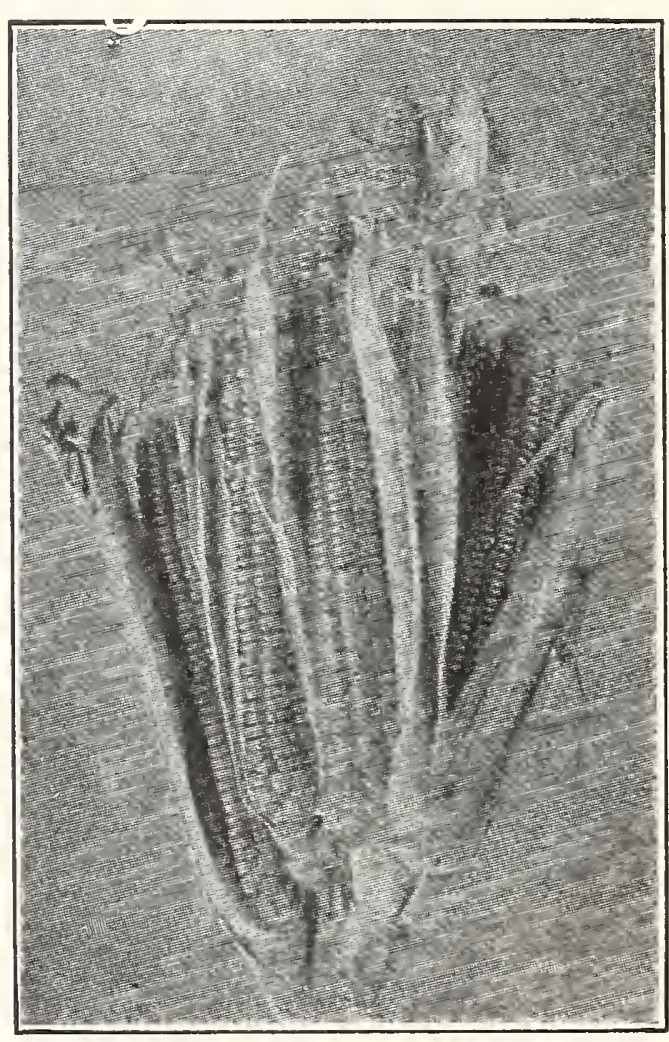

Longfellow Corn

Eureka. One of the finest and most productive field Corns grown. The plants grow 12 to $15 \mathrm{ft}$. Peck Bush. high. Valuable for ensilage or as a yellow Dent Corn ........................ $\$ 1.25 \$ \$ 4.50$

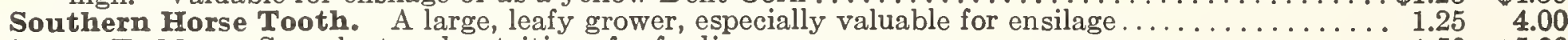

Sweet Fodder. Succulent and nutritious for feeding green $\ldots \ldots \ldots \ldots \ldots \ldots \ldots \ldots \ldots \ldots$

\section{MILLET}

Golden. Very large crop, though not so early as Hungarian. Grows 3 to $5 \mathrm{ft}$. high. Requires good soil. Sow 1 bushel to the acre, 48 lbs. to the bushel......... \$0.15 $\$ 4.25 \$ 8.00$

Hungarian. A favorite Summer forage crop. Sow in June, can be cut in about 60 days. Will yield two to three tons of hay per acre. Withstands heat and drought well. Plant about 3 pecks to 1 bushel per acre, 48 Ibs. to the bushel............

Japanese. Sometimes called Barnyard Millet. Grows very tall, 6 to $7 \mathrm{ft}$.; makes valuable forage and is the greatest yielder of all the Millets. Sow about $15 \mathrm{lbs}$. lbs. per acre, 35 lbs. to the bushel
Lb. Bus. $100 \mathrm{lbs}$.

$\begin{array}{lll}.15 & 4.00 & 7.50\end{array}$
$.20 \quad 3.00 \quad 7.50$

\section{OATS}

Sow 2 to 3 bushels to the acre, 32 lbs. to the bushel.

Storm King. The heads measure from 8 to $10 \mathrm{in}$. and the kernels are of immense size, thick, plump and heavy. It is very early, has great length of straw, producing 70 bushels per acre. We can safely say it is the greatest producer of any variety of Oats grown in this country. Bus. $\$ 2.75,10$ bus. or over $\$ 2.50$ per bus.

Canada Cluster. A very early variety with long straw and thick, plump heavy grains. A true side Oat and heavy cropper. Bus. $\$ 2.50,10$ bus. or over, $\$ 2.25$ per bus.

Swedish Select. A strong grower, grain rather short, plump and heavy. Yields well on any soils and under varied conditions. They have a stiff straw and are a branching variety with a great root development. Bus. $\$ 2.75,10$ bus. or over, $\$ 2.50$ per bus.

Prices on all Farm Seeds are subject to market fluctuations. 


\section{PEAS}

Canada Field. Valuable for cattle feeding. Also used for ensilage. Sown broadcast in the Spring at the rate of two bushels to the acre. Pk. $\$ 1.50$, bus. $\$ 5.50$.

Cow Peas, Clay. This variety is of extra strong growth and specially adapted for sowing in Northern States. Sow 2 bushels per acre, 60 lbs. per bushel. Bus. $\$ 6.00$.

Cow Peas, Whippoorwill. A very early maturing variety of upright or bush growth. Bus. $\$ 6.50$.

\section{RAPE}

Dwarf Essex. Fine for sheep pasture; valuable as a soil enricher. Plant in June or July in drills at the rate of 3 lbs. per acre, broadcast 5 lbs. per acre. Can be planted alone or with other forage crops. Lb. 25 c., 100 lbs. $\$ 15.00$.

\section{RYE}

For grain, 1 bushel to the acre; for forage or soiling, $11 / 2$ bushels, 56 lbs. to the bushel.

Spring. This is excellent for a catch-crop, as it may be sown somewhat later than other grains and produces an abundance of green feed in the Summer season. $\mathrm{Pk}$. $\$ 1.25$, Bus. $\$ 4.50$.

Giant Winter. This variety is fast gaining in popularity as a cover crop. If allowed to mature will produce a heavy crop of grain, and a fine quality of straw if cut about July 1 . Pk. $\$ 1.00$, bus. $\$ 3.50$. .

New Rosen. A four-row Winter variety introduced in Michigan. $\mathrm{Pk}$. $\$ 1.25$, bus. $\$ 4.00$.

\section{SORGHUM}

Early Amber Sugar Cane. The earliest and most productive variety. Height, 10 to $12 \mathrm{ft}$. For ensilage or fodder it possesses good qualities: stock of all kinds relish it. Sow 7 lbs. in drills, or 15 lbs. broadcast, to acre. Lb. 15c., 100 lbs. $\$ 12.00$.

\section{SUDAN GRASS}

A new forage crop of immense value. Sudan Grass is strictly an annual and dies each year like Millet and must be seeded again each Spring. Sudan Grass reaches a height of from 7 to 9 feet, yet the stems are small and tender. The plant stools wonderfully and produces under favorable conditions as many as 100 stalks from a single root. The seed should not be planted until the soil has become warm in the Spring, and preferably on warm, light soil. Sow in drills 2 to 3 lbs. per acre; broadcasted, 16 to 24 lbs. per acre. Cut just after bloom, so ample time may be had for second growth. Lb. 25c., 100 lbs. $\$ 20.00$.

\section{SUNFLOWER}

Mammoth Russian. Very productive, large heads with large seeds. Valuable for poultry ; $5 \mathrm{lbs}$. will plant 1 acre. Lb. 25c., 25 lbs. $\$ 4.50,100$ lbs. $\$ 16.00$.

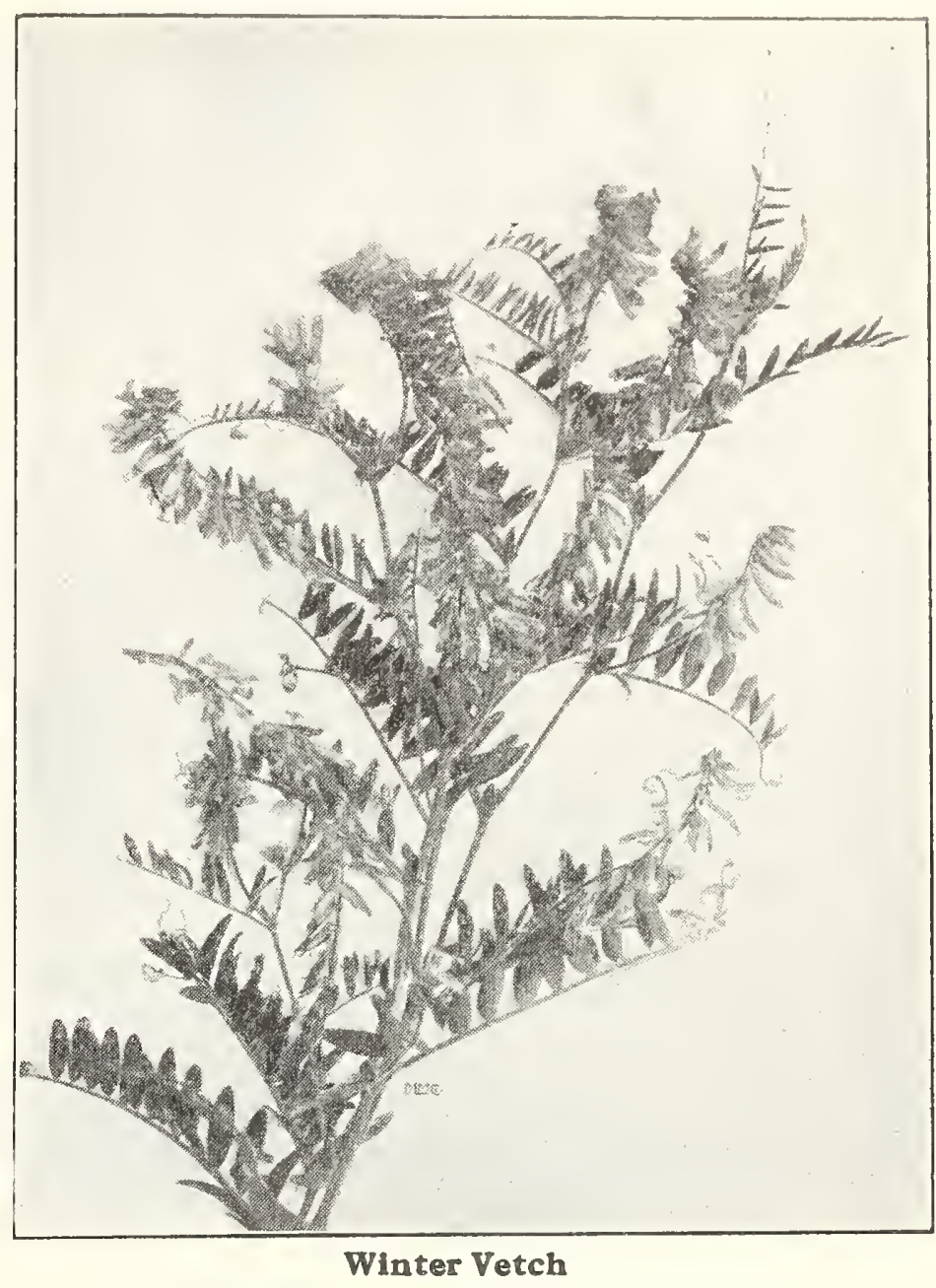

VETCHES, OR TARES

Spring Vetches (Vicia sativa). Highly valuable for soiling or for green manuring. Sometimes grown with Oats for mowing and feeding to stock. Use 40 to $60 \mathrm{lbs}$. to the acre. Sow in Spring while ground is cool and moist, or in early Autumn. Lb. 15c., 100 lbs. $\$ 10.00$.

Winter Vetches (Vicia villosa). Also called Sand Vetch, or Hairy Vetch. Recommended for Fall sowing with Rye. A valuable food for stock in early Spring. Use 30 to $50 \mathrm{lbs}$. per acre. Lb. 30c., 100 lbs. $\$ 25.00$.

\section{WHEAT}

The seed Wheat we offer is grown in Pennsylvania by a very reliable grower, especially for seed purposes. Sow $11 / 2$ bushels to the acre.

Marquis Spring. A very early beardless Wheat that succeeds well in the East, producing larger yields than any other kind. Sow as early as possible about $21 / 2$ bushels per acre. Bus. $\$ 4.50$.

Leap's Prolific. A very hardy, beardless white chaff and dark amber grain. Straw long land stiff and ripens early. Market price.

Pennsylvania 44. A bearded, large red variety originated at the Pennsylvania State College Experiment Station some years ago. Market price.

Trumbull. A medium size, red hard grain, beardless, great yielder, and stands up well. Market price.

Prices on all Farm Seeds are subject to market fluctuations.

\section{DU PONT SEMESAN}

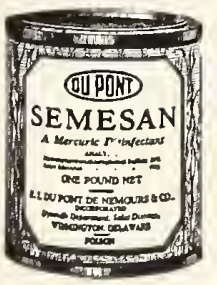

Accelerates Seed Germination. Stimulates Plant Growth. Controls Diseases. In. creases Crop Yields.

Semesan, a complex organic mercurial, while primarily a disinfectant for the control of seed borne diseases, possesses at the same time the remarkable properties of accelerating and increasing germination, producing more vigorous seedling growth and increasing crop yields from 5 to 40 per cent. It is suitable for the treatment of field, truck, forage and cereal crops, as well as flowers, grasses and ornamental plants. Applications of Semesan by either the dusting or liquid methods will in no way harm the seed germ.

Price 60c. per 2 oz. bottle; 4 oz. bottle, $\$ 1.00 ; \$ 1.60$ per 8 oz. can; 1 lb. can, $\$ 2.75 ; \$ 13.00$ per 5 lb. can; 25 lb. can, $\$ 62.50$. 


\section{Marshall's Matchless Flower Seeds}

\section{ALL FLOWER SEEDS ARE MAILED FREE AT PACKET, OUNCE AND POUND RATE TO ANY POST OFFICE IN THE UNITED STATES}

The following list contains a most complete assortment of the choicest and most popular flowers for either conservatory, greenhouse or garden culture.

Annuals grow from seed, flower, mature their seed, and die in one year, or, in other words, the same season.

Hardy Annuals are those which can be sown in the open ground.

Half-Hardy Annuals are those which should be started early in the house, conservatory or hotbed, and transplanted to the garden in settled warm weather.

Biennials grow from seed, sown from June to August, flower, ripen their seed and die the next year, though some varieties bloom the same season if sown early in gentle heat.

Hardy Biennials will winter in the open ground without protection.

Perennials grow from seed, and continue flowering annually for many years after the first season. Some varieties flower the first season if planted early in gentle heat.

Half-Hardy Biennials require the protection of a coldframe or cool house during Winter.

Hardy Perennials can remain in the open ground during Winter without protection.

Half-Hardy Perennials require the protection of a coldframe or cool house during the Winter.

Tender or Greenhouse Perennials require window or greenhouse culture, free from frost during Winter and thrive in the garden during the warm months.

\section{EXPLANATION OF FLOWER SEED ABBREVIATIONS}

H.A. designates Hardy Annuals-I - asting but one year. H.H.A. " Half-Hardy Annuals-Lasting but one year. H.B. " Hardy Biennials-Lasting but two years.

H.H.B. " Half-Hardy Biennials-Require protection . . during Winter.

H.P. “ Hardy Perennials-Lasting three or more years.
H.H.P. designates Half-Hardy Perennials-Require protection H during Winter.

G.P. “ “ Greenhouse Plant.

H.A.C. “ Hardy Annual Climber.
ABOBRA virdiflora. H. A. C. A rapid-growing climbing plant, scarlet fruit. $10 \mathrm{ft}$.

ABRONIA umbellata. H.A. Trailing annual, pink flower trusses 9 in.........1/4 oz. 25c.

ABUTILON. New Hybrids. G.P. Mixed, large bell-shaped flowers.

ACACIA. G.P. Finest mixed, elegant Winter and Spring flowering plants.

ACHILlEA ptarmica, "The Pearl." H.P Double white flowers........ $\frac{1}{16}$ oz. $\$ 1.00$

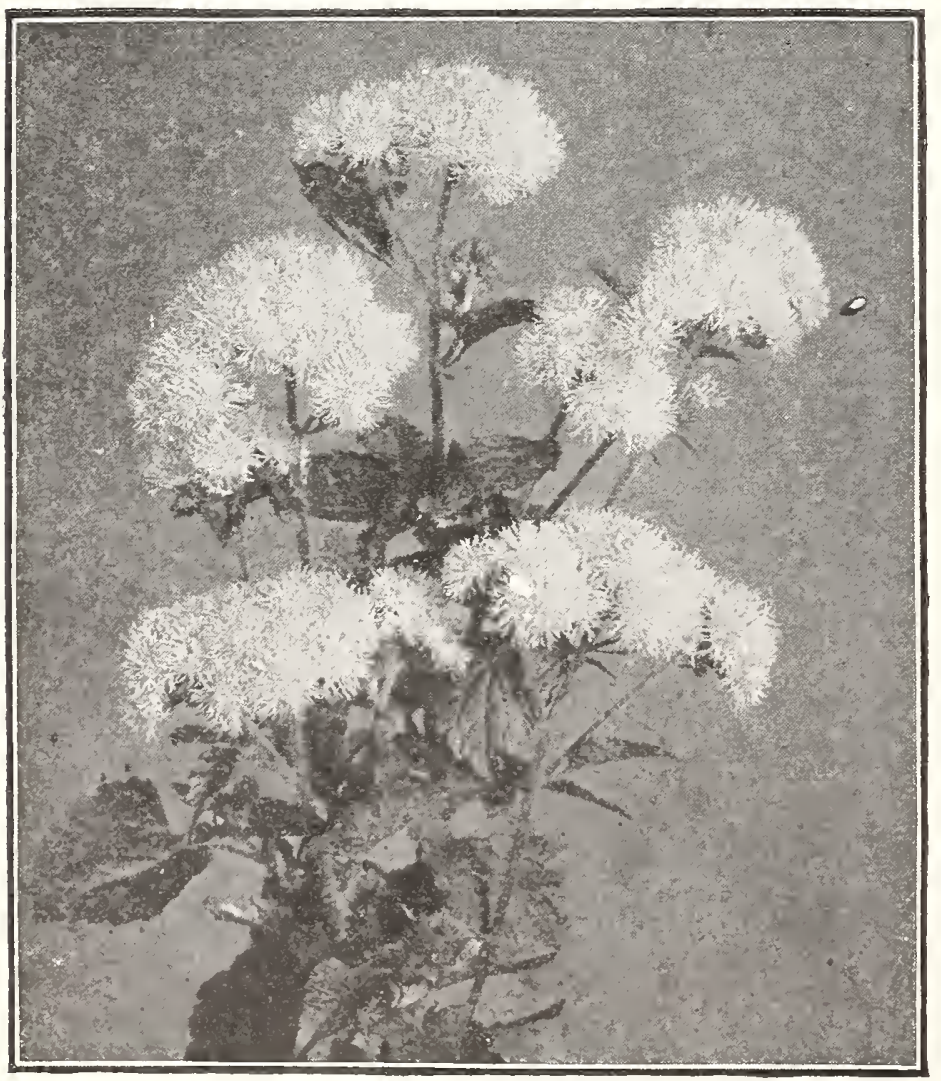

Ageratum, Dwarf Blue
Pkt.

ACONITUM napellus. H.P. Large, dark blue flowers in August..............1/4 oz. \$1.00\$0.15

wilsoni. Light blue flowers in large trusses. . . . 25

ACROCLINIUM. H. A. Pretty everlasting flowers; fine for Winter bouquets. $1 \mathrm{ft}$.

album. Pure white; double flowers. 1/4 oz. 25c. $\quad .10$

roseum. Bright rose; double flowers. $1 / 4$ oz. $30 \mathrm{c} . \quad .10$

Finest Mixed Colors............1/4 oz. 20c. $\quad .10$

ADLUMIA, cirrhosa (Mountain Fringe) H.B.

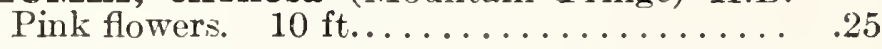

ADONIS autumnalis. H.A. Flowers crimson with dark center. $1 \mathrm{ft} . \ldots . . . \ldots \ldots 1 / 4$ oz. 25c. $\quad .15$

vernalis. H.P. Large, yellow; flowers in early Spring. $11 / 2 \mathrm{ft} \ldots \ldots \ldots \ldots \ldots \ldots$ oz. $75 \mathrm{c}$.

AGATHAEA coelestis (Blue Marguerite). H.H.P. Pretty blue Daisy-like flowers. An excellent pot plant. $1 \frac{1}{2} \mathrm{ft} \ldots \ldots \ldots \ldots$

AGERATUM. H.A. Blooms throughout the Summer; feathery flowers in clusters.

mexicanum. Fine for bedding or pot culture. Blue. $11 / 2 \mathrm{ft} \ldots \ldots \ldots \ldots \ldots \ldots \ldots$. $1 / 4 . \ldots$. $30 \mathrm{c}$. mexicanum album. A beautiful white variety. $11 / 2 \mathrm{ft} . \ldots \ldots \ldots \ldots \ldots \ldots \ldots$ oz. $30 \mathrm{c}$.

Imperial Dwarf Blue. Extra neat; fine for edging. 9 in................ . . oz. 50c.

Imperial Dwarf White. Pretty for contrast; fine for edgings. 9 in..........1/4 oz. $50 \mathrm{c}$. Blue Perfection. Very fine dwarf. 9 in . . . $1 / 4 \mathrm{oz} .50 \mathrm{c}$.

Little Blue Star. Light blue; fine for carpet bedding. 6 in............... $\frac{1}{16}$ oz. $\$ 1.00$

Princess Victoria Louise. " white center. 9 in...........1/4 oz. $\$ 1.00$

Swanley Blue. A fine, large-flowered sort.

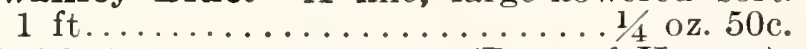
AGROSTEMMA coelirosa (Rose of Heaven). H.A. Bright rose; excellent for cutting. $18 \mathrm{in.}$

Thite $1 / 4$ oz. $35 \mathrm{c}$. coelialba. White............... oronaria (Rose Campion). H.P. Crimson flowers, silver fol iage. $2 \mathrm{ft} \ldots \ldots \mathrm{r} / 4 \mathrm{oz} .35 \mathrm{c}$. ALSTROEMERIA HYBRIDS. Mixed. Lilylike perennials with clusters of flowers on long stems in yellow and orange-red shades. $3 \mathrm{ft}$. 


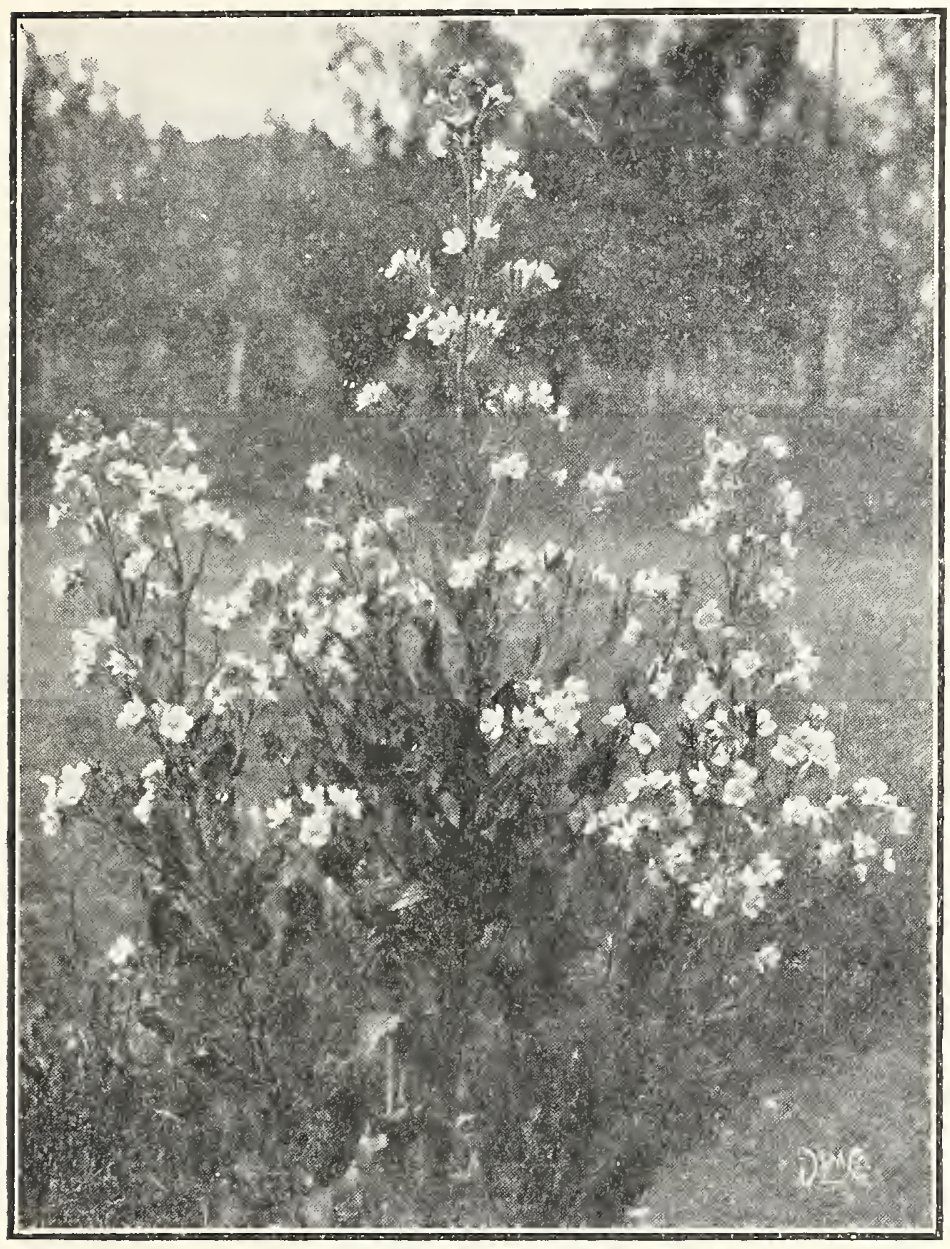

Anchusa grandiflora

ALISSUM. H.A. Pretty little plants for beds, vases, baskets, edgings or rockwork; blooming profusely all summer.

maritimum (Sweet Alyssum). Fragrant, white; flowers all Summer. 6 in. ....oz. 50c. $\$ 0.10$ maritimum compactum, Little Gem. Grows erect; fine for edging. . . . . . . oz. \$1.00 benthami compactum. Lilac Queen. Pure lilac flowers, dwarf and compact growth. 6 in..................... oz. $35 \mathrm{c}$

benthami compactum lutescens. Ycllowish flowers on strictly upright flower spikes. 6 in. $1 / 4$ oz. $40 \mathrm{c}$.

procumbens. Carpat of Snow. Dwarf; pure white. 4 in............... oz. $50 \mathrm{c}$. saxatile compactum. H.P. Spring-blooming Alyssum with yellow flowers. $12 \mathrm{in..1/4} \mathrm{oz} .75 \mathrm{c}$.

AMARAPTHUS. H. A. Ornamental foliage plants, producing a striking effect either in the conservatory or flower garden.

caudatus (Love Lies Bleeding). Long drooping crimson spikes. $3 \mathrm{ft} \ldots \ldots \ldots 1 / 4 \mathrm{Oz} .35 \mathrm{c}$. salicifolius (Fountain Plant). Distinct variety, with graceful drooping leaves. $2 \mathrm{ft.} .1 / \mathrm{oz} .35 \mathrm{c}$.

tricolor (Joseph's Coat). Leaves red, yellow and green. $2 \mathrm{ft} \ldots \ldots \ldots \ldots \ldots .1 / 4 \mathrm{oz} .50 \mathrm{c}$.

AMPELOPSIS veitchi (Japanese Woodbine, or Boston Ivy). H.C......... . $1 / 4$ oz. 40c.

ANAGALLIS grandifiora (Pimpernel). H.H.A. Showy garden plant. $6 \mathrm{ft} \ldots \ldots 1 / 4 \mathrm{oz} .35 \mathrm{c}$

ANCHUSA capensis. H.A. Flowers resembling large Forget-me-nots. $18 \mathrm{in} \ldots 1 / 4$ oz. $75 \mathrm{c}$. grandiflora (Dropmore Variety). H.P. Large flowered, dark blue, $5 \mathrm{ft}, 1 / 8$ oz, $50 \mathrm{c}$

ANEMONE. H.P. A very pleasing perennial, producing large flowers. 12 in,

coronaria, St. Brigid (Poppy Anemone). Mixed colors..............1/8 oz. $50 \mathrm{c}$

ANGEL ONIA grandifiora. G.P. A sweet-scented greenhouse plant with dainty mauve sprays of flowers. $2 \mathrm{ft}$.

ANTHEMIS kelwayi. H.P. Very pretty small flower, like a yellow Chrysanthemum. 6 in.

$1 / 4 \mathrm{OZ} .75 \mathrm{c}$.
ANTIRRHINUM. H.H.B. The Snapdragon is one of our finest biennials, flowering the first year as annuals. Their rich spikes are beautiful for cutting, and keep fresh a long time. From seed sown in the open ground plants will bloom in July and August.

Large-flowering Half-Dwarf Varieties. The best for bedding purposes, growing about 18 inches high.

Dwarf Black Prince. Dark-leaved, blackish crimson purple..............1/8 oz. 50c.\$0.15

Dwarf Defiance. Fiery scarlet....1/8 oz. 50c. .15

Dwarf Golden Queen grandifiora. Pure yellow....................... $1 / 8$ oz. $50 \mathrm{c}$.

Dwarf Queen of the North. White. $1 / 8 \mathrm{oz} .50 \mathrm{c}$. Dwarf roseum superbum. Rosy-pink. $1 / 8$ oz. $75 \mathrm{c}$.

Dwarf the Bride. White, changing to delicate rose the Bride. $1 / 8$ oz. $50 \mathrm{c}$.

Dwanf Fine Mixed. All colors. . . 1/4 oz. 60c.

Collection of six above varieties.

Marshall's Giant-flowering Varieties. These grow about 3 feet high and are all of the large flowering types.

Matchless White. A selected strain for grow-

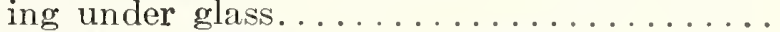

Matchless Yellow. A fine strain for greenhouses.

Bonfire. Bright cinnabar red, yellow blotch.

$\begin{array}{lll}1 / 4 & \text { Oz. } 75 \mathrm{c} . & .15\end{array}$

Coral Red. Rich, with red throat. $1 / 4$ oz. 75c. .15

Defiance. Fiery scarlet..........1/4 oz. 75c. .15

Firefly. Scarlet and white.......1/4 oz. 50c. .15

Indian Summer. A rich velvety and glossy copper color

Keystone. Fine foreing pink

Nelrose. Rich coral pink. A splendid forcer.

Philadelphia Pink. A beautiful greenhouse pink.

Queen Victoria. Large white. . . . 1/4 oz. 50c. .15

roseum. Rose............1/4 oz. 50c. .15

Ruby. Pure ruby red............1/4 oz. 50c. .15

Salmon Pink. Very large flowering $1 / 4$ oz. $75 \mathrm{c} . \quad .15$

Silver Piniz. A large flowering variety. Ramsburg strain

Scarlet Giant. A fine forcer

Striped. Odd and pretty........

Venus. Delicate rose on white ground.

Giant Yellow..............1/4 oz. $60 \mathrm{c}$.

Giant Large-flowered Mixed. Fine variety of colors $1 / 4$ oz. 50c.

Col ection of six distinct varieties

Collection of twelve distinct varieties

AQUILEGIA or Columbine. H.P. Fine, free flowering, hardy border plant-one of our most desirable perennials. Seed may be planted in the open ground early in Spring and will in some varieties bloom in the same season. Best results, however, are obtained by planting in August for the next season's blooming.

Marshall's Matchless Long-spurred Hybrids. A grand variety of color's of the longspurred and large-flowered forms. $3 \mathrm{ft}$.

$1-16 \mathrm{oz} . \$ 1.00$
caerzlea hybrida. Large flowered blue hy-
brids. $3 \mathrm{ft}$ brids. $3 \mathrm{ft} \ldots \ldots \ldots \ldots \ldots \ldots \ldots 1 / 8$ oz. $75 \mathrm{c}$. chrysantha. Long-spurred, golden yellow. $2 \mathrm{ft} \ldots \ldots \ldots \ldots \ldots \ldots \ldots \ldots \ldots \ldots \ldots . \ldots \ldots$ oz. $75 \mathrm{c}$. chrysantha grandifiora alba. Large pure white. $2 \mathrm{ft} \ldots \ldots \ldots \ldots \ldots \ldots \ldots 1 / 8$ oz. $\$ 1.00$ glandulosa vera. Dark blue, with white. 12 in. skinneri. A beautiful scarlet, tipped green. $2 \mathrm{ft}$. $1 / 8 \quad$ oz. $\$ 1.00 \quad .25$ Collection of frve choice varieties....... 1.00 Single. Mixed colors ..........1/4 oz. $75 \mathrm{c} . \quad .15$

Douńle-fiowering. Mixed colors. $1 / 4 \mathrm{oz} .75 \mathrm{c} . \quad .15$ Special Mixture. Double and Single Hykrids. This mixture includes many longspur:ed Irybricis in all colors....1/4 oz. $75 \mathrm{c}$. 
ARABIS alpina. H.P. Excellent for borders or rockwork. Pure white. 6 in....1/4 oz. 50c.\$0.15 grandiflora rosea. A beautiful pink variety.

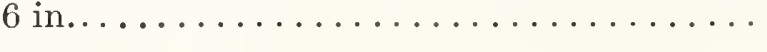

ARCTOTIS grandis. H.A. Daisy-like flowers; white shaded blue. $2 \mathrm{ft} . \ldots \ldots \ldots 1 / 4 \mathrm{oz} .50 \mathrm{c}$.

ARMERIA, Giant Thrift. H.P. A pretty edging plant with deep pink flowers. 12 in...

ASPARAGUS plumosus nanus. G.P. Graceful and feathery bright green foliage. $8 \mathrm{ft}$. 100 seeds $\$ 1.00$

sprengeri. A handsome variety of rapid growth for hanging baskets. $3 \mathrm{ft}$.

100 seeds, $50 \mathrm{c}$.

ASPERULA odorata (Woodruff). H.P. The white flowers and foliage are perfumed. 12 in....

Pkt. .50 .15 .15

.15

\section{ASTERS}

Plants from seeds sown in the open ground in May bloom finely in September and October, when the flowers are seen at their best. For July and August flowers sow in March or April, in coldframe, spent hotbed, or pots and boxes in the house. Cover the seeds about half an inch deep with rich, light soil, and when the plants have three or four leaves, transplant about 18 inches apart each way into well-prepared beds.

CERTSANTHEMUM - FLOWERED. Dwarf. A splendid variety of compact habit. $12 \mathrm{in}$.

\section{Apple Blossom}

Dark Blue.

Fiery Scarlet.

Light Blue

White.

Rose.

$\$ 1.25 \$ 0.15$

$1.25 \quad .15$

$1.25 \quad .15$

$1.25 \quad .15$

Finest Mixed Colors

CREGO'S GIANT. Very early; on style of Queen of the Market, but with fluffy, graceful large flowers. $2 \mathrm{ft}$.

\section{Crimson.}

Lavender. . . . . . . . . . . . . . . . 1.00

Purple........................ 1.00

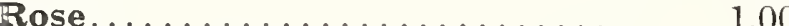

White ......................... 1.00

Finest Mixed. All colors............ $\quad .75$

GIANT BRANCHING COMET. A Giant Conet type of Branching Asters. All large, full flowers. $2 \mathrm{ft}$.

\section{Crimson}

Lavender.

Light Pink

Royal Purple.

Rose.

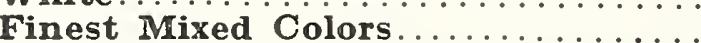

IMPROVED GIANT BRANCHING. The flowers are large and fine for cutting. $2 \mathrm{ft}$

Crimson................. 1.00

Dark Blue. . . . . . . . . . . . 1.00

Light Blue.................. 1.00

Rose . . . . . . . . . . . . . . . . . 1.00

Shell Pink................... 1.00

White ..................... 1.00

Finest Mixed. All colors............ 1.00

Collection of six varieties................

MARSHALL'S KING. Upright growth; large flowers with long and narrow petals. $2 \mathrm{ft}$.

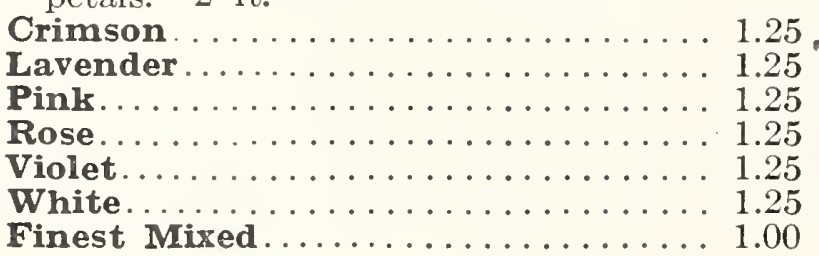

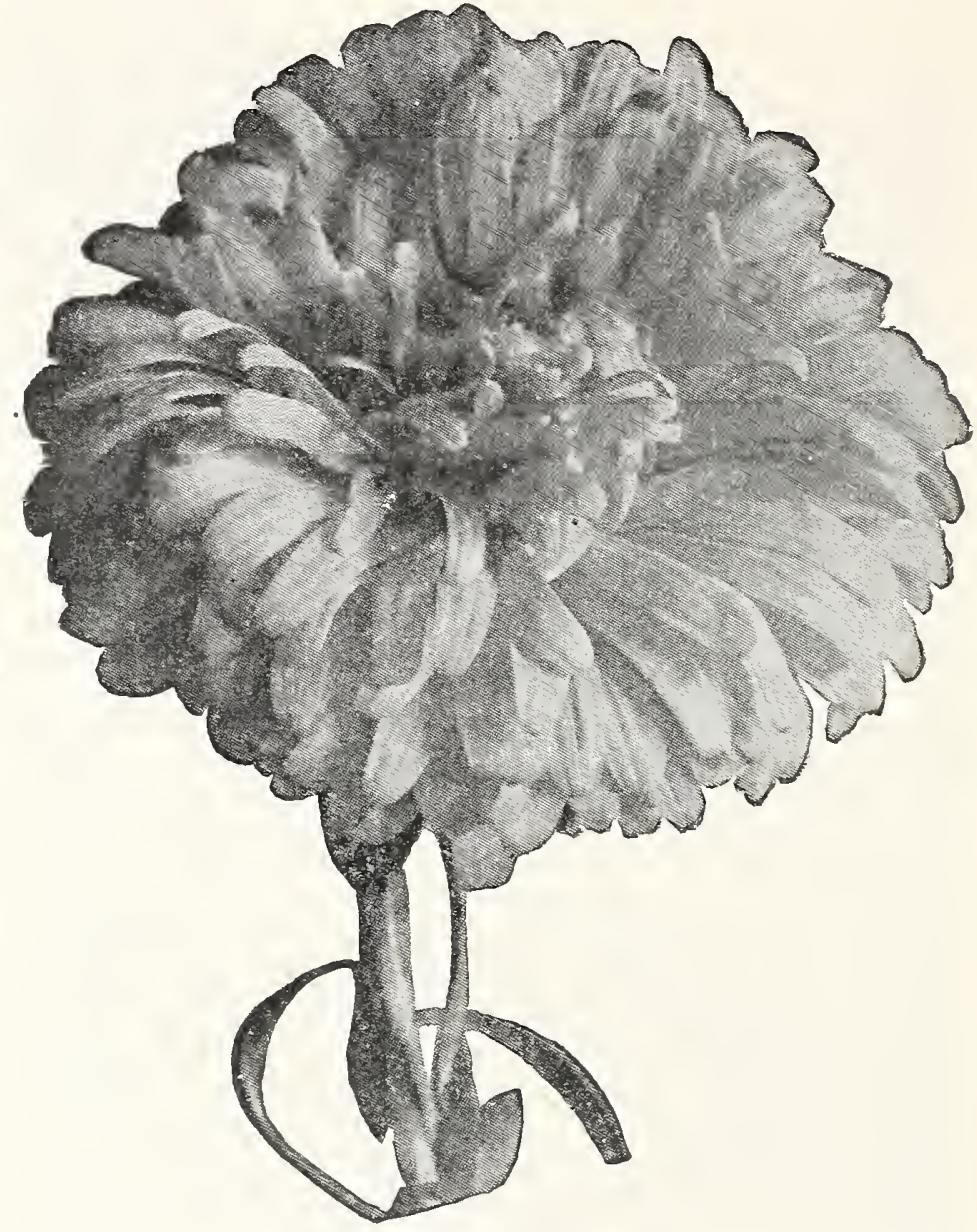

Aster, Queen of the Market

$1 / 4 \mathrm{Oz} . \mathrm{Pkt}$

OSTRICH PLUME. Splendid class, fine for cutting. $18 \mathrm{in.}$

Crimson.......................\$1.00 $\$ 0.10$

Light Blue.................... $1.00 \quad .10$

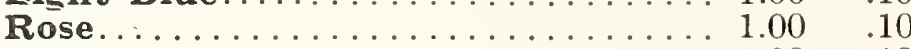

White ............................ $1.00 \quad .10$

Finest Mixed Colors.......... 1000

QUEEN OF THE MARIRT. The earliest of all; in full bloom two weeks before most other sorts. $18 \mathrm{in.}$

Crimson.................... .75 .10

Dark Blue. $\ldots \ldots \ldots \ldots$

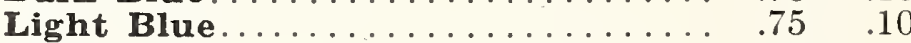

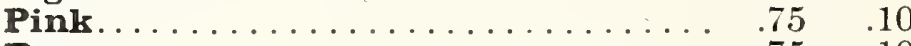

Rose.........

White........................ .75 .10

Choice Mixed. Ail colors........... . .60 $\quad .10$

SINGLE SINENSIS. Popular for cut flowers. 18 in.

Light Blue . . . . . . . . . . . . . . . . . $1.00 \quad .15$

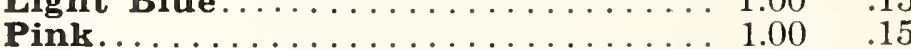

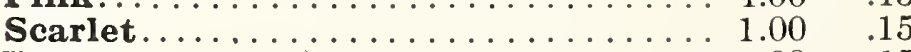

Violet................................. 15

White....................... $1.00 \quad .15$

Finest Mixed Colors...............

VARIOUS ASTERS.

Daybreak. A delicate pink Aster. The flowers are very double and globeshaped. $2 \mathrm{ft} . \ldots \ldots \ldots \ldots \ldots \ldots \ldots . .25$

Enchantress Pink. Very large flowers, delicate $\operatorname{pink} \ldots \ldots \ldots \ldots \ldots \ldots \ldots \ldots . \ldots \ldots$

Purity. Of the same type as Daybreak, differing only in color, which is a pure white. $2 \mathrm{ft} \ldots \ldots \ldots \ldots \ldots \ldots \ldots \ldots .25$

Yellow Fancy. Canary-yellow flowers as large as the Giant Comet. Fine for cutting. $2 \mathrm{ft} \ldots \ldots \ldots \ldots \ldots \ldots \ldots . \ldots \ldots$

ASTER. Mích aelmas Daisy. H.P. Large flowering, hardy mixed, Fall flowering

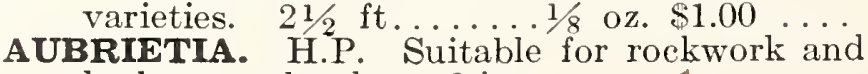
herbaceous borders. 9 in.

graeca. Purple; trailing. . . . . . . . . . . . .25

leichtlini. Carmine; trailing. . . . . . . . . . . $\quad .25$

hybrida grandiflora. Finest mixed colors... .25 
AURICULA, Finest Mixed. H.H.P. The flowers resemble the Primrose. 6 in....... \$ \$0.25

BACHELOR BUTTON. (See Centaurea cyanus).

BALLOON VINE. H.H.C. White flowers, followed by balloon-like seed pods. $15 \mathrm{ft}$.

BALSAM (Lady's Slipper). H.A. Showy and easily grown tender annuals, succeeding best in sunny situations where there is rich loam. 18 in.

Double Dark Blue 1 oz. 50 c Double Salmon............... . . . . . . . $50 \mathrm{c}$. Double Scarlet................ . . . . . . . . 50c.

Double Yellow. . . 1/4 oz. $50 \mathrm{c}$.

Double White................ oz. $50 \mathrm{c}$.

Mixed Colors. Extra choice; double. oz. $\$ 1.00$

Collection Camellia-flowered. Six separate

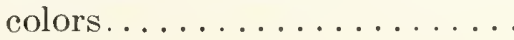

BARTONIA aurea. H.A. Showy garden annual, with large single yellow flowers. 12 in $1 / 4$ oz. $30 \mathrm{c}$.

BEGONIA, Bedding Varieties. H.H.A. The following are of the Semperflorens type. Fine for bedding in full sun or shaded situations.

Dwarf Vernon. Scarlet flowers, dwarf habit. 6 in .................. 1-16 oz. $\$ 2.00$ erfordi. The best carmine bedding variety 6 in. . . . . . . . . . . . . 1-32 oz. $\$ 2.00$ gracilis rosea. Free flowering, delicate rose. 9 in

gracilis luminosa. Flowersfiery deep scarlet. 9 in.

gracilis Mignon. Scarlet flowers, foliage deep green, with red spots and border. 6 in....

gracilis "White Pearl." Pure white flowers, $1 / 2$ in. in diameter, with light green foliage. 9 in.

Salmon Queen. Bright salmon flowers. 6 in. Vernon. Bronze foliage with scarlet flowers. 9 in..... . 1-16 oz. $\$ 2.00$

BEGONIA, Tuberous-rooted. G.P. Produce magnificent flowers; grown either in pots or for bedding.

Marshall's Giant Single, Mixed. Large

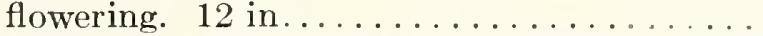

Marshall's Giant Double, Mixed. Large

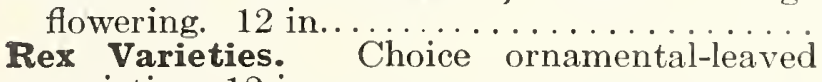

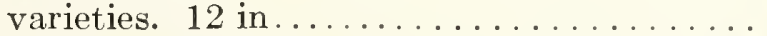

BELLIS perennis fl. pl. (Double English Daisy). H.P. Popular Spring-flowering perennial often used with Pansies and Forget-me-nots. 6 in. Longfellow. Dark rose........... 1/8 oz. $\$ 1.00$ Snowball. Pure white..........1/8 oz, $\$ 1.00$ Giant Red. Good dark red. Very rare..... $1-16 \mathrm{oz} . \$ 1.00$

Giant Mixed................ 1/8 oz. $\$ 1.00$

BLUE LACE FLOWER (See Didiscus caerulea).

BOCCONIA japonica. H.P. A very ornamental, hardy perennial; fine in large beds; flower's white. $6 \mathrm{ft} \ldots \ldots \ldots \ldots \ldots . \ldots \ldots$ oz. 50 .

BOLTONIA asteroides. H. P. Pure white Aste1like flowers. $4 \mathrm{ft}$.

latisquama. Pink flowers, tinged with lav-

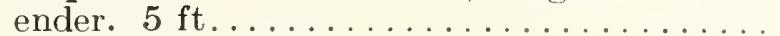

BRACHYCOME iberidifolia. H.H.A. The well known "Swan-River Daisy" is a beautiful little, half-hardy annual; pretty blue flowers. 18 in ................... oz. 50 c.

iberidifolia, Mixed (Swan-River Daisy). For edging. 12 in..............1/4 oz. $50 \mathrm{c}$.

BROWALLIA. H.A. Profuse-blooming annual, highly prized for summer bedding or as greenhouse plants. Fine for cutting. $2 \mathrm{ft}$. elata caerulea. Bright blue; fine for cutting. roezli. Free flowering, bluish white

speciosa major. Flowers $1 \frac{1}{2}$ to 2 in. across;

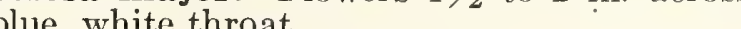

.25
Pkt.

CACALIA coccinea (Tassel Flower). H.A. Scarlet flowers. $21 \mathrm{t} \ldots \ldots \ldots \ldots \ldots 14$ oz. $35 \mathrm{c} . \$ 0.10$

CALCEOLARIA hybrida grandifora. G.P. Highly prized plants for conservatory and house decoration.

Marshall's Matchless Strain. Of the richest and most delicate colors, in the most marvelous variety of sluades and marking, selfspotted and blotelied

Large Flowering "Dalkeith Park Strain." Finest varieties.

rugosa Mixed. The woll-known bedding valieties. $12 \mathrm{in}$.

CALENDULA (Cape Marigold), H.A. Free and continuous flowering gididen plants. 12 in

Meteor. Double yellow, stiped orange. oz. $50 \mathrm{c}$

Marshall's Orange King, grandiflora. Dar] orange red.................. oz. \$1.00

Prince of Orange. Orange, with dark eye.

Sulphur Crown. Very large double oz. $75 \mathrm{c}$.

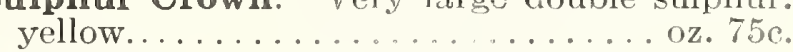

The Ball. Very layge, double orange flowers with long stems...........1/4 oz. $\$ 2.00$

Finest Mixed. A] varicties........... oz. 50c.

CALIIOPSIS. H.A. Nothing is more effective than a large bed of these golden flowers; exceedingly free flowering.

atrosanguinea. Rich dak red. $18 \mathrm{in.}$

$1 / 4 \mathrm{oz} .30 \mathrm{c}$. compacta. Crimson Ixing. Deep bright scallet. 18 in ...................1/4 oz. $50 \mathrm{c}$. Golden Wave (Drummondi). Pure yellow flowers, very large and slowy...1/4 oz. $50 \mathrm{c}$. marmorata. Maloon and gold. 18 in

1 '́ oz. $500^{\circ}$ tinctoria. Large bright yellow and maroon flowers. $2 \mathrm{ft} \ldots \ldots \ldots \ldots \ldots 1_{4} \mathrm{oz} .50 \mathrm{c}$

Dwarf, Finest Mixed. All shades of yellow, red and brown. $12 \mathrm{in} \ldots, \ldots . .1 / 4 \mathrm{oz} .30 \mathrm{c}$.

Tall Mixed. A grand variety for cutting. $2 \mathrm{ft}$ $1,4 \mathrm{Oz} .30 \mathrm{c}$

CALLIRHOE involucrata, (Poppy Mallow). H.P. Beautiful triling plant with palmate foliage; flowers Jary, erimson, with white center. 12 in............... 1/4 oz. $75 \mathrm{c}$.

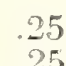
25
.25 .15 .25

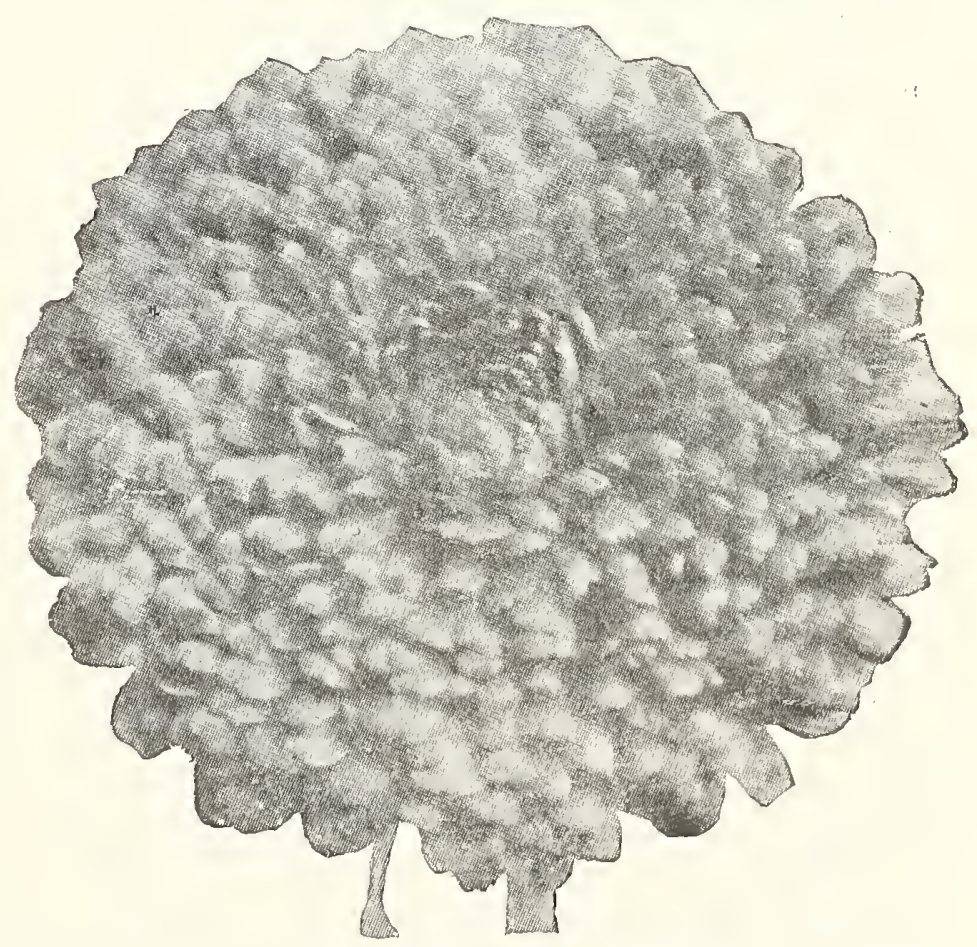

Calendula, The Ball 
CAMPANULAS. H.P. All the Campanulas can be grown in ordinary gardens and will flower from seeds the following year.

carpatica. Deep blue; for rockeries, beds and edgings. 6 in ................1/4 oz. $50 \mathrm{c} . \$ 0.15$

carpatica alba. Flowers white. 6 in..1/4 oz. 50c. .15 grandiflora mariesi. A fine dwarf dark blue variety. 12 in

pyramidalis (Chimney Bell). Very conspicuous towering spikes, with clear blue flowers. $4 \mathrm{ft}$. $1 / 4$ oz. $\$ 1.00$

pyramidalis alba. Pure white. $4 \mathrm{ft} .1 / 4 \mathrm{oz} . \$ 1.00$ persicifolia grandiflora, Blue. Superb large flowers. 2 ft............. $1 / 8$ oz. $\$ 1.25$ persicifolia grandifiora alba. A white-flowered variety..............1/8 oz. $\$ 1.25$ persicifolia Telham Beauty. China blue, very large flowers. $2 \mathrm{ft}$.

persicifolia grandiflora, Fine Mixed. Very showy. $2 \mathrm{ft} \ldots \ldots \ldots \ldots \ldots \ldots \ldots$. $1 / 8 \mathrm{oz} . \$ 1.25$

CANTERBURY BELLS. H. B. Well-known, handsome, hardy biennials, bearing large bell and saucer-shaped flowers in profusion; well adapted for borders. $2 \mathrm{ft}$.

medium Blue.

medium Rose

medium Striped

$1 / 4$ oz. $50 \mathrm{c}$ medium White medium Mixed. All colors.......1/4 oz. 50c. medium Double Blue. Rich, heavy, curious flowers $.1 / 4$ oz. $\$ 1.00$ medium Double White.

medium Double Rose.

medium Double Mixed .

$1 / 4$ oz. $\$ 1.00$

$1 / 4$ oz. $\$ 1.00$ $1 / 4$ oz. $75 \mathrm{c}$.

medium calycanthema ("Cup and Saucer"). A race of Canterbury Bells having large, semidouble flowers resembling a cup and saucer. $2 \mathrm{ft}$.

calycanthema Blue

caly canthema Lavender.

calycanthema Rose.

calycanthema White.

calycanthema Mixed.

$1 / 4$ oz. $\$ 1.25$

$1 / 4$ oz. $\$ 1.25$

$1 / 4$ oz. $\$ 1.25$

$1 / 4$ oz. $\$ 1.25$

$1 / 4$ Oz. $\$ 1.00$

CANARY BIRD VINE. H.A.C. Pretty climber, with yellow, butterfly-like flowers: $10 \mathrm{ft}$.

oz. $50 \mathrm{c}$

CANDYTUFT. H.A. Showy branching plants, much grown in masses in beds or for edging also grown extensively for cut flowers. 12 in. coronaria Empress. A large-flowered variety of purest white, grown extensively for cut flowers. $12 \mathrm{in} . . . \ldots \ldots \ldots \ldots \ldots 1 / 4 \mathrm{oz} .30 \mathrm{c}$ coronaria Little Prince. Very large heads of pure white flowers. 6 in.....1/4 oz. 50c. coronaria Giant Hyacinth-flowered. White. $1 / 4 \mathrm{Oz} .30 \mathrm{c}$.

Marshall's White Perfection. A grand white variety ................1/4 oz. 50c. Queen of Italy. Dwarf, rosy white. 6 in. $1 / 4$ oz. $35 \mathrm{c}$

Rose Cardinal. Bright rosy cardinal, a rich and striking color............1/4 oz. $50 \mathrm{c}$. umbellata dunnetti. Dark crimson. $1 / 4$ oz. $30 \mathrm{c}$. umbellata lilacina. Lilac-purple. $1 / 4$ oz. $30 \mathrm{c}$. umbellata Dwarf Hybrids. Mixed colors; neat and pretty. 6 in.........1/4 oz. $50 \mathrm{c}$. Mixed Annual Sorts ............... oz. 50c sempervirens. H.P. White flowers. 12 in. $1 / 4$ oz. $\$ 1.25$

gibraltarica. H.P. Beautiful bluish-white, 12 in ................ . oz $\$ 1.25$

CANNAS. G.P. Handsome foliage and flowering plants, producing striking effects in beds or borders. Soak the seed in hot water 24 hours before sowing. 3 to $4 \mathrm{ft}$.

Mixed. Dark-leaved variety..........oz. 50c.

Crozy's Large Flowering. Dwarf, mixed varieties.

10

.10

.10

10

.10

.15

15

.15

.15

.15

15

15

.15

.10

.10

.10

.10

.15
Pkt.

CARDINAL CLIMBER (See Ipomoea cardinalis). H.A.C.

CARNATION. Marguerite. H.H.P. The perpetual flowering Carnations produce a large proportion of double flowers in six months from sowing. $18 \mathrm{in.}$

Marshall's Giant, Double Scarlet

Marshall's Giant, Double White. Large, perfect flowers............ $1 / 8$ oz. $\$ 1.25$

Marshall's Giant, Double Yellow. A elear soft shade..............1/8 oz. $\$ 1.25$

Marguerite, Giant Double Mixed. Extra large and perfect flowering, in a rich variety of colors................... 1/8 oz. $\$ 1.00$

Chaubaud's Everblooming Mixed. Blooms in five months after being sown, and continues to flower in the greatest profusion indefinitely. $18 \mathrm{in}$.

Early Dwarf Vienna. Double mixed. 12 in.

$1 / 4 \mathrm{oz} .75 \mathrm{c}$.

Grenadine Double Scarlet. Very early flowering. 18 in ............. .1/4 oz. $\$ 1.00$

Finest Double Mixed. Border. Saved from extra fine flowers. $18 \mathrm{in} \ldots \ldots \ldots 1 / 4 \mathrm{oz} . \$ 1.00$

Pkt.

CASTOR BEANS. (See Ricinus).

CELOSIA cristata, or Cockscomb. H.H.A. Popular annual of easy culture, producing Cockscomb-like heads.

childsi (Chinese Wool Flower). A variety of feathered Celosia with large globular flowerheads like balls of wood. $2 \mathrm{ft}$.

childsi Crimson............1/8 oz. 75c. .15

childsi Pink.............1/8 oz. 75c. .15

childsi Yellow.............1/8 oz. 75c. .15

childsi Mixed..............1/8 oz. 50c. .15

Empress. Crimson combs; dark foliage. 9 in.

$1 / 4 \mathrm{oz} . \$ 1.25$ Glasgow Prize. Large, deep crimson. 12 in. $1 / 8 \mathrm{oz} . \$ 1.00$

Queen of the Dwarfs. Very dwarf form, deep crimson. 6 in ............ 1/8 oz. $\$ 1.00$

Dwarf. Mixed colors. Extra fine strain. 9 in. $1 / 4$ Oz. $\$ 1.00$

CELOSIA plumosa, or Ostrich Plume. H.H.A. Producing large, graceful plumes. Makes fine plants for large beds or groups, and the plumes or flowers can be cut and dried for Winter bouquets. $3 \mathrm{ft}$.

pyramidalis magnifica aurea. Golden-yellow plumes...............1/4 oz. $75 \mathrm{c}$.

pyramidalis magnifica kermesina. Crimson plumes...............1/4 oz. $75 \mathrm{c}$. pyramidalis magnifica coccinea. Scarlet plumes...............1/4 oz. $75 \mathrm{c}$ pyramidalis magnifica purpurea. Dark crimson................1/4 oz. $75 \mathrm{c}$

pyramidalis, Thompson's Superb. Of pyramidal growth and producing graceful, feathery plumes; dwarf habit, dark crimson.

pyramidalis plumosa, Mixed. $\frac{1 / 4 \mathrm{Oz}, 75 \mathrm{c} .}{\text { Feathered }}$ varieties in all colors.........1/4 oz. $75 \mathrm{c}$.

Pride of Castle Gould. All shades in choicest mixture; branching habit.......1/8 oz. $\$ 1.00$

CELSIA arcturus. G.P. Long spikes of bright yellow flowers. Fine for pot culture in cool

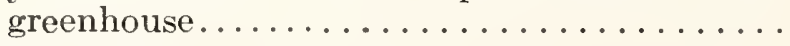

CENTAUREA. H.A. Beautiful silvery foliaged bedding plants; used for bordering and edging. candidissima. Round, compact plants, white leaves, broadly cut. $12 \mathrm{in} . . .1 / 8 \mathrm{oz} .75 \mathrm{c}$. gymnocarpa. Fine cut silvery foliage. $18 \mathrm{in}$. $1 / 4$ oz. $50 \mathrm{c}$. 
CENTAUREA. H.A. They flower finest in full sun and poor soil. Sow in the open ground in Spring.

americana. Bushy garden plants; lavenderblue, fragrant. $3 \mathrm{ft} \ldots \ldots \ldots \ldots \ldots 1 / 4 \mathrm{oz} .60 \mathrm{c} . \$ 0.15$ Chameleon. Large; yellow and rose. $18 \mathrm{in.}$

$1 / 4 \mathrm{oz} .75 \mathrm{c}$.

Margaritae. Pure white, 21/2 inches across, exquisitely laciniated and delightfully scented. 18 in ....... $1 / 4$ oz. $50 \mathrm{c}$. montana. H.P. Large flowers of deep purple, very showy. $2 \mathrm{ft} \ldots \ldots \ldots \ldots \ldots \ldots .1 / 8 \mathrm{oz} .35 \mathrm{c}$. suaveolens, Yellow Sweet Sultan. Fine for cutting. 18 in ............. $1 / 4$ oz. $50 \mathrm{c}$.

CENTAUREA cyanus (Bachelor Button, Cornflower, Blue Bottle, or Ragged Sailor). H.A. This is one of the most popular annuals; will grow in the poorest of soil, either on seashore or mountain. 18 in.

Marshall's Double Blue. Fine for cutting.

$1 / 4 \mathrm{oz} .75 \mathrm{c}$.

Liberty Blue. The true Emperor deep blue Bachelor Button................ 1/4 oz. 50c.

rosea, Double. Rose-pink.......1/4 oz. 40c,

White, Double. Very pretty for decorations and borders................ $1 / 4$ oz. 40c.

Finest Mixed, Double.........1/4 oz. $25 \mathrm{c}$.

CENTAUREA imperialis, Giant Imperial Sweet Sultan. H.H.A. The finest of all Sweet Sultans for cut flower purposes. $3 \mathrm{ft}$.

\section{Lilac.}

Purple.

Rose.

White

White, shading to rose

Finest Mixed. All colors. $1 / 4$ oz. $50 \mathrm{c}$. $1 / 4$ oz. 50c. $1 / 4$ oz. $50 \mathrm{c}$. oz. $50 \mathrm{c}$. $1 / 4$ oz. $50 \mathrm{c}$.

CERASTIUM tomentosum (Snow in Summer) H.P. A dwarf, white-leaved edging plant with small white flowers. 6 in. $.1 / 8$ oz. $75 \mathrm{c}$.

CHELONE barbata. H.P. Long racemes of scarlet flowers. $2 \mathrm{ft} . . . . .$.

CHEIRANTHUS allioni (Alpine Wallflower). H.H.P. Excellent for rockery or border; brilliant orange flowers. 9 in....1/4 oz. $\$ 1.00$

CHR YSANTHEMUM, Annual Varieties. Showy, hardy annuals of easiest cultivation, blooming from July until frost. 12 to 18 in. coronarium compactum, White Pearl. Fine for cutting............... $1 / 4 \mathrm{oz} .35 \mathrm{c}$. coronarium compactum, Primrose Queen. coronarium, Double White.....1/4 oz. 35c. coronarium, Double Yellow .......1/4 oz. $35 \mathrm{c}$. coronarium, Double Mixed. Yellow, white, etc.................1/4 oz. 35c.

inodorum plenissimum. Free flowering variety of spreading habit, with pure white flowers, resembling Asters........1/4 oz. 50c.

tricolor, Lord Beaconsfield. White and rose. $1 / 4 \mathrm{oz} .35 \mathrm{c}$.

tricolor, Morning Star. Large primrose flowers...................1/4 oz. 35c.

Northern Star. Large ivory white flowers with sulphur zone.................1/4 oz. 50c.

tricolor, Single. Finest mixed...1/4 oz. 35c. tricolor, Double-fringed Mixed. This is a

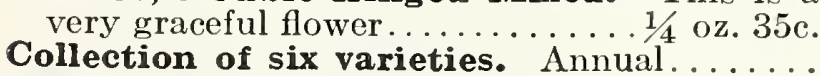

CIRTSANTHEMUM, Perennial Varieties.

frutescens (The White Paris Daisy). Charming plant for greenhouse or Summer bedding outdoors. $18 \mathrm{in} . . . \ldots \ldots \ldots \ldots 1 / 8 \mathrm{oz} .50 \mathrm{c}$.

japonicum. From finest Japanese flowers. 3 ft. Extra choice mixture

Japanese Mountain. H.H.P. A dwarf free Fallflowering variety. Various colored flowers...

maximum "Perfection." Very free-flowering; pure white. 18 in .........1/4 oz. $50 \mathrm{c}$

maximum grandiflorum (The Shasta Daisy). Pure white; very large. $18 \mathrm{in} . \mathrm{I}_{1 / 4} \mathrm{oz} .50 \mathrm{c}$.
Pkt. .15

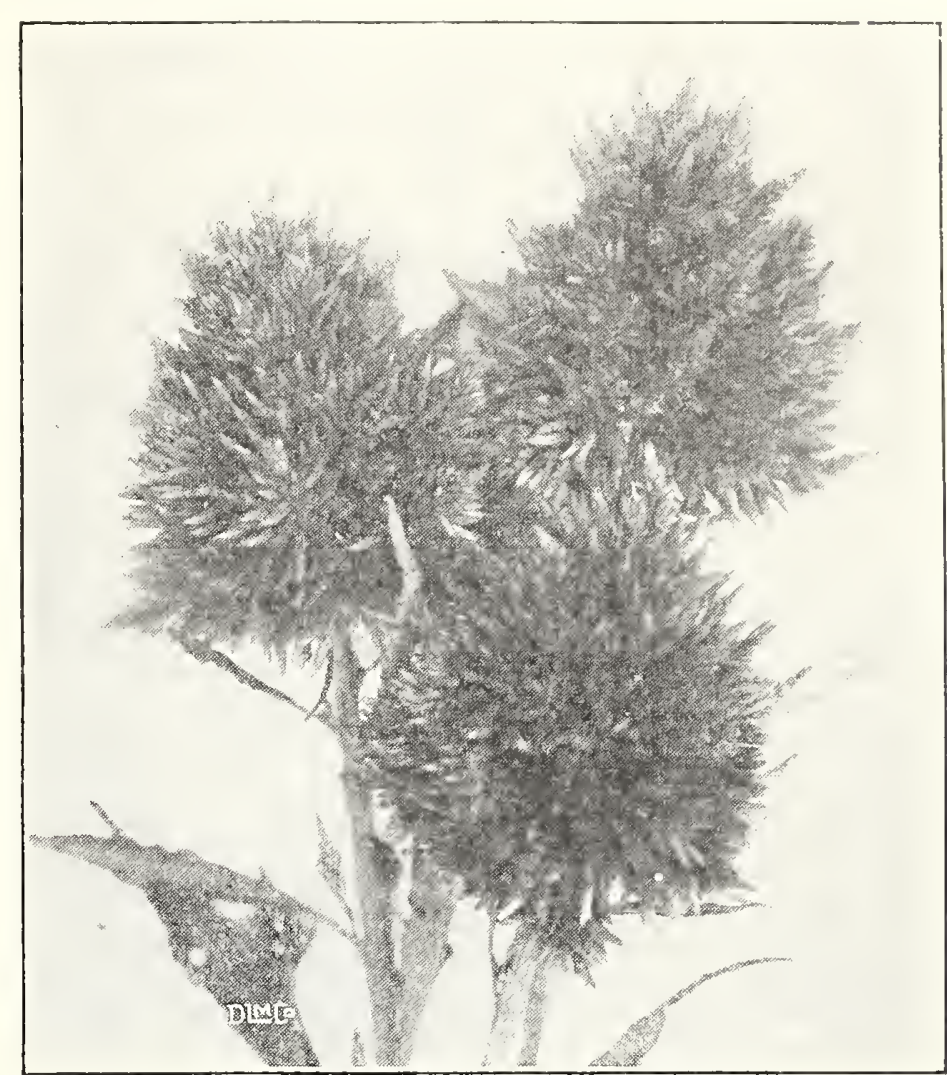

Celosia childsi. See page 32

Pkt.

CINERARIA maritima candidissima. H.H.P. A white-leaved "Dusty Miller," used for edging. $1 \mathrm{ft} \ldots \ldots \ldots \ldots \ldots \ldots \ldots$. $1 / 4 \mathrm{oz} .35 \mathrm{c} . \$ 0.15$

CINERARIA hybrida. G.P. One of the most gorgeous colored flowering plants for either greenhouse or conservatory. Seeds should be sown in July, August or September.

Marshall's Matchless Prize Mixed. Every shade of blue, crimson, violet and pink, both in self-colors and with white edge or center. The flowers are often 3 inches in diameter and the plants of excellent habit. $2 \mathrm{ft}$. .

Cactus-flowered Mixed. Large flowers with narrow rolled petals radiating from the center. Fine for conservatory. $2 \mathrm{ft}$.

grandiflora, Matchless Dwarf Prize Mixed. This strain is just as choice as above, but different in height. 18 in...

hybrida multiflora nana. The dwarfest and most compact strain, with large flowers. 9 in. stellata, Blue Star-flowered. Tall, pyramidal plants, bearing star-like flowers. $2 \mathrm{ft}$. .

stellata, Pink Star-flowered.

stellata, White Star-flowered.

stellata hybrids, Mixed Colors

CLARKIA. H.A. This pretty and easily grown annual has been much improved in recent years, and the varieties offered below are fine, seen as cut flowers in most of the large cities of Europe; they do well either in sun or shade. $2 \mathrm{ft}$.

Brilliant. Double salmon-scarlet flowers.

$1 / 4$ oz. $50 \mathrm{c}$.

Queen Mary. Very bright rose-carmine, double flowers................. rosea flore plena. Double rose... . 1/4 oz. $50 \mathrm{c}$ Salmon Queen. Extra double, salmon-pink. $1 / 4$ oz. $50 \mathrm{c}$.

Scarlet Queen. Fine double, brilliant salmonorange-scarlet .............. $1 / 4 \mathrm{oz} .50 \mathrm{c}$.

White. Very double, pure white flowers.

Double Mixed. All colors.......1/4 oz. $35 \mathrm{c}$.

CLEOME gigantea (Giant Spider Flower). H.A. Bright rosy-crimson flowers; adapted for large beds or borders. $31 / 2 \mathrm{ft} . \ldots 1 / 4 \mathrm{Oz} .50 \mathrm{c}$.

CLIANTHUS dampieri. G.P. (Austrian Glory Pea). Scarlet flowers................ 
CLERODENDRON fallax. G.P. Erect growing greenhouse plant, with large spikes of scarlet flowers.

COBAEA scandens. H. A. C. Tender climber, large, bell-shaped blue flower. $20 \mathrm{ft}$.

White. Large white, bell-like flowers. $1 / 4 \mathrm{oz} .60 \mathrm{c}$. COCKSCOMB. (See Celosia cristata).

COLEUS, Marshall's Matchless Mixed. G.P. Richly colored foliage plants.

thyrsoideus. Flowers light blue, borne in panicles; fine leaves.

CoLlinsia, Mixed. Free flowering, hardy annuals of deserved popularity, blooming from June to October, and suited to dry situations. $1 / 4 \mathrm{Oz} .35 \mathrm{c}$.

COLUMBINE. (See Aquilegia).

CONVOLVULUS, or Morning Glories. (See also Ipomoea). H.A.C. Deservedly very popular, as they are of the most free-flowering and rapid growing plants in cultivation, thriving in almost any situation.

major. Mixed colors. Climbers of rapid

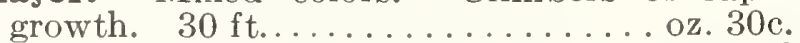

minor, or Bush Morning Glories. Mixed colors. 12 in................. oz. 30c.

COREOPSIS. H.P. Long stemmed, large, single flowers. $2 \mathrm{ft}$

grandiflora. Large flowers of rich yellow. $1 / 4$ oz. $35 \mathrm{c}$.

CORN, Rainbow. H.A. Variegated leaves, striped in green, white and yellow. $5 \mathrm{ft} . \mathrm{oz} .50 \mathrm{c}$.

CORNFLOWER. (See Centaurea cyanus.)

COSMOS. H.A. This is one of our most useful and beautiful Autumn flowers. To get it in bloom early, seed should be sown in May in the open ground where the plants are desired to bloom, and the seedlings allowed to grow and flower without being transplanted. $5 \mathrm{ft}$.

Double - crested, Early - flowering. Semidouble flowers in great profusion. $5 \mathrm{ft}$.

Crimson King. Bright red.....1/4 oz. $\$ 1.50$ Pink Beauty. A lovely shade of pink, crested flowers......... $1 / 4$ oz. $\$ 1.50$ White Queen. Pure white, crested flowers. $1 / 4$ oz. $\$ 1.50$ Crested Mixed. The above colors in mixture. $1 / 4$ oz. $\$ 1.25$

Extra Early Giant-flowering. Flowers 4 to 5 inches across. $4 \mathrm{ft}$.

Crimson....... 1/4 oz, 60c. Pink...................... White....................

Mixed Colors. $1 / 4$ oz. 50c.

Giant Late-flowering. Blooms in September and October. $5 \mathrm{ft}$.

Lady Lenox. Pink.....1/4 oz. 50c.

Lady Lenox. White................ . 1/4 oz. $50 \mathrm{c}$.

Red.

Mixed. All shades.

$1 / 4$ Oz. $50 \mathrm{c}$

COWSLIP, Mixed (Primula veris). H.P. A Springflowering plant. Beautiful colors, rich brown, crimson and yellow, 6 in.

CUPHEA platycentra (Cigar P̈lant). ”Ḧ.̈. Valuable as a bedding and border plant. The flowers are scarlet with a black and white lip. $1 \mathrm{ft}$

CYNOGLOSSUM amabile Ḧ Beautiful rich blue, sweet-scented flowers. Fine for cutting. $18 \mathrm{in} . . . . . . . . . . . .1 / 4$ oz. $\$ 1.00$

CYPERUS alternifolius (Umbrella Plant). G.P. Handsome plants easily raised from seed; used for table decorations and combining with palms; semi-aquatic. $2 \mathrm{ft}$.

CYPRESS VINE. H.A.C. A fast growing annual vine, with feathery, dark-green foliage and star-like flowers. $10 \mathrm{ft}$.

Bright Scarlet.................1/1/ oz. 25c.

Finest Mixed...............
Pkt.

.10

10

.10

.10

10

.10

.25

.25 .10
CYCLAMEN. G.P. These are among the choicest of flowering greenhouse plants. Seed should be sown from October until January.

Marshall's Giant Varieties (Persicum giganteum). New crop seeds usually arrive in August.

Crimson King. Dark crimson. 100 seeds, $\$ 2.00 \$ 0.50$

Giant White............100 seeds, $\$ 2.00 \quad .50$

Mrs. Buckston. Salmon-pink, heavily fringed. 100 seeds, $\$ 3.001 .00$

Salmon Queen. Salmon ..... 100 seeds, $\$ 2.00 \quad .50$
St. George. Pale salmon, with marbled foliage. 100 seeds, $\$ 3.001 .00$

Victoria. A pretty form with colored fringe at the top of the petals. In several colors. 100 seeds, $\$ 2.501 .00$

Marshall's Giant Mixture. Includes all the brilliant colors..........100 seeds, $\$ 2.00$

Papillio, or Giant-fringed Butterfiy. Mixed colors; flowers beautifully fringed.

100 seeds, $\$ 3.001 .00$

DAHLIA. H.H.P. This popular flower can be easily raised from seed, flowering the same season. Seed should be sown early in gentle heat. 4 to $6 \mathrm{ft}$.

Coltness Hybrids. Single varieties in many colors, growing from 18 to 24 inches in height.

Collarette. Single flowers in various colors, with white quilled and tufted centers; very showy

Double, Large-flowering. Double mixed colors.

Cactus. New choice varieties. Mixed colors.

Single, Large-flowering. Mixed. Self and striped flowers.

DAISY, Double. (See Bellis perennis.)

DAISY, Single. (See Chrysanthemums.)

DATURA (Trumpet Flower). H.H.A. Robust garden annual, bearing large trumpet-shaped flowers. $4 \mathrm{ft}$.

Double-flowering (Fastuosa fl. pl.) Mixed.

Cornucopia (Horn of Plenty). Flowers white and purple.............1/4 oz. $40 \mathrm{c}$

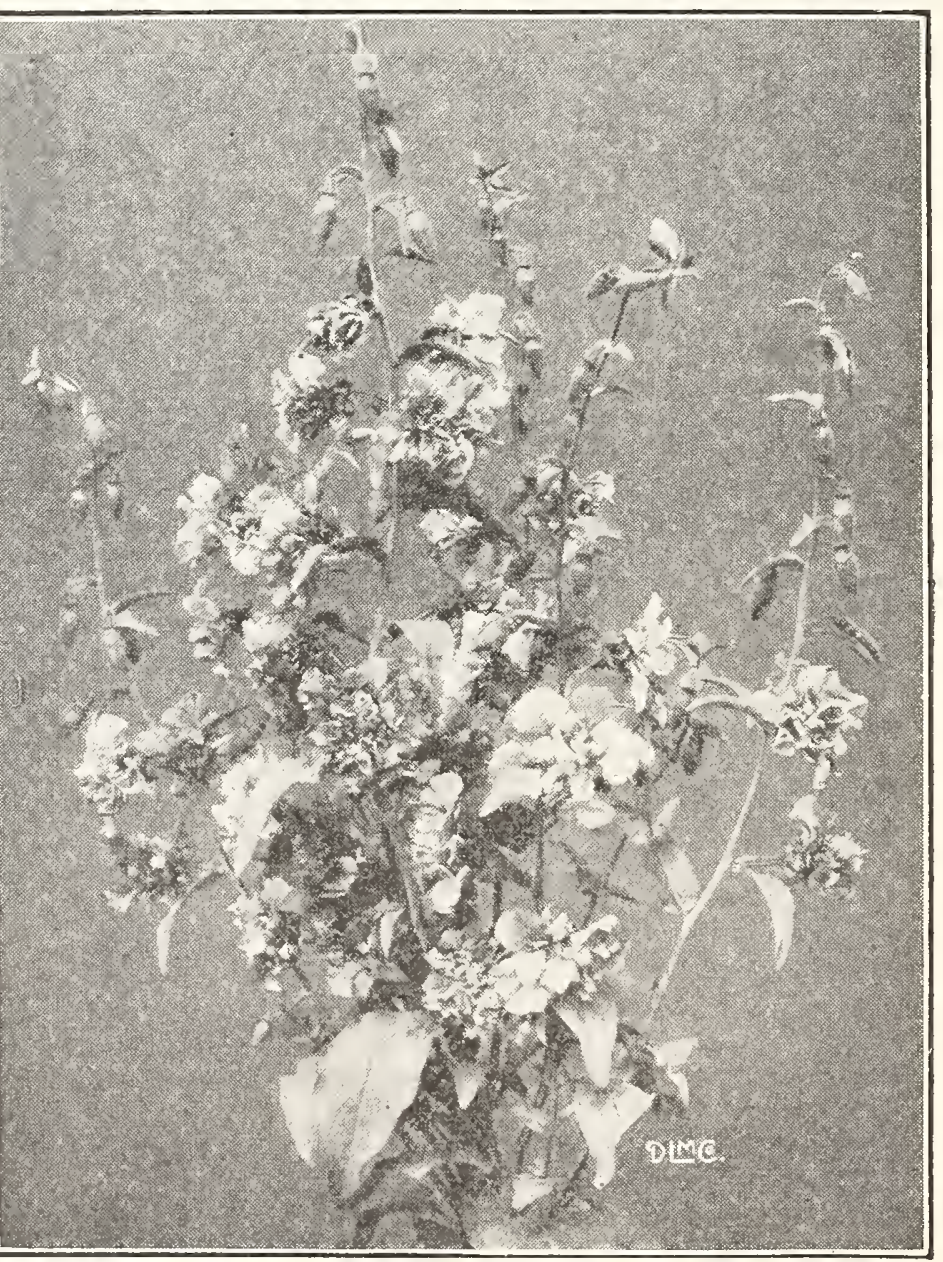

Glarkia Salmon Queen. See page 33. 
DELPHINIUM (Larkspur). H.P. Delphiniums are hardy and can be grown in any garden. They are handsome plants for the herbaceous border and shrubbery and are splendid for cut flower use.

belladonna. Very large-flowered, light azure blue ........... 1/8 oz. $\$ 1.00$

Blue Butterfy. Graceful spikes of large azureblue flowers.................1/8 oz. $\$ 1.00$ bellamosa. An improved Formosum which is not subject to mildew. Dark blue in color. $1 / 8 \mathrm{oz} . \$ 1.00$ 18 in. $1 / 4$ oz. $50 \mathrm{c}$ chinensis azureum. Azure blue. 18 in.

chinensis Mixed (grandiflorum). Shades of blue and pure white. 18 in .....1/4 oz. 50c. formosum. (See Bellamosa.)

formosum coelestinum. Sky-blue; handsome................. $1 / 8$ oz. $75 \mathrm{c}$

Blackmore \& Langdon's Hybrids. Containing the latest and best varieties in cultivation. $5 \mathrm{ft}$.

Marshall's Matchless Hybrids. Choice show hybrids, saved from the best named varieties. $1 / 8$ oz. $\$ 1.00$

zalil (sulphureum). Very beautiful, with long

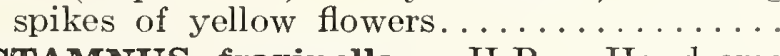

DICTAMNUS fraxinella. H.P. Handsome spikes of reddish flowers and fragrant leaves. $3 \mathrm{ft} \ldots \ldots \ldots \ldots \ldots \ldots \ldots \ldots \ldots \ldots . \ldots \ldots$ oz. $50 \mathrm{c}$.

DIANTHUS (Chinese or Indian Pinks). H.H.A. These, although biennials, bloom the first season, and should be treated as hardy annuals. They flower early in Summer and continue until frost. They are excellent for small beds or edgings, flowering profusely and in great variety of colors. $12 \mathrm{in.}$

\section{SINGLE ANNUAL PINKS.}

heddewigi. Large, attractive flowers of most brilliant colors. Finest mixed.. 1/4 oz. 50c.

laciniatus Single Mixed. Fringed flowers of all colors.

DOUBLE ANNUAL PINKS.

chinensis fl. pl. (ChinesePink). Large, double flowers in unlimited variety of colors. Finest Mixed....................1/4 oz. 50c.

diadematus fi. pl. (Double Diadem Pink) Large, double flowers. Mixed....1/4 oz. 50c.

heddewigi fl. pl. (Japanese Pink). Large, double flowers of exquisite colors. Finest Mixed..................1/4 oz. 50c.

"Fireball." Large double; brilliant red.

laciniatus “Salmon Queen." Very striking double flowers, rich salmon scarlet. $1 / 4 \mathrm{oz} . \$ 1.00$ laciniatus "Snowball." Extra large, double, pure white...............1/4 oz. $75 \mathrm{c}$.

laciniatus ff. pl. Double-fringed flowers; beautifully striped; many colors. Mixed. 1/4 oz. 75c.

Collection of Double Annual Pinks. Six varieties.

HARDY PERENNIAL PINKS.

plumarius fl. pl. Pheasant's Eye. Pretty fringed double flowers.......1/4 oz. 75c.

plumarius semperflorens (Perpetual Pink). Mixed, single and double.....1/8 oz. $\$ 1.00$

DIDISCUS coerulea (Blue Lace Flower). H.A. An attractive annual, blooming from July until frost. Pale lavender flowers, valuable

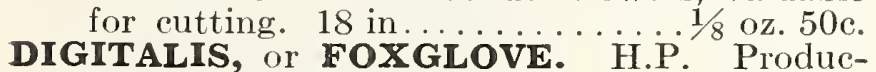
ing long spikes of tubular flowers. Used extensively with good effect for naturalizing in shrubberies and half-shady places. $3 \mathrm{ft}$.

Marshall's Superb Purple......1/4 oz. $50 \mathrm{c}$. Marshall's Superb Rose.........1/4 oz. 50c. Marshall's Superb Yellow.........1/4 oz. 50c Marshall's Superb White........1/4 oz. 50c Marshall's Superb Mixed. All colors. $1 / 4 \mathrm{oz} .35 \mathrm{c}$. monstrosa, Mixed. Very large flowers. $1 / 4 \mathrm{oz} .75 \mathrm{c}$ Finest Mixed (Common Foxglove).1/4oz.30c.
Pkt.

0.25

.25

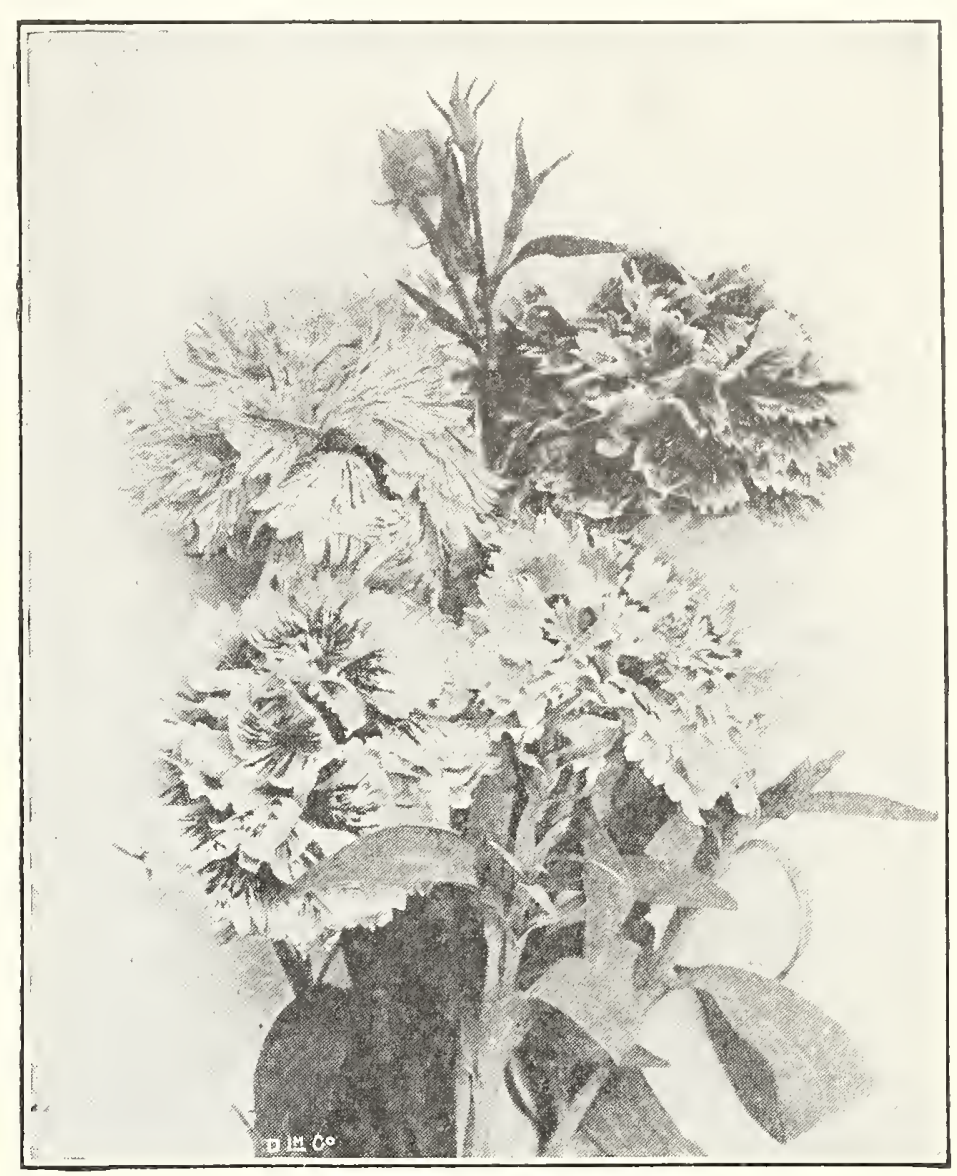

Dianthus chinensis

DIMORPHOTHECA aurantiaca. H.A. DaisyPkt. like blossoms of a rich orange color; the disc is dark and surrounded by a black zone. 18 in. $1 / 4$ oz. 75 c. $\$ 0.15$

aurantiaca hybrida. Mixed hybrids. $1 / 4$ oz. $50 \mathrm{c} . \quad .15$ eklonis. Large star-shaped pure white flowers with a small deep blue disc. $2 \mathrm{ft}$.

DOLICHOS, or HYACINTH BEAN. H.A.C. Annual climbers, with clusters of Bean-like flowers. $10 \mathrm{ft}$.

"Daylight." This grand Hyacinth Bean comes from Japan. Flowers pure white..... oz. 50c.

"Darkness." Identical in every way to the above, except in color, which is a rich purpleviolet.........oz. 50c.

lablab, Mixed. Purple and white.....oz. 40c.

DRACAENA indivisa. G.P. For vases, pots, etc., narrow green leaves...........1/4 oz. 35c.

ECHINOCYSTIS lobata (Wild, or California Cucumber). H.A.C. The fastest growing annual vine in existence; will grow 20 feet in six weeks. Pretty foliage and inconspicuous white flowers. $20 \mathrm{ft} \ldots \ldots \ldots \ldots \ldots$......... $50 \mathrm{c}$.

ECHINOPS ritro (Blue Globe Thistle). H.P. Purple..................1/4 oz. 35e.

EDELWEISS (Leontopodium). H.P. Silvery white everlasting flowers; fine for rcck gardens. 6 in...

EREMURUS (Gold Medal Hybrids). H.P. Stately plant with long spikes of flowers. $8 \mathrm{ft}$.

ERIGERON speciosus (The Midsummer Daisy). H.P. Pale mauve flowers with golden centers. Fine for cutting. $18 \mathrm{in.}$

ERYSIMUM arkansanum. H.A. Bright yellow flowers resembling the Wallflower. $18 \mathrm{in.}$

pulchellum. H.P. Pale yellow flowers. Useful for rockwork. 9 in.

ERYNGIUM amethystinum (Sea Holly). H.P. Spiny foliage and small amethyst-blue flowers in large panicles. $3 \mathrm{ft} . \ldots \ldots \ldots 1 / 8 \mathrm{oz} . \$ 1.00$

ERINUS alpinus. H.P. Blue; beautiful for baskets. 6 in .....................

\section{.25}


ESCHSCHOLTZIA, Or CALIFORNIA POPPY.

H.A. Very attractive annuals for beds, edgings, masses; profuse flowering; fine cut, glaucous foliage; in bloom from June to frost. $12 \mathrm{in.}$ californica. Bright yellow.......1/4 oz. 30c.\$0.10 californica alba. Thite........1/4 oz. 30c. .10 Carmine King. Beautiful deep red.1/4 oz. 35c. .10 Chrome Queen. A beautiful clear chrome yellow................ $1 / 8$ oz. $75 \mathrm{c}$

Crimson King. Beautiful crimson scarlet. Dainty Queen. Blush-pink on cream ground.

$1 / 4 \mathrm{Oz} .75 \mathrm{c}$

Golden West. Large flowers of deep yellow shade................... oz. $35 \mathrm{c}$

Mandarin. Large, scarlet, inside orange

$1 / 4$ oz. $35 \mathrm{c}$ Single Mixed. All colors.............. oz. $50 \mathrm{c}$

The Geisha. Petals prettily fluted. Color inside golden and outside intense orange-crimson. Very beautiful..........1/4 oz. 50c.

EUCAL YPTUS globulus (Blue Gum Tree). G.P. Used as greenhouse plant for decorations

EUPATORIUM fraseri. H.P. White, fine for cutting. $2 \mathrm{ft} \ldots \ldots \ldots \ldots \ldots \ldots 1 / 4$ oz. $50 \mathrm{c}$.

EUPHORBIA heterophylla (Fire on the Mountain). H.A. Leares large and glossy green, often tipped with orange-scarlet. $3 \mathrm{ft}$...

$1 / 4$ oz. $50 \mathrm{c}$

variegata (Snow on the Mountain). White and green bracts, excellent for bouquets. $2 \mathrm{ft}$. $1 / 4$ oz. $35 \mathrm{c}$

FERNS, Greenhouse Variety, Mixed. G.P..

FORGET-ME-NOT. (See MYOSOTIS.)

FOXGLOVE. (See DIGITALIS.)

FOUR O'CLOCKS. (See MARVEL OF PERU.)

FRANCOA ramosa alba. H.B. Elegant sprays of pure white flowers. $2 \mathrm{ft}$

FREESIA, New Hybrids Mixed. G.P. Shades of pink, red, violet, yellow, etc.

GAILLARDIA. H.A. Showy garden annuals; they flower uninterruptedly from early Summer until frost; the flowers are of large size and afford charming tints in their color schemes. $2 \mathrm{ft}$

amblyodon. Blood red..........1/1/ oz. 35c. picta Mixed, Single. Annual varieties.

lorenziana, Double Mixed $\quad 1 / 4 \mathrm{Oz} .35 \mathrm{c}$. Giant Hybrids, Mixed. $35 \mathrm{c}$. Marshall's Matchless Hybrids. H.P. A grand new improved strain; enormous flowers and very strong habit......1/8 oz. $\$ 1.00$

GALEGA officinalis. H.P. A hardy plant producing a number of blue miniature pea-like flowers in sprays throughout the Summer. $3 \mathrm{ft} \ldots \ldots \ldots \ldots \ldots \ldots \ldots \ldots \ldots . .1 / 4 \mathrm{oz} .35 \mathrm{c}$.

officinalis alba. White flowers...1/4 oz. 35c.

GAURA lindheimeri. H.P. Graceful spikes of rosy-white flowers. $3 \mathrm{ft} . \ldots \ldots 1 / 4 \mathrm{oz} .50 \mathrm{c}$.

GENTIANA acaulis (Gentian). H.P. Intense blue bell-shaped flowers. 6 in.

GERANIUM. G.P. Well-known plants for garden or pot culture.

zonale. Finest Mixed.

GERBERA jamesoni hybrida (The Transvaal Daisy). H.H.P. Fine for cut flowers or bouquets. 18 in .............100 seeds, $\$ 1.00$

GEUM. H.P. Showy, hardy perennial of easy culture and well adapted for the flower garden; fine for cutting. $2 \mathrm{ft}$.

atrosanguineum. Large, double crimson flowers.....................1/4 oz. $50 \mathrm{c}$.

Lady Stratheden. Free flowering double yellow

Mrs. Bradshaw. Double orange-scarlet flowers; very large and full.........1/8 oz. $75 \mathrm{c}$.
Pkt.

GLOBE AMARANTH (GOMPHRENA). H.A

Clover-like heads of flowers; esteemed as everlastings. $12 \mathrm{in}$.

globosa alba. White...........1/4 oz. 35c. $\$ 0.10$

globosa rubra. Purple............1/4 oz. 35c. .10

globosa. Mixed colors............1/4 oz. $35 \mathrm{c} . \quad .10$

GLOXINIA. G.P. Charming pot plants, flowering during Summer in the greenhouse or window

Marshall's Matchless. Erect, giant-flowering, mixed. Saved from the very choicest erect flowering varieties in cultivation. A grand variety of colors.

GODETIA. H.A. Bushy annual, with showy large flowers. They grow quickly, bloom abundantly and are excellent for beds and borders. The double varieties are splendid for cutting. 18 in.

Brilliant. Glowing carmine.....1/4 oz. 35̄c. Double Rose. A delicate rose-pink shade. $1 / 4 \mathrm{oz} .50 \mathrm{c}$.

Duchess of Albany. Satiny-white. $1 / 4$ oz. $35 \mathrm{c}$ Gloriosa. Compact, brilliant blood-red

$1 / 4$ oz. $35 \mathrm{c}$.

Rosy Morn. A lovely coral-pink, very double flowers....................1/4 oz. $75 \mathrm{c}$.

Finest Mixed Colors...............oz. 60c.

GOMPHRENA. (See GLOBE AMARANTH.)

GOURDS. H.A.C. Thrifty annual climbers, bearing "Ornamental Gourds." $10 \mathrm{ft}$.

Apple-shaped. Small fruit, striped yellow and dark green........................ 40 c.

Bottle-shaped. Fruit yellowish-white and dark green.

Calabash, or African Pipe Gourd .oz. 50c.

Dipper-shaped.................... oz. 40c.

Dishcloth (Chinese Loofa, or Sponge Gourd). Large, elongate fruit; spongy inside. Flowers deep golden yellow................. oz. 40c.

Egg. Fruit white; resembles eggs.......oz. 40c.

Hercules' Club. Enormous fruit; often 4 feet long, thicker at the base............ $50 \mathrm{c}$.

Mock Orange, or Orange-shaped .... oz. 50c.

Pear-shaped. Very pretty striped fruit..0z. 50c.

Sugar Trough..................

Mixed Ornamental Varieties........... oz. 40c. .10

Collection of Ten Varieties of Gourds......75

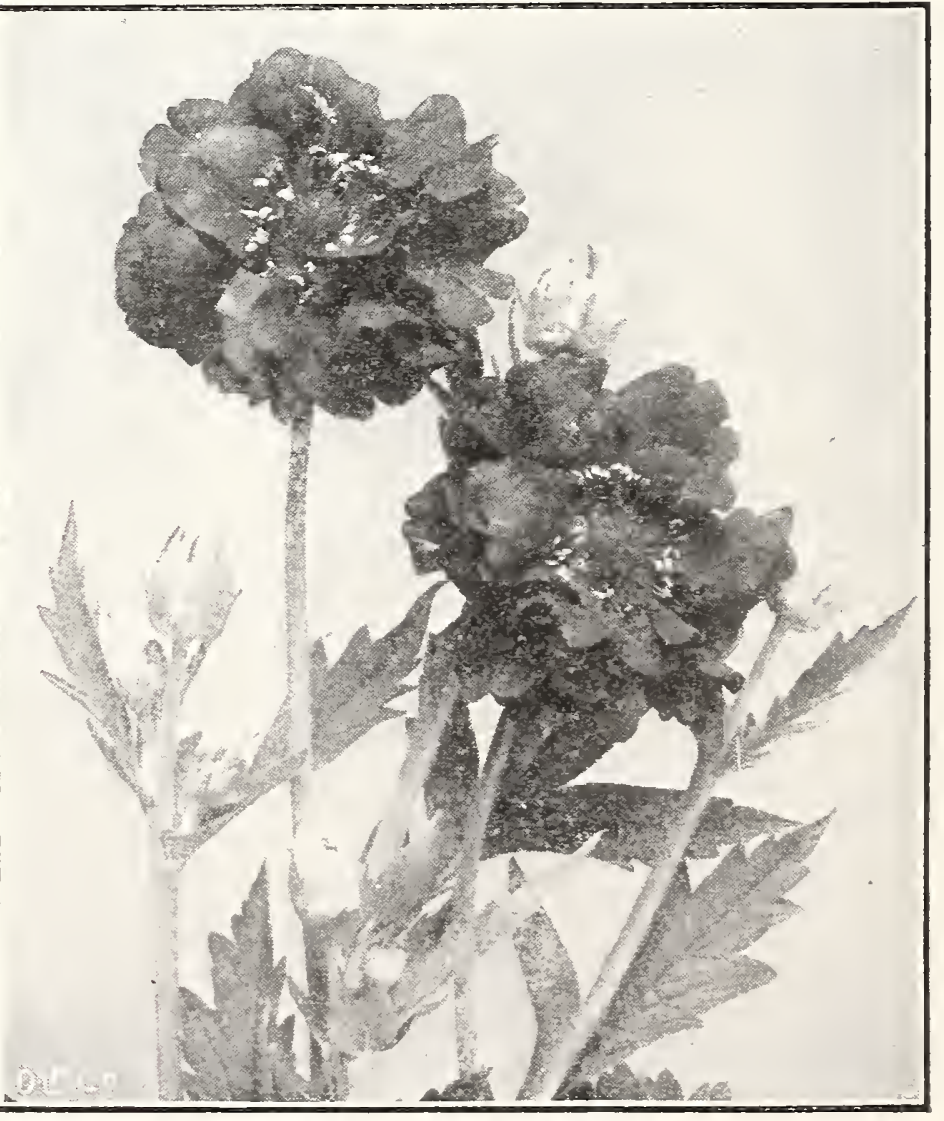

Geum, Mrs. Bradshaw 


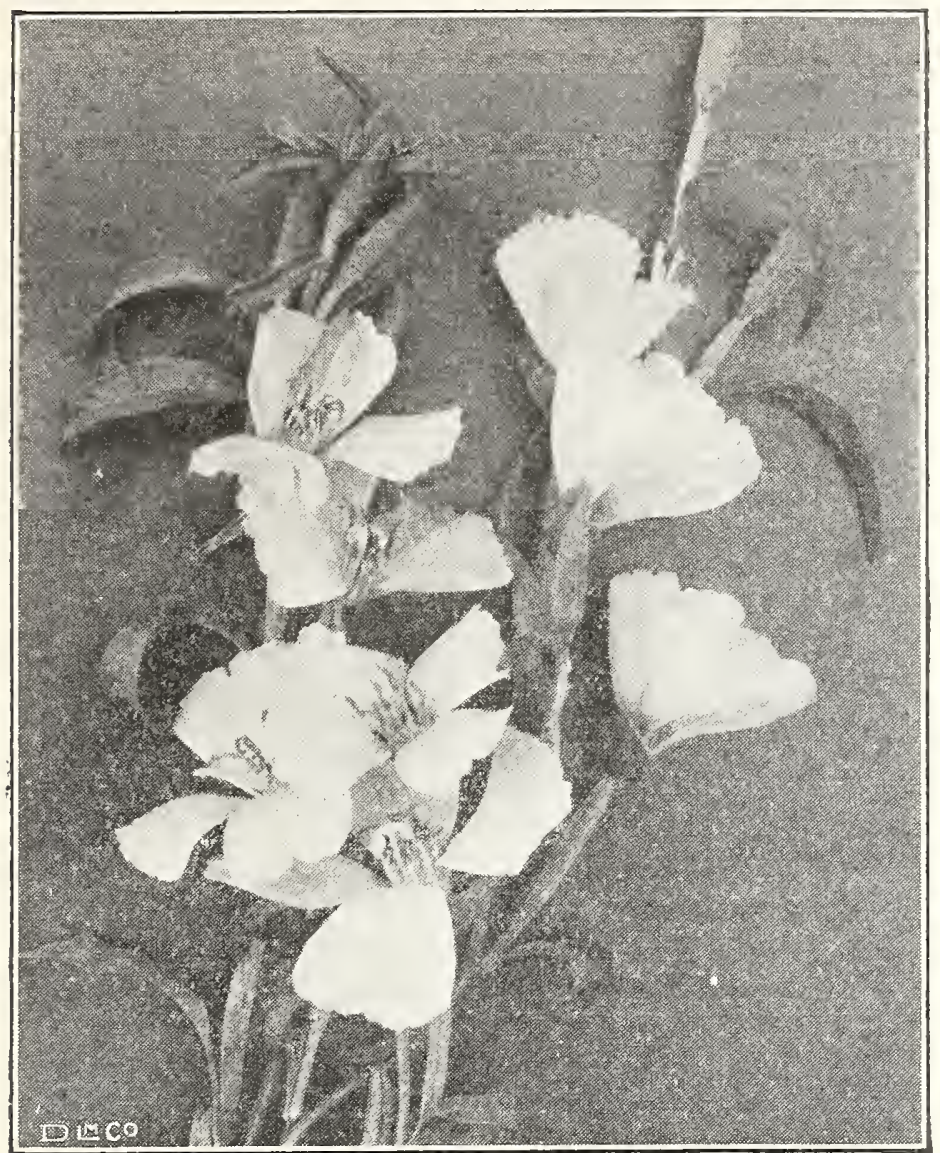

Godetia, Rosy Morn. See page 36 .

GRASSES, ORNAMENTAL. A most valuable class of plants for the lawn, shrub bed, border or tropical bed. The perennial varieties, many of which have variegated foliage, are excellent for borders, clumps on lawn or neal ponds. The annual sorts are particularly pretty on account of the graceful, feather flower panicles, which are used in bouquets.

Agrostis nebulosa. H.A. Very graceful and

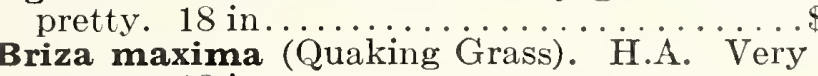

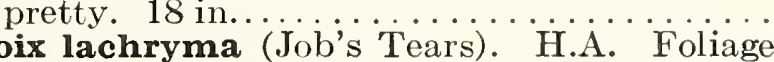
Coix lachryma (Job's Tears). H.A. Foliage
quite broad. Seeds prominent, very large quite broad. Seeds prominent, very large

rianthus ravennae. H.P. Silvery plumes, resembling Pampas Grass. $8 \mathrm{ft}$.

Eulalia zebrina. H.P. White striped foliage, very ornamental. $4 \mathrm{ft} \ldots \ldots \ldots \ldots 1 / 4 \mathrm{oz} .35 \mathrm{c}$.

Gynerium argenteum (Pampas Grass). H.P. Beautiful silvery plumes. $10 \mathrm{ft} .1 / 4 \mathrm{oz} .35 \mathrm{c}$.

Hordeum jubatum (Squirrel-tail Grass). H.A. A pretty variety, with bushy panicles of flowers. $3 \mathrm{ft}$.

Pennisetum longistylum. H. grass, with gracefully drooping heads. $2 \mathrm{ft}$.

Pennisetum ruppelianum. H.P $1 / 4$ oz. $35 \mathrm{c}$. perennial grass, growing 3 feet high with violet-tinted silvery plumes. The deep green foliage is long and slender.......1/4 oz. 35c.

GREVILLEA robusta (Silk Oak). G.P. With graceful foliage. $4 \mathrm{ft}$..........1/4 oz. $50 \mathrm{c}$.

GYPSOPHILA (Baby's Breath). H.A. Extremely useful for bouquets. Flowers small and come in delicate sprays and panicles.

elegans alba grandiflora. An improved large flowering, pure white form of the annual Baby's Breath...................oz. 50c. elegans carminea. Carmine rose......oz. 60c. rosea grandiflora. Delicate rose....... oz. $60 \mathrm{c}$. muralis. Bright rose... 1/4 oz. 35c. paniculata. H.P. One of the finest for cutting. Pure white flowers, very small and borne in large panicles. $2 \mathrm{ft} . \ldots .1 / 4 \mathrm{oz} .50 \mathrm{c}$. paniculata fiore plena. H.P. A doubleflowering variety; pure white. $2 \mathrm{ft}$.......
HELENIUM. H.P. Striking hardy plants, very useful for decorating.

Crimson Beauty. A fine crimson-red, blooming from June to October. $2 \mathrm{ft} \ldots \ldots \ldots \ldots . \$ 0.15$

Riverton Gem. Yellow, changing to red. Long stems. $5 \mathrm{ft}$.

HELIANTHUS. (See SUNFLOWER.)

HELICHRYSUM, or STRAWFLOWER. H.A Large, double "everlasting" flowers. $2 \mathrm{ft}$. montrosum, Fire Ball. Double red. 1/4 oz. $50 \mathrm{c}$ montrosum, Golden Globe. Double yellow. $1 / 4$ oz. $50 c$ monstrosum. Salmon.........1/4 oz. 50c. monstrosum, Silver Globe. Glistening white. $1 / 4$ Oz. 50c. 4 Colors. Large Flowering, Double, Mixed Colors.

HELIO'TROPE. G.P. Well-known fragrant flowering plants for pots or gardens.

Marshall's Blue Perfection. Dark blue.

Anna Tureil. Light blue

White Lady. A popular white variety Finest Mixed............. $1 / 8 \mathrm{oz} 40 \mathrm{c}$. Lemoine's Giant Hybrids, Mixed

HEUCHERA sanguinea splendens. H.P. Long spikes of fiery-red flowers. 18 in

sanguinea hybrida. H.P. Fine for borders. 18 in. Mixed colors

HIBISCUS. Showy plants of vigorous growth. africanus. H.A. Yellow with black center. $18 \mathrm{in} . . . . . . . .1 / 4 \mathrm{oz} .25 \mathrm{c}$

Marshall's Rainbow grandiflorus hybrids. H.P. New Giant-flowering Marshmallows. Very large flowers in various colors. $5 \mathrm{ft}$. $1 / 4$ Oz. $50 \mathrm{c}$

moscheutos (Swamp Rose Mallow). H.P. Flowers of a light rosy-red, with dark center.

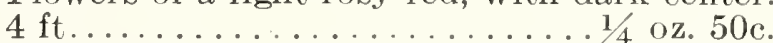

HOLLYHOCKS. H.P. One of the showiest of hardy garden plants. No garden is complete without these stately flowers. Hollyhocks are troubled of late with a rust, which can be prevented if plants are sprayed frequently in early Spring with Bordeaux Mixture. $6 \mathrm{ft}$.

Marshall's Giant. Double Apple Blossom.

1/8 oz. $50 \mathrm{c}$.

Marshall's Giant. Pink Queen. A pretty salmon-pink................1/8 oz. $\$ 1.00$ Marshall's Giant. Double Scarlet. $1 / 8 \mathrm{oz} .50 \mathrm{c}$. Marshall's Giant. Double Rose. 1/8 oz. $50 \mathrm{c}$. Marshall's Giant. Double Sulphur Yellow.

Marshall's Giant. Double White $1 / 8 \mathrm{oz} .50 \mathrm{c}$. Marshall's Giant. Double Violet Purple. 1/8 oz. 50c. Marshall's Giant. Double Fine Mixed.

Chater's Extra Choice, Double Mixed Colors

Hybrid Everblooming, Double, Mixed. Flowers the first season from seed. Very fine colors................... o o. $50 \mathrm{c}$.

Collection of Double Hollyhocks. Six colors.

Marshall's Giant. Single Pink. . 1/4 oz. $75 \mathrm{c}$.

Marshall's Giant. Single Red... 1/4 oz. 75c. Marshall's Giant. Single Yellow.1/4 oz. $75 \mathrm{c}$. Marshall's Giant. Single White. 1/4 oz. $75 \mathrm{c}$. Marshall's Giant. Single Mixed. All colors. 1/4 Oz. 50c Mixed.

HONESTY. (See LUNARIA biennis.)

HUMULUS japonicus (Japanese Hop). H.A.C. A climber with dense green foliage; $20 \mathrm{ft}$.

japonicus fol. variegatus. Variegated foliage. 
HUNNEMANNIA fumariaefolia (Giant Yellow Tulip Poppr). H.A. Flowers are tulip-shaped, pure golden yellow. Wher cut and put in water they will last a full week. $2 \mathrm{ft}$.. $1 / 1$ oz. 30 c. $\$ 0.10$

HYACINTH BEAN. (See DOCICHOS.)

IBERIS. (See CANDYTUTT.)

ICE PLANT. (SEe MESEMBR YANTHEMUM CRYSTALLINUM.)

CMPATIENS (Sultan's or Zanibar Balsam). G.P. Charming plants for decoration of the greenhouse or table, producing waxy looking fiowers profusely and continuously. $2 \mathrm{ft}$. sultani. Flowers of brilliant rosy-scarlet color. holsti Hybrids. Form strong bushy plants covered with attractive flowers. As pot plants they bloom the year round. Choicest mixed colors.

INCARVILLEA delavavi。 H.P. The flowers are horne on long, stout scems, tube-shaped. Color bright rose. $2 \mathrm{ft}$......1/8 oz. $75 \mathrm{c}$.

IONOPSIDIUM acaule. H.H.P. Pale maure flowers adapted for rockeries and carpet beding: rery dwarf habit. $t$ in.

IPOMOEA, Morning Glory. (See also CONVOLVULUS.) H.A.C. Climbers of rapid growth, with beautiful and varied flowers; for corering walls, trellises, arbors or stumps of trees they are invaluable. $20 \mathrm{ft}$.

cardinalis, (Cardinal Flower). A rapid growing annual, with deep cardinal red flowers and laciniated foliage............... oz. $50 \mathrm{c}$. grandiflora alba (Moonflower). Large, heartshaped leares and large, pure white flowers, which open only late in the evening. $1 / 4$ oz. 35c. rubro coerulea (Heavenly Blue). Beautiful, sky-blue flowers..............1/4 oz. 35̌c. setosa (Brazilian Morning Glory). Large, ormental foliage, with bright rose flowers.

Imperial Japanese, Mixed. A great improveinent orer the old-fishioned sorts..oz.50c. quamoclit. (See CPRESS VINE.)

KENILWORTH IVY。 El.P. Neat, hardy climber, clinging to walls etc. $6 \mathrm{ft} . . . .$.

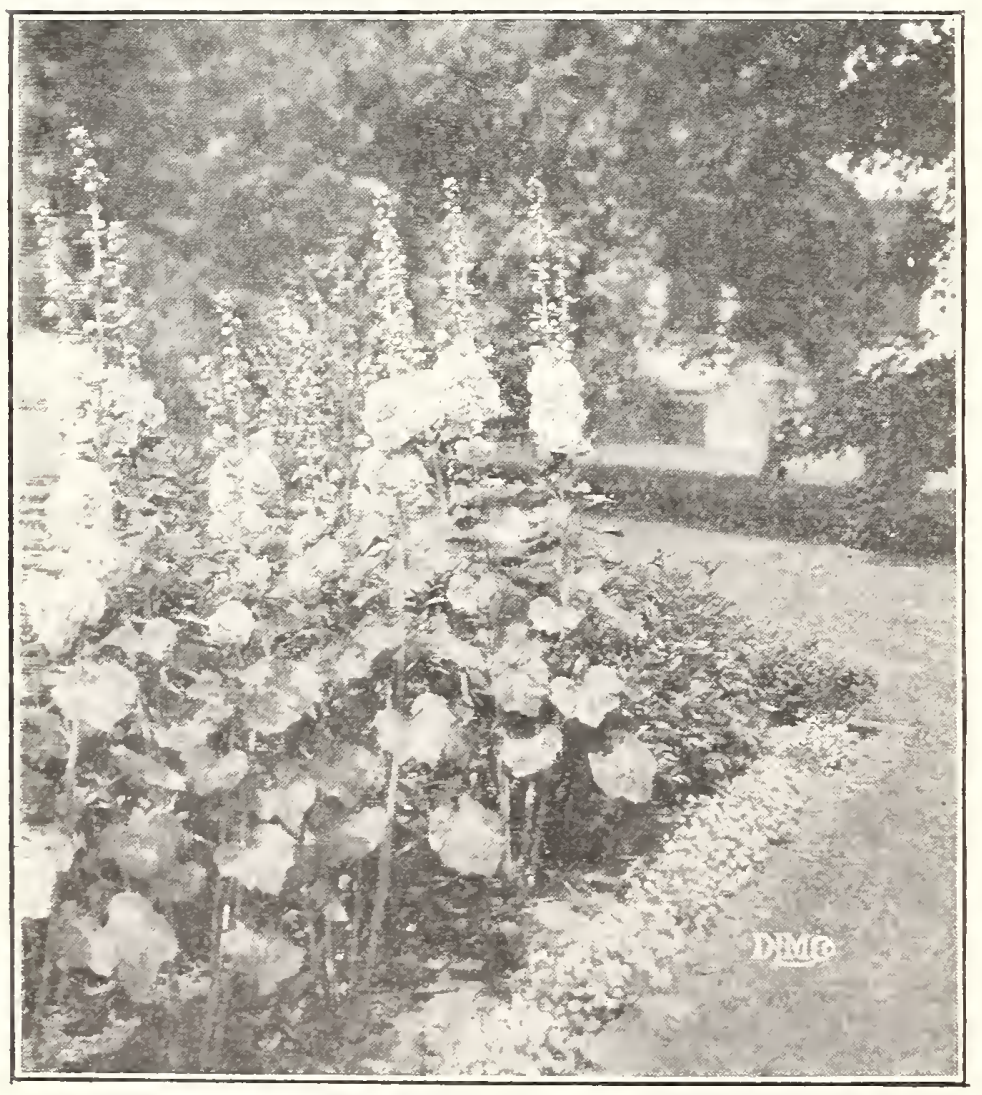

Hollyhock, Marshall's Giant. See page 37 .
KOCHIA tricophylla (Belvedere Summer CyPkt. press, or Mexican Firebush). H.A. Grows in a pefectly pyramidal shaped cypress bush, with small, feathery, light-green foliage. Becomes a lovely crimson hue about September. $21 / 2 \mathrm{ft} . . \ldots \ldots \ldots \ldots \ldots \ldots \ldots 1 / 4$ oz. 35 c. $\$ 0.10$

KUDZU VINE (Pueraria thunbergiana). H.P. A splendid climber for corering permanent rerandas, dead trees, etc. Large green foliage and pea-shaped blossoms...1/4 oz. $50 \mathrm{c}$.

LANTANA. G.P. One of the most desirable greenhouse or bedding plants; constantly in bloom. $2 \mathrm{ft}$. Newest hybrids, mixed...... $1 / 4$ oz. $50 \mathrm{c}$.

LATHYRUS latifolius, Perennial Sweet Pea. H.P. Hardy climbers. Fine for cutting. $6 \mathrm{ft}$. latifolius. Purplish-red..........1/4 oz. 50c. .15

latifolius albus. Pure white.....1/4 oz. 50c. White Pearl. A large flowering, robust growing rariety of the abore..........1/4 oz. $\$ 1.00$

Pink Beauty. Rosy pink........1/4 oz. 50c.

Finest Mixed. All colors.........1/4 oz. 30c.

LARKSPUR. H.A. Elegant and ornamental plants, producing in great variety of form some of the most beautiful flowers in cultivation.

Marshall's Invincible Branching. Double flowers; excellent for cutting. Offered in the following choice of colors. $2 \mathrm{ft}$.

Azure Blue............ . 1/4 oz. 50c. Dark Blue.............1/4 oz. 50c. Carmine.............. 1/4 oz. 50c.

Flesh color............1/4 oz. 50c. Rose................1/4 oz. $50 \mathrm{c}$. White............. 1/4 oz. 50c. Finest Mixed..........1/4 oz. 40c.

Collection Invincible, Branching, 6 Varieties.

Newport Scarlet. Can be treated either as an annual or biennial............ $1 / 4 \mathrm{oz} .60 \mathrm{c}$.

Dwarf Rocket. Finest Colors. Fine for bedding. 12 in................ 1/4 oz. $25 \mathrm{c}$.

Tall Rocket. Mixed. Long showy spikes...

Perennial Larkspur. (See Delphinium.)

LAVATERA splendens, rosea (Pink Nallow). H.A. Bushy plants; produce large, open, pink, mallow-like flowers in great profusion. $3 \mathrm{ft}$. $1 / 4$ oz. $50 \mathrm{c}$.

splendens, alba. Large, glossy white flowers.

Finest Mixed Colors..........1/4 oz. $50 \mathrm{c}$.

LEMON VERBENA. (See VERBENA.)

LEPTOSYNE maritima. H.A. Large lemonyellow Marguerite-like flowers on tall stalks. $3 \mathrm{ft}$.

LINARIA cymbalaria. (See KENIWWORTH IVY.)

LINARIA. H.A. Very showy annual resembling Snapdragon. Used extensively as a Winter cut flower in greenhouses. $1 \mathrm{ft}$.

Choice Mixed Varieties.

LINUM. H.A. Free flowering plants for borders. grandiflora rubrum. Single scarlet flowers. 12 in ................... . . oz. $25 \mathrm{c}$. perenne. H.P. A lovely plant with blue flowers. 18 in............... 1/4 oz. $35 \mathrm{c}$.

LUNARIA biennis (Honesty). H.B. A curious plant grown for its peculiar, transparent seed pods, which are used as Winter decoration. $2 \mathrm{ft} \ldots \ldots \ldots \ldots \ldots \ldots \ldots \ldots$. $1 / 4$ oz. $50 \mathrm{c}$. 


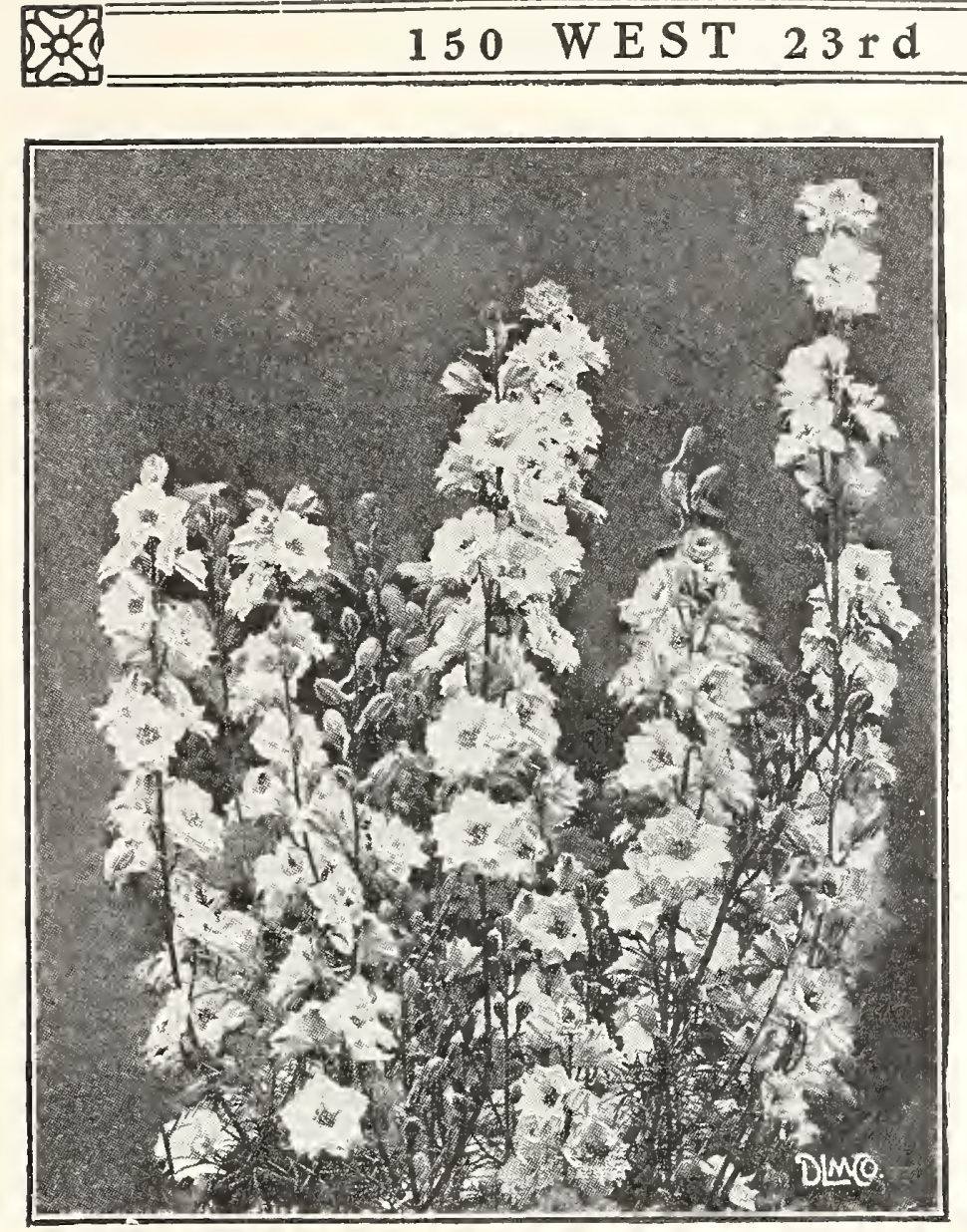

Larkspur, Marshall's Invincible. See page 38.

LOBELIA. H.H.A. Bushy plants, with pendant branches; very profuse flowering. Fine for baskets or edging borders. 6 in.

Marshall's Compact. The finest dark blue Lo-

belia; the plants are compact, covered with a profusion of bloom..........1-16 oz. $\$ 1.00$ erinus compacta, Crystai Palace. Dark blue. $1 / 8$ OZ. $\$ 1.00 \quad .15$ erinus compacta, Emperor. light blue. erinus speciosa. Bright blue flowers...... $1 / 8$ oz. $50 \mathrm{c} . \quad .15$ erinus gracilis. Blue flowers; trailing. $1 / 8 \mathrm{Oz} .50 \mathrm{c}$ erinus, Mixed Colors. White, blue, rose, etc. tenuior (Ramosa). Upright habit with very large blue flowers; adapted for pots or borders.

Perennial Varieties:

cardinalis (Cardinal Flower). A native variety, with spikes of scarlet flowers; fine border plant. $3 \mathrm{ft}$.

cardinalis Hybrids. Splendid hybrids, mixed

LOPHOSPERNUM scandens. H.H.C. Dark rose. A rapid growing climber.

LOVE-LIES-BLEEDING. (See AMARANTHUS)

LOVE-IN-A-MIST. (See NIGELLA.)

LUPINUS. Free flowering plants, with long spikes of flowers. The Annual and Perennial varieties are among the most useful of our garden flowers, either for mixed borders or house decorations. $2 \mathrm{ft}$.

hartwegi Blue. A delicate shade. . 1/4 oz. 30c. hartwegi white. Splendid for cutting.

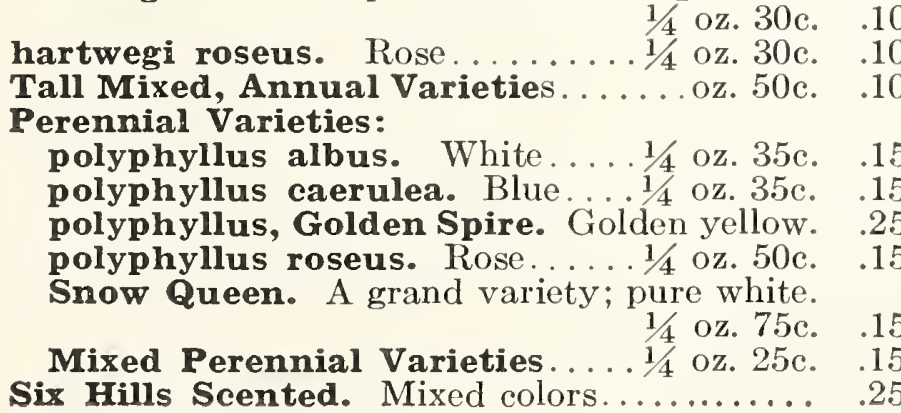

LYCHNIS chalcedonica. H.P. The old favorite Scarlet Lychnis. 18 in.......1/4 oz. 50c.\$0.15 arkwrighti. Large brilliant flowers varying in color from orange-scarlet to soft salmon-pink.

haageana Hybrids, Mixed Colors. Bushy little plants. $12 \mathrm{in} . . . . \ldots \ldots \ldots 1 / 8 \mathrm{oz} .35 \mathrm{c}$.

MALOPE grandiflora. H.A. Very showy border annual; large flowers. $2 \mathrm{ft}$.

Mixed Colors.................1/4 oz. 25c.

15

MARIGOLD. H.A. Widely grown hardy annuals invaluable for bedding and producing an elegant display of yellow, orange and brown flowers from early Summer till frost.

African varieties. Showy flowers. $3 \mathrm{ft}$. Marshall's Lemon Queen. A charming shade.............. 1/4 oz. 60c Marshali's Prince of Orange. Beautiful orange color............1/4 oz. 60c. Mixed Double.............1/4 oz. 50c. Collection Double African. Six colors separate.

French Varieties. Small double flowers 12 in Dwarf Gold Striped. Rich and quaintly striped double flowers........1/4 oz. 50c. Legion of Honor. Single yellow blooms, marked with red ...........1/4 oz. 50c Dwarf, Mixed, Double.......... . . 1/4 oz. $35 \mathrm{c}$ Collection, Double French Dwarf. Six

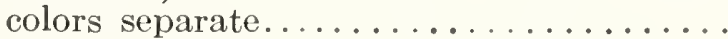

MARVEL OF PERU (Four o'Clocks). H.A. A well-known handsome, free flowering garden favorite; does well everywhere. $2 \mathrm{ft}$. Mixed. oz. $50 \mathrm{c}$.

MATHIOLA bicornis (Évening Scented Stock). H.H.A. Very sweet-scented lilac flowers. 12 in................. $1 / 4$ oz. $35 \mathrm{c}$.

MATRICARIA (Feverfew). H.H.P. Low growing. plants; suitable for beds and edgings. 12 in.

capensis plena. Dwarf double white

Golden Ball. V $1 / 4$ oz. 50c. Golden Ball. Very striking double goldenyellow flowers............... oz $\$ 1.00$

Silver Ball. Dainty double white spherical flowers.................1-16 oz. $\$ 1.00$

MAURANDIA, Mixed Colors. H.H.P. Tender climber.

MESEMBRYANTHEMUM crystallinum (Ice Plant). H.H.A. A dwarf trailing annual plant; flowers white. 6 in.....1/4 oz. 35c.

MIGNONETTE, Large Flowering. H.A. The popular fragrant garden annual. The seed can be sown at any time, and if successive sowings are made, its fragrant, modest colored flowers may be gathered outdoors until November. 12 in..

Allen's Defiance. Full round spikes of great length.................1/4 oz. $35 \mathrm{c}$. Bismarck. Improved $\mathrm{D}$ warf. $\dot{M}$ achet variety. $1 / 4$ oz. $35 \mathrm{c}$.

Crimson Giant. Deep red flowers. $1 / 4$ oz. 35c. Goliath. Red; enormous spikes....1/4 oz. 50c. Golden Queen. Compact yellow flowers.

Machet, Dwarf. Strong plants of pyramidal growth; long, broad spikes of deliciously scented red flowers. 9 in.......1/4 oz. 35c.

Majesty. Selected strain for pots or benches. $1-16$ oz. $\$ 1.00$

New York Market. The finest of all the fancy varieties of Mignonette for Winter forcing. $1-16 \mathrm{oz} . \$ 1.00$

Sweet-Scented (Reseda odorata grandiflora). The large flowering garden variety..oz. 50c.

MIMOSA pudica (Sensitive Plant). H.H.A. An interesting plant with rosy-lilac flowers. The leaves close when touched. $12 \mathrm{in} .1 / 4 \mathrm{oz} .50 \mathrm{c}$.
.15

15

.10 
MIMULUS. Showy half-hardy annuals, with handsome flowers; excellent for pots or garden. 6 in.

tigrinus, Spotted, Mixed

$\$ 0.15$

moschatus (Musk Plant). Fragrant; for pots. $1-16 \mathrm{oz} . \$ 1.00$

MINA lobata. H.A.C. Rapid climber with crimson and orange flowers. $10 \mathrm{ft}$

MIRABILIS. (See MARVEL OF PERU.)

MOMORDICA. H.A.C. Trailing plants, with curious and ornamental foliage and remarkable fruit.

balsamina (Balsam Apple). Orange fruit. $1 / 4$ oz. $25 \mathrm{c}$. let fruit................1/4 oz. 25c.

MOON FLOWERS. (See IPOMOEA grandiflora.)

MORNING GLORIES. (See IPOMOEA and CONVOLVULUS.)

MUSK. (See MIMULUS.)

MYOSOTIS, or FORGET-ME-NOTS. H.H.P. Fine for edging or in beds with Pansies, Daisies, etc. Seed may be sown any time from Spring until Midsummer. 9 in.

alpestris, Blue............1/4 oz. 50c. alpestris, Mixed Colors. White, blue, pink, etc....................1/4 oz. 50c. dissitiflora. Blooms very early; flowers blue. $1 / 8$ oz. $\$ 1.00$ palustris semperflorens. The true water Forget-me-not. Blooms from early Spring until Autumn. Dark blue.......... .1/4 oz. $\$ 1.00$

Marshall's Royal Blue. Early and free flowering; color deep indigo blue. Fine for borders or cutting.............. 1/8 oz. $\$ 1.00$

robusta grandiflora, Eliza Fonrobert. A very strong growing variety.....1/4 oz. $75 \mathrm{c}$

Ruth Fischer. Compact growth; blue flowers.

Victoria. The plants are of dwarf, compact growth, with a multitude of bright blue flowers in dense umbels............1/4 oz. $\$ 1.00$

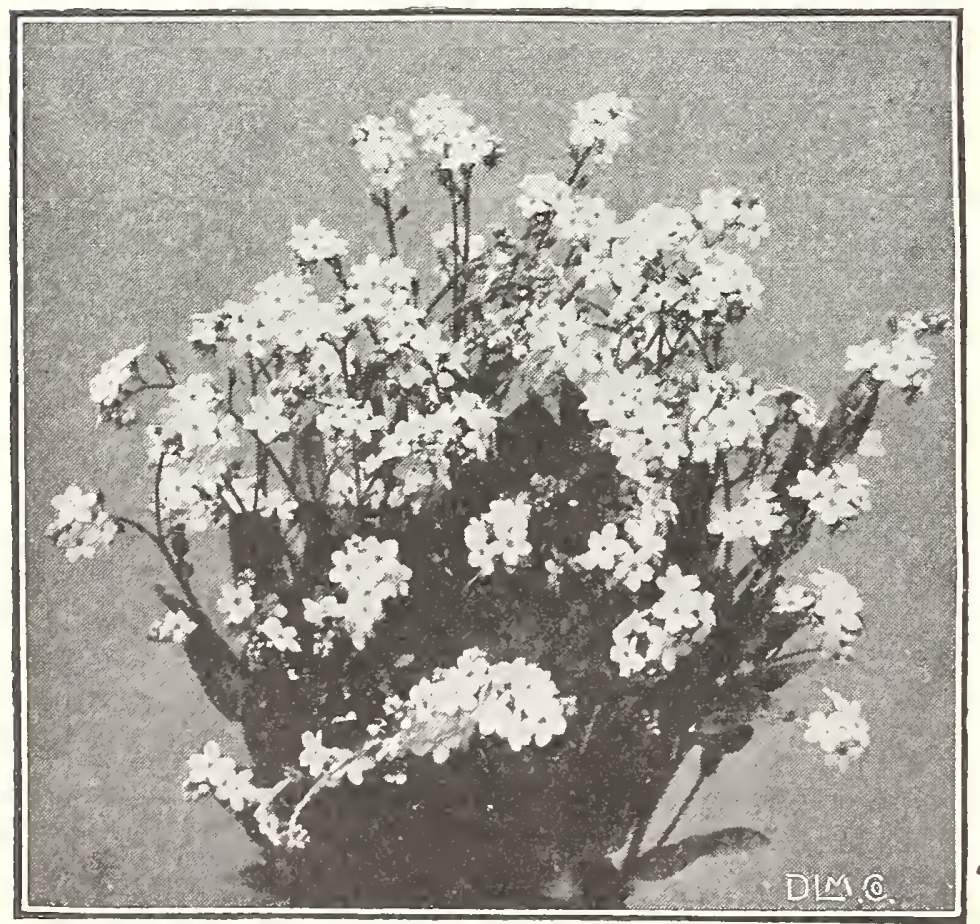

Myosotis, Marshall's Royal Blue
NASTURTIUM (Tropaeolum nanum). H.A.

Tom Thumb, or Dwarf Varieties. These have a compact habit and attractive foliage; are not disturbed by insects; bloom in two months from sowing, and most profusely the whole season. 12 in.

Aurora. Yellow-veined ..............oz. 25c.\$0.10

Beauty. Yellow and scarlet...........oz. 25c. $\quad .10$

Cloth of Gold. Scarlet, yellow foliage. oz. 25c. $\quad .10$

Empress of India. Crimson, dark foliage.

King Theodore. Oz. 25c. .10

King of Tom Thumbs. Scarlet..... oz. 25c. .10

luteum. Bright yellow; no blotches...oz. 25c. .10

Pearl. Creamy white................. oz. 25c. .10

Rose Color.......................... 25c. .10

Marshall's Dwarf Rainbow Mixture. These contain all the leading named sorts, mixed. oz. 20c., $1 / 4$ lb. 60c., lb. $\$ 2.00$

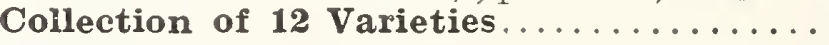

NASTURTIUM (Tropaeolum majus). H.A.C.

Tall, or Climbing Varieties. Adapted for rockwork, banks, covering trellises or rustic work; the seeds, if picked young, are an excellent substitute for capers. $6 \mathrm{ft}$

Chameleon. Various colors on one plant.

Dark Crimson......... Oz. 25c. $\quad .10$

King Theodore. Crimson; dark foliage .oz. 25c. $\quad .10$

Pearl. Creamy white.................oz. 25c. .10

Rose (Von Moltke)................. oz. 25c. .10

Scarlet...........................oz. 25c. .10

Yellow......................... oz. 25c. .10

Vesuvius. Salmon-rose................0z. 25c. .10

Marshall's Tall Rainbow Mixture. From the best varieties..oz. 20c., 1/4 lb. 60c., lb. $\$ 2.00$

Collection of 12 varieties.............

LOBB'S NASTURTIUMS (Tropaeolum lobbianum). H.A.C. Very free blooming, embracing the most brilliant colors, climbing about 6 feet. Excellent for window boxes, vases and hanging baskets.

Lobb's Finest Mixture............... oz. 25c

Madame Gunther Hybrids. A French strain; noted for wide range of fine colors...oz. $25 \mathrm{c}$.

NEMESIA. H.A. Splendid plants for bedding or forcing in greenhouse.

strumosa grandiflora suttoni. Mixed colors. Bushy plants; flowers of unique form. 12 in. $1-16$ oz $\$ 1.00$

compacta Blue Gem. Large flowers of a pretty Forget-me-not blue; a fine pot plant. $1-16$ oz. $\$ 1.00$

compacta Triumph. New dwarf compact. 6 in. Finest mixture.........1-16 oz. $\$ 1.00$

NEMOPHILA. H.A. Splendid free flowering annual, with cup-shaped flowers of many bright colors. 12 in.

Mixed colors..............1/4 oz. 25c.

NICOTIANA affinis. H.A. Fragrant, starshaped white flowers. $3 \mathrm{ft} \ldots \ldots 1 / 4 \mathrm{Oz} .35 \mathrm{c}$. affinis Hybrids. Large flowered; scented. All shades mixed..............1/4 oz. 50c sanderae Hybrids. All colors. $4 \mathrm{ft} .1 / 4 \mathrm{oz} .35 \mathrm{c}$. sylvestris. Large drooping clusters of pure white flowers. $4 \mathrm{ft} . \ldots \ldots \ldots \ldots 1 / 4 \mathrm{oz} .35 \mathrm{c}$.

NIEREMBERGIA frutescens. H.H.P. For hanging baskets or borders; large, cup-shaped lilac flowers................1/4 oz. $50 \mathrm{c}$

NIGELLA (Love-in-a-mist). H.A. Beautiful border plants. $18 \mathrm{in.}$

Miss Jeykll. A lovely variety with cornflowerblue blossoms; splendid for cutting. $1 / 4 \mathrm{oz}$. $35 \mathrm{c}$.

Miss Jeykll, White. Valuable for borders and cutting................... oz. 35c Finest Mixed. Blue, white and purple.

$1 / 4 \mathrm{oz} .30 \mathrm{c}$ 10

\section{.60} 10 10 0 要 60

5

.

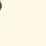


OENOTHERA (Evening Primrose). H.A. Useful for exposed sunny positions, blooming the entire Summer.

Afterglow. Yellow with brilliant red calyx

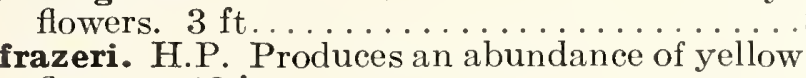
flowers. 12 in

Finest Mixed. i ft..........

PANSY. H.H.P. The most popular flower grown. They thrive best in a cool, moist, but welldrained soil. Sow the seeds in April and May for Summer flowering and August for early flowers the following Spring. Our mixtures contain a large variety of colors.

Marshall's Special Mix.ture. Saved from only the largest and best shaped flowers of the richest colors. Fine for greenhouse flowering..............1-16 oz. $\$ 3.00$

Marshall's Greenhouse Mixture. A selection of varieties adapted for growing under glass.

$1-16 \mathrm{oz} . \$ 1.25$

Marshall's Matchless Mixture. This matchless strain consists entirely of the newest best shaped and most handsome flowers, including an immense variety of brilliant colors. The seeds we offer are carefully saved from the largest selected flowers.........1/8 oz. $\$ 2.00$

Marshall's Superb Giant Mixed. A rich and most choicely varied mixture producing only the finest colors, largest flowers and beautiful forms. ...... 1/8 oz. $\$ 1.50$

Masterpiece. A beautiful strain of blotched and curled varieties............1/8 oz. $75 \mathrm{c}$.

Giant Trimardeau, Mixed. Large flowers in a good variety of colors...... . 1 $1 / 4 \mathrm{oz} . \$ 1.00$

GIANT PANSIES, in Varieties.

Giant Adonis. A beautiful light blue. Giant Cardinal. A very brilliant red ......

$1 / 8$ oz. $75 \mathrm{c}$.

Giant Emperor. Ultramarine blue. $1 / 8$ oz. $75 \mathrm{c}$

Giant Fire King. Crimson-purple and golder yellow..................1/8 oz. $75 \mathrm{c}$

Giant Golden Queen. Beautiful pure yellow.

Giant Golden Yellow, with dark eye.

Giant King of the Blacks.

Giant Lord Beaconsfield. Violet, shaded white.......... $1 / 8$ oz. $75 \mathrm{c}$

Giant Orange King. Vivid orange. $1 / 8$ oz. $\$ 1.00$

Giant Prince Bismarck. Light brown shade with black eye...........1/8 oz. $75 \mathrm{c}$

Giant Snow Queen. Pure white... $1 / 8$ oz. $75 \mathrm{c}$.

Giant Striped. Variety of markings. $1 / 8 \mathrm{oz} .75 \mathrm{c}$.

Giant Victoria. Wine-red shades. 1/8 oz. $75 \mathrm{c}$.

Giant White, with black eye.....1/8 oz. $75 \mathrm{c}$.

Collection of Six Varieties, Giant named.

Collection of Twelve Varieties, Giant named....................... 1.50

PAPAVER. (See POPPIES.)

PASSIFLORA coerulea (Passion Flower). H.H.C. Fast growing and free flowering, ornamental perennial climbers, with large, showy blue flowers, suitable for conservatory or outside in Summer......1/4 oz. $75 \mathrm{c}$.

PENTSTEMON. H.P. Highly useful and attractive hardy perennials, and much used in the hardy border. $2 \mathrm{ft}$.

gentianoides, Fine Mixed Colors. $1 / 4 \mathrm{oz} .75 \mathrm{c}$. gloxinioides "Sensation." A grand variety of colors. Will bloom from seed in June if sown early in March.

Marshall's Matchless Hybrids. A superb mixture of the best perennial sorts.

PERILLA nankinensis. H.A. Ornamentalleaved plants. 18 in ...........1/4 oz. 25c.
Pkt. 0.15

.50

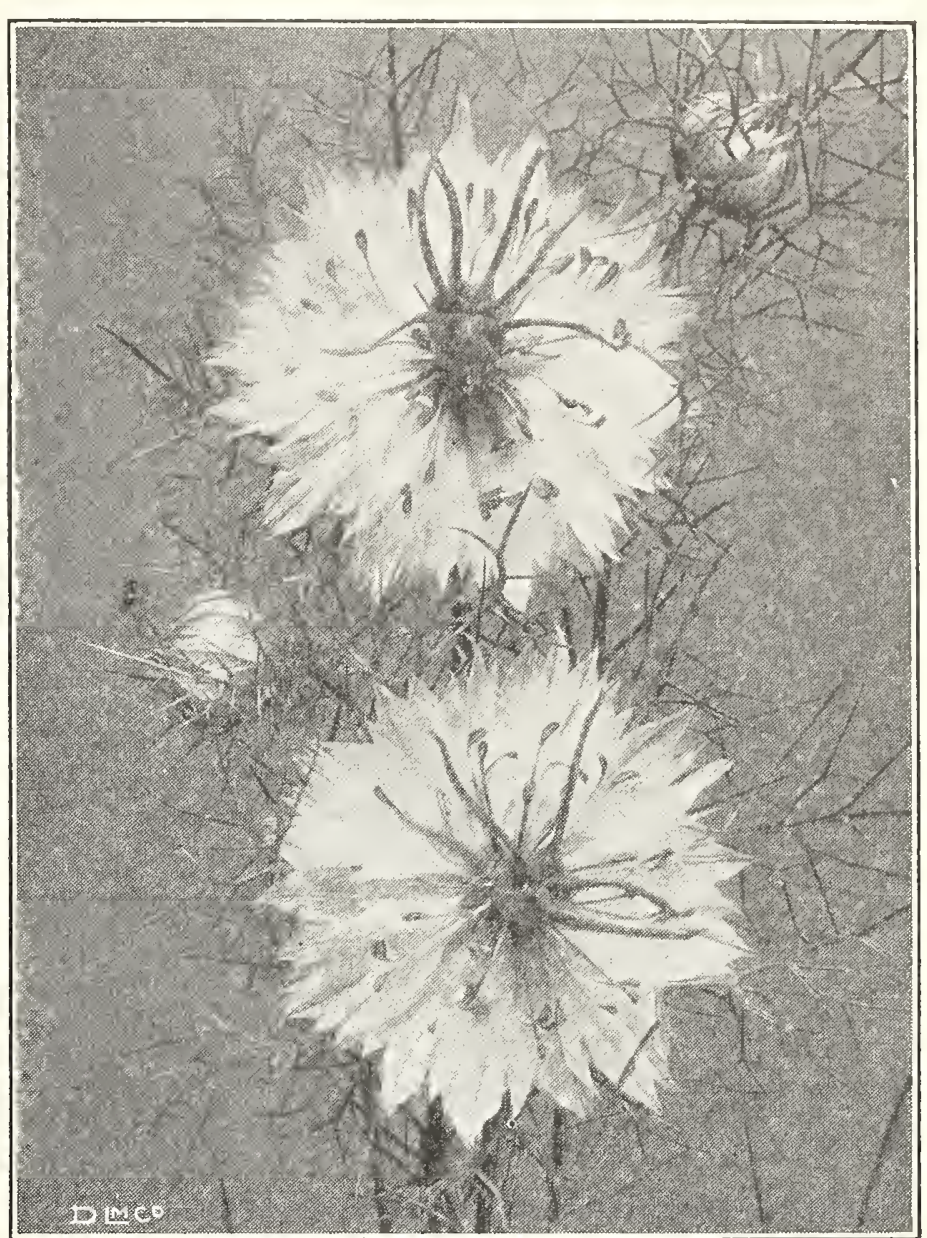

Nigella, Miss Jeyk1l. See page 40.

PETUNIA. H.A. One of our easiest cultivated and freest flowering annuals. Will succeed almost anywhere and give a continuity of the most brilliant bloom from June till killed by frost. $18 \mathrm{in.}$

Marshall's Double Giant, Fringed, Finest Mixed Hybrids. An exceptionally fine strain, remarkable for the large, beautiful, colored double flowers. . . . . . . . . ...\$0.50

Single Varieties:

Marshall's Superb Large-flowered Mixed (California Giants). Magnificent flowers with throats beautifully veined.

Marsha1l's Superb Large-flowered Fringed, Mixed. Flowers with fringed and frilled edges; distinct and beautiful.

Large-flowered, Finest Mixed. Fine large flowers in superb mixture. $1-16$ oz. $\$ 1.50$

Fine Mixed. An assortment of mediumsized flowers; fine for bedding. $1 / 4 \mathrm{oz} .50 \mathrm{c}$. maculata, Striped and Blotched (Inimitable). Flowers quite large and handsomely

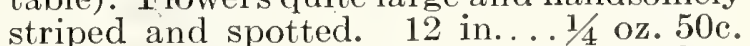

Adonis. Very showy, fiery carmine, white throat, free blooming and compact growth. $1 / 8 \mathrm{oz} . \$ 1.00$

Balcony Blue. Adapted for vases and window boxes.

Balcony Rose

Balcony White.

General Dodds. Very fine dark red

$$
1 / 4 \text { oz. } \$ 1.00
$$

Howard's Star. Crimson with white star. $1 / 8$ Qz. 50c.

Marshall's Purple Bedder. A beautiful purple bedding variety.... 1-16 oz. $\$ 1.00$ Marshall's Violet Queen. A grand Petunia for bedding, growing about 18 inches high and very free flowering.

Norma. Blue with white star, compact habit. very showy............1-16 oz. $\$ 1.00$ Rosy Morn. Soft carmine pink. 1/8 oz. $75 \mathrm{c}$. Snowball. Dwarf pure white; a fine bedding variety ................1/8 oz. 50c. snowstorm. Pure white; large flowering.
Pkt. 
PHACELIA campanularia. H.A. Tery showy with bright blue bell-shaped flowers. 9 in. $1 / 4$ oz. 50 c. $\$ 0.10$

PHLOX drummondi grandiflora. H.A. Improved large-flowering strains of this famous garden annual. It will grow and thrive in any kind of soil if given a sunny position, but prefers a light, rich loam. Seed may be sown in the open ground any time after danger from frost is past. $12 \mathrm{in.}$

Blood-Purple............... 1/4 oz. $75 \mathrm{c}$. Brilliant Rose................ 1/4 oz. 75c. Crimson..................... oz. 75c.

Salmon Rose. Salmon with yellow eye

$1 / 4 \mathrm{Oz} .75 \mathrm{c}$.

Scarlet.................... $75 \mathrm{c}$.

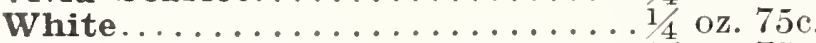

Yellow

stellata splendens. Star-like crimson.

$1 / 4$ oz. $75 \mathrm{c}$.

Choicest Mixed. Contains a very large variety of color.................. 1/4 oz. 50c.

PHLOX, Large-flowering, Dwarf Varieties. Effective for beds or borders. $6 \mathrm{in}$.

nana compacta Fireball. Bright red.

$1 / 8$ oz. $\$ 1.00$ nana compacta Snowball. Compact, pure white................... oz. $\$ 1.00$ nana compacta, Mixed Colors. Star-shaped flowers..................... 1/8 oz. $\$ 1.00$

PHLOX, Hardy Perennial decussata. Most brilliant colored flowers in late Summer and Fall. $3 \mathrm{ft} \ldots \ldots \ldots \ldots \ldots . . . . .1 / 4$ oz. $\$ 1.00$

PHYSALIS francheti (Chinese Lantern). H.B. Balloon-like fruits. $3 \mathrm{ft}$.

PHYSOSTEGIA (False-Dragonhead). H.P. $3 \mathrm{ft}$. virginica. One of the prettiest hardy perennials. It forms dense bushes bearing freely spikes of delicate pink tubular flowers.

virginica alba. Pure white......1/8 oz. 50c. .15 PINKS. (See DIANTHUS.)

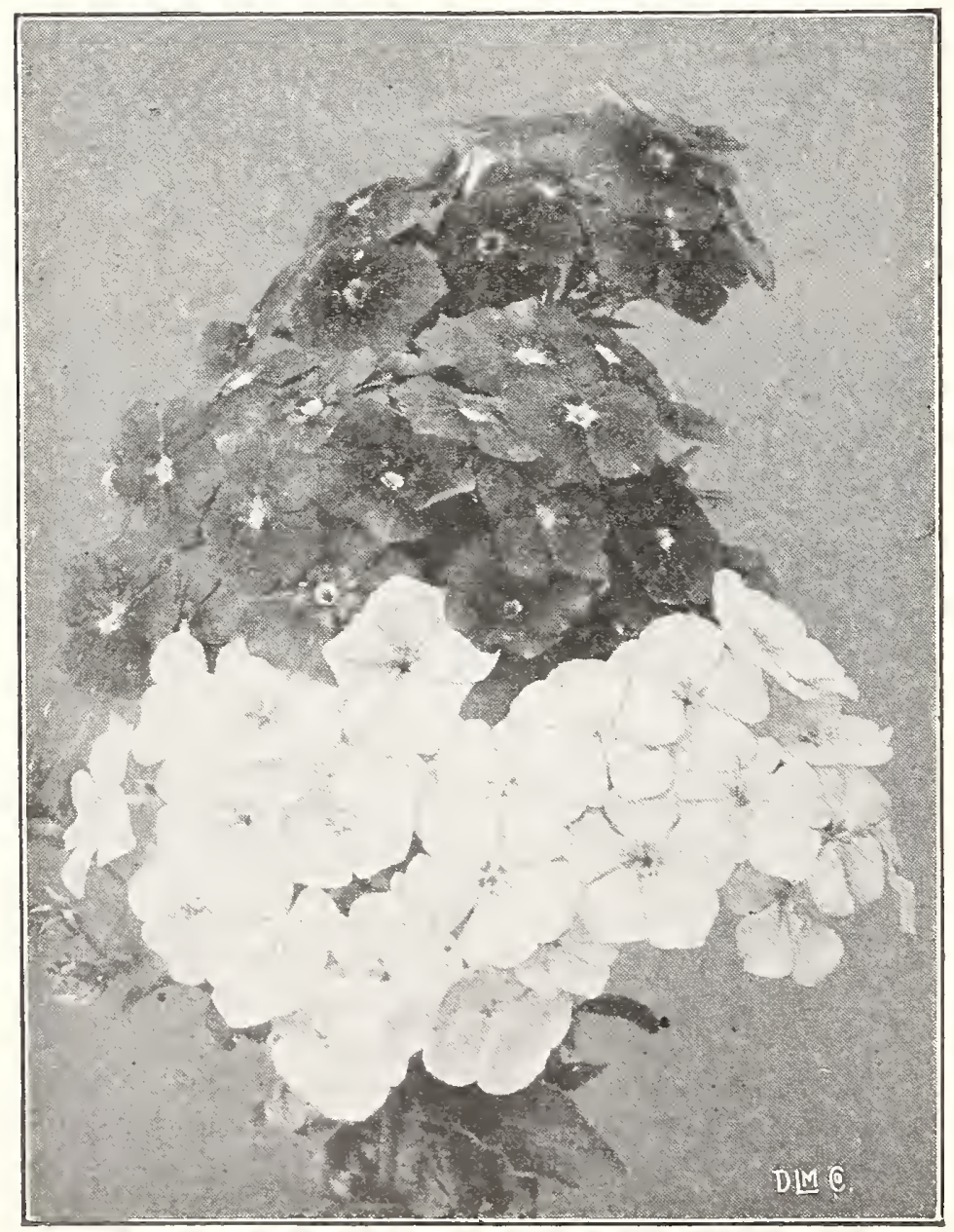

Phlox drummondi, Mixed
PLATYCODON. H.P. The large-flowering ChiPkt. ese Bell Flowers. $2 \mathrm{ft}$.

grandiflorum. Large, steel-blue flowers.

album. Pure white rariety $1 / 8$ oz. 50c.\$0.15

mariesi. Dwarf, large-flowered blue. $12 \mathrm{in}$.

$1 / 8$ oz. $50 \mathrm{c}$.

POLEMONIUM coeruleum grandiflorum (Jacob's Ladder). H.P. Deeply cut foliage and clusters of handsome blue flowers. $2 \mathrm{ft}$. $1 / 1 \mathrm{Oz} . \$ 1.00$

grandiflorum album. Pure white. $1 / 4$ oz. $\$ 1.00$

POLYANTHUS (Primula elatior). H.H.P. Desirable for greenhouse flowering or bedding out in the Spring. 9 in.

Marshall's Matchless Gold Laced. Saved from the largest flowers in a wide range of colors

Munstead Giants. A magnificent strain of Bunch Primroses in shades of yellow and white.

PORTULACA. H.A. One of the freest flowering dwarf annuals, especially adapted for sunny locations. Flowers of the most brilliant colors. 6 in.

Single Rose:...............1/4 oz. 50c.

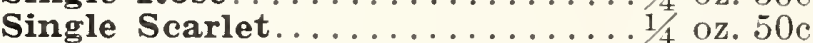

Single White.................1/1 oz. 50c

Single Yellow................. oz. 50c.

Single Mixed. All colors......... . . 1/4 oz. $35 \mathrm{c}$.

Double Large Flowering WVill produce a large percentage of double flowers in many colors.

Finest Mixed............... $1 / 4$ oz. $\$ 1.25$

POPPIES. Showy, free blooming, old-fashioned flowers. T'ery effective in mixed borders.

Single Annual Varieties, 12-in.: glaucum. The Scarlet Tulip Poppy...... King Edward. Free flowering, beautiful scarlet...................1/4 oz. 35c. Miss Sherwood. Flowers satiny-white and chamois-rose............... 1/4 oz. 30c.

Marshall's Extra Selected Shirley. A grand variety of colors, saved from selected flowers. Their brilliant dazzling coloring and wonderful variety make a very effective display in the garden or for cut flowers................... oz. 35c.

Rose-pink Shirley. A beautiful pink rariety.................1/4 oz. 50c. The Bride. A beautiful variety with large pure white flowers.........1/1 oz. 30c. Virginia. Flowers white, edged soft pink; fringed............... $1 / 4$ oz. $30 \mathrm{c}$. Single Mixed Poppies. All kinds. $1 / 4 \mathrm{oz} .25 \mathrm{c}$. Double Annual Varieties:

American Flag. White, edged red.1/4 oz. $25 \mathrm{c}$. Carnation-flowered. Mixed colors.

$1 / 4$ oz. $25 \mathrm{c}$

Eldorado Double Mixed. A double form of Shirley Poppy, in choice mixture.

Mikado. White, edged scarlet...1/4 oz. $25 \mathrm{c}$.

Paeony-flowered. Mixed colors. $1 / 4$ oz. $25 \mathrm{c}$

White Swan. Large, beautifully fringed white flowers............... $1 / 4 \mathrm{oz} .25 \mathrm{c}$.

Hardy Perennial Varieties:

bracteatum. Orange-scarlet hardy Poppy. $1 / 4$ oz. $25 \mathrm{c}$

Iceland Poppies. While these are hardy perennials, they flower the first year from seed, blooming almost as quickly as the annual sorts. $12 \mathrm{in}$.

nudicaule (Iceland Poppy). Dwarf, bright yellow..................1/4 oz. 50c. nudicaule aurantiacum. Orange.

nudicaule album. Pure white. $1 / 4 \mathrm{oz} .50 \mathrm{c}$. nudicaule Mixed Iceland Poppies.

$1 / 4$ oz $50 \mathrm{c}$

Oriental Poppies Mixed Hybrids. $3 \mathrm{ft}$

Finest shades............1/4 oz. 50c. 
POTENTILLA. H.P. Splendid hardy perennials with ornamental foliage and brilliant flowers in shades of yellow and red from June to August. $2 \mathrm{ft}$.

Single Mixed. Various shades of yellow and brown.

Double Hybrids, Mixed $\$ 0.15$ .25

PRIMULA sinensis, fimbriata (Chinese Primrose). G.P. A charming profuse flowering plant indispensable for Winter and Spring decoration

Marshall's Giant. Deep blue

Marshall's Giant. Pure white

Marshall's Giant. Salmon.

Marshall's Giant. Scarlet.

Marshall's Giant. Matchless Mixed.

PRIMULA obconica. One of the most useful greenhouse plants.

obconica gigantea alba. White.

obconica gigantea lilacina. Lilac.

obconica gigantea kermesina. Crimson..

obconica gigantea rosea. Rose

obconica gigantea, Finest Mixed

PRIMULA malacoides. A charming free flowering pot plant; delicate lilac.

malacoides alba. Pure white.

malacoides rosea. Charming rose-pink

malacoides superba. Larger flowers and much deeper in color than malacoides.

malacoides robusta. A clear rosy-lavender

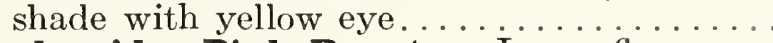

malacoides Pink Beauty. Large flowers of a beautiful rosy-pink, shading to mauve.

Eureka. A new Giant form of obconica. Rich rosy carmine, shaded cerise, a clear yellow eye. kewensis. Bright yellow, fragrant flowers. .

stellata (The Star Primula). Excellent pot plants for decoration purposes. Mixed colors.

Hardy Primulas or Primroses:

beesiana. Very free flowering. Glowing velvety-purple with yellow eye.......... japonica (Japanese Primrose). Mixed colors.

PRIMROSE, Marshall's New Blue. H.P. Many shades of blue to deep violet.

vulgaris. English yellow Primrose. $1 / 8$ oz. $\$ 1.00$

vulgaris Hybrids. Very choice hybrids of the English Yellow Primrose...

PYRETHRUM. H.H.P. Fine for edging and borders. 6 in.

aureum Golden Feather. Bright yellow foliage................ aureum Golden Gem...........1/4 oz. 50c.

hybridum. H.P. Large Daisy or Cosmos-like flowers; blooms in early Summer and late Fall. 18 in.

Single. Large-flowering, mixed colors . .

$1 / 4$ oz. $\$ 1.00$

fi. pl., Double. Large-flowering, beautiful colors............. 1/8 oz. $\$ 2.00$

REHMANNIA angulata. H.H.P. Flowers rosepurple with spotted throat. $3 \mathrm{ft} . \ldots \ldots \ldots$.

RHODANTHE (Swan River Everlasting). H.A Handsome pink and white, annual everlasting; excellent for bouquets of dried flowers. $1 \mathrm{ft}$.

maculata. Rose with dark center. $1 / 4$ oz. 35c. maculata alba. Pure white.....1/4 oz. $35 \mathrm{c}$.

Finest Mixed ..............1/4 oz. 35c

RICINUS (Castor Oil Plant). H.A. From seed they quickly attain gigantic proportions and are ornamental till destroyed by frost. $6 \mathrm{ft}$. cambogensis. Maroon foliage........oz. 35c. gibsoni. Purplish leaves and stems...oz. 35c. panormitans. Large dark brown leaves, blue powdered stems, upright habit....... oz. 35c. sanguineus. Red stems............. oz. 35c. zanzibarensis, Mixed. Immense leaves. $8 \mathrm{ft}$.

Mixed Varieties. oz. $35 \mathrm{c}$ oz. 25c.
ROCKET, SWEET (Hesperis). H.P. A very interesting, useful and free-flowering plant. $18 \mathrm{in}$.

Purple. Beautiful purple color.... 1/4 oz. 35c. $\$ 0.10$

White. Flowers rosy white........1/4 oz. 35c. .10

Finest Mixed Colors.

$1 / 4$ oz. $35 \mathrm{c}$.

ROMNEYA coulteri (The California Tree Poppy). H.H.P. Large snowy white flowers. Requires protection in Winter. $2 \mathrm{ft}$.

RUDBECKIA bicolor superba. H.A. Yellow flowers. $2 \mathrm{ft} \ldots \ldots \ldots \ldots \ldots \ldots$. $1 / 4.50 \mathrm{c}$.

newmanni. H.P. Bright orange with black cone. $2 \mathrm{ft}$

purpurea hybrida grandiflora. H.P. Beautiful large-flowered hybrids. $2 \mathrm{ft}$.

SALPIGLOSSIS. H.A. One of the prettiest annuals, of easy culture; very showy in beds or borders. A great favorite among annuals, of easy culture, with orchid-like flowers from early Summer until late Fall. $2 \mathrm{ft}$.

Marshall's Matchless Varieties:

Chamois..............1/8 oz. 50c. Golden Yellow.............1/8 oz. $50 \mathrm{c}$

Scarlet....................1/8 oz. $50 \mathrm{c}$

Rose and Gold..........1/8 oz. 50c.

Scarlet and Gold...........1/8 oz. 50c.

Violet...................1/8 oz. 50c.

Violet and Gold..........1/8 oz. 50c.

Yellow and White..........1/8 oz. 50c.

Matchless Mixture. All colors. 1/4 oz. 75c.

Large-flowering. Mixed colors....1/4 oz. 35c.

Collection of Six Separate Colors

SALVIA (Flowering Sage). H.A. One of our most handsome Summer and Autumn-flowering plants, growing into compact bushes 2 to 3 feet high and literally ablaze with brilliant flowers.

Marshall's Fireflame. A dwarf, large-flowering Salvia; very early-flowering.....1/8 oz. $\$ 1.00$

America, or Globe of Fire. The earliest, freest and most continuous bloomer.....1/8 oz. $\$ 1.00$

Blue Beard (Clary). Elegant plant with showy spikes of bright purple flowers....1/4 oz. 35c

Bonfire. A splendid dwarf variety, with large erect spikes of rich scarlet flowers. $1 / 8 \mathrm{oz} .75 \mathrm{c}$

farinacea. H.H.P. Light blue flowers, long spikes................1/8 oz. 75c.

Harbinger, Early Flowering. A dwarf variety which will come into flower in early Summer. Spikes of dazzling bright scarlet flowers. $1 \mathrm{ft}$.

Ostrich Plume. The plants are well covered with brilliant scarlet plumes of flowers.

$1 / 8$ oz. $\$ 1.00$

splendens grandiflora (Scarlet Sage). A rich flowered bedder........ 1/4 oz. $\$ 1.00$

Summer-flowering Fireball. A brilliant scarlet variety that will come into flower in July. $2 \mathrm{ft}$.

Zurich. Early flowering; color brilliant scarlet. $12 \mathrm{in} . . . \ldots \ldots \ldots \ldots \ldots$. . . 16 oz. $75 \mathrm{c}$. patens. H.H.P. Magnificent blue flowers .

$1 / 8$ oz. $\$ 1.50$

SANVITALLIA procumbens fl. pl. H.A. Pretty bright double yellow flowers. 6 in.. $1 / 4$ oz. $50 \mathrm{c}$.

SAPONARIA calabrica. Dwarf annual with pink starry flowers. $2 \mathrm{ft} . \ldots . .1 / 4 \mathrm{oz} .35 \mathrm{c}$.

vaccaria. Graceful sprays of pale rose flowers. Also used as a greenhouse pot plant. $2 \mathrm{ft}$.

$1 / 4 \mathrm{oz} \cdot 35 \mathrm{c}$ 


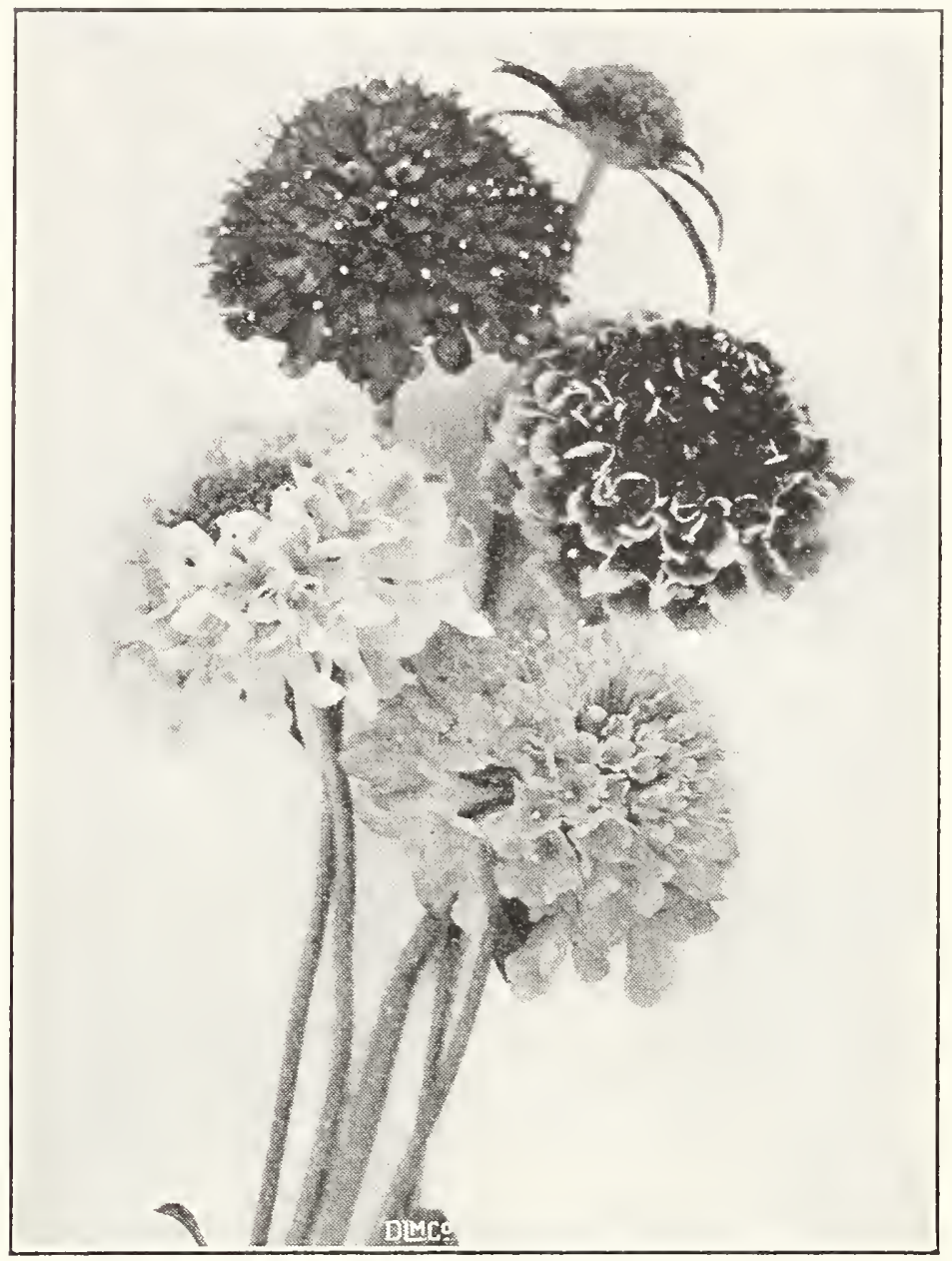

Scabiosa Tall Double, Mixed

SCABIOSA, or MOURNING BRIDE. H.A. Pkt.

One of our best Summer flowering annuals. The rich and beautiful colored flowers are very handsome and excellent for cutting; profuse bloomer. June to October. $21 / 2 \mathrm{ft}$.

Large-flowering Tall Double Varieties: Cherry Red.

Fiery Scarlet

$1 / 4$ oz. 40 c. $\$ 0.10$

King of the Bla

$1 / 4$ oz. $40 \mathrm{c} . \quad .10$

Lavender Blue $1 / 4 \mathrm{oz} .40 \mathrm{c}$.

Rose-pink............

Pure White...................

Finest Mixed. All colors......1/4 oz. 35c

Dwarf Double. Many colors mixed

35c. .10

Perennial Varieties:

$1 / 4$ oz. $35 \mathrm{c}$

caucasica alba. Delicate white flowers.' $2 \mathrm{ft}$.

caucasica. Silvery lavender-blue $1 / 8$ oz. $75 \mathrm{c}$.

SCHIZANTHUS (Butterfly Flower). H.H.A. Beautiful and showy, erect growing, hardy annuals for house or garden; very free-flowering, continuing through the Summer and Autumn. $11 / 2 \mathrm{ft}$.

Dr. Badger's Hybrids. Fern-like bright green foliage, covered with a beautiful range of colors. Grand for pot culture.

grahami. Free flowering red variety

hybridus grandiflorus. Finest Mixed. Very choice................1/4 oz. $35 \mathrm{c}$.

Pink Beauty. Flowers an exquisite shade of rose-pink. Fine for pot plants.

retusus. Beautiful red and yellow flowers.

retusus albus. White blotched with golden yellow. .

wisetonensis, Marshall's Select Hybrids. Flowers varying from white with yellow eye to rose with bronze center. Fine for pots.

wisetonensis compacta, Mixed. Beautiful and varied colors.

wisetoniensis snowflake. Pure white flowers, beautifully fringed.
SENECIO elegans F1. Pl. (Jacobaea) H. A. Free flowering pretty annual. Mixed colors. 18 in..\$0.15 SENSITIVE PLANT. (S̄ee MIMOSA pudica.)

SHAMROCK. G.P. True small-leaved variety.

SILENE (Catchfly). Very pretty and profuse .15 blooming plants.

compacta. H.A. Double. Mixed colors. $2 \mathrm{ft}$. $1 / 4 \mathrm{Oz} .35 \mathrm{c}$

orientalis. H.P. Large, globular heads of bright rose flowers, which are clove-scented. Useful for cutting. $2 \mathrm{ft} \ldots \ldots \ldots \ldots \mathrm{oz} .35 \mathrm{c}$.

SMILAX (Myrsiphyllum asparagoides). G.P. Popular greenhouse climber with small dark green fol iage................. $1 / 4 \mathrm{oz} .25 \mathrm{c}$.

SNAPDRAGON. (See ANTIRRHINUM.)

SOLANUM capsicastrum nanum (Jerusalem Cherry). G.P. Ornamental plant for Winter decoration, with bright scarlet berries.

$1 / 4$ oz. $50 \mathrm{c}$

Cleveland. Valuable as a pot plant. Brilliant red fruit................................... Beautiful free-flowering plants

STATICE. H.A. Beautiful free-flowering plants when dried, make pretty decorations for Winter use. $11 / 2$ to $2 \mathrm{ft}$.

bonduelli. Bright yellow flowers. . 1/4 oz. 35c. incana Hybrida nana Mixed. A charming variety of Sea Lavender. Fine for bouquets. $1 / 4$ oz. $50 \mathrm{c}$.

latifolia. H.P. Lavender-blue flowers $1 / 4 \mathrm{oz} .50 \mathrm{c}$ perezi. H.H.P. A beautiful bright blue. Adapted for borders and greenhouse forcing. $11 / 2 \mathrm{ft}$

sinensis. Very graceful plant; flowers pure white with canary yellow.......1/8 oz. $50 \mathrm{c}$.

sinuata Blue. A light shade of blue........

sinuata candidissima. Pure white........ sinuata rosea superba. Fine bright rose....

sinuata True Blue. Fine deep blue.........

sinuata hybrida Mixed. Flowers mauve, purple, white and yellow.......1/4 oz. 50c. suworowi. Flowers bright rosy color; fine for Winter decorations............1/8 oz. 50c.

STEVIA serrata. G.P. A greenhouse plant with fragrant, tiny white flowers; exceedingly valuable for cutting. $2 \mathrm{ft} . \ldots \ldots 1 / 4 \mathrm{oz} .75 \mathrm{c}$.

STOKESIA cyanea. H.P. Lavender-blue flowers. $2 \mathrm{ft} \ldots \ldots \ldots \ldots \ldots \ldots \ldots 1 / 4$ oz. $\$ 1.00$ cyanea alba. A pure white flowering form.

Finest Mixed. A mixture of pink, purple, blue and white shades..........1/4 oz. $75 \mathrm{c}$.

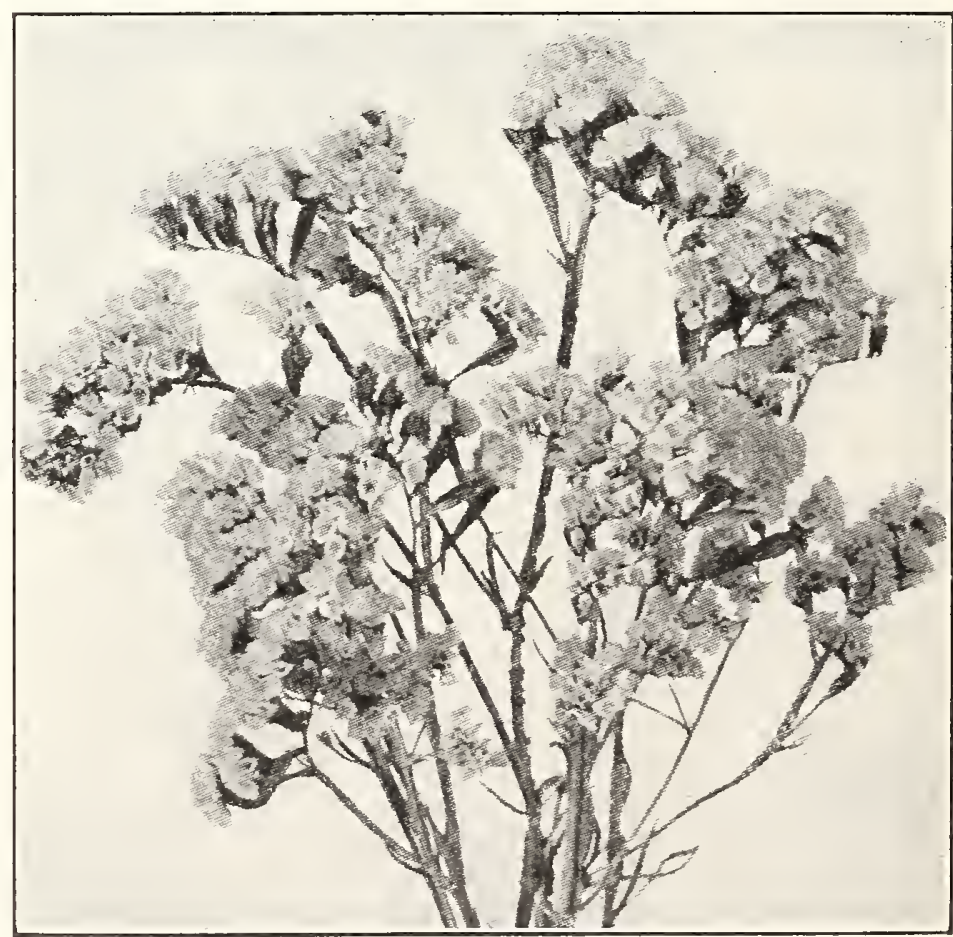

Statice sinuata 
STOCKS (Gilliflower). H.A. One of the most highly prized of all our cultivated flowers. The delightful fragrance, free-blooming character and beautiful colors have made them as desirable for Winter cultivation in the greenhouse as for the garden in Summer; invaluable as cut flowers.

Marshall's Giant Perfection Ten-Weeks. A splendid double-flowered strain; especially adapted for bedding or pot culture.

Chamoise Rose........... . . oz. $\$ 1.00 \$ 0.2$

Dark Blue ................ . 1/8 oz. $\$ 1.00 \quad .25$

Crimson................1/8 oz. $\$ 1.00 \quad .25$

Flesh Color .............. . oz. $\$ 1.00 \quad .25$

Light Blue . . . . . . . . . . . . .1/8 oz. $\$ 1.00 \quad .25$

Pure White..............1/8 oz. $\$ 1.00 \quad .25$

Rose.................. . 1/8 oz. $\$ 1.00 \quad .25$

Scarlet................ . . oz. $\$ 1.00 \quad .25$

Yellow................... oz. $\$ 1.00 \quad .25$

Finest Mixed. All colors. ....1/8 oz. $\$ 1.00 \quad .25$

Collection of Six Colors . . . . . . . . . . . 1.25

Collection of Nine Colors.

Large Flowering Ten-Weeks, Mixed Colors.

Winter Flowering Stocks:

Cut-and-Come-Again, Princess Alice. Double white.

Beauty of Nice. Splendid rose color . . . . . Crimson King. Brilliant fiery crimson.

Empress Elizabeth. Carmine-rose....... Giant Abundance. Carmine-rose.

Mont Blanc. Pure white.

Queen Alexandra. Delicate rosy lilac... .

Summer Night. Deep blue

White Lady. Large, double, snow-white. Yellow, Monte Carlo. Clear yellow.

Any of the above varieties, $1 / 8$ oz. $\$ 1.25$

East Lothian. Valuable for beds or borders and for greenhouses during the Winter months. For early Summer flowering, the seed should be sown in the Fall and plants wintered over in frames.

Finest Mixed..............1-16 oz. $\$ 1.00$

STREPTOCARPUS. Handsome greenhouse perennial, with Achimene-like flowers in clusters on slender stems. Treatment same as for Gloxinia.

Choice Mixed Hybrids.

SUNFLOWER. H.A. Well-known hardy annuals, the small-flowering sorts being very useful for cutting, while the larger sorts are very ornamental and useful, blooming all Summer

Double Californian. Deep yellow. $5 \mathrm{ft} . \mathrm{oz} .50 \mathrm{c}$. Single Russian. Enormous flowers. $6 \mathrm{ft}$ oz. $30 \mathrm{c}$.

Double Globe-shaped. Orange. $5 \mathrm{ft} . .0 z .35 \mathrm{c}$ Chrysanthemum-flowered. Rich golden yel-

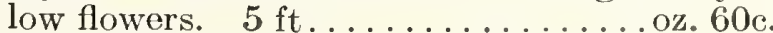
cucumerifolius (Miniature Sunflower). of pyrmidal growth; covered with bright orange, small single flowers, $3 \mathrm{ft} \ldots . . .1 / 4 \mathrm{oz}, 25 \mathrm{c}$

Marshall's "Excelsior" cucumerifolius Hybrids. The colors vary from shades of red, purple, mahogany and yellow. Very free flowering and valuable for cutting. $4 \mathrm{ft}$. $1 / 8$ oz. $50 \mathrm{c}$.

Orion. A variety of Stella with twisted petals. $3 \mathrm{ft} . . . . . . . . . .1 / 4 \mathrm{Oz} .25 \mathrm{c}$ Red Hybrids. "The Red Sunflower." Large flowers in various shades of red and dark centers. $4 \mathrm{ft}$........... $1 / 4 \mathrm{Oz} .25 \mathrm{c}$.

Stella (Improved Miniature Sunflower). Yellow. $3 \mathrm{ft} \ldots \ldots \ldots \ldots \ldots \ldots \ldots$. . . . . . $25 \mathrm{c}$. cucumerifolius hybridus fi. pl. Splendid double varieties. $3 \mathrm{ft} . \ldots \ldots \ldots 1 / 4 \mathrm{oz} .30 \mathrm{c}$ perennis Hybrids. Mixed hardy varieties. $3 \mathrm{ft}$.

questifolius "Autumn Glory "' $\dot{\mathrm{H}} \dot{\mathrm{P}}$ 'The flowers are golden yellow. Plants grow about 6 feet and bloom profusely in the late Fall. $1 / 4$ oz. $\$ 1.00$

.50 .10
SWEET SULTAN. (See CENTAUREA.)

SWEET PEAS. Sce pages 47 and 48 .

SWEET ROCKET. (See ROCKET.)

SWEET WILLIAM (Dianthus barbatus).

H.B. Showy hardy biennials of easy culture splendid for beds and borders with their rich varied flowers. $11 / 2 \mathrm{ft}$.

Double-flowering, Mixed.........1/4 oz. 50c. $\$ 0.10$

Single-flowering. Dark crimson..1/4 oz. $50 \mathrm{c} . \quad .10$

Carmine Beauty. A charming shade of color. 4 oz. $75 \mathrm{c}$.

Diadem. A deep rich crimson, with white eve.

Giant White. A fine type of self-colored white..................1/4 oz. $75 \mathrm{c}$

Newport Pink. Salmon rose-pink flowers borne on long stems..........1/4 oz. $75 \mathrm{c}$.

Pink Beauty. Very free flowering. $1 / 4$ oz. $75 \mathrm{c}$.

Scarlet Beauty. Intensely rich deep scarlet. $1 / 4 \mathrm{Oz} . \$ 1.00$

Single-flowering, Finest Mixed Colors.

$1 / 4$ oz. $25 \mathrm{c}$

Single Annual Mixed. Flowers of good size. Will bloom the first year. $12 \mathrm{in} . .1 / 4 \mathrm{oz} .50 \mathrm{c}$.

Collection of Sweet William. Six varieties.

TAGETES signata pumila. H.A. A dwarf, bushy Marigold with golden yellow flowers. Fine for bedding. $12 \mathrm{in} . . . \ldots 1 / 4 \mathrm{oz} .50 \mathrm{c}$

THUNBERGIA. H.A.C. Beautiful, rapidgrowing climbers. $5 \mathrm{ft}$.

Finest Mixed............. . . . oz. $50 \mathrm{c}$

TORENIA. H.H.A. Tender trailing plants for vases or baskets. $12 \mathrm{in.}$

fournieri. Velvety blue.

"The Bride." White and rose.

.10

.10

.10

THALICTRUM H.H.P. Graceful plants resembling Maidenhair ferns. Extensively used for bouquets.

adiantifolium. Yellow flowers. $1 \mathrm{ft}$.

dipterocarpum. Rosy-purple with citronvellow anthers, $3 \mathrm{ft}$...

TRACHELIUM coeruleum. G. P. A freeflowering plant with cloud-like heads of mauve flowers. $11 / 2 \mathrm{ft}$.

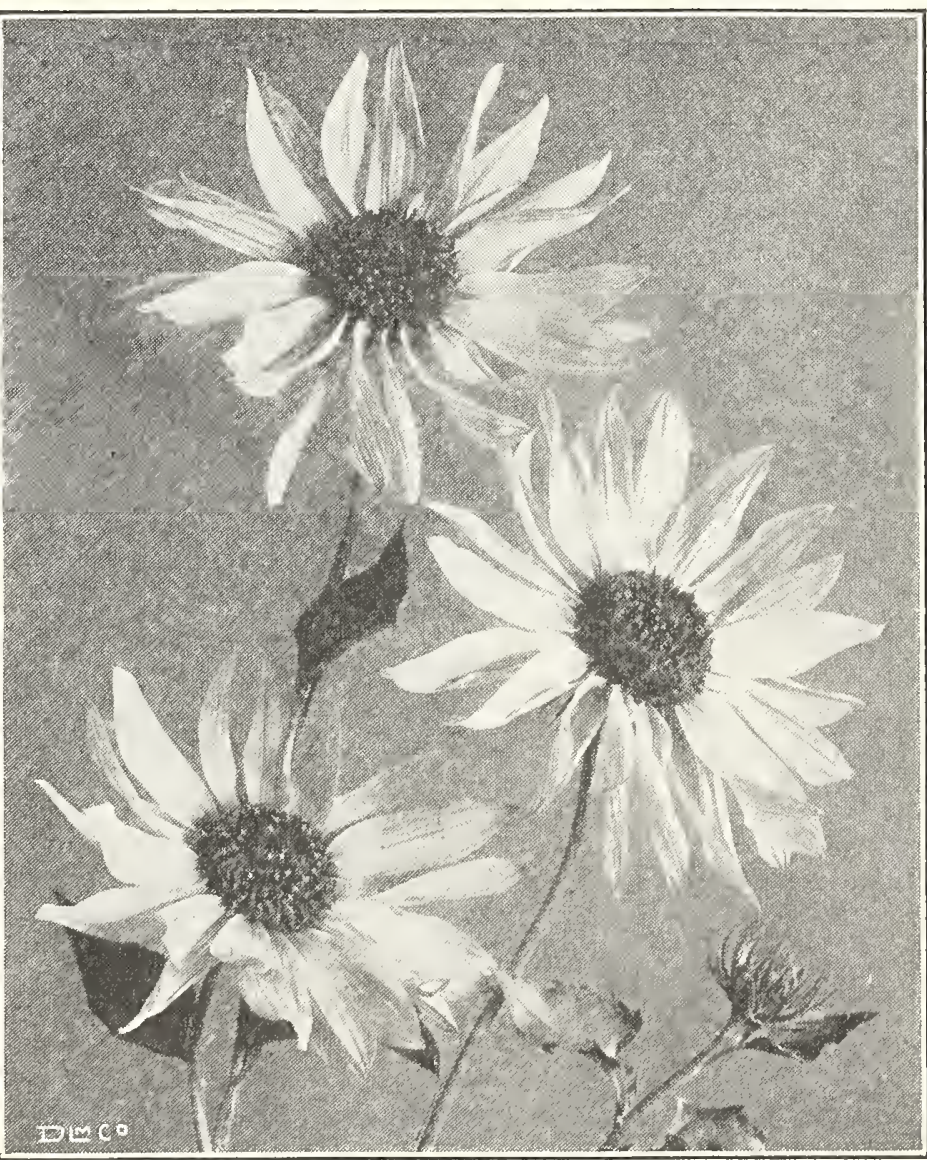

Sunflower, Stella 
TRITOMA. H.H.P. Often called the Flameflower, useful for borders and cutting. Plants should be well protedted in Winter. $3 \mathrm{ft}$.

hybrida Mixed. Red and orange colors.

semperflorens. Orange-red...

Stark's Early Hybrids. A new perpetual flowering race. The colors embrace yellows and salmons to deep crimsons.

TROLLIUS (Globe Flower). Charming Springflowering, hardy perennials with large, globular, Buttercup-like flowers varying in color from creamy white to orange. $2 \mathrm{ft}$.

Orange Globe Hybrids. Newest large-flowering varieties.

TROPAEOLUM lobbianum. (See NASTURTIUM.)

VALERIAN, Red. H.P. Showy, hardy plant for the garden and rockery. $2 \mathrm{ft} . . .1 / 4 \mathrm{oz} .30 \mathrm{c}$.

VERBENA. H.A. The Verbena is a universal garden favorite, very few plants making a more gorgeous display of brilliant flowers from Spring till late in the Autumn. 12 in.

Helen Willmott. A very pretty bright salmonrose, with white eve..........1/4 oz. $\$ 1.00$

Mammoth candidissima. Large trusses of white flowers................1/4 oz. $75 \mathrm{c}$.

Mammoth coerulea. Bright blue and purple in various shades........... $1 / 4 \mathrm{oz} .75 \mathrm{c}$.

Mammoth Lucifer. Intense brilliant scarlet with no eye $1 / 1$ oz. $75 \mathrm{c}$

Mammoth Mayflower. $A$ beautiful pink variety ................ $1 / 4$ oz. $75 \mathrm{c}$.

Mammoth Yellow. Primrose color. $1 / 4$ oz. $75 \mathrm{c}$. hybrida gigantea Mixed. A greatly improved strain producing giant florets in many colors. $1 / 4$ oz. $\$ 1.00$

Mammoth Finest Mixed. Extra choice.

Lemon Verbena (Aloysia citriodora). Scented leaves.....................

venosa. Purple flowers. Blooms the first year from seeds............. 1/4 oz. 50c.

VERBASCUM phoeniceum. H.P. Long, slender stems with numerous flowers in various colors, including white, pink, blue, mauve and purple. 12 in......1/4 oz, $50 \mathrm{c}$.

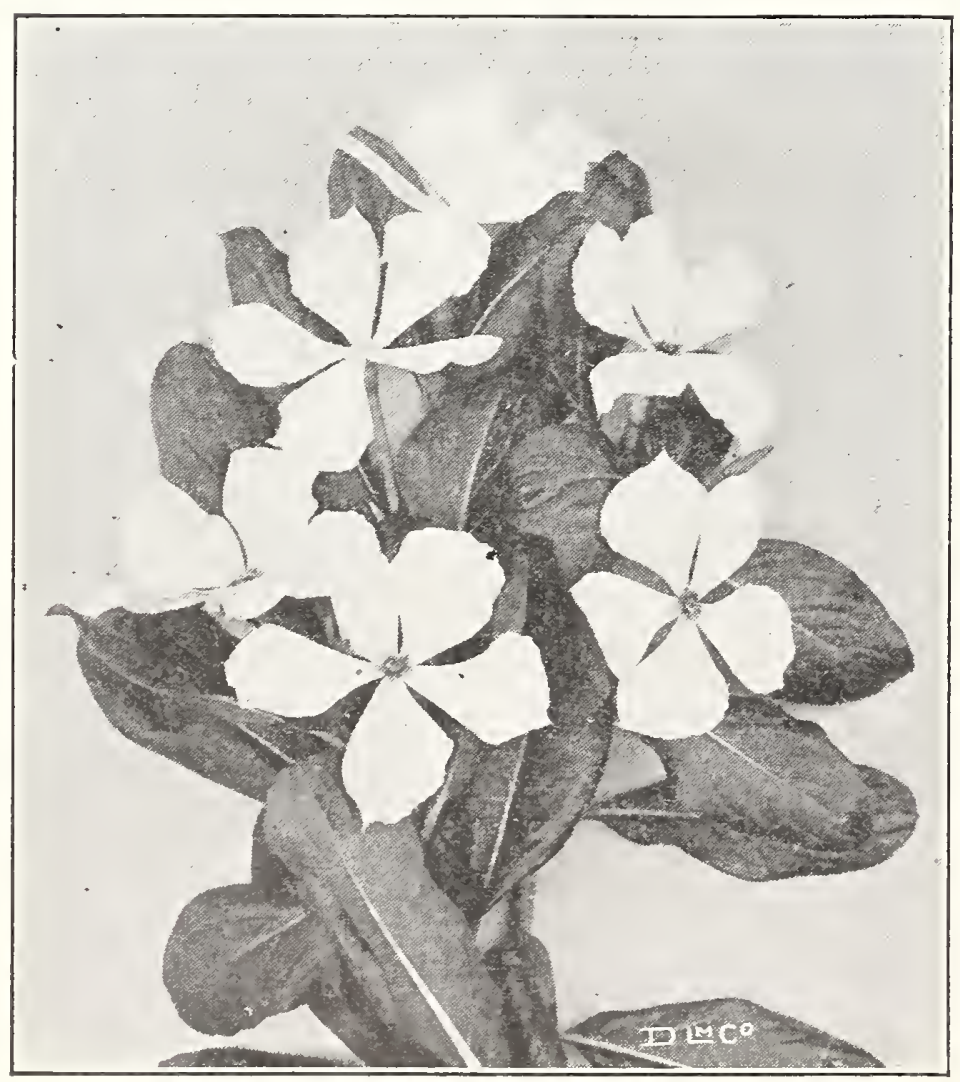

Vinca, Mixed
VERONICA. H.P. Splendid, hardy perennials, with showy spikes of bright-colored flowers; fine border plant. $11 / 2$ to $2 \mathrm{ft}$.

spicata Blue. Bright blue.......1/4 oz. 50c.\$0.15

VINCA. H.H.P. Splendid, free flowering plants, much used for bedding and edging; glossy, dark-green foliage and pretty pink and white flowers. They are free blooming and one of the most satisfactory flowering bedding plants we have. $2 \mathrm{ft}$.

alba pura. Pure white........1/4 oz. 60c. alba rosea. White, crimson eye...1/4 oz. 60c. delicata. A beautiful soft rose color. $1 / 4 \mathrm{oz} .60 \mathrm{c}$. rosea. Rose, dark eye...........1/4 oz. 60c. Mixed..................1/4 oz. 60c.

VIOLA, Bedding Varieties. H.H.P. Largeflowering, self colors. Used for bedding. 6 in.

Marshall's Giant Blue ......... 1/8 oz. $\$ 1.25$ Marshall's Giant White........1/8 oz. $\$ 1.25$ Marshall's Giant Yellow........ $1 / 8$ oz. $\$ 1.25$

Mixed. From best named Scotch varieties.

VIOLA, Tufted Pansies. H.H.P. ${ }^{1 / 8}$ Oz. $\$ 1.00$ for bedding and may be grown in the same manner as Pansies. Very free flowering. 6 in.

Admiration. Soft purple, dark blotched Mauve Queen White Perfection. The best white. $1 / 8 \mathrm{oz} .75 \mathrm{c}$

Finest Mixed. All colors........1/4 oz. $\$ 1.00$ VIOLET, Viola odorata. H.P. Sweet-scented

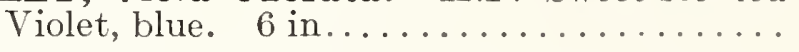

VISCARIA. H.A. Showy and profuse blooming plants, very effective in small beds or borders. $1 \mathrm{ft}$.

Finest Mixed............ $1 / 4$ oz. $25 \mathrm{c}$.

WALLFLOWER. H.H.P. Well known, deliciously fragrant, half-hardy perennials, blooming early in the Spring, with spikes of beautiful flowers. They should be protected in a coldframe in the Winter, and planted out in April. 12 in.

allioni (Alpine Wallflower). (See CHEIR. ANTHUS.)

kewensis. Very fragrant, sulphur-yellow flowers, passing to orange-yellow or purpleviolet. Fine for Winter flowering in greenhouse....................1/8 oz. $75 \mathrm{c}$

Single Fine Mixed. Hardy varieties.

$1 / 4$ Oz. $35 \mathrm{c}$

Double Fine Mixed. Hardy varieties.

$1 / 8$ oz. $\$ 1.00$

Annual Varieties. If sown in heat during March these will flower during the Summer and Autumn. Excellent for forcing.

Early Paris Market. Bright brown.

$1 / 4$ oz $50 \mathrm{c}$

Fine Mixed.....................

WILD CUCUMBER. (See ECHINOCYSTIS.)

XERANTHEMUM. H.A. Showy, hardy annual of easy culture, giving a profusion of flowers; well suited to drying as everlastings. $11 / 2$ to $2 \mathrm{ft}$.

Double Mixed.

$1 / 4$ Oz. $50 \mathrm{c}$.

\section{WILD GARDEN FLOWER SEEDS}

This mixture contains over 100 varieties of the oddest and choicest annuals imaginable. For naturalizing purposes or sowing broadcast, nothing approaches wild flower seeds for effect and cheapness. No care is necessary, and a never-ending succession of bloom and fragrance can be obtained throughout the entire Summer and Fall. Pkt. 10, oz. 25c., 1/4 1b. 75c.
.15

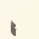


ZINNIAS (Youth and Old Age). H.A. These well-known garden favorites are one of the most brilliant Summer-flowering plants. The flowers are large, very handsome, and borne in great profusion. They succeed best in a sunny situation. $2 \mathrm{ft}$.

Matchless, Double Tall Varieties.

Double, Crimson..........1/4 oz. 60c. $\$ 0.15$

Double, Lavender. . . . . . . . . . . .1/4 oz. 60c. $\quad .15$

Double, Purple.............1/4 oz. 60c. .15

Double, Rose..................1/4 oz. $60 \mathrm{c} . \quad .15$

Double, Scarlet. .............1/4 oz.60c. .15

Double, White.............1/4 oz. 60c. .15

Double, Yellow................1/4 oz. $60 \mathrm{c} . \quad .15$

Double, Fine Mixed...........1/4 oz. 50c. $\quad .15$

Collection of Six Colors, Matchless

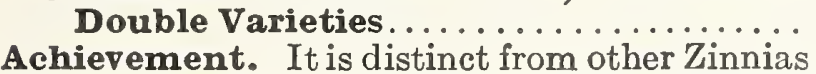
by the shape of its petals, which are tubular at the base and expand in a Cactus-like form at the tips. Very large flowers in various shades................1/4 oz. 60c.

Giant Dahlia-flowered. These are similar to the Double Dahlia in size and shape of flowers. $21 / 2 \mathrm{ft}$. Buttercup. Deep creamy-yellow. .......
Crimson Monarch. Largest of the red shades..............................

Dream. Deep lavender, turning to purple.
Exquisite. Light rose, with center a deep

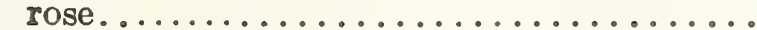

Golden state. $\AA$ very rich orange-yellow.

Oriole. An immense orange and gold bicolor.

Polar Bear. A very large pure white.....

Scarlet Flame. A large, beautiful bright

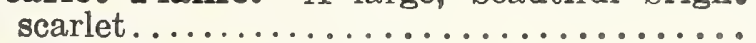

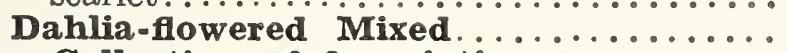
Collection of 8 varieties.......... "Puble haageana "Perfection." Small, double flowers in many colors, makes a beautiful border. 9 in. Finest mixed.... $1 / 8$ oz. $\$ 1.00$

Tall Double Mixed. Very double; a fine

Pkt.


0.15
.15
.15
.15
.15
.15
.15
.15
.75

.15

.25
.25
.25
.25
.25
.25
.25
.25
.25
.75
.10

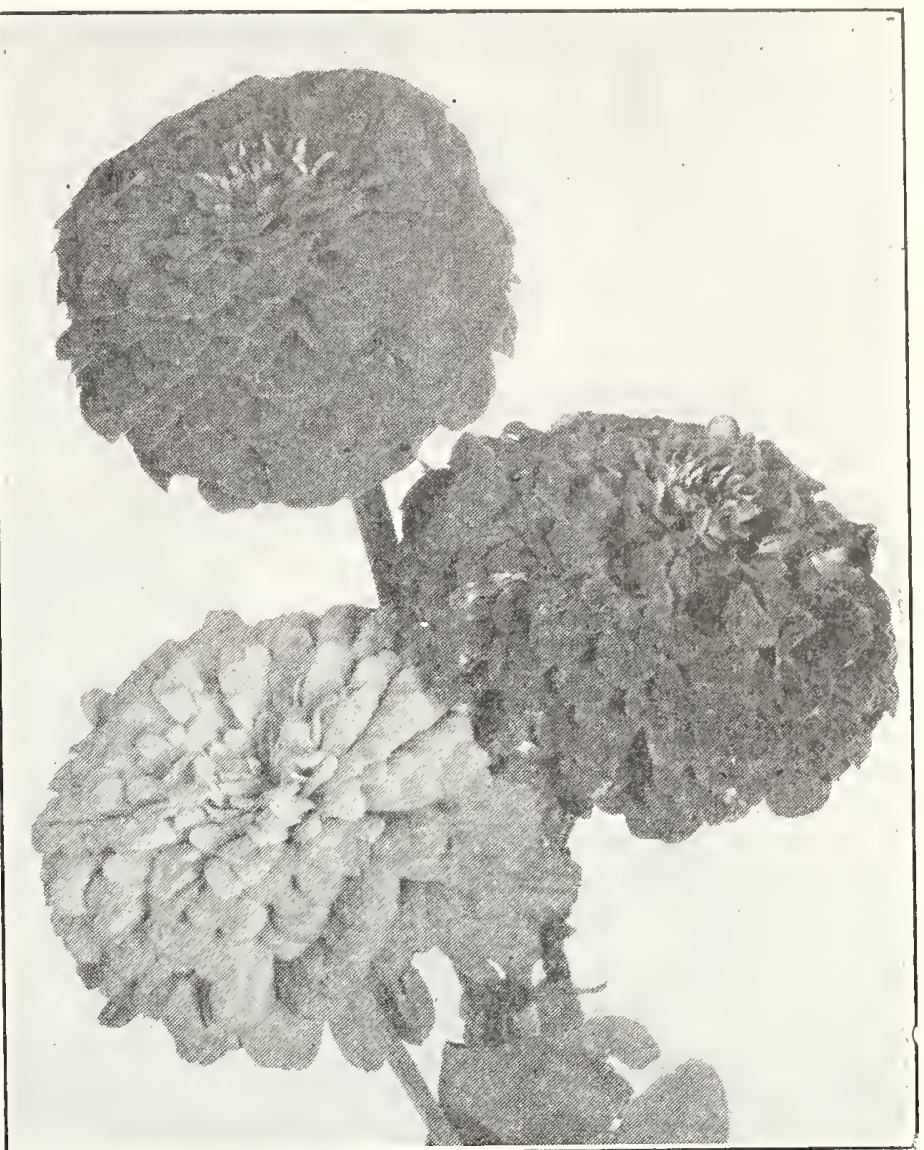

Zinnia, Matchless Double

Pkt.

Dwarf Double Varieties. Height $1 \mathrm{ft}$.

Dwarf Salmon Rose. A good bedder....

$1 / 4$ oz. $50 \mathrm{c} . \$ 0.10$

Dwarf Scarlet Gem. Fine for bedding....

$1 / 4 \mathrm{oz} .50 \mathrm{c}$. .10

Dwarf. Double mixed. Large flowering. $1 / 4$ oz. $35 \mathrm{c}$. $\quad .10$

\section{Marshall's Early or Winter-Flowering Sweet Peas}

The following varieties are a selection of the best Winter flowering varieties. They are also suitable for outside planting.

Aviator. Dazzling crimson scarlet..... $1 / 4 \mathrm{oz}$

Canary Bird. A splendid cream of primrose colored self...............

Chevalier. True rose color............

Early Hercules. A mammoth rosy pink.

Early King Improved. A glowing, rich,

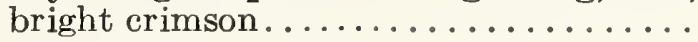

Enchantress. Bright rose pink........

Lavender King. Lavender. True color .

Loveliness. White, edged rose-pink....

Mauve Beauty. Rosy mauve, beautifully waved, four flowers on stem..........

Morning Star. A deep orange-scarlet, with rich orange-pink wings.........

Mrs. A. A. Skaach. A beautiful bright pink self...................

Mrs. Kerr. A very large salmon........

Mrs. Warren G. Harding. A beautiful shade of silvery blue.............

New Blue. A splendid deep blue........

Snowflake. A pure white, early flowering, white seeded Spencer..............

Snowstorm Improved. The finest of all

the white varieties..................
Spring Maid. The color is a light pink

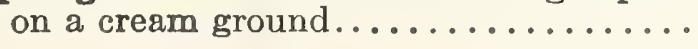

$\mathrm{Oz}$.
1.00

1.00

1.00

1.00

1.00

1.00

1.00

1.50

1.50

1.50

1.00

1.00

1.00
$1 / 4$ oz. Oz.

Sunburst. An attractive shade of rich salmon-pink, overlaid with amber and

salmon..................... \$0.35 $\$ 1.00$

Superior Pink. A beautiful rose pink, very slightly shaded with salmon...

$$
\text { Pkt. } 50 \mathrm{c} .1 .50
$$

True Blue. A charming shade of true or

light violet-blue...................50 1.00

White Star. A first-class black-seeded white........................ .50 1.00

Yarrawa. The finest pink forcer....... . .35 1.00

Zvolanek's Blue. A very bright blue.... $.35 \quad 1.00$

Zvolanek's Rose. A beautiful self, rose color.........................50 1.50

Early Flowering Mixed.............. .35 1.00 Each of the above varieties, pkt. $15 \mathrm{c}$.

\section{Grandiflora Winter Varieties} Pkt. Oz.

Christmas Pink. Pink and white.....\$0.10 \$0.30

Christmas White.................. .10 .30

CUPID, or DWARF SWEET PEAS

These grow about 9 inches high and are adapted for borders or beds.

Finest Mixed Colors. Pkt. 10c., Oz. 30c., 1/4 lb. $\$ 1.00$. 


\section{SWEET PEAS}

There are no Annual Climbers that are more popular or more admired by everybody than Sweet Peas. They are of the easiest culture, unrivaled for cutting, delightfully fragrant and of the brightest and daintiest colors imaginable. As soon as the ground can be worked in the Spring, sow the seed in trenches at least 6 inches in depth, then as the plants grow fill in the soil about one inch at a time until the trenches are full, taking care not to cover the young plants. Liquid manure applied occasionally will be found very beneficial. Pick the flowers frequently, for if allowed to form seed the plants will soon stop blooming.

\section{MARSHALL'S SPENGER TYPE SWEET PEAS}

The Spencer Types of Sweet Peas are a great improvement over the large flowering varieties. For cutting and exhibition purposes they are indispensable. The following varieties are a selection of the many kinds of this class best adapted for general use.

Afterglow. Reddish-mauve, violet wings.

Annie Ireland. Pure white, edged terra cotta pink. Apple Blossom Spencer. Rose standards, blush rose wings beautifully waved.

Asta Ohn. Lavender, tinted with mauve.

Barbara. The best salmon for exhibition purposes.

Blanche Ferry Spencer. Rose standard with white wings.

Captain of the Blues. Maroon purple, wings blue. Commander Godsall. A beautiful violet-blue.

Constance Hinton. Very large, black-seeded white. Countess Spencer. Soft rose pink; large, wavy petals. Defiance. Glowing orange scarlet, burnless.

Edward Cowdy. The best orange scarlet.

Elfrida Pearson. Blush pink, deepening toward the edges.

Fiery Cross. A fine red or scarlet, with no shading.

Florence Nightingale. One of the largest lavenders.

Flora Norton Spencer. Bright blue with a small tint of purple.

Hawlmark Cerise. Glowing rose-cerise on cream ground.

Hawlmark Pink. Bright rose-pink, flushed salmon.

Hercules. Rich clear rose-pink.

Helen Lewis. A fine crimson-orange, wings orange-rose.

Helen Pierce. White, mottled light blue.

Illuminator. Brilliant salmon-pink, very beautiful.

Jean Ireland. Creamy buff, standards margined carmine-rose.

King White. A perfect white Spencer, immense petals.

Lavender George Herbert. Bluish lavender.

Lady Evelyn Eyre. Blush pink, white ground.

Margaret Atlee. Salmon-pink, suffused over a cream ground.

Margaret Madison. Delicate azure-blue, slightly shaded mauve.

Marks Tey. Large maroon standard, bluish wings.

Miriam Beaver. Beautiful shell salmon-pink, cream ground.

Mrs. Tom Jones. A bright Delphinium blue.

New Buttercup. Deep rich cream.

Nubian. Deep chocolate self; one of the best.

Othello. A rich deep maroon of true Spencer type.

Picture. Flesh pink suffused creamy apricot.

Primrose Spencer. Primrose or creamy yellow.

R. F. Felton. The best lavender.

Rosabelle. A large and finely waved bright rose.

Robert Sydenham. A bright orange-salmon selfcolored; immense size.

Royal Purple. A rich royal-purple.

Scarlet Emperor. The largest and brightest scarlet.

Sincerity. The finest scarlet cerise.

Sterling Stent. Salmon-orange-pink.

The President. A dazzling bright orange-scarlet.

Tangerine Improved. A beautiful glowing orange.

Any of the above varieties:

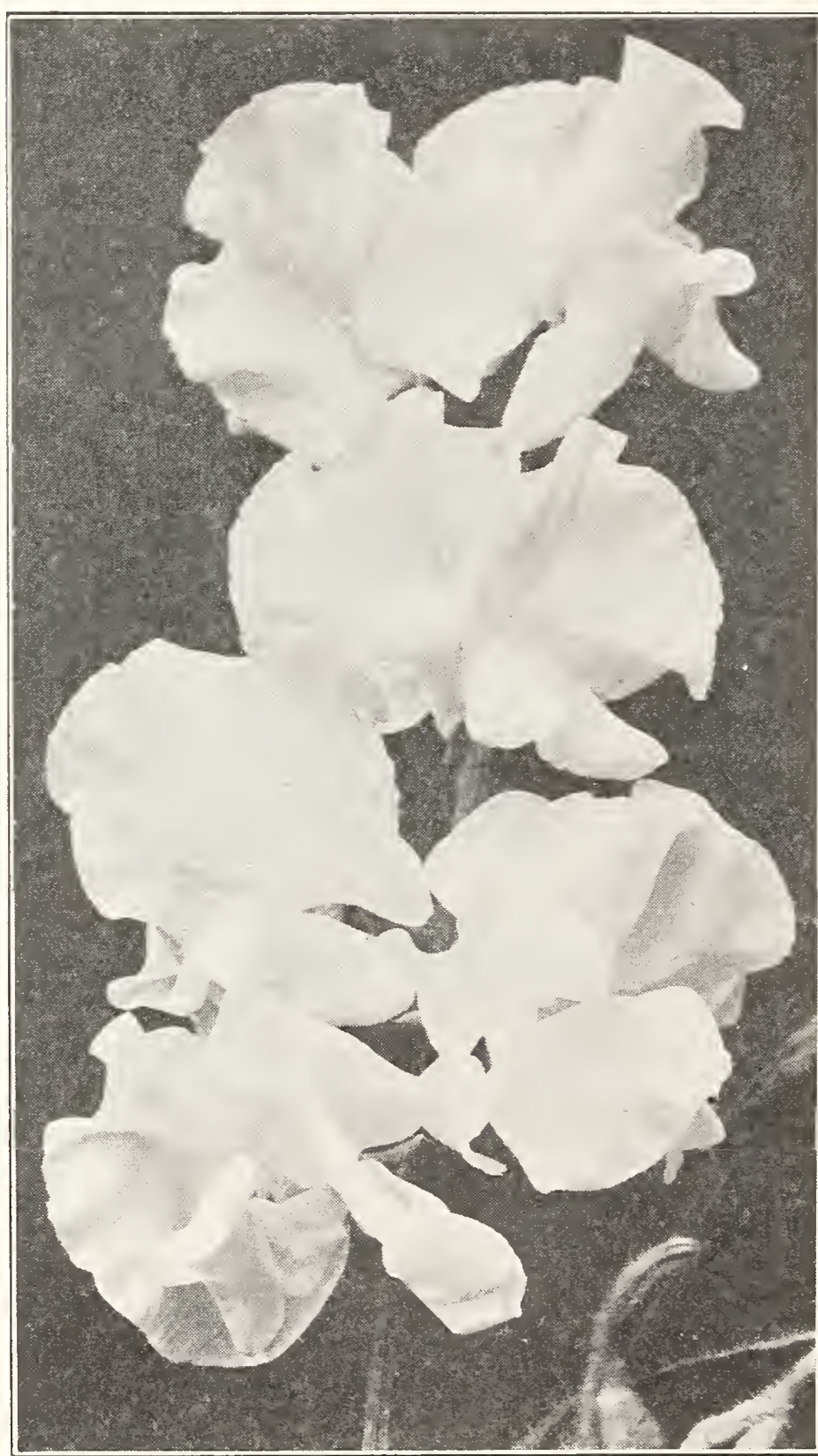

Sweet Peas-R. F. Felton

The Cardinal. Intense Poppy scarlet; waved flowers. Valentine. Blush pink; flowers of large size and waved. Warrior. Deep maroon; the best of its color.

Wedgwood. Silvery blue; flowers on long stems.

White Spencer. A pure white with long stems. Pkt. 10c., oz. 50c., $1 / 41 \mathrm{~b}$. $\$ 1.50$.

\section{MARSHALL'S MATCHLESS MIXED SPENGER HYBRIDS}

A mixture of 75 varieties of Spencer's, the grower of which was awarded a Silver Gilt Medal of the National Sweet Pea Society of Great Britain. Pkt. 10c., oz. 35c., 1/4 lb. $\$ 1.00,1 b . \$ 3.00$.

\section{COLLEGTIONS OF SPENGER SWEET PEAS}

12 varieties of Spencer Hybrids named for $\$ 1.00$, 18 varieties named for $\$ 1.50,24$ varieties named for $\$ 2.00$. 


\section{FLOWER SEEDS FOR DIFFERENT PURPOSES AND SITUATIONS}

For description and prices, see general list.

\section{CLIMBING VINES FROM SEEDS}

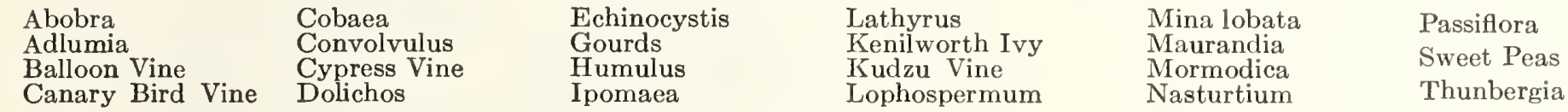

FRAGRANT FLOWERS FROM SEEDS

\begin{tabular}{|c|c|c|c|c|c|}
\hline $\begin{array}{l}\text { Alyssum } \\
\text { Asperula } \\
\text { Carnations } \\
\text { Cleome }\end{array}$ & $\begin{array}{l}\text { Dianthus (Hardy) } \\
\text { Heliotrope } \\
\text { Lavender } \\
\text { Mathiola }\end{array}$ & $\begin{array}{l}\text { Mignonette } \\
\text { Mimulus moschatus } \\
\text { Nicotiana affinis } \\
\text { Polyanthus }\end{array}$ & $\begin{array}{l}\text { Scabiosa } \\
\text { Stock } \\
\text { Sweet Pea }\end{array}$ & $\begin{array}{l}\text { Sweet Rocket } \\
\text { Sweet Sultan } \\
\text { Sweet William }\end{array}$ & $\begin{array}{l}\text { Verbena, Lemon } \\
\text { Violet } \\
\text { Wallflower }\end{array}$ \\
\hline
\end{tabular}

\section{PLANTS ADAPTED FOR EDGING BORDERS}

$\begin{array}{lllll}\text { Ageratum } & \text { Bellis } & \text { Marigold } & \text { Nigella } & \text { Portulaca } \\ \text { Alyssum } & \text { Candytuft } & \text { Myosotis } & \text { Pennisetum } & \text { Pyrethrum } \\ \text { Armeria } & \text { Centaurea } & \text { Nasturtium } & \text { Petunia } & \text { Sweet William } \\ \text { Begonia } & \text { Lobelia } & \text { Nemesia } & \text { Phlox, Dwarf } & \text { Sweet Pea, Cupids }\end{array}$

\section{GREENHOUSE AND POT PLANTS FROM SEEDS}

$\begin{array}{lllll}\text { Abutilon } & \text { Begonias } & \text { Clerodendron } & \text { Ferns } & \text { Impatiens } \\ \text { Acacia } & \text { Calceolaria } & \text { Clianthus } & \text { Francoa } & \text { Lantana } \\ \text { Antirrhinum } & \text { Celosia } & \text { Coleus } & \text { Freesia } & \text { Primula } \\ \text { Angelonia } & \text { Celsia } & \text { Cyclamen } & \text { Gloxinia } & \text { Shamrock } \\ \text { Aralia } & \text { Chrysanthemum } & \text { Dracaena } & \text { Grevillea } & \text { Smilax } \\ \text { Asparagus } & \text { Cineraria } & \text { Geranium } & \text { Heliotrope } & \text { S Solanum }\end{array}$

\section{EVERLASTING FLOWERS FOR WINTER DECORATIONS}

Acroclinium Edelweiss
Globe Amaranth

Helichrysum
Honesty, Lunaria

Rhodanthe
Statice

Xeranthemum

\section{ORNAMENTAL FOLIAGE PLANTS FROM SEEDS}

Amaranthus

Centaurea candidissima

Centaurea gymno-

Coleus Euphorbia

Perilla

Pyrethrum aureum Ricinus

\section{PLANTS FROM SEEDS SUCCEEDING IN PARTIALLY SHADED PLACES}

\section{Anemone Antirrhinum Aquilegia Auricula}

$\begin{array}{ll}\text { Begonia, Tuberous } & \text { Cowslip } \\ \text { Bellis } & \text { Delphinium } \\ \text { Canterbury Bells } & \text { Digitalis } \\ \text { Coreopsis (Hardy) } & \text { Ferns }\end{array}$

$\begin{array}{ll}\text { Hardy Primrose } & \text { Myosotis } \\ \text { Linum } & \text { Oenothera } \\ \text { Matricaria } & \text { Pansy } \\ \text { Mimulus } & \text { Polyanthus }\end{array}$

Poppies (Hardy)

Schizanthus

Torenia

ANNUAL FLOWERS FROM SEED, SUITABLE FOR CUTTING

$\begin{array}{lllll}\text { Agrostemma } & \text { Carnation } & \text { Dianthus } & \text { Hunnemannia } & \text { Phlox } \\ \text { Antirrhinum } & \text { Celosia plumosa } & \text { Didiscus } & \text { Larkspur } & \text { Poppies } \\ \text { Arctotis } & \text { Centaurea } & \text { Dimorphotheca } & \text { Lavatera } & \text { Salpiglossis } \\ \text { Asters } & \text { Chrysanthemums } & \text { Eschscholtzia } & \text { Lupinus } & \text { Sweet Peas Wiliam } \\ \text { Calendula } & \text { Clarkia } & \text { Gaillardia } & \text { Marigolds } & \text { Scabiosa } \\ \text { Calliopsis } & \text { Cosmos } & \text { Godetia } & \text { Mignonette } & \text { Statice } \\ \text { Candytuft } & \text { Dahlias } & \text { Gypsophila } & \text { Nigella } & \text { Wallfower }\end{array}$

HARDY PERENNIALS WHICH CAN BE RAISED FROM SEEDS

$\begin{array}{lllll}\text { Achillea } & \text { Bellis } & \text { Digitalis } & \text { Helianthus } & \text { Phlox } \\ \text { Aconitum } & \text { Bocconia } & \text { Echinops } & \text { Heuchera } & \text { Physalis } \\ \text { Adonis } & \text { Boltonia } & \text { Edelweiss } & \text { Hibiscus } & \text { Physostegia } \\ \text { Agrostemma } & \text { Callirhoe } & \text { Eremurus } & \text { Hollyhocks } & \text { Platycodon } \\ \text { Alstroemeria } & \text { Campanula } & \text { Erigeron } & \text { Incarvillea } & \text { Polemonium } \\ \text { Alyssum } & \text { Candytuft } & \text { Erysimum } & \text { Lathyrus } & \text { Polyanthus } \\ \text { Anchusa } & \text { Centaurea } & \text { Erinus } & \text { Linaria } & \text { Poppies } \\ \text { Anemone } & \text { Cerastium } & \text { Eupatorium } & \text { Linum } & \text { Potentilla } \\ \text { Anthemis } & \text { Chelone } & \text { Gaillardia } & \text { Lobelia } & \text { Primula } \\ \text { Aquilegia } & \text { Chrysanthemum } & \text { Galega } & \text { Lupinus } & \text { Pyrethrum } \\ \text { Arabis } & \text { Coreopsis } & \text { Gaura } & \text { Lychnis } & \text { Rehmannia } \\ \text { Asperula } & \text { Cowslip } & \text { Geum } & \text { Vatricaria } & \text { Rocket } \\ \text { Aster } & \text { Delphinium } & \text { Grasses } & \text { Nierembergia } & \text { Romneya } \\ \text { Aubrietia } & \text { Dictamnus } & \text { Gypsophila } & \text { Pansies } & \text { Rudbeckia } \\ \text { Auricula } & \text { Dianthus } & \text { Helenium } & \text { Pentstemon } & \text { Salvia }\end{array}$

Description and prices of any of the above seeds will be found on pages 28 to 49 


\section{SUMMER-FLOWERING BULBS}

\section{ACHIMENES}

Profuse blooming tender perennials for greenhouse or conservatory decoration during Summer.

Galathea, Imp. Deep blue.

Magnifica. Deep blue, light center.

Dainty Queen. White, with lavender eye.

Swansona. Light blue, mottled dark.

Bulbs of any of the above varieties, doz. $\$ 3.00$, $100 \$ 20.00$.

\section{AGAPANTHUS}

umbellatus (Blue Lily of the Nile). A most desirable plant for outdoor decoration; planted in large pots or tubs on the lawn or piazza. Pot-grown plants. 6-in. each $\$ 1.00$, doz. $\$ 10.00$.

\section{AMARYLLIS}

They should be grown in rich, sandy loam, with good drainage, and require abundant moisture when growing; but at their season of rest water should be given sparingly.

Hippeastrum, Veitch's and Ker's New Hybrids. The finest race of Amaryllis in cultivation. Each $\$ 1.25$, doz. $\$ 12.00$.

equestris (Barbados Lily). A garden variety with orange-scarlet flowers. Each 30c., doz. $\$ 3.00,100$ $\$ 20.00$.

formosissima (Jacobean Lily). Brilliant scarlet. Each 35c., doz. \$3.50.

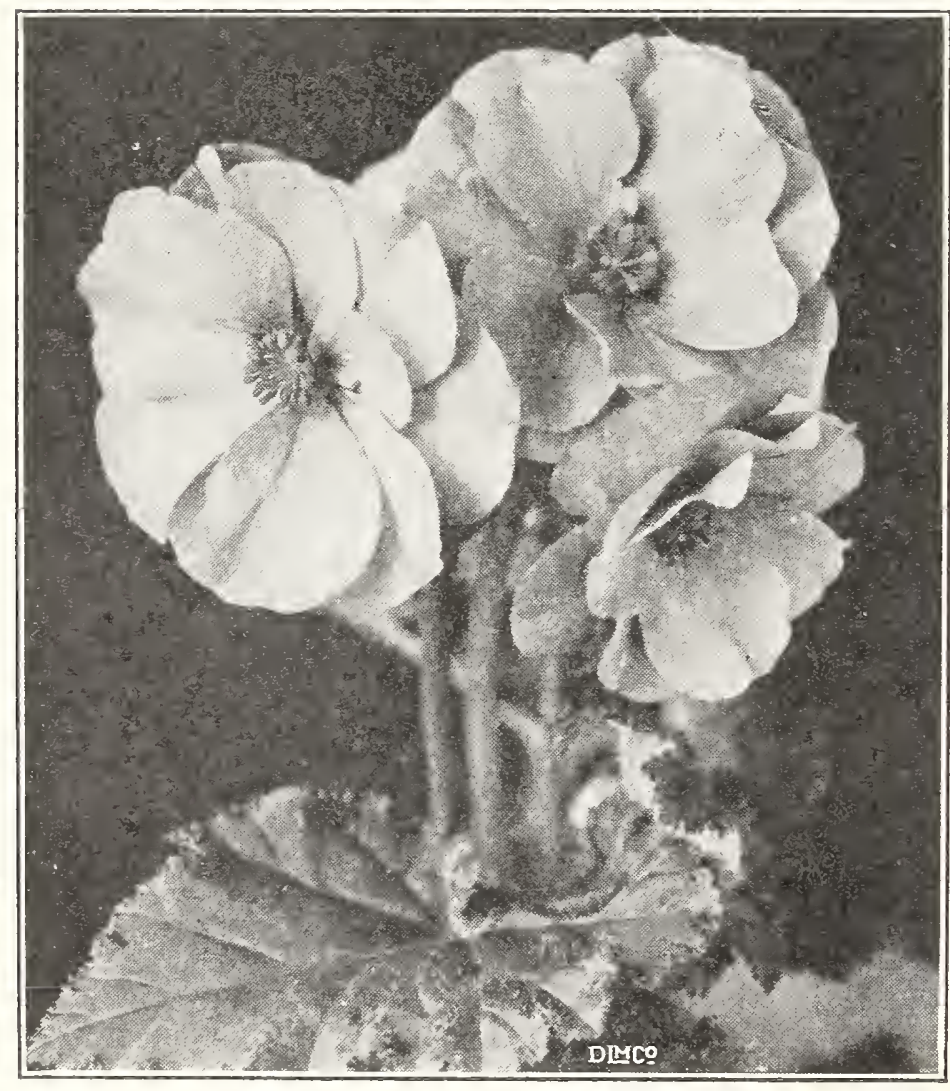

Begonia, Single Tuberous-rooted

\section{BEGONIAS}

Splendid pot plants for the house or greenhouse, and especially valuable for bedding, flowering in the greatest profusion throughout the Summer. For bedding they should be started in hotbed in March and April.

\section{SINGLE TUBEROUS-ROOTED}

Separate Colors: Crimson, Pink, White, Yellow or Mixed. Each 35c., doz. $\$ 3.50,100 \$ 25.00$.

\section{DOUBLE TUBEROUS-ROOTED}

Separate Colors: Crimson, Pink, White, Yellow or Mixed. Each 35c., doz. $\$ 3.50,100 \$ 25.00$

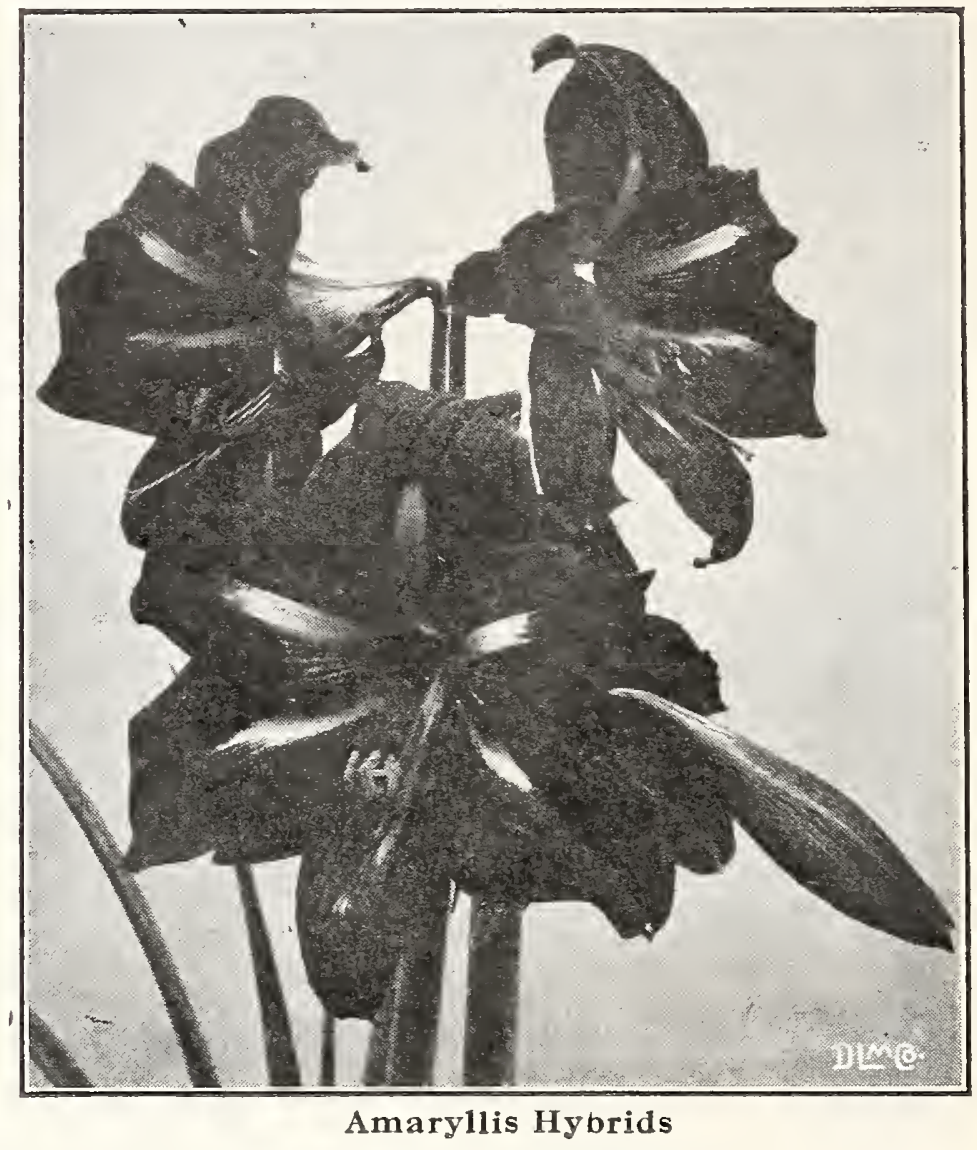

\section{CALLAS (Richardia)}

Splendid as pot plants or for outside planting. They may be started inside and safely planted out in May.

Elliottiana. Flowers are large, rich dark golden yellow. Leaves beautifully spotted with white. $\$ 0.50 \quad \$ 5.00 \quad \$ 35.00$ Mrs. Roosevelt. White flowers tinged with yellow, leaves spotted. Will bloom continuously through the Summer..

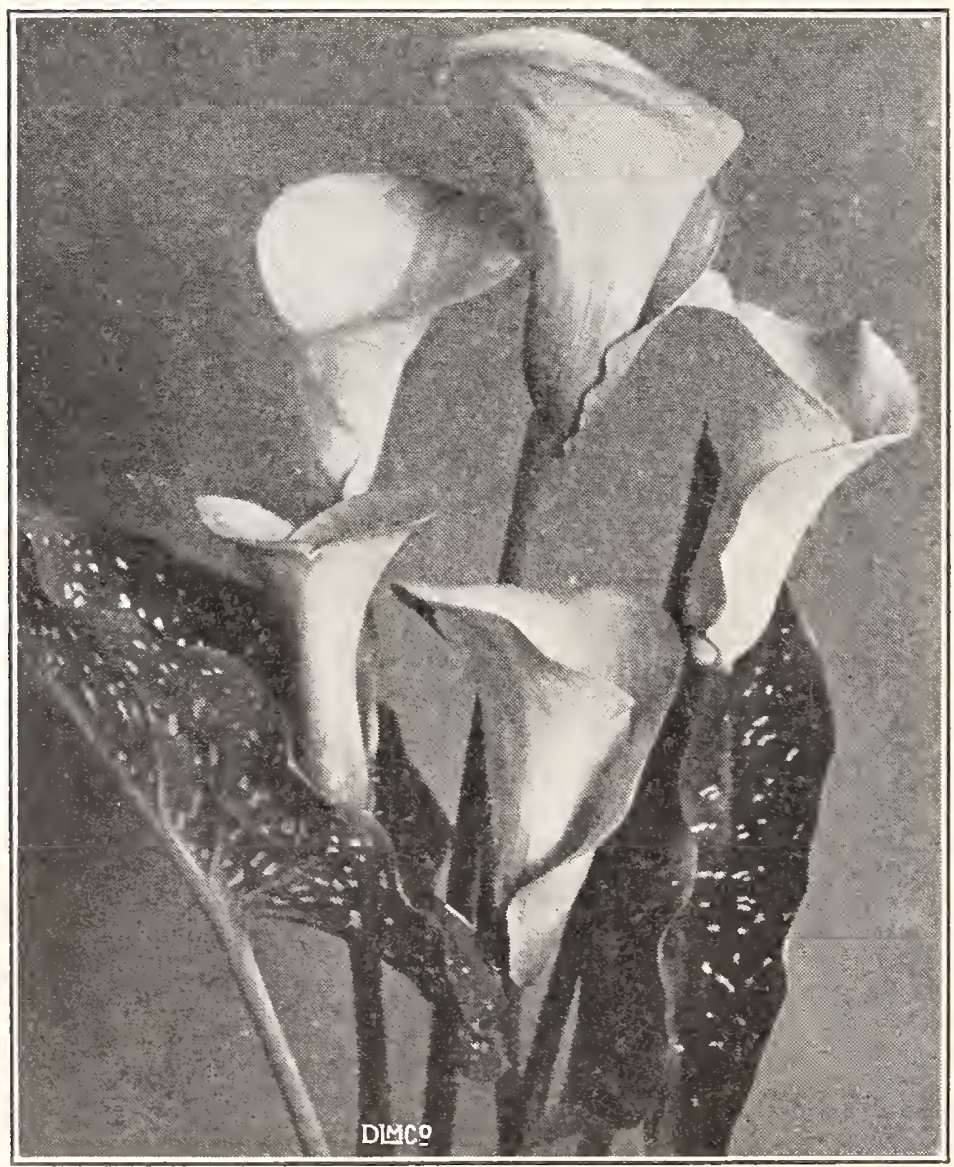

Calla, Mrs, Roosevelt 


\section{CAMASSIA}

There are few bulbous plants that meet climatic or soil conditions better, or give a more attractive bloom. They are hardy without protection, and thrive either under ordinary garden conditions or when naturalized in open moist woods or in not too dense a grassy growth. The flower stems are 4 feet high with as many as a hundred star-shaped flowers measuring 11/2 inches across and flowering in long succession.

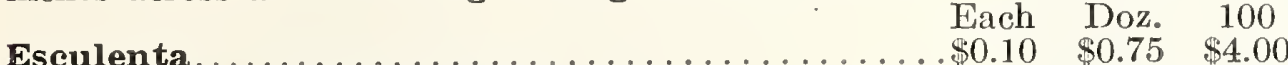

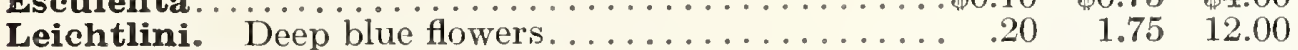

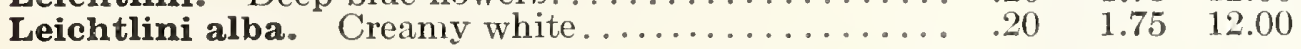

\section{GALADIUM ESCULENTUM (Elephant's Ear)}

Grand tropical plant. A favorite for specimens on the lawn. Height 3 to 4 feet.

Large Bulbs, 7 to 9 in. in circum...............\$0.20 \$2.00

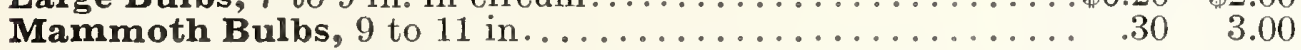

\section{FANCY-LEAVED CALADIUMS}

Beautiful variegated leaved plants adapted for pot culture or bedding if given sheltered positions.

Fancy-leaved Mixed Varieties. Each 40c., doz. $\$ 4.00,100 \$ 30.00$.

\section{GANNAS}

Cannas should not be planted until the warm weather sets in, or about May 15th. If planted too early the bulbs are apt to rot.

The following are a selection of the largest flowering varieties which we can recommend for bedding or borders. We shall be pleased to supply other varieties not named at catalogue prices.

American Red Cross. A glowing cardinal scarlet. Large

deep green leaves. $31 / 2 \mathrm{ft} \ldots \ldots \ldots \ldots \ldots \ldots \ldots \ldots \ldots \ldots 1.20 \$ \ldots 8.00$ Eureka. A very free blooming creamy white with green foliage. 1.00

Gladiiflora. Crimson, changing to carmine-rose, edged gold. $4 \mathrm{ft} .1 .00$

Hungaria. The ideal pink bedder; large trusses of flowers. $3 \mathrm{ft} .1 .50$

King Humbert. Bronze foliage, with orange-scarlet flowers.

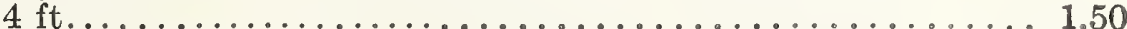

Martha Washington. One of the most superb pink varieties. 1.20

Maros. Very free flowering, creamy white; one of the best... 1.20

Mrs. Alf. Conard. Exquisite salmon-pink; very free flower-

ing. $4 \mathrm{ft} . \ldots \ldots \ldots \ldots \ldots \ldots \ldots \ldots \ldots . . . \ldots \ldots$

Orange Bedder." Bright orange, with scarlet suffusion. 4 ft. 1.00

Doz. 100
$\$ 8.00$

7.00

10.00

10.00

8.00

8.00

15.00

7.00

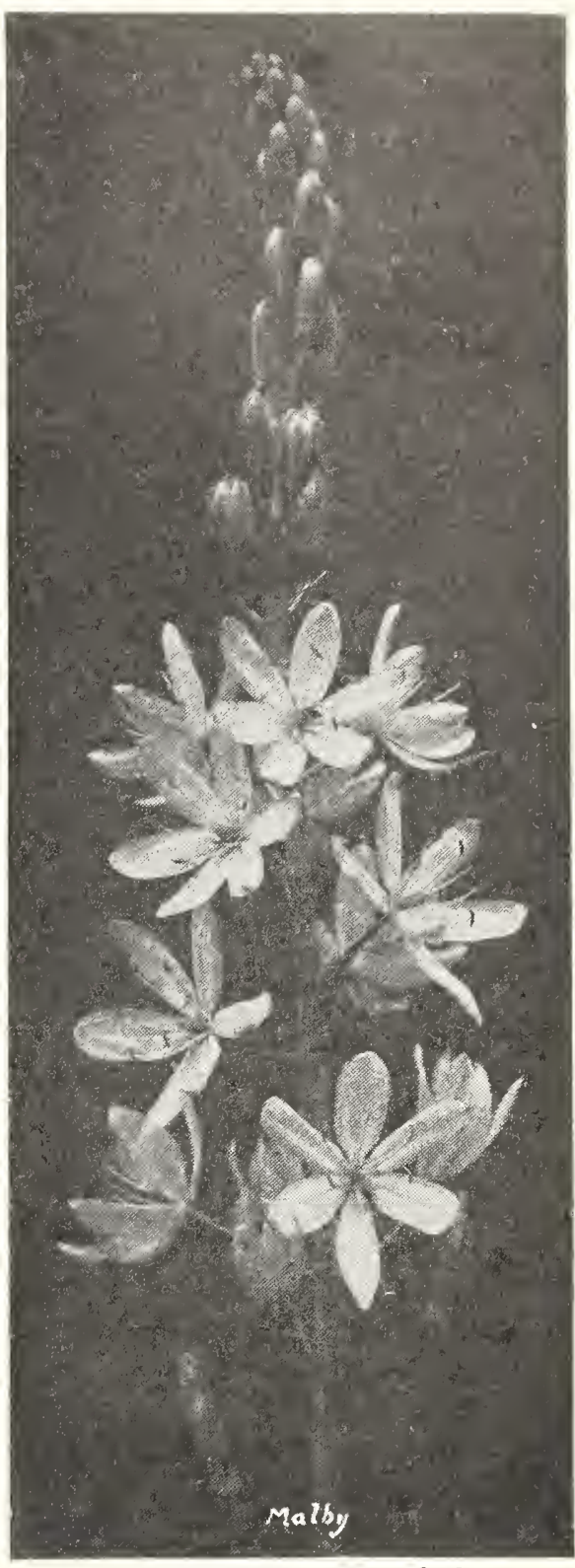

Camassia Leichtlini

Doz。

100

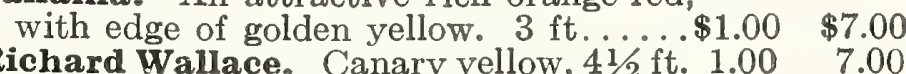

Panama. An attractive rich orange-red

Richard Wallace. Canary yellow, $41 / 2 \mathrm{ft}$.
The President. A gorgeous green leaf

variety with great trusses of bright red

flowers............................. 1.00

Wintzer's Colossai. The largest Canna.

Vivid scarlet flowers. $5 \mathrm{ft} . . . \ldots \ldots \ldots .1 .00 \quad 7.00$

Yellow King Humbert. A beautiful yellow, lightly spotted red, with green

foliage. $5 \mathrm{ft} \ldots \ldots \ldots \ldots \ldots \ldots \ldots \ldots . \ldots 1.50 \quad 10.00$

Mixed Varieties................. $.75,5.00$

Not less than half dozen of any variety supplied.

\section{GINNAMON VINE}

DIOSCOREA batatas. A rapid growing Summer climber, with bright green, glossy foliage and spikes. of cinnamon-scented white flowers. Each 10c., doz. $\$ 1.00,100 \$ 7.50$.

\section{GRINUM FIMBRIATUM}

One of the most popular Crinums. Pure white with lavender-pink stripes through centers of petals. Each $30 \mathrm{c} .$, doz. $\$ 3.00$.

\section{DAHLIAS}

See pages 54,55 and 56 .

\section{GLADIOLUS}

See pages 56, A, B, C, and D, for color plates, description and prices. 


MAR S A L L'S B ULB S

SUMMER FLOWERING BULBS-Continued

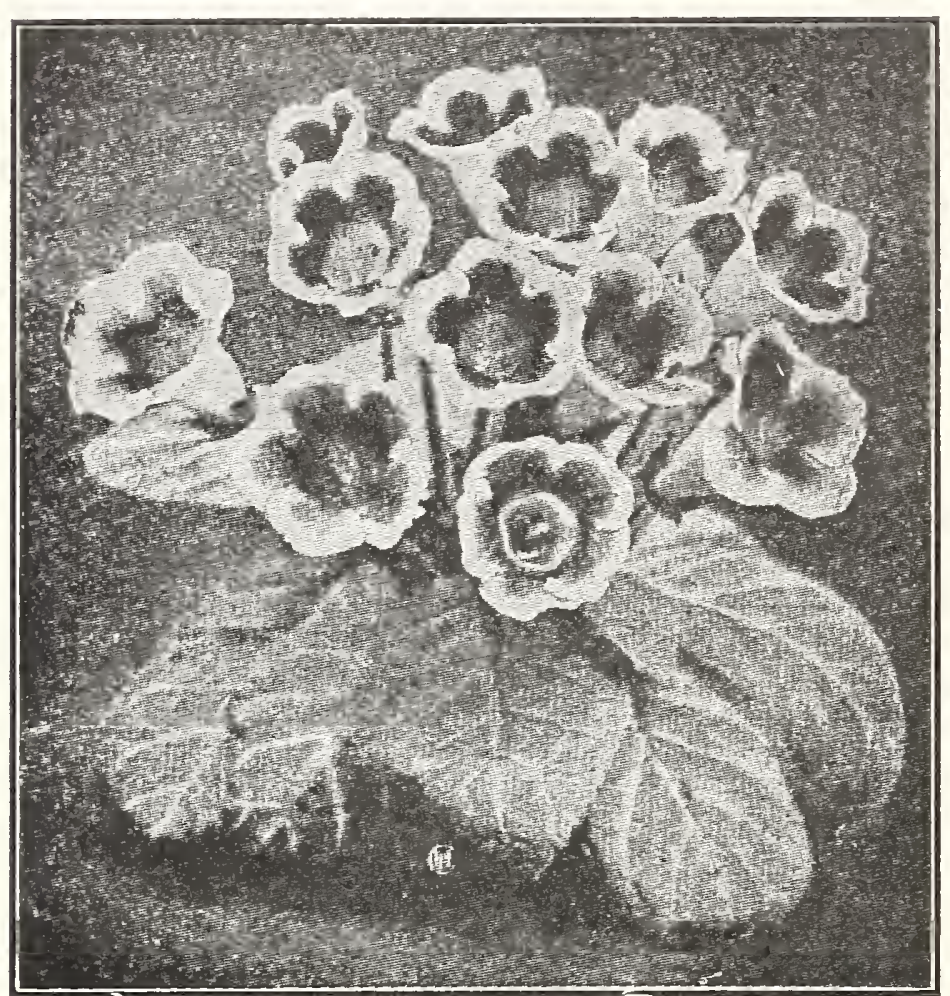

Gloxinias

\section{GLOXINIAS}

Handsome Summer blooming greenhouse plants. The flowers are gorgeous, and the foliage has a velvety appearance. Each Doz. Red, Spotted, White or Blue ........ \$0.50 \$5.00 Choice Mixed Colors.............. . .50 5.00

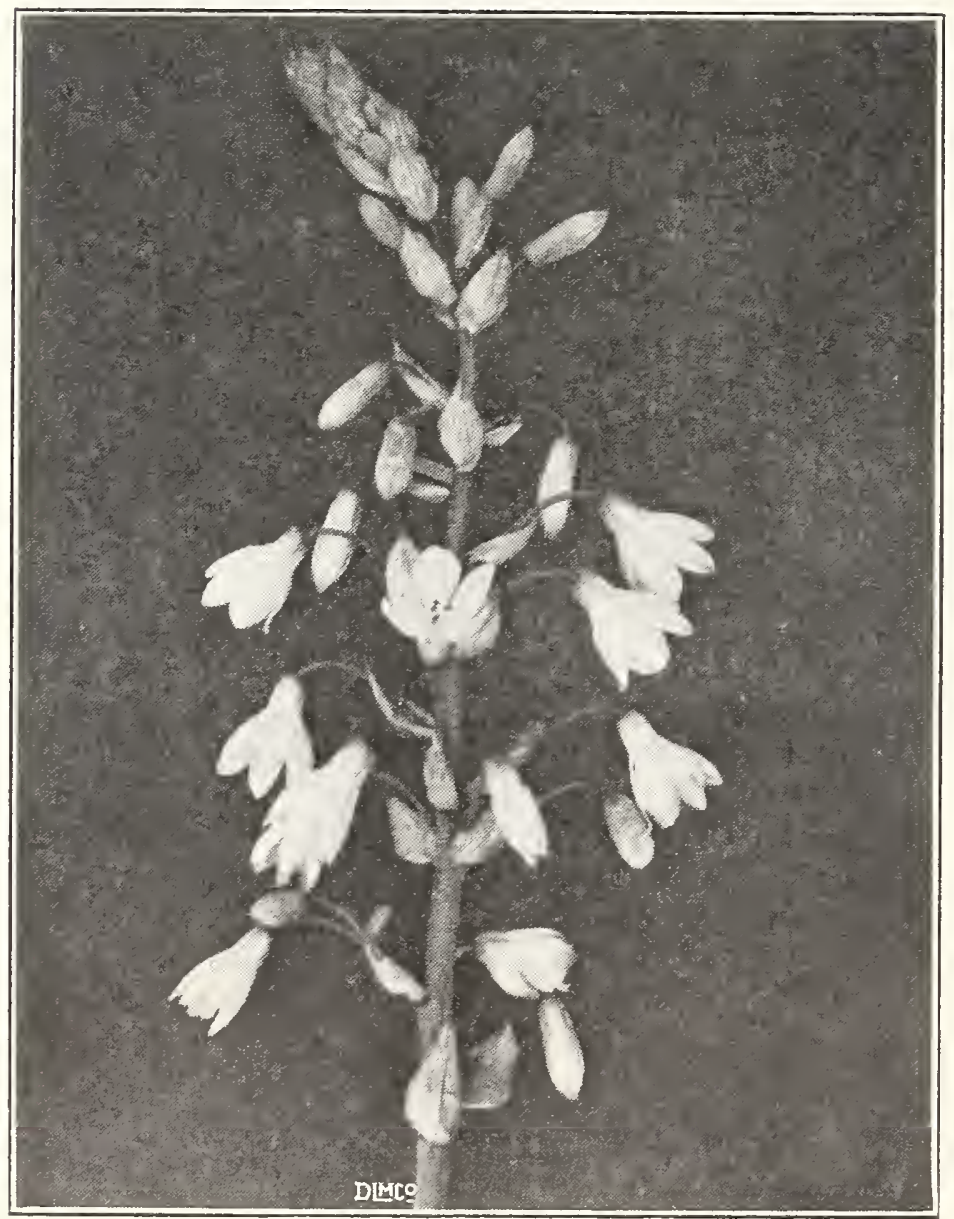

Hyacinthus candicans

\section{HYACINTHUS CANDICANS} (Cape Hyacinths)

A snow-white Summer flowering Hyacinth, growing 3 to 5 feet in height, gracefully surmounted with from twenty to thirty pure white, bell-shaped flowers. Large Bulbs. Each 15c., doz. $\$ 1.50,100 \$ 10.00$.

\section{LILIES}

See pages 56, E, F, G, and H, for color plates, description and prices.

\section{LYCORIS purpurea}

An introduction from Japan, but now very scarce. The foliage is produced in Spring and ripens up in August, after which the flower stalks appear, producing flowers in clusters of 6 and 8 flowers of 6 petals each The bud is wine color, changing to royal purple when expanded, giving a startling and beautiful effect. Perfectly hardy. 2 feet high.

Strong Flowering Bulbs. Each $\$ 1.00$, doz. $\$ 10.00$.

\section{LYCORIS squamigera}

A perfectly hardy bulb of the Amaryllis family. They produce attractive green foliage in the early Spring, which later dies away, and about a month later the flower stalks appear, growing about 2 feet high and developing an umbel of large Lily-shaped delicate pink flowers shaded with clear blue.

Extra Large Flowering Bulbs. Each \$1.00, doz. $\$ 10.00$.

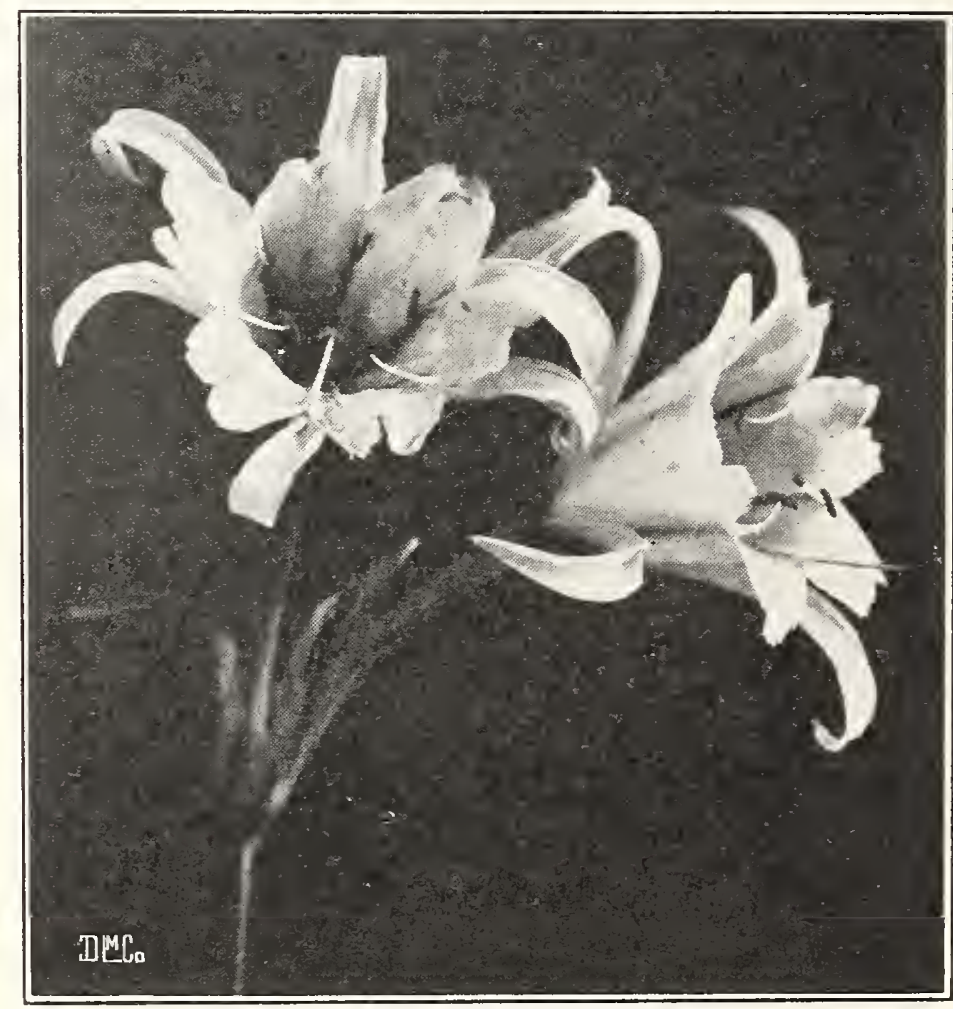

Ismene cala thina grandiflora

\section{ISMENE (Calathina Grandiflora)}

One of the best of our Summer flowering bulbs. Clusters of large, fragrant, pearly white flowers, resembling the Amaryllis family.

Large Bulbs. Each 25c., doz. \$2.50, $100 \$ 16.00$.

\section{MADEIRA or MIGNONETTE VINE}

A rapid growing, beautiful and popular vine, covering a large space in a short time. Heart-shaped leaves of a light green, with numerous racemes of feathery flowers of delightful fragrance.

Mammoth Bulbs. Each 15c., doz. $\$ 1.50,100 \$ 10.00$.

\section{OXALIS}

No bulb is more valuable for edging the borders of walks or flower beds. Elegant foliage and pretty flowers, bloom quickly after planting.

Dieppei. Pure white.

Lasiandra. Rosy pink, cut foliage.

Shamrock. Clover-like foliage; pink flowers.

Mixed Colors. Several varieties.

Mammoth Bulbs. Doz. 30c, $100 \$ 2.00$. 


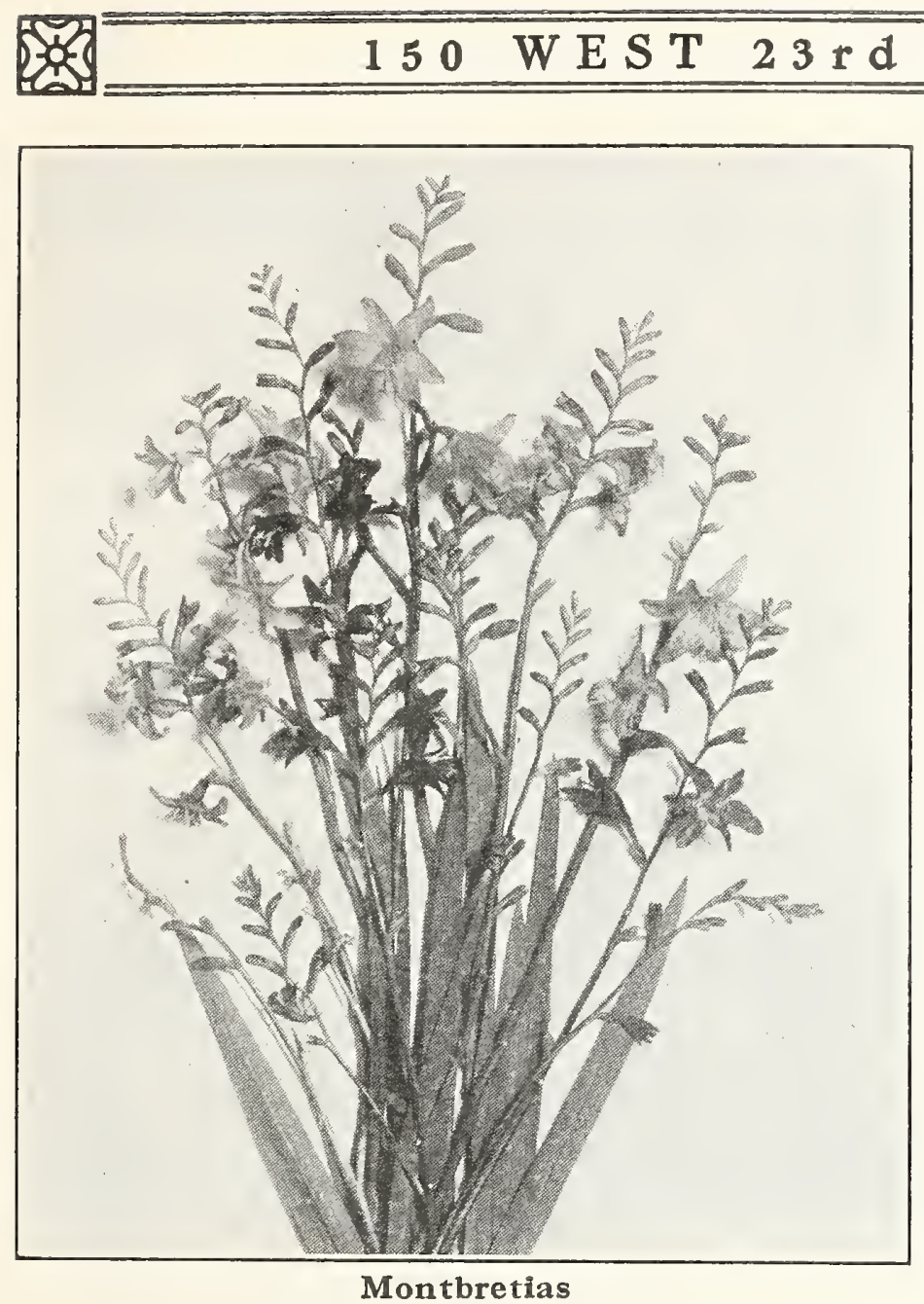

\section{MONTBRETIAS}

Hardy Summer flowering bulbous plants which should be planted in the early Spring and will flower in September. Bulbs may be left in borders during the Winter, if well covered, and will flower earlier than Spring-planted stock.

Croesus. Very large apricot yellow, 24 Doz. 100

in. high; late flowering............ \$2.00 $\$ 15.00$

George Davidson. Free flowering yellow $1.50 \quad 10.00$

King Edmund. Giant rich golden with brown markings in throat. Tall, sturdy grower................ 1.50

macrophylla. Orange externally, inside purple; a beautiful variety........... 1.50

Meteor. Orange with red tips on backs of flowers. Early flowering......... 1.25

Rheingold. Golden yellow with brown

throat. Strong grower, free flowering.. 2.00 15.00

Mixed Varieties.................... $1.50 \quad 10.00$

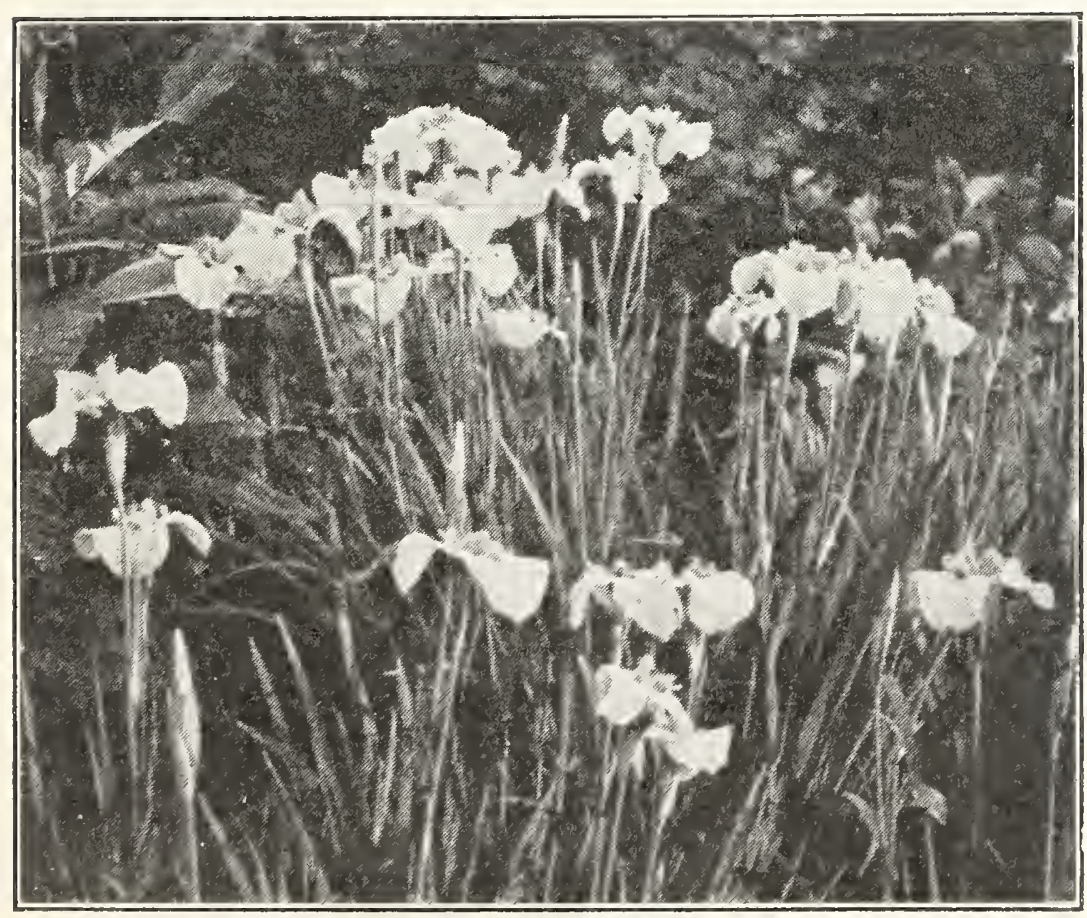

10.00

10.00

8.00

Japanese Iris

\section{TIGRIDIA (Shellflower)}

Very showy Summer flowering bulbs growing about 24 inches in height. Bulbs should be planted 2 inches deep and 6 inches apart and treatment similar to Gladiolus should be given them.

Mixed Colors. Each 20c., doz. \$1.75, $100 \$ 12.00$.

\section{TUBEROSES}

One of the most fragrant and popular of the Summer flowering bulbs. May be started in hotbeds or pots, or planted in open ground after first day of May.

Excelsior Double Pearl. Extra

Each Doz. 100

fine bulbs................ \$0.10 \$1.00\$6.00 Armstrong's. The single ever-

blooming Tuberose........... . . 10 $1.00 \quad 6.00$

\section{ZEPHYRANTHES}

\section{ZEPHYR IFLOWER OR FAIRY LILIES}

A hardy, dwarf, bulbous plant, flowering in great profusion in the Summer.

rosea. Beautiful clear rose, very large flowers. Doz. $\$ 2.00,100 \$ 15.00$ 。

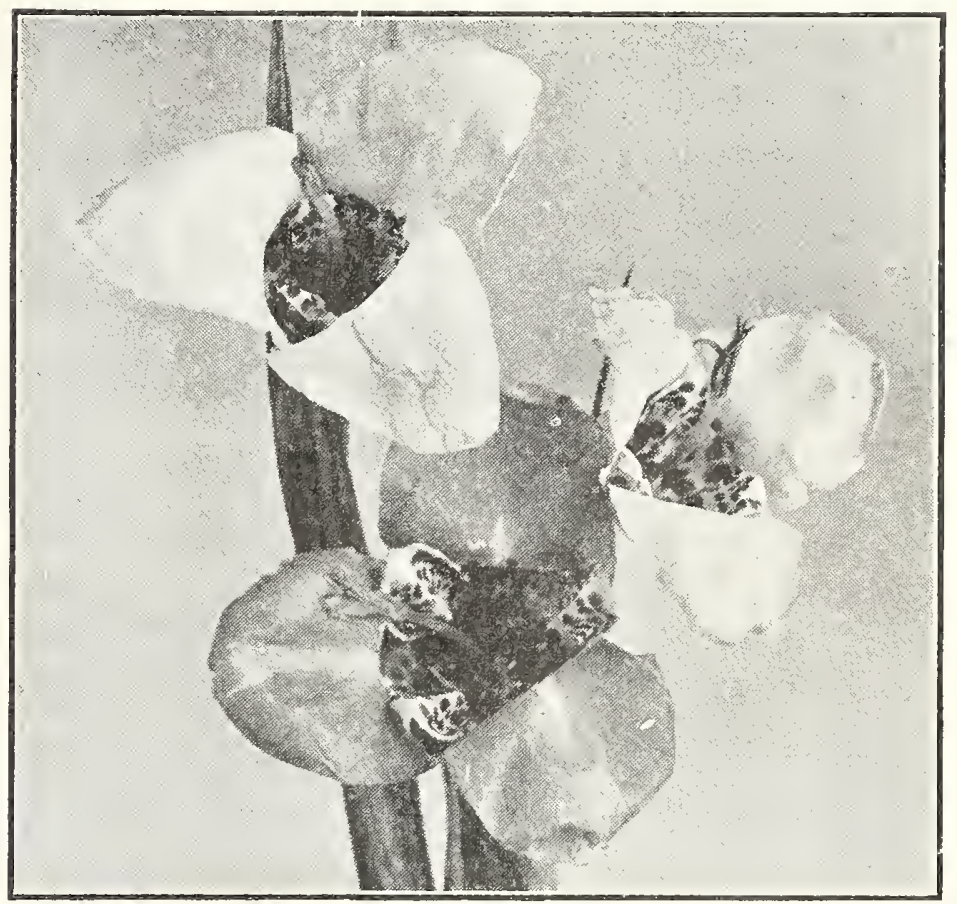

Tigridias

\section{IRIS, JAPANESE}

The Japan Iris is perfectly hardy and flowers in great profusion in July and August.

The large size of the flowers is noteworthy, as they often reach 6 to 8 inches across in most fascinating combinations.

Distinction. Light lavender-pink, shading bright yellow at base of petals.

Gold Bound. Large, pure white, yellow center. Mahogany. Deep velvety, mahogany-red.

Pyramid. Violet-blue, veined white in center of each petal.

Toledo. Large white petals with faint light blue veins and light blue center.

Victor. White, veined violet-blue, purple center. Prices of the above, strong clumps, 50c. each, $\$ 4.50$ for 10

Large individual clumps, $\$ 1.00$ each, $\$ 9.00$ for 10 . 


\section{DAHLIAS}

The renewed popularity of the Dahlia in recent years has brought out many new sorts, and anyone wishing to get the cream will find most of them in our collection, which can be recommended either for growing in competition, market purposes, or private collections, and embrace all classifications.

\section{NEW DECORATIVE DAHLIAS}

The following are a selection of the best varieties from the leading introducers.

Eastern Star. Flowers of great substance and good keeping qualities, with full centers held on strong, erect stems. Color a soft saffron yellow with old gold shadings. Plants $\$ 2.50$, tubers $\$ 5.00$.

Elite Glory. A brilliant glowing red color. The flowers immense in size and breadth of petal. Strong, stiff stems and heavy foliage. Plants $\$ 5.00$, tubers $\$ 10.00$.

Emma Marie. H. C. A pleasing shade of clear pink with cream white center. A robust grower and large flowers on stiff stems. Plants $\$ 1.50$, tubers $\$ 3.50$.

Fort Washington. A dark mahogany red flowers oi immense size. Strong, robust grower. Plants $\$ 3.00$, tubers $\$ 6.00$.

Jersey's Beacon. The color is a Chinese scarlet with a paler reverse. A prolific bloomer. Plants $\$ 2.50$ tubers $\$ 5.00$

Jersey's Beauty. This fine true pink Decorative was again the feature where shown during the past year, with its long, stiff, straight stems. Its keeping qualities are unsurpassed after being cut. Tubers \$1.00.

Jersey's Ideal. Lavender-pink flowers on ideal stems. A vigorous grower. Plants $\$ 5.00$ each; tubers $\$ 10.00$.

Jersey's Radiant. H. C. A radiant Dahlia of bittersweet orange, produced on long, stiff stems. Plants $\$ 2.50$, tubers $\$ 5.00$.

Margaret Masson. A beautiful silvery-rose pink color. A wonderful exhibition flower on account of its fine keeping qualities. Plants $\$ 2.50$, tubers $\$ 5.00$ each.

Mordella. A bright apricot-buff color. Flowers 9 inches on long, graceful stems. Plants $\$ 2.00$, tubers $\$ 3.50$ each.

Mrs. F. A. C. Perrine. Dec. Lilac-pink ground with pale Cattleya reverse. Twisted and curled petals. Blooms 8 in. in diameter on long, stiff stems. Plants $\$ 2.50$, tubers $\$ 5.00$.

Pop Stewart. Dec. Flower of great size. Rosy-pink changing to lilac-pink as the flowers mature. A wonderful grower, with splendid stem. Plants $\$ 2.00$, tubers $\$ 4.00$ each.

Robert Treat. Dec. A brilliant American Beauty Rose shade. Stiff, upright stems, strong grower. Plants $\$ 1.50$, tubers $\$ 2.50$ each.

Sanhican's Bluebird. Dec. The nearest approach to a blue Dahlia. Very large flowers on strong stems. Plants $\$ 1.50$, tubers $\$ 3.00$ each.

Sanhican's Gem. Dec. A delightful shade of old rose. True staghorn týpe. Plants \$2.00, tubers $\$ 3.50$ each.

Sanhican's Ruby. A deep shade of pigeon's blood, suffused with bronze. Has tremendous size and fine stem. Plants $\$ 1.00$, tubers $\$ 2.00$ each.

Stacy Trent. Dec. A clear rosy-pink. A beautiful flower, free blooming and fine lasting quality. Plants $\$ 1.00$, tubers $\$ 2.00$.

Trentonian. A perfect flower in brown tones. Free flowering and perfect stems. Plants $\$ 2.00$, tubers $\$ 3.50$ each. World's Best White. The best white, fine stem, free bloomer and full to the center. Plants $\$ 2.00$, tubers $\$ 3.50$.

\section{NEW HYBRID GACTUS DAHLIAS}

Elsie Daniels. H. C. A fine type with full center creamy white shading to a lilac-pink on outer row of petals. Tubers $\$ 3.50$.

Islam Patrol. H. C. Very dark velvety scarlet, tipped and flushed with gold. Wonderful long stems. Tubers $\$ 3.00$.

Jersey's Delight. H. C. A beautiful old rose color borne on stiff stems. Plants $\$ 5.00$, tubers $\$ 10.00$.

King Solomon. H. C. A pleasing combination of burnt orange and burnished copper; free flowering and good keeper. Plants $\$ 2.50$, tubers $\$ 5.00$.

Siskiyou. H. C. A very large flower, pink suffused mauve. Tubers $\$ 2.50$. 


\section{SUPERB DEGORATIVE DAHLIAS}

The Decorative Dahlias have very large flowers with broad petals; they all flower freely on long, strong stems. Our list of varieties are selected from the varieties best adapted for exhibition and cutting.

Agnes Haviland. Rose-pink, slightly suffused Each

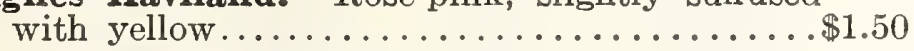

Amun Ra. Copper and orange................ 1.00

Bashful Giant. Apricot, shaded gold....... 1.50

California Superba. Delicate pink....... 2.50

Carmencita. Yellow, striped red; dwarf habit. 1.50

Catherine Wilcox. A beautiful variegated pink and white, dependable variety in every way.. 3.00

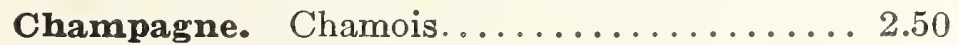

Charm. Burnt orange shading to yellow...... 1.00

Dakota. Flame color, a good exhibition flower. 1.00

Delice. Beautiful pink, medium size......... .50

Dr. Tevis. Very large old rose, suffused with gold, shaded amber.................. .75

Earl Williams. A brilliant crimson and white. 1.50

Eldorado. Golden yellow. Plants $\$ 1.50 \ldots \ldots 3.00$

E. T. Bedford. Purple with silver reverse..... 1.00

Hortulanus Fiet. Beautiful shrimp-pink, salmon and gold suffusion................ 1.00

Insulinde. Beautiful golden orange; large, broad, waxy petals, magnificent variety..... 1.00

Jersey's Beauty. A real rose-pink. The finest pink decorative variety.............. 1.00

Jersey's Gem. Lavender-pink. Strong stems and perfect form. Plants $\$ 2.50 \ldots \ldots \ldots . . .500$

Jersey's Jewel. A monstrous mallow-pink.

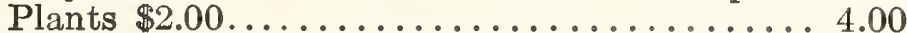

Jersey's King. Begonia rose. Very large.... 1.50

Judge Alton D. Parker. Color golden buff.... 1.50

Judge Marean. Orange with salmon-pink suffusion, tinted yellow............... 1.50
King of the Autumn. Buff yellow, suffused with terra cotta, erect, stout stems........\$0.75

Marcella Gill. Clear pink, tinted yellow...... 1.00

Millionaire. Dainty lavender with pink sheen, shading to white in center.

Mr. Crowley. Salmon-pink, with yellow at base of petals

Mrs. G. W. Elkins Jr. Old gold suffused with salmon, with faint reflex of rosy-pink.

Mrs. I. de Ver Warner. A deep mauve-pink. One of the finest Dahlias ever introduced..... 1.00

Mrs. J. T. Scheepers. Canary yellow with pink suffusion........................ 1.50

Myra Valentine. A golden bronze. Very free bloomer and vigorous grower............. 2.00

Paul Michael. A pure gold color of immense size. 1.00

Pride of California. A perfect red......... 1.00

Princess Pat. Large, old rose flower......... 1.00

Robert Treat. Color of the American Beauty Rose; erect habit with long stems...............

Rookwood. A pure bright cerise rose. Immense flowers on stiff stems.............. 2.00

Rosa Nell. Clear bright rose; large attractive flowers........................ 1.00

Shudow's Lavender. 'Lavender-mauve........ 2.50

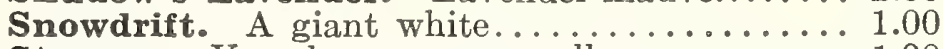

Stunner. Very large canary yellow............... 1.00

Susan G. Tevis. A shade of lilac with bluish sheen. Very fine stem................ 2.00 Venus. White with pink and cream suffusion... 1.00

Wm. Slocombe. Bright yellow; very fine...... 1.00

Wizard of $\mathbf{O z}$. Very large, amber-pink........ 2.00

\section{CACTUS AND HYBRID CACTUS DAHLIAS}

The following varieties comprise the cream of the novelties which have proved to be of extra merit.

Each

Ambassador. Yellow and pink.........\$2.00

Amber Glow. Bright yellow, deepening to orange at center. Large flower............... 1.00

Attraction. H. C. Clear lilac rose, strong

stems........................... 75

Ballet Girl. Orange with white edge and variations..........................................

Countess of Lonsdale. Deep salmon-red...

Conquest. Deep crimson maroon, |large with twisted petals.

Daddy Butler. H. C. Rosy carmine, reverse

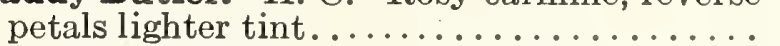

Esther R. Holmes. Lavender-pink

Francis Lobdell. H. C. Mallow-pink shading to white in the center.................

F. W. Fellows. Orange, with terra cotta shad-

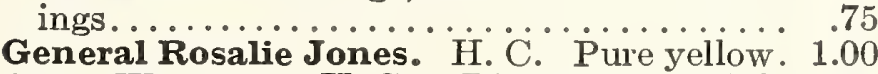

Geo. Walters. H.C. Rich salmon-pink, shaded gold to center; fine for every purpose.

Gladys Bates. Incurved petals of tan, with

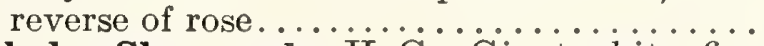

Gladys Sherwood. H. C. Giant white, fine

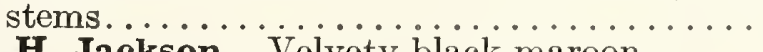

J. H. Jackson. Velvety black maroon.

Kalif. Pure deep scarlet, perfect flower.

La Favorita. Beautiful shade of orange

Mariposa. H. C. Lavender-pink.

Mephistopheles. H. C. Ruby-red, ..........

Mrs. C. Cooper. Creamy-salmon.......... 1.25

Mrs. W. E. Estes. H. C. A fine pure white.. 1.00

Pierrot. Deep amber, shading to salmon

center, white tips. Beautiful exhibition

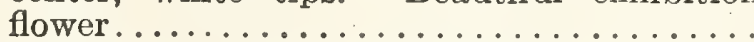

Red Cross. Yellow, with salmon-red shadings. 1.00

The Grizzly. Dark velvety maroon....... 1.00
Tom Lundy. H. C. Rich, velvety red; fine for cutting...................\$ 0.75

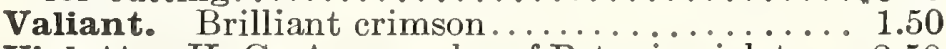

Violetta. H. C. A rare color of Petunia violet... 2.50

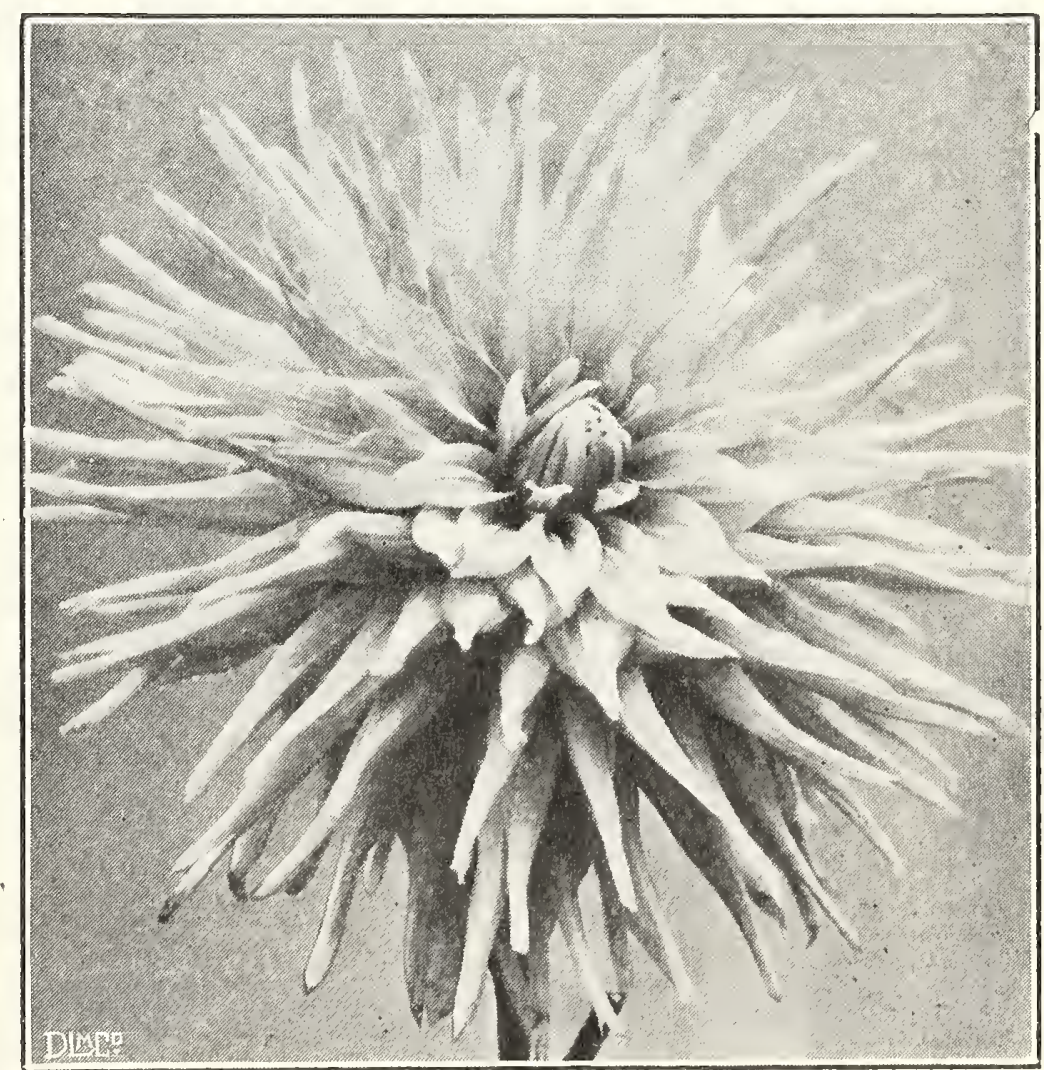

Dahlia, Ambassador 


\section{POMPON DAHLIAS}

These tiny Dahlias are greatly in demand for table decorations and cutting. The many colors make it possible for any color scheme. The habit of the plant is dwarf and they require very little supportwhen growing. Each Aimee. A wee flower of bronze........... \$0.50 Arthur. A brilliant scarlet, long stems....... $\quad .75$

Barbara Purvis. A fine white for cutting. . . . . .50 Belle of Springfield. Crushed strawberry ..... .50 Bob. Attractive shade of plum............. .50

Bronze Beauty. Golden apricot.

Charming. A very. fine lavender pink

Deedee. A dainty small lavender.

Elizabeth. Golden yellow, edged red.

Gandymede. A blending of mauve and $\tan$.

George Ireland. Beautiful mauve.

Glow. Light rose or coral.

Goldie. A tiny flower of pure gold

Hazel. A small buff, deepening to brown.

Helen Cottrell. A perfect flower of baby pink...

Johnny. A dark deep red, tiny flower.......... 50

Kim. An exceptionally good orange.......... .50

Lassie. Yellow base, old rose shadings........ . .50

Little Beeswing. Golden yellow, tipped red.... .50

Little Helen. A lovely pale lavender........ .50

Pee Wee. Soft yellow, center shading to brown... $\quad .50$

Regulus. A small cerise purple............ .50

San Toy. White tipped with carmine........ 50

Sunset. A delightfu] orange.............. .50

Tom. Small yellow tipped red...

Yellow Gem. Creamy yellow, small flower..

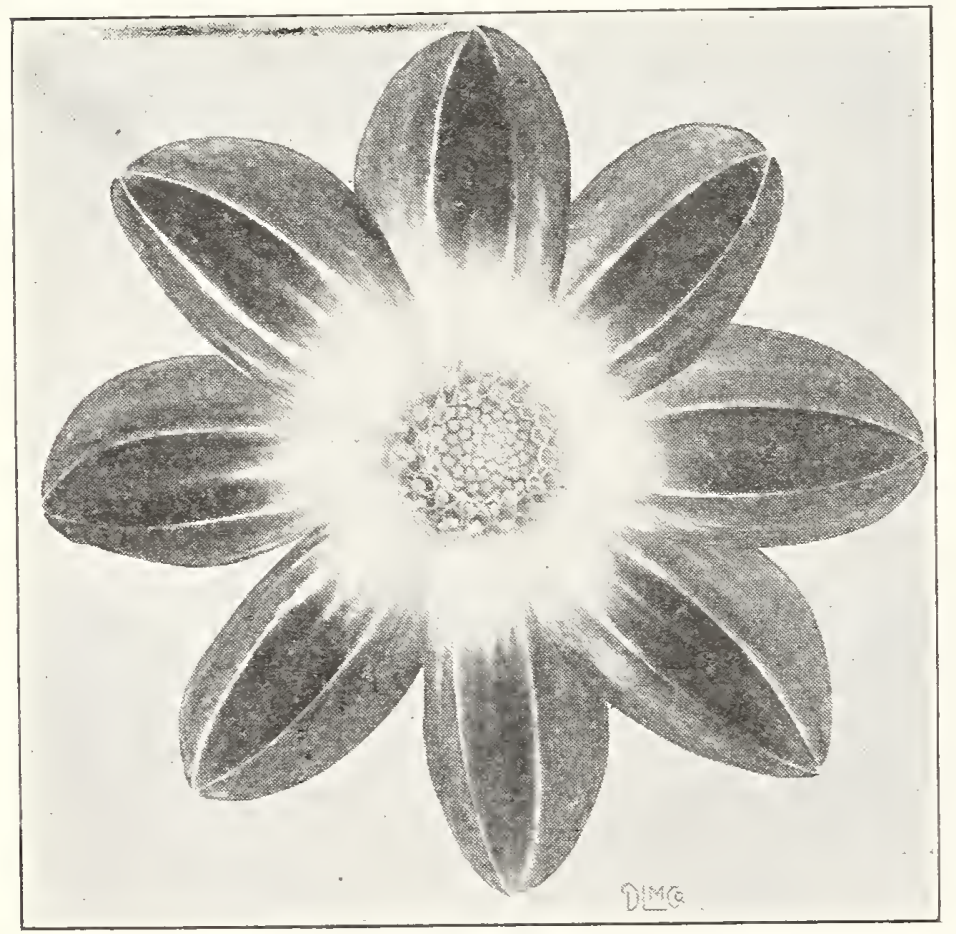

Single Dahlia

\section{CHOICE SINGLE DAHLIAS}

These have become very popular for cutting purposes. We list a few of the best varieties. Each Autumn Century. Old rose and yellow.....\$0.50 Geisha Century. Red and yellow......... 40 Golden Century. Deep yellow............ .50 Gladys Century. A fine pink........... .40 Jack Century. Bright scarlet............ .50 Margaret. A very large clear pink.......... 1.00 Newport Angel. White................ 2.00

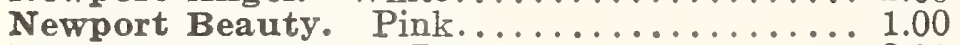
Newport Triumph. Bronze............. 2.00

Newport Wonder. Salmon buff........... 2.00 Sachem. A beautiful orange-scarlet........... .50 Tango Century. A very large bronze............. 1.00 Twentieth Century. White and rose pink..... .50 White Century. Pure white............. .50

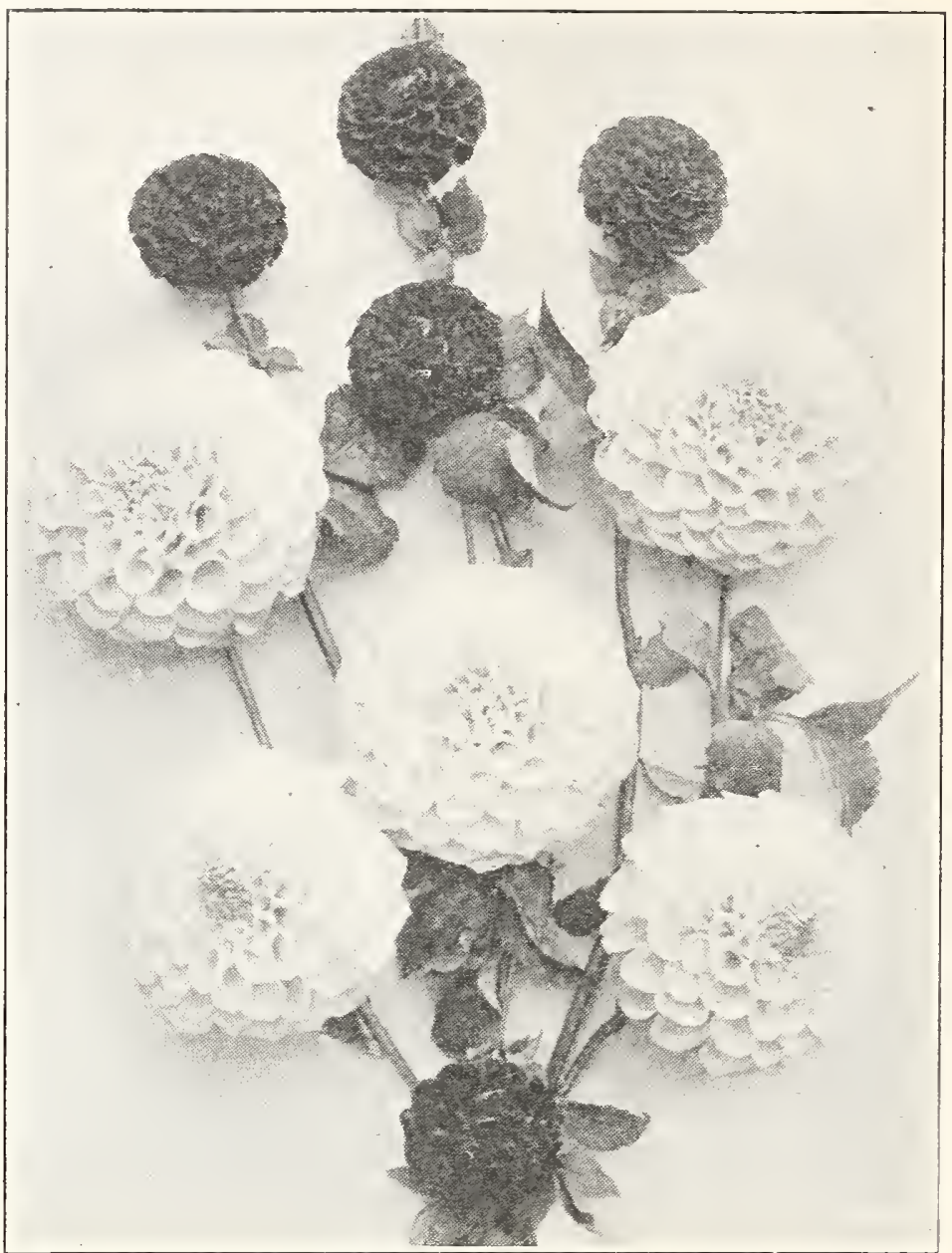

Pompon Dahlias

\section{CHOICE SHOW DAHLIAS}

The Show Dahlias are closely quilled, ball-shaped flowers, full to the center, showing regular arrangements of florets.

The following are a selection of the best varieties for $\begin{array}{lr}\text { cut flowers. } & \text { Each } \\ \text { A. D. Livoni. Pure pink.................... } & \end{array}$ Cuban Giant. Black velvety crimson.......... .40 Gold Medal. Canary yellow and red......... .50

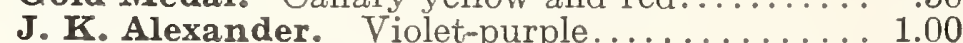
Red Duke. Crimson red.................. $\quad .50$ Striped Banner. Crimson tipped with white... .50 Vivian. Old rose and white; very good........ .40 White Swan. White; free.. 40 W. W. Rawson. White quilled, petals suffused lilac. Rawson. White quilled, petals suffused 50

Yellow Colosse. Large pure yellow.......... . . .50

\section{PAEONY-FLOWERED DAHLIAS}

The flowers of this type are very large, averaging 8 inches across when well grown. The petals are broad and ribbon-like, the center shows, adding an artistic charm, closely resembling the semi-double Paeonies in appearance.

Duchess of Brunswick. Apricot and reddish

bronze........................... $\$ 0.50$

Electra. $₫$ d dainty lavender................... .50

Geisha. Brilliant scarlet and gold.................. 1.00

John Wanamaker. A lavender pink......... .50

King Albert. A rich magenta..................... 1.00

Mrs. W. C. Noonan. A beautiful clear pink... 2.00 Mysterious. Dark velvet with twisted petals... 2.00 Peg O'My Heart. Old rose, shaded golden yellow 2.00 Queen Wilhelmina. Pure white.......... .50 Von Hindenburg. Very large golden yellow.... 1.00

\section{DOUBLE DAHLIAS}

We have some fine tubers of unnamed varieties in Lavender, Pink, Red, White or Yellow colors, separate. Each $25 \mathrm{c}$., doz. $\$ 2.50,100 \$ 15.00$. 


\section{GLADIOLUS}

There are no other Summer flowering bulbs so satisfactory, needing so little attention and thriving so well in almost any ordinary soil as the Gladiolus. Set the bulbs from 3 to 6 inches apart in rows, or for massing 6 inches apart, and about 4 inches deep.

The following varieties are illustrated in color on pages $56 \mathrm{~B}$ and $56 \mathrm{C}$. $\begin{array}{lcc}\text { Each } & \text { Doz. } & 100 \\ \$ 0.35 & \$ 3.5() & \$ 25.00\end{array}$

$\begin{array}{lll}60 & 6.00 & 45.00\end{array}$

Cyron s. Smith. Very delicate lavender pink on white ground, yellow throat.

Desdemone. Immense flowers of ashy-rose color, striped violet, large black blotch edged with ivory white.

Dixie. Very dark, almost black, fine long stems and large flower.

Elora. Creamy white, rich cream spots in throat, overlaid with dainty pink featherings. Fay Lamphier. Coral luster with cerise blending, making a beautiful combination of color. Flowerfield Gem. Large, perfect flowers of light yellow with a crimson blotch.

Gold. Considered the best yellow in existence. Pure golden yellow.

Joerg's White. The greatest white, long stems and exceptionally large flowers, often six open at one time.

Kirchoff's Violet. Deep, dull, bluish-violet slightly veined ivory white.

Orange Glory. Grand orange-colored, with lighter throat

Pythia. Scarlet-red with blotch of pomegranate purple.

Rosa Lindt A charming violet shade. Large open flowers ...

Rose Precose. A beautiful salmon-rose, slightly ruffled.

\section{KUNDERDI RUFFLED VARIETIES}

The following include some of the best varieties introduced by A. E. Kunderd in the ruffled petal type. 'The flowers and spikes are unusually large, and are extensively grown for exhibition purposes.

\begin{tabular}{|c|c|c|}
\hline & & $\$ 1.2$ \\
\hline Creamy apricot with light tint of pink and red on the lower & & 1.25 \\
\hline arie Kunderd. Pure white, with almost invisible lines of soft pink in center of petals. & & 5.00 \\
\hline ona Lisa. Palest rose-pink or blushed white. A gorgeous flower & & 2.00 \\
\hline rs. H. E. Bothin. Flesh salmon-pink, flame scarlet center. Beautiful combination of & & 3. \\
\hline nge Glory. Grand orange colored with beautiful lighter throat; ruffled. & .15 & 1.50 \\
\hline le of Goshen. A very large salmon or fresh pink. Exceptionally tall spike. & & 5 \\
\hline ple Glory. Velvet maroon. Large ruffled flowers; extra fine spike. & .30 & 3.00 \\
\hline Precose. A beautiful salmon- & & 5 \\
\hline te Glory. A gorgeous pure white, with beautiful Iris-blue throat; ruffled. & & 2.00 \\
\hline triking rosy lavenc & & \\
\hline
\end{tabular}

\section{GLADIOLUS, NAMED HYBRIDS}

Our selection of varieties has been made from many and includes all those of exceptional merit and a wide range of colors.

\section{BLUE AND PURPLE SHADES}

Each

Anna Eberius. Dark velvety purple, pansy-purple blotch in the throat. Beautiful variety $\$ \$ 0.15$

Baron Hulot. A fine violet-blue.

Blue Jay (True). Bright light blue, with white shadings

Dixie. Very dark, almost black.

Duchess of York. The best blue, large flower well placed on long stems

Herada. Pure mauve with deeper markings on throat.

Kirchoff's Violet. Violet, slightly veined white.

Mary Fennel. A beautiful deep lavender, lower petals penciled primrose-vellow on pale lavender ground.

Mr. Mark. Light blue with darker throat; robust grower

Rev. Ewbank. A fine porcelain blue

Rosa Lindt. A beautiful violet shade.

Viola. Mauve blue, gradually shading to rich violet, throat toned soft canary with purple blotch in lower petals.

\section{PINK SHADES}

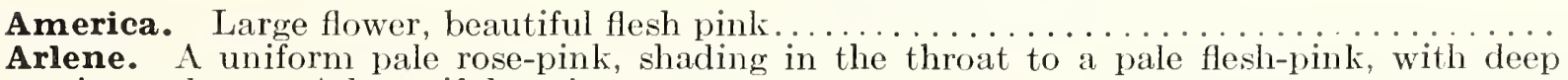

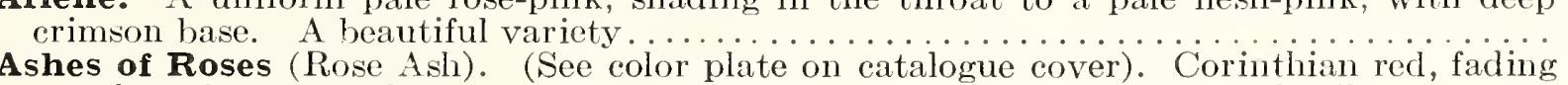
to ashes of roses on the outer edges. Flowers well set on a very large, tall spike.

Arizona Rose. A charming shade of light old rose.

Byron L. Smith. Lavender pink on white ground.

Cameo Pink. Dark coral salmon throat, lower petals yelo

Desdemone. Rose striped violet, edged white.

Fay Lamphier. Coral with cerise blending.

Evelyn Kirtland. Rose-pink, darker at the edges and fading to shell-pink in center........

Gretchen Zang. Pink, blending into scarlet on lower petals. . ...

Halley. A very attractive delicate salmon-pink

Ida Van. A beautiful deep salmon-red or flaming orange pink

La Couronne. Creamy white with throat blotched with dark maroon, bordered with pale yellow......

Loveliness. A beautiful cream colored variety

Le Marechal Foch. Pure pink of immense size.

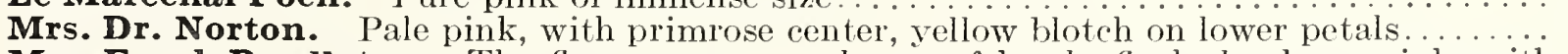
Mrs. Frank Pendleton. The flowers are very large, of lovely flushed salmon-pink, with brilliant carmine blotches in the throat.

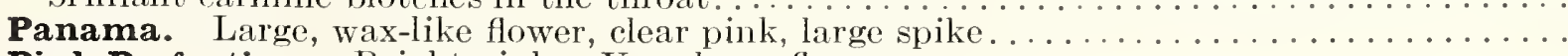

Pink Perfection. Bright pink. Very large flower.

\section{.15}

.25

.35

.50

.10

.20

.20

.20

.25

\subsection{0}




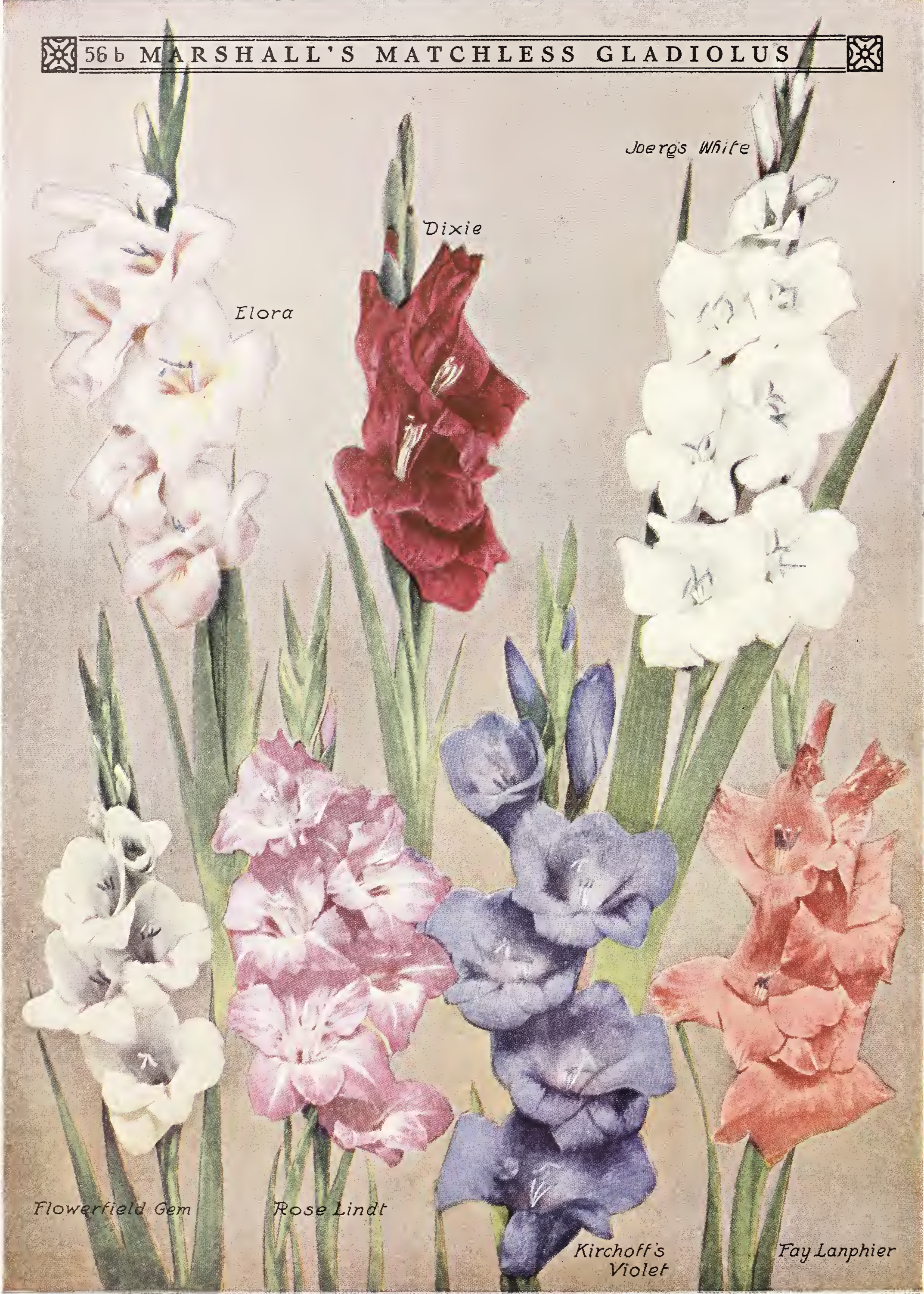




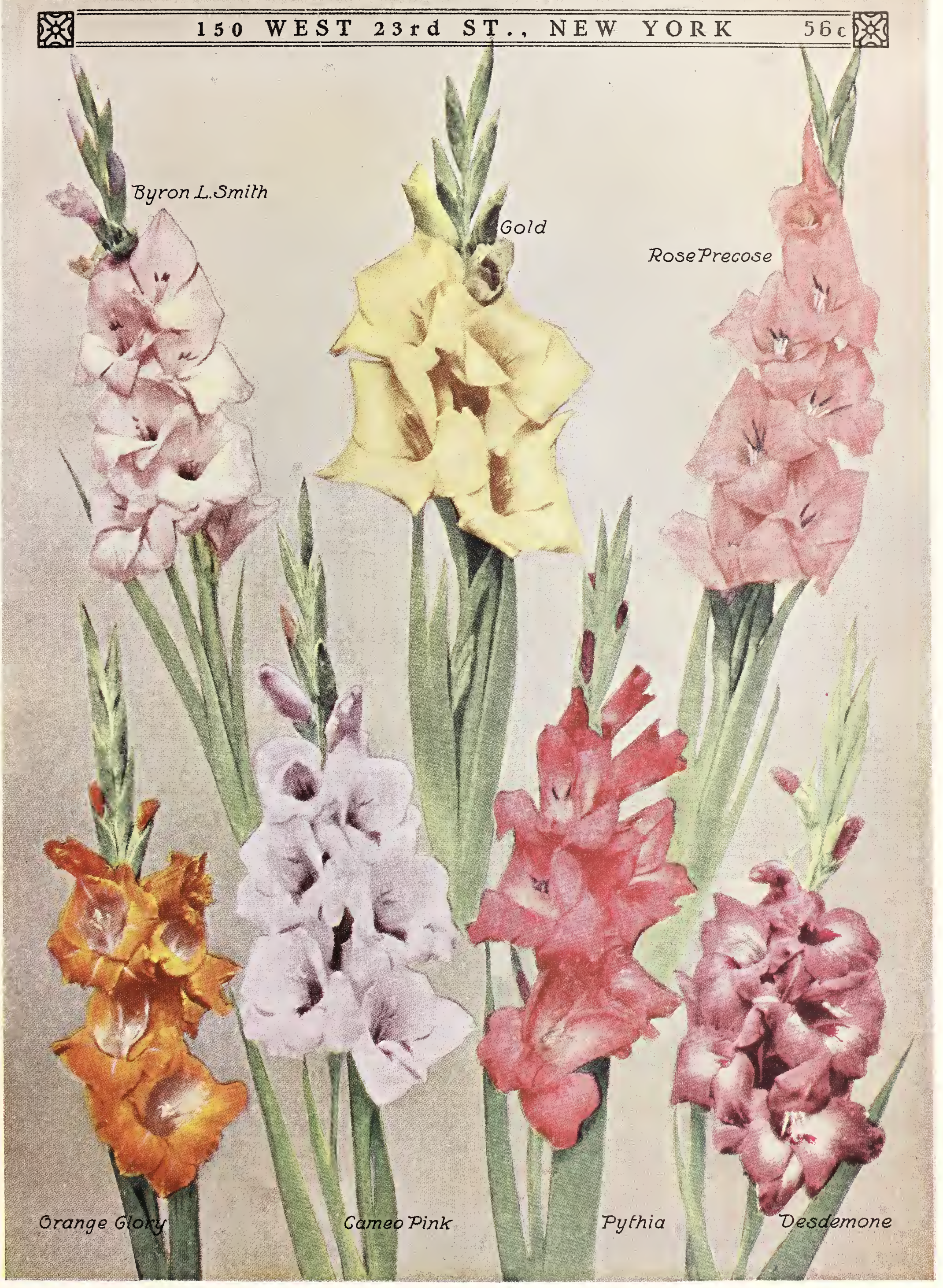


PinklWonder. A beautiful pink slightly lighter than Panama................\$0.25

Prince of Wales. Beautiful light salmon with orange shade, very early $\ldots \ldots \ldots \ldots \ldots \ldots \ldots .10$

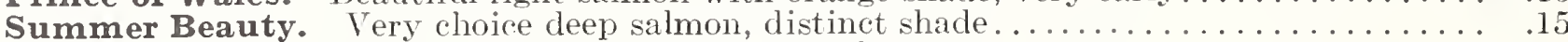

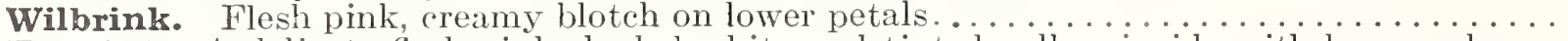

Twotint. A delicate flesh-pink shaded white and tinted yellow inside with large, salmontinted scarlet blotches.

\section{RED AND SCARLET SHADES}

Crimson Glow. A perfect scarlet of a deep tone on a tall spike.................... 15

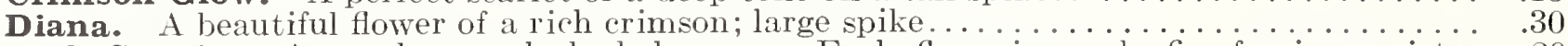

Early Sumrise. A very large red, shaded orange. Early flowering and a fine forcing variety.

Fire King. Long, graceful spikes of intense fire scarlet flowers.

Flaming Sword. A very early soft red flower; open six or more together............. Pythia. Scarlet with blotch of purple.

Mrs. Francis King. Light scarlet of pleasing shade; long spikes, one of the best.........

Red Canna. An exceptionally fine, deep scarlet. .

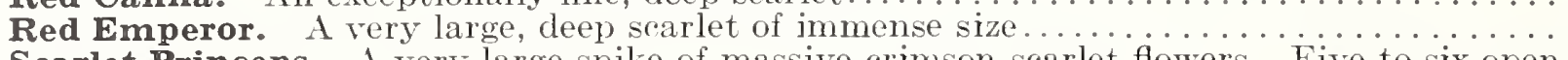

Scarlet Princeps. A very large spike of massive crimson-scarlet flowers. Five to six open at one time. .

\section{WHITE SHADES}

Elora. Creamy white overlaid with pink

s White. The largest white. Stems arera

Lily White. A fine snow-white of good height and large flower.......................

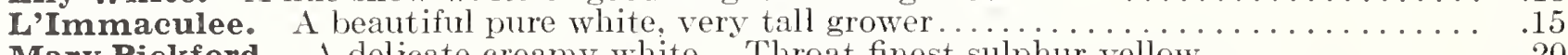

Mary Pickford. A delicate creamy white. Throat finest sulphur-yellow.............. .20

Peace. The flowers are large, white with a pale lilac feathering on the interior petals..... $\quad .10$

White America. Clear white with a slight mark of blue in the throat................. 10

White City. Very large, almost pure white flowers, spikes $5 \mathrm{ft}$. tall, A grand variety..... .15

$\$ 2.50$

1.00

2.00

8.00

2.00

1.25

YELLOW SHADES

Canary Bird. Fine yellow; extra good.

Flora. One of the best yellows. Pale corn-yellow with delicate lines on lower petals......

Gold. A very fine pure yellow.

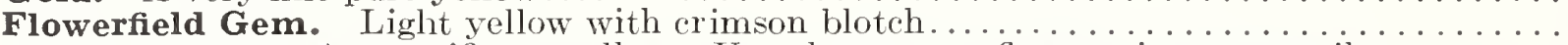

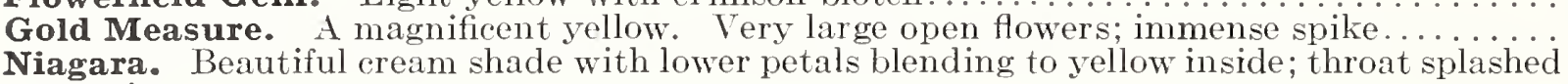
carmine.

Schwaben. Delicate, pale yellow, dark blotch in center

Sulphur King. Deep, pure yellow. The best of its color.

Yellow Hammer. Pure yellow, with a small red mark in the throat. $A$ fine forcer.
1.50

1.00

1.25

3.00

1.75

1.00

3.50

.75

1.50

2.00

2.00

1.50

2.00

.70

1.00

1.50

16.00

7.00

9.00

7.00

14.00

8.00

20.00

12.00

6.50

25.00

60.00

5.00

10.00

12.00

10.00

12.00

10.00

8.00

12.00

5.00

6.00

10.00

1.75

1.25

12.00

9.00

15.00

$2.00 \quad 12.00$

$2.00 \quad 15.00$

$\begin{array}{ll}1.00 & 6.00\end{array}$

6.00
5.00

10.00

8.00

\section{PRIMULINUS GLADIOLUS}

This race of Gladiolus has come to be extremely popular; they are easy to grow, beautiful for decorations; the colors are very artistic and embrace shades of yellow, pink and scarlet. Each Doz. 100 Alice Tiplady. A grand, large, beautiful orange-saffron color. . . . . . . . . . . . . . . . \$ \$0.10 $\$ 1.00 \quad \$ 7.00$

Dorothy Wheeler. Flowers richest rose-pink with lighter throat. Very large and nassive. $\quad .15 \quad 1.50 \quad 10.00$

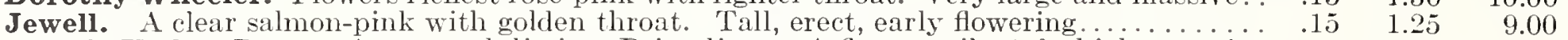
Joerg's Yellow Prim. A new and distinct Primulinus. A flower spike $5 \mathrm{ft}$. high, carrying

12 to 18 large pure yellow flowers. Flowers large and wide open.

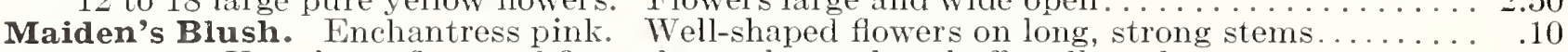

Ming Toy. Very large flower of finest form, showy deep buff, yellow throat....................

Myra. A deep salmon over yellow ground, yellow throat with pink lines. Tall, slender stem.

Orange Brilliant. Brilliant orange.

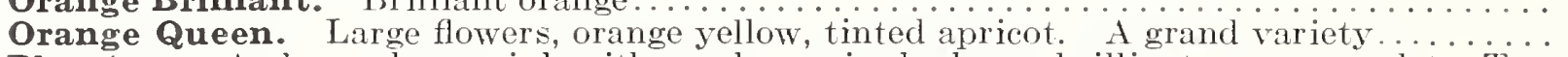

Phantasy. A clear salmon-pink with coral margin, buds are brilliant orange-scarlet. Two

lower petals are pale yellow, edged pink, with crimson veined throat. The upper petal folds back. Early flowering.

Salmon Beauty. Deep salmon with rich salmon-yellow throat $\ldots \ldots \ldots \ldots \ldots \ldots$

Souvenir. A superb large flowering deep yellow .........................

Sunbeam. A beautiful pure yellow. Good forcer.

25.00

1.00

3.00

1.25

1.00

$\begin{array}{ll}.10 & 1.00 \\ .35 & 3.50\end{array}$

6.00

20.00

7.00

6.00

25.00

$3.50 \quad 26.00$

$\begin{array}{ll}1.25 & 7.00\end{array}$

$\begin{array}{ll}1.25 & 8.00\end{array}$

$1.00 \quad 7.00$

\section{PRIMULINUS HYBRIDS}

A very select mixture from the newest hybrids; the most beautiful and delicate tints are found among them and no race of Gladiolus contains such harmonious blendings of color.

Doz. $\quad 100 \quad 1000$

Selected Mixed Hybrids.

\section{GLADIOLUS IN MIXTURE}

Our mixtures are made up from fine varieties and are all selected first size bulbs. Doz.

Marshall's Matchless Hybrids. This is our general mixture and is composed of fine sorts

in all colors, in extra large size bulbs only . . . . . . . . . . . . . . . . . . . . . . . $\$ 0.60 \quad \$ 4.00 \quad \$ 35.00$

Marshall's Special Mixture. This mixture is made up from named varieties and seedlings.

They are splendid for cutting and borders.

$.75 \quad 5.00$

45.00

\section{GLADIOLUS FOR LATE PLANTING}

Gladiolus can be had in flower in late September and October if the bulbs are retarded in cold storage.

We are prepared to place in cold storage any varieties if ordered before the end of April and ship at any date required for later planting.

Gladiolus bulbs dipped in a solution of Semesan will prevent hard rot and other diseases. 


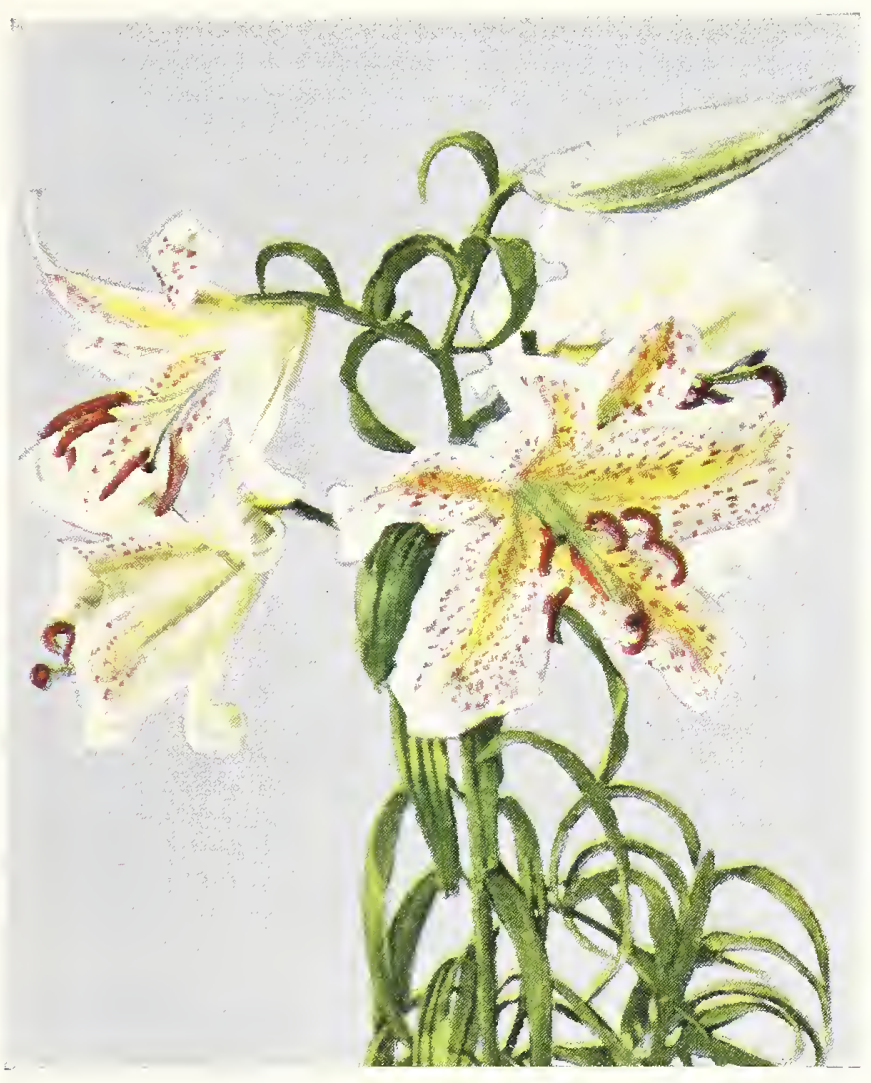

Auratum (See page 56f)

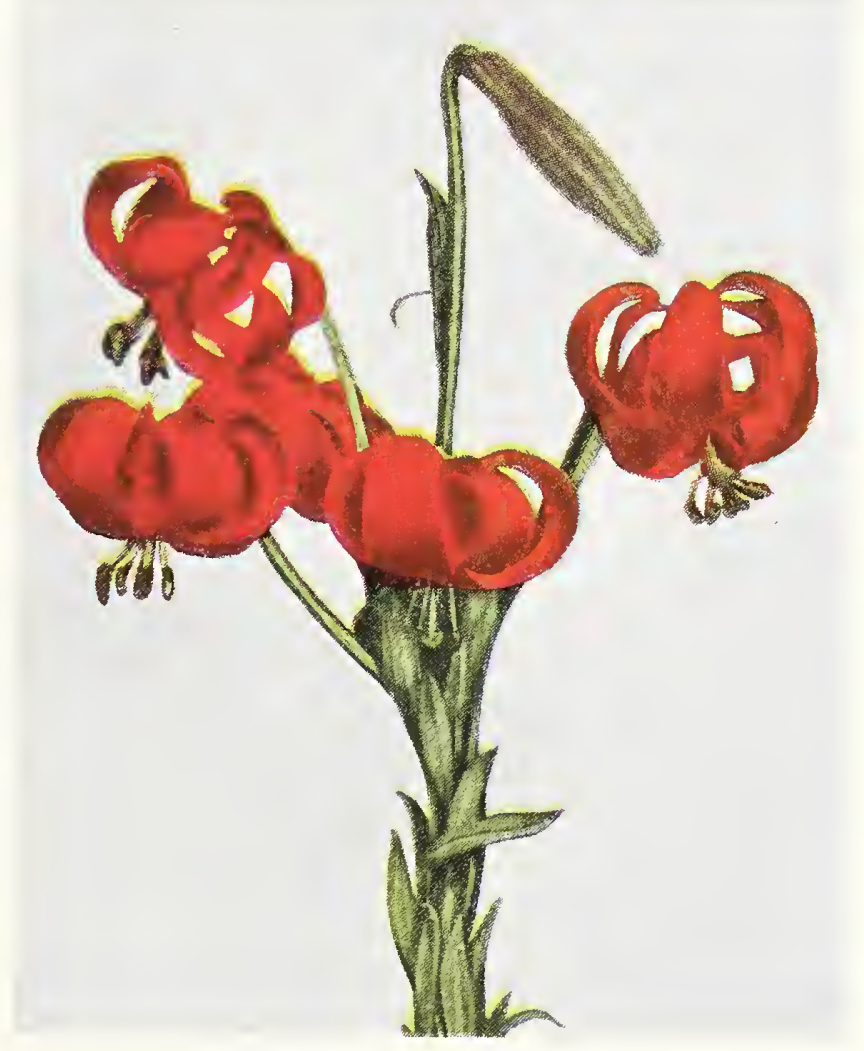

Chalcedonium (See page j6f)

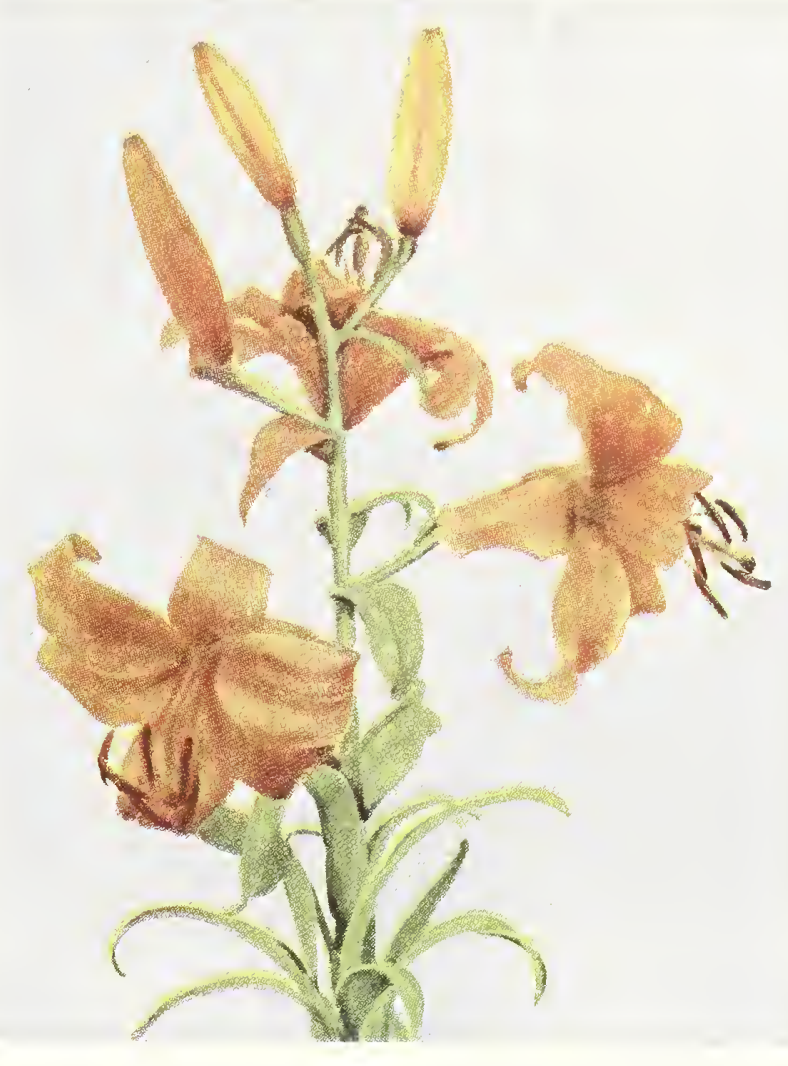

Batemanniae (See page $56 \mathrm{f}$ )

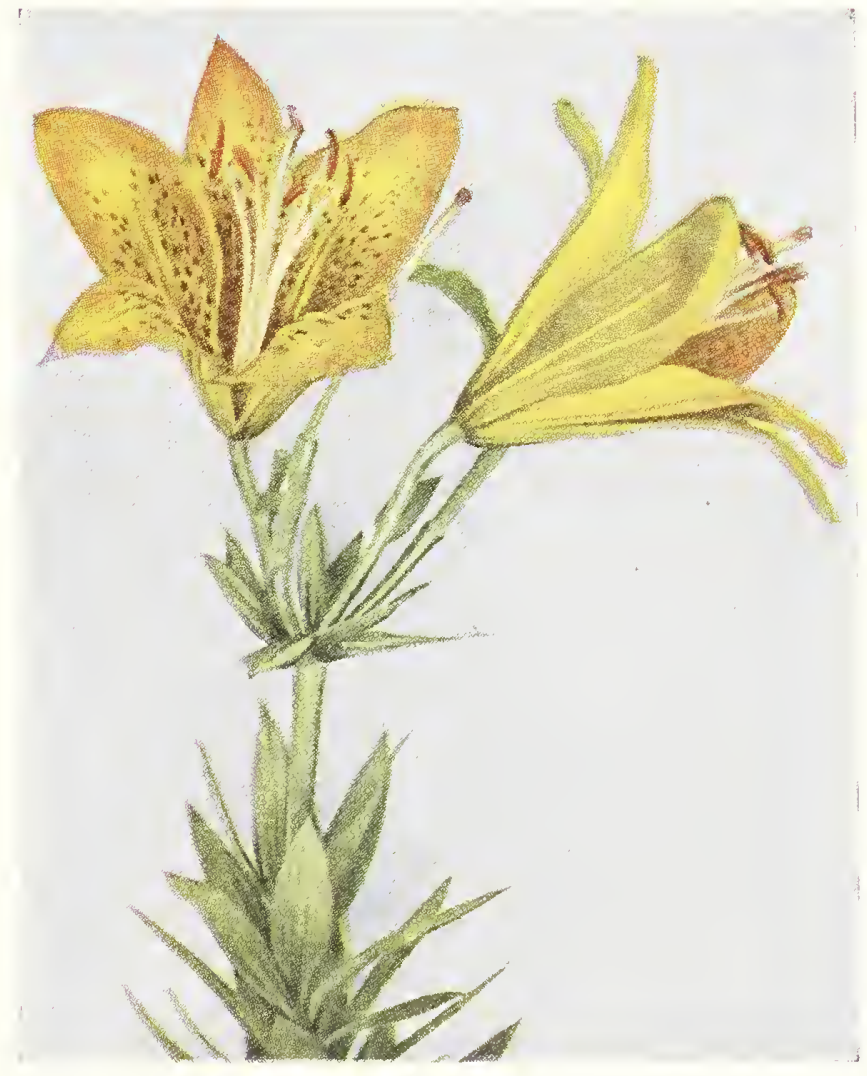

Davuricum (See page $56 \mathrm{f}$ )

\section{HARDY GARDEN LILIES For Spring Planting}

One of our specialities is "The Lily," and on that most interesting subject we have compiled the most comprehensive catalogue ever published and wherein all details of planting and culture will be found, including colored plates of nearly all the varieties in commerce. Owing to the great expense incurred in producing this valuable Lily book we are obliged to charge one dollar for same, which will be eredited to the purchase of the first order for Lilies to the amount of three dollars or over. This means that credit slip for one dollar received with book should be sent with your first order for three dollars or over. 


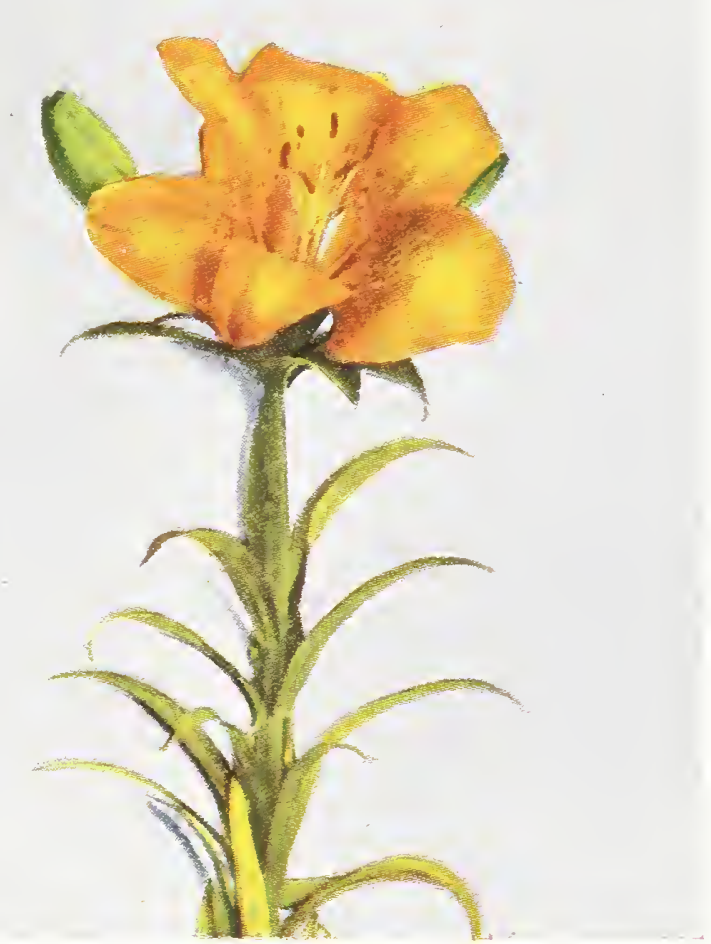

Elegans Leonard Joerg (See page $56 \mathrm{~g}$ )

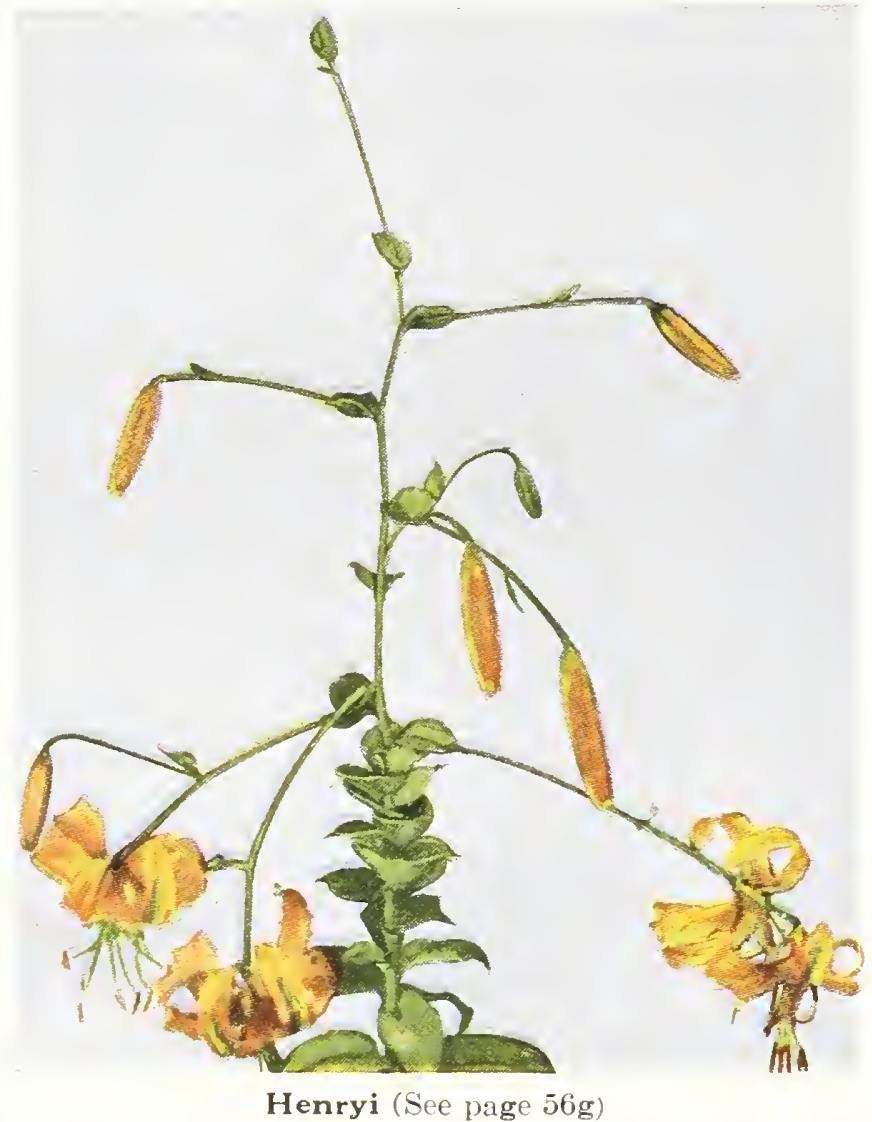

HARDY GARDEN LILIES-Continued

Each Doz. 100

Auratum. July-August.

Large bulbs. Height $3 \mathrm{l} / \mathrm{ft} \ldots \ldots 0.55 \quad \$ 5.50 \$ 40.00$

Mammoth bulbs. 4-5 ft...... $.80 \quad 8.00 \quad 60.00$

Monster bulbs. $5-6 \mathrm{ft} \ldots \ldots \ldots .61 .50 \quad 15.00 \quad 125.00$

Auratum platyphyllum. With yellow spots.

$\begin{array}{lllll}\text { Large bulbs. } 4-5 \mathrm{ft} \ldots \ldots \ldots & .75 & 7.50 & 55.00\end{array}$

Mammoth bulbs. $5-6 \mathrm{ft} \ldots \ldots \ldots \quad 1.00 \quad 10.00 \quad 75.00$

Auratum pictum. Crimson-

tipped petals. Large bulbs... $1.00 \quad 10.00 \quad 75.00$

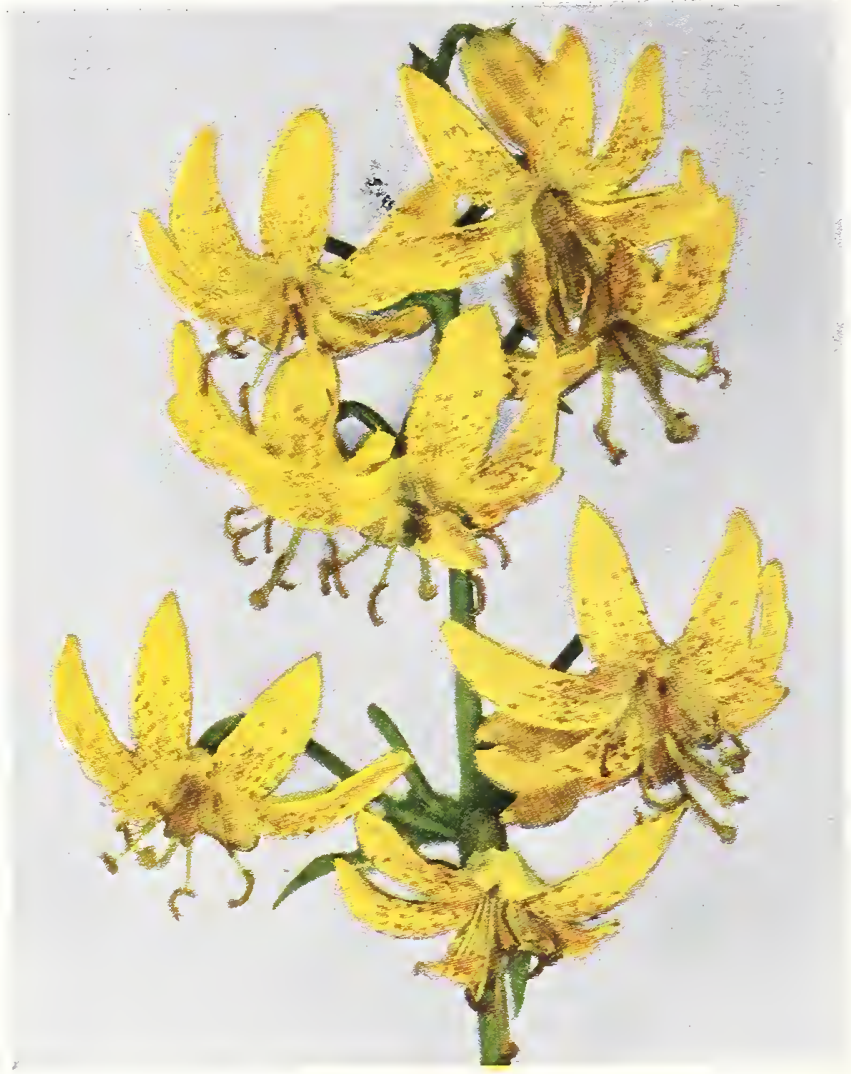

Hansoni (See page 56g)

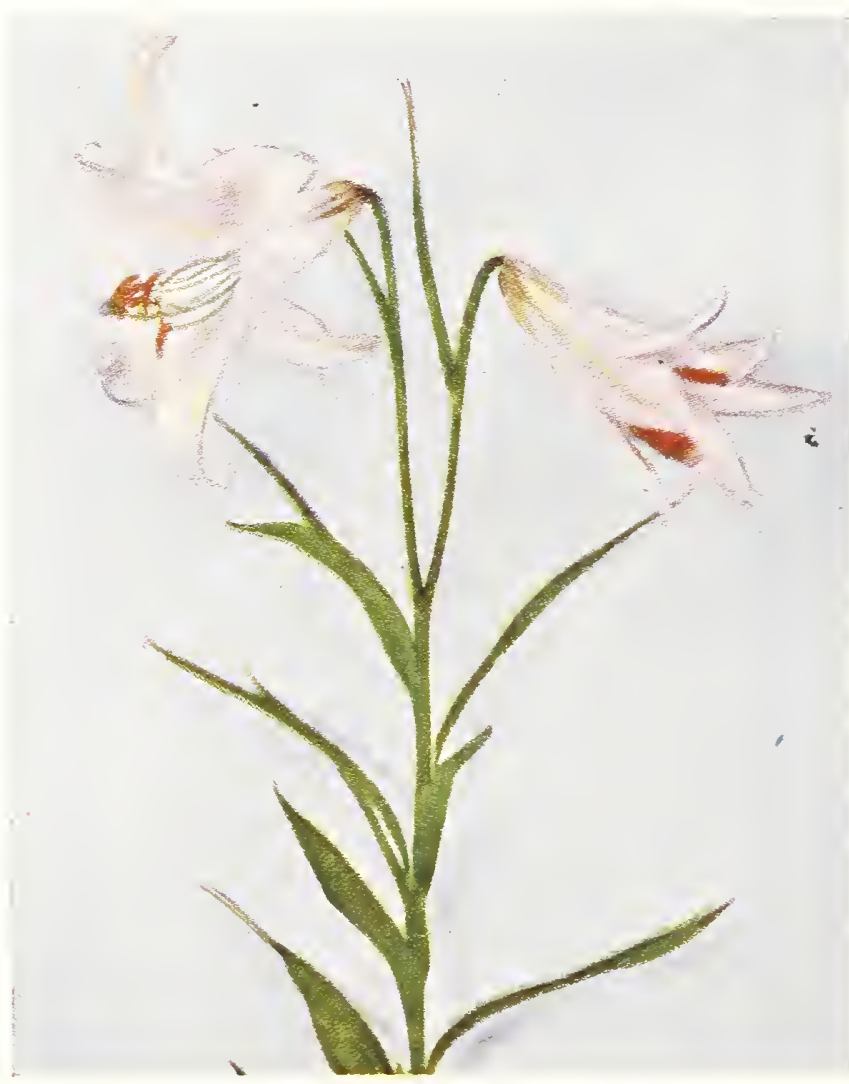

Japonicum (Krameri) (See page 56g) 


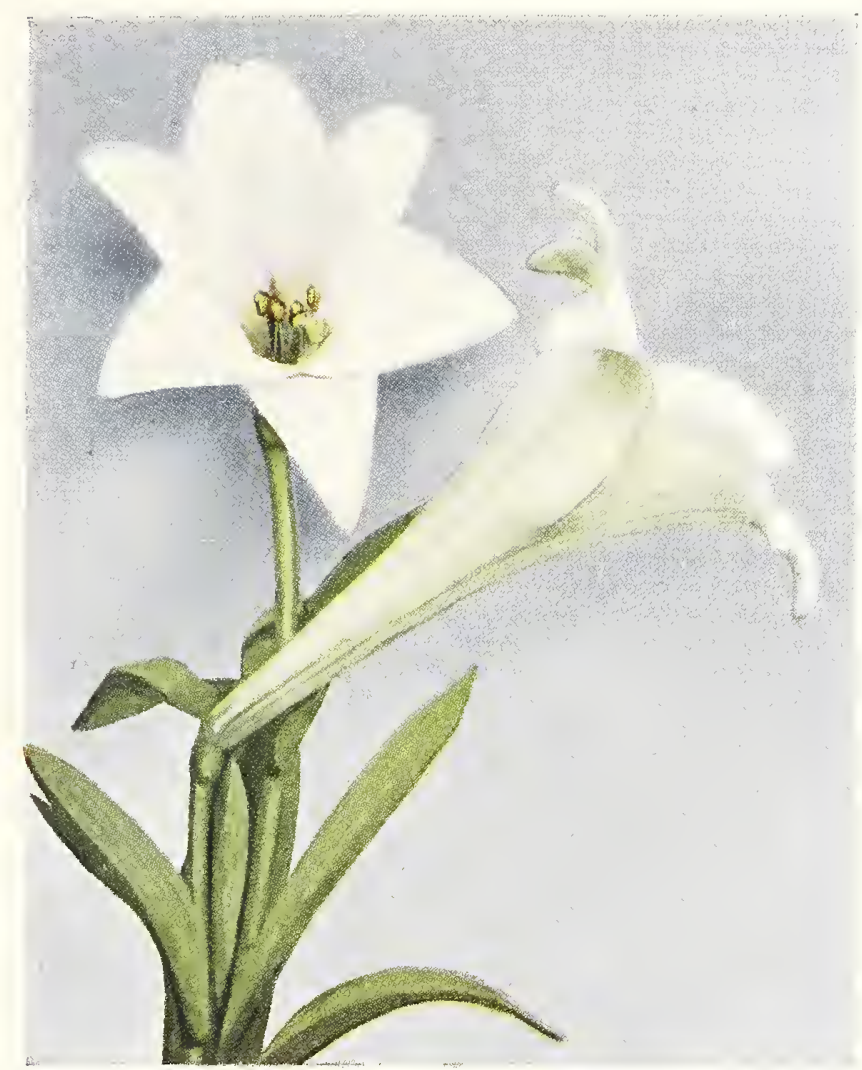

Longiflorum multiflorum

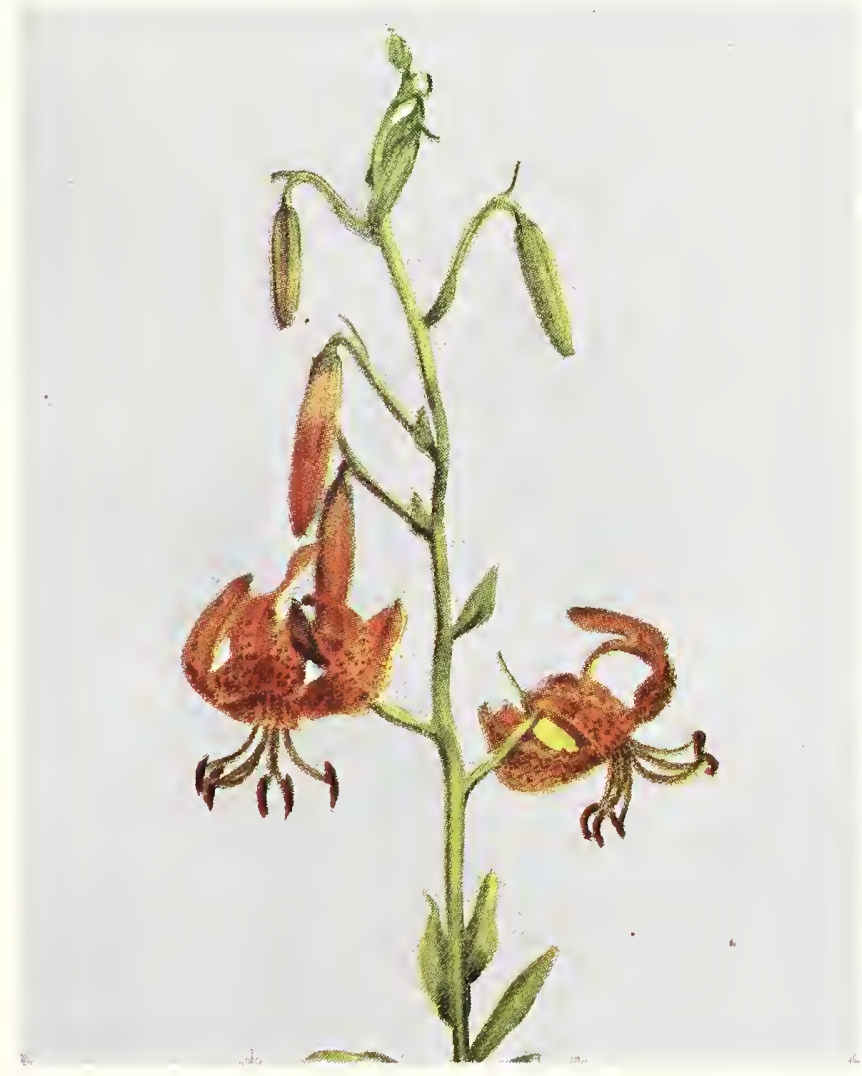

Maximowiczi

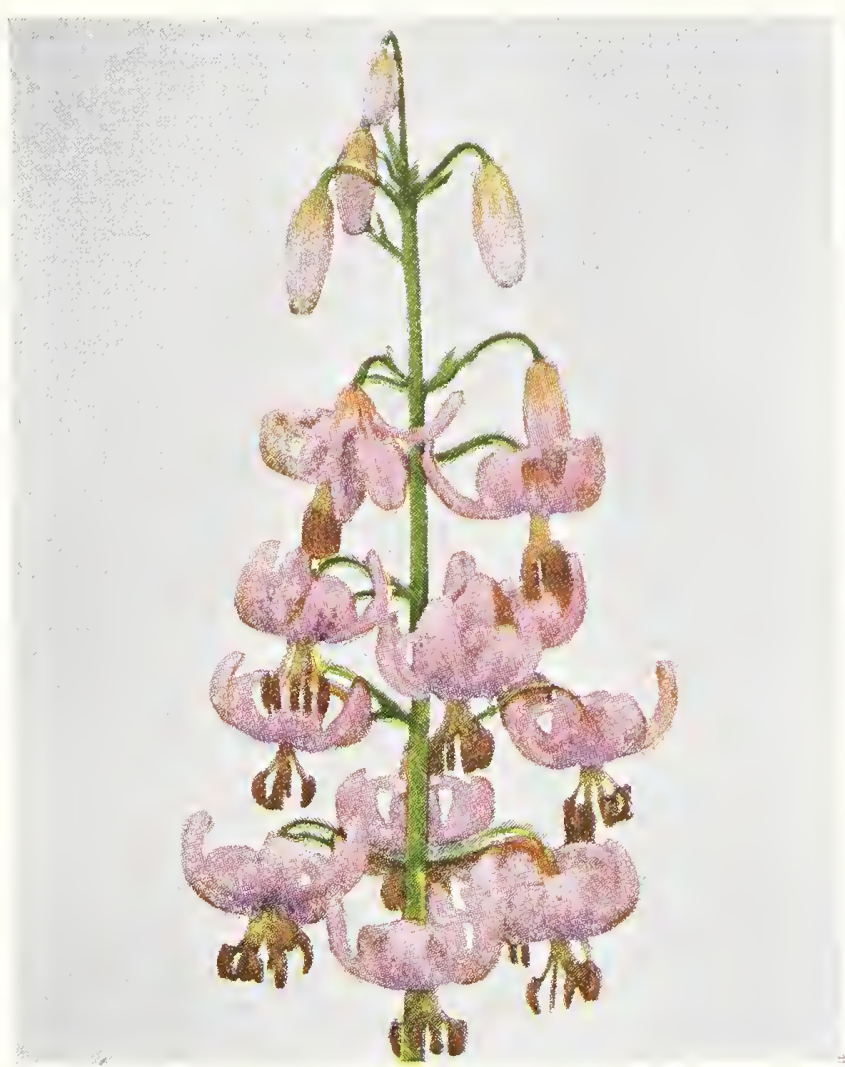

Martagon
Pomponium

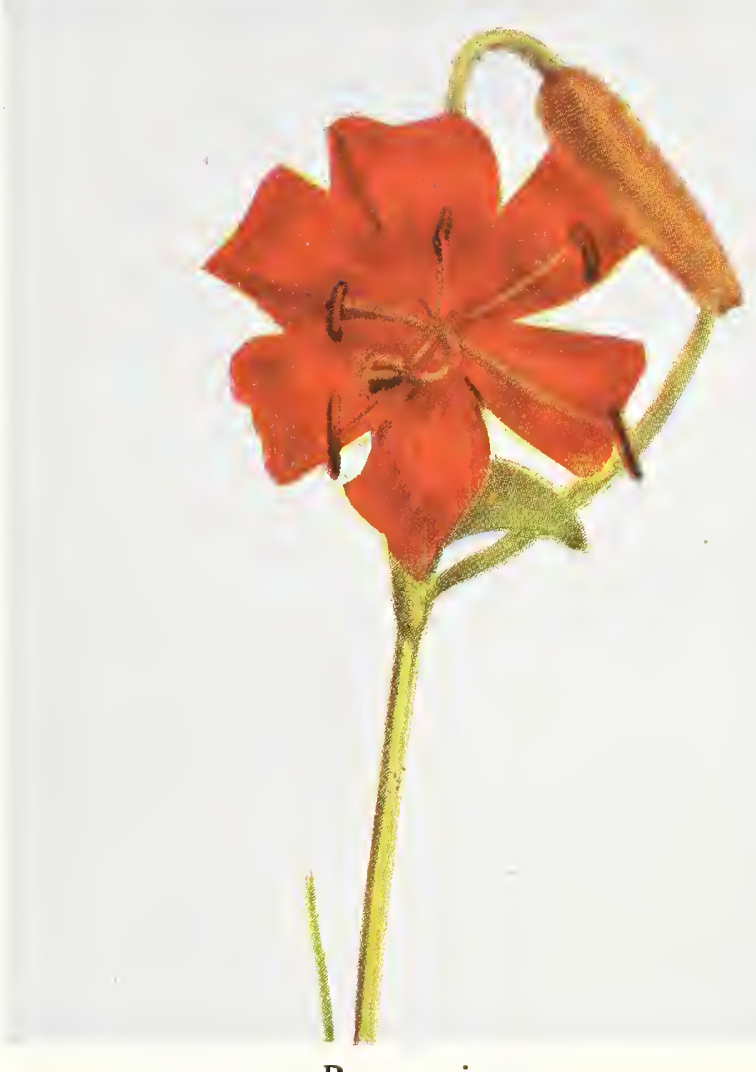

HARDY GARDEN LILIES-Continued

Elegans Leonard Joerg. Apricot, dark spots. June $2 \mathrm{ft} \ldots \ldots . \$ 0.30 \quad \$ 3.00 \$ 22.00$

Elegans Mixed. All colors..... . .25 $2.50 \quad 16.00$

Hansoni. June. $4-5 \mathrm{ft} \ldots \ldots \ldots .75 \quad .75 \quad 7.50 \quad 58.00$

Henryi July-Aug.

Large bulbs. $4-6 \mathrm{ft} \ldots \ldots \ldots \ldots .75 \quad 7.50 \quad 58.00$

Mammoth bulbs. $6-8 \mathrm{ft} \ldots \ldots \ldots 1.00 \quad 10.00 \quad 75.00$

Japonicum (Krameri). July. 3 ft. $\quad .60 \quad 6.00 \quad 45.00$

Longiflorum multiflorum. Pure

white. July. $3 \mathrm{ft} . \ldots . \ldots$.

$6.00 \quad 45.00$

Each Doz. 100

Martagon. The purple Turks-cap

Lily. June. $4-5 \mathrm{ft} \ldots \ldots \ldots . \$ 0.50 \$ 5.00 \$ 40.00$

Martagon album. Pure white... $1.50 \quad 15.00 \quad \ldots$

Monadelphum (Colchicum).

Deep straw color. June. 5-6

ft................... $1.75 \quad 18.00$

Maximowiezi. Vivid orange-red.

Dark spots. Sept. $4 \mathrm{ft} \ldots \ldots . .75 \quad 7.50 \quad 55.00$

Pomponium. The Red Turks-

cap. June. $3-4 \mathrm{ft} \ldots \ldots \ldots \ldots, \quad .75 \quad 7.50 \quad 55.00$ 


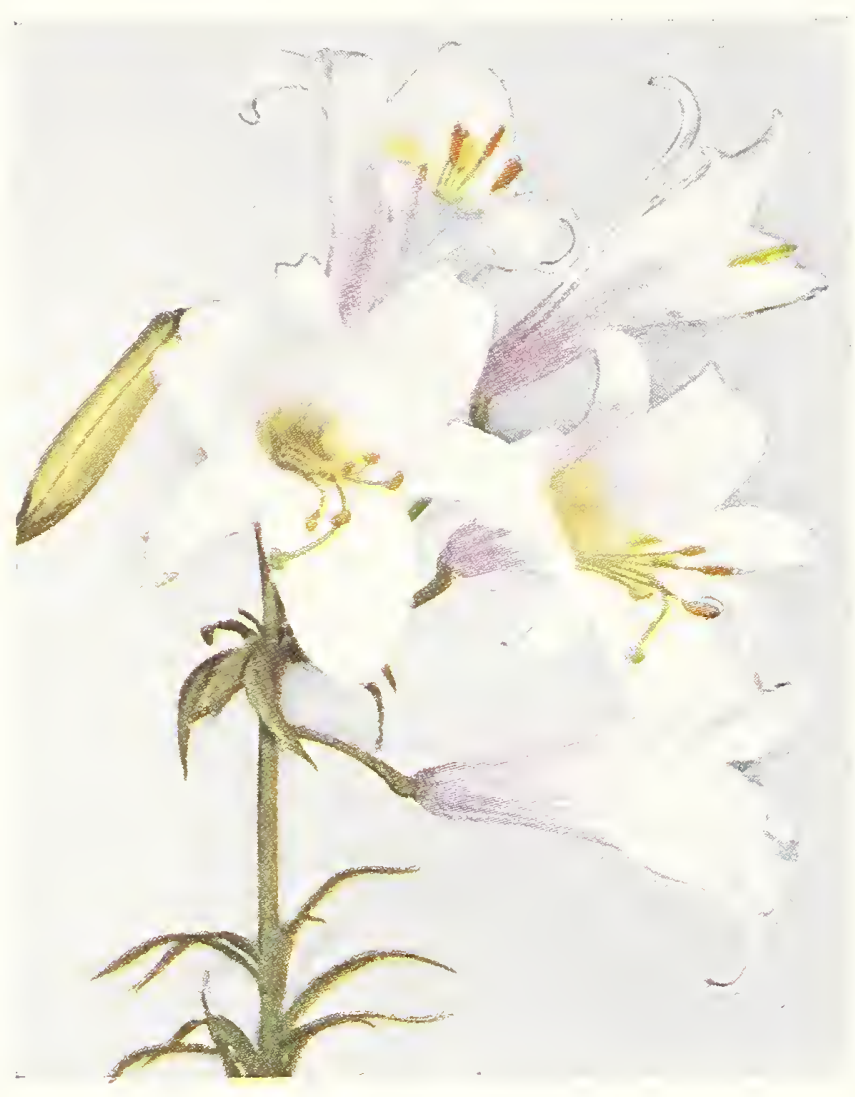

Regale (myriophyllum)

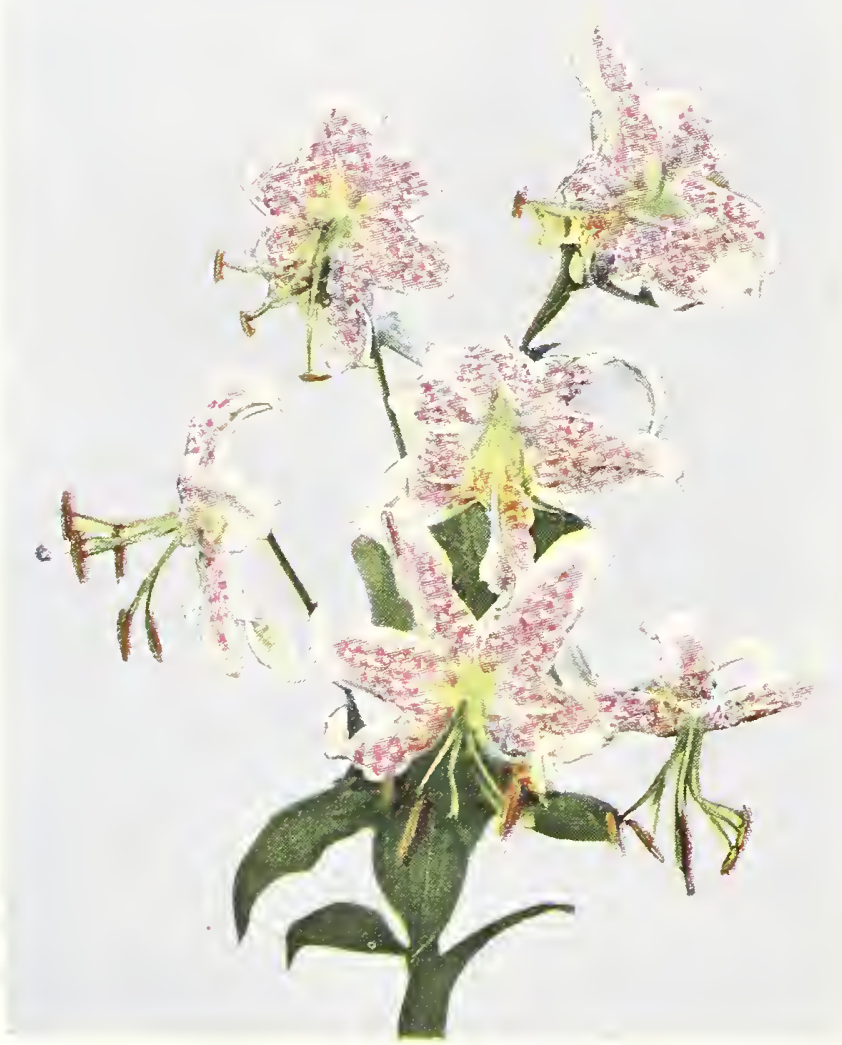

Speciosum rubrum magnificum

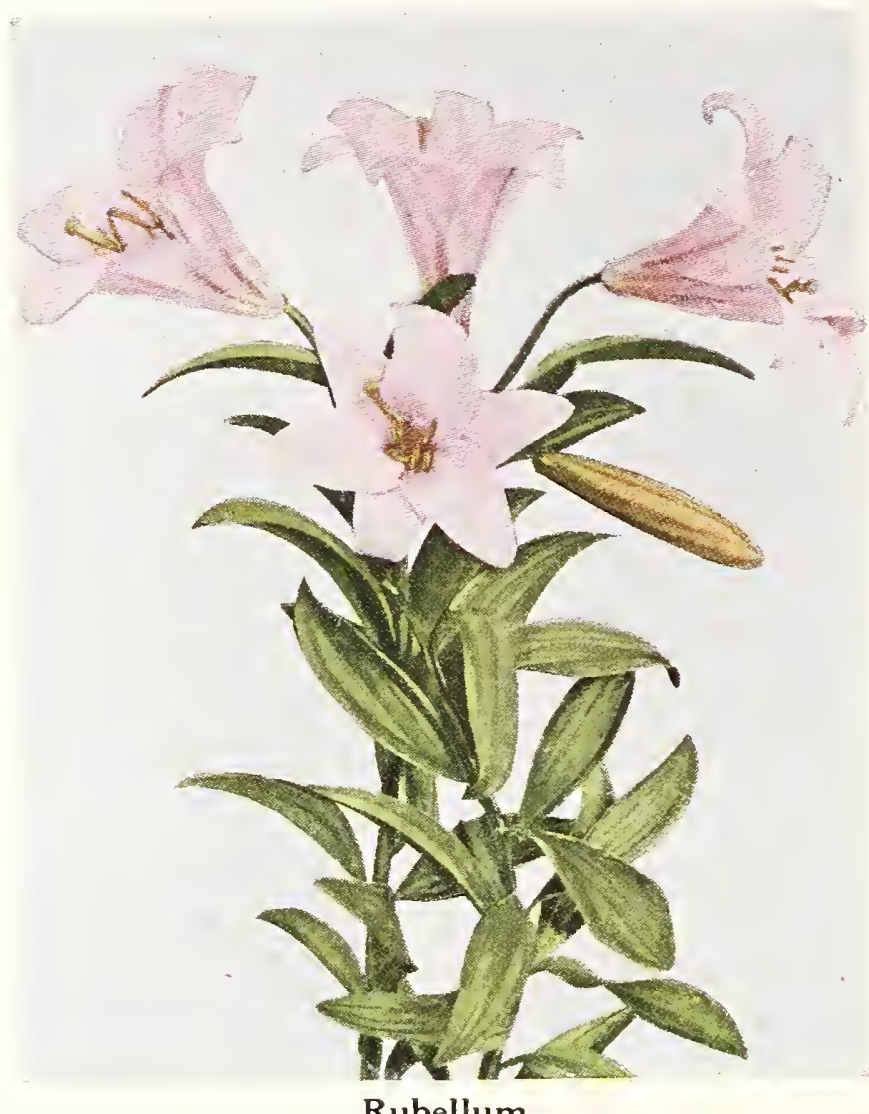

Rubellum

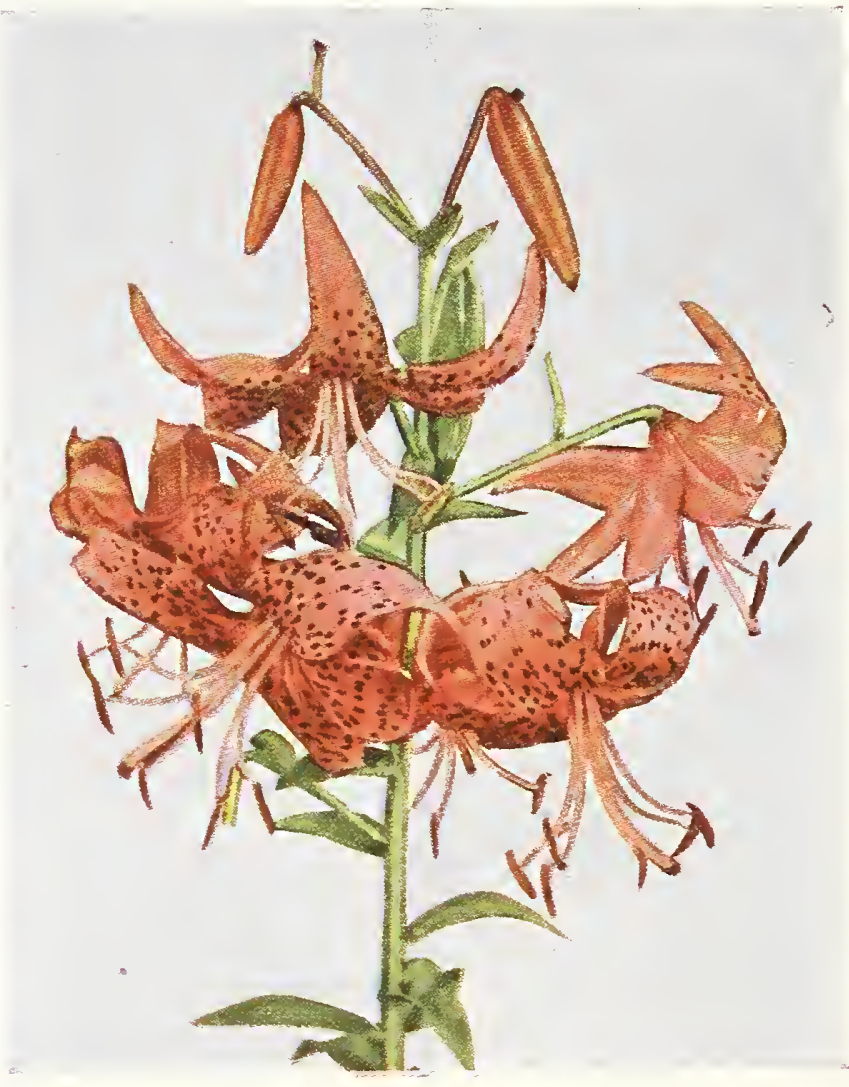

Tigrinum splendens

HARDY GARDEN LILIES-Continued

Pyrenaicum (The Yellow Turks-

Each Doz. 100 rap Lily). June. $2-3 \mathrm{ft} \ldots \ldots . \$ 0.60 \$ 6.00 \$ 15.00$

Regale (Myriophyllum). Astately Lily. White, flushed yellow inside, pink outside. July.

$\begin{array}{llrrr}\text { Large bulbs } 3 \mathrm{ft} & \ldots \ldots & .75 & 7.50 & 60.00 \\ \text { Mammoth bulbs. } 4 \mathrm{ft} \ldots \ldots & 1.00 & 10.00 & 80.00\end{array}$

Rubellum. Beautiful rose-pink.
June. $1 \frac{1}{2} \mathrm{ft}$
$.60 \quad 6.00 \quad 45.00$

Speciosum rubrum mag. Sept.

Large bulbs. $21 / 2-3 \mathrm{ft} \ldots \ldots \ldots+45 \quad \$ 4.50 \$ 32.00$

Mammoth bulbs. $4 \mathrm{ft} \ldots \ldots \ldots . .75 \quad 7.50 \quad 55.00$

$\begin{array}{lllll}\text { Monster bulbs. } 5 \mathrm{ft} \ldots \ldots \ldots \ldots & 1.30 & 13.00 & 95.00\end{array}$

Speciosum album. Pure white. $\begin{array}{lllll}\text { Large bulbs. } 21 / 2-3 \mathrm{ft} \ldots \ldots \ldots & .60 & 6.50 & 50.00 \\ \text { Mammoth bulbs. } 3-4 \mathrm{ft} \ldots \ldots & .80 & 8.00 & 60.00\end{array}$

Tigrinum splendens. Sept. 4-5

$\begin{array}{rrrr}\text { ft................... } & .30 & 3.00 & 20.00 \\ \text { Tigrinum flore pleno. Double... } & .35 & 3.50 & 25.00\end{array}$ 


$\quad 150$ WEST $23 \mathrm{rd} \mathrm{ST}, \mathrm{NEW}$ Y R K 57 .

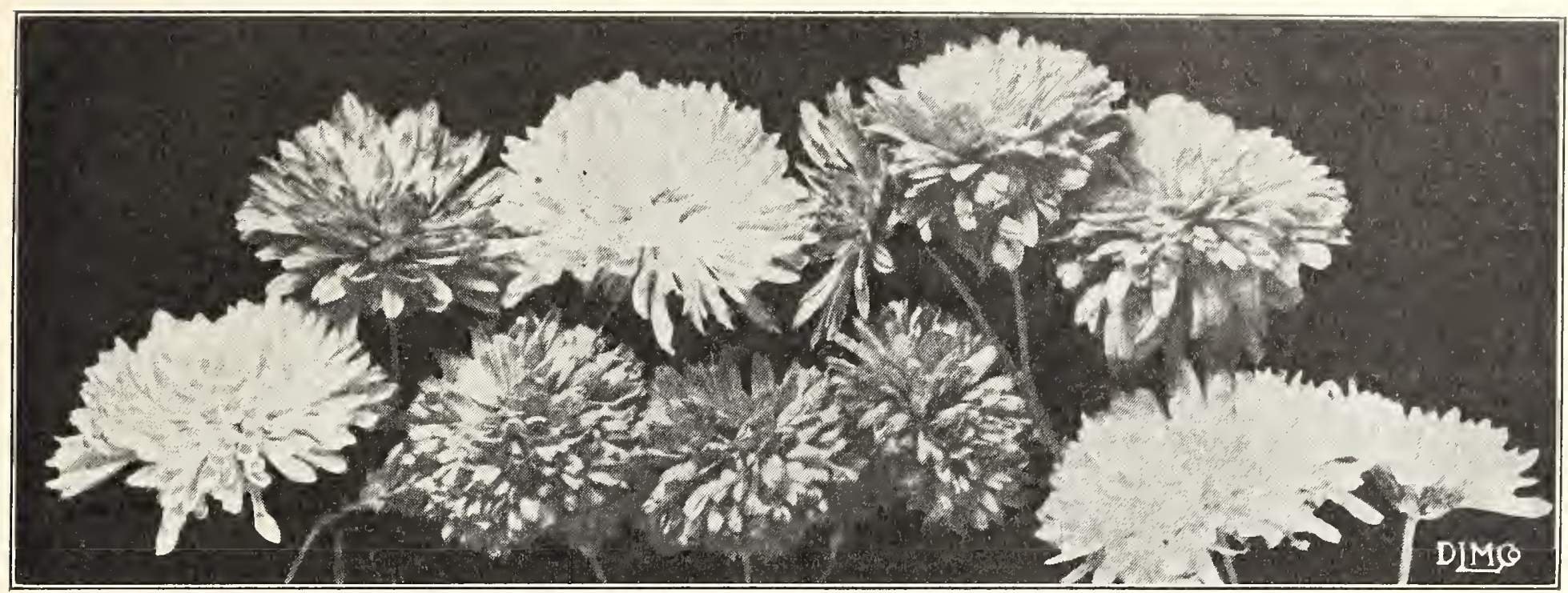

\section{HARDY GHRYSANTHEMUMS}

The Hardy Chrysanthemums should be in every garden, as they produce an abundance of flowers long after the ordinary garden flowers have been destroyed by frost.

Our collection is divided into four groups: The Large Flowering or Aster Type; the Pompon; the Button or Baby Type, and the Single. The later varieties coming into bloom and lasting well into October.

Prices of the following: Doz. $\$ 2.00,100 \$ 15.00$.

\section{LARGE FLOWERING, or ASTER VARIETIES}

Angelo. A beautiful light pink.

Florence Stanton. Large bronze flower; late.

Marie du Pont. Free flowering, pure white.
Queen of Whites. Pure white, very full.

Yellow Source d'Or. The best yellow.

Zelia. Old gold, large flower; bushy plant.

\section{POMPON VARIETIES}

Acto. Rose-pink, tall grower.

Anna L. Moran. Bronze with yellow.

Fairy Queen. Large light pink, full center.

Firelight. Bright red. Pretty flower.

Frances Huckvale. Flesh with bronze center.

Juliana. Fine yellow, good grower.

Lucifer. The darkest red of all.

\section{SINGLE FLOWERING VARIETIES}

Alice Howell. Orange-yellow.

Mrs. Roberts. Deep rose-pink.

Summer Gold. Large golden yellow.
Mrs. Chester Robinson. Pink shading to old rose.

Nellie. Golden yellow, very full.

Nellie Blake. A good deep red.

Petit Louis. Light pink, bronze center.

Pink Pop. A very good pink.

Rosea. Large pink flower.

Uvalda. Large white, strong grower.

\section{BUTTON VARIETIES}

Davenport. Bronze tinged with red.

Helios. Reddish-bronze.

Liber. Red with yellowish shade.

Ouray. Rich dark mahogany-brown.

\section{BEDDING PLANTS}

Doz. 100

AGERATUM fraseri. Bright blue, 3-in . $\$ 2.00 \$ 15.00$

Dwarf Blue. 3 in.............. 2.00 12.00

ASTERS. Double assorted, 2 in ....... $1.00 \quad 6.00$

BEGONIA Chatelaine, red, 21/4-in. pots. 2.0015 .00

Chatelaine Supreme. Pink, 21/4-in.

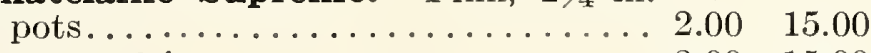

Vernon, 3 in . ..................... $2.00 \quad 15.00$

Luminosa, 3 in . . . . . . . . . . . . . . 2.0015 .00

CANNAS. From 3-in. pots.

King Humbert. Red, bronze leaf... . . $2.00 \quad 15.00$

Hungaria. The best pink.......... $2.00 \quad 15.00$

The President. Green leaf, red ...... 2.00 15.00

Yellow King Humbert. Green leaf. . . 2.00 15.00

Mixed French Varieties........... 2.00 15.00

CENTAUREA gymmocarpa .......... 2.00 12.00

COBAEA scandens. Blue........... 1.5010 .00

COLEUS. In variety, $21 / 4$-in. . . . . . 1.5010 .00

FORGET-ME-NOT. Blue, 3 -in....... $1.00 \quad 7.00$

FUCHSIAS. Named varieties, 3-in. . . . 2.00 15.00
Doz. 100

GERANIUM. Named varieties, 4-in.... .\$5.00 \$35.00 Ivy-leaved Sorts. 4 -in ........... $6.00 \quad 40.00$

HELIOTROPE. Standard varieties, 3 in. 2.5015 .00

Centefleur. 3 -in............... $3.00 \quad 20.00$

Royal Fragrance. 3 -in............ $4.00 \quad 30.00$

IVY, English. 4-in. pots. . . . . . . . . 5.00 35.00

LANTANAS. Named varieties, 21/4-in . . 2.0015 .00

LOBELIAS, Blue Dwarf . . . . . . . . . . . $1.50 \quad 10.00$

LEMON VERBENA. 3 -in . . . . . . . . 4.00 30.00

MOONFLOWER. White flower's...... 2.00 15.00

PANSIES. Large, fancy mixed . . . . . . 1.007 .00

PETUNIA. Double varieties, $2-i n . \ldots \ldots .1 .50 \quad \ldots$

Single varieties, 2 -in ............ $1.00 \quad \ddot{10.00}$

SALVIA Bonfire. Scarlet, 21/4-in . . . . 1.25 9.00

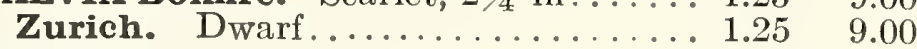

VERBENAS. Finest mixed, 2 in ...... $1.25 \quad 8.00$

VINCAS rosea and alba ... . . . . . 2.50 15.00

VIOLA Jersey Gem. Pure violet flowers. $4.00 \quad 30.00$ 


\section{ANTIRRHINUM. Snapdragon}

One of the most widely grown plants for greenhouse flowering and outside bedding. Geneva Pink. A glistening rose-pink. Giant Red. A fine red variety.

Golden Pink Queen. A superb variety.

Helen. A beautiful light pink.

Nelrose. Deep pink.

Orlando. A beautiful bronze.

Philadelphia Pink. The best pink.

Silver Pink. A beautiful shade of light pink.

White Rock. Best forcing white.

Yellow Giant. Very large flowering; yellow.

Plants of any of the above in season, 21/4-in. pots: Doz. $\$ 1.75,100 \$ 12.00$.

\section{CARNATIONS. Choice Varieties}

Aviator. Scarlet.

Belle Washburn. A fine red.

Benora. Color cream white, red markings.

Enchantress Supreme. Salmon-pink.

Harvester. Snow-white.

Matchless. A very fine white.

Pink Delight. Salmon-pink.

Pink Matchless. Clear silver pink.

Any of the above varieties, rooted cuttings, Spring delivery: Doz. $\$ 1.50,100 \$ 11.00$

Field grown plants (Fall delivery): Doz. $\$ 3.50,100 \$ 25.00$.

\section{CARNATIONS. Recent Introductions}

Doz.

Arctic. A pure snow white seedling from Matchless. Iuarge flower and very free flowering... . . . \$3.00

Betty Lou. A pleasing shade of medium pink. A good grower and very free flowering......... 3.00

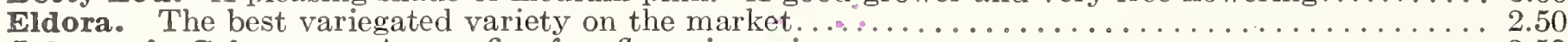

Johnson's Crimson. A very fine free flowering crimson......................... 2.50

Laddie. A warm rose-salmon pink, very large flowers, rooted cuttings. . . . . . . . . . . . . . . 3.00

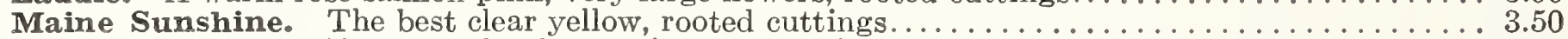

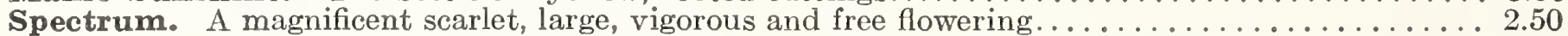

Winsome. A Ward and Enchantress seedling with Ward color. A free bloomer............. 2.50

GREENHOUSE PLANTS 21/4-in. pots

beautiful shade of pink........... Doz. 100

BEGONIA, Glory of Cincinnati. A beautiful shade of pink..... . . . . . \$ \$7.00 $\$ 50.00$

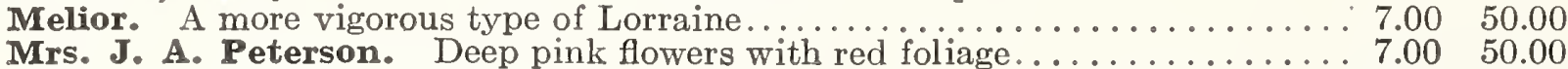

Peerless. Red, bronze foliage............. $8.00 \quad 60.00$

Winter Flowering. Hybrid type vars .......... Each $\$ 2.50$, doz. $\$ 25.00 \ldots 300$. 20.00

BOUGAINVILLEA sanderiana. A free Easter flowering plant. . . . . . . . 3.0020 .00

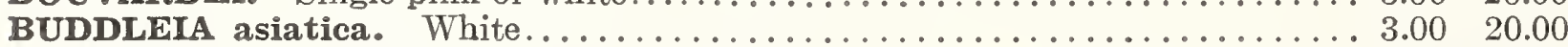

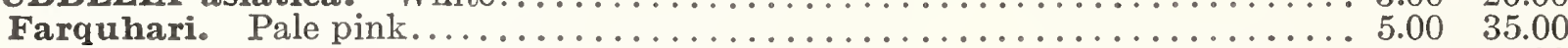

CALCEOLARIA, Mixed, hybrida gladiflora

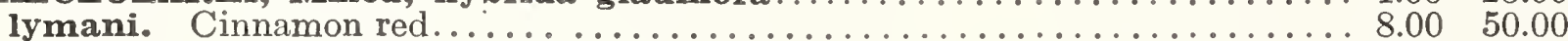

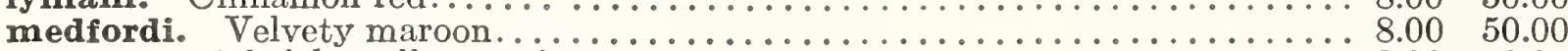

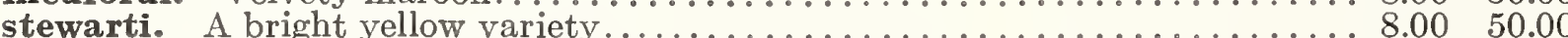

CALENDULA, Selected, Double Orange King or Bail's . . . . . . . . . . . . 1.5010 .00

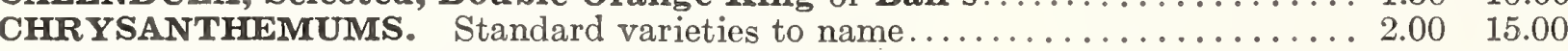

CINERARIA, Marshall's Half Dwarf Hybrids . . . . . . . . . . . . . . . . . . 2.00 15.00

CYCLAMEN giganteum, Mixed. . . . . . . . . . . . . . . . . . . . . 3.0020 .00

EUPHORBIA jacquiniaeflora. A Christmas plant.................... $5.00 \quad 35.00$

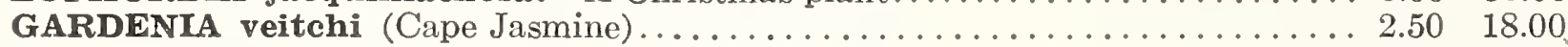

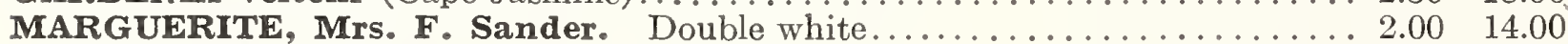

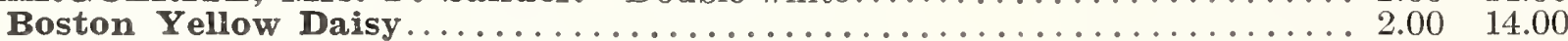

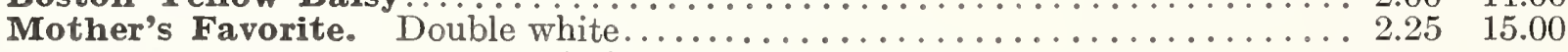

MYOSOTIS, Matchless. A true Winter flowering variety . . . . . . . . . . . . . 2.0012 .00

POINSETTIA. Oak Leaf. An improved variety which does not drop its lower

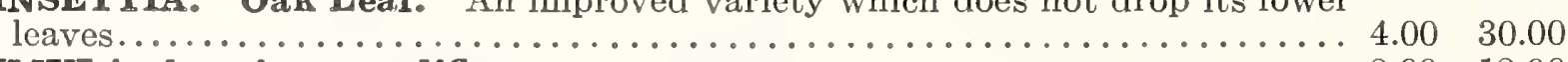

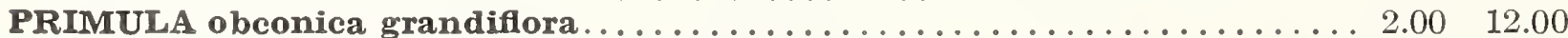

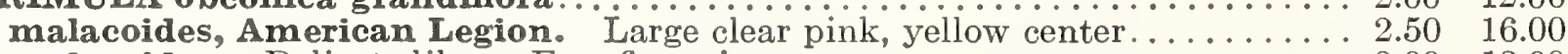
malacoides, Delicate lilac. Free flowering. . . . . . . . . . . . . . . $2.00 \quad 12.00$

malacoides, King Albert. Pink .......... 2.00 12.00

malacoides lelandi. A beautiful lilac-pink with large yellow eye. Long, stiff stems for cutting.

malacoides, Princess Mary Bright pink $\ldots \ldots \ldots \ldots \ldots \ldots \ldots$

malacoides, Radio. Giant flowering, fringed, clear rose..................

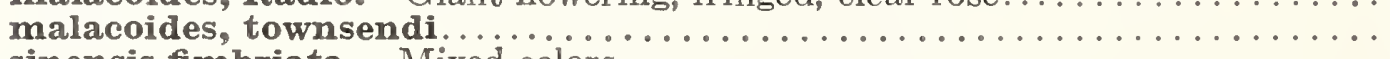

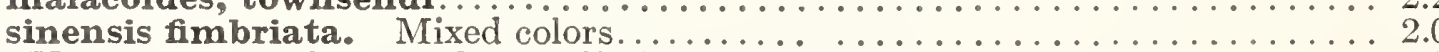

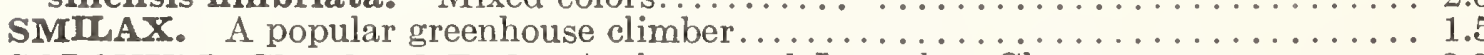

SOLANUM, Cleveland Red. An improved Jerusalem Cherry . . . . . . . . . . 2.

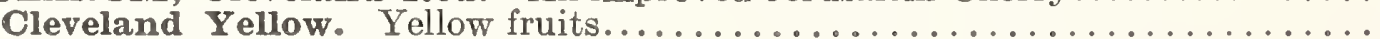

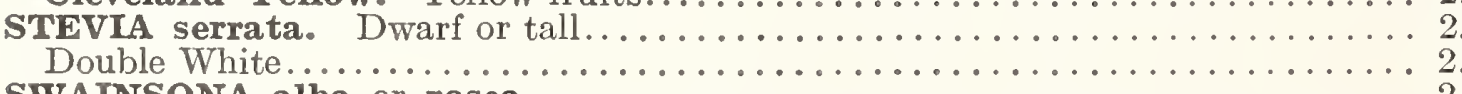

SWAINSONA alba or rosea.

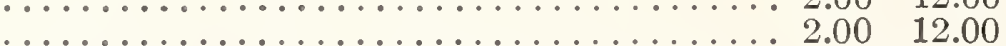

24.00

$00 \quad 12.00$

15.00

15.00

12.00

10.00

14.00

14.00

12.00

12.00

3-in. pots

Doz. 100

$\$ 10.00 \$ 75.00$

$10.00 \quad 75.00$

$10.00 \quad 75.00$

$11.00 \quad 85.00$

$4.50 \quad 30.00$

$\ddot{4} .00 \quad \ddot{25} .00$

... ...

$\ldots \ldots$

... $\ldots$

$\ldots$

$\ldots \ldots$

... $\ldots$

... $\ldots$

$\ddot{5.00} \quad 3000$

$\ddot{3.50} \quad \dot{25.00}$

.... ...

$\ldots \ldots$

... $\ldots$

... . .

$3.00 \quad 20.00$

$\ddot{3.00} 2 \ddot{0} 000$

... ...

... $\ldots$.

$\ldots \ldots$

... $\ldots$.

$3.00 \quad 20.00$

$\ddot{3.00} 20000$

$3.00 \quad 20.00$

$2.50 \quad 16.00$

$2.50 \quad 16.00$

$3.00 \quad 20.00$

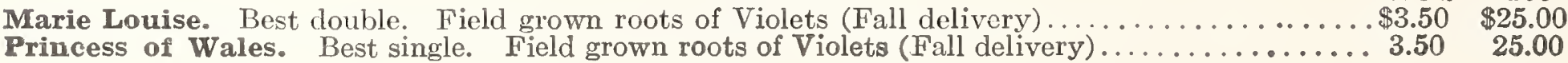




\section{PALMS AND DECORATIVE PLANTS}

ADIANTUM gloriosum. The hardiest Maidenhair. 4 -in. pots, each $\$ 1.00 ; 3$-in. pots, each $\$ 0.75$.

ASPARAGUS plumosus nanus. Graceful, climbing Asparagus; beautiful, feathery foliage. 3-in. pots, doz. $\$ 2.50$; extra size, 4 -in. pots, doz. $\$ 4.50$.

Sprengeri. Fine for baskets. 3-in. pots, doz. $\$ 2.50 ; 4$-in. pots, doz. $\$ 4.50$.

cocos Weddelliana. Fine for table decorations. 21/2-in. pots, each 50c.; 3-in. pots, each $75 \mathrm{c}$.

DRACANA indivisa. Long, graceful foliage. Extensively used for vases. 4 -in. pots, each $75 \mathrm{c}$., doz. $\$ 7.50 ; 5$-in. pots, each $\$ 1.00$, doz. $\$ 10.00$.

KENTIA Belmoreana or Forsteriana. The most popular parlor palm. 4-in. pots, each $\$ 1.25$; 5-in. pots, each $\$ 3.00 ; 6$-in. pots, each $\$ 5.00$.
NEPHROLEPIS Bostoniensis (Boston Fern). 4-in. pots, each $\$ 1.00 ; 5$-in. pots, each $\$ 1.50 ; 6$-in, pots, each $\$ 2.00$.

Dwarf Boston. 21/4-in. pots, doz. $\$ 2.00,100 \$ 12.00$.

Scotti. Fine for house decoration. 4-in. pots, each $\$ 1.00 ; 5$-in. pots, each $\$ 1.50$.

PANDANUS Veitchi. Graceful, light green leaves, beautifully marked, with broad stripes and bands of pure white. 5-in. pots, each $\$ 3.00 ; 6$-in. pots, each $\$ 4.50$.

PHCNIX Roebeleni. Combines the graceful appearance of the Cocos and the hardiness of the Kentia. 4-in. pots, each $\$ 2.00 ; 6$-in. pots, each $\$ 4.00$.

TABLE FERNS. In variety. For fern dishes and ferneries. Doz. $\$ 3.00,100 \$ 15.00$.

\section{AQUATIC PLANTS FOR FOUNTAINS, LAKES, ETG. \\ CHOICE HARDY NYMPHAEAS}

The following are a selection of the best hybrids for ponds and fountains. We recommend planting in May.

Eugenia de Land. Extra large, deep rose-pink flowers........ $\$ 1.75$

Gladstoniana. One of the finest white Lilies in cultivation.............................. 1.75

Helen Fowler. Color very deep pink and very

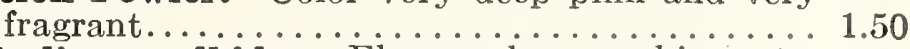
Marliacea albida. Flowers large, white; stamens yellow; fragrant................ 1.25

Marliacea carnea. A soft flesh pink, deepening at the base of petals............. 1.25

Marliacea chromatella. The bloom is bright yellow...................... 2.25

Mary. A beautiful pink of the Odorata type.... 1.25 odorata gigantea. Very large, pure white flowers. Excellent for naturalizing in ponds... $\quad .75$ odorata, W. B. Shaw. A rich rose-pink color

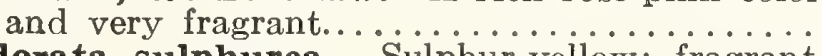
odorata sulphurea. Sulphur-yellow; fragrant

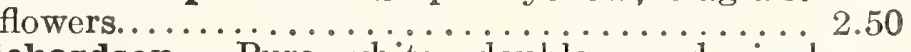

Richardson. Pure white, double, good sized flower Pigmy. The smallest of all Waterlilies

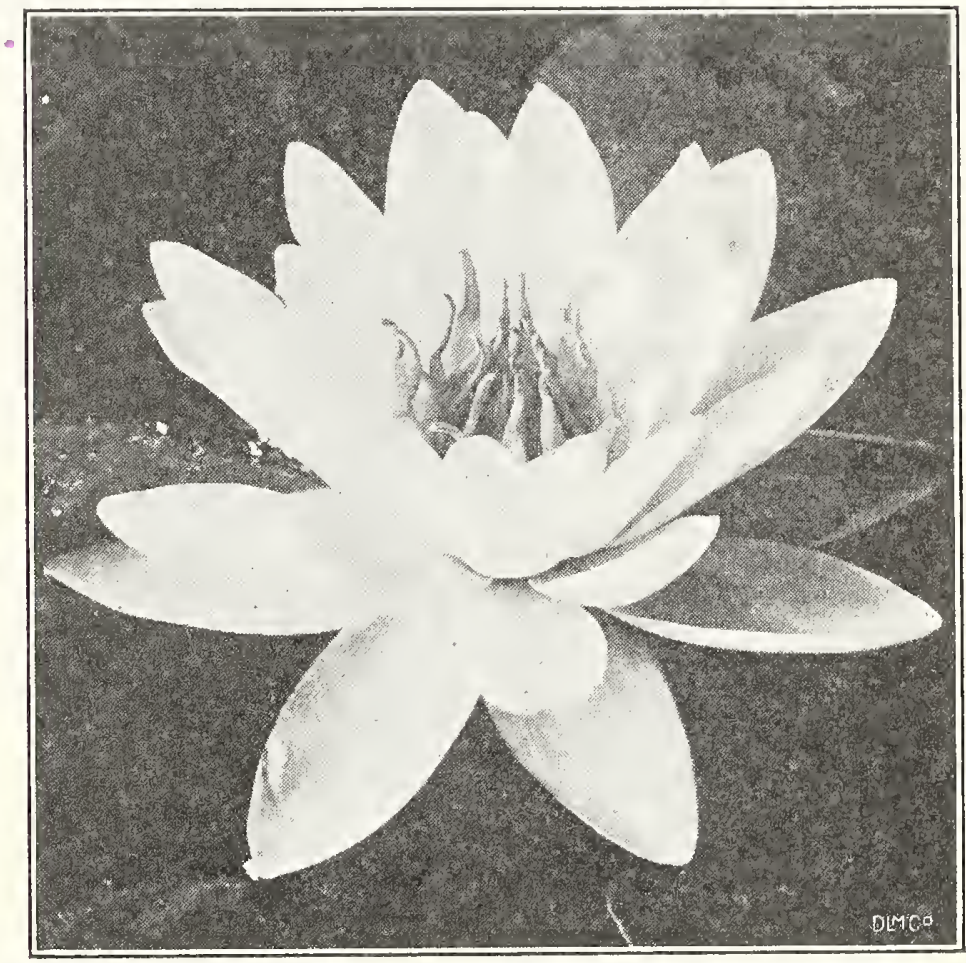

Nymphra odorata

\section{TENDER NYMPHAAS}

Tender Nymphæas should be planted about the first of June, when warm settled weather is assured.

\section{DAY BLOOMING}

Coerulea. The Egyptian blue Lotus. Light blue paling to white at the center............... $\ldots 1.50$

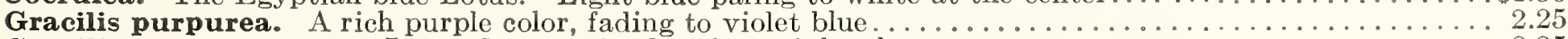

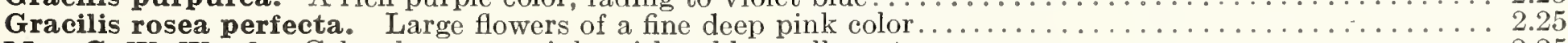

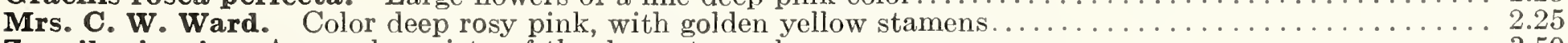

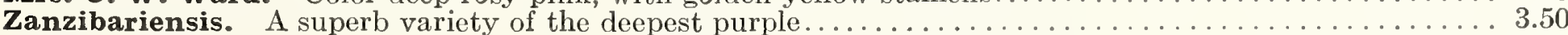

Zanzibariensis rosea. Flowers rose, of various shades.

\section{NIGHT BLOOMING}

Bissetti. Beautiful rose-pink, flowers 8 to $10 \mathrm{in.} \mathrm{In} \mathrm{diameter..........}$

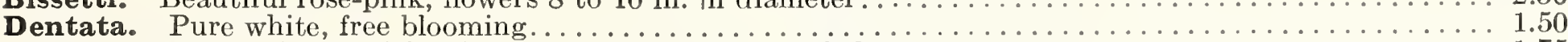

Frank Trelease. Large, rich crimson flowers, leaves mottled . . . . . . . . . . . . . . . . . 1.75

O'Mara. Reddish pink flowers with white stripes. A strong grower . . . . . . . . . . . . . . . . . 2.00

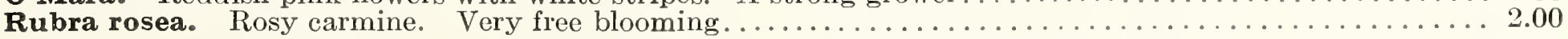

\section{NELUMBIUMS, or Sacred Lotus}

They are of easy culture and are hardy, providing the tubers are kept free from frost.

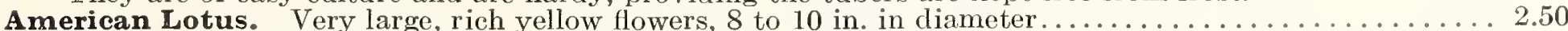

Egyptian Lotus. An excellent pink variety, hardy and free growing . . . . . . . . . . . . . . . . . . .

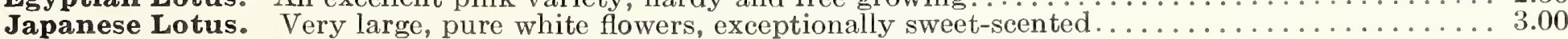

\section{MISGELLANEOUS AQUATICS}

PARROT FEATHER. A pretty trailing aquatic plant.................

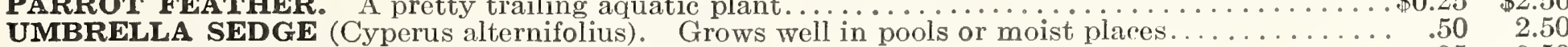

WATER HYACINTH. A very showy floating aquatic. Lavender flowers................... . . .

WATER POPPY. The leaves float on the water. Flowers are large and yellow ............ .25 2.50

WATER SNOWFLAKE。 Like a Lily in appearance with fringed white blooms...... . . . . . . .75 7.50 


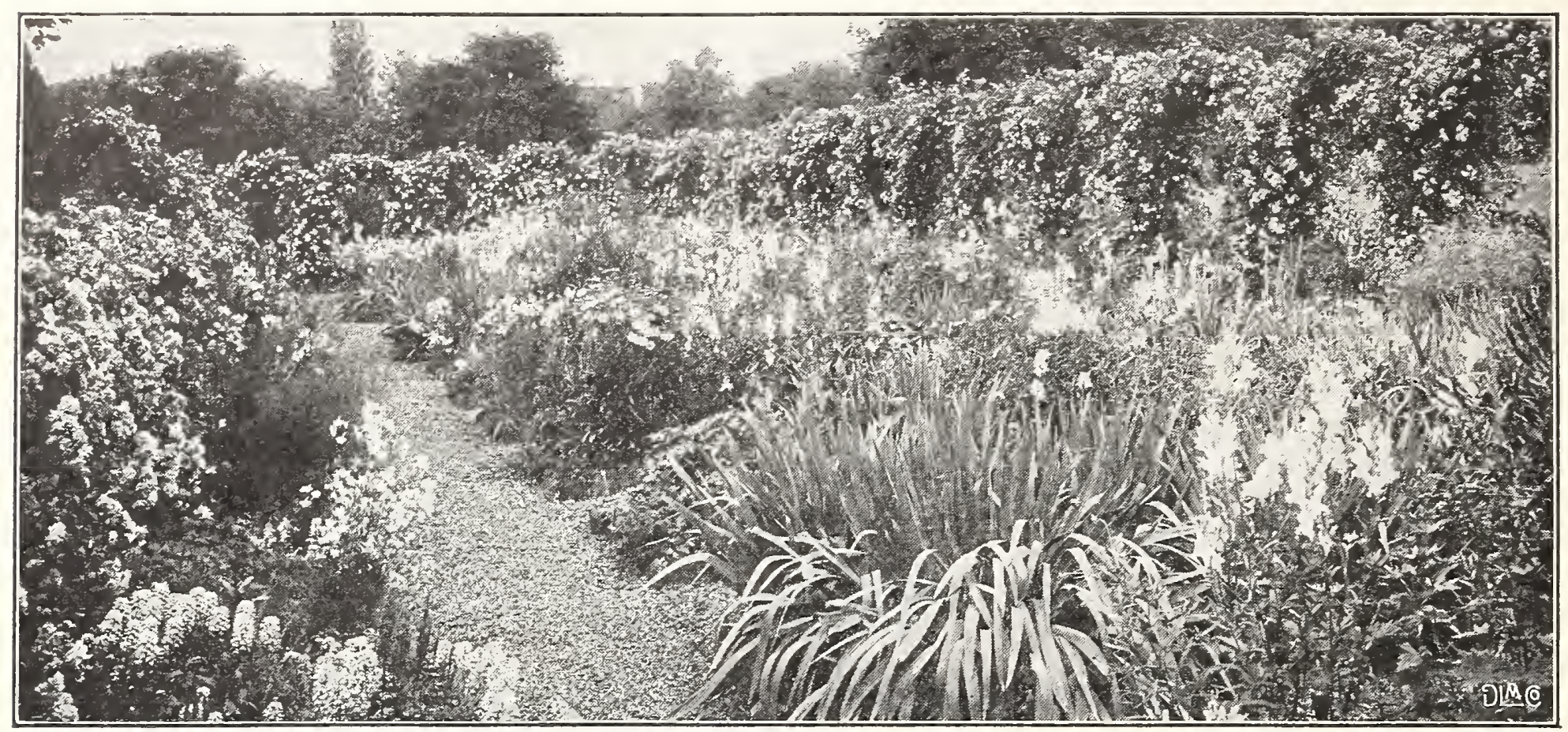

\section{Hardy Perennial Plants For Permanent Planting in Open Borders}

Herbaceous plants should be used where a constant supply of flowers is desired, for, out of the large lists of herbaceous or perennial plants, such varieties may be selected as begin to flower very early, others that are almost continuous bloomers and some that continue to bloom even after frost sets in.

The approximate height of the Hardy Perennials in this catalog is represented in feet and inches and the flowering periods are taken in the vicinity of New York.

ACHILLEA Millefolium roseum. Pink flowers in compact heads. $2 \mathrm{ft}$. June-Sept.

filipendulina. Fern-leaved Yarrow; Milfoil. A showy variety with dense heads of yellow flowers. $3 \mathrm{ft}$. June, July

Ptarmica Boule de Neige. Ball of Snow. An improvement on The Pearl with fuller and more perfect flowers.

Ptarmica, The Pearl. Double pure white flowers in great profusion. $2 \mathrm{ft}$. June-Sept.

ACONITUM autumnale (Monkshood). Showy blue, helmet-shaped flowers. 3 to $4 \mathrm{ft}$. Aug., Sept.

Fischeri. Strong spikes of large, dark blue flowers. 2 to $3 \mathrm{ft}$. Sept., Oct.

Wilsonii. A tall variety from China, with violetblue flowers. 5 to $6 \mathrm{ft}$. Sept.

All Aconitums, 50c. each, $\$ 4.50$ for 10 .

AGROSTEMMA. See L YCHNIS.

ALYSSUM saxatile compactum (Rock Madwort, Golden Tuft). Compact masses of yellow flowers in early Spring. $1 \mathrm{ft}$. April, May.

AMSONIA Tabernæmontana. A strong, shrublike plant, with spikes of delicate blue flowers. $2 \mathrm{ft}$. May, June.

ANCHUSA italica, Dropmore. Large, gentianblue flowers. 4 to $5 \mathrm{ft}$. May-July.

-myosotidiflora. Bright blue Forget-me-not flowers. 10 to 12 in. May. 50c., 10 for $\$ 4.50$.

ANEMONE (Windflower). Japanese Anemones are among the best Autumn flowering plants. 2 to $3 \mathrm{ft}$. Sept., Oct.

japonica alba. Single, pure white.

elegantissima. Semi-double, satin-pink.

Montrose. Semi-double pink.

rubra. Single, reddish rose.

Whirlwind. Semi-double, white.

ANTHEMIS montana (Marguerite). One of the most satisfactory perennials; flowers creamy white. $2 \mathrm{ft}$. June-Oct.

tinctoria Kelwayi (Golden Marguerite). Rich yellow; fine for cutting. $2 \mathrm{ft}$. June-Oct.

AQUILEGIA corulea (Rocky Mountain Columbine). Large, blue and white, long-spurred flowers.

chrysantha (Golden-Spurred Columbine). Flowers fragrant, yellow. 2 to 3 in. across.
AQUILEGIA-Continued

canadensis (American Columbine). A compact plant with red-and-yellow flowers.

Mrs. Scott Elliott Hybrids. There is not a better mixture grown in the world than by Mrs. Scott Elliott who has taken the highest awards at all the European exhibtions. Our stock is from seed. from this source, absolutely true strain.

Nivea grandiflora. A splendid robust growing large pure white

ARABIS alpina (Rock Cress). Adapted for rock gardens; pure white. 5 in. April, May.

ARTEMISIA Abrotanum (Southernwood, Old Man). Usually grown for its handsome, pleasant-scented leaves. 2 to $3 \mathrm{ft}$.

lactilora. Large, branching panicles of sweetly scented, creamy white flowers. 3 to $4 \mathrm{ft}$. Aug., Sept.

Stelleriana (Old Woman). Foliage deeply cut; silvery white; a fine plant for rockeries. $1 \frac{1}{2} \mathrm{ft}$.

ASCLEPIAS tuberosa (Butterfly Weed). Orangescarlet. $2 \mathrm{ft}$. July, Aug.

ASPERULA odorata (Sweet Woodruff, Waldmeister) A sweet-scented herb; white. 6 to 8 in. May, June.

ASTER (Michlæmas Daisy).

Climax. Large, soft mauve flowers with golden center, 5 to 6 ft. Sept., Oct.

Lil. Fardel. Rich, clear pink. 4 to $5 \mathrm{ft}$. Aug. Sept

Maggie Perry. Large flowers of soft, rosy mauve. $4 \mathrm{ft}$. Sept. Oct.

Perry's Pink. Glistening, reddish-pink flowers, Sept., Oct.

Perry's White. Pure white, free flowering. $5 \mathrm{ft}$. Sept., Oct.

St. Egwin. Pink, compact habit. $3 \mathrm{ft}$. Sept.

Tataricus. Tall straight growth, large violet flowers. $6 \mathrm{ft}$. Oct.

White Climax. Pure white, large flowers. 5 to 6 ft. Sept., Oct.

ASTILBE Arendsii (New Hybrids). July.

Gruno. Salmon-pink. 3 to $4 \mathrm{ft}$. $50 \mathrm{c}$.

Juno. Rosy-purple. 3 to $4 \mathrm{ft}$. $50 \mathrm{c}$.

Salmon Queen. Soft salmon-pink. $4 \mathrm{ft}$.

All plants on this page, except where noted, 30c. each, $\$ 2.50$ for 10. 


\section{HARDY PERENNIAI. PLANTS-Continued}

AUBRIETIA deltoidea. Fine for rockeries; dari: violet. 6 in. April and May.

BAPTISIA australis (False Indigo). Has racernes of lupine-like flowers, dark blue in color. 3 to $4 \mathrm{ft}$. May-July.

BOCCONIA cordata (Plume Poppy). Creamy white flowers. 6 to $8 \mathrm{ft}$. July, Aug.

BOLTONIA asterioides. Has pure white, Asterlike flowers. 5 to $6 \mathrm{ft}$. Aug., Sept.

latisquama. Similar to the preceding, with pinkish lavender flowers. 5 to $6 \mathrm{ft}$. Aug., Sept.

-nana. A dwarf form. $3 \mathrm{ft}$. Aug., Sept.

CALLIRHOE involucrata (Poppy Mallow). An elegant trailing plant, with large, saucer-shaped flowers of deep rosy crimson, with white center. $1 \mathrm{ft}$. June-Sept.

CAMPANULA (Bellflower). These are among the most important of hardy plants.

carpatica (Harebell). Flowers large, erect, light blue. 5 to 7 in. July, Aug.

-alba. A white form of the above.

glomerata. Globular, dark blue flowers. 11/2, ft. June, July.

medium (Canterbury Bells). In blue, rose or white. $2 \mathrm{ft}$. June.

- calycanthema (Cup-and-saucer. Canterbury Bells). In blue, lilac, rose and white.

persicifolia (Peach-leaved Bellflower). Large, cupshaped blue flowers. $2 \mathrm{ft}$. June, July.

- alba grandiflora. White.

pyramidalis (Steeple Bellflower). Long spikes of blue flowers. 4 to $5 \mathrm{ft}$. Aug., Sept.

-alba. A white form of the above.

CARYOPTERIS incana, Mastacanthus (Blue Spiræa). Lavender-colored flowers. 3 to $4 \mathrm{ft}$. Sept., Oct.

CASSIA marilandica. Bright yellow, odd-shaped flowers. 5 to $6 \mathrm{ft}$. July-Sept.

CATANANCHE coeruleabicolor (Cupid's Dart). White flowers with slight suffusion of purple in center. $2 \mathrm{ft}$. June-Aug.

CENTAUREA dealbata. Compact habit; deep pink flowers. $11 / 2 \mathrm{ft}$. July, Aug.

macrocephala. The most showy Centaurea, with large, thistle-like yellow flowers. $3 \mathrm{ft}$. July, Aug.

montana (Perennial Cornflower). Large blue flowers. $2 \mathrm{ft}$. June-Sept.

-alba. A fine white form of the above.

CEPHALARIA alpina (Roundheads). Very tall. Flower heads pale primrose-yellow. $5 \mathrm{ft}$. June, July.

CERASTIUM tomentosum (Snow-in-Summer). Bright, silvėry foliage, with white flowers. 6 in. May, June. See also Rock Plant list.

CHR YSANTHEMUMS, Hardy. These make a grand show late in the Fall; all colors. See page 57 for list of varieties. 2 to $3 \mathrm{ft}$. Sept.-Oct. 20 c. each, $\$ 2.00$ for doz.

arcticum (Arctic Daisy). Multitudes of white, slightly tinged flowers, 2 in. wide. 12 to $18 \mathrm{in}$. Sept.-Nov.

maximum, Shasta Daisy. Large white flowers; blooms profusely all Summer.

CIMICIFUGA racemosa. Tall, hardy and ornamental; white racemes of flowers. 4 to $5 \mathrm{ft}$. June, July.

--simplex. Tall, graceful spikes of white flowers, lasting a long time when cut. 2 to $3 \mathrm{ft}$. Sept., Oct. $75 \mathrm{c}$. each, $\$ 7.00$ for 10 .

CONVALLARIA majalis (Lily of the Valley). May, June. Field grown clumps. 40c. each, $\$ 3.50$ for 10.

COREOPSIS lanceolata. Golden yellow; the flowers are borne on long, graceful stems, making them invaluable for cutting. $2 \mathrm{ft}$. June-Oct.
DELPHINIUM (Larkspur). June till late Fall

Belladonna. Large, semi-double flowers, sky-blue, tipped lilac; dwarf growing.

formosum. Dark blue, white center.

English Hybrids. From the palest to the deepest blues; single and double.

- grandifforum chinense (chinense). Low-growing, with gentian-blue flowers.

- - alba. A pure white form of the preceding.

DIANTHUS (Hardy Pinks). A very interesting and useful class of plants, blooming in early Spring.

Alwoodii. (Perpetual Flowering Pinks). A new race introduced from England. Tall branching habit. Very fragrant.

-Mary. Pale rose-pink with light maroon center.

- Phyllis. Delicate pale pink with light maroon center; very strongly scented.

-Robert. A delicate shade of old rose with light maroon center; very free.

The above three varieties, 35c. each.

barbatus (Sweet William). In separate colors; red, white and rose. $2 \mathrm{ft}$.

-Newport Pink. A distinct variety in this favorite flower, being a salmon-rose-pink.

-Double Assorted Colors. $2 \mathrm{ft}$.

deltoides (Maiden Pink). A dwarf variety with sprays of pink flowers. 8 in.

plumarius (Grass Pink). Single fringed flowers in mixed colors. $1 \mathrm{ft}$. June-July.

Hardy Pink Abbottsford. Deep rose. Double.

Hardy Pink Her Majesty. Pure white. Double.

Hardy Pink White Reserve. Pure white. Double.

DICENTRA formosa. Rose color, with finely divided foliage. $1 \mathrm{ft}$. May-Aug.

spectabilis (Bleeding Heart). Long, drooping racemes of rose-crimson; useful for forcing. $1 \frac{1}{2} \mathrm{ft}$. April-June. 75c. each.

DICTAMNUS fraxinella (Gas Plant). This is also called Burning Bush. 2 to $3 \mathrm{ft}$. June, July. 50c. each.

DIGITALIS (Foxglove). These old garden favorites produce bold masses of leaves and flowers.

lanata. Long, dense spikes of grayish or creamy yellow flowers. 2 to $3 \mathrm{ft}$. June, July.

purpurea gloxiniæflora (Gloxinia-flowered Foxglove). Flowers spotted rose, purple and white. 2 to $3 \mathrm{ft}$. June, July.

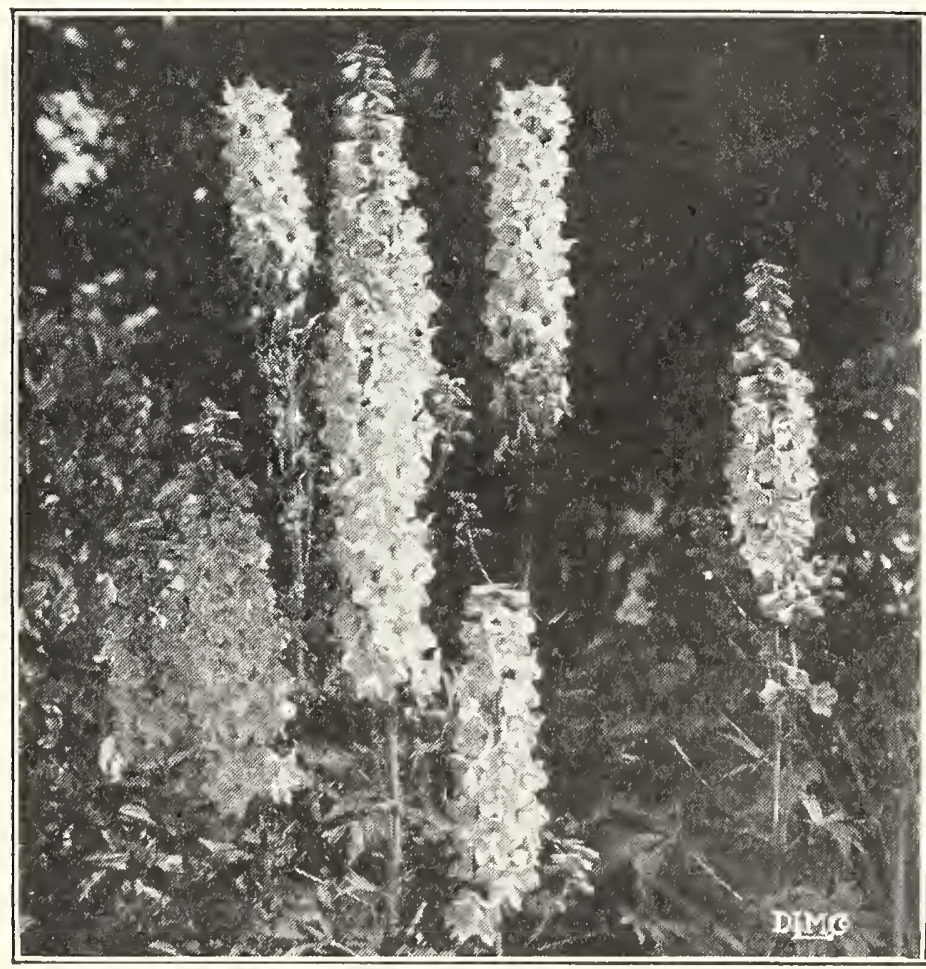

Delphinium

All plants on this page, except where noted, 30c. each, $\$ 2.50$ for 10 . 


\section{HARDY PERENNIAL PLANTS-Continued}

ECHINACEA purpurea (Purple Coneflower). Reddish purple flowers, 4 in. in diameter. 3 to $4 \mathrm{ft}$. July, Aug.

ECHINOPS (Globe Thistle). A showy plant, with globular heads of blue flowers.

Ritro. Metallic blue flowers; thistle-like foliage. 3 to $4 \mathrm{ft}$. July, Aug.

EREMURUS himalaicus. Creamy white flowers borne in immense graceful spikes. 6 to $8 \mathrm{ft}$. May, June. Strong plants, $\$ 12.50$ each.

robustus. A very fine, strong growing variety, with rosy pink flowers. 6 to $10 \mathrm{ft}$. May, June. Strong plants, \$12.50 each.

ERYNGIUM alpinum (Sea Holly). Flowers 3 in. across, of a steel blue. $2 \mathrm{ft}$. July, Aug.

amethystinum. Beautiful thistle-like heads of glistening amethyst-blue. 2 to $3 \mathrm{ft}$. July-Sept.

planum. Numerous small, blue heads of flowers on branching stems. $3 \mathrm{ft}$. July, Aug.

EUPATORIUM cœlestinum (Mist Flower). A good hardy plant, with light blue flowers, similar to Ageratum. 2 ft. Aug.-Oct.

purpureum (Joe Pye Weed). Purple; fine for wild garden. 6 to $7 \mathrm{ft}$. July-Sept.

urticæfolium (ageratoides) (White Snakeroot). White flowers; good for cutting. 4 to $5 \mathrm{ft}$. Aug., Sept.

EUPHORBIA corollata (Flowering Spurge). Pretty little white flowers. 2 to $3 \mathrm{ft}$. July, Aug.

epithymoides (polychroma). Bears masses of chrome-yellow flowers in early Spring.

FERNS, HARDY. Valuable for planting in shady, moist situations and under trees where blooming plants will not thrive. As a rule they should be grown in a moist, shady and protected place, in a soil composed of rich loam and leafmold.

Adiantum pedatum (Hardy Maidenhair Fern).

Aspidium acrostichoides (Christmas Fern). An evergreen variety with deep green fronds about a foot high.

Aspidium Filix-mass (Male Fern). A rare evergreen type, growing about $2 \mathrm{ft}$. high in rich soil.

Aspidium spinulosum. Another evergreen variety growing 18 to $24 \mathrm{in}$. high.

Asplenium angustifolium. A charming Fern with light green, graceful fronds 1 to $3 \mathrm{ft}$. high.

Asplenium Filix-fœmina. A large, handsome Fern with finely cut foliage about 2 to $3 \mathrm{ft}$. high.

Dicksonia punctilobula. A variety which will grow in sun or shade, growing about 18 in. high. Where masses of Ferns are desired, this variety cannot be surpassed.

Onoclea struthiopteris (Ostrich Fern). A very handsome variety which resembles a palm, growing from 2 to $4 \mathrm{ft}$. high. A very good Fern for growing as a background for smaller varieties.

Osmunda cinnamomea (Cinnamon Fern).

Osmunda regalis (Royal Fern).

FUNKIA. Very handsome and will thrive in almost any position. $1 \frac{1}{2}$ to $2 \mathrm{ft}$. July, Aug.

coerulea. Purple flowers; large, green foliage.

lancifolia albo-marginata. Leaves edged with white.

- undulata variegata. It has ovate leaves, the margins deep green and center a beautiful creamy white.

plantaginea grandiflora ( $F$. subcordata grandiflora). Large, pure white flowers and bold foliage make this a very attractive variety. 50c. each.

GAILLARDIA grandiflora (Blanket Flower). Yellow and orange-red. $11 \frac{1}{2} \mathrm{ft}$. May-Nov.

GALEGA officinalis (Goat's Rue). Rosy purple flowers. 3 to $4 \mathrm{ft}$.

-alba. White flowers; fine for cutting. 3 to $4 \mathrm{ft}$. July.
GENTIANA Andrewsii (Closed, or Bottle Gentian). Flowers of a fine blue. 18 to 24 in. Aug., Sept.

GERANIUM sanguineum. Fire-red; very effective. 1 to $1 \frac{1}{2} \mathrm{ft}$. May-July.

GEUM atrosanguineum (Avens). Dark crimson. 1 to $2 \mathrm{ft}$. Niay-July.

coccineum, Mrs. J. Bradshaw. Double dark red flowers. $2 \mathrm{ft}$. June-Sept.

Heldreichii. Orange; one of the best; very free flowering; fine foliage. $11 / 2 \mathrm{ft}$. May-July.

\section{GRASSES-}

Arrhenatherum bulbosum folia variegata. Leaves green and white; fine for edging. 6 to 8 in.

Arundo Donax (Great Reed). Grows $15 \mathrm{ft}$. and forms dense clumps. 35c. each, $\$ 3.00$ for 10 .

-variegata. Foliage creamy white and green. 6 to $8 \mathrm{ft}$. $35 \mathrm{c}$. each, $\$ 3.00$ for 10 .

Elymus glaucous (Blue Lyme Grass). Has narrow, glaucous silvery foliage. $3 \mathrm{ft}$.

Eulalia gracillima univittata. Foliage narrow, bright green, with a silvery midrib. 5 to $6 \mathrm{ft}$.

-japonica variegata. Its long, narrow leaf blades are striped green, white and often pink and yellow. 4 to $6 \mathrm{ft}$.

-japonica zebrina. Very striking with leaves banded transversely with pale yellow. 5 to $6 \mathrm{ft}$.

Festuca glauca. A pretty dwarf grass, with tufts of fine, bluish green foliage. $1 \mathrm{ft}$.

Phalaris arundinacea picta (arundinacea variegata). Variegated Ribbon Grass; Gardener's Garters. 2 to $3 \mathrm{ft}$.

G YPSOPHILA paniculata (Baby's Breath). Masses of minute, pure white flowers. 2 to $3 \mathrm{ft}$. June, July.

-flore-pleno. Charming, double flowers borne on branched panicles in great profusion. July, Aug. $50 \mathrm{c}$. each, $\$ 4.50$ for 10 .

acutifolia (Chalk Plant). Rose-colored flowers. 3 to $4 \mathrm{ft}$. July, Aug.

HELENIUM autumnale superbum (Sneezeweed). A grand plant, with large, flat, lemon-yellow flowers. 4 to $5 \mathrm{ft}$. Aug., Sept.

Hoopesii. The earliest flowering of all the Heleniums and the only one with pure orange-colored flowers. 2 to $3 \mathrm{ft}$. May, June.

-Riverton Beauty. Rich lemon-yellow, with large purplish black cone. $5 \mathrm{ft}$. Aug., Sept.

-Riverton Gem. Yellow, changing to red. $5 \mathrm{ft}$. Aug., Sept.

HELIANTHUS (Hardy Sunflower). The large flowers on long stems are fine for cutting.

Maximilianii. One of the latest blooming of all; clear yellow. 6 to $8 \mathrm{ft}$. Oct., Nov.

mollis. Thick, velvety foliage of a silvery tinge; flowers lemon-yellow. $5 \mathrm{ft}$. Aug., Sept.

orgyralis. Graceful stalks, clothed with very long, willowy, drooping foliage; flowers deep lemonyellow. 8 to $10 \mathrm{ft}$. Aug.

Wolley Dod. Very free flowering, bright yellow semi-double. 6 to $7 \mathrm{ft}$. Sept.

HELIOPSIS Pitcheriana. The flowers are deep golden yellow, about 2 in. in diameter. 3 to $4 \mathrm{ft}$. July-Sept.

HEMEROCALLIS flava (Lemon Lily). Flowers lemon-yellow, sweet-scented. $3 \mathrm{ft}$. May.

fulva Kwanso. Large, double flowers of a rich bronze orange. 2 to $3 \mathrm{ft}$. June-Aug.

Middendorffi. Flowers deep orange-yellow. Desirable for cutting. 2 to $3 \mathrm{ft}$. June, July.

Thunbergii. Flowers lemon-yellow, very fragrant. $3 \mathrm{ft}$. July, Aug.

HEUCHERA sanguinea. The bright crimson flowers are borne in long, graceful, arching sprays. $11 / 2 \mathrm{ft}$. May-Sept.

hybrida. Assorted colors. $11 / 2 \mathrm{ft}$. May, Sept. 


\section{HARDY PERENNIAL PLANTS-Continued}

HOLLYHOCK rosea. 5 to $6 \mathrm{ft}$. July, Aug.

Single. In crimson, rose, salmon, white or yellow colors.

Double. In carmine-rose, crimson, yellow, rosesalmon and white colors.

HIBISCUS Hybrids. The flowers range in color from white to intense crimson. 5 to $8 \mathrm{ft}$. July-Sept. $2-y r .$, each 35c., 10 for $\$ 3.00$; 3-yr., each 50c., 10 for $\$ 4.50$; 4-yr., strong clumps, 75c. each, 10 for $\$ 6.50$.

HYPERICUM Moserianum (Gold Flower). Beautiful golden yellow flowers, with crimson stamens. $11 / 2 \mathrm{ft}$. June-Sept.

INULA ensifolia (Fleabane). Yellow; small flowers, 8 in. July-Sept.

glandulosa. Old-gold; pretty. 3 to $4 \mathrm{ft}$. July, Aug.

IRIS germanica (Garden Iris). See Fall catalogue.

IRIS Kaempferi (Japanese Iris). See Fall Catalogue.

LATHYRUS latifolius (Everlasting Pea). Flowers rose-colored, large, on many-flowered stems, similar to the annual Sweet Pea. $3 \mathrm{ft}$. June-Aug.

-albus. A variety of the preceding, with white flowers. A very desirable plant. $3 \mathrm{ft}$. JuneAug.

-White Pearl. With pure white flowers, which are double the size of the ordinary Lathyrus. 2 to 3 ft. June-Aug. 35c. each, $\$ 3.00$ for 10 .

LAVANDULA vera (Sweet Lavender). Fragrant blue flowers. $11 / 2 \mathrm{ft}$. July-Sept.

LIATRIS pyenostachya (Kansas Gay Feather). Flowers purple, in dense spikes. 4 to $5 \mathrm{ft}$. July, Aug.

spicata (Button Snakeroot). Spikes 6 to $15 \mathrm{in.}$ long; purple. 2 to $3 \mathrm{ft}$. July-Sept.

LINUM perenne (Flax). A lovely plant, with blue flowers. $1 \frac{1}{2} \mathrm{ft}$. May-Aug.

-album. A white form of the above.

LOBELIA cardinalis (Cardinal Flower). Flowers intense scarlet. $3 \mathrm{ft}$. July, Aug.

syphilitica. Fine spikes of blue flowers. $3 \mathrm{ft}$. Aug., Sept.

LUPINUS polyphyllus (Lupine). Deep blue, peashaped. 3 to $4 \mathrm{ft}$. June, July.

-albiflorus. A white form of the above.

-Morheimii. Color soft rose. June, July.

LYCHINIS chalcedonica. Flowers bright scarlet, in dense clusters. $2 \mathrm{ft}$. June, July.

Coronaria (Agrostemma Coronaria). Flowers rich crimson, produced in great abundance on long stems. $2 \mathrm{ft}$. June, July.

viscaria splendens flore-pleno. A fine variety, with double, crimson flowers. $1 \mathrm{ft}$.

LYTHRUM Salicaria roseum, Perry's Variety. A most beautiful shade of cherry red. 2 to $3 \mathrm{ft}$. July-Sept.

- Rose Queen. A remarkably free-blooming variety, with long, graceful spikes of rosy pink flowers. 2 to $3 \mathrm{ft}$. July-Sept.

- roseum superbum (Purple Loosestrife). Tall spikes of rosy purple. 3 to $4 \mathrm{ft}$.

L YSIMACHIA clethroides (Japanese Loosestrife). A fine hardy variety from Japan, with long spikes of pure white flowers. $2 \mathrm{ft}$. July-Sept.

Nummularia (Creeping Jenny). Moneywort.

MALVA moschata (Musk Mallow). Flowers rose; swe et scented. 1 to $2 \mathrm{ft}$. June-Sept.

-alba. A charming plant; flowers white. 1 to 2 ft. June-Sept.

MERTENSIA virginica (Virginian Cowslip). Flowers blue, funnel-formed, in nodding clusters. $11 / 2 \mathrm{ft}$. May, June.

MONARDA didyma. Compact heads of bright red flowers. $3 \mathrm{ft}$. June-Aug.

didyma, Cambridge Scarlet. Next to the scarlet lobelia, the most brilliant of our wild flowers.

didyma violacea superba. Deep amaranth-red.
MYOSOTIS palustris semperflorens (Forget-menot). Color blue; good for shady spots in the rock garden. 10 in. May-Sept.

NEPETA hederacea (Glechoma). Blue; a beautiful evergreen plant of creeping habit; fine for rockwork. 5 in. May, June.

For other varieties see Rock Plant List.

aNOTHERA fruticosa major (Evening Primrose). Bright yellow flowers. $2 \mathrm{ft}$. June.

missouriensis. Large, yellow flowers. 10 in. JuneAug.

PAPAVER nudicaule. White, yellow, orange. 9 in May-Aug.

orientale. 2 to $3 \mathrm{ft}$. May, June.

Grossfurst. Dark red. $3 \mathrm{ft}$. May, June. 40c.

Mrs. Perry. Pink. $3 \mathrm{ft.}$ May, June. 40c.

Perry's White. White. $3 \mathrm{ft}$. May, June. $40 \mathrm{c}$.

Princess Victoria Louise. Soft salmon-pink.

PENTSTEMON barbatus Torreyi (Beard Tongue). Tall spikes of brilliant scarlet flowers. $4 \mathrm{ft}$. JuneAug.

Digitalis. White, tubular flowers with purple throat. $2 \mathrm{ft}$. July, August.

PEONIES. See special Fall List.

PHLOX, PERENNIAL. Phloxes are among the very showiest and most valuable of all hardy plants, and, by growing a complete collection, they can be had in bloom from early June until late Fall. 2 to $3 \mathrm{ft}$. June-Oct.

New and Rare Varieties

Antoine Mercier. Pure white, lilac center. 35c. B. Comte. Satiny amaranth. $35 \mathrm{c}$.

Australia. Brilliant, dark carmine-violet. $35 \mathrm{c}$.

Elizabeth Campbell. Very large spikes of salmonpink. $35 \mathrm{c}$.

Europe. White, with crimson eye. Very large. $50 \mathrm{c}$.

Frau Anton Buchner. Pure white, with flowers of enormous size. $35 \mathrm{c}$.

Geo. A. Strohlein. Bright scarlet-orange, with carmine eye. $35 \mathrm{c}$.

Mme. M. Van Hoboken. The finest pink and a most consistent bloomer. 60c.

Mrs. Scholten. Very fine rose color and one of the best. $60 \mathrm{c}$.

Thor. Deep salmon-pink, suffused scarlet. 35c.

Wanadis. Lilac-blue, with violet eye. $35 \mathrm{c}$.

Widar. Violet-blue; white eye; very fine. 35c.

W. C. Egan. Delicate lilac, with red eye. $35 \mathrm{c}$.

The following varieties can be supplied at 30c. each,

$\$ 2.50$ for 10 :

Adonis. Rosy-salmon, carmine center.

Champ Elysees. Dark purple, large trusses.

Gen. Van Heutz. Salmon red, white center.

Jeanne d'Arc. Snow-white; very late.

Miss Lingard. Pure white, with pale pink center. A continuous bloomer.

Rhynstroom. Deep pink.

Tapis Blanc. The finest of all dwarf white Phlox. Enormous size.

DWARF OR CREEPING PHLOX.

subulata alba. Flowers large; white.

-atropurpurea. Purplish rose.

-lilacina. Light blue.

PHYSALIS Franchetii (Chinese Lantern Plant). Enormous orange-colored fruits; useful for Winter decorating. $2 \mathrm{ft}$. April, May.

PHYSOSTEGIA virginiana (False Dragonhead). Strong spikes of delicate pink flowers. 2 to $3 \mathrm{ft}$. June, July.

-alba. Flowers pure white. 2 to $3 \mathrm{ft}$. June, July.

PLATYCODON grandiflorum (Balloon Flower). A dense branching plant of upright habit; flowers 3 in. across, blue. 1 to $2 \mathrm{ft}$. June, July. -album. A white flowered form of the above.

All plants on this page, except where noted, 30c. each, $\$ 2.50$ for 10 . 


\section{HARDY PERENNIAL PLANTS-Continued}

POTENTILLA HYBRIDS (Cinquefoil).

Doctor Andre. Semi-double, yellow, red; veined and margined. $2 \mathrm{ft}$. June, July.

Don Quixote. Soft yellow, splashed scarlet.

Monsieur Rouillard. Crimson edged yellow.

Mont d'Or. Yellow.

MacNabiana. Double; rich crimson.

Plantii. Flowers single; red. 50 c. each, $\$ 4.50$ for 10 .

PRIMULA acaulis (vulgaris) (Common English Primrose). Bright lemon yellow and fragrant. 6 to 9 in. April, May.

PYRETHRUM. Single mixed varieties.

POL YGONATUM multiflorum (Solomon's Seal). Arching sprays of greenish white flowers; useful for cutting. $2 \mathrm{ft}$. May, June.

Sieboldii. A strong-growing plant; stems curving gracefully outward. Produces creamy white flowers; effective for massing. 3 to $5 \mathrm{ft}$. Aug., Sept.

RUDBECKIA laciniata, Golden Glow (Coneflower). Masses of double, golden yellow flowers. 6 to $8 \mathrm{ft}$. Aug., Sept.

maxima. Has immense grayish-green leaves and bright yellow flowers on long stems. 4 to 6 in. across. 6 to $8 \mathrm{ft}$. June-Sept.

speciosa (Newmannii). Dark orange-yellow flowers; fine for cutting. $2 \mathrm{ft}$. June-Oct.

subtomentosa. Densely branched masses of brilliant lemon-yellow flowers with dark purple centers. 4 to $5 \mathrm{ft}$. July-Oct.

SALVIA azurea grandiflora. A Rocky Mountain species, with pretty sky-blue flowers. 3 to $4 \mathrm{ft}$. Aug., Sept.

pratensis. Deep blue flowers. $2 \mathrm{ft}$. June, July.

nemorosa (virgata nemorosa). An effective border plant, with dark blue flowers. $2 \mathrm{ft}$. May, June. 50c.

SCABIOSA caucasica. Beautiful, soft lilac flowers, vigorous grower. 2 to $3 \mathrm{ft}$. June-Aug. $50 \mathrm{c}$. -alba. Very rare; pure white; 2 to $3 \mathrm{ft}$. $50 \mathrm{c}$.

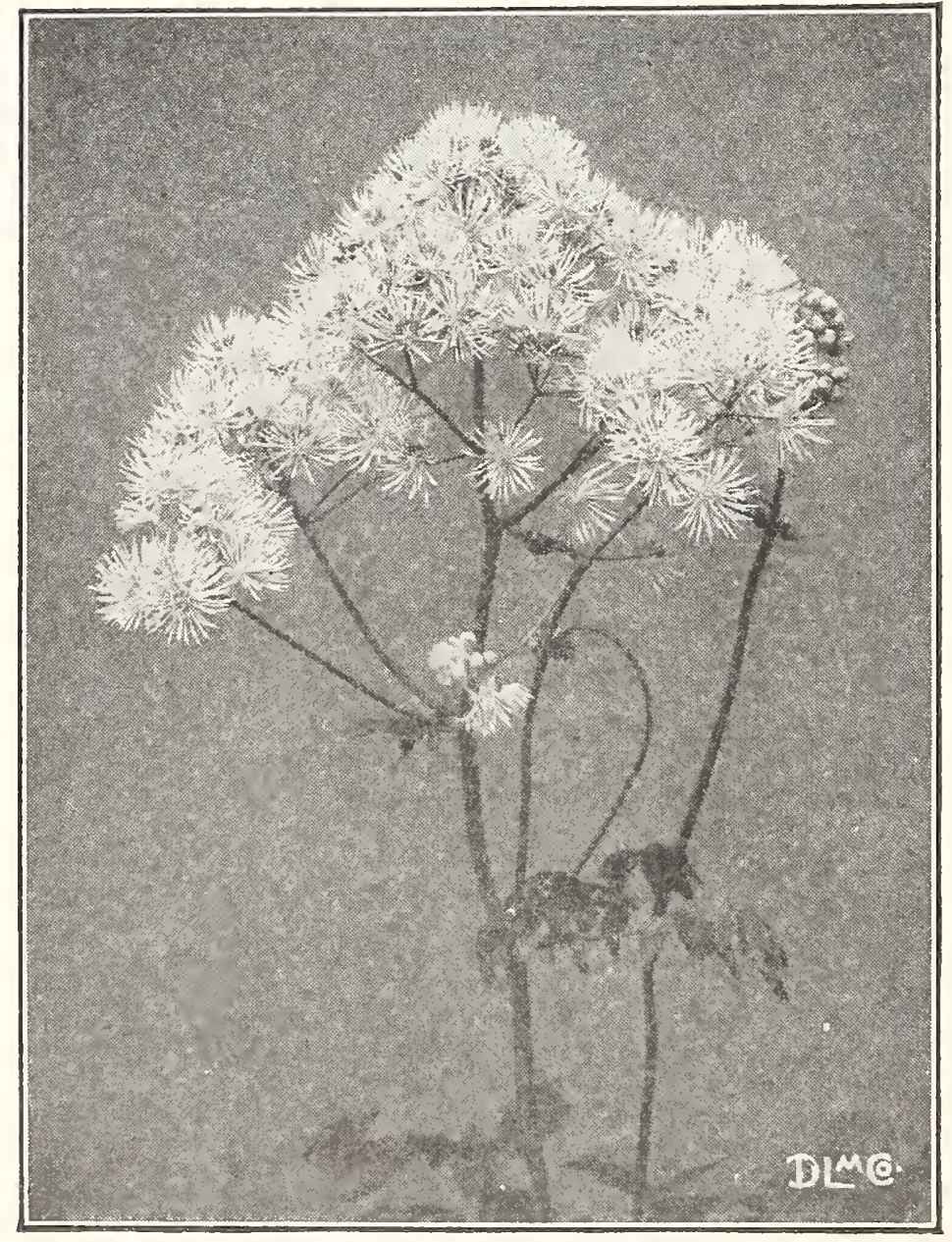

Thalictrum Aquilegifolium
SCABIOSA-Continued

japonica. Divided leaves, branching habit. Lavender-blue. $3 \mathrm{ft}$. June to Aug.

SEDUM acre (Golden Moss, Stonecrop). Flnwers bright yellow. 2-3 in. May-July.

album Foliage green; flowers white. 2-3 in.

Sieboldii. Foliage changing from blue and cream to coral-rose; flowers rose-pink. 9 in. Aug.-Sept.

spectabile (Stonecrop). Large heads of pink flowers. Fine border plant. $11 / 2 \mathrm{ft}$. Aug.-Sept.

For other varieties see Rock Plant List.

SPIREA Filipendula. White. $2 \mathrm{ft}$. June, July. UImaria fl. pl. Double white. $2 \mathrm{ft}$. June, July.

STACHYS lanata. Purple spikes of flowers; soft silvery foliage. $11 / 2 \mathrm{ft}$. June, July.

STATICE latifolia (Sea Lavender). Fine spreading panicles of lavender flowers.

STOKESIA cyanea (Cornflower Aster). Flowers 3 to 4 in. across, of a fine sky-blue. $2 \mathrm{ft}$. July-Oct. alba. A white form of the above.

SWEET WILLIAM. See Dianthus.

THALICTRUM aquilegifolium (Meadow Rue). Graceful foliage and masses of pure white flowers. 1 to $3 \mathrm{ft}$. May-July.

-adiantifolium. Leaves resemble those of the maidenhair fern; flowers yellow. $1 \mathrm{ft}$. June, July.

dipterocarpum. One of the handsomest Thalictrums, with graceful flowers on stems $4 \mathrm{ft}$. high; rosy purple, citron-yellow anthers. Aug., Sept.

THERMOPSIS caroliniana. A fine plant with clover-like foliage; long spikes of bright yellow, pea-shaped, lupine-like flowers. $4 \mathrm{ft}$. June, July.

THYMUS citriodorus aureus. Golden variegated foliage. $8 \mathrm{in.} \mathrm{June-Aug.}$

TRADESCANTIA virginiana (Spiderwort). Long, grass-like leaves, violet flowers. $2 \mathrm{ft}$. May-Aug. -alba. White flowers. $2 \mathrm{ft}$. May-Aug.

TRITOMA Rufa. A very dainty yellow flower; a constant bloomer from June until frost; fine for cutting. $2 \frac{1}{2} \mathrm{ft}$. June to Nov. 40c.

- grandis (T. Pfitzeri). The freest flowering of all; orange-scarlet, shading to salmon-rose at the edge. 2 to $3 \mathrm{ft}$. Aug., Sept.

TROLLIUS europæus (European Globe Flower). A pretty plant, with large, lemon-colored, buttercuplike flowers, 1 to $1 \frac{1}{2}$ in. across, on long stems. Should be planted in moist soil. $2 \mathrm{ft}$. May, June.

Orange Globe. A profuse bloomer, of robust growth; large orange flowers; very fine. $2 \mathrm{ft}$. May, June.

All Trollius 50c. each, $\$ 4.50$ for 10 .

VALERIANA officinalis (Hardy Garden Heliotrope). Fragrant, light pink flowers. 3 to $5 \mathrm{ft}$. June, July.

VERBASCUM longiflorum pannosum (Mullein). Clear yellow, very ornamental; fine large, silvery foliage. $6 \mathrm{ft}$. June-Aug.

olympicum. Yellow flowers. Very attractive variety. $8 \mathrm{ft}$. May, June.

phoniceum. Purple and pink flowers. $2 \mathrm{ft}$. June, July.

thapsiforme (densiflorum). Large, yellow flowers. 2 to $5 \mathrm{ft}$.

VERONICA (Speedwell). All Veronicas love moist situations and are excellent for rockwork.

incana. Deep blue flowers with silvery foliage. $1 \mathrm{ft}$. July, Aug.

longifolia subsessilis (Blue). Attractive; blooms until late Fall. $2 \mathrm{ft}$. Aug., Sept.

spicata. Spikes of blue flowers. $1 \frac{1}{2} \mathrm{ft}$. June, July. VINCA minor (Periwinkle). Evergreen trailer; fine for covering bare places. April, May.

VIOLA cornuta G. Werning. This is a true Viola cornuta, with large blue flowers.

VIOLA, Tufted Pansies.

Admiration. Soft purple, dark blotched.

lutea splendens. Golden yellow.

White perfection. White.

YUCCA filamentosa (Adam's Needle). Pyramidal clusters of creamy flowers. 4 to $6 \mathrm{ft}$. June, July.

All plants on this page, except where noted, 30c. each, $\$ 2.50$ for 10 . 


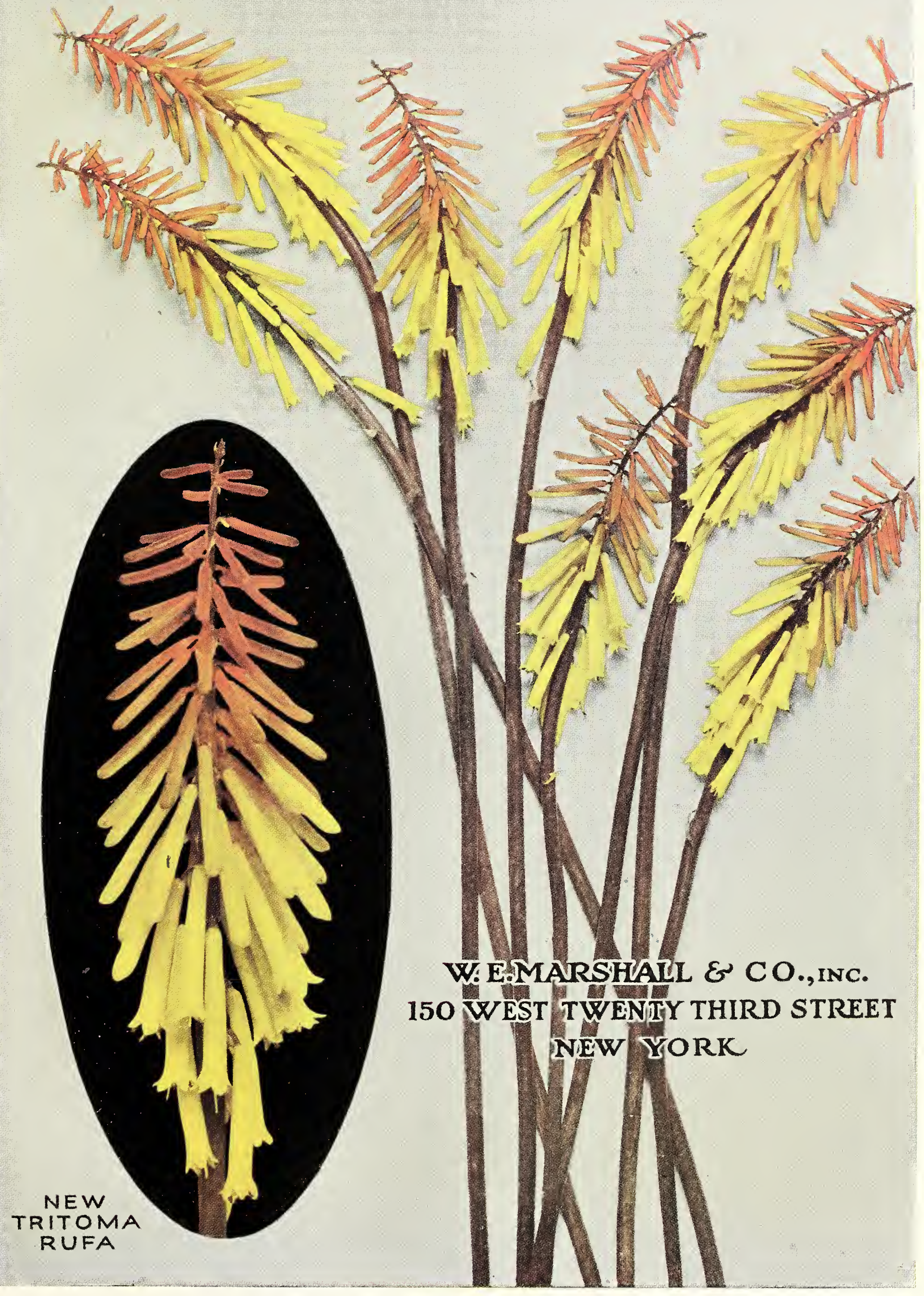




\section{TRITOMA RUFA}

The New Everblooming

$\checkmark$ Tritoma

HERE is nothing more dainty than a vase of this beautiful new Tritoma. The stems are so long that they can be placed in a deep and narrow vase where, with the natural bend to the stalk, they will attain a neat and graceful attitude without any arrangement.

The color is so sweet and pleasing that it adapts itself to any surroundings.

A remarkable feature of this Tritoma, unlike all others, is that it will commence blooming late in June and will continue to throw up its flower spikes until cut down by frost, although it is not affected by light frosts. From individual plants as many as 25 flower stalks have appeared in one season.

We would recommend planting in a well drained situation, and a mulching of manure should be applied as a protection in Winter. Otherwise they should be lifted and placed in a cool cellar with a covering of soil or planted in a coldframe.

\section{Strong Flowering Roots}

40 cents each; $\$ 3.50$ per $10 ; \$ 30.00$ per 100

Delivered free 


\section{Hardy Vines}

\section{and Climbers}

ACTINIDIA arguta. Shining, dark green foliage. Flowers white, with purplish center. Pot grown plants...................\$1.50 each

AKEBIA quinata. Numerous bunches of violetbrown flowers; does best in sunny places. Strong, pot grown plants...... .75c. to $\$ 1.00$ each Field grown plants..............50c. each

AMPELOPSIS heterophylla. Well adapted for covering rocks and low trelliswork.

Field grown plants................50e. each Pot grown plants................ each quinquefolia (Virginia Creeper). Very large, green foliage, changing to brilliant scarlet in the Fall Field grown plants, 5 to $7 \mathrm{ft} \ldots \ldots \ldots . .50 \mathrm{c}$. each Pot grown plants, strong, 5 to $6 \mathrm{ft} \ldots \ldots 1.00$ each

Engelmannii. Similar to the preceding, with smaller and more dense foliage.

Field grown plants, 5 to $7 \mathrm{ft}$.

50c. each Pot grown plants, strong, 5 to $6 \mathrm{ft} \ldots \ldots \$ 1.00$ each

tricuspidata Lowii (Lowii) (New Japanese Ivy). The small, prettily lobed foliage changes to a brilliant crimson in Autumn. Pot grown plants, $\$ 1.00$ each.

Veitchii (Japanese or Boston Ivy). Rapid growing vine, handsome green foliage, assuming charming sun tints in the Fall.

Field grown plants, $2-y$ r., $50 \mathrm{c}$. each, $\$ 4.50$ for 10 Field grown plants, 3 -yr., $75 \mathrm{c}$. each, $\$ 7.00$ for 10 Pot grown plants......\$1.00 each, $\$ 9.00$ for 10 Extra strong pot grown plants, $\$ 1.50$ each, $\$ 14.00$ for 10 .

ARISTOLOCHIA Sipho (Dutchman's Pipe). vigorous and rapid flowering climber.

Pot grown plants.............\$1.00 each

BIGNONIA (Tecoma) grandiflora (Chinese Trumpet Vine). Orange-red flowers.

True grafted plants............ \$2.00 each radicans (Common Trumpet Vine). Brilliant orange-scarlet flowers in July and August.

Pot grown plants.................. each

CELASTRUS scandens (False Bittersweet). A native vine, of rapid growth, with large leaves and yellow flowers.

Field grown plants.......50c. each, $\$ 4.50$ for 10

CLEMATIS. Beautiful and attractive vines.

Jackmanii. One of the best; large, rich, velvety purple flowers in profusion.

Henryi. Large, creamy white, fine form.

Mme. Edouard Anare. Bright red flowers. Pot grown plants of above. $\$ 1.50$ each.

paniculata (Japanese Virgin's Bower). The white flowers are very pretty, fragrant and resemble snowflakes in late Summer.

Field grown plants.....40c. each, $\$ 3.50$ for 10 Pot grown plants......75c. each, $\$ 6.50$ for 10

EUON YMUS radicans. Very hardy, dense growing, trailing vine; dull green leaves, with whitish veins. Field grown plants......50c. each, $\$ 4.50$ for 10 Strong, pot grown plants...75c. each, $\$ 7.00$ for 10

variegatus. Fine vine, with clinging tendrils. Compact, variegated, small leaves.

Field grown plants.....50c. each, $\$ 4.50$ for 10 Strong, pot grown plants. . .75c. each, $\$ 7.00$ for 10 vegetus. Has round leaves and produces an abundance of showy red fruits with yellow pods. Field grown plants.......50c. each, $\$ 4.50$ for 10 Strong, pot grown plants. . $\$ 1.00$ each, $\$ 9.00$ for 10

HEDERA helix (English Ivy). This is the popular, small-leaved variety and has proved perfectly hardy. Pot grown plants.......50c. each, $\$ 4.50$ for 10 Extra strong plants......75c. each, $\$ 6.50$ for 10 Specimens with many branches trained on sticks. 4 to $5 \mathrm{ft} \ldots \ldots \ldots \ldots \ldots . \$ 2.00$ each, $\$ 18.00$ for 10 5 to $6 \mathrm{ft} \ldots \ldots \ldots \ldots \ldots \ldots \$ 3.00$ each, $\$ 27.00$ for 10 6 to $7 \mathrm{ft} . \ldots \ldots \ldots \ldots \$ 4.00$ each, $\$ 36.00$ for 10

HUMULUS Lupulus (Hop Vine). 'The Hop has fine, large, three-lobed leaves, rough on both sides.

Pot grown plants..................50c. each

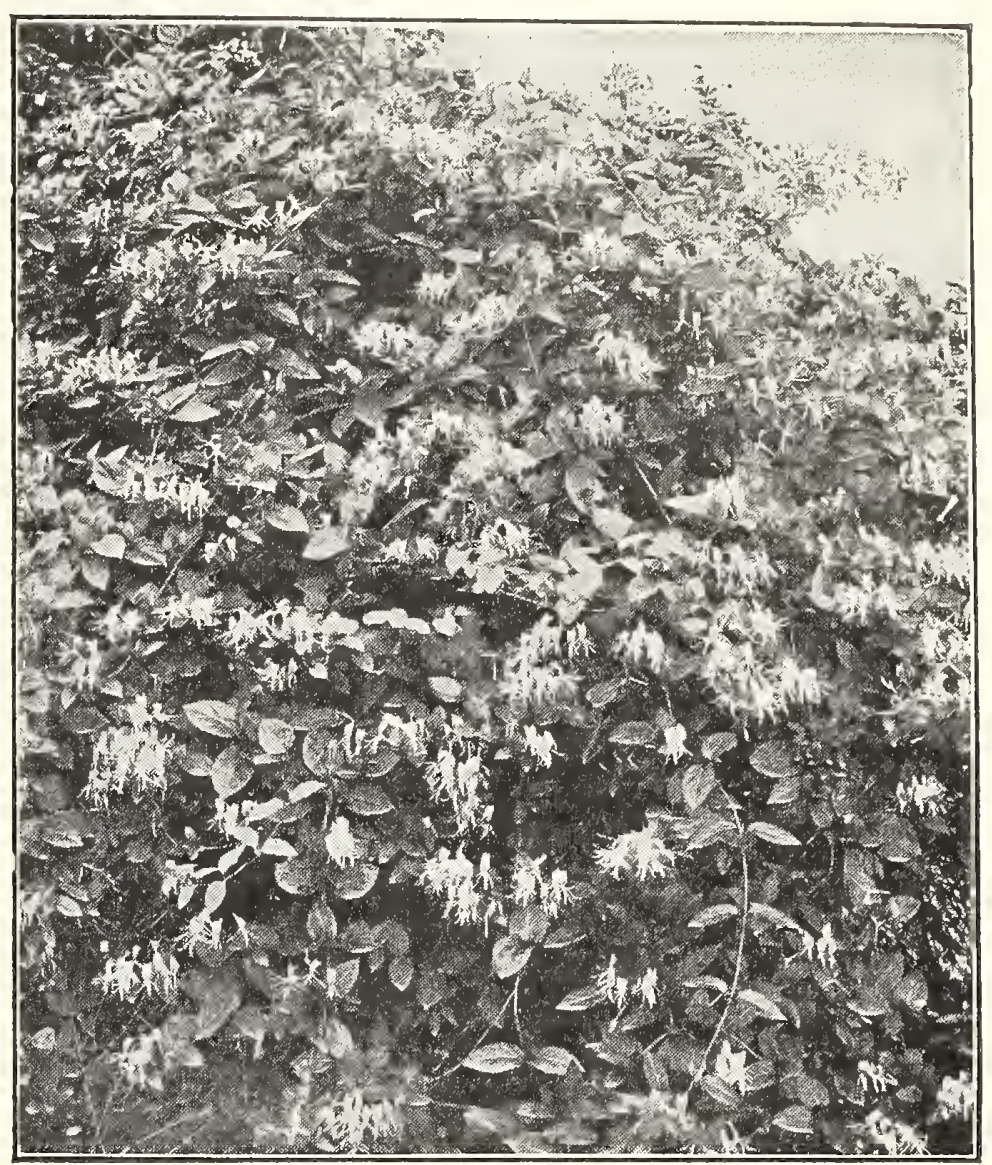

Lonicera Halliana

LONICERA japonica aureo-reticulata. Handsome foliage, netted and spotted bright yellow. 2 -year plants.50c. each, $\$ 4.50$ for $10, \$ 35.00$ per 100 - Halliana (Hall's Japanese Honeysuckle). A strong grower and constant bloomer. A choice variety.

2 -year plants .40c. each, $\$ 3.50$ for $10, \$ 30.00$ per 100

POL YGONUM baldschuanicum. A useful climbing plant, perfectly hardy, a strong grower, covering itself with a sheet of snowy white flowers.

Pot grown plants...............\$1.00 each

PUERARIA Thunbergiana (Kudzu Vine). A most remarkable rapid growing vine, unparalleled for ornament and shade.

2-year plants..................35c. each

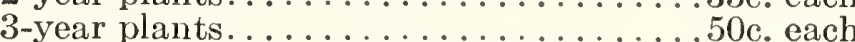
Strong, pot grown plants............70c. each

SCHIZOPHRAGMA hydrangeoides (Climbing $\mathrm{Hy-}$ drangea). Has bright green, round leaves, and flowers similar to Hydrangeas.

Pot-grown plants.

$\$ 2.50$ each Extra strong plants.

$\$ 4.00$ each

TECOMA. See Bignonia.

WISTERIA macrobotrys (multijuga) (Japanese Loose-clustered Wisteria). A rare species, with purplish or lilac-colored flowers, borne in immense clusters, sometimes $2 \mathrm{ft}$. in length. $\$ 1.00$ each; pot grown plants, $\$ 2.00$ to $\$ 4.00$ each; specimens in tubs, $\$ 5.00$ to $\$ 10.00$.

-alba (multijuga alba). Very rare; large, white clusters of flowers. $\$ 1.00$ each, $\$ 9.00$ for 10 ; pot grown plants, $\$ 2.00$ to $\$ 4.00$ each; specimens in tubs, $\$ 5.00$ to $\$ 10.00$.

sinensis (chinensis) (Chinese Wisteria). Flowers sky--blue, in long, pendulous clusters. 75c. each; pot grown plants, $\$ 1.00$ to $\$ 3.00$ each; specimens in tubs, $\$ 4.00$ to $\$ 10.00$ each.

-alba (chinensis alba) (White Chinese Wisteria) A choice variety with white flowers. 75c. each; pot grown plants, $\$ 1.50$ to $\$ 3.00$ each; specimens in tubs, $\$ 4.00$ to $\$ 5.00$ each. 


\section{ROSES - Hybrid Tea, or Everblooming}

This selection will produce a mass of Roses to cut from the entire season. The plants are American, twoyear-old, and the varieties are the very best for outdoor culture; invaluable either for display or cutting and are hardy with protection.

Being almost as hardy as the June Roses, they can be treated in a similar way with regard to pruning.

All strong, American two-year-old field grown plants, $\$ 1.00$ each, $\$ 9.00$ for 10 .

\section{SUGGESTIONS FOR SPRING PLANTING OF ROSES}

The soil should be thoroughly cultivated and a liberal supply of rotted manure added. In planting, dig a hole sufficiently large to accommodate the roots when spread out on the bottom of the hole. In filling in the soil, shake the plant lightly in order that the soil may mix between the roots. Fill in the soil and firm it in order that the plant may be solid. Be sure to see that the lower parts of the lower branches are below the surface of the soil. Do not plant in a mound, the surface should be level. Cut back the branches to within 4 to 6 fnches of the surface of the ground. With this treatment the best results may be obtained.

\section{PINK AND ROSE SHADES}

Columbia. A large beautiful pink.

Killarney Queen. A distinct clear pink.

Konigin Carola. A satin-rose with silvery reflexes, very large, pointed buds, slightly fragrant.

Lady Alice Stanley. Deep coral rose on the outside of the petals, pale flesh on the inside.

Lady Ashtown. Pale carmine-pink, shading to golden yellow at base of petals.

La France. Bright pink flowers with curled petals showing silvery tints. Very fragrant.

La Tosca. Silvery pink with deeper center, large, full flowers.

Los Angeles. A luminous flame pink, toned with coral and shaded with translucent gold.

Mme. Butterfly. Bright pink apricot and gold. Large buds and flowers.

Mme. Caroline Testout. Bright, satiny rose, with brighter center; free flowering.

Mme. Segond-Weber. Beautiful rosy salmon.

Miss Cynthia Forde. Large flowers of deep, brilliant rose pink, with light rosy pink reflex.

Mrs. Henry Morse. A lovely pink, shaded salmon, deeper at the base. Each $\$ 1.50$.

Ophelia. Delicate rose, heavily flushed but opening to a salmon flesh shaded with rose.

Premier. A handsome dark pink. The large full blooms are an exquisite pure rose-pink which is very lasting.

Radiance. Beautiful carmine rose flushed with copper; large round flowers.

Rose Marie. Clear rose-pink flowers of large size; one of the finest Roses.

Secretaris Zwart. Rose, shaded salmon. Each $\$ 1.50$.

Souvenir de Georges Pernet. Brick-red buds, opening to terra cotta pink. Each $\$ 1.50$

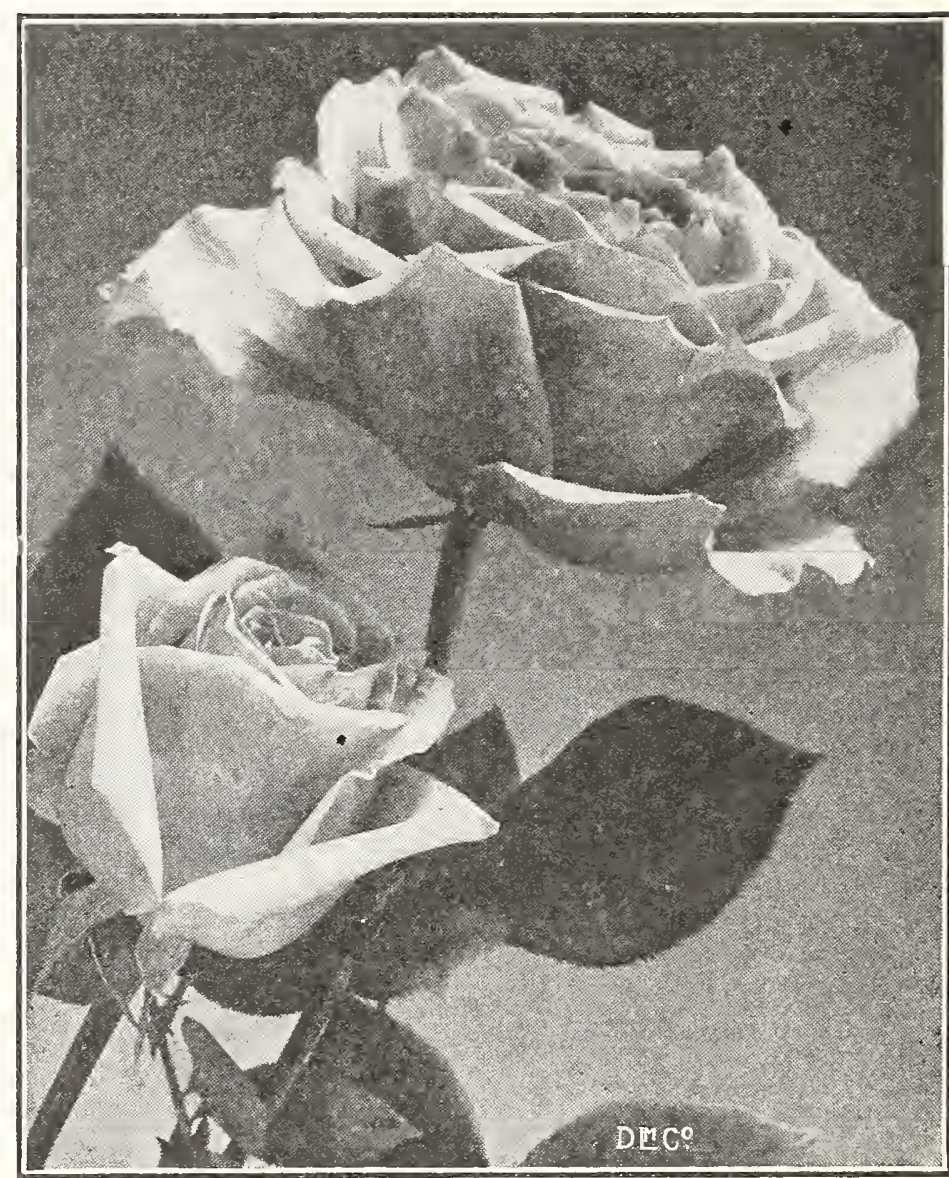

Rose, Premier

Willowmere. Coral-red buds opening to shrimp-pink. William F. Dreer. Beautiful, shell-pink petals, with golden yellow bases.

\section{SCARLET, GARMINE AND GRIMSON SHADES}

Chateau de Clos-Vougeot. Soft, velvety scarlet opening to a deep crimson.

Etoile de France. A soft, velvety crimson, with a vivid shade of cerise.

Francis Scott Key. A glorious rose of blazing red. Perfectly formed, large size, fragrant.

General Superior Arnold Janssen. Light crimson.

General MacArthur. Bright crimson; large, free flowering; highly perfumed; very hardy.

George C. Waud. Distinct orange-red, with fine scent; large, full and well formed; very profuse.

Gruss an Teplitz. Brightest scarlet crimson; satiny texture; very free flowering.

H. V. Machin. Intensely black-grained, scarletcrimson blooms carried on rigid flower stalks.

Jonkheer J. L. Mock. Carmine, changing to imperial pink. A variety of distinct merit.

Laurent Carle. Brilliant, velvety carmine.

Mme. Edouard Herriot (Daily Mail Rose). Coralred, shaded with yellow and bright rosy scarlet, passing to shrimp-red.

Red Radiance. Color deep red. The enormous, globular flowers are borne on heavy canes.

\section{PURE WHITE AND WHITE SHADES}

Edel. A wonderful Rose, producing white flowers that open ivory-white.

Kaiserin Auguste Viktoria. White, shading to primrose. A fine Rose; very vigorous.

Killarney, Double White. Very fine form, of pure delicate appearance.

Mme. Jules Bouche. Handsome white blooms, with centers shaded primrose.

Miss Willmott. White flowers of enormous size.

Silver Columbia. A white sport of Columbia. 


\section{Roses, Hybrid Tea and Everblooming-Continued.}

\section{YELLOW, SALMON, GOPPER SHADES}

Betty. Flowers ruddy gold; very large.

Constance. Orange buds, streaked crimson, developing large, rich yellow flowers.

Duchess of Wellington. Flowers saffron-yellow, which become deep coppery yellow as they open.

Golden Emblem. A most desirable truly yellow Rose.

Golden Ophelia. Golden yellow in center, paling slightly at outer petals.

Harry Kirk. Clear yellow, sweetly perfumed.

Independence Day. Flame-colored flowers, show also petals of gold and apricot. Each $\$ 1.50$.

Louise Catherine Breslau. Large, oval bud of coralred, shaded chrome-yellow.

\section{Hybrid Perpetual, or Remontant Roses}

These are commonly called the June Roses, owing to their greatest crop being borne in that month. Require hard pruning annually. Our list of varieties is selected with a view to suit all lovers of the Rose who desire the best.

Extra strong, 2-year-old, field grown plants, $\$ 1.00$ each, $\$ 9.00$ for 10 .

American Beauty. Deep pink to soft carmine.

Baroness Rothschild. Superb rose, of rich satiny pink.

Frau Karl Druschki. Fine snow-white; vigorous grower and very hardy.

General Jacqueminot. Brilliant scarlet-crimson; superb flower.

George Arends. Strong grower with delicate pink flowers.

Hugh Dickson. Crimson, shaded scarlet.

J. B. Clark. Intense deep scarlet.

Magna Charta. Bright pink, suffused with carmine; a beautiful Rose.

Mrs. John Laing. Immense blooms of soft clear pink. A strong grower.

Paul Neyron. Deep rose; largest of all Roses; fine foliage.

Ulrich Brunner. Bright, cerise red; flowers large.

Any of the above Roses, $\$ 1.00$ each, $\$ 9.00$ for 10 .

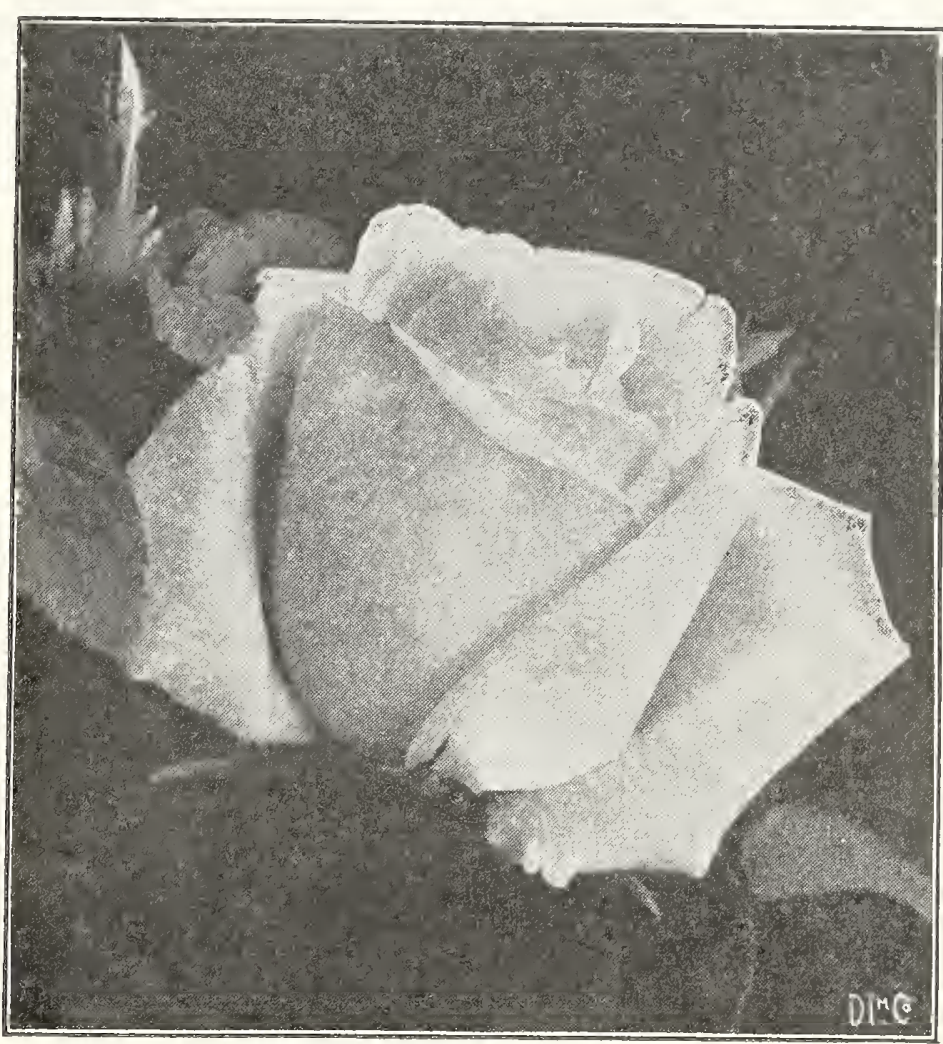

Rose, Frau Karl Druschki

\section{Climbing and Trailing Roses}

This class is easily distinguished by their peculiar habits. They may be grown either on trellis, pergolas, or used in covering banks. The Roses in this class mostly flower in clusters.

Strong, 2-year-old plants, $\$ 1.00$ each, $\$ 9.00$ for 10 .

Alida Lovett. Bright shell-piink flowers of Hybrid Tea size and quality, lightly shaded with sulphur yellow at base of petals.

Aviateur Bleriot. Saffron buds and flowers streaked with crimson in small clusters.

Bess Lovett. Resembles Climbing American Beauty in shape of bloom, but is very much brighter in color and more fragrant.

Climbing American Beauty. Fragrant flowers of a rich crimson color.

Crimson Rambler. Small, ruffled flowers of dazzling scarlet-red borne in giant sprays on a strong growing plant.

Dorothy Perkins (Hybrid Wichuraiana). Soft light pink, flowers profusely in large clusters.

Dr. W. Van Fleet. The long pointed buds are of a rich flesh-pink on long stems; vigorous grower.
Mme. Leon Pain. Inside of petals light silvery Miss

Lolita Armour. Chrome-yellow at base, shading to orange and copper hues. Each $\$ 1.50$.

lare. Ravary. Golden yellow buds, opening to very lowe, orange-yellow flowers. yo flowers expand, they shade lighter

padre. Coes.

petals. Each $\$ 1.50$ length, opening to golden yellow. Each $\$ 2.50$. uvenir de Claudius Pernet. Fine buds of fadeless yellow. Each $\$ 1.50$. 


\section{Dwarf Polyantha Roses}

The Polyanthas are a charming class of everblooming Roses, of a dwarf, bushy habit.

Ellen Poulsen. The flowers are large size and brilliant pink in color.

Greta Kluis. A lovely shade of deep carmine-pink, passing to a glowing carmine-red.

Gruss an Aachen. Large flowers of flesh pink overlaid with cream yellow; deep pink at base.

Miss Edith Cavell. A brilliant scarlet color.

Orleans. Brilliant geranium-red, tinted pink, with creamy white centers.

Triomphe Orleanais. A bright, cerise-red.

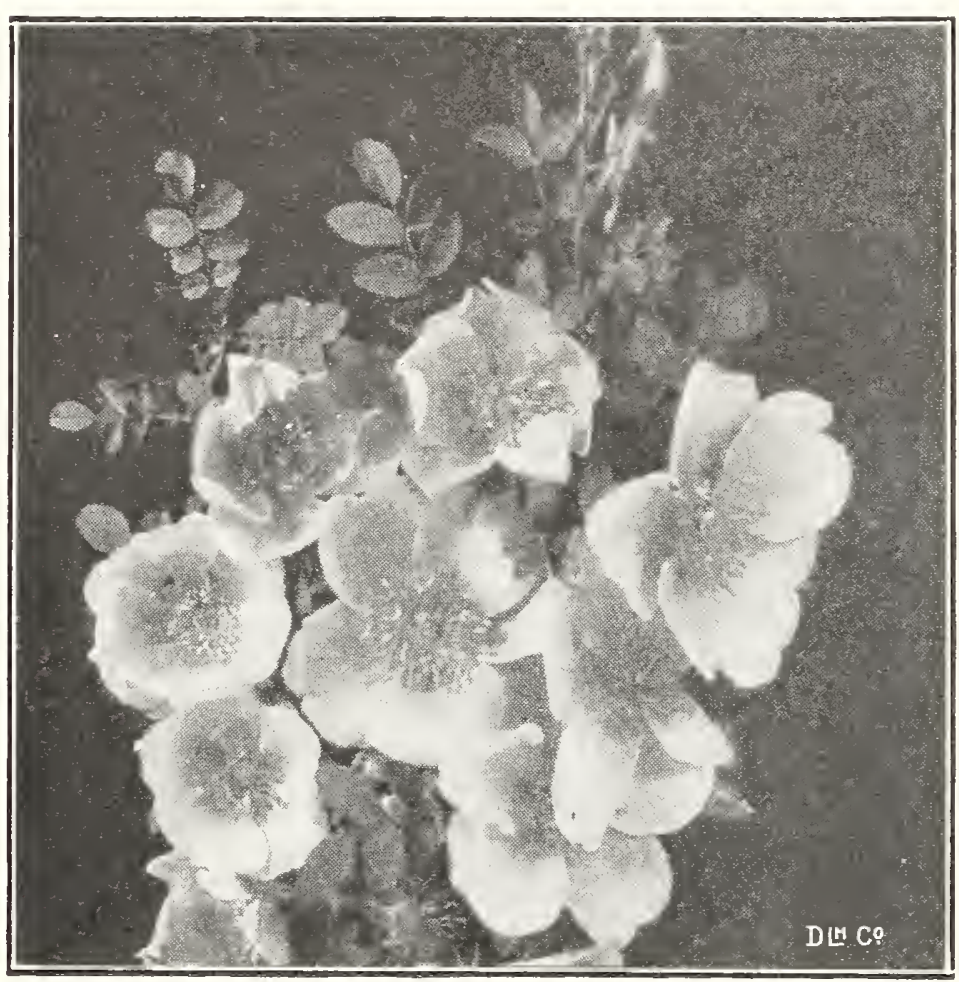

Rosa Hugonis

\section{Moss Roses}

The Moss Roses are very fragrant and bloom profusely in June.

Blanche Moreau. Pure snowy white.

Crested Moss. Pale, rosy pink, beautifully crested.

Red Moss. The color is a clear red, heavily mossed with deep green.

Any of the above Roses, $\$ 1.00$ each, $\$ 9.00$ for 10 .

\section{STANDARD ROSES}

We can supply many of the leading varieties in standard or tree form. Each $\$ 3.50$.

\section{MISCELLANEOUS ROSES}

Cabbage Rose. An old favorite. Large, full, rosypink, sweet scented flowers. Hardy and rugged. $\$ 1.00$ each.

Persian Yellow. Double yellow flowers in great profusion in Spring. 75c. each.

Rosa Hugonis. Fine for shrub planting, as it reaches a height of $6 \mathrm{ft}$. when fully matured. The long, arching branches are thickly set with the lovely single yellow flowers in May, and it is one of the earliest Roses to bloom. Makes a most spectacular show. Never winterkills. $\$ 1.50$ each.

Rosa rugosa, Conrad F. Meyer. A clear, silverypink, with double flowers. 75c. each.

Rosa rugosa, F. J. Grootendorst. A continuous bloomer bearing red, double flowers in clusters. $\$ 1.00$ each.

Rosa Wichuraiana (Memorial Rose). Single. A handsome Rose for covering banks and rockeries. Fragrant, white flower clusters; half evergreen, glossy foliage. $75 \mathrm{c}$ each.

Rugosa Nova Zembla. Large double sweet-scented, nearly white in color. $75 \mathrm{c}$. each.

\section{GREENHOUSE ROSES}

Florex. The new Rose of exceptional merit. Color, bright coral salmon. Free bloomer, good grower and fine keeping qualities.

Mrs. F. R. Pierson. A wonderful new Rose. A fine sport of Premier with all its sterling qualities.

Souvenir de Claudius Pernet. A beautiful yellow Pernetiana Rose. Grafted on Rosa odorata.

Grafted stock of the above, $21 / 4-$ in. pots, doz. $\$ 10.00,100 \$ 75.00$.

Briarcliff. The color is more brilliant than Columbia, without the salmon undertones, being a true rosepink.

Senator. A wonderful new dark scarlet rose without the slightest trace of blue. Bud is long, pointed and well formed, fragrance wonderful.

Grafted stock of the above, 21/4-in. pots, Doz. $\$ 9.00,100 \$ 65.00$.

Commonwealth. A beautiful dark pink.

Mrs. Calvin Coolidge. The new golden yellow.

Premier. Rose pink, free and easy grower.

Templar. A clear bright red; very fragrant.

Grafted stock only. 21/2-in. pots, doz. $\$ 7.00,100$ $\$ 50.00 ; 3$-in. pots, doz. $\$ 9.00,100 \$ 65.00$.

Columbia. Pleasing rose pink.

Crusader. Rich velvety crimson.

Double White Killarney. The best white.

Golden Ophelia. A bright yellow.

Hadley. Velvety crimson. Very fragrant.

Mrs. Aaron Ward. A rich yellow.

Mme. Butterfy. Bright pink, apricot and gold.

Ophelia. Clear salmon pink.

Pilgrim. A beautiful shade of rose pink.

Silver Columbia. A white sport of Columbia.

Grafted stock only. $21 / 2$-in. pots, doz. $\$ 6.00,100$ $\$ 45.00 ; 3$-in. pots, doz. $\$ 8.00,100 \$ 55.00$.

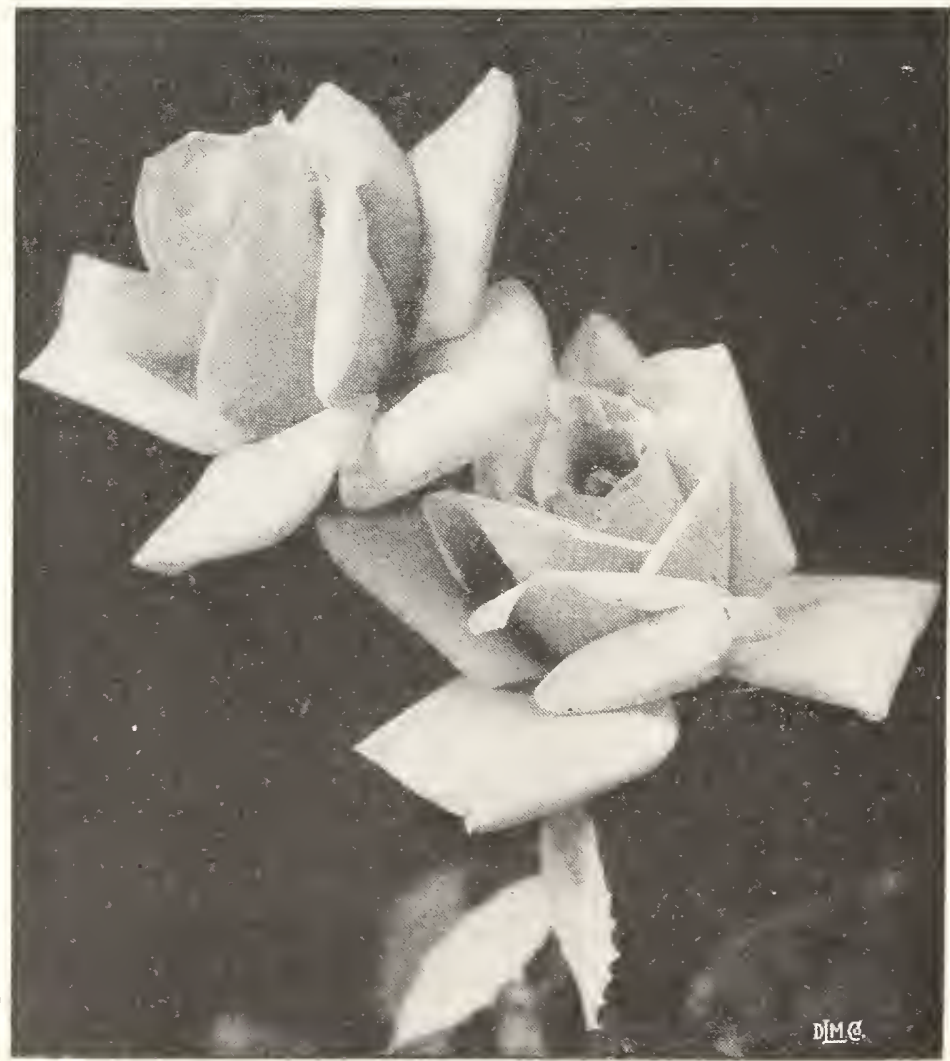

Ophelia

Greenhouse Roses ordered in advance will be shipped in due season for planting. 


150 WEST 23rd ST., NEW YORK 69

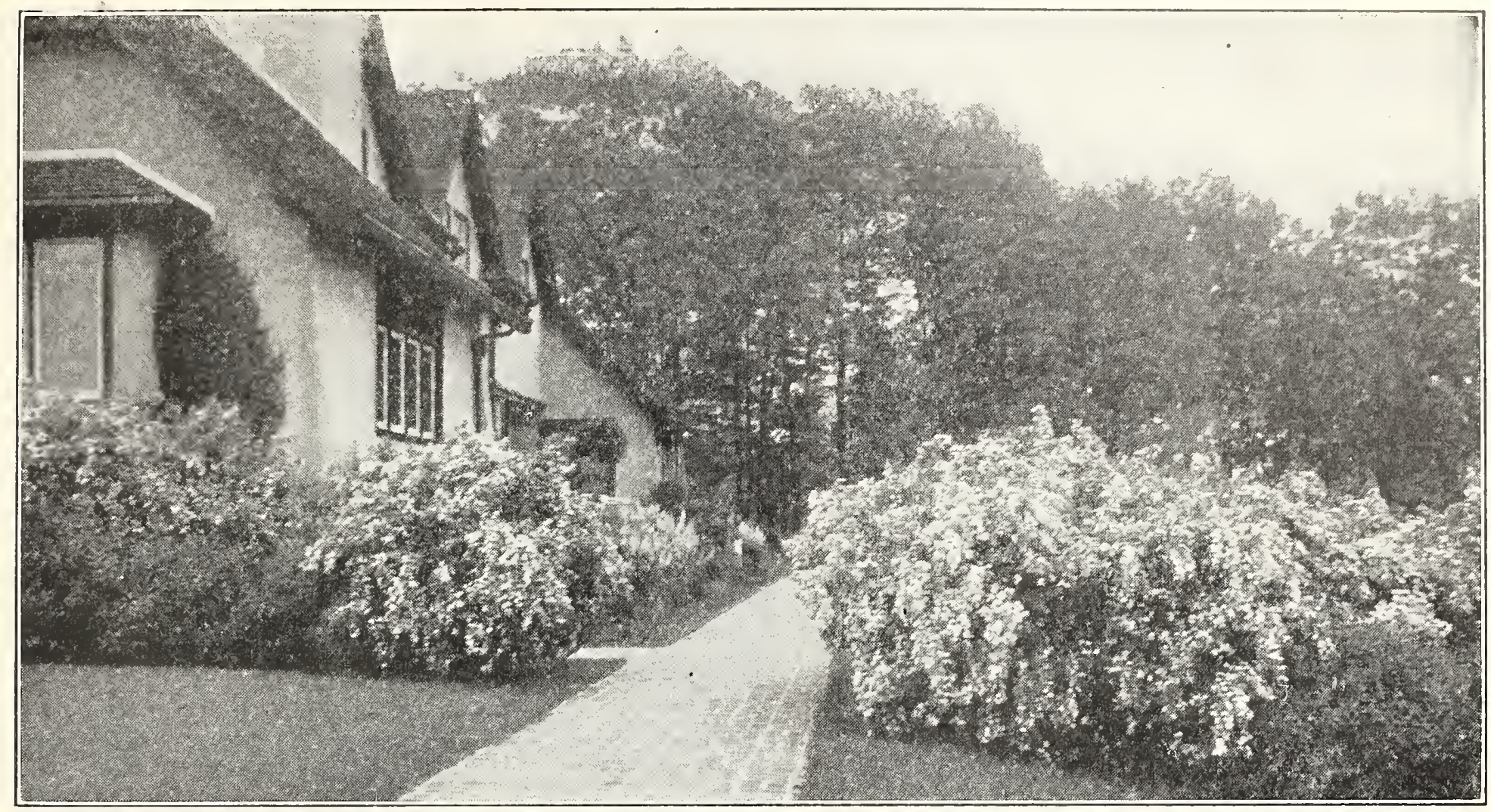

\section{Flowering and Foliage Shrubs}

Please note that the prices below are based upon actual values. Shape, buds and roots are what you want, not merely height. We will send out only plants that are sure to give ultimate satisfaction. We have arger specimen plants, and if ordered, will supply them at proportionate rates.

ALTHAEA (Rose of Sharon). Strong, erect growing shrub of symmetrical habit. Very desirable for flowering all Summer.

Double Pink, Purple, Rose, or White.

2 to $3 \mathrm{ft} . \ldots \ldots \ldots \ldots \ldots \ldots$............ each, $\$ 6.50$ for 10 3 to $4 \mathrm{ft} \ldots \ldots \ldots \ldots \ldots \ldots \ldots$. $\$ 1.00$ each, $\$ 9.00$ for 10 AMELANCHIER canadensis (Dwarf Juneberry). White flowers in early Spring before the leaves.

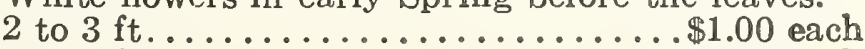

3 to $4 \mathrm{ft} . \ldots \ldots \ldots \ldots \ldots \ldots \ldots \ldots \ldots \ldots \ldots$ each

AMYGDALUS chinensis alba flore pleno (Double White Flowering Almond).

$3 \mathrm{ft} \ldots \ldots \ldots \ldots \ldots \ldots \ldots \ldots \ldots \ldots$ each - rosea plena (Double Pink Flowering Almond).

$3 \mathrm{ft} \ldots \ldots \ldots \ldots \ldots \ldots \ldots \ldots \ldots \ldots \ldots$ each

ANDROMEDA catesbaei. A valuable shrub for planting under trees, on the margins of woodland drives and in other shady positions. Flowers are fine white and are borne on long, pendulous racemes, with a characteristic fragrance. 15 to 18 in............ $\$ 2.00$ each, $\$ 17.50$ for 10 $11 / 2$ to $2 \mathrm{ft} . \ldots \ldots \ldots \ldots \ldots \$ 3.00$ each, $\$ 27.50$ for 10

AZALEA amoena. Evergreen shrub of bushy habit and perfect hardiness. Flowers are of bright rosy purple.

12 to 15 in.................. \$2.50 each

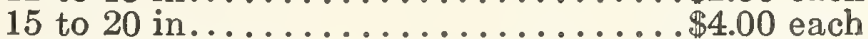
Specimen plants............. $\$ 5.00$ to $\$ 10.00$ each

hinodegiri. A bright scarlet form of the well-known and charming Azalea amoena.

12 to 15 in...............\$3.50 each

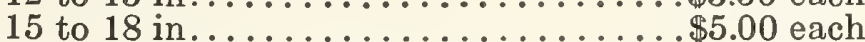

vicosa (Swamp Honeysuckle). White, fragrant flowers in June and July.

12 to 18 in........... \$2.50 each, $\$ 20.00$ for 10

BENZOIN aestivale (Spicewood). Tall spreading bush with red berries in Summer and Autumn.

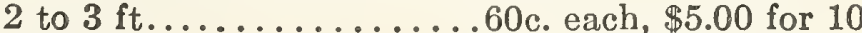
3 to $4 \mathrm{ft} \ldots \ldots \ldots \ldots \ldots \ldots 75 \mathrm{c}$. each, $\$ 6.00$ for 10
BERBERIS thunbergi (Barberry). A beautiful Japan variety of dwarf habit. Small foliage, changing to beautiful red in Autumn.

$11 / 2$ to $2 \mathrm{ft} . . .50 \mathrm{c}$. each 2 to $3 \mathrm{ft} . . .775 \mathrm{c}$. each

Box Barberry. A perfectly hardy edging plant.

2 yr. old plants.....\$2.00 per $10, \$ 16.00$ per 100

3 yr. old plants......\$3.00 per 10, $\$ 25.00$ per 100

BUDDLEIA magnifica (variabilis magnifica). Purple-lilac flowers borne in long, graceful panicles, commencing to open in Midsummer and continuing until frost.

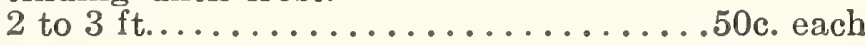

CAL YCANTHUS floridus (Sweet Scented Shrub).

2 to $3 \mathrm{ft} . \ldots .75 \mathrm{c}$. each 3 to $4 \mathrm{ft} . \ldots \$ 1.00$ each

CERCIS canadensis (Japan Judas Tree, or Redbud). 2 to $3 \mathrm{ft} . . . \ldots \ldots . . . . .75 \mathrm{c}$. each, $\$ 7.00$ for 10 3 to $4 \mathrm{ft} \ldots \ldots \ldots \ldots \ldots \ldots 1.00$ each, $\$ 9.00$ for 10

CHIONANTHUS vixginica (White Fringe). One of the most decorative of all the flowering shrubs. 2 to $3 \mathrm{ft} . \ldots \$ 1.50$ each 3 to $4 \mathrm{ft} \ldots \ldots \$ 2.00$ each

CLETHRA alnifolia (Sweet Pepper Bush).

$21 / 2$ to $3 \mathrm{ft} . \ldots \ldots \ldots \ldots . . .75 \mathrm{c}$. each, $\$ 7.00$ for 10 3 to $4 \mathrm{ft} . \ldots \ldots \ldots \ldots \ldots . \$ 1.00$ each, $\$ 9.00$ for 10

CORNUS alba sibirica (Red Osier Dogwood).

3 to $4 \mathrm{ft} . \ldots \ldots \ldots \ldots . . .75 \mathrm{c}$. each, $\$ 6.00$ for 10 florida. Pure snow-white flowers.

3 to $4 \mathrm{ft} . \ldots \ldots \ldots \ldots \ldots . \$ 1.00$ each, $\$ 9.00$ for 10 4 to $5 \mathrm{ft} \ldots \ldots \ldots \ldots \ldots \ldots 1.25$ each, $\$ 10.00$ for 10 5 to $6 \mathrm{ft} \ldots \ldots \ldots \ldots \ldots \ldots \$ 1.50$ each, $\$ 12.00$ for 10 6 to $8 \mathrm{ft} \ldots \ldots \ldots \ldots \ldots 2.00$ each, $\$ 18.00$ for 10

-rubra (Red Flowering Dogwood). A good bright, pink Dogwood.

$21 / 2$ to $3 \mathrm{ft} \ldots \ldots \ldots \ldots . \$ 2.00$ each, $\$ 18.00$ for 10 3 to $4 \mathrm{ft} \ldots \ldots \ldots \ldots \ldots 3.50$ each, $\$ 30.00$ for 10 sanguinea. The well-known red-branched Dogwood.

3 to $4 \mathrm{ft}$..............75c. each, $\$ 6.50$ for 10

ROCK PLANTS. See our Special List of Plants for Rock Gardens. 


\section{FLOWERING AND FOLIAGE SHRUBS-Continued}

CORYLUS purpurea (Purple-leaved Filbert) (Hazelnut).

2 to $2 \frac{1}{2} \mathrm{ft}$. $\$ 1.50$ each. 3 to $4 \mathrm{ft} . \ldots \$ 2.00$ each

CRATAGUS coccinea (Scarlet Fruited Thorn). Crus-galli (Cockspur Thorn).

Oxyacantha (English Hawthorn). Single white flowers.

-alba plena. Double white flowers.

-flore rosea plena. Beautiful pink, double.

W. Paul's Scarlet. Rich brilliant scarlet flowers.

Prices of above varieties:

3 to $4 \mathrm{ft}, \$ 1.25$ each. 4 to $5 \mathrm{ft} \ldots \ldots \$ 1.50$ each 5 to $6 \mathrm{ft} \ldots \ldots \ldots \ldots \ldots \ldots \ldots \ldots \ldots$ each

CYDONIA japonica (Japan Quince).

$1 \frac{1}{2}$ to $2 \mathrm{ft} . . . \ldots \ldots \ldots 75 \mathrm{c}$. each, $\$ 6.50$ for 10

DAPHNE Cneorum (Garland Flower). Flowers bright pink.

15 to 18 in........\$ $\$ 1.00$ each, $\$ 9.00$ for 10

Mezereum (Mezereon Pink).

12 to 15 in. $\$ 1.00$ each. 15 to 18 in. $\$ 1.50$ each

DEUTZIA crenata A. pl. Flowers double, pinkish white.

2 to $3 \mathrm{ft} . \ldots \ldots \ldots 60.6 .6$ c. each, $\$ 5.50$ for 10

3 to $4 \mathrm{ft} \ldots \ldots \ldots \ldots .75 \mathrm{c}$. each, $\$ 7.00$ for 10

gracilis. A fine hardy shrub, forming a round and compact mass of white in June.

1 to $11 / 2 \mathrm{ft} . . . \ldots \ldots . .50 \mathrm{c}$. each, $\$ 4.50$ for 10 $11 / 2$ to $2 \mathrm{ft} \ldots \ldots \ldots \ldots .75 \mathrm{c}$. each, $\$ 7.00$ for 10

Lemoinei. 2 to $21 / 2 \mathrm{ft}$............75c. each

Pride of Rochester. Double white flowers, tinged pink.

2 to $3 \mathrm{ft} . \ldots \ldots \ldots 60.6 .6$ c. each, $\$ 5.50$ for 10 3 to $4 \mathrm{ft} . \ldots \ldots \ldots \ldots 75 \mathrm{c}$. each, $\$ 7.00$ for 10

ELAEAGNUS longipes (Silver Thorn). The foliage is bright green above and silvery white beneath. 2 to $3 \mathrm{ft} . \ldots \ldots \ldots \ldots . . . .75 \mathrm{c}$. each, $\$ 7.00$ for 10 3 to $4 \mathrm{ft} \ldots \ldots \ldots \ldots \ldots \$ 1.00$ each, $\$ 9.00$ for 10

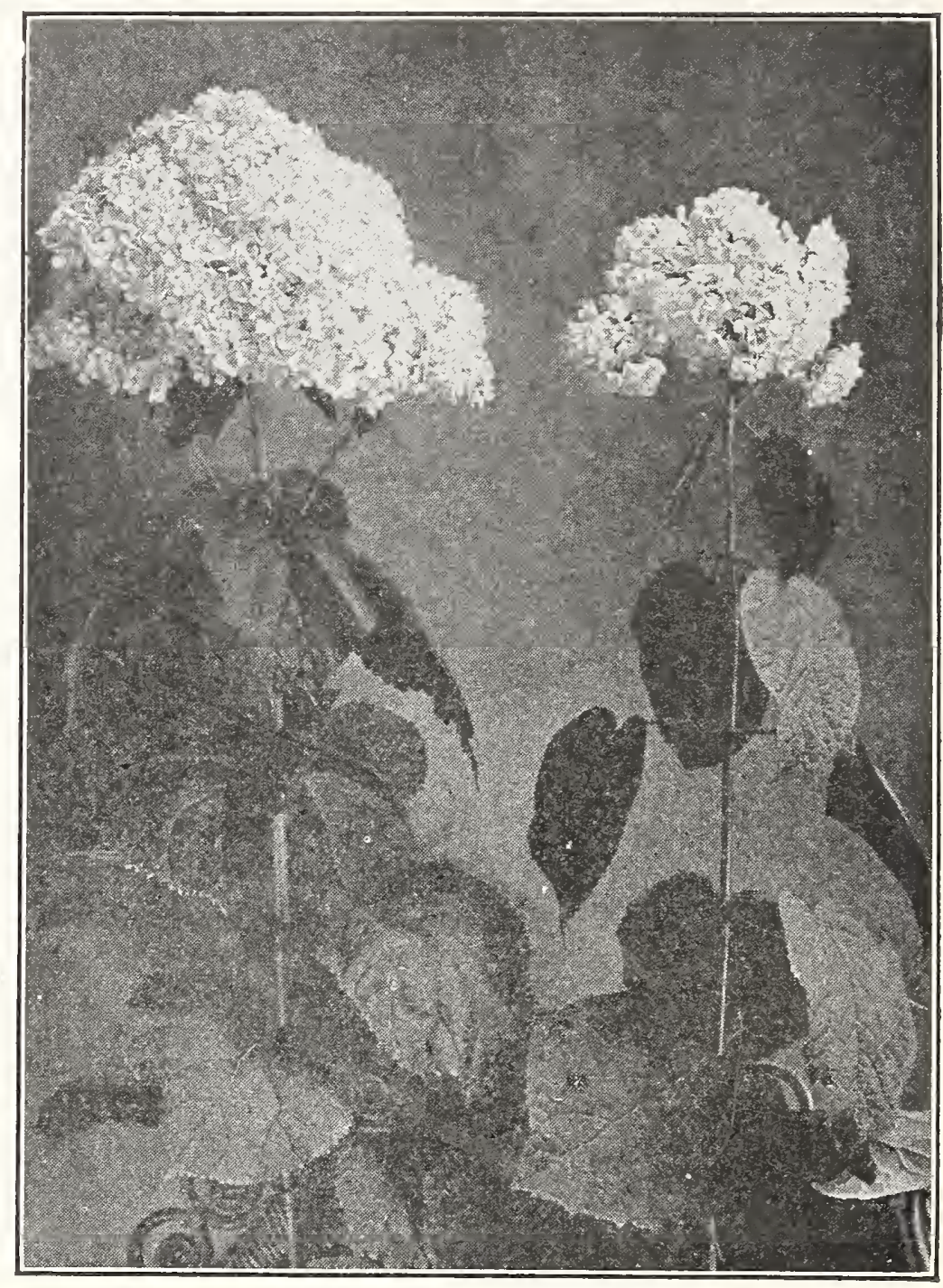

Hydrangea arborescens

\section{HYDRANGEA, French Varieties-Continued}

Eclaireur. Bright carmine rose.

General de Vibraye. Large; bright rose.

Louis Foucard. Distinct, deep, cheerful reddish carmine.

2 to $3 \mathrm{ft}$
3 to $4 \mathrm{ft}$

.75 c. each, $\$ 6.50$ for 10 3 to $4 \mathrm{ft} \ldots \ldots \ldots \ldots \ldots \ldots 1.00$ each, $\$ 9.00$ for 10 alatus. The foliage is fine rose color in the Autumn. 2 to $3 \mathrm{ft} . \$ 1.00$ each. 3 to $4 \mathrm{ft} . \ldots . . \$ 1.25$ each

FORSYTHIA Fortunei (Golden Bell). Bark bright yellow; blooms in dense masses of golden flowers in April.

suspensa. (Weeping Golden Bell). Somewhat pendulous in habit.

viridissima. Blooms early in Spring, before the leaves appear.

2 to $3 \mathrm{ft} . \ldots \ldots \ldots \ldots . . .60$ c. each, $\$ 5.50$ for 10 3 to $4 \mathrm{ft} \ldots \ldots \ldots . . . . . .75 \mathrm{c}$. each, $\$ 6.50$ for 10 4 to $5 \mathrm{ft} \ldots \ldots \ldots \ldots \ldots \ldots \$ \ldots$ each, $\$ 9.00$ for 10

HALESIA tetraptera (Silver Bell) (Snowdrop Tree). A beautiful large shrub, with pretty, white, bellshaped flowers.

2 to $3 \mathrm{ft} . \$ 1.00$ each. 3 to $4 \mathrm{ft} \ldots \ldots \ldots \$ 1.50$ each

HYDRANGEA arborescens grandiflora (Hills of Snow). Foliage green, bluish underneath. Flowers June and July.

2 to $3 \mathrm{ft}$. $75 \mathrm{c}$. each. 3 to $4 \mathrm{ft} . \ldots \ldots . \$ 1.00$ each

-paniculata grandiflora. This is a grand plant, showy and attractive, lasting in bloom for months. 2 to $3 \mathrm{ft} \ldots \ldots \ldots \ldots \ldots \ldots \$ 1.00$ each, $\$ 9.00$ for 10 3 to $4 \mathrm{ft} \ldots \ldots \ldots \ldots \ldots \ldots \$ 1.25$ each, $\$ 11.00$ for 10 Standards, 3 yr. head ...........\$2.00 each

Otaksa. Immense heads of either pink or blue flowers.

Extra heavy pot grown plants. $\$ 1.00$ to $\$ 2.00$ each Plants in tubs.............. $\$ 4.00$ to $\$ 10.00$ each Specimens............. $\$ 15.00$ to $\$ 25.00$ each

\section{French Varieties}

Baby Bimbenet. Very dwarf, free, and early; large, compact trusses of silvery rose flowers.
Mme. Maurice Hamar. Very good pink.

Souv. de Mme. E. Chautard. The most popular, early, free pink.

Pot grown plants......\$1.00 each, $\$ 9.00$ for 10

HYPERICUM aureum (St. John's Wort). Flowers of bright yellow, July to August.

Moserianum. Beautiful golden yellow flowers, crimson stamens. Of dwarf habit.

All Hypericums..........50c. each, $\$ 4.50$ for 10

ITEA virginica (Virginian Willow). One of the prettiest native shrubs; produces racemes of pure white flowers during June, which have a fragrance not unlike the Pond Lily.

$11 / 2$ to $2 \frac{1}{2} \mathrm{ft} . . . \ldots \ldots 60.6$ c. each, $\$ 5.50$ for 10

JASMINUM nudiflorum (Winter Jasmine). Golden yellow flowers very early in Spring, flowering before the foliage appears.

18 to $24 \mathrm{in} . .75 \mathrm{c}$. each 2 to $21 / 2 \mathrm{ft} . . \$ 1.00$ each

LIGUSTRUM amurense (Japanese Privet). Large, oblong, glossy green foliage, half evergreen; grows to $15 \mathrm{ft}$.

3 to $4 \mathrm{ft} . . . \ldots \ldots \ldots . .75 \mathrm{c}$. each, $\$ 6.50$ for 10

Ibota (New Japanese Privet). Large, glossy, distinct foliage.

3 to $4 \mathrm{ft} . . . .6 . . . .6 .60 \mathrm{c}$. each, $\$ 5.50$ for 10 of excellent habit.

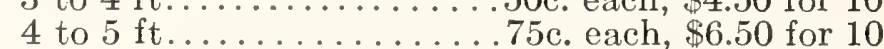
Globe-shaped, clipped, $21 / 2 \mathrm{ft} \ldots \ldots \ldots \$ 4.00$ each $3 \mathrm{ft} . \$ 5.00$ each. $31 / 2 \mathrm{ft} \ldots \ldots \ldots \ldots \ldots \$ 6.00$ each
3 to $4 \mathrm{ft} . . . \ldots \ldots \ldots . . .50 \mathrm{c}$. each, $\$ 4.50$ for 10 


\section{FLOWERING AND FOLIAGE SHRUBS-Continued}

\section{LIGUSTRUM-Continued}

Regelianum. Splendid dense horizontal growing shrub. $1 \frac{1}{2}$ to $2 \mathrm{ft} . . . . . .50 \mathrm{c}$. each, $\$ 4.50$ for 10 2 to $21 / 2 \mathrm{ft} \ldots \ldots \ldots \ldots \ldots 75 \mathrm{c}$. each, $\$ 6.50$ for 10

LILACS. Syringa persica. Purple flowers.

2 to $3 \mathrm{ft} \ldots \$ 1.00$ each. 3 to $4 \mathrm{ft} \ldots \$ 1.25$ each

rothomagensis. Large red flowers.

2 to $3 \mathrm{ft} . \ldots \$ 1.00$ each. 3 to $4 \mathrm{ft} \ldots \$ 1.25$ each

vulgaris. The common purple species.

2 to $3 \mathrm{ft} . . .75 \mathrm{c}$. each. 3 to $4 \mathrm{ft} \ldots \$ 1.00$ each

vulgaris alba. Fragrant single white.

2 to $3 \mathrm{ft} . \ldots \$ 1.00$ each. 3 to $4 \mathrm{ft} . \ldots \$ 1.25$ each

French Hybrids. Own root stock. See our Special List of 100 varieties.

LONICERA (Bush, or Upright Honeysuckle).

fragrantissima (Fragrant Upright Honeysuckle). Graceful spreading habit, rich dark green foliage; fragrant flowers.

Morrowi. Pure white flowers; bright red fruit; August till late Fall.

tatarica (Tartarian Honeysuckle). Pink flowers. -alba (White Tartarian Honeysuckle).

Prices of all varieties.

2 to $3 \mathrm{ft} . \ldots \ldots \ldots \ldots \ldots .660$. each, $\$ 5.50$ for 10 3 to $4 \mathrm{ft} . \ldots \ldots \ldots \ldots \ldots .75 \mathrm{c}$. each, $\$ 7.00$ for 10

MALUS atrosanguinea (Crab). Makes a good head; covered with deep carmine flowers.

floribunda (Profuse Flowering Crab). Forms a shapely bush or small tree; bud warm red, opening to light pink, delicately shaded.

Scheideckeri (Double Flowering Crab). Has fine double flowers of a light rose color.

3 to $4 \mathrm{ft} \ldots \$ 1.50$ each 4 to $5 \mathrm{ft} \ldots \ldots 2.00$ each 5 to $6 \mathrm{ft} \ldots . . . \% 2.50$ each

PACHYSANDRA terminalis. One of the most valuable evergreen shrubs for dense shade. 6 to $9 \mathrm{in} \ldots \ldots \ldots \ldots . \$ 2.00$ for $10, \$ 18.00$ per 100

PHILADELPHUS coronarius (Common Mock Orange). Flowers pure white and very fragrant. Blooms in June.

2 to $3 \mathrm{ft} \ldots \ldots$ 60. each, $\$ 5.50$ for 10 3 to $4 \mathrm{ft} \ldots . . \ldots \ldots . . .75 \mathrm{c}$. each, $\$ 6.50$ for 10

-aureus. Foliage golden yellow; very effective. 2 to $3 \mathrm{ft} . . . \ldots \ldots \ldots \ldots . \$ 1.00$ each, $\$ 9.00$ for 10

grandiflorus. Flowers creamy white, vigorous shrub. 2 to $3 \mathrm{ft} . . .60 \mathrm{c}$. each, $\$ 5.50$ for 10 3 to $4 \mathrm{ft} \ldots \ldots \ldots \ldots \ldots .75 \mathrm{c}$. each, $\$ 7.00$ for 10

PRUNUS Pissardii (Purple-leaved Plum). Vigorous, upright growth.

3 to $4 \mathrm{ft} \ldots \ldots \ldots \ldots \ldots \$ 1.00$ each, $\$ 9.00$ for 10

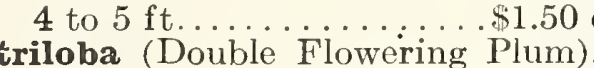

2 to $3 \mathrm{ft} \ldots \$ 1.25$ each 3 to $4 \mathrm{ft} \ldots \ldots \$ 1.50$ each

RHAMNUS cathartica (Buckthorn). A tall growing shrub or hedge plant. Lustrous green leaves and black berries follow the white flowers. Extremely hardy and very ornamental.

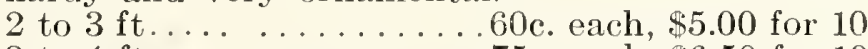
3 to $4 \mathrm{ft} \ldots \ldots \ldots . . . . . .75 \mathrm{c}$ each, $\$ 6.50$ for 10

RHODOTYPOS kerriodes (White Kerria). Showy white flowers in May followed by black berries that last all Winter. 18 to 24 in

$75 \mathrm{c}$. each, $\$ 6.50$ for 10 2 to $3 \mathrm{ft}$.

$\$ 1.00$ each, $\$ 9.00$ for 10

RHUS cotinus (Sumach) (Purple Fringe, or Smoke Tree). A curious, large growing shrub, forming broad, round headed bushes.

18 to 24 in ........... \$1.00 each, $\$ 9.00$ for 10 2 to $3 \mathrm{ft} . \ldots \ldots \ldots \ldots \ldots . \$ 1.50$ each, $\$ 13.00$ for 10 typhina (Staghorn Sumach).

3 to $4 \mathrm{ft} . \ldots \ldots \ldots \ldots \ldots . \ldots 75$. each, $\$ 6.50$ for 10 4 to $5 \mathrm{ft} \ldots \ldots \ldots \ldots \ldots \ldots \ldots 1.00$ each, $\$ 9.00$ for 10 -laciniata (Fern leaved Staghorn Sumach)

2 to $3 \mathrm{ft} . \ldots \ldots \ldots \ldots \ldots$. each, $\$ 5.50$ for 10 3 to $4 \mathrm{ft} \ldots \ldots \ldots \ldots \ldots \ldots .75 \mathrm{c}$. each, $\$ 7.00$ for 10
RUBUS odoratus (Flowering Raspberry). Clusters of beautiful pink or purple fragrant blossoms all Summer

2 to $3 \mathrm{ft}$.....60c. each 3 to $4 \mathrm{ft} . . .75 \mathrm{c}$. each

SAMBUCUS (Elder). These are large, showy shrubs, ornamental in flower, fruit and foliage; of easy cultivation.

canadensis (Common Elder).

nigra aurea. Golden yellow foliage.

2 to $3 \mathrm{ft} \ldots \ldots \ldots \ldots . . .60 \mathrm{c}$. each, $\$ 5.50$ for 10

3 to $4 \mathrm{ft} \ldots \ldots \ldots \ldots \ldots . . .75 \mathrm{c}$. each, $\$ 7.00$ for 10

SPIRAEA Bumalda. Very handsome; rose colored flowers. Dwarf. 18 in...75c. each, $\$ 6.50$ for 10

Anthony Waterer. Grows dwarf. The brighteat colored of all the Spiræas.

$11 / 2$ to $2 \mathrm{ft} . . .75 \mathrm{c}$. each 2 to $3 \mathrm{ft} \ldots . \$ 1.00$ each

opulifolia (Ninebark). Of vigorous growth, with flat cluster's of white flowers.

2 to $3 \mathrm{ft} . . . \ldots . . . . . .60 \mathrm{c}$. each, $\$ 5.50$ for 10 3 to $4 \mathrm{ft} \ldots \ldots \ldots \ldots \ldots .75 \mathrm{c}$. each, $\$ 6.50$ for 10

prunifolia fi. pl. (Bridal Wreath). Small, double, white flowers, borne close to the branches.

2 to $3 \mathrm{ft}$.....75c. each 3 to $4 \mathrm{ft} \ldots . \$ 1.00$ each

Thunbergii. Pure white flowers.

2 to $21 / \mathrm{ft}$. Pur.

Vanhouttei. Pure white flowers. Tall.

2 to $3 \mathrm{ft} . . .75 \mathrm{c}$. each 3 to $4 \mathrm{ft} \ldots . . \$ 1.00$ each

STEPHANANDRA flexuosa. The leaves are finely and delicately cut. Flowers are creamy white. 2 to $3 \mathrm{ft} . . . .75 \mathrm{c}$. each 3 to $4 \mathrm{ft}$....\$1.00 each

STYRAX japonica. Leaves resemble those of the Dogwood; flowers pure white; bell-shaped.

2 to $3 \mathrm{ft} . . . .75 \mathrm{c}$. each 3 to $4 \mathrm{ft} . \ldots \$ 1.00$ each

SYMPHORICARPOS racemosus (Snowberry) Small pink flowers in Summer, followed by large, waxy white berries in Autumn.

2 to $3 \mathrm{ft} . . . .75 \mathrm{c}$. each 3 to $4 \mathrm{ft} \ldots . . \$ 1.00$ each

vulgaris (Coral Berry). Vigorous and quick grower, covered with purple berries all Summer.

2 to $3 \mathrm{ft} . . . .60 \mathrm{c}$. each 3 to $4 \mathrm{ft} . . . .675 \mathrm{c}$. each

SYRINGA (Lilac). See Special Lilac list.

TAMARIX africana (Tamarisk). Strong, growing shrubs, with feather foliage and small, delicate flowers.

2 to $3 \mathrm{ft} . . . .60 \mathrm{c}$. each 3 to $4 \mathrm{ft}$....\$1.00 each

VIBURNUM. A very popular shrub, known as the Snowball.

dentatum. Curious dentated leaves and greenish white flowers; pretty berries in Autumn.

2 to $3 \mathrm{ft}$ 3 to $4 \mathrm{ft}$

$75 \mathrm{c}$. each, $\$ 6.50$ for 10

. May and are followed by red fruits.

2 to $3 \mathrm{ft}$.....75c. each 3 to $4 \mathrm{ft}$...\$1.00 each

Opulus (High Cranberry). Very fine in flower, and berries are scarlet. Leaves are three-lobed and coarsely toothed.

3 to $4 \mathrm{ft}$.

$75 \mathrm{c}$. each, $\$ 6.50$ for 10 4 to $5 \mathrm{ft}$

$\$ 1.00$ each, $\$ 9.00$ for 10

Opulus sterile (Snowball). A variety of the above with globes of pure white flowers in May.

3 to $4 \mathrm{ft}$

4 to $5 \mathrm{ft}$

$\$ 1.00$

WEIGELA (Diervilla). A valuable, bold, graceful shrub. Flowers trumpet-shaped, varying in color from pure white to dark red.

amabilis. Vigorous and attractive shrub, with light pink flowers.

2 to $3 \mathrm{ft} . . . .75 \mathrm{c}$. each 3 to $4 \mathrm{ft} \ldots \$ 1.00$ each candida. Flowers pure white; strong grower. 2 to $3 \mathrm{ft} . . . .75 \mathrm{c}$. each 3 to $4 \mathrm{ft} \ldots . . \$ 1.00$ each Eva Rathke. Rich reddish purple. $1 \frac{1}{2}$ to $2 \mathrm{ft} . . .75 \mathrm{c}$. each 2 to $2 \frac{1}{2} \mathrm{ft}$...\$1.00 each rosea. Handsome rose-colored flowers. 2 to $3 \mathrm{ft}$.....75c. each 3 to $4 \mathrm{ft} \ldots . . \$ 1.00$ each - nana variegata. Leaves variegated with white. 2 to $3 \mathrm{ft} . . . . . . . . . .75 \mathrm{c}$. each, $\$ 6.50$ for 10

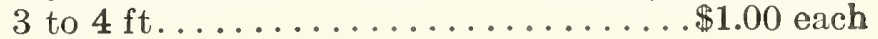




\section{Ornamental Evergreens and Conifers}

BOXWOOD (Buxus) sempervirens (Common Tree Box). A large shrub with thick, leathery dark green leaves. Bears shearing well and can be shaped in any form desired.

Bush Form. In various sizes. . $\$ 1.00$ to $\$ 15.00$ each Pyramids. In various sizes....\$7.00 to $\$ 20.00$ each BOXWOOD EDGING, Dwarf Box (suffruticosa). The well-known Box used for edging, and invaluable for that purpose.

6 in.

$\$ 20.00$ per 100 8 in

$\$ 50.00$ per 100

JUNIPERUS (Juniper) excelsa stricta. Foliage glaucous and arranged around the branches in threes, dense and prickly.

$1 \mathrm{ft} . \ldots \ldots \ldots \$ 2.50$ each $\quad 11 / 2 \mathrm{ft} \ldots \ldots \ldots \$ 3.00 \mathrm{each}$
$2 \mathrm{ft} \ldots \ldots \ldots 4.00$ each $\quad 21 / 2 \mathrm{ft} \ldots \ldots . \$ 5.00$ each $2 \mathrm{ft} \ldots . . . \$ 4.00$ each $\quad 21 / 2 \mathrm{ft} \ldots \ldots \$ 5.00 \mathrm{each}$ variety, of erect, dense, conical outline.

12 in.....\$1.50 each 18 in .....\$2.25 each

pfitzeriana. Very distinct, being of striking, graceful habit; the color bright silvery green; perfectly hardy.

18 to $24 \mathrm{in}$. .\$3.50 each 2 to $21 / 2 \mathrm{ft} . . \$ 5.00$ each sabina (Compact Savin Juniper). Low, trailing habit and fine for massing.

12 in.... \$2.00 each is in .....\$\$4.00 each

virginiana (Red Cedar). Of medium compact growth. $3 \mathrm{ft} . \ldots \ldots \ldots \$ 3.50$ each $4 \mathrm{ft} \ldots \ldots \ldots \$ 6.00$ each $5 \mathrm{ft} . . . \ldots \ldots 10.00$ each $6 \mathrm{ft} \ldots \ldots \ldots \$ 12.00 \mathrm{each}$ - glauca (Silvery Red Cedar).

$2 \mathrm{ft} . \ldots . \ldots \$ 4.00$ each $3 \mathrm{ft} . \ldots \ldots . \$ 7.00$ each

KALMIA latifolia (Mountain Laurel, or Calico Bush). 1 to $11 / 2 \mathrm{ft}$., nursery grown........\$2.50 each $11 / 2$ to $2 \mathrm{ft}$, nursery grown.......\$5.00 each 2 to $3 \mathrm{ft}$., nursery grown........\$6.00 each

Prices for carload lots of collected stock on application.

PICEA excelsa (Norway Spruce). Leaves dark green; very handsome; of pyramidal, lofty appearance. $11 / 2$ to $2 \mathrm{ft} . . \$ 2.00$ each 2 to $3 \mathrm{ft} \ldots \ldots 4.00$ each

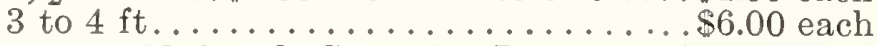
pungens (Colorado Spruce). Leaves bluish.

18 to 24 in. $\$ 5.00$ each 2 to $3 \mathrm{ft} \ldots . . \$ 7.50$ each

PINUS austriaca (Austrian Pine). A robust, stately tree of rapid growth and very hardy.

$2 \mathrm{ft} \ldots . . . \$ 3.00$ each $21 / 2 \mathrm{ft} \ldots \ldots . \$ 4.00$ each mughus (Dwarf Mugho Pine).

12 to 18 in. diam............\$3.50 each $11 / 2$ to $2 \mathrm{ft}$. diam............\$5.00 each

strobus (White Pine). One of the best native Pines; pale light green foliage.

2 to $3 \mathrm{ft} . \ldots \$ 3.50$ each 3 to $4 \mathrm{ft} \ldots \$ 5.00$ each

sylvestris (Scotch Pine). Of rapid growth, with strong branches and short, stiff, bluish-green foliage.

$2 \mathrm{ft} . . . . . \$ 3.00$ each $3 \mathrm{ft} \ldots \ldots . \$ 4.50$ each

RETINOSPORA filifera (Japanese Cedar). Threadbranched, drooping branches, bright green; very pretty.

$11 / 2 \mathrm{ft} . \ldots . \$ 3.50$ each $2 \mathrm{ft} \ldots \ldots \ldots \$ 5.00$ each -aurea. Golden; most attractive.

18 in., bushy shaped...........\$4.00 each

obtusa. Graceful tree, foliage bright clear green.

$2 \mathrm{ft} . \ldots \ldots \ldots \$ 4.00$ each $3 \mathrm{ft} . \ldots \ldots \ldots \$ 7.00$ each

pisifera (Sawara Cypress). Branches horizontal, with leaves feathery green above, whitish lines beneath.

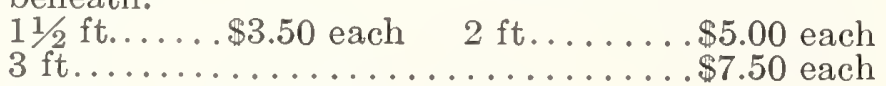

- aurea. Golden feathery foliage.

$11 / 2 \mathrm{ft} . . . \ldots \$ 3.50$ each $2 \mathrm{ft} . \ldots \ldots \ldots 5.00$ each

plumosa. Graceful habit.

$11 / 2 \mathrm{ft} . . \ldots . \$ 3.00$ each

$21 / 2 \mathrm{ft} . \ldots \ldots \$ 5.00$ each

$2 \mathrm{ft} \ldots \ldots \ldots \$ 4.00$ each $3 \mathrm{ft} \ldots \ldots \ldots \$ 7.00$ each

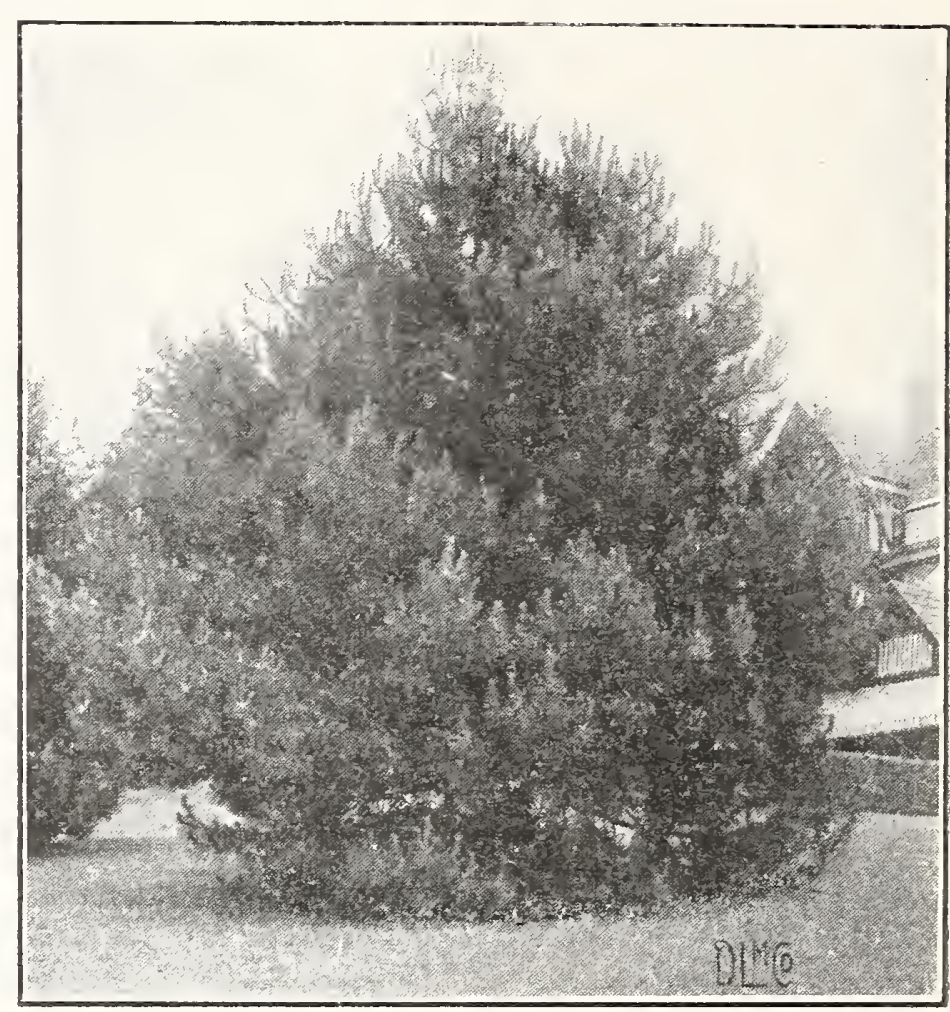

Pinus sylvestris

RETINOSPORA plumosa aurea. Golden foliage. $11 / 2 \mathrm{ft} . . . \ldots \$ 3.00$ each 2 to $3 \mathrm{ft} . \ldots \$ 5.00$ each - squarrosa veitchi. Light bluish green foliage. $11 / 2 \mathrm{ft} . \ldots \ldots \$ 3.00$ each $2 \mathrm{ft} \ldots \ldots \ldots \$ 5.00$ each

RHODODENDRONS (Hardy Hybrid Varieties). Handsome grouping and border effects can be created by using these charming hybrids.

18 to 24 in. $\$ 7.50$ each 24 to 30 in. $\$ 10.00$ each 30 to 36 in ...............\$12.00 each maximum (Great Laurel). Is admirably adapted to massing, will thrive in shady or exposed positions, and is perfectly hardy. Nursery grown.

2 to $21 / 2 \mathrm{ft}$. $\$ 5.00$ each $21 / 2$ to $3 \mathrm{ft} . \ldots \$ 7.00$ each 3 to $4 \mathrm{ft} \ldots \ldots \ldots \ldots \ldots \ldots \ldots \ldots \ldots 9 . \ldots$ each

Prices for carload lots of collected stock on application.

TAXUS baccata repandens (Yew). This is the hardiest of all prostrate varieties and will grow in almost any position. It is excellent for hedging, grouping and covering banks.

$11 / 2$ to $2 \mathrm{ft}$. diam............\$4.00 each cuspidata. Spreading form.

12 to 18 in. high.............\$3.50 each 18 to 24 in. high............ \$5.00 each

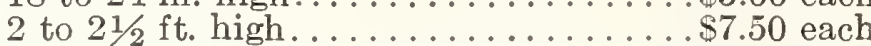

-nana brevifolia. Really an excellent Yew, with fine, spreading branches and rich deep green, short leaves. Highly recommended.

$15 \mathrm{in} . . . . \$ 3.50$ each $11 / 2 \mathrm{ft} \ldots \ldots . \$ 6.00$ each $2 \mathrm{ft} \ldots \ldots \ldots \ldots \ldots \ldots \ldots \ldots . \ldots \ldots$ each

THUJA pyramidalis (Pyramidal Arborvitae). A most valuable, upright evergreen, of dense, compact habit. Foliage light green.

$21 / 2 \mathrm{ft} . \ldots . \$ 4.00$ each 3 to $4 \mathrm{ft}$...\$\$7.00 each

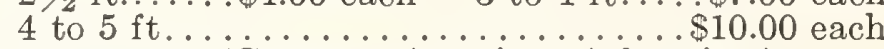
occidentalis (Common American Arborvitae) 2 to $3 \mathrm{ft} . \ldots \$ 3.50$ each 3 to $4 \mathrm{ft} \ldots \$ 5.00$ each

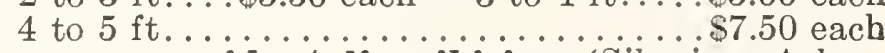
wareana occidentalis sibirica (Siberian Arborvitae). Large, bold, glaucous green foliage.

$2 \mathrm{ft} . . . . . \$ 3.50$ each $21 / 2 \mathrm{ft} \ldots \ldots . \$ 5.00$ each

TSUGA canadensis (Common Hemlock). One of the most handsome and graceful evergreens.

18 to 24 in. $\$ 3.50$ each 2 to $3 \mathrm{ft} . \ldots \$ 5.00$ each 3 to $4 \mathrm{ft} . \ldots \ldots \ldots \ldots \ldots \ldots \ldots \ldots \ldots$ each

All above prices include packing charges. 


\section{Ornamental and Shade Trees}

ACER dasycarpum (White or Silver-leaved Maple). Large sized tree, rapid grower.

8 to $10 \mathrm{ft} .11 / 4$ in. diam...........\$2.50 each 10 to $12 \mathrm{ft} ., 11 / 2$ in. diam...........\$3.00 each 12 to $15 \mathrm{ft} ., 13 / 4$ in. diam...........\$4.00 each -wieri laciniatum (Wier's Cut-leaved Silver Maple). Very beautiful variety, with delicately cut leaves and graceful drooping branches.

8 to $10 \mathrm{ft}, 11 / \mathrm{in}$. diam..........\$3.00 each 10 to $11 \mathrm{ft} ., 11 / 2$ in. diam..........\$4.00 each 11 to $12 \mathrm{ft} ., 13 / 4$ in. diam........... \$5.00 each platanoides (Norway Maple). Vigorous growing tree, of spreading rounded form.

8 to $10 \mathrm{ft} .11 / 4 \mathrm{in}$. diam..........\$5.00 each 10 to $11 \mathrm{ft} ., 11 / 2$ in. diam...........\$6.00 each 11 to $12 \mathrm{ft.}, 13 / 4$ in. diam...........\$\$ $\$ 7.00$ each saccharinum (Sugar, or Rock Maple). Of vigorous growth; more or less pyramidal form.

10 to $11 \mathrm{ft} ., 11 / 4$ in. diam............\$4.00 each 11 to $13 \mathrm{ft}, 11 / 2 \mathrm{in}$. diam...........\$5.00 each 13 to $14 \mathrm{ft} ., 13 / 4$ in. diam..........\$ $\$ 7.00$ each

AESCULUS hippocastanum (European White-Flowering Horse Chestnut). A compact, handsome tree. Foliage appears very early in Spring. 10 to $12 \mathrm{ft} ., 21 / 2 \mathrm{in}$. diam...........\$8.00 each 12 to $14 \mathrm{ft} ., 3$ in. diam.........\$10.00 each

BETULA alba laciniata (Cut-leaved Weeping Birch). Silvery white bark, graceful drooping habit of growth.

4 to $6 \mathrm{ft} . \ldots \$ 3.00$ each 6 to $8 \mathrm{ft} . \ldots \$ 4.50$ each

papyrifera (Paper, or Canoe Birch). Handsome tree; tall growing. Leaves large; bark silvery white.

6 to $8 \mathrm{ft} . \ldots \$ 3.00$ each 8 to $10 \mathrm{ft} . \ldots \$ 4.00$ each

CATALPA bungei. A rapid growing tree, with a dense mass of large, heart-shaped light green leaves. Excellent for formal effects. Handsome, globeheaded standards.

Medium heads..................\$3.00 each Large heads..................\$4.00 each

FAGUS sylvatica (European or English Beech). 3 to $4 \mathrm{ft} . \ldots \$ 2.50$ each 4 to $5 \mathrm{ft} . \ldots \$ 4.00$ each sylvatica pendula (Weeping Beech). $4 \mathrm{ft} . \ldots \ldots \ldots \$ 6.00$ each 6 to $8 \mathrm{ft} . \ldots \$ 10.00$ each - purpurea (Purple-leaved Beech).

3 to $4 \mathrm{ft} . \ldots \$ 5.00$ each 4 to $5 \mathrm{ft} . \ldots \$ 7.50$ each

FRAXINUS americana (White Ash). A splendid tall growing tree.

10 to $12 \mathrm{ft} ., 11 / 2$ in. diam..........\$3.00 each 12 to $14 \mathrm{ft} ., 2$ in. diam..........\$ \$5.00 each

GINKGO biloba (Salisburia adiantifolia) (Maidenhair Tree). A remarkable tree of spreading growth in age. Deep green, thick leaves, similar in shape to those of the Maidenhair fern. Rapid grower and very hardy.

8 to $10 \mathrm{ft} . \$ 4.00$ each 10 to $12 \mathrm{ft} \ldots \$ 5.00$ each 12 to $14 \mathrm{ft} . \ldots \ldots \ldots \ldots \ldots \ldots \ldots \ldots . \ldots \ldots$ each

LIQUIDAMBAR (Sweet Gum Tree), is native tree of rapid growth, beautiful Fall color.

4 to $6 \mathrm{ft}$...\$2.50 each 6 to $8 \mathrm{ft} \ldots . \$ 4.50$ each

LIRIODENDRON tulipifera (Tulip Tree). A noble looking pyramidal tree with clean trunk. Leaves are alternate and have long stalks.

6 to $8 \mathrm{ft} . \ldots \$ 2.50$ each 8 to $10 \mathrm{ft} . \ldots \$ 4.00$ each 10 to $12 \mathrm{ft} \ldots \ldots \ldots \ldots \ldots \ldots \ldots \ldots . \ldots \ldots$ each

MORUS pendula (Teas' Weeping Mulberry). A beautiful, hardy, ornamental tree; forms a perfect umbrella-shaped head.

5 to $7 \mathrm{ft}$., 1-yr. heads.............\$3.50 each

5 to $7 \mathrm{ft}$., strong, 2 -yr. heads.......\$\$5.00 each
PAULOWNIA imperialis (Empress Tree). A tree with immense leaves and decidedly tropical appearance, bearing very large panicles of blue trumpet-shaped flowers.

6 to $8 \mathrm{ft}$...\$3.00 each 8 to $10 \mathrm{ft} \ldots \$ 4.00$ each

PLATANUS orientalis (Oriental Plane). A superb tree of gigantic proportions, extensively used in Europe, for park, street and avenue planting.

8 to $10 \mathrm{ft}, 11 / 4 \mathrm{in}$. diam........... \$3.50 each 10 to $11 \mathrm{ft} ., 11 / 2$ in. diam..........\$5.00 each 11 to $12 \mathrm{ft} ., 13 / 4$ in. diam..........\$6.00 each

POPULUS carolinensis, syn. monolifera (Carolina Poplar). Rapid grower; very valuable for screening.

8 to $10 \mathrm{ft} . . \$ 1.50$ each 10 to $12 \mathrm{ft} . . \$ 2.25$ each 12 to $14 \mathrm{ft} . \ldots \ldots \ldots \ldots \ldots \ldots \ldots \ldots . \ldots \ldots$ each

fastigiata, or dilatata (Lombardy, or Italian Poplar). An ornamental and picturesque tree.

8 to $10 \mathrm{ft.,} 1 \mathrm{in}$. diam............\$1.50 each 10 to $12 \mathrm{ft} ., 11 / 2$ in. diam............. \$2.25 each 12 to $14 \mathrm{ft} ., 13 \frac{1}{4}$ in. diam...........\$3.50 each

QUERCUS americana rubra (American Red Oak). Beautiful tree of rapid growth.

8 to $10 \mathrm{ft} ., 11 / 2$ in. diam..........\$5.00 each 10 to $12 \mathrm{ft} ., 2$ in. diam............\$8.00 each

palustris ( $P$ in Oak). A superb and very distinct tree, with graceful drooping branches.

$8 \mathrm{ft} .11 / 4$ in. diam. .......... $\$ 5.00$ each 8 to $10 \mathrm{ft} ., 11 / 2$ in. diam...........\$6.00 each 10 to $12 \mathrm{ft} ., 2$ in. diam........... \$8.50 each

SALIX babylonica (Babylonian, or Weeping Willow). A well known and graceful variety.

6 to $8 \mathrm{ft} \ldots \$ 1.75$ each 8 to $10 \mathrm{ft} \ldots \$ 2.50$ each 10 to $12 \mathrm{ft} \ldots \ldots \ldots \ldots \ldots \ldots \ldots . \ldots . \ldots$ each

caprea (Pussy Willow).

3 to $4 \mathrm{ft} . \ldots \$ 1.00$ each 4 to $6 \mathrm{ft} \ldots . \$ 1.50$ each elegantissima (Thurlow's Weeping Willow). Long, spreading branches, beautifully drooping.

6 to $8 \mathrm{ft}$...\$1.50 each 8 to $10 \mathrm{ft} \ldots \$ 2.00$ each 10 to $12 \mathrm{ft} \ldots \ldots \ldots \ldots \ldots \ldots \ldots \ldots \ldots . \ldots \ldots$ each

pentandra (Laurel-leaved Willow). Broad glossy dark green leaves.

4 to $6 \mathrm{ft} \ldots \$ 1.00$ each 6 to $8 \mathrm{ft} . \ldots \$ 1.50$ each

SORBUS aucuparia (Mountain Ash). A fine tree, dense and regular; covered all Summer with greàt clusters of scarlet berries.

5 to $6 \mathrm{ft} \ldots \$ 2.50$ each 6 to $8 \mathrm{ft} \ldots . \$ 3.50$ each pendula (Weeping Mountain Ash).

$6 \mathrm{ft}$. stems, 3-yr. heads.........\$5.00 each

TILIA argentea (White, or Silver Linden). Distinct ornamental shade tree.

8 to $10 \mathrm{ft}$., $11 / 2 \mathrm{in}$. diam..........\$5.00 each 10 to $12 \mathrm{ft} ., 13 / 4$ in. diam...........\$6.50 each 12 to $14 \mathrm{ft} ., 2$ in. diam............ $\$ 7.50$ each platyphyllos (Broad-leaved European Linden).

9 to $10 \mathrm{ft}, 11 / 2 \mathrm{in}$. diam........... \$4.50 each 10 to $12 \mathrm{ft} ., 13 / 4$ in. diam............ $\$ 6.00$ each 12 to $13 \mathrm{ft.,} 2$ in. diam..........\$7.50 each vulgaris (European Linden).

10 to $11 \mathrm{ft} ., 11 / \mathrm{in}$. diam..........\$4.50 each 11 to $12 \mathrm{ft} ., 13 / 4$ in. diam............ $\$ 6.00$ each 12 to $14 \mathrm{ft} ., 2$ in. diam..............\$7.50 each 14 to $15 \mathrm{ft} ., 2 \frac{1}{2}$ in. diam......... \$10.00 each Specimens...........\$15.00 to $\$ 20.00$ each

ULMUS americana (American White, or Water Elm). Very tall growing and stately.

8 to $10 \mathrm{ft}, 11 / 4 \mathrm{in}$. diam..........\$3.50 each 10 to $12 \mathrm{ft} ., 13 / 4$ in. diam............. $\$ 5.00$ each

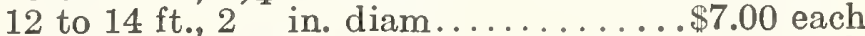
14 to $15 \mathrm{ft}, 21 / 2 \mathrm{in}$. diam..........\$9.00 each 


\section{FRUIT TREES}

Planting.-Make the holes large enough to admit the roots without cramping or bending, and deep enough to set the trees to their natural depth. Fine surface soil should be used for covering the roots, and this should be carefully mixed among them. If the ground is dry, it is well to pour in some water when the hole is partially filled. See that the ground is firmly and solidly packed over all parts of the roots. Fill the holes full enough to be even with the surrounding surface after the fresh earth settles. Never use manure in contact with the roots.

\section{SUMMER VARIETIES}

*Early Harvest. Medium, yellow.

*Red Astrachan. Small, red.

* Yellow Transparent. Large, yellow.

*Baldwin. Medium, red.

Greening. Large, greenish.

King. Large, red.

McIntosh. Large, red.

Prices on above standard trees, 1 -in. diameter, $\$ 2.00$ each; 11/4-in., $\$ 3.00$ each; $1 \frac{1}{2}$-in., $\$ 4.00$ each; larger specimens, $\$ 6.00$ to $\$ 10.00$ each.

Varieties marked with a star (*) can be supplied in Dwarf trees at the above prices.

\section{WINTER VARIETIES}

*Farmeuse. Medium, black red.

Gravenstein. Large, yellow and red.

*oldenburg. Large, red striped.

* Northern Spy. Medium crimson.

*Peasgood Nonsuch. Large, red.

Russet. Medium, russet.

*Spitzenburg。 Large, red.

\section{APPLES}

\section{PEARS}

*Bartlett. Large, early.

*Beurre d'Anjou. Large, late.

Comice. Very large, late.

Duchess. Large, late.
Louis Bonne. Large, early.

Kieffer. Large, late.

Seckel. Small, late.

Beurre Diel. Very large, late.

Prices on above standard trees, 1 -in. diameter, $\$ 2.00$ each; 11/2-in., $\$ 3.00$ each; 2 -in., $\$ 5.00$ each.

Varieties marked with a star (*) can be supplied in Dwarf trees at the above prices.

\section{GHERRIES}

Black Tartarian. Sweet, late June.

May Duke. Dark red, sour. June.

Prices, 1-in. diameter, $\$ 2.00$ each; 11/4-in. diameter, $\$ 3.00$ each.

Montmorency. Red, sour. June.

Napoleon. Yellow, sweet. July.

\section{PEACHES}

Belle of Georgia. White Freestone. July.

Champion. White Freestone. Aug.

Stump of the World. White Freestone. Sept.

Mountain Rose. White Freestone. Aug.

Early Crawford. Yellow Freestone. Aug.

Late Crawford. Yellow Freestone. Aug.

Elberta. Yellow Freestone. Aug.

Carmen. White Freestone. Aug. Prices of above, $5 / 8$-in. diameter, 75 c. each; $3 / 4$-in. diameter, $\$ 1.00$ each.

\section{PLUMS}

Bradshaw. Large, dark red. August.

Coe's Golden Drop. Large, yellow, late.

Damson. Small, purple. Sept.

Prices of above, 11/4-in. diameter, $\$ 2.00$ each; 11/2-in. diameter, $\$ 3.00$ each.

\section{QUINGES}

Champion. Yellow. November.

Orange. Golden. November.

Prices of above, $5 / 8$-in. diameter, $\$ 1.50$ each; $3 / 4$-in. to 1 -in. diameter, $\$ 2.00$ each.

\section{NUTS}

Butternut. 4-6 ft., $\$ 1.50 ; 6-8 \mathrm{ft} ., \$ 2.00 ; 8-10 \mathrm{ft}$, $\$ 3.50$.

Chestnut (American). 3-4 ft., \$1.25.

Pccan. $3-4 \mathrm{ft} ., \$ 1.50 ; 4-6 \mathrm{ft} ., \$ 2.00$.

Talnut, Black. $3-4 \mathrm{ft} ., \$ 1.50 ; 4-6 \mathrm{ft} ., \$ 2.00$.

Walnut, English. $3-4 \mathrm{ft} ., \$ 2.00$.

Hickory. $4-5 \mathrm{ft} ., \$ 2.00$.

Walnut, Japan. $4-6 \mathrm{ft} ., \$ 2.00 ; 8 \mathrm{ft}$., $\$ 3.00$.

\section{Deciduous Hedge Plants}

BERBERIS Thunbergii (Japanese Barberry). 9 to 12 in., 2 year old, 25 for $\$ 5.00,100$ for $\$ 18.00 ; 12$ to 18 in. 3 year heavy, 25 for $\$ 11.00,100$ for $\$ 40.00$; 18 to 24 in., 2 year old, 25 for $\$ 11.00,100$ for $\$ 40.00 ; 18$ to 24 in., 3 year heavy, 25 for $\$ 16.00,100$ for $\$ 60.00$.

LIGUSTRUM Ibota (New Japanese Privet). Large, glossy, distinct foliage. $11 / 2$ to $2 \mathrm{ft}$., bushy, 25 for $\$ 5.50$, 100 for $\$ 20.00 ; 2$ to $3 \mathrm{ft}$., bushy, 25 for $\$ 7.00,100$ for $\$ 25.00 ; 3$ to $4 \mathrm{ft}$., bushy, 25 for $\$ 10.00,100$ for $\$ 35.00$. ovalifolium (California Privet). Large, glossy, dark green foliage; one of the most popular hedge plants. Rugged and enduring in almost any situation; retains its foliage until late in Winter. $11 / 2$ to $2 \mathrm{ft}$., bushy, 25 for $\$ 2.50$, 100 for $\$ 8.00 ; 2$ to $3 \mathrm{ft}$., bushy, 25 for $\$ 3.50,100$ for $\$ 12.00 ; 3$ to $4 \mathrm{ft}$., bushy, 25 for $\$ 4.00,100$ for $\$ 15.00$.

amurense (Amoor River Privet). Large, oblong, glossy green foliage and clusters of white, fragrant flowers; half evergreen. A variety of sterling merit; useful for hedges. 2 to $3 \mathrm{ft} ., 25$ for $\$ 7.00,100$ for $\$ 25.00 ; 3$ to 4 ft., 25 for $\$ 11.00,100$ for $\$ 40.00$. 


\section{SMALL FRUITS}

\section{BLACKCAPS}

Black Diamond. Very large; ripens early; very sweet Yand of fine flavor. Pulpy, few seeds.

Cumberland. Very large, glossy berries; firm, juicy and sweet. Heavy cropper. $\$ 1.25$ for $10, \$ 8.00$ per 100 .

\section{BLACKBERRIES}

Eldorado. Medium size; jet-black; pleasant, melting flavor, sweet and rich. The vine is very hardy and productive.

Kittatinny. Large; glossy black; sweet and juicy; excellent when fully ripe; fine for dessert or preserving.

Strong plants, $\$ 1.25$ for $10, \$ 8.00$ per 100 .

\section{CURRANTS}

Cherry. Bush vigorous, stocky and compact; fruit large; color bright red; berry thin-skinned, juicy and fine flavored.

Fay's Prolific. A popular red Currant; very large and sweet. Productive.

Perfection. Bush vigorous, hardy and very productive; berries larger than Cherry, with large clusters; color bright red.

White Grape. An excellent white variety; of large size; very sweet.

Strong, 2-year-old bushes, 45 c. each, $\$ 4.00$ for 10 .

\section{GOOSEBERRIES}

Josselyn. Large red fruit.

Smith's Improved. Fruit greenish yellow.

Triumph. Fruit golden yellow.

2-year-old bushes, 50c。 each, $\$ 4.50$ for 10 .

\section{Grapes}

\section{BLACK GRAPES}

Campbell's Early. Handsome black berries, with purple bloom; rich.

Concord. Fine black variety; splendid flavor; reliable and productive; one of the most popular.

Eubbard. Black, sweet and delicious. Berries and bunch large. 2-year-old. 75c. each.

Moore's Early. Bunch medium; berry very large, with heavy blue bloom; good quality.

\section{RED AND REDDISH PURPLE GRAPES}

Agawam. Large bunches; red berries, tender and juicy. Good bearer. Ripens early.

Brighton. Flesh rich, sweet and of the best quality; ripens early, with the Delaware. Very productive.

Caco. Large, wine red in color, bunches good size and extra good quality. Each, 1-year, 75c.; 2-year, $\$ 1.25$.

Catawba. Bunches large and loose; berries large coppery-red, becoming purple when well ripened.

Moyer. Cluster has large berries and ripens early.

\section{WHITE GRAPES}

Champagne. Very large amber berry. Fine for dessert or making wine. Each, 2-year-old, 75c.

Duchess. Bunch medium to large, long and compact; berries medium, roundish; skin thick, greenish yellow when ripe, juicy and sweet.

Empire State. Bunch large; berry medium to large; flesh tender, sweet and juicy.

Niagara. Bunch medium to large; berry large, roundish, uniform; skin thin, with a thin, whitish bloom; flesh slightly pulpy; tender and sweet.

Extra strong, 3-year-old canes, 50c. each, $\$ 4.50$ for 10 .

\section{Foreign Pot-Grown Grape Vines \\ BLACK VARIETIES}

Black Hamburg. erries large, juicy and rich. Golden Hamburg. Large, oval, golden berries. Gros Colman. Large bunches of fine berries. Madrisfield Court. Large berries, rich Muscat flavor.

\section{WHITE VARIETIES}

Foster's White Seedling. Full size oval berries. Muscat of Alexandria. Best white variety. Strong fruiting canes, 2-year-old, $\$ 5.00$ each; 3-year-old, $\$ 7.00$ each.

\section{LOGANBERRIES}

Fruit similar to the Blackberry; color dark bright red; excellent for table and canning. Strong plants, $50 \mathrm{c}$. each, $\$ 4.50$ for 10 .

\section{RASPBERRIES}

Cuthbert. Deep, rich crimson.

Golden Queen. Large, amber-color, firm; fine quality. Remarkably productive.

Herbert. Very large berry and a heavy cropper. It has a distinctly rich flavor and is all meat.

St. Regis (Perpetual). Bright crimson; large berries all through Summer and Fall.

Strong plants, 2-year-old, $\$ 1.25$ for $10, \$ 8.00$ per 100 .

La France. The giant everbearing red Raspberry. Strong canes, $\$ 3.00$ for $10, \$ 25.00$ per 100 .

The Latham. Without doubt the best red Raspberry to plant today. Berries large in size and a rich red color, maturing very early. Canes hardy in northern latitudes. $\$ 3.00$ for $10, \$ 25.00$ per 100 .

\section{Strawberry Plants}

For full description see our Special Strawberry List.

Barrymore, Brandywine, Campbell's Early, Gandy, Glen : Mary, Hundred Dollar, Joe, McKinley, Marshall, New York, Nick Ohmer, Premier, Success, Stevens' Late Champion.

Layer plants of above, 60c. for 25, \$2.00 per 100 .

Chesapeake, Early Jersey Giant, Lupton, Howard No. 17, John H. Cook, William Belt.

Layer plants, 75c. for $25, \$ 2.50$ per 100 .

Bushel Basket, Edmund Wilson, St. Martin. Pearl. Layer plants, $\$ 1.25$ for $25, \$ 4.00$ per 100 .

\section{EVERBEARING STRAWBERRIES}

If planted in Spring, a good crop of fruit will be picked in Fall.

Progressive. $\$ 1.00$ for $25, \$ 3.00$ per 100 .

Francis, Ideal, Superb. $\$ 1.25$ for $25, \$ 4.00$ per 100 , Lucky Boy. $\$ 2.00$ for 25, $\$ 6.00$ per 100 .

\section{WINEBERRIES}

A very hardy and vigorous berry. Large clusters of scarlet wine colored fruit. Strong plants, $\$ 1.50$ for 10 . 


\section{Horticultural ToOls AND ReQuisites}

APRONS, Gardener's Waterproof, with bib; 34 in. long, 26 in. wide. Each \$1.50.

Gardener's. Blue drill with bib. Each \$1.25.

Gardener's Rubber. Extra heavy, each $\$ 4.00$.

English Blue Serge. Each $\$ 3.50$.

English Blue Serge. With bib and pocket. Each $\$ 4.00$.

ASPARAGUS BUNCHER.

Useful on all private estates.

It will not bruise the grass,

is easily and quickly adjusted

to any length. Double band

springs and knife guard.

Each $\$ 4.50$

ASPARAGUS KNIVES, English. Each \$3.50.

ASPARAGUS KNIVES, American. Each 50c.

AXES, Felling. With handle, $\$ 3.00$ to $\$ 3.50$.

BASKETS, Hanging, Wire. Painted, 8 in. $35 \mathrm{c.}$ 10 in. 40 c., 12 in. 50 c., 15 in. 60 c., 18 in. $\$ 1.00$ 21 in. $\$ 1.35$ each.

BELLOWS, Duster No. 600. Made with 12 in. handles and cone-shaped distributor. Each $\$ 1.75$.

BELLOWS, Powder.

Small, Single Cone.

Each $\$ 3.00$.

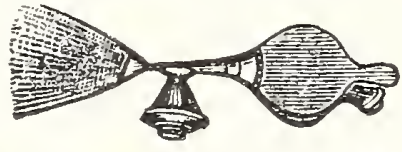

Large, Single Cone. Each $\$ 5.00$.

Double Cone. Each \$6.50.

"JUMBO" POWDER GUN. Each 40c.

BLAKE'S LEVER CLIPS. For fastening Rose wires. Per box of $500, \$ 1.75$.

BOXES, Corrugated. Extra strong for shipping cut lowers.

$\begin{array}{lrl}\text { Lengt } & \text { Width } & \text { Depth } \\ 24 \mathrm{in.} & 8 \mathrm{in.} & 4 \mathrm{in} . \\ 28 \mathrm{in.} & 8 \mathrm{in.} & 5 \mathrm{in} . \\ 30 \mathrm{in.} & 12 \mathrm{in.} & 6 \mathrm{in.} \\ 36 \mathrm{in.} & 12 \mathrm{in.} & 8 \mathrm{in} . . \\ 48 \mathrm{in.} & 14 \mathrm{in.} & 8 \mathrm{in} . .\end{array}$

Extra staples, 25c. per 100.

Doz. 100

$\$ 4.00 \$ 30.00$

$4.50 \quad 35.00$

$5.00 \quad 40.00$

$7.00 \quad 55.00$

$9.50 \quad 70.00$

BOXES, Folding. For cut flowers. Made of strong

$\begin{array}{lllll}\text { Doz. } & 100 \\ \text { No. } 2 & 18 \text { in. } 5 \text { in. } 3 \text { in. deep. . . \$0.75 } & \$ 4.00\end{array}$

No. 521 in. 7 in. $31 / 2$ in. deep.... $1.00 \quad 6.00$

No. 824 in. 8 in. 4 in. deep.... 1.508 .00

No. $1128 \mathrm{in.} 8 \mathrm{in.} 5$ in. deep.... 2.0012 .00

No. 1936 in. 8 in. 5 in. deep... 2.50 15.00

BOXES, Flower, Fiber or Leatheroid. Used for shipping cut flowers or fresh vegetables by express. Lock and keys with each case.

Each

30 in. $x 14$ in. $x 16$ in. with 3 wicker trays... $\$ 45.00$

34 in. $x 15$ in. $x 16$ in. with 3 wicker trays... 47.50

38 in. $x 16$ in. $x 16$ in. with 3 wicker trays... 50.00

BROOMS, Birch. For lawns. Each 75c.

Barn or Floor. Corn with rattan center. Each $\$ 1.60$.

Kongo. Coir bass. Made with coir fiber. Each $\$ 2.00$.

Rattan Stable or Push. 16 in., extra quality. Each $\$ 2.00$.

Tennis Court. Made with fiber, 36 in. long, for dragging dirt courts, Each $\$ 6.00$.

BRUSHES, Flower Pot, Cone-Shaped. Made of - bristle, wood handle. Each \$1.75.

BRUSH HOOKS. With handle. Each $\$ 3.00$

BURLAP. In 36-in., 42-in. or 48-in. widths. Per yd. 25c. Price subject to market change.

CANES, Bamboo. Doz.

Green, 21/2 ft., Japanese....... \$0.15

Green, 3 ft., Japanese........... .20

Green, 4 ft., Japanese......... .20

Green, $5 \mathrm{ft}$. Japanese......... .25

Natural, 6 ft., Japanese.......... .30

Japanese, heavy, $8 \mathrm{ft}$........... .50

Japanese, heavy, $10 \mathrm{ft} . \ldots \ldots \ldots . .60$

$100 \quad 1000$

$\$ 1.00 \$ 7.00$

$1.25 \quad 10.00$

$1.50-12.00$

$2.00 \quad 15.00$

2.0016 .00

$4.00 \quad 35.00$

$5.00 \quad 40.00$
CANES, Chinese Bamboo.

$4 \mathrm{ft}$. long, $1 / 4$ in. diam................ $\$ 2.00$

$4 \mathrm{ft}$. long, $1 / 2$ in. diam................ 4.00

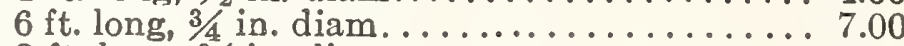

$8 \mathrm{ft}$. long, $3 / 4$ in. diam................ 8.00

$9 \mathrm{ft}$. long, $3 / 4$ to $7 / 8$ in. diam.......... 16.00

$6 \mathrm{ft}$. long, 11/2 in. diam. for Dahlias; doz. $\$ 4.50 .35 .00$

CARNATION BANDS, Rubber.

30c. per oz.

CARNATION STAPLES. For split Carnations. $100050 \mathrm{c}$.

Cokely's Staples. $\$ 1.00$ per 1000.

Cokely's Pliers for the above. Each $\$ 3.00$.

CARNATION SUPPORTS.

"Model Extension." Made with strong galvanized wire, neat and durable. Doz. 100 Wire, 2 ring........\$1.25 $\$ 7.50$ Wire, 3 ring............ $1.25 \quad 8.50$

CELER Y BLEACHERS. $6 \frac{1}{2} \times 13$ in. Doz. 60c., $100 \$ 4.50$

Celery Handler for above. Each $\$ 1.50$.

CELERY BLEACHING PAPER. Flexible, odorless and waterproof, in rolls of $100 \mathrm{ft} .12 \mathrm{in.} \mathrm{wide.} \mathrm{Per} \mathrm{roll,} \mathrm{in-}$ cluding 25 42-in. wire arches, $\$ 5.00$; Roll holders, each $\$ 1.50$.

CEL-O-GLASS. A high-grade substitute for glass. Adapted for coldframes, hotbed, sash, etc. Made with wire mesh cloth, transparent and indestructible. In rolls 36 in. wide and any length desired. Per sq. ft. $25 \mathrm{c}$. In rolls of $300 \mathrm{sq}$. ft., $18 \mathrm{c}$. per $\mathrm{ft}$.

COTTON BATTING. Large sheets, $40 \times 40$ in. Doz. sheets $\$ 1.00$.

CORK BARK. For rustic work. Lb. 40c.

CUCUMBER GLASSES, English. Each \$2.50.

CULTIVATORS. (See pages 83, 88, 89.)

DIBBLES. Iron point, with wood handle, for transplanting. Small, 65c.; large, 75c.

\section{DIRT BANDS, Harris Square}

Locked. Used for transplanting seedling plants.

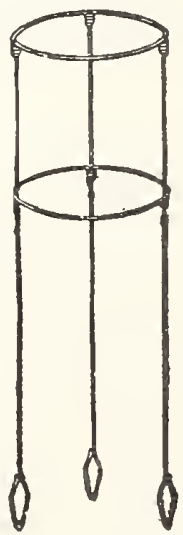
B, size $2 \times 2$, depth $21 / 2$ in ...... $.60 \quad 4.00$

No. 3 B, size $3 \times 3$, depth 3 in....... . .70 5.00

No. $4 \quad B$, size $4 \times 4$, depth 3 in........... $.75 \quad 5.50$

FIBER. Peat in bales. Each $\$ 1.50$ and $\$ 4.00$.

FLOWER POTS, Standard Earthenware.

We pack carefully but are not responsible for breakage in transit. All earthernware pots are shipped by freight only.

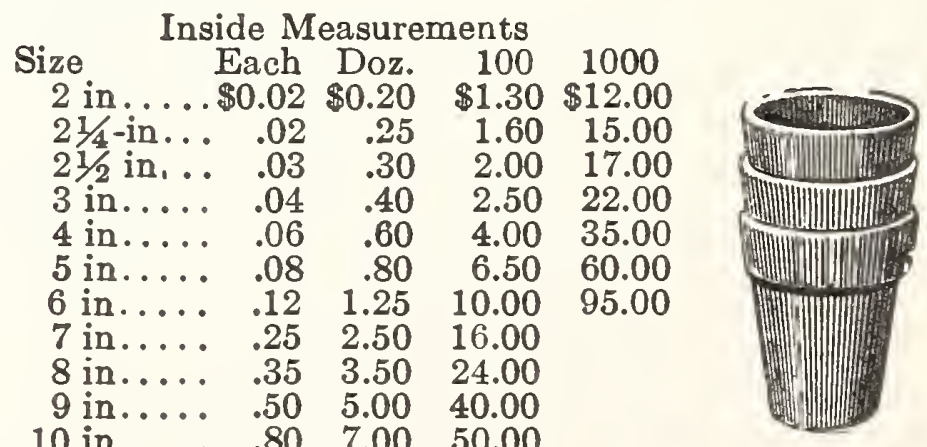

(1000 100.00

FLOWER POT SAUCERS, Earthenware.
Size Each Doz.
Size Each Doz. 4 in .....\$ \$0.04\$0.40
5 in....... .05 .50
6 in....... $.06 \quad .70$
7 in...... . 10 90
8 in ....... $\quad .12 \quad 1.10$
9 in ......\$0.14 $\$ 1.40$
10 in ....... $\quad .17 \quad 1.70$
11 in......... $\quad .22 \quad 2.20$
12 in...... .28 2.70
$14 \mathrm{in} . . . . . \quad .40 \quad 4.00$ 


\section{HORTICULTURAL TOOLS AND REQUISITES-Continued}

AZALEA POTS.

Wide Deep

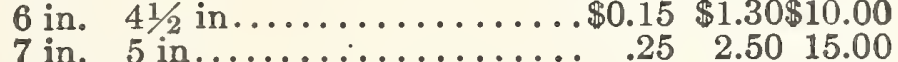

8 in. 6 in....................................... $30 \quad 3.0022 .00$

9 in. 7 in..................... $50 \quad 5.0040 .00$

10 in. 8 in............................. $70 \quad 7.00 \quad 50.00$

ROUND BULB OT LILY PANS.

Wide Deep

1. $3 \%$ in............... \$0.15 \$1.50\$10.00

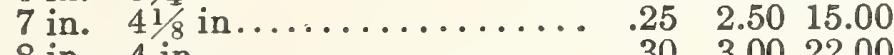

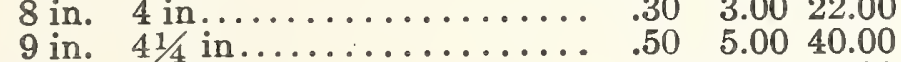

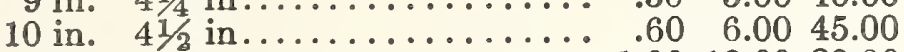

12 in. $4 \frac{3}{4}$ in................... 1.0010 .0080 .00

NEPONSET WATERPROOF PAPER FLOWER

POTS. Made of waterproof paper and are light, clean and unbreakable.
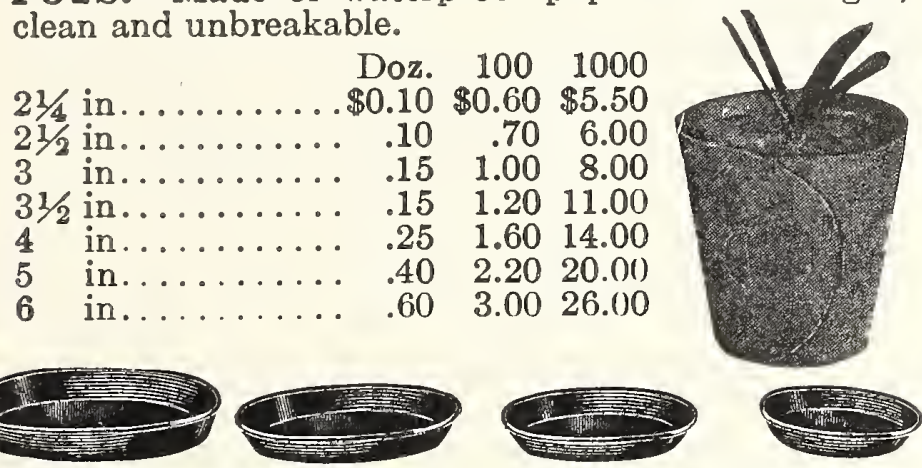

METAL FLOWER POT SAUCERS. Made with heavy metal, painted green, waterproof and unbreakable.

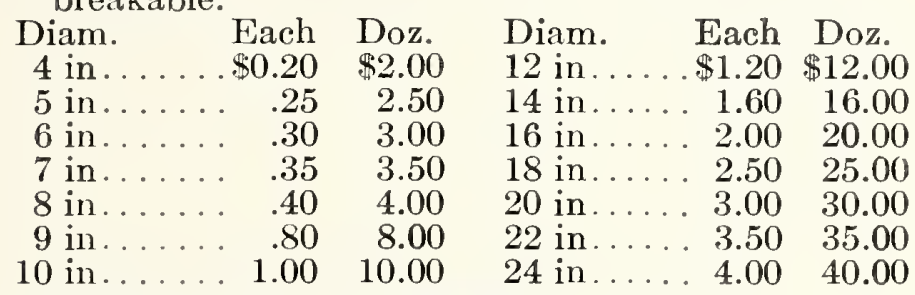

FLOWER POT SAUCERS

Indurated Wood Fiber. Very light and durable. Not porous and will protect tables on which plants stand. Each Doz. Each Doz. 5 in . . . . \$0.40 \$4.00 14 in . . . \$0.90 $\$ \$ 9.00$ 18 in above are the only sizes obtainable.

FLOWER VASES, Fiber and Metal. See page 84 .

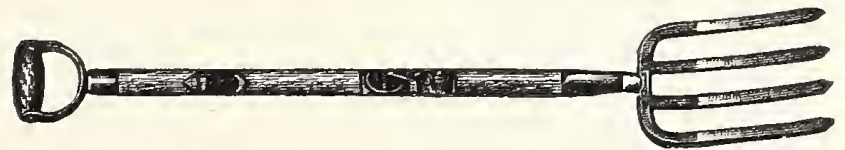

\section{FORKS.}

Digging or Spading, "Keen-Kutter," Each

4-tine, long or short handle.......... \$2.50 English, 4 square tine, short handle........ 3.50

Best Steel. 4-tine, long or short handle..... 2.25 5-tine, short handle................ 3.00

Manure. 4-tine, short handle........... 2.50

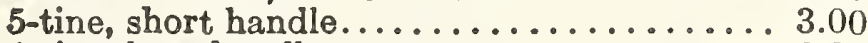
4-tine, long handle.................. 3.00

Transplanting, Johnson's. 3 tine, length over all 11 in. Each 60c.

Transplanting. Malleable. Each 35c.

FRUIT PICKERS. Galvanized wire, "Perfect." Each. 60c.

FUMIGATOR, "EUREKA," For fumigating with tobacco stems.

No. 2, holds 1 pk. stems.........\$3.25

No. 3 , holds $1 / 2$ bus. stems........ 4.00

FUMIGATING LAMP, "Defiance." For nicoticide, nico-fume liquid, etc. No glass, burns kerosene oil. $\$ 1.00$.
FUMIGATOR, SULPHUR, Camplell's Patent. Designed to vaporize sulphur in greenhouses without danger of the sulphur taking fire or disfiguring the foliage.

No. 1, for houses up to $5,000 \mathrm{cu}$. ft., each $\$ 7.50$. No. 2, for houses up to $10,000 \mathrm{cu}$. ft., each 10.50 . Glass Balls for above, each 10c.

Yellow powder for above. Per can 25c.

Metal containers for above. Each \$4.00.

FUMIGATOR, $\mathbf{X}$. L. Lamp and stand, $\$ 2.00$. Glass lamps, separate, each 60c. Extra wicks, each $10 \mathrm{c}$.

GARDENER'S GLOVES, Hog Skin. With or without gauntlets. Per pair $\$ 1.75$.

Horse Hide. Best quality, with gauntlets. Per pair $\$ 2.00$.

GARDEN LINES. Finest braided hemp. $100 \mathrm{ft}$. $\$ 1.75,200 \mathrm{ft}$. $\$ 3.50$.

GARDEN PENCILS. Indelible black. Each 15c.

GARDEN REELS for above of wrought iron. Small $\$ 1.75$; large $\$ 3.00$.

GLASS

CUTTERS.

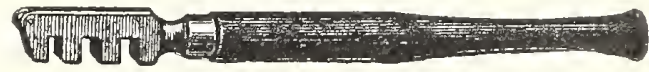

"Red Devil." No. 023, 25c.; No. 3 in 1, 60c., No. 45 , with 6 extra cutters $75 \mathrm{c}$.

Diamond. High quality finish. Each \$7.50.

GLASS FOR GLAZING SASH. Box of 50 sq. ft. Market price.

GLASSES, Magnifying. Each $\$ 1.00$.

GLASS CLOTH. For using on hotbeds or sash in place of glass. $36 \mathrm{in}$. wide, 1 to 10 yards, $45 \mathrm{c}$. per yard: 11 to 25 yards, $40 \mathrm{c}$. per yard; 25 to 50 yards, 38c. per yard; 50 to 100 yards, 35c. per yard.

GLAZING POINTS, "Peerless." 1000 80c.

GLAZING POINT PLIERS for the above. Ea. 60c. GLAZING POINTS, Zinc. $5 / 8$ in. or $3 / 4$ in. Box $60 \mathrm{c}$.

GRAFTING WAX. For grafting cuts and bruises on trees. $1 / 4 \mathrm{lb}$. $15 \mathrm{c}, 1 / 2 \mathrm{lb} .25 \mathrm{c}, \mathrm{lb}$. $40 \mathrm{c}$.

GRAPE BAGS, Paper. Made with patent metal clasp. $10075 \mathrm{c} ., 1000 \$ 6.00$. With string, 100 $\$ 1.50,1000 \$ 12.00$.

GRASS EDGING KNIVES. See knives. Page 78.

\section{GRASS HOOKS} or SICKLES.

Best English welded back.

Each

No. 2, medium............\$1.00

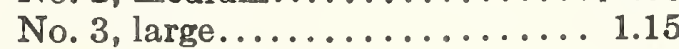

American, large size......... .35

GRASS SHEARS. See Shears.

HAMMERS, GARDEN. With claw. Each \$2.00. HAMPERS, Willow. For shipping vegetables. Size $30 \times 17 \times 17$ in. Each $\$ 25.00$.

HATCHETS. With claw. Each $\$ 2.00$.

HEDGE TRIMMER. See page 87.

HOES, DRAW. With handles. 5 in. $\$ 1.00,6$ in. $\$ 1.10,7$ in. $\$ 1.20,8$ in. $\$ 1.30$.

HOES, SCUFFLE, or DUTCH. English make. Handles, 50c. extra.
4 in... $\$ 1.00$
5 in ... 1.10
6 in.... 1.20
8 in....\$1.40
9 in.... 1.50
10 in.... 1.60
7 in.... 1.30 12 in.... 1.75

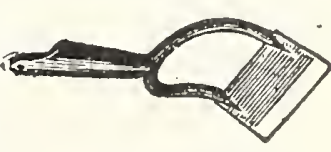

HOES, American Scuffe. 7 in. with handles, $\$ 1.35$.

HOES, WARREN. Heart-shaped, $71 / 2$ in., $\$ 1.75$. 


\section{HORTICULTURAL TOOLS AND REQUISITES-Continued}

FORSE BOOTS. For lawns; made of heavy leather. Medium size, set of four, $\$ 18.00$; large size, $\$ 20.00$ Baker's Metal. See page 94. $\$ 10.00$.

HOSE BANDS. Made of brass wire. For putting on couplings. Doz. 35c.

HOSE PLIERS for the above. Each 50c.

HOSE CLAMPS. Bolt pattern. Doz. 60c.

HOSE COUPLINGS. Brass for $1 / 2$ in. or $3 / 4$ in. hose. Each 20c.

Clincher Style. $1 / 2$ in. or $3 / 4$ in. Each 30 c.

HOSE CONNECTION. Gooseneck for connecting hose to faucet. Each $\$ 1.00$.

HOSE CONNECTION. Siamese for connecting two leads of hose. Each \$1.75.

HOSE HOLDER. Gem. For holding hose when watering. Each 30c.

HOSE HYDRANT ATTACHMENT. Used for connecting hose to smooth faucets. Brass, each $35 \mathrm{c}$.

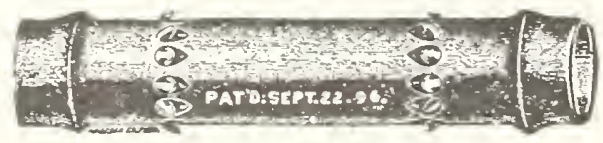

HOSE MENDERS.

"Cooper's." (See cut.) Brass, 1/2 or

$\$ 0.15 \$ 1.50$

"The Perfect Clinching." $1 / 2$ or $3 / 4$ in. . .20 2.00

HOSE NOZZLES.

"Aquamatic." For sprinkling gardens, washing automobiles, etc. Wastes no water. Spray or stream. Each $\$ 2.00$. Nozzles only, each $40 \mathrm{c}$.

"Gem," or "Graduating." $3 / 4$-in. hose. Can be regulated to give three different streams. Each 60c.

Hose Rose. Made with brass for 3/4-in. hose. 3-in face $\$ 1.50,4$-in. face $\$ 1.75$.

"Hose Rose," or "Boston Spray." With coarse or fine spray, for $3 / 4$-in. hose. Each $\$ 1.50$.

Magic Spray Pipe. A spray, stream or shutoff combined. All brass. Each $\$ 1.00$.

"Newport or Knox." Fine for spraying under the foliage or sprinkling. Each $\$ 1.50$.

Rain King. Coarse or fine spray with only a slight turn of nozzle. Each $\$ 1.50$.

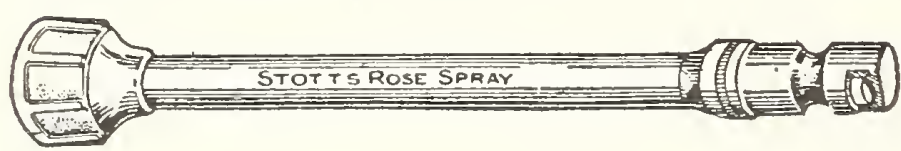

Stott's. A favorite among Rose growers. Single, spray, each $\$ 1.75$, double spray $\$ 3.00$.

"The Boss." Spray or stream, with shutoff. Each $\$ 1.10$.

"Water Gun." A combined hose nozzle and lawn sprinkler. Makes a solid stream or spray. Each $\$ 1.50$.

HOSE NOZZLES FOR SPRAY PUMPS. "Bordeaux," Adjustable. Each $\$ 1.25$.

"Vermorel." A fine spray. Each \$1.15.

"Shower." Will not clog and does the work without waste of material and time. 1/4-in. thread pipe. Each $\$ 1.00$.

Kant Clog Nozzle. Each \$1.10.

Mystry, Jr. A fine spray. Each $\$ 1.25$.

HOSE, RUBBER.

............... $\$ 0.21$

"Marshall." 3/4 in., braided...............23

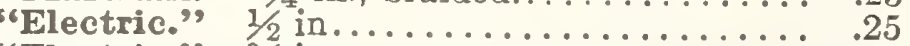

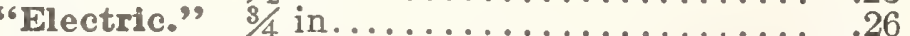

Special Spray Pump. $1 / 2$ in............... .30
HOSE REELS. Made with tubular iron; strong and durable.

No. 10. For $100 \mathrm{ft} ., 3 / 4$ in. hose. Each $\$ 6.00$.

No. 20. For $150 \mathrm{ft} ., 3 / 4$ in. hose. Each $\$ 6.75$.

No. 31. For $500 \mathrm{ft} ., 3 / 4$ in. hose. Each $\$ 18.00$.

HOSE REEL. Victor. All metal steel frame, 9-in. corrugated steel drum. For 100 feet of hose. Each \$3.50.

HOSE WASHERS. $3 / 4$ in. Doz. 10c., 100 50c.

HYACINTH STAKES. Dyed green.

12 in. long.............100 35c., $1000 \$ 3.00$.

18 in. long.............100 40c., $1000 \$ 3.50$. KEEP OFF THE GRASS. Enameled metal sign. Each 50c.

KNIVES, ASPARAGUS, American. Each 50c. KNIVES, ASPARAGUS, English. Each $\$ 3.50$.

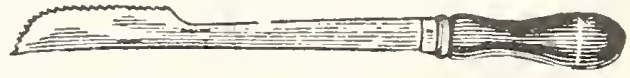

KNIVES, CORN. Forged steel. Each 75c. KNIVES, BUDDING.

\section{$\longrightarrow 0$}

American. No. R1717. Round point, brass lined........................\$3.00

American. No. 1687. Sharp point, brass lined 3.00

American. No. 1697. Round point, brass lined 3.00

American. No. 1707. Round point, long han-

dle, brass lined.................. 4.00

American, two blades, brass lined............. 2.00

American. No. R1568. Florists, sharp point, cocobolo round handle 4 in. long......... 1.25

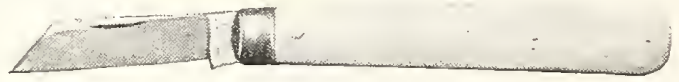

English. No. 1916. Ivory handle, brass lined, sharp point.................. 5.00

English. No. 919. Ivory handle, brass lined, round point................. 5.00

English, No. 0217, coco handle, round point... 3.00

English, No. 145, ivory handle, sharp point... 4.00

English, No. 217, ivory handle, round point... 4.00 KNIVES, PRUNING.

American, No. R708, coco handle, medium size............................... 1.50

American, No. R3 353 , stag handle two blades. 2.00

American. No. R1608. Blade 21/2 in. Cocobola handle, 4 in. long. . . . . . . . . . . . 1.25 American, Allen's Metal Handle, 3 in. blade. 1.00

American, Keen Kutter, large size, wood handle, curved blade................ 1.50

English, No. 924, stag handle, small size, one blade. Each $\$ 3.00$.

No. 924

English, No. 928, stag handle, large size, one blade. Each $\$ 3.25$.

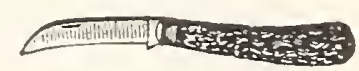

No. 928

Dahlia Knife. For dividing tubers, blade $31 / 2$ in. long. Each $\$ 2.00$

KNIVES, EDGING.

English. Best stoel, handles 50c. extra; 8 in. $\$ 2.25 ; 9$ in. $\$ 2.50$.

American. Each 75c.

American. With handles. Each $\$ 1.50$.

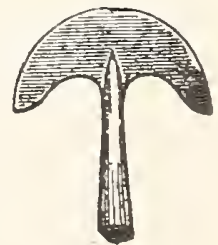


HORTICULTURAL TOOLS AND REQUISITES-Continued

LABELS, POT and GARDEN, Wooden.

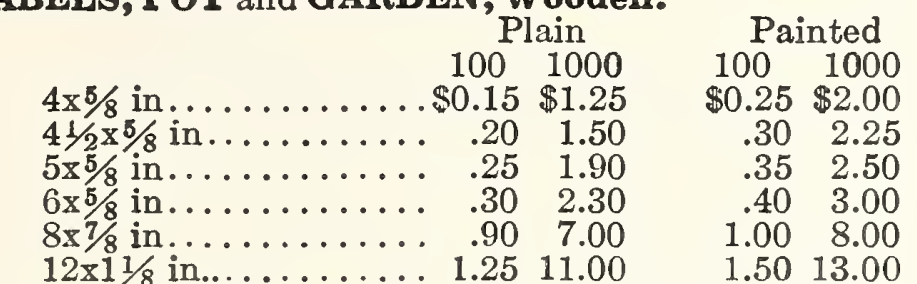

LABELS, TREE, Copper Wired. $3 \frac{1}{2}$ in. Painted. 10035 c., $1000 \$ 2.50$.

LABELS, HANGING, Celluloid, with copper wires, $31 / 2$ in. long by $11-16$ in. wide. Doz. 20c., $100 \$ 1.00$. $3 \frac{1}{2}$ in. long, $11 / 2$ in. wide. Doz. 75 c., $100 \$ 5.00$.

LABELS, POT, Celluloid. 5 in. long, $3 / 4$ in. wide. Doz. 60 c., $100 \$ 3.50 ; 6$ in. long by 1 in. wide, doz $70 \mathrm{c} ., 100 \$ 5.50$.

LABELS. Seerite. A round glass label holder, with $4 \frac{1}{2}$ in. wooden peg to go in ground. Box of 8 for $\$ 1.00$.

LABELS, The Simplex. Waterproof Doz. 100 No. 1. $3 x^{1} / 2$ in ................\$0.35 $\$ 2.50$ No. 2. $4 x \frac{3}{4}$ in................... .70 4.50

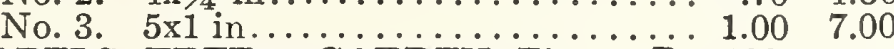

LABELS, TREE or GARDEN, Zinc. Per 100:
No. 1 .. $\$ 3.00$
No. 5 ...\$3.50
No. $13 . \$ 1.50$
No. $15 . .2 .00$
No. $2 \ldots 3.00$
No. 6 ... 1.50
No. 4 ... 3.00
No. $7 . .1 .50$
No. 21.2 .00

Ask for shapes and sizes.

INDELIBLE INK. For above. Bottle 30c.

LEAD WIRE. For tying zinc labels. 1-lb. coils, No. 18. $60 \mathrm{c}$

LADIES' TOOL SETS, "Keen-Kutter." Fork, spade, hoe and rake. Set $\$ 3.50$.

LAWN SPRINKLERS. (See pages 100 to 101.)

LAWN RAKES. (See Rakes.)

LAWN MOWERS. (See pages 90 to 93.)

LAWN MOWER SHARPENING COMPOUND. Per can, 60c.

LAWN MOWER SHARPENER, "Bergman." Each $\$ 1.00$.

LAWN SWEEPERS. (See page 94.)

LEAF-MOULD. Pk. 30c.; 1 barrel bag, \$2.00.

LINES. (See Garden Lines.)

MASTICA. Forreglazing greenhouses.Qt.90c., gal. $\$ 3.00$

MASTICA GLAZING MACHINE. Each $\$ 3.50$.

MATTOCKS.

"Oak Leaf."

Hoe, 41/4-in

Cutter, 3 in.

Each $\$ 1.50$.

Handles,50c.

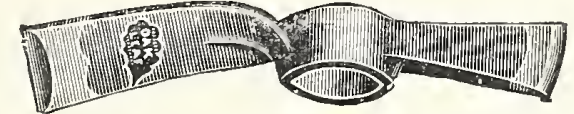

MATS, FROST-PROOF, Burlap. These mats are $76 \times 76$ in. square and made of strong burlap filled with cotton. Each $\$ 3.50$, doz. $\$ 40.00$.

Size $40 \times 76$ in., each $\$ 2.50$, doz. $\$ 26.00$.

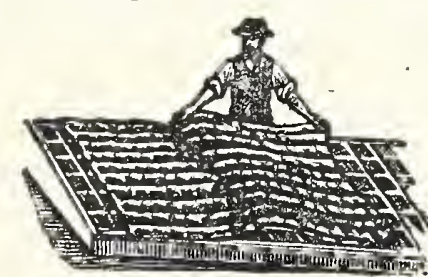

MATS, Hotbed. Waterproof one side, burlap on other. $40 \times 76$ in., each $\$ 3.50$, doz. $\$ 36.00 ; 76 \times 76$ in., each $\$ 5.50$, doz. $\$ 60.00$

MATS, Milo Waterproof. Made from heavy burlap, felt and absorbent pulp, cemented together with a special waterproof compound. Impervious to rain, proof against frost and repellent to rats and mice. Size, 80 by 78 in. Each $\$ 4.50$ doz. $\$ 50.00$.

MELON NETS. English make. Doz. $\$ 2.50$.

MOLE TRAPS.

Schroeter Improved. Low built and self setting. Each $\$ 2.25$.

“The Reddick." Each $\$ 1.50$. MO-LO. A preparation for destroying moles. Pkg. 25c.
MOSS, SPHAGNUM, LIVE. For orchids. Bag $\$ 2.50$.

For packing, 5-bbl. bale, $\$ 4.00$

Green, in sheets. Bag $\$ 4.50$

Dyed Green, in sheets. Bag $\$ 6.50$.

NAILS, English Wall. $11 / 2$ in. Chandler's patent with lead tip to turn over vine. About 40 nails to $1 b$. Lb. $70 \mathrm{c}$.

Cast Iron. $1 \frac{1}{2}$ in. About 140 nails to pound. Lb. $20 \mathrm{c}$.

NETTING, Bird, for Strawberry beds, etc.; 20 or 30 ft. wide. Per lb. $\$ 2.50 ; 1 \mathrm{lb}$. will cover $200 \mathrm{sq}$. ft. NOzzLES. (See Hose Nozzles.)

OIL CANS. For lawn mower's, etc., brass bottom. 30c. PAPER.

Kraft. Sheets $40 \times 48$ in. or $30 \times 40$ in. Per lb. 15c

Kraft. Rolls 18 in. or 24 in. wide. Per lb. 15c.

Tissue. Ream (480 sheets.) 24x36 in. $\$ 2.00$.

Waxed Tissue. Ream (480 sheets), $24 \times 36$ in., $\$ 3.50$

Coarse. For parceling. Lb. 16c.

Prices of paper are subject to change.

PEAT MOSS. Small bale $\$ 1.50$, large bale $\$ 4.00$.

PEAT, Rotted. 1-bbl. bag $\$ 2.25$.

PEAT, Orchid. 1-bbl. bag $\$ 2.75$.

PENCILS, GARDEN. For labels. Each 15c

PICK MAT'TOCKS, "Oak Leaf." Hoe $41 / 4$ in.

Pick $81 / 2$ in.

Fach $\$ 1.50$.

Handles 50c.

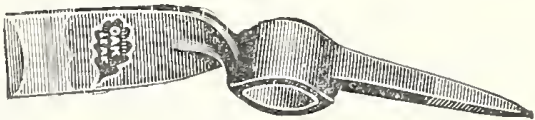

PICKS. Pointed both ends. Each $\$ 1.50$, handles 50c. PLANT PROTECTORS. For Tomato or Egg Plants; wire with cotton covering. Each $25 \mathrm{c} .$, doz. $\$ 2.50$. PLANT SPRINKLERS。 (See Sprinklers.)

PLANT STAKES. Round, green, tapering (light).

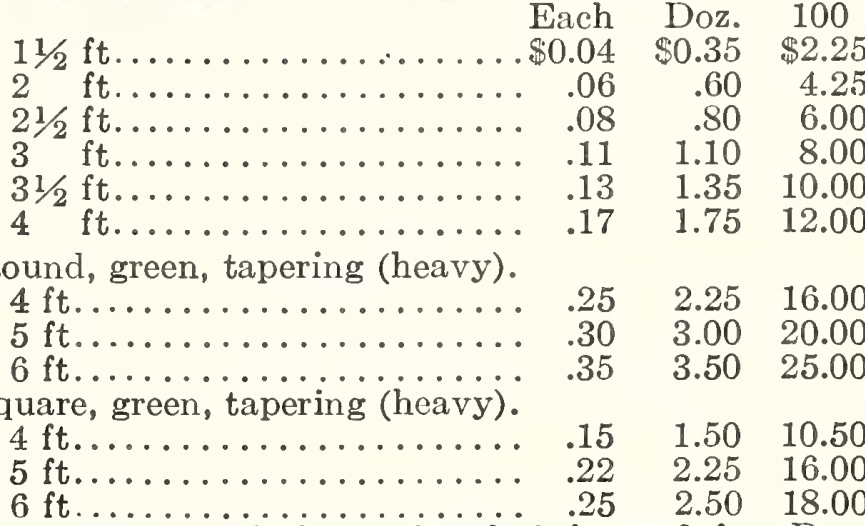

BEAN POLES. Cedar, pointed, $8 \mathrm{ft}$. to $9 \mathrm{ft}$. Doz. $\$ 3.50,100 \$ 26.00$.

DAHLIA POLES. Heavy, round, green; tops painted white. Each Doz. 100 $3 \mathrm{ft} . \ldots \ldots \ldots \ldots \ldots \ldots \ldots \ldots 0.17 \quad \$ 1.75 \$ \ldots 12.00$ $4 \mathrm{ft} . \ldots \ldots \ldots \ldots \ldots \ldots \ldots \ldots . .20 \quad 2.00 \quad 15.00$

$\begin{array}{lllll}5 \mathrm{ft} \ldots \ldots & .27 & 2.75 & 20.00\end{array}$

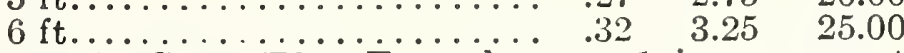

DAHII STAKES. Extra heavy. 1 in. square at bottom tapering to $3 / 4$ in. at top, painted.

Doz. 100

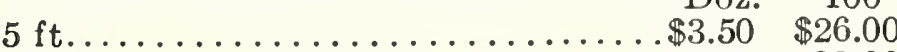

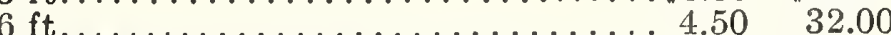

GALVANIZED WIRE, for Roses, etc. Plain or Anchored. No. 9 wire.

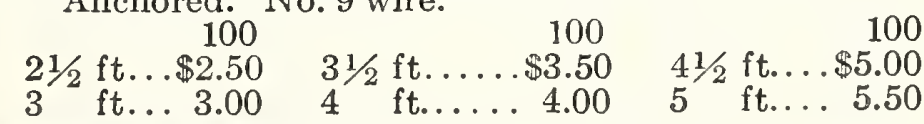

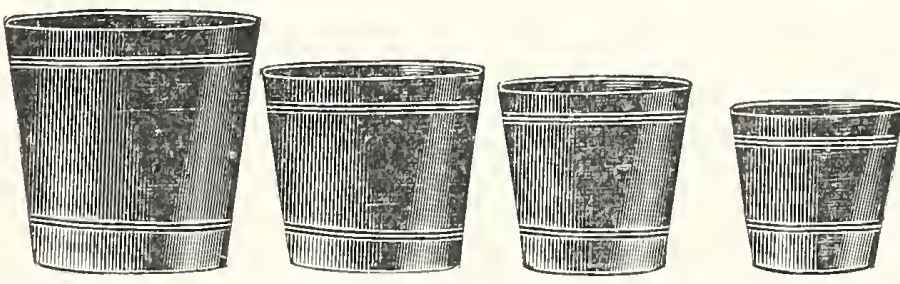

POT COVERS. Made with metal painted green to fit standard size pots. 5 in. $75 \mathrm{c}$; 6 in. $85 \mathrm{c}$; 7 in. $\$ 1.00 ; 8$ in. $\$ 1.20$ each. 


\section{HORTIGULTURAL TOOLS AND REQUISITES-Continued}

PLIERS. Side cutting, 6 in. $\$ 1.50 ; 7$ in. $\$ 2.00$.

POST HOLE DIGGER. Each \$2.50.

POT HANGERS. Wire. Each $20 \mathrm{c}$., doz. $\$ 2.00$.

POTATO HOOKS. Broad, round prongs. 4-prong $\$ 1.50$, 5-prong $\$ 1.75$.

POTS. (See Flower Pots, page 76.)

POWDER DUSTER. For Slug Shot. Each 75c.

POWDER GUN.

"Jumbo." Each 40c.

"Leggett's Little Giant." Each $\$ 12.00$.

"Leggett's Champion Duster." Fach \$16.00.

PROTECTING CLOTH. Valuable for protecting early plants from frost. Pieces contain from 40 to 60 yards.

Heavy Grade. By piece of 50 yds., per yd. 35c.

Medium Grade. By piece of $60 \mathrm{yds}$., per yd. $30 \mathrm{c}$.

PRUNER, or Lopping Shears.

Handy Andy. A small lopping shear, 14 in. long. Very useful for small work. Each $\$ 2.00$.

"Keen-盀ut-

ter." Han-

dles 22 in

C u r v e d

blade. Each $\$ 3.50$.

Eagle Lopping shear.

20-in. handle.

Each $\$ 2.00$.

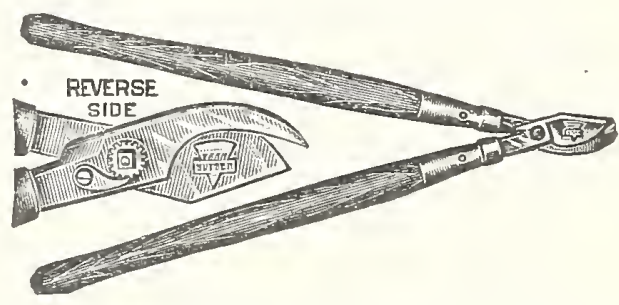

Rhodes'. Cuts on both sides and does not bruise the bark. Length 26 in. Each $\$ 6.50$.

PRUNERS, TREE.

Bartlett Compound Lever. Does double the work of any other pruner with less exertion. 10 foot. Each $\$ 4.50$.

Little Giant Prun.

er Hook and Saw Combined. Attaches to pole of any length. Each $\$ 3.50$.
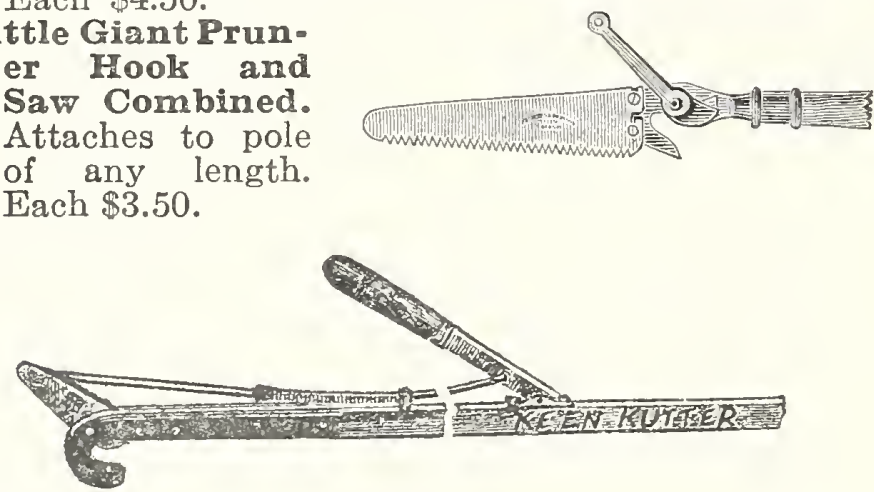

Waters'. 8-ft. handle, $\$ 2.75 ; 10-\mathrm{ft}$. handle, $\$ 3.00$ $12 \mathrm{ft}$. handle, $\$ 3.25$. Extra blades, $30 \mathrm{c}$. each.

PUMP, "The Kinney." For distributing water and liquid manure through the hose at the same time. Each $\$ 2.25$.

PUMPS. (See Spray Pumps, pages 96, 97, 98.)

PUTTIUr. A new glazing cement used in place of putty. Color gray. Gal. can $\$ 3.00$.

PUTTY BULB, Rubber. For glazing, $\$ 1.35$.

RAFFIA. The best material for tying plants. Per lb. 30c. Green, dyed, lb. $\$ 1.25$.

RAFFIA TAPE. Green, on spools of 100 yards. Each $\$ 1.50$.

RAKES.

Bamboo, Lawn. Each $\$ 1.00$. (See page 83.)

Garden. Best steel, 8 teeth, $\$ 1.00 ; 10$ teeth, $\$ 1.20$; 12 teeth, $\$ 1.30 ; 14$ teeth, $\$ 1.40 ; 16$ teeth, $\$ 1.50$; 18 teeth, $\$ 1.60$.

Gem Dandelion. 15 in. wide. Each \$2.50.

Hay. Wooden, 3 bows, 12 teeth, $\$ 1.10$.

Hoover. Flexible steel for leaves, etc. $\$ 1.00$.

Lawn. Wooden, 3 steel bows, 22 teeth, $\$ 1.25$.

Reversible. Galvanized, 24 teeth, $\$ 1.25$.

Lawn, "Olsen." 26 wood teeth, iron brace. Each $\$ 1.10$

Rake and Hoe. A combination tool, \$1.10.

REELS, GARDEN. Each $\$ 1.75$ and $\$ 3.00$.

RIFLES, EMERY. For sharpening. Each $15 \mathrm{c}$.

ROLLERS. (See page 94).

RUBBER BANDS. For split Carnations. Oz. 30c.

RUBBER BOOTS, Gardeners and Farmers. State size when ordering. Per pair, hip length, $\$ 7.00$, knee length $\$ 5.50$.

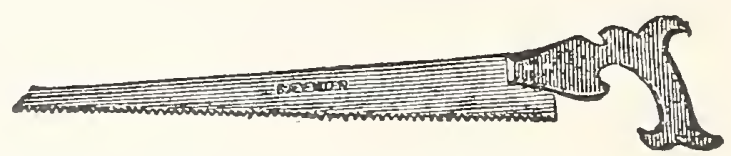

SAWS.

Pruning, Disston. Single edge, 16 in. $\$ 1.50,18$ in. $\$ 1.75,20$ in. $\$ 2.25$. Double edge, 16 in. $\$ 1.75$, $18 \mathrm{in.} \$ 2.00,20 \mathrm{in} . \$ 275$

Double Swivel. Blade 14 in. long. Very useful for pruning. Each \$2.25. Extra blades 35c.

Oak Leaf. 14 in. blade, which can be used at any angle. Each $\$ 2.00$. Extra blades 35c.

Crescent Pattern, "Keen-Kutter." 16 in., each $\$ 2.00$.

Hand or Pruning, "Keen-Kutter." 20 in. blade, each $\$ 2.25$.

Cross-cut, One-Man. Cuts easily and rapidly. $4 \mathrm{ft}$. Each $\$ 4.75$.

SAW FILES. Best make. Each 20c. and 2.50

SCISSORS.

Grape or Vine. Best make, 7 in., $\$ 1.50$

Flower Gatherers. Best quality. $\quad 63 / 4$ in., $\$ 1.75$.

SCISSORS, PRUNING. English make, 4 in., $\$ 2.25$. 5 in.. $\$ 2.50$

SASH, HOTBED, Extra strong.

Unglazed. Made of best cypress. Regular size $3 \times 6 \mathrm{ft}$., for using $6 \times 8$ in. glass. No. 4 , each $\$ 3.50$.

Glazed (Packing extra). Size $3 \times 6 \mathrm{ft}$., using $6 \times 8$ in. glass. Painted two coats white. No. 4, each $\$ 6.50$.

Glazed. Size $3 \mathrm{ft} .2$ in. $x$ $6 \mathrm{ft}$., using $8 \times 10$ in. glass. No. 9 , each $\$ 7.00$.

Glazed with $10 \times 12$ in. double thick glass. Size $3 \times 6 \mathrm{ft}$. Iron cross bar No. 11, each $\$ 7.50$.

"Sunlight." Double Giass. Glazed with $10 \times 12$ in. double, two layers thick glass, painted two coats, white. No. 12 , each $\$ 11.00$.

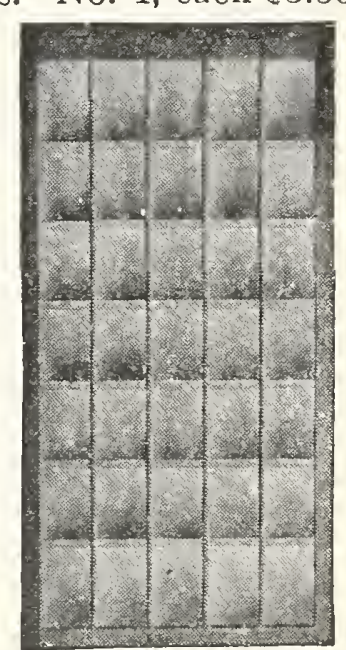

Hotbed Frames for Sash. Painted. For 2 sash, earh $\$ 14.00$; for 3 sash, each $\$ 18.00$; for 4 sish, each $\$ 23.00$; for 5 sash, each $\$ 28.00$.

\section{SCYTHES.}

Lawn, English. 30 to 34 in., each $\$ 3.00$.

Grass, American. 30 to 40 in., each $\$ 2.50$.

Brush or Weed. 18 to 21 in., each $\$ 2.25$.

SCYTHE SNATHS (or Handle). Each $\$ 2.00$.

SCYTHIE STONES. Flat, each 25c., doz. \$2.50.

English. Round pointed. Each $35 \mathrm{c}$

SEEDLING PRICKER. For transplanting ssedlings. Each 25c.

SEEDERS. (See pages 85,88 and $9 t$ ).

SEEDERS, Sowrite. Fiberloid for fine flower seeds. F.ach $\$ 1.00$. (See page 85.)

Sowrite. For all seeds to size of Sweet Peas Metal, nickle plated. Each $\$ 1.50$.

SHADING, Summer Cloud. English shading for greenhouses. $\quad 1 / 2 \mathrm{lb}$. pkg. $60 \mathrm{c}$.

SHADE-O. For shading greenhouses. Lb. \$1.25

SHEARS.

Grass Border.

English (with-

out wheel.)

8 in.....\$5.50

9 in...... 6.00

10 in.....6. 6.50

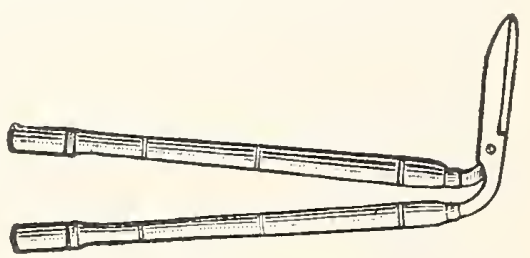

American. Without wheel. 9 in., $\$ 4.00$. 


\section{HORTICULTURAL TOOLS AND REOUISITES-Continued}

\section{SHEARS-Continued}

Grass, Improved No. 09. 6 in. steel blades with 7 in. metal handle and spiral steel spring. $\$ 1.50$. Grass or Sheep. Best trowel shank. \$1.25.

Goodwin Patent Ball Bearing Grass. Each $\$ 2.25$

\section{Hedge. American.}

(With notch, 25c. extra.) 8 in. $\$ 2.50$; 9 in., \$3.00;

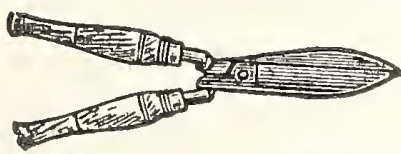

Hedge, English Make. 8 in. $\$ 3.00 ; 9$ in., $\$ 3.50$ 10 in., $\$ 4.00$. With notch, 35c. extra.

Hedge, Serrated Edge. 9 in. $\$ 2.25 ; 10$ in., $\$ 2.50$

Extra Bolts, Nuts and Washers. Per set $25 \mathrm{c}$.

Lopping Shears. (See Pruners.)

California

Pattern.

9 in. long

(See cut)

$\mathrm{E} a \mathrm{c} b$

$\$ 1.00$.

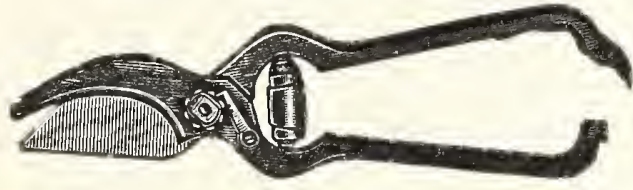

Disston Pruning No. 152. $8 \frac{3}{4}$ in., extra strong. Each $\$ 350$.

Ladies' Pruning. $61 / 2$ in. Nickel plated, $\$ 1.50$.

Perfection Pruning. Cuts

on both sides. $61 / 2$ in.,

$\$ 3.50 ; 71 / 2$ in., $\$ 4.00$;

$81 / 2$ in., $\$ 4.50 ; 91 / 2$ in.。 $\$ 5.00$.

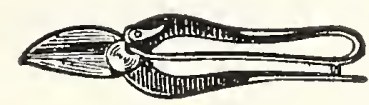

Plucca Pruner. Made to hold the twig that is cut off. $\$ 3.00$

Watch Spring Pruning. Imported French, 7 in., $\$ 3.00 ; 8$ in., $\$ 3.50 ; 9$ in., $\$ 4.00$.
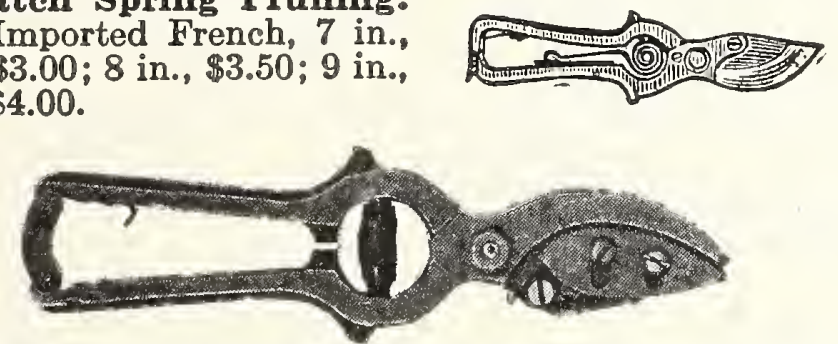

Wiss, Hand Pruning. (Solid Steel). 9 in., $\$ 3.50$; 10 in., $\$ 4.00$; extra blades, $\$ 1.00$ each.

Wiss Pruning No. 209. Blade and handle one piece of steel. 9 in. $\$ 1.50$.

Wiss Pruning No. 309. Forged steel blades. 9 in. $\$ 2.50$.

SHREDS, Medicated Garden. For nailing on trees, vines, etc. 3 in., $10060 \mathrm{c} . ; 4$ in., $10075 \mathrm{c}$.

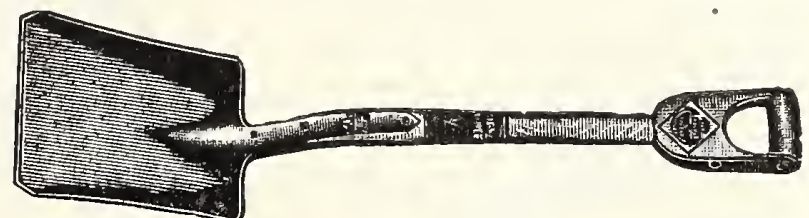

SHOVELS, "Keen-Kutter." Square and Diamond Pointed. Long or short handles. Each \$2.50.

Best Steel, Square or pointed. Each $\$ 1.75$.

SIEVES, WIRE. For sifting loam, gravel, etc. $1 / 8$ in., $1 / 4$ in., $1 / 2$ in., or $3 / 4$ in. mesh, 18 in. in diam., each $\$ 2.50$.

SIGN, "Keep Off the Grass." Metal with enameled letters. Size $31 / 4 \times 19$ in. Each 50c.

SLKaLINE, Meyer's Green. Fast color. Spool $50 \mathrm{c}$. Box of 8 spools $\$ 3.50$.

Florists' Thread. 2-oz. spools, each $25 \mathrm{c}$., doz. $\$ 2.50$.

SMILAX TWINE. Green. Box of 8 balls $\$ 1.25$.

SOAP DISPENSER, "Wilson's Sanitary." To use with Wilson's Liquid Soap. Each $\$ 2.50$.

SOIL TESTER, "Soiltex." The new pocket soil tester, contains enough material for making 75 to 100 soil tests. Outfit complete, $\$ 1.00$.

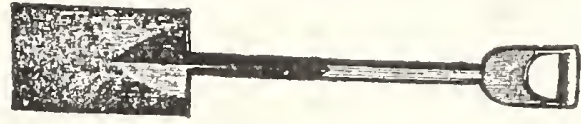

SPADES. Best cast steel. Long or short handles. Each \$1.75.

"Keen-Kutter," extra quality, each $\$ 2.50$.

SPRA YERS. (See pages 96, 97 and 98.)

SPRINKLERS.

Rubber. Scollay's straight neck. No, 1, 12-oz. size, $\$ 1.50$.

The Ideal. Made entirely of metal and fits any bottle; can be used at any angle for insecticides or water. Each $\$ 1.00$.

STAKES. (See Plant Stakes and Canes.)

STAKES, HYACINTH. Green. 18 in. long. Doz. 5c., 10040 c., $1000 \$ 3.50$.

STICKS, Match. 18 in. long. $1000 \$ 3.00$.

STYPTIC. To prevent bleeding of vines. Bottles, each $\$ 1.25$.

SULPHUR VAPORIZER, Campbell's Patent. (See Fumigators, page 77.)

SUNDIALS. Made with cast bronze. Diam. 11 in. Each $\$ 10.00$

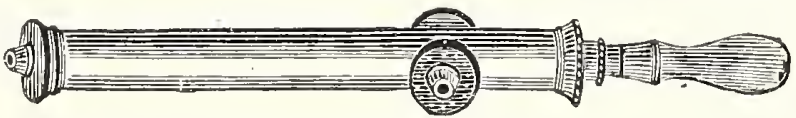

S YRINGES, GARDEN, BrasS

No. C, length $141 / 2$ in., diam. $13 / 4$ in., one spray rose and stream. Each $\$ 4.50$.

No. 11 , length 18 in., diam. $11 / 2$ in., two spray roses and one stream. Each $\$ 6.00$.

No. 5, length 18 in., diam. $11 / 2$ in. two spray roses and one stream, extra heavy and strongly mounted. Each $\$ 8.00$.

Goosenecks. For syringes. Each \$1.00.

TARRED FELT DISCS. For Cabbage plants. 100 50c. $1000 \$ 4.00$.

TENNIS NETS. Single court, $27 \times 3 \mathrm{ft}$. Double court, $36 \times 3 \mathrm{ft}$., canvas bound. Prices on application.

TENNIS MARKER, No. o Dry Marker. For marking tennis courts. $\$ 3.50$

THERMOMETERS.

Mushroom Bed. All metal. each $\$ 3.75$; wood, brass tip $\$ 2.00$.

Brooder, "Tycos." Each $\$ 1.00$.

Distance Scale. Metal frame. Each $\$ 1.00$.

Household. Wood frame. 8 or 10 in., $75 \mathrm{c}$. to $\$ 1.50$.

Incubator, Tycos.

Each $75 \mathrm{c}$

Japan Tin Case, Metal Scale. 8 in., 90c.; 10 in., $\$ 1.10$.

Maximum Registering. Wood frame. Each $\$ 2.75$.

Minimum Registering. Wood frame, each $\$ 2.75$.

Porcelain Scale. For conservatory. Each $\$ 1.50$.

Self-Registering, "Tycos." frame. Size 8 in. $\$ 7.00$.

Self-Registering, "Hicks." English make, boxwood scale. 10 in. $\$ 8.00$.

Self-Registering. Imported, metal frame, $10 \mathrm{in.}$ porcelain scale. Each $\$ 3.00$.

Temprite. Heavy metal, for greenhouse or outside. White with black figures. 9 in. Each \$1.25.

Window. Round glass with metal hangers. 8 in. Each $\$ 1.00$.

Magnets. For self-registering. 75c. 


\section{HORTICULTURAL TOOLS AND REQUISITES-Continued}

TINFOU. Lb. 30c., violet or green, lb. $75 \mathrm{c}$.

TOOL SETS, "Keen-Kutter." Fork, spade, hoe and rake. Set $\$ 3.50$.

TOOTHPICKS. Wired. $100075 \mathrm{c}$.

TORCHES, Asbestos. For burning tent caterpillars. Each 60c.

Collin's Caterpillar Torch. A swinging lamp with attachment to pole with pan to catch the caterpillars that fall. Torch and catcher, $\$ 1.00 ; 12 \mathrm{ft}$. pole in 3 sections, $\$ 1.00$.

TOMATO SUPPORTS. Heavy galvanized wire rings. Each 40c., doz. \$4.00.

Adjusto. (See page 95).

Wooden Tomato and Plant Supports. Four square legs and cross bars, $3 \mathrm{ft}$. high and $16 \mathrm{in}$. wide. Each 35c., doz. \$3.50.

TREE CLIMBERS. For attaching to the legs, to climb tall trees. With leather straps. Pair $\$ 5.50$.

TREE GUARDS, “Excelsior." Close mesh style. Wires No. 9 horizontal, and No. 8 vertical. Fastens with hooks and eyes. Rustproof finish. Diameter 8 in., height $6 \mathrm{ft}$. Each $\$ 2.50$, doz. $\$ 27.50$.

TREE SCRAPERS. Large iron with handle. Each $\$ 1.25$. Extra blades $60 \mathrm{c}$.

\section{TROWELS.}

Steel. 6 in., $75 \mathrm{c} . ; 7$ in., $80 \mathrm{c} . ; 8$ in., $90 \mathrm{c}$.

Cast Steel. Ea. 35c.

Clere's Angle. Large, size, each $25 \mathrm{c}$.

Maynard. Heavy, one-piece steel. Each $\$ 1.10$.

TUBS, PLANT. (See page 85.)

TURFING IRONS. English, with handles. Each $\$ 8.00$.

American. With handles. Each $\$ 2.75$.

TWINE.

Cotton. White, per lb. $\$ 1.20$.

Green Smilax. Box of 8 balls, $\$ 1.25$.

Marline (Tarred Twine). Lb. $60 \mathrm{c}$.

Marline. Small size. Per ball \$1.00.

Hemp. All sizes. Lb. $\$ 1.00$.

Jute. Three- or four-ply, for trees. Lb. 50c.

\section{WEEDERS.}

"Adjustable." Three Prong (See cut.) Each $75 \mathrm{c}$.

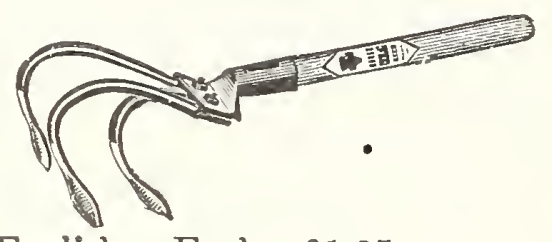

Daisy Grubber. English. Each \$1.25.
WEEDERS-Continued

"Excelsior." Five-claw fingers. Each 20c.

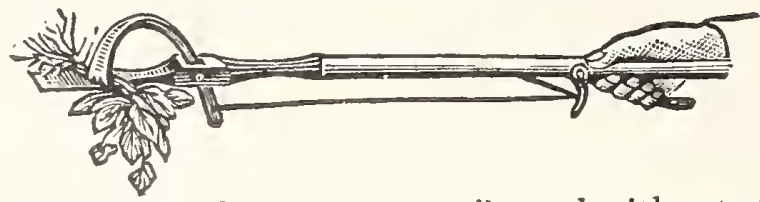

"Cleveland." Can be used easily and without stooping. (See cut.) Each \$1.25.d

"Eureka." Very useful for garden purposes. Each 60c.

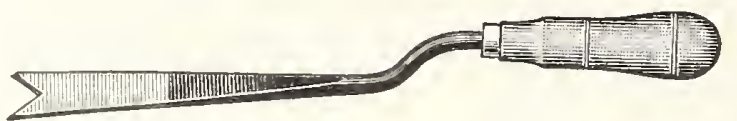

Lawn. For removing docks, dandelion, etc.; can also be used as an Asparagus knife. 50c.

Spud Weeder. English, with 2 in. blade. Very handy for cutting out weeds in lawns or borders. Each $65 \mathrm{c}$.
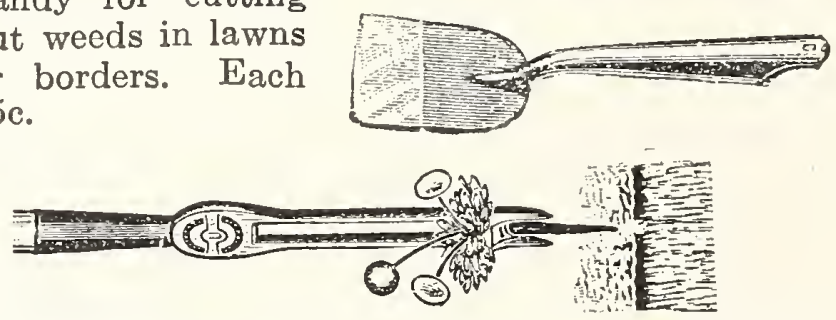

The Out=U-Come. A useful tool for pulling Dandelions, etc., from lawns. Each $\$ 1.00$.

WEATHER VANES, No. 170A. Made with copper. A rooster standing on an arrow. 14 in. high with 18 in. arrow. Each $\$ 15.00$.

WHEELBARROWS, GARDEN. Painted, iron leg

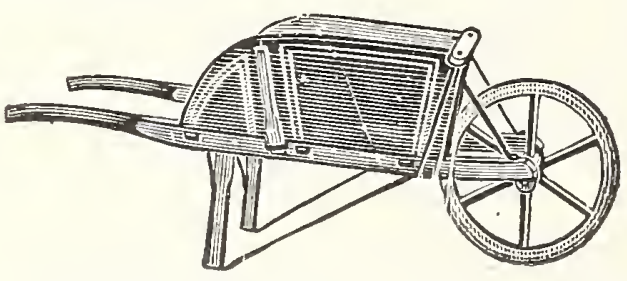
braces, bolted on frame, superior finish. Small size, No. $3, \$ 7.50$. Medium size, No. 4 , each $\$ 8.50$. Large size, No. 5, each $\$ 9.50$.

WHEELBARROWS, GREENHOUSE. A very narrow barrow for use in greenhouses. Each $\$ 12.00$.

WIRE, Annealed for Stemming.

Per lb.

No. 23. Coarse. 18 in. lengths...........\$0.30

No. 26. Coarse. 12 in. lengths................40

No. 34. Fine hair. 12 in. lengths.............60

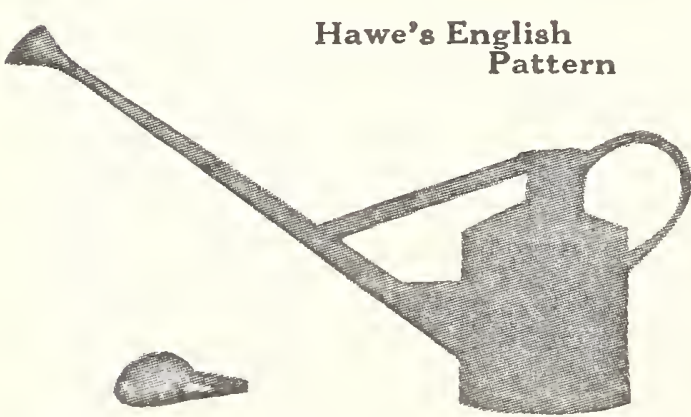

French Pattern, Oval. With long spout and brass bow handle. 2 roses. 6 qts. $\$ 6.00,8$ qts. $\$ 6.50,10$ qts. $\$ 7.00,12$ qts. $\$ 7.50$.

Philadelphia Pattern, Round. With two copper-faced roses. 4 qts. $\$ 4.25,6$ qts. $\$ 5.25$, 8 qts. $\$ 5.50,10$ qts. $\$ 6.00,12$ qts. $\$ 6.50$.

Extra Roses. Fine or coarse. Each 70c.

Hawe's English. Valuable for watering fine seeds as well as for all greenhouse and garden work. One very fine and one coarse rose. Made with heavy material, painted red. No. 2, 4 qts. $\$ 6.50$. No. 3, 6 qts. $\$ 7.50$. No. 4,8 qts. $\$ 8.50$. No. 5,10 qts. $\$ 9.50$.

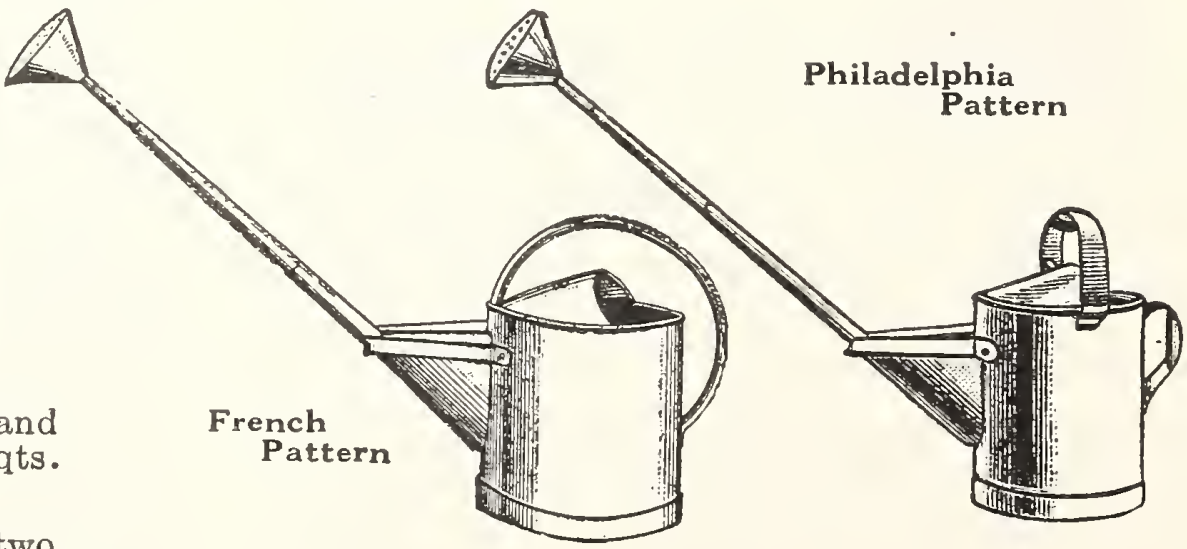

Low, or Strawberry Pattern. One fine rose. 4 qts. $\$ 4.50$.

Galvanized Watering Pot. It is made with heavy galvanized material. 4 qts. $90 \mathrm{c} ., 6$ qts. $\$ 1.00,8 \mathrm{qts}$. $\$ 1.10,10$ qts. $\$ 1.50,12$ qts. $\$ 1.75,16$ qts. $\$ 2.00$. 


\section{BAMBOO LAWN RAKE}

\section{A Superior Make}

This rake cannot be compared with the cheaper quality that is often offered. The head is wired top and bottom and has a four-foot wood handle clamped onto the rake.

Made with split bamboo. Very light and flexible; for raking leaves, grass or paths. An excellent rake for removing crab or August grass in lawns.

Each $\$ 1.00$.

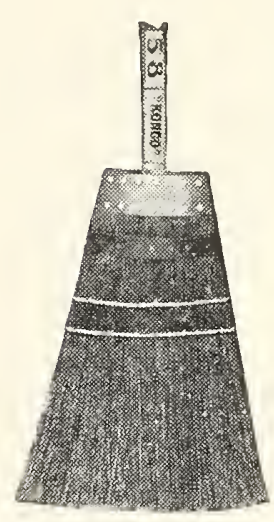

\section{"KONGO" GOIR BASS BROOM}

This broom is made with Coir Fibre with a metal case fastening. It sweeps fine, is tough, impervious to hot or cold water and does not dry up and break off. Makes a fine broom for stable, garage, greenhouse work, also for cleaning gutters on roads. Each $\$ 2.00$.

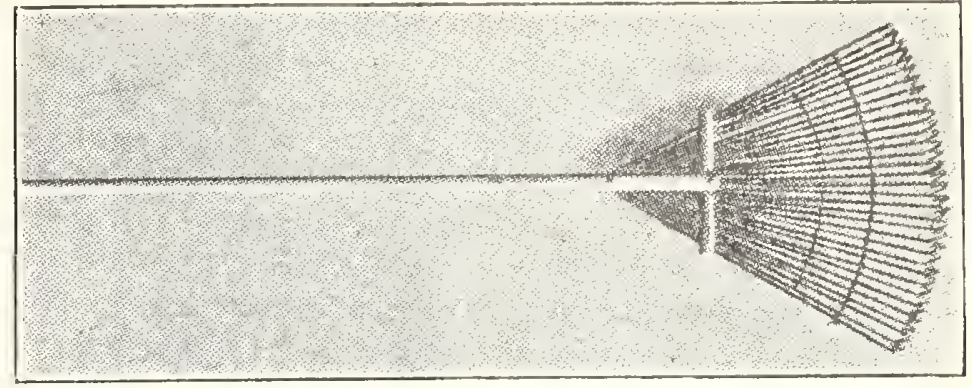

HOOVER LAWN RAKE

The teeth of this rake are made with flexible steel spring wire and will fit into any irregularities on the surface of the ground, taking all leaves, dead grass of refuse without any injury to the living grass. Each $\$ 1.00$.

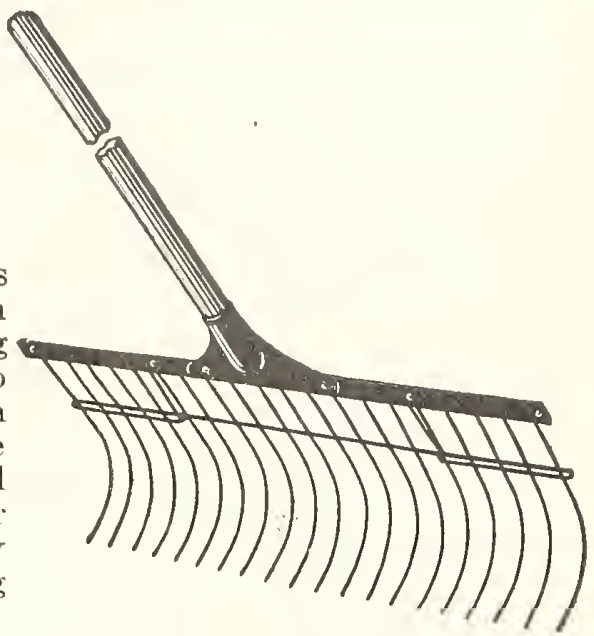

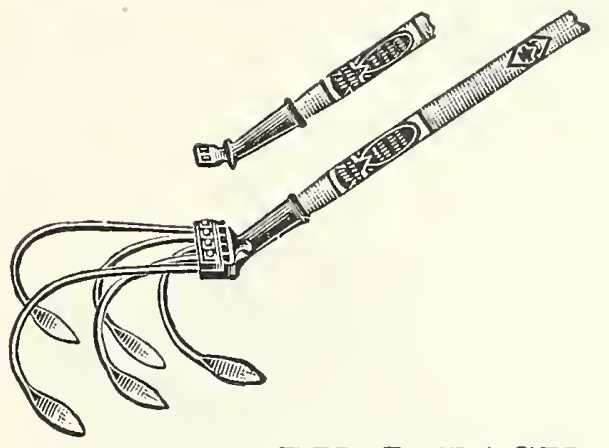

PULL-EASY GULTIVATOR

This adjustable cultivator can be adjusted to fit rows of any width from 7 to 18 in. 'The middle tooth can be instantly removed to straddle the row. Furnished with a $41 / 2-\mathrm{ft}$. wood handle. Each $\$ 1.25$. by sliding the top plate. It is the lightest, weighing but 3 lbs. complete with long handle. The blades are forged out of a solid steel rod. 3 prong, $\$ 1.00 ; 5$ prong, $\$ 1.25$.

\section{ADJUSTABLE GARDEN GULTIVATOR}

The most useful hand garden tool on the market.

It will pull out the weeds, pulverize the ground thoroughly, leaving it level. It will work between the rows, or the center shovel can be removed and straddle the row if desired. It is adjustable in width

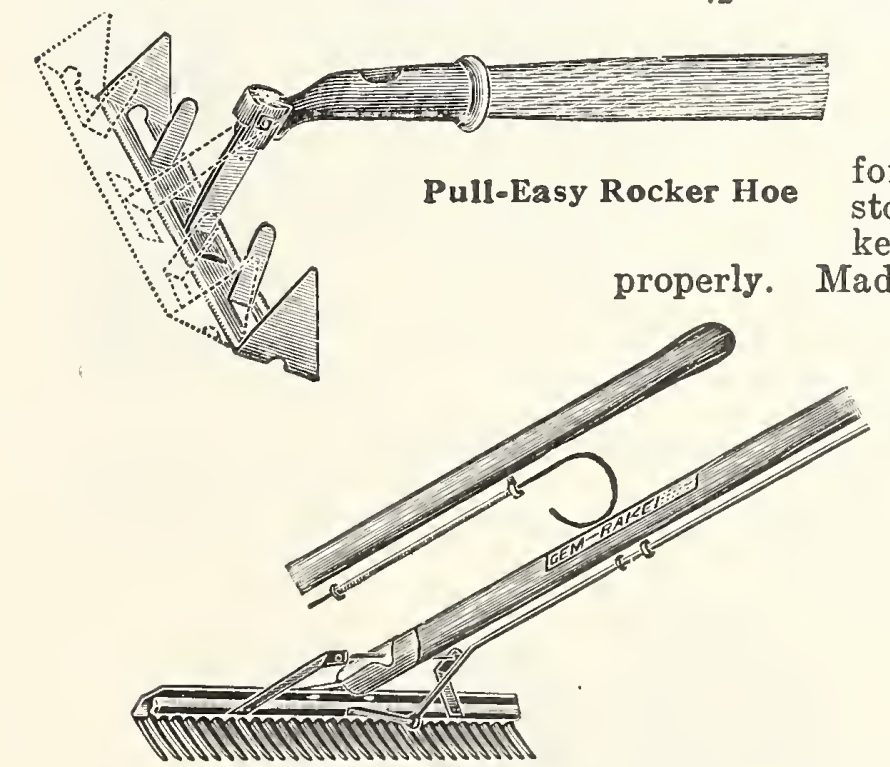

THE PULL-EASY ROGKER HOE

The two-edged, keen blade of this hoe cuts on both the forward and backward motion. The socket casting has ride stops which limit the oscillating movement of the blade, keeping it at just the right angle under the surface to cut

THE GEM DANDELION RAKE

A scientifically constructed tool for eliminating Dandelions and other seeds of weeds in lawns. It has fine, blade-like teeth that lie flat against the sod and clip off all buds and flowers. The self-cleaning attachment combs the teeth clean and is connected to a rod on the handle which cleans the teeth on a slight pull on the finger hook. The spring sending the cleaning bar back to its position. Width 15 in. Each $\$ 2.50$.

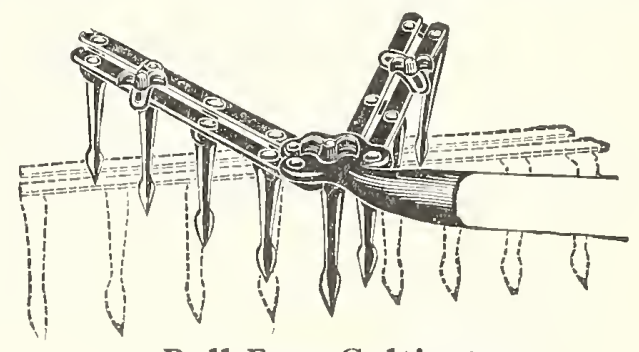

Pull-Easy Cultivator

\section{.}




\section{LANSING HANDY GART}

This cart is well built of the best materials. The 36 -inch wheels have 2-inch tires with 12 spokes. The axles and framework are of steel. It can be used for carrying milk cans, barrels of feed or water, fodder, feed and other purposes. The platform is $28 \times 32$ inches. Price $\$ 13.00$.

\section{COMBINATION WATER BARREL, TRUGK AND LEAF GART}

Barrel can be detached from truck without difficulty, or tilted to empty contents. Either barrel, leaf rack and box can be used. Furnished with wheels with 3 -inch tires.

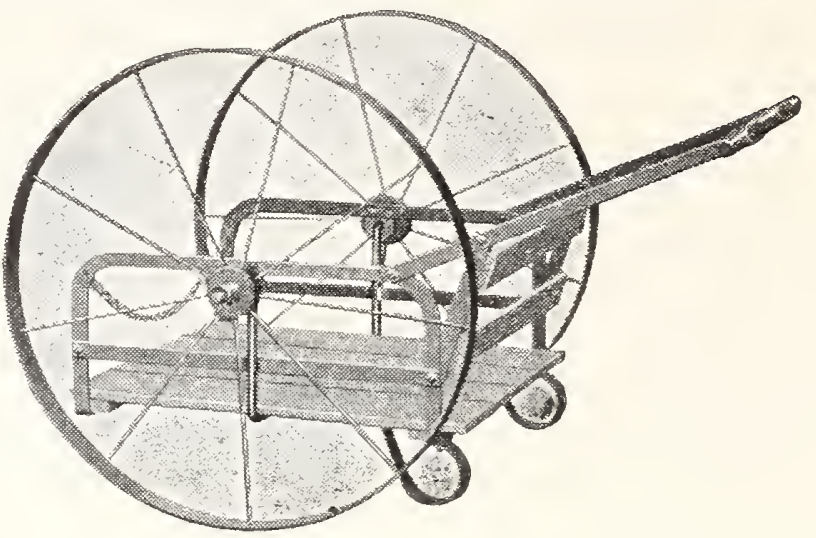

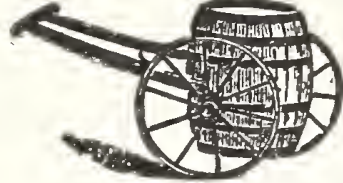

Fig. 6
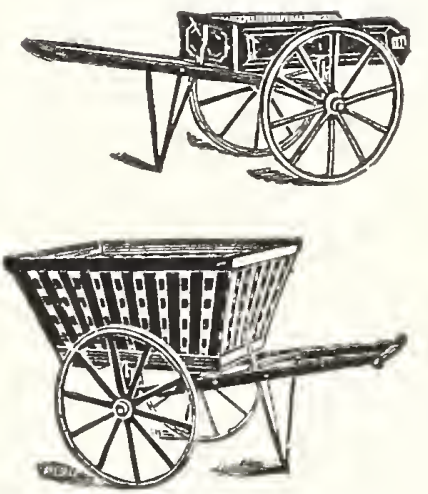

Fig. 162

TRUCK AND WATER BARREL

Fig. 6. Truck, with 3 -in. tires and barrel. . . . . . . . . . . . . . . . . \$20.00 Truck without barrel, 3 -in. tires...................... 15.00

TRUCK AND LEAF RACK

Fig. 162. Truck, with 3 -in. tires.......................... 24.00

TRUCK, BARREL, LEAF RACK AND CART

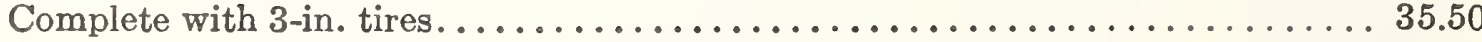

TRUCK, HANDCART AND BARREL

Fig. 7. Truck, with 3 -in. tires.......................... 27.50

ADDITIONAL ATTACHMENTS

Box for Handcart, 24 in. wide, 38 in. long, 10 in. deep............. 7.00

Leaf Rack for Truck. . . . . . . . . . . . . . . . . . . . . . . . . . . . . . . . 8.00

Extra Barrels with Trunnions........................ 6.50

Truck and Box Cart. . . . . . . . . . . . . . . . . . . . . . . . . .

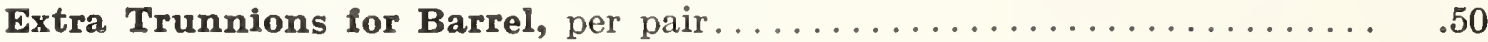

Stay Rods for Barrel. ............................... 1.00

\section{WHEELBARROW LEAF-RAGK}

Can be attached to any style or size wheelbarrow with removable sides. Most convenient for gathering leaves, cut grass and rubbish. One of these attachments should be in use on every small suburban place, as well as the larger estates. Capacity 10 bushels; made of galvanized wire, with wood base to stand on wheelbarrow. Each $\$ 8.50$.

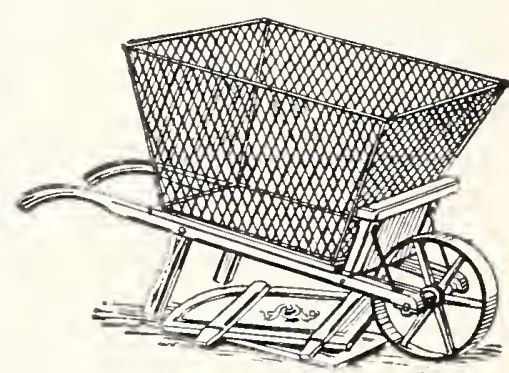

\section{FIBER FLOWER VASES}

Cordleyware flower vases are moulded in one piece, absolutely waterproof, and artistically finished on the outside to resemble the bark of a tree.

\begin{tabular}{|c|c|c|c|}
\hline \multicolumn{4}{|c|}{ MEASUREMENTS INSIDE } \\
\hline No. & High & Wide & Each \\
\hline 01 & 20 in. & $71 / 2$ in. & $\$ 1.60$ \\
\hline 11 & $18 \mathrm{in.}$ & $63 / 4$ in. & 1.50 \\
\hline 22 & 15 in. & $51 / 4$ in. & 1.35 \\
\hline 0 & $13 \mathrm{in.}$ & $83 / 4$ in. & 1.50 \\
\hline 1 & 10 in. & 6 in. & 1.25 \\
\hline 3 & $51 / 2$ in. & $41 / 4$ in. & 1.00 \\
\hline 33 & $12 \mathrm{in.}$ & $43 / 4$ in. & 1.35 \\
\hline
\end{tabular}

\section{FLOWER VASES, GALVANIZED}

Made with heavy galvanized metal, will not break or rust.

\begin{tabular}{|c|c|c|c|c|}
\hline $\begin{array}{l}\text { No. } 1 . \\
\text { No. } 1 \mathrm{~A} . \\
\text { No. } 2 \mathrm{~A} . \\
\text { No. } 3 . \\
\text { No. } 4 .\end{array}$ & $\begin{array}{l}\text { Width } \\
51 / 2 \text { in. } \\
6 \text { in. } \\
61 / 2 \text { in. } \\
8 \text { in. } \\
8 \text { in. }\end{array}$ & $\begin{array}{l}\text { Depth } \\
91 / 2 \text { in } \\
121 / 2 \text { in } \\
15 \text { in } \\
17 \text { in } \\
20 \text { in }\end{array}$ & $\begin{array}{r}\text { Each } \\
. \$ 0.50 \\
. \quad .70 \\
.90 \\
. \quad 1.10 \\
. \quad 1.50\end{array}$ & $\begin{array}{r}\text { Doz. } \\
\$ 5.00 \\
7.00 \\
9.00 \\
11.00 \\
15.00\end{array}$ \\
\hline
\end{tabular}

\section{REFUSE BURNERS}

Useful for burning papers, leaves, rubbish, etc. Made with heavy galvanized wire, with heavy iron supports, in using this you prevent the spread of fire and damage to other property.

No. Diameter Height Weight Each

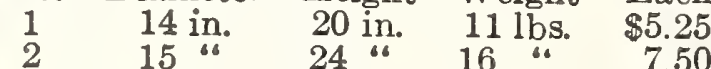
$3 \quad 18$ " 30 " 22 “ 10.00

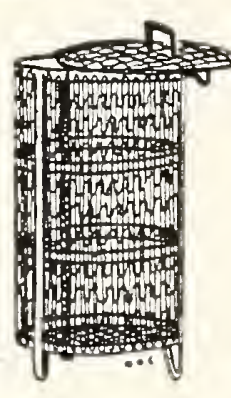

\section{THE "SAVO” WINDOW BOX}

Self-watering and sub-irrigating, for windows, porches. sun parlors, etc.

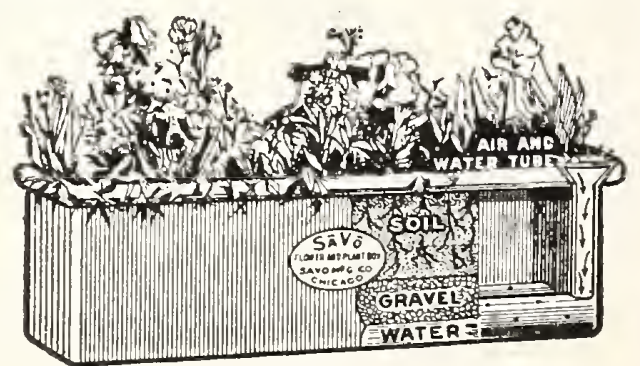

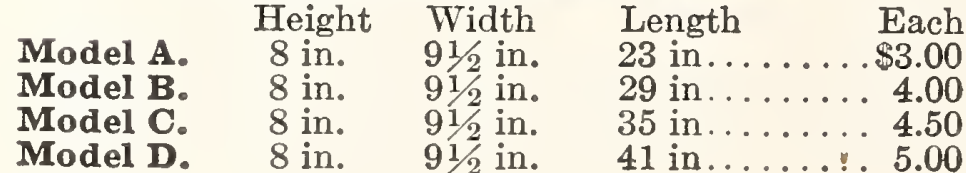




\section{NEW YORK GEDAR TREE TUBS}

Are made of cedar with extra heavy staves and hoops and will be found very strong and durable. Painted green in regular stock. Any color desired to order. Outside measurements.

\begin{tabular}{|c|c|c|c|c|c|}
\hline & Diame & & Heigl & & Each \\
\hline No. 00 & .32 & in. & 26 & in. & \\
\hline No. 0 & .30 & in. & 24 & in. & 18 \\
\hline ฟo. 1 & .28 & in. & 22 & in. & \\
\hline To. 2 & .26 & in. & 20 & in. & 13. \\
\hline No. 3 & .24 & in. & $181 / 2$ & in. & \\
\hline No. 4 & .22 & in. & 17 & in. & \\
\hline Jo. 5 & .20 & in. & 16 & in. & \\
\hline 0.6 & $.181 / 2$ & in. & 15 & in. & \\
\hline U. & $.161 / 2$ & in. & 14 & in. & \\
\hline 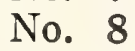 & $.151 / 2$ & in. & 13 & 11 & \\
\hline o. & .14 & in. & 12 & in. & \\
\hline 1 & .12 & & & & \\
\hline
\end{tabular}
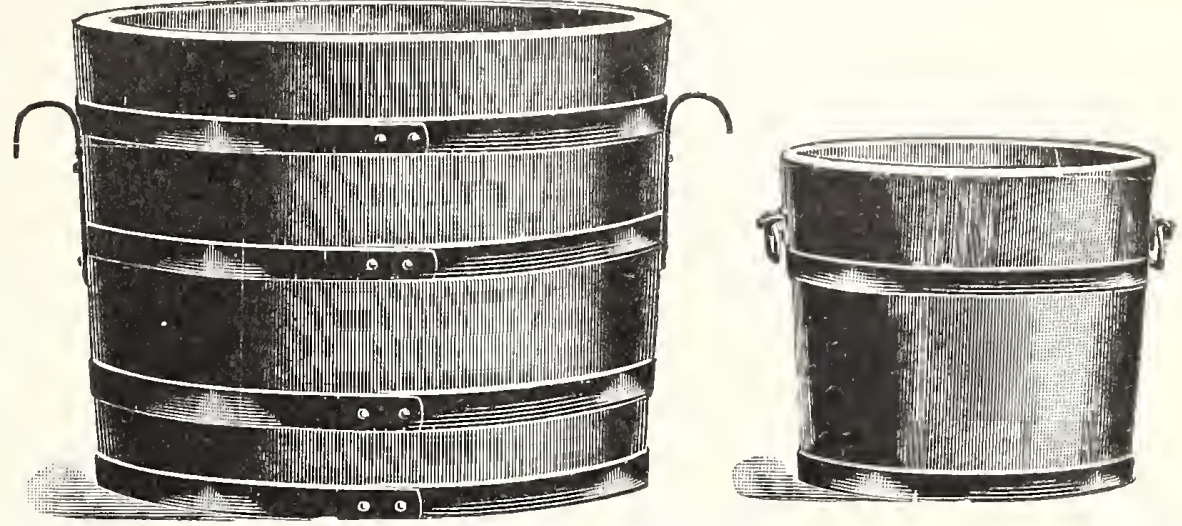

No. 00, 0, 1 and 2 have hook handles. Smaller sizes drop handles. Furnished without feet unless specially ordered. Four feet for Nos. 00, 0, 1 and 2, 50c. each foot. Three feet for all others, 35c. each foot.

Made from selected Virginia white cedar, bound with electric welded wire hoops (galvanized). Painted green, furnished without handles, or we can supply drop handles if wanted at 30 cts. per pair. Inside measurements.

\section{MARSHALL'S PLANT TUBS}

Diamete

No. $3 \ldots \ldots \ldots \ldots \ldots$........... 8 in.

No. $4 \ldots \ldots \ldots \ldots \ldots . .9$ in.

No. $5 \ldots \ldots \ldots \ldots \ldots \ldots$ in.

No. $6 \ldots \ldots \ldots \ldots \ldots . .11$ in.

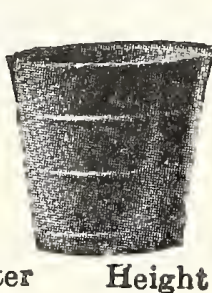

Height

9 in.

9 in.

$10 \mathrm{in}$.

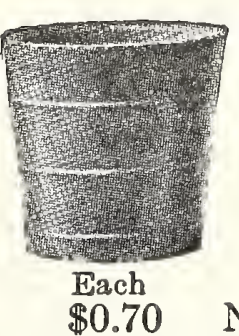

1.00

1.30

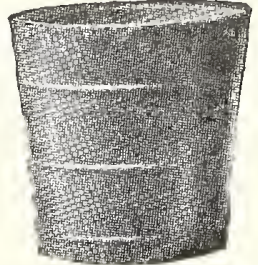

No. $8 \ldots \ldots \ldots \ldots \ldots$ Diameter

No. 10...............15 in.

No. $12 \ldots \ldots \ldots \ldots \ldots . . . .17$ in.

No. 14...............19 in.

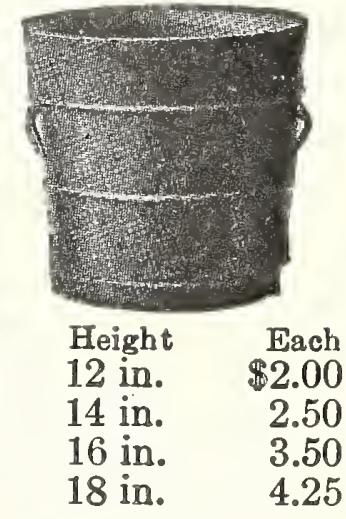

GAHOON'S BROADGAST SEED SOWER
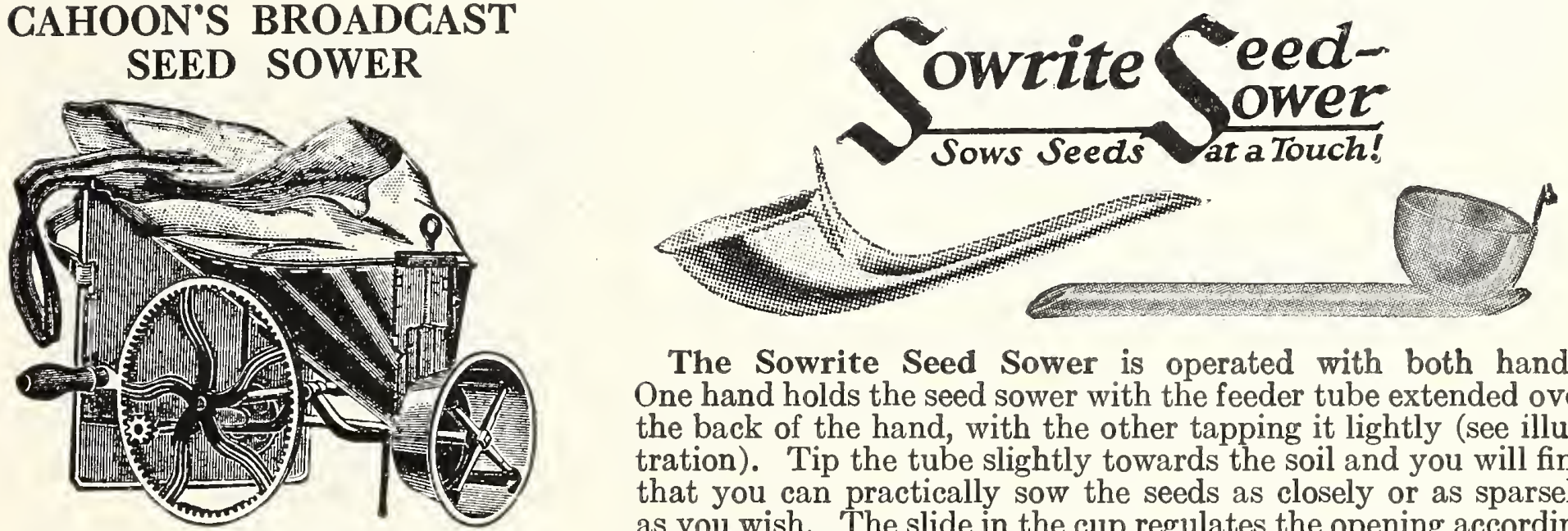

The Sowrite Seed Sower is operated with both hands. One hand holds the seed sower with the feeder tube extended over the back of the hand, with the other tapping it lightly (see illustration). Tip the tube slightly towards the soil and you will find that you can practically sow the seeds as closely or as sparsely as you wish. The slide in the cup regulates the opening according to the size of the seed, and the graduating hole controls the outflow of even the finest seeds.

Model 1922 is used for sowing any of the fine seeds of flowers or vegetables. Made of fiberloid non-breakable. Each $\$ 1.00$. Rye, Oats, Barley, Hemp, Timothy, Clover, Millet and Hungarian seed, throwing from 8 to 20 feet on each side of the operator. $\$ 6.50$.

\section{EVER-READY FROST PROTEGTOR}

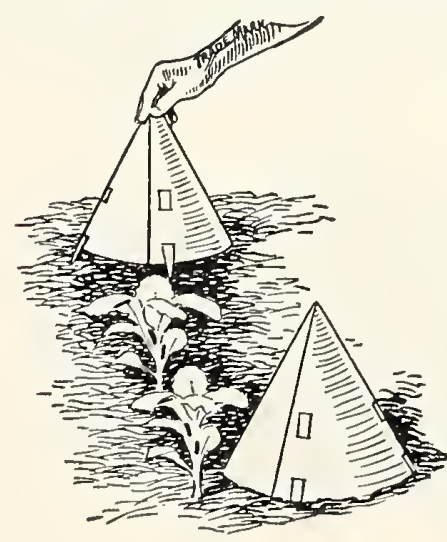

This Plant Protector is made from a black, weatherproof paper, which will last indefinitely. They come packed flat with stakes for locking the edges and anchoring the cone to the ground. Once as sembled they can be nested for storage and used from year to year. They can also be used for shade and windbreaks for plants just set out. Doz. 60c., 50 for $\$ 2.25,100$ for $\$ 4.00,1000$ $\$ 35.00$.
Model 1923 will sow any seeds up to the size of Sweet Peas. Made of metal, nickel-plated. Each $\$ 1.50$.

\section{HAND CORN-PLANTERS}

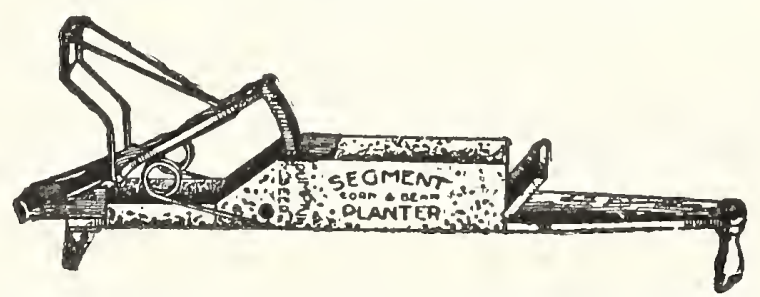

The "Segment" is light, strong, accurate and withal the cheapest and most up-to-date planter on the market. Price, $\$ 2.75$. 


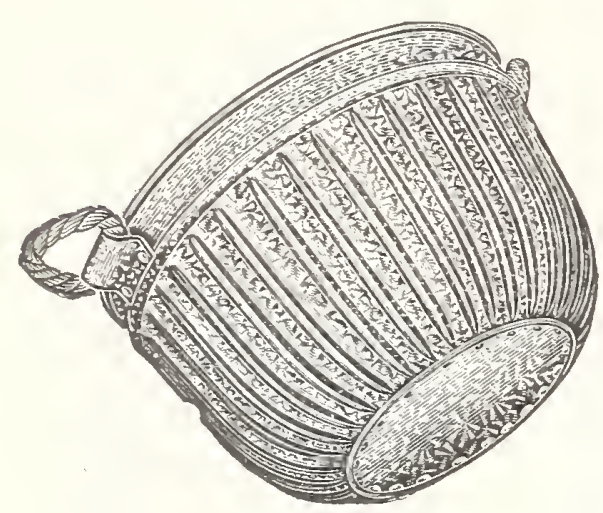

GARDENERS' BASKETS

Adapted for gathering Fruits, Vegetables, Flowers and other purposes around the garden or greenhouse.

Made with splint and bamboo bound with metal straps. Very strong and durable.

No. 1 gize 19 in. $\times 11 \frac{1}{2}$ in. $x 7$ in. deep.

No. 2 size $201 / 2$ in. $x 13$ in. $x 7$ in. deep..

No. 3 size 23 in. $x 14 \frac{1}{2}$ in. $x \quad 8$ in. deep..

No. 4 size 24

in. $x 15 \frac{1}{2}$ in. $x \quad 9$ in. deep.

2.50

No. 5 size 30

in. $x 20$

in. $x 11$ in. deep..

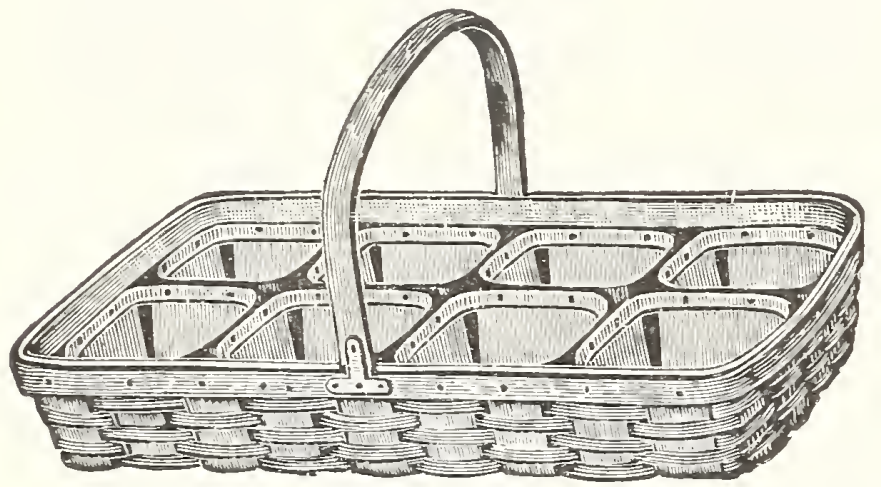

\section{STRAWBERRY BASKETS}

Useful for gathering strawberries and raspberries. One quart size. Per $100 \$ 1.50$. Per $1000 \$ 13.00$. 2 quart size per $100 \$ 3.00$. 3 quart size per 100, $\$ 3.50$. 4 quart size per 100, $\$ 4.00$.

\section{GENERAL FARM BASKETS}

Made with best oak splint, reinforced with hoops. Handy for carrying leaves, rubbish, wood, coal, etc.

1 bushel size............Each $\$ 2.00 \quad 2$ bushel size............Each $\$ 3.00$ $11 / 2$ bushel size......... Each $2.50 \quad 3$ bushel size.............Each 3.50

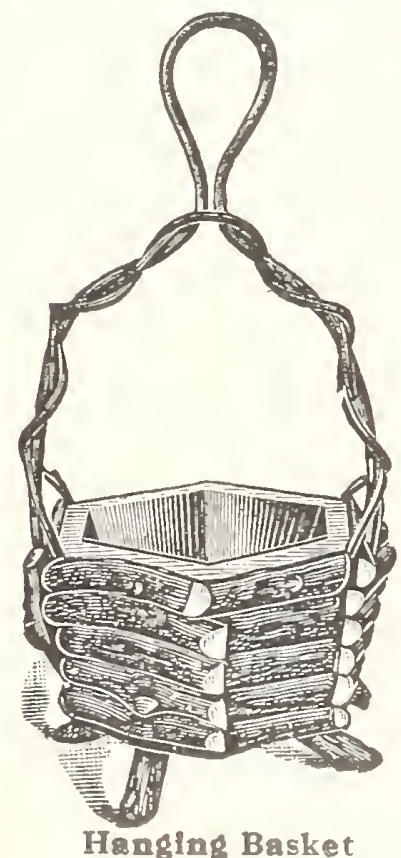

\section{PICKING BASKETS}

Used for gathering apples, pears and other varieties of fruit. 1/2 bushel size with drop handle, each $\$ 1.25$.

\section{ENGLISH GARDEN BASKETS}

Made with wood with strong wooden handle and feet. Handy for cut flowers and vegetables.

No. 2. $11 \frac{1}{2}$ in. long 6 in. wide.........Each $\$ 1.25$

No.4. 15 in. long 8 in. wide........Each 2.00

No. 6. $181 / 2$ in. long 10 in. wide.........Each 2.50 No. 8. 23 in. long 12 in. wide........Each 3.75

\section{RUSTIC HANGING BASKETS}

Made from laurel roots, elegantly finished and rattan handle. These baskets cannot be equaled in style, finish or make. They will stand severe weather, and with a little care are good for 10 to 12 years' wear. Each, 10 in., $\$ 2.25 ; 12$ in., $\$ 2.50 ; 15$ in., $\$ 3.50$.

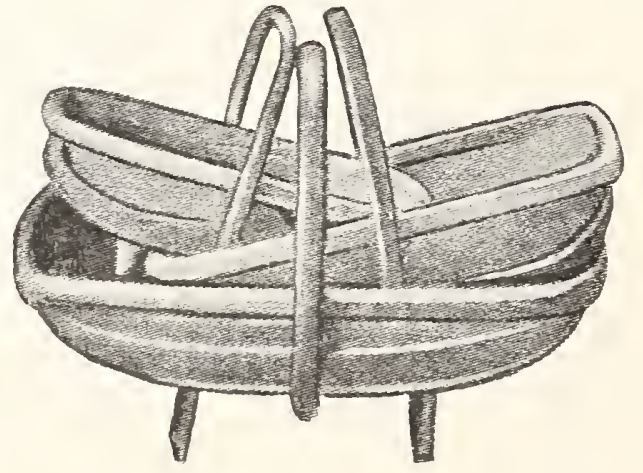




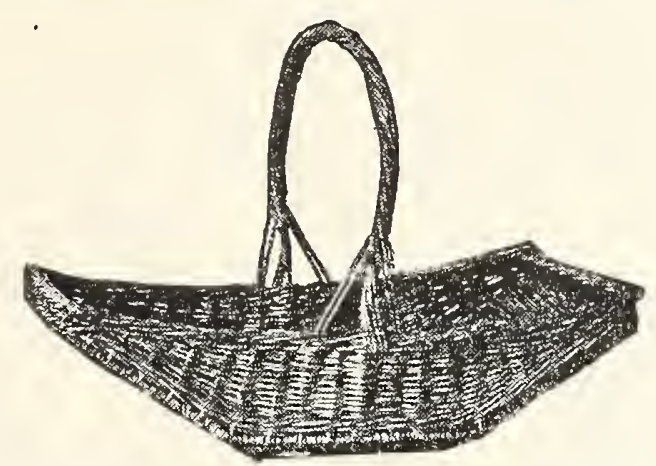

\section{FLOWER GATHERING BASKET}

A well made willow basket, $161 / 2$ inches long, 3 inches deep in the center, and 10 inches wide; 10 -inch bow handle with holder for scissors on the side. Each $\$ 3.50$.

\section{GARDEN BASKET}

A very handy basket for gathering flowers. Made with spruce wood with handle and feet. Size 16 inches long, 9 inches wide, 3 inches deep; dyed green. Each 50c.

\section{SIMPLICITY TRIMMER AND PRUNER}

Actually doing more work with less work. Accomplishing in an hour what formerly took four hours with the old style shears.

Simplicities cut both in opening and closing. Think of it ! What a time and energy saver this is.

Simplicities seem to almost work automatically and you must actually try them to realize how easy they work.

Simplicity Trimmer for first year growth only weighs but 2 lbs.

Simplicity Pruner and Trimmer for pruning back old growth of hedge and shrubbery and trimming new growth as well, weighs but 3 lbs.

Simplicities are made of the finest high grade carbon steel and will give you long service and satisfaction.

Trimmer $\$ 4.00$; Pruner and Trimmer $\$ 6.00$.
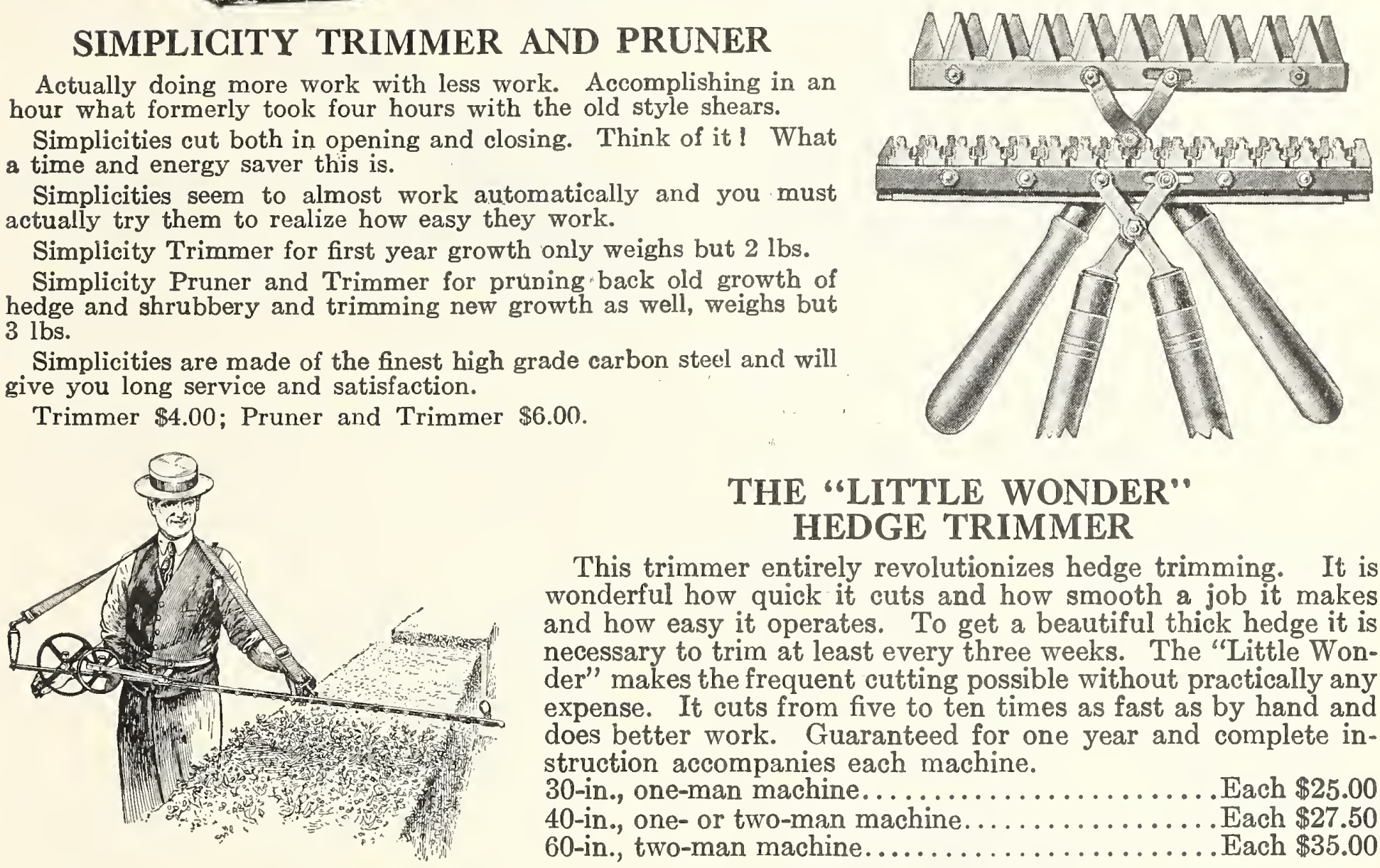

\section{THE "LITTLE WONDER" HEDGE TRIMMER}

This trimmer entirely revolutionizes hedge trimming. It is wonderful how quick it cuts and how smooth a job it makes and how easy it operates. To get a beautiful thick hedge it is necessary to trim at least every three weeks. The "Little Wonder" makes the frequent cutting possible without practically any expense. It cuts from five to ten times as fast as by hand and does better work. Guaranteed for one year and complete instruction accompanies each machine.

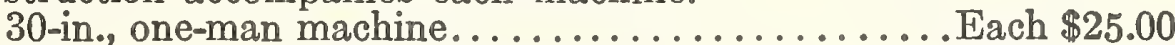

40-in., one- or two-man machine..............Each $\$ 27.50$

60 -in., two-man machine................. Each $\$ 35.00$

\section{THE ELEGTRIC LITTLE WONDER HEDGE TRIMMER}

A marvel for hedge trimming. The most rapid and easy method yet devised. Saves untold hard labor and a tremendous amount of time. Operated with a one-tenth H. P. General Electric motor. Control switch on handle. Cord can be plugged into nearest light socket.

Electric Gear Head, with 100 feet of waterproof cord and gear frame, complete, all ready to be attached to cutting bar. Price $\$ 90.00$. 40-in. Cutting Bar (1 man), each $\$ 16.50 ; 60$-in. Cutting Bar (2 men), each $\$ 24.00$. Extra $100 \mathrm{ft}$. lengths of No. 18 wire, each $\$ 6.00$.

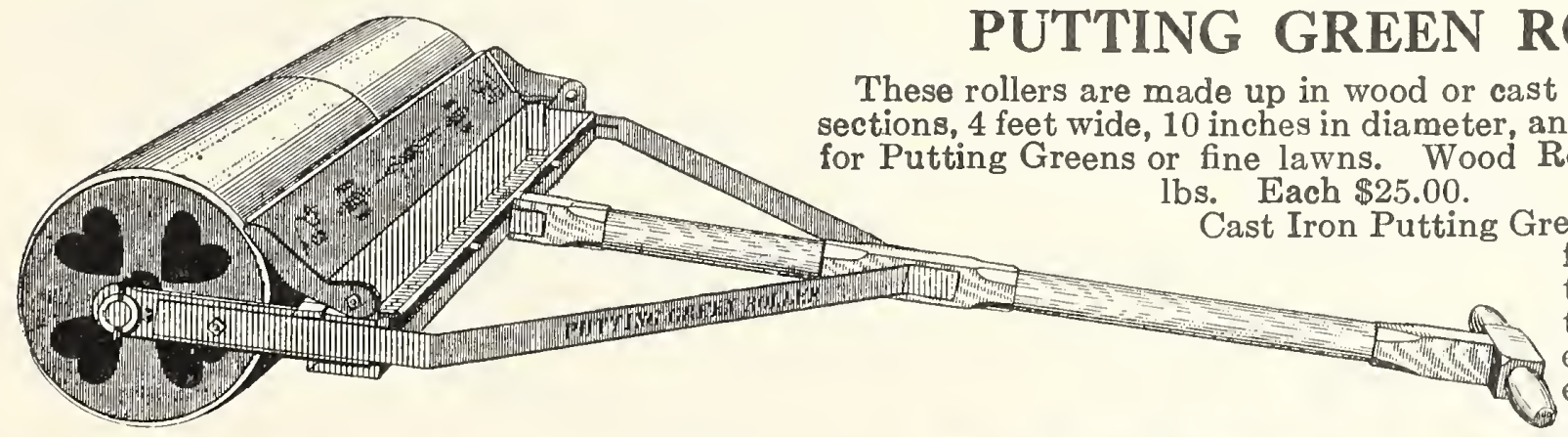

These rollers are made up in wood or cast iron in four 12-inch Tetions 4 feet wide, 10 inches in diameter, and are used especially for Putting Greens or fine lawns. Wood Roller. Weight 200

lbs. Each $\$ 25.00$. four 1 -foot sections turned smooth on the face and equipped with scraper. Weight, 225 lbs. Each $\$ 31.00$.

\section{MARSHALL'S RUBBER HOSE}

This hose is adapted for use on private estates, in the garden, greenhouse, lawns, barns, garage, or livestock buildings. Also on golf courses, tennis, courts, athletic fields, engineering or construction work.

It is smooth or corrugated, non-kinkable and will stand the highest water pressure. Coupled in 250 r 50 feet lengths with $3 / 4$-inch couplings. We will also supply it in any lengths required with couplings.

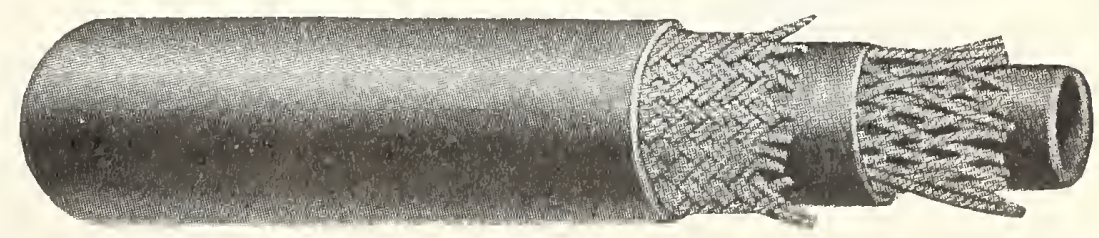

Marshall's Smooth Ifubber Hose. 1/2-in., per ft. 21c. Marshall's Smooth Rubber Hose. 3/4-in., per ft. 23c. Marshall's Corrugated Hose. $3 / 4$-in., per ft. 20 c. 


\section{PLANET JR. TOOLS}

Products of 36 years' experience by a practical farmer and manufacturer who has made a science of tool building. All guaranteed. Illustrated catalogue FREE. Prices subject to change

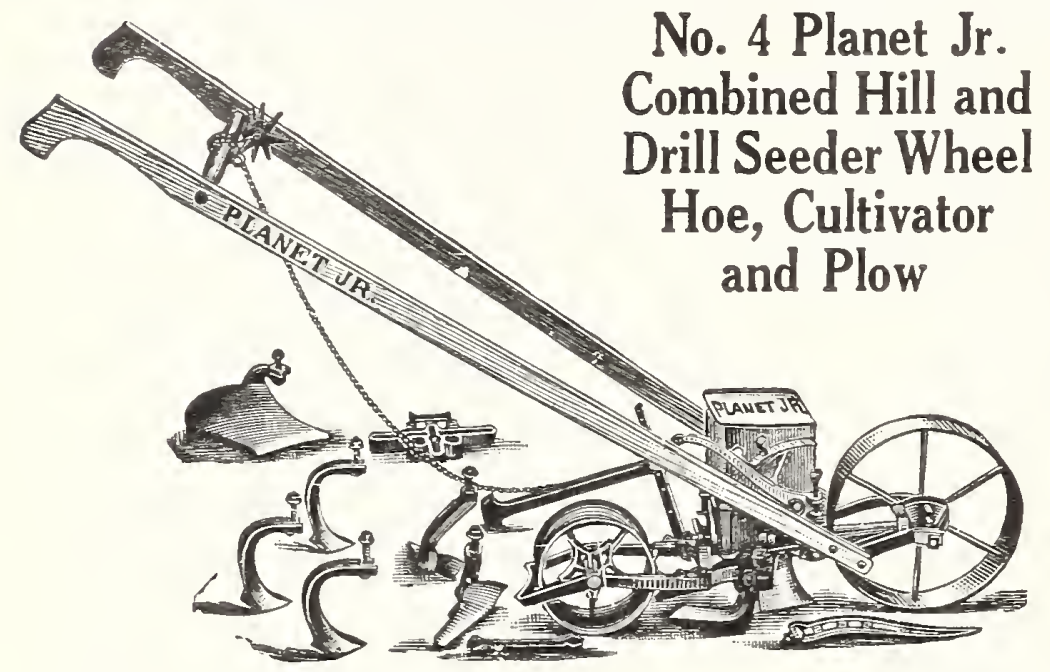

No. 4 complete

$\$ 18.00$

No. $4 \mathrm{D}$, as a Seeder only.

14.25

Does the work of almost all garden tools combined. It sows accurately all garden seeds in drills or in hills $4,6,8,12$ or 24 inches apart, cultivates, furrows and plows.

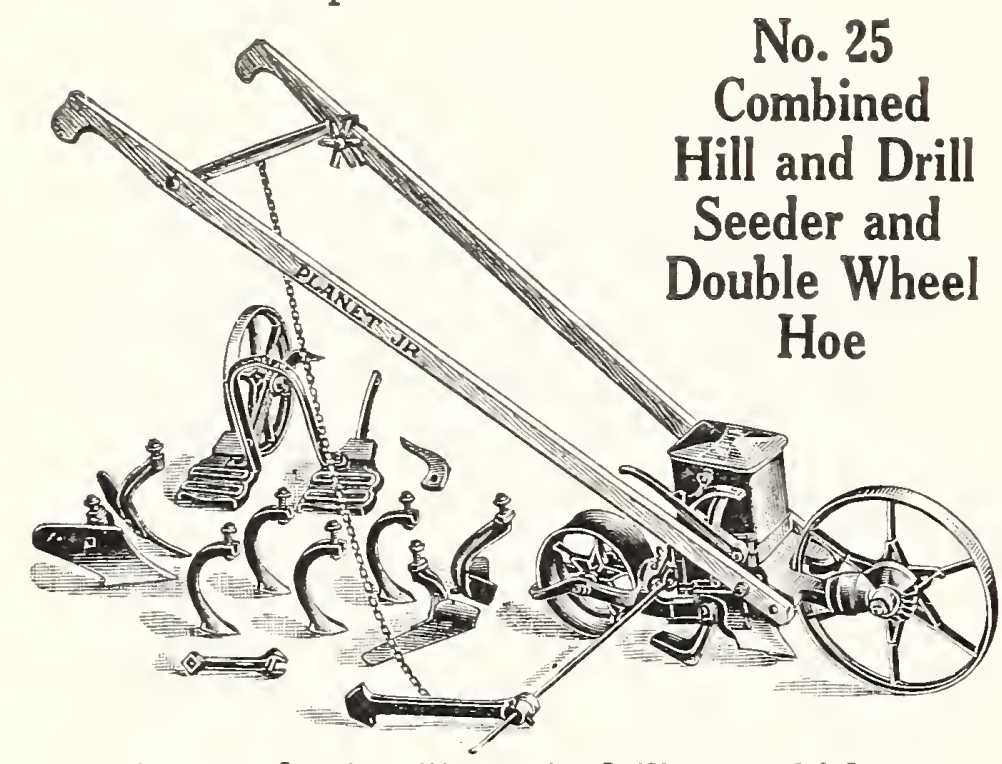

As a seeder it will sow in drills any thickness or drop in hills $4,6,8,12$ or 24 inches apart. It is thoroughly substantial and is accurate in planting all kinds of garden seeds in either hills or drills.

As a wheel hoe it is practically the same as the admirable Planet Jr. No. 12 Double Wheel Hoe, Cultivator and Plow. No. 25, complete, $\$ 21.50$.

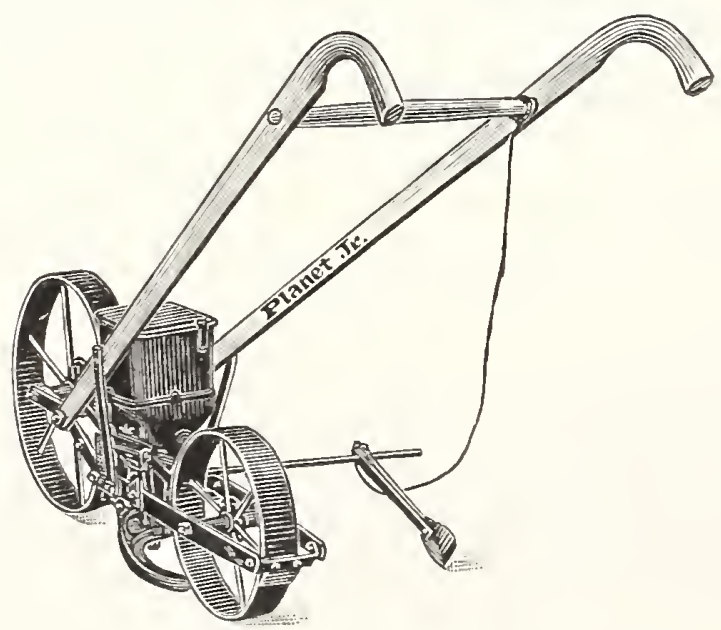

No. 26 Planet Jr. Drill Seeder

A new seeder that will sow large or small seeds. Hopper holds 4 qts. Has automatic shut off. $\$ 20.00$.
No. 11 Planet Jr. Double Wheel Hoe, Cultivator

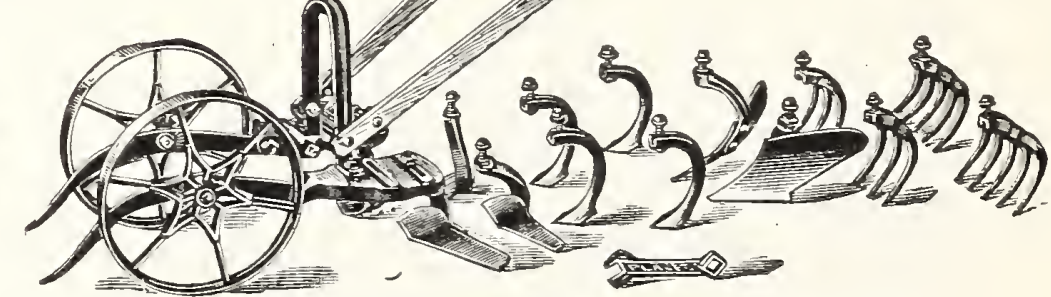

Price, with attachments, as in cut, $\$ 13.75$.

\section{No. 12 Double Wheel Hoe, Price $\$ 10.75$}

This is identical with No. 11 Wheel Hoe, ercept that it has one pair plows, one pair hoes, two pair cultivator teeth and a pair of leaf lifters only.

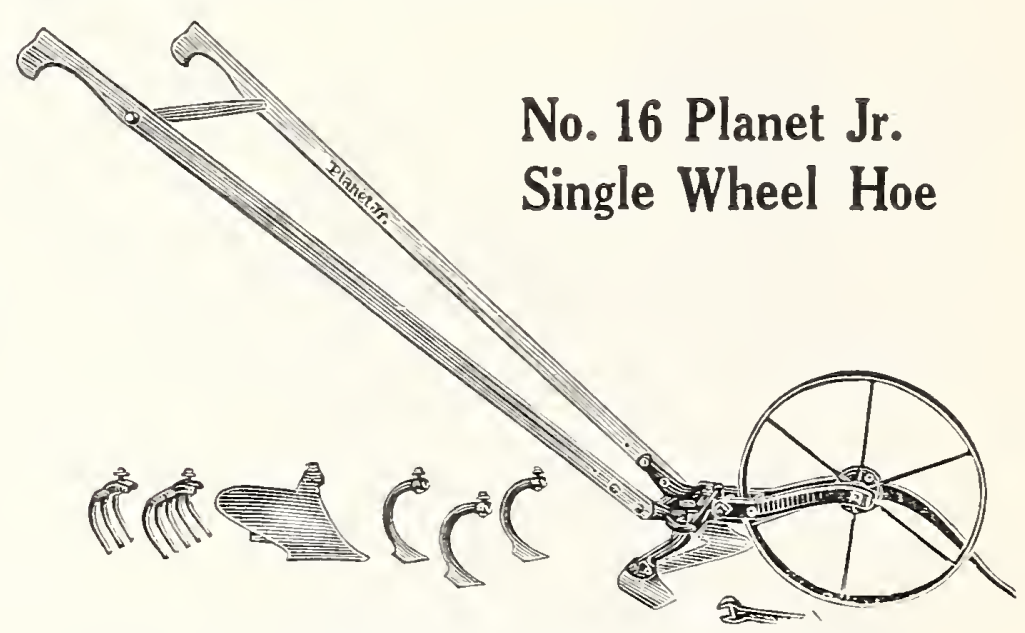

Price, with attachments, as in cut, $\$ 9.00$.

\section{No. 17 Single Wheel Hoe, Price $\$ 7.75$}

The No. 17 has a pair of 6-inch hoes, a plow and a set of cultivator teeth, an outfit sufficient for most garden work.

\section{No. 18 Single Wheel Hoe, Price $\$ 5.75$}

Has one pair of 6-inch hoes only-the tools that are most constantly useful. Other tools can be added as needed.

\section{No. 35 Seeder Attachment}

The above can be attached to any Planet Jr. Single or Double Wheel Hoe. The Hopper holds a pint of seed, is indexed for all the principal seeds and will sow the last seed, so that a

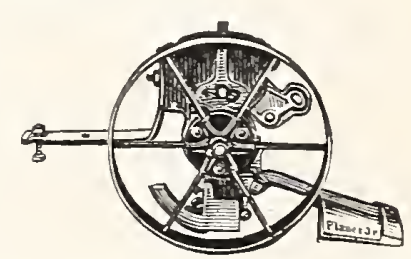
small packet can be sown without waste. Price, $\$ 6.50$. 


\section{PLANET JR. TOOLS.-Continued}

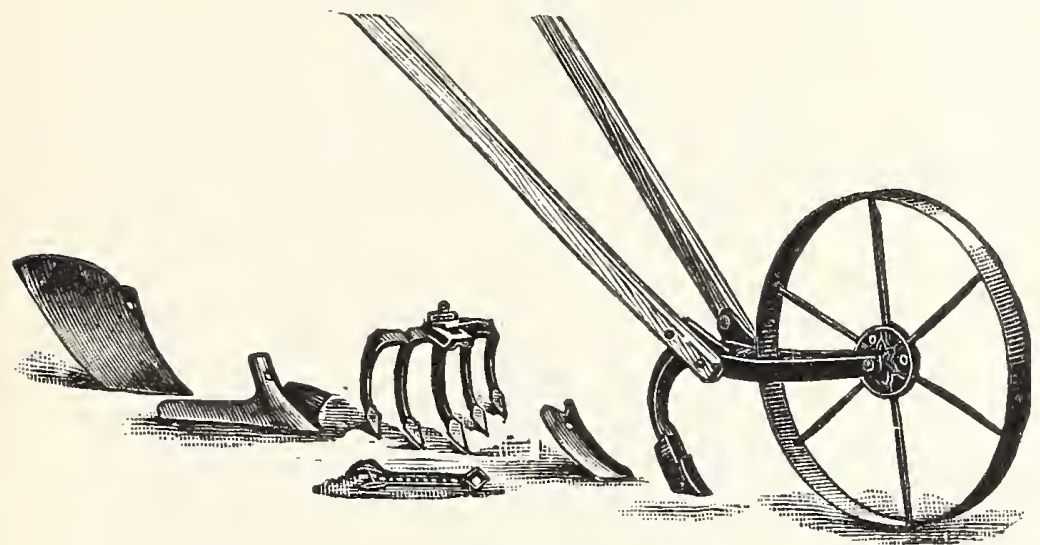

\section{No. 19 Farmers' Single Wheel Hoe, Cultivator and Plow}

A cheap and efficient garden tool, consisting of one plow, one 10-in. sweep, one 5-in. sweep, one 2-in. cultivator and one 4-in. cultivator. Price, complete, $\$ 6.00$.

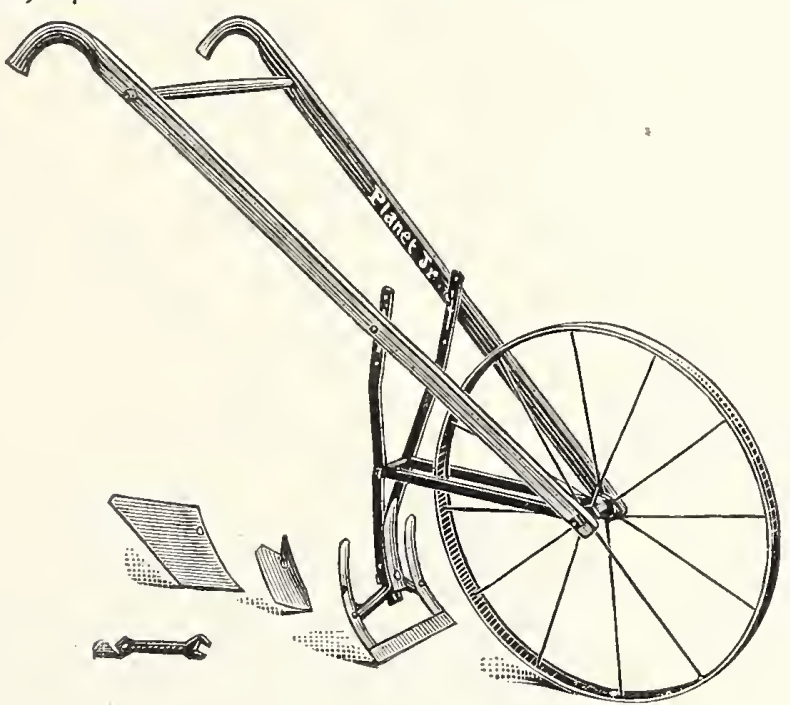

No. 119 Garden Plow and Cultivator

A new cultivator with a 24-in. wheel. A very useful tool for small gardens. Price, $\$ 4.75$.

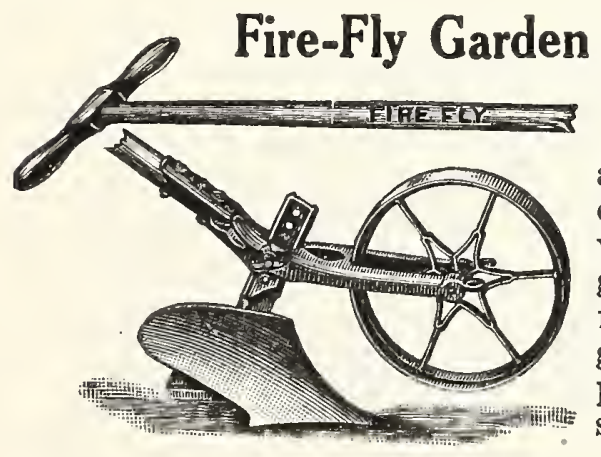

Price, \$4.25.

This tool will enable a busy man to do nearly all the work of a family g a r d e n. Chicken raisers find it of great advantage in plowing up their

\section{Planet Jr. No. 2 Lawn Edger}

\section{(6)}

Every one who uses a lawn mower should have a Planet Jr. No. 2 Grass Edger. The cutting blade is made of the best quality steel and well sharpened. The handle is strong, being made of good quality wood. In order to have attractive lawns, keep the edges well trimmed. There is no better tool for this purpose than the Planet Jr. No. 2 Edger. Price $\$ 1.60$.
Planet Jr. Juvenile Wheel Hoe

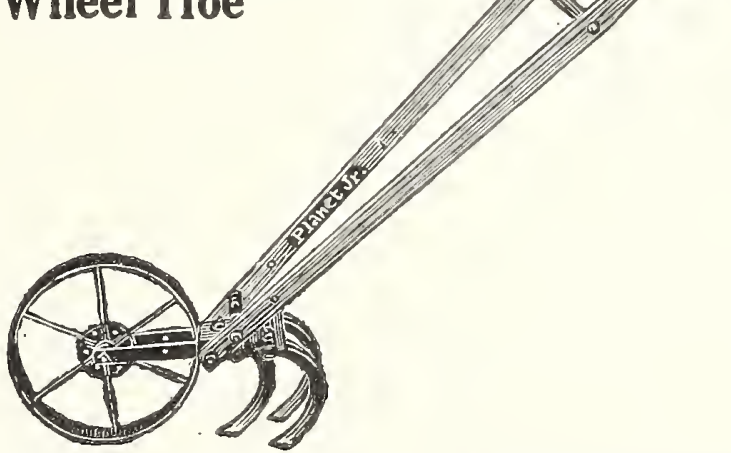

A very desirable tool for the boys and girls who desire to imitate their "daddies" in garden work. Strong and easily handled. Proper size for youngsters 6 to 16 . Price $\$ 4.00$.

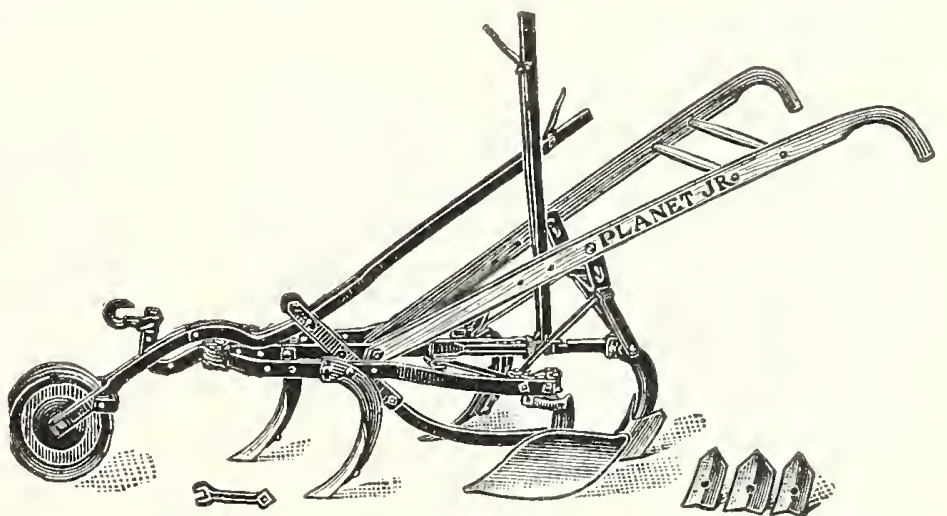

No. 8 Planet Jr. Horse Hoe and Cultivator

The above as illustrated can be used for cultivat. ing almost every known crop in rows. Price, complete, $\$ 17.50$.

\section{Planet Jr. Star Pulverizer, Cultivator, Leveler, and Weeder}

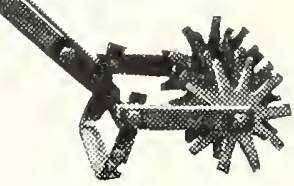

Very useful in flower gardens where plants are close. The star wheels break up the soil and the oscillating blade pulverizes it, and also cuts off the weeds directly beneath the surface. Used as a cultivator after a rain, this tool will not leave the ground in a lumpy condition. $7 \frac{11}{2}$ in Pulverizer $\$ 3.25$.

\section{Extra Parts for Planet Jrs.}

We shall be pleased to supply any parts or attachments shown on pages 30 and 64,65 and 66 of the regular Planet Jr. catalogue. Always give No. of Tool or send broken part when ordering.

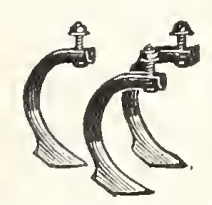

Cultivator Teeth.

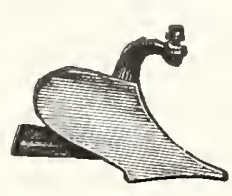

Plow.

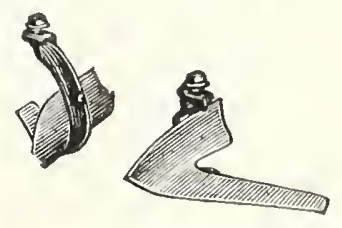

Hoes.
Cultivator Teeth. Each 40 cts. Hoes 6-inch per pair, \$1.30. Plow for S. W. H., each, \$1.35. 


\section{COLDWELL'S LAWN MOWERS}

\section{IMPERIAL HIGH WHEEL MOWER}

The Imperial is one of our best mowers. It can be sharpened in a few minutes without removing any of its parts. We positively guarantee this mower to give entire satisfaction.

Price: 14-in., 4 blades....\$18.00 18-in., 4 blades. $\$ 20.00$ Price: 16-in., 4 blades.... 19.00 20-in., 4 blades 21.00

\section{COLDWELL'S JEWEL LAWN MOWER}

This machine has 8-inch driving wheels, four blades in the revolving cutter and double ratchet, fine cut gears. The bearings are provided with split brass bushings, by means of which all wear can be taken up.

14-inch. .$\$ 8.50$ 16-inch $\$ 9.50$

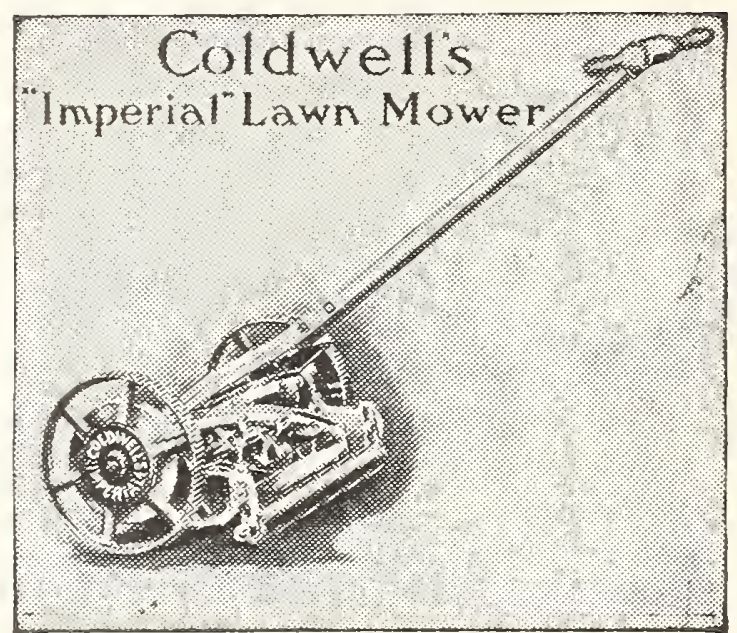

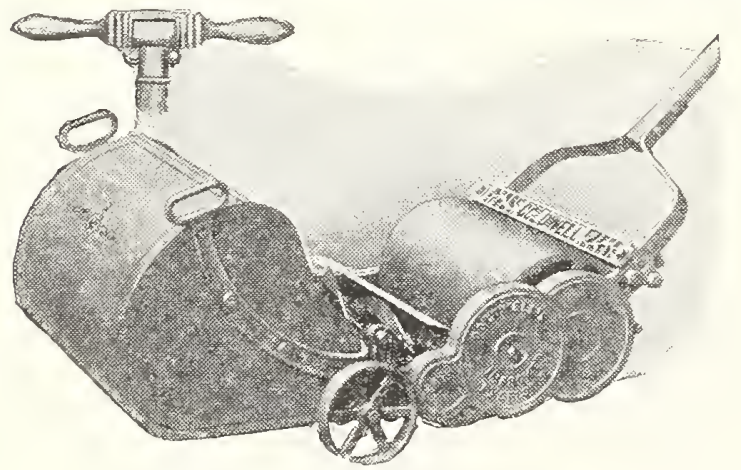

Improved Excelsior Mower

\section{IMPROVED EXCELSIOR MOWER}

This mower is made to meet the demand for a machine that will more perfectly cut borders, verges, etc., and yet retain all the other features necessary in a mower for general work.

Net Price: 12-in., 6 blades.

$\$ 38.00$

Net Price: 14-in., 6 blades. 40.00

Net Price: 16-in., 6 blades. 42.00

Net Price: 18-in., 6 blades. 44.00

\section{GOLDWELL'S IMPERIAL ROLLER- BEARING LAWN MOWER}

The lightest running machine. Has 101/4-inch wheels, five blades, standard Hyatt Roller Bearings, triple pawl ratchet gears and finest finished parts.

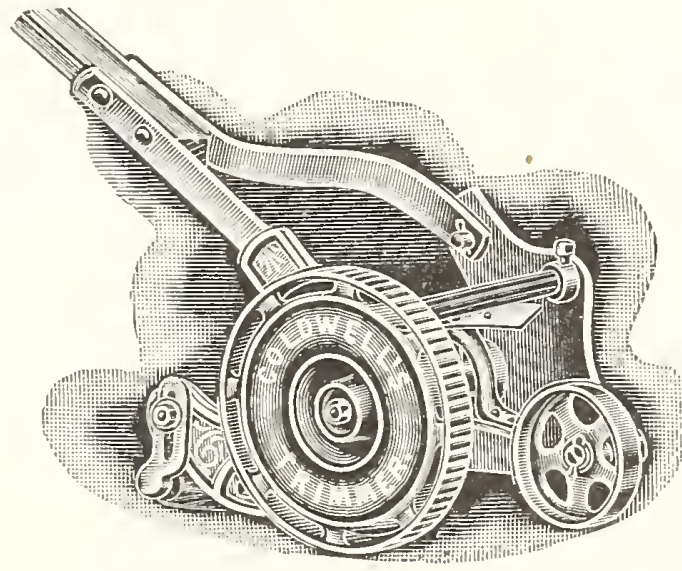

\section{COLDWELL'S LAWN TRIMMER} AND EDGER

\section{(Ball-Bearing)}

Does what lawn mowers leave undone. It can be run close to walls and trees, cutting grass clean and quickly. Can also be used for trimming edges of walks, etc. It has four blades, 8 inches wide, $\$ 12.00$ each.
Metal Grass Catchers, each $\$ 6.50$.

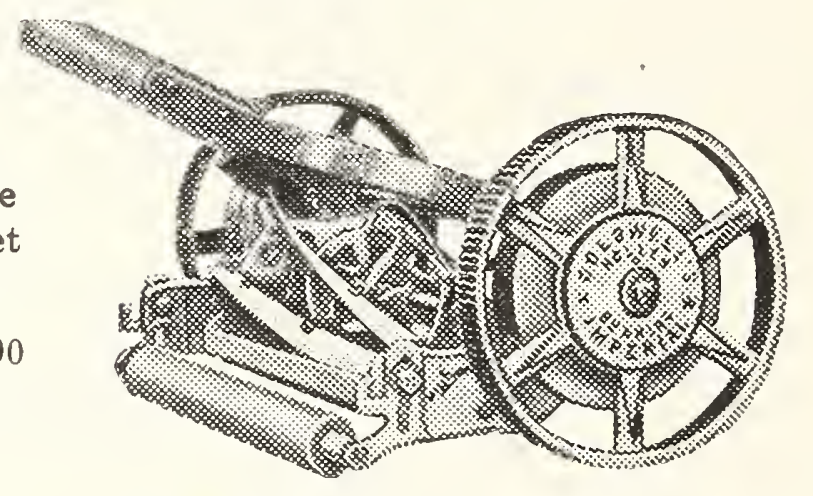

Imperial Roller-Bearing Mower

\section{GRASS CATCHERS}

Galvanized sheet metal bottom with heavy duck canvas sides. Hooks to frame of Mower and handle. Easily detached for emptying.

Net prices: 12-in., 14-in., or 16-in., $\$ 2.50$; 18-in or 20 -in., $\$ 2.75$.

\section{COLDWELL'S UNIVERSAL HORSE LAWN MOWER}

It has side draft attachment to enable the horse to walk on the cut only. We secure evenness of cut by an adjustment which raises or lowers the two sides at the same time by means of a simple lever movement; the same lever serves the purpose of raising the knives from the ground when driving over gravel walks or roads.

30 -in., 4 blades................................................ $\$ 140.00$

30-in., 6 blades................................................ 150.00

35-in., 4 blades....................................................... 155.00

35-in., 6 blades....................................................... 165.00

40 -in., 4 blades.............................................. 175.00

40 -in., 6 blades................................................... 190.00 All Lawn Mower prices are subject to change without notice. 


\section{"EASY" BORDER LAWN MOWER}

The only mower made that will cut borders, mounds, terraces, close to walls and fences, and all kinds of uneven surfaces with the same ease and efficiency as the smoothest lawn.

It has a steel open roller, four spiral blades, self-adjusting ball-bearings with detachable handle.

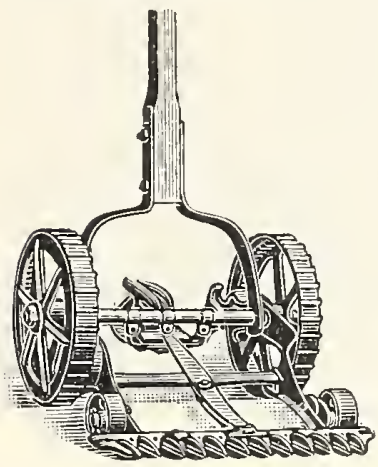

Net Prices:

12 in.. $\$ 25.00 \quad 14$ in... $\$ 27.00 \quad 16$ in... $\$ 30.00$

\section{THE "GLIPPER" MOWER}

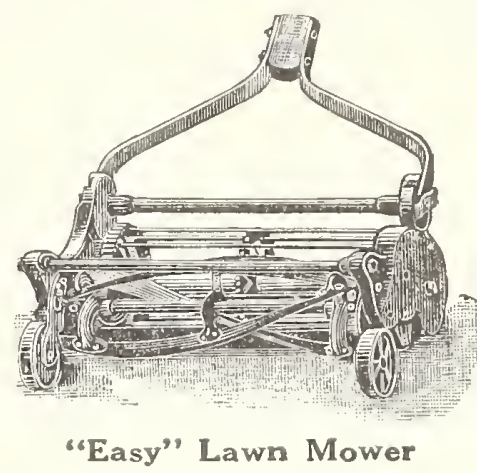

The cut shows a perspective view of the "Clipper" Mower. In the first place you will observe the cutter bar is directly in front of the wheels. The wheels travel over ground where the grass is cut, never rolling down the standing grass with the wheels, as other lawn mowers do. The small gauge wheels at the side are to gauge the height you wish to cut the grass.

Net prices: 15 inches, $\$ 11.00 ; 18$ inches, $\$ 13.00 ; 21$ inches, $\$ 15.00$.

\section{GREAT AMERICAN MOWER}

A double geared mower which gives fine results.

101/2-inch high wheel, 5-blade cylinder, ball-bearing. $15-i n \ldots \ldots \ldots \ldots \ldots \ldots 20.00$ 19 -in.............. \$25.00

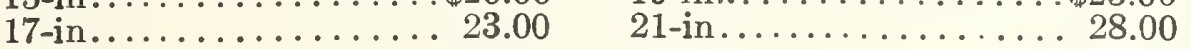

\section{PENNSYLVANIA STANDARD, OR JUNIOR LAWN MOWERS}

The Pennsylvania is the pioneer of all lawn mowers, having an open cylinder, open wheels and a train of gears. High wheel, 101/2inch diameter.

15-in., 4 blades........\$27.00 17-in., 4 blades. . . . . . $\$ 31.00$ 19-in., 4 blades........ $\$ 35.00$

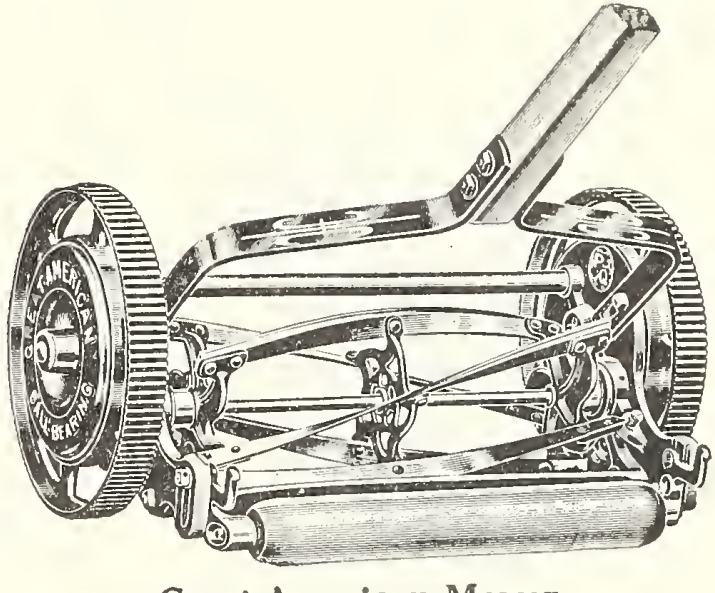

Great American Mower

PENNSYLVANIA PUTTING GREEN ROLLER MOWER

Has 6 blades, 7-in. iron rollers, all highly finished. 14 in. $\$ 33.00,16$ in. $\$ 36.00,18$ in. $\$ 41.00$. Grass Catchers, $\$ 10.00$ each.

\section{TOWNSEND'S GOLF WONDER MOWER}

Especially designed for cutting Putting Greens and fine Lawns. Runs very easy, due to high speed; has gear drive and six-blade knife reel. 16 in. $\$ 28.00,18$ in. $\$ 30.00,20$ in. $\$ 32.00$. Grass Catcher, complete with elevator and deflector, $\$ 8.00$.

\section{SUPERB BALL-BEARING LAWN MOWER}

This mower has 12-inch wheels, 7-inch, 5-blade reel, 2-gear drive and pinion with double pawl.

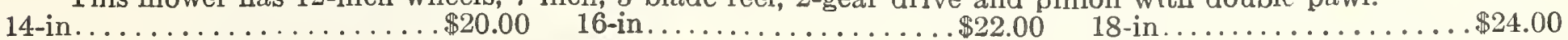

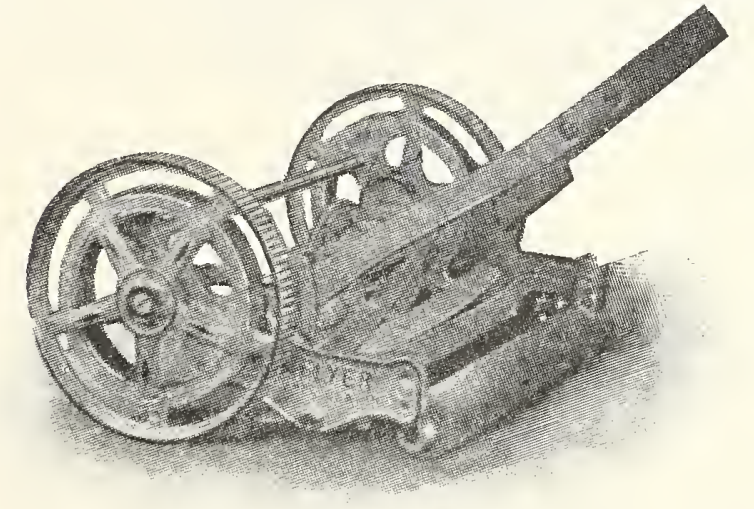

\section{TOWNSEND’S FLYER BALL-BEARING LAWN MOWER}

A good, free cutting, easy running mower with open wheel and frame, made on the two-gear principle. Gears well up from the ground and fully shielded so as to exclude dirt and cut grass. Has 9-inch wheels, four-bladed reel.

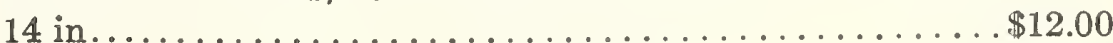

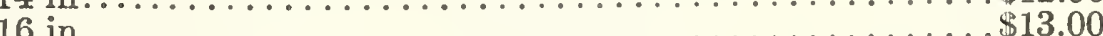

\section{"VICTORY" BALL-BEARING LAWN MOWER}

This mower is fitted with Ball Bearings. The gear is entirely closed, so that no dirt or cut grass can find its way into the pinions and clog them. The cutter bar is easily removed for sharpening without disturbing the frame. The knives cut the instant the mower is moved.

14 in.............\$18.00

18 in ...........\$22.00

16 in ................. 20.00

20 in ................. 24.00

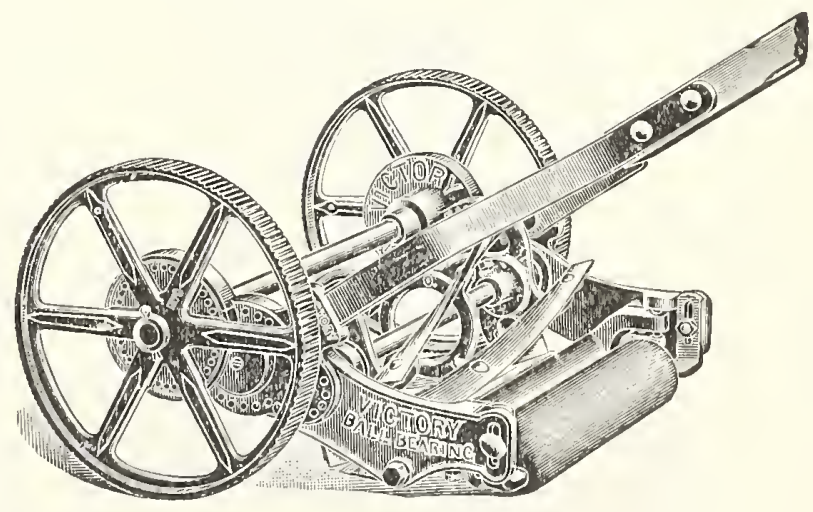

TOWNSEND TRIPLEX LAWN MOWER

Made with three units of 30 inches each, cutting a swath of 86 inches, $\$ 380.00$. 


\section{COLDWELL'S COMBINATION ROLLER AND MOTOR LAWN MOWER}

Simplicity more than anything else has been sought in these models. Mechanical experience is not necessary to operate them and they can be cared for by anyone.

In using these machines you simply have to guide the mower, negotiating any grade that a horse-mower can be used on, and running a keen 30 -inch or 35 -inch cutter over 6 or 8 acres per day. Model " $H$ " weight 850 lbs. Model "G" (same type), 35-inch cut, weight 1000 lbs.

The operating handles are also used for raising and lowering the cutter unit over obstacles.

Model G, 35 in., $\$ 475.00$. F. O. B., Newburgh, N. Y.

Model H, 30 in., $\$ 425.00$. F. O. B. Newburgh, N. Y. Grass Catchers for Model G and H, $\$ 30.00$.

Riding Sulky for Model G or H, $\$ 20.00$.
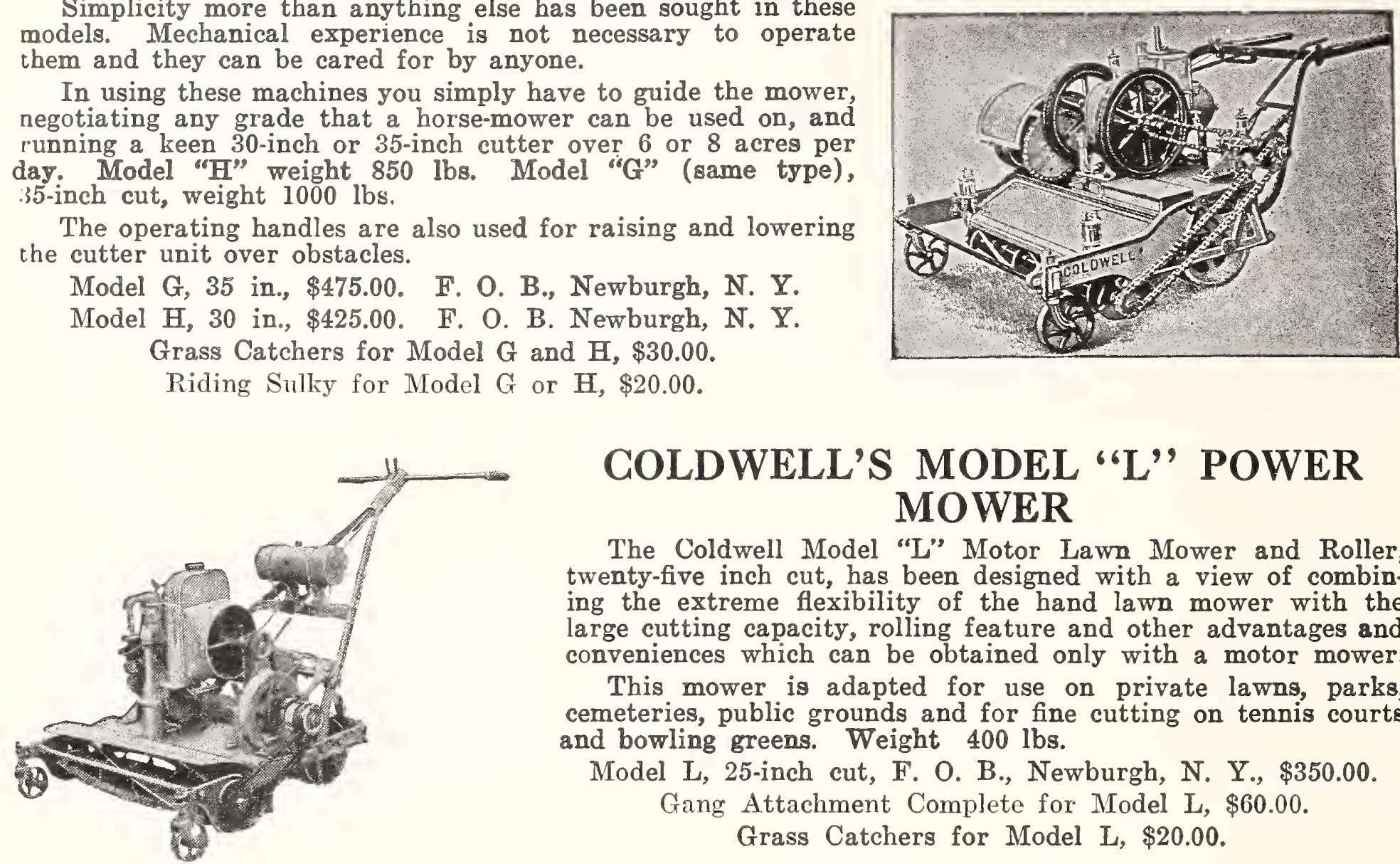

\section{COLDWELL'S MODEL “L” POWER MOWER}

The Coldwell Model "L" Motor Lawn Mower and Roller, twenty-five inch cut, has been designed with a view of combining the extreme flexibility of the hand lawn mower with the large cutting capacity, rolling feature and other advantages and conveniences which can be obtained only with a motor mower.

This mower is adapted for use on private lawns, parks, cemeteries, public grounds and for fine cutting on tennis courts and bowling greens. Weight $400 \mathrm{lbs}$.

Model L, 25-inch cut, F. O. B., Newburgh, N. Y., $\$ 350.00$.

Gang Attachment Complete for Model L, $\$ 60.00$.

Grass Catchers for Model L, $\$ 20.00$.

\section{COLDWELL MODEL "R" LAWN MOWER}

The Coldwell Model " $R$ " mower will cut from 6 to 10 acres of lawn per day, fuel consumption, 1 to $1 \frac{1}{2}$ gallons gasoline for 10 hours running. It has an 8-inch diameter, full width drive roller in two sections. Revolving cutter 6 inches with 5 blades. It has also two gang units that can be attached, making an extreme cutting width of 60 inches. Weight without gang units, 385 lbs.

Model R, 25 inches, $\$ 285.00$. With gang attachment, 60 inch cut, $\$ 345.00$, f.o.b. Newburgh, N. Y.

Grass Catcher for Model R, $\$ 20.00$.
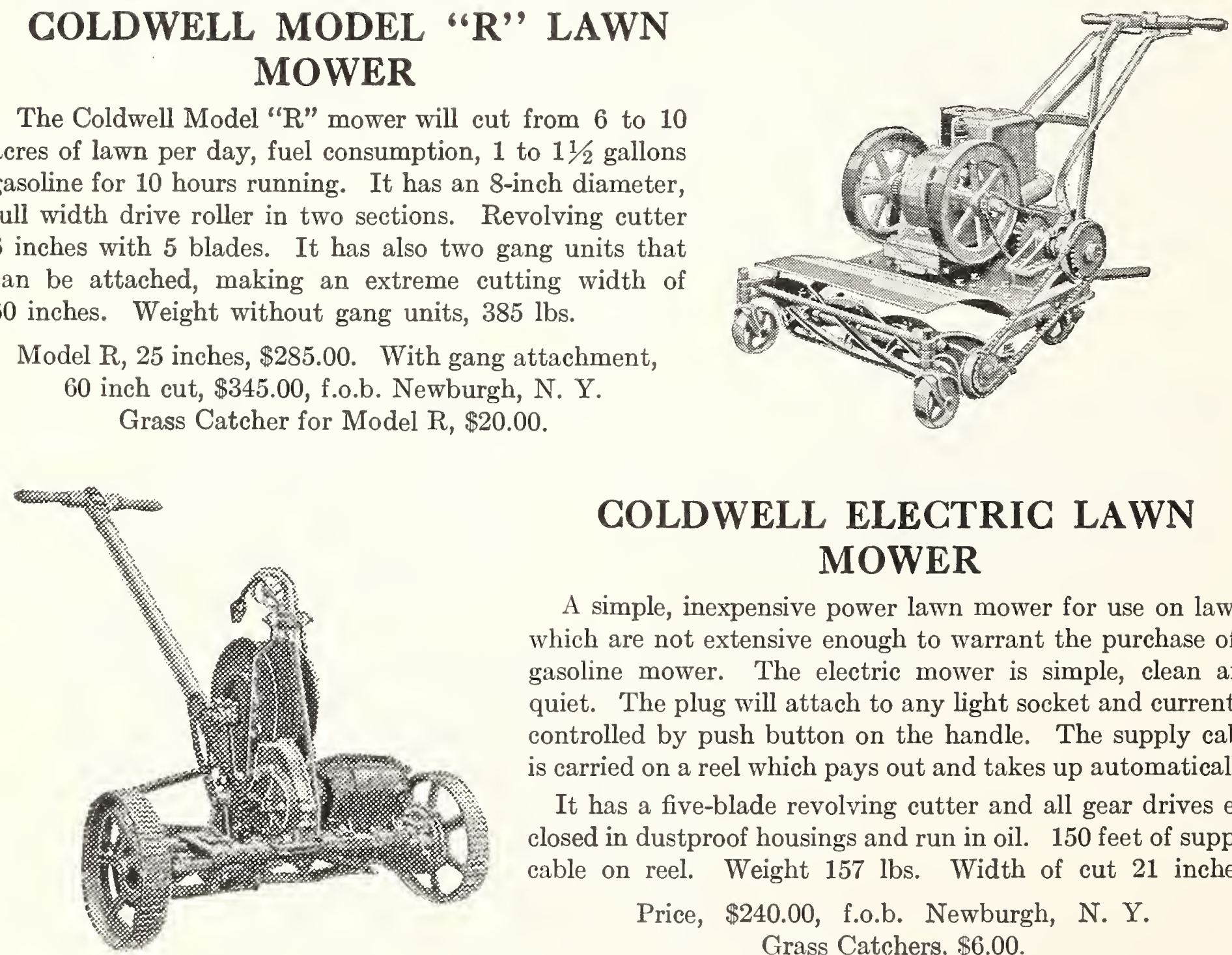

\section{COLDWELL ELEGTRIC LAWN MOWER}

A simple, inexpensive power lawn mower for use on lawns which are not extensive enough to warrant the purchase of a gasoline mower. The electric mower is simple, clean and quiet. The plug will attach to any light socket and current is controlled by push button on the handle. The supply cable is carried on a reel which pays out and takes up automatically.

It has a five-blade revolving cutter and all gear drives enclosed in dustproof housings and run in oil. 150 feet of supply cable on reel. Weight 157 lbs. Width of cut 21 inches.

Price, $\$ 240.00$, f.o.b. Newburgh, N. Y.

Grass Catchers, $\$ 6.00$. 


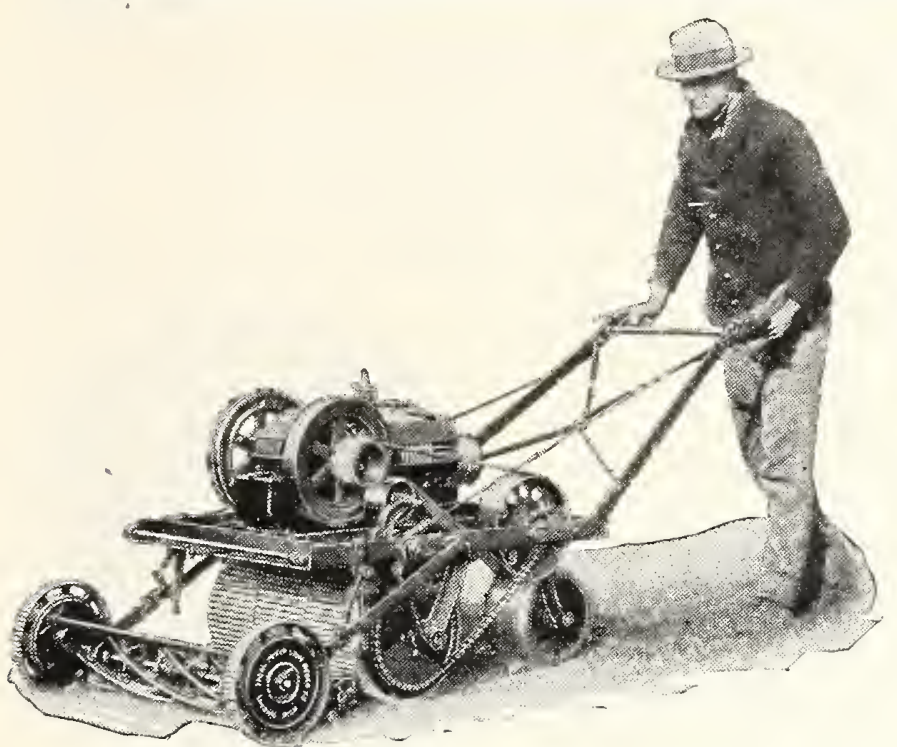

\section{THE IDEAL POWER LAWN MOWER}

The most popular and the most adaptable of the "Ideal" line. Cuts a 30-inch swath. Rolls as it cuts. Will cut six to seven acres per day. Loosely suspended cutting unit tilts to ride over any irregularity of ground. A general purpose mower that cuts close to trees, shrubbery and flower beds. Mechanically simple-fool-proof-easy to operate.

Either the Model 30 or the Junior rolls as it cuts, thereby insuring a smooth, velvety lawn. All unsightly bumps are leveled, and there is no marring the lawn with hoof-prints or mutilation of shrubbery, as is the case with horse-drawn mowers and rollers. Weight $630 \mathrm{lbs}$.

Ideal Power Mower, 30-inch, with one cutting mower,

F. O. B. New York................... \$385.00 Extra for riding trailer, $\$ 20.00$; grass catcher ....... 10.00 Extra for one additional cutting unit.......... 50.00

\section{THE IDEAL JUNIOR POWER LAWN MOWER}

A baby brother to the Model 30-this Junior cuts from three to four acres per day. Cuts a swath 22 inches wide. Built for small grounds, cemetery work, and as an auxiliary unit to the Model 30 on larger grounds. Cuts clean. Adapted to trimming in close quarters. Weight, $430 \mathrm{lbs}$.

Ideal Junior, 22-inch Power Mower with one cutting mower; F. O. B.

New York, $\$ 260.00$.

Extra for one additional cutting unit, $\$ 35.00$.

Extra for grass catcher, $\$ 7.50$.

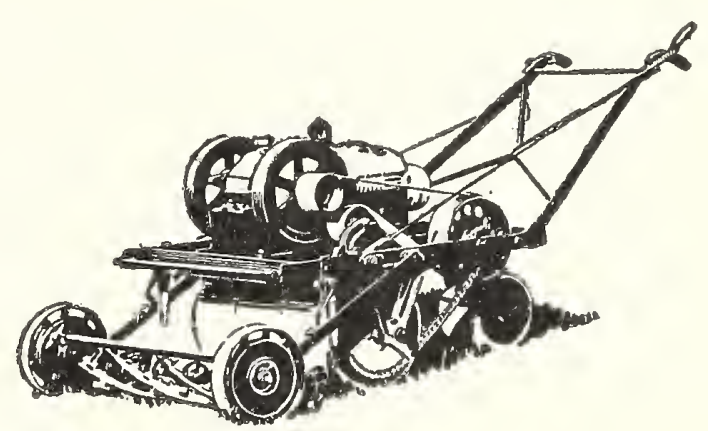

\section{IDEAL TWENTY-FIVE POWER MOWER}

The Ideal "Twenty-Five" is a wheel type power mower adapted to work on lawns that are hilly and have steep grades and terraces to negotiate. It operates on both drive wheels and the cutting unit. Capacity about 5 acres per day. Weight, $310 \mathrm{lbs}$.

Ideal, 25 -inch cut, complete with one cutting unit. ...........................\$290.00

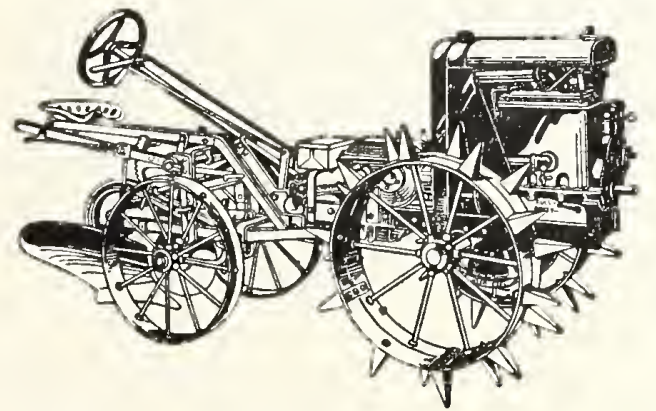

Riding Sulky

Plow and Roller Coulter.

\section{CENTAUR TRACTOR}

The "Centaur" is the highest type power unit made for general farm use. It is an ever-ready, all-purpose tool, positive in action and flexible in control. In all kinds of work the "Centaur" is easy to operate, quicker and cheaper than it can be done in any other way. It is a riding tractor and the entire construction is of the unit type. All implements are quickly and easily attached.

A fully illustrated catalogue sent on request, or machine can be seen at our store set up.

Model G Centaur Tractor, with Automatic Governor Extension Rims and complete Lug Equipment.......\$484.00

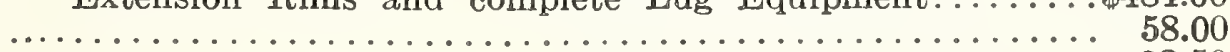

List of all other attachments sent on request.

Prices f. o. b. Greenwich, O., or $\$ 15.00$ additional for shipment from Philadclphia or Poughkcepsie, N. Y.

\section{BOLEN'S GARDEN TRAGTOR}

A light weight gasoline propelled power unit ready to hitch to a great variety of useful implements. It can be used for cultivating, hilling, hoeing, seeding, etc. The instant hitch attachment can be used with the interchange of tools. The speed is easily controlled with two driving sprockets from one to three miles per hour. The engine is air cooled and consumes about one gallon of gasoline in ten hours. The arched axle gives a clearance of 16 inches and the width of tractor is 18 inches. It has a double clutch drive with power turn for either wheel. Fully illustrated booklet mailed free on request.

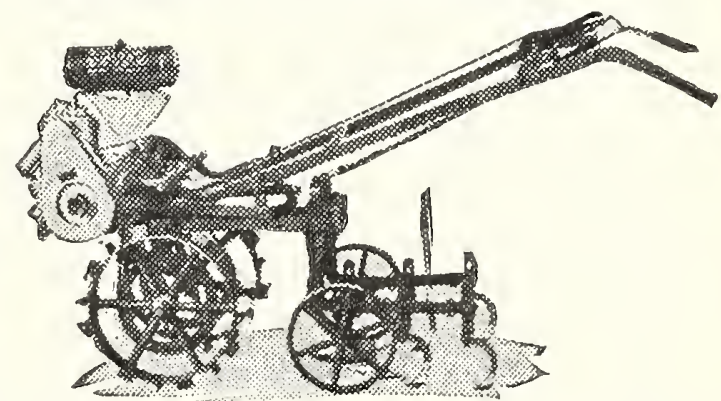

Outfit D-3. Model D. Tractor with D101 instant hitch, one and two row cultivator frame with tool holders, 2 pair of 6 inch hoes and 6 cultivator teeth. Price $\$ 206.40, F$. O. B. factory.

Outfit D-4. Model D Tractor with D111 three row cultivator frame with tool holders, 3 pair 6 inch hoes and 10 cultivator teeth. Price $\$ 220.00$, F. O. B. factory.

\section{BOLEN'S LAWN MOWER ATTAGHMENT}

The Bolen Garden Tractor can be used to great advantage for lawn mowing by simply attaching the lawn mower hitch to the front of the tractor. Extra rims for the whcels are quickly snapped over the wheel lugs to prevent marking the lawn.

No. D-250. Crestlawn cutting unit. Will cut 22 in. wide, with Timken sclf-adjusting bearings, with lawn mower attachment and extra rims for bull wheels. Price $\$ 65.00$.

No. D-251. Crestlawn Cutting Unit. Will cut $30 \mathrm{in.} \mathrm{wide,} \mathrm{with} \mathrm{Timken} \mathrm{self-adjusting} \mathrm{bearings,} \mathrm{lawn} \mathrm{mower}$ attachments and extra rims for bull wheels. Price $\$ 75.00$. 
PENNSYLVANIA

\section{LAWN CLEANER}

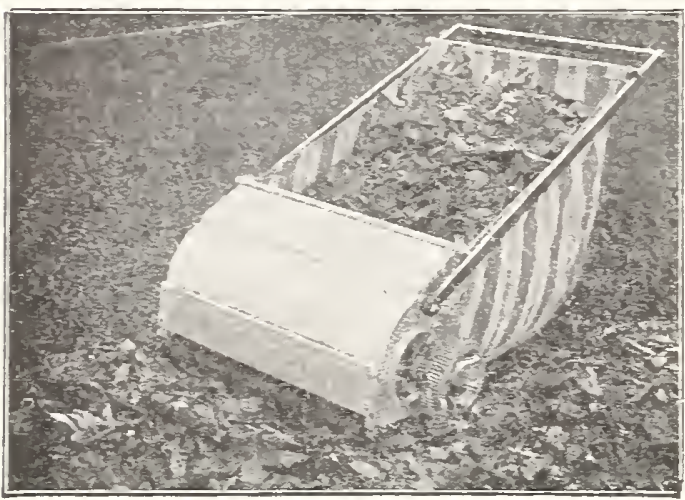

A revolving fan with metal teeth creates an air current which carries into the canras baskets all leares, dead grass, stone, etc., that the rake encounters. It straightens up crab grass and other running weeds so that they may be cut by lawn mower. It com bines strength and durability with light construction. 24 inches wide. $\$ 35.00$. 36 inches wide, $\$ 50.00$.

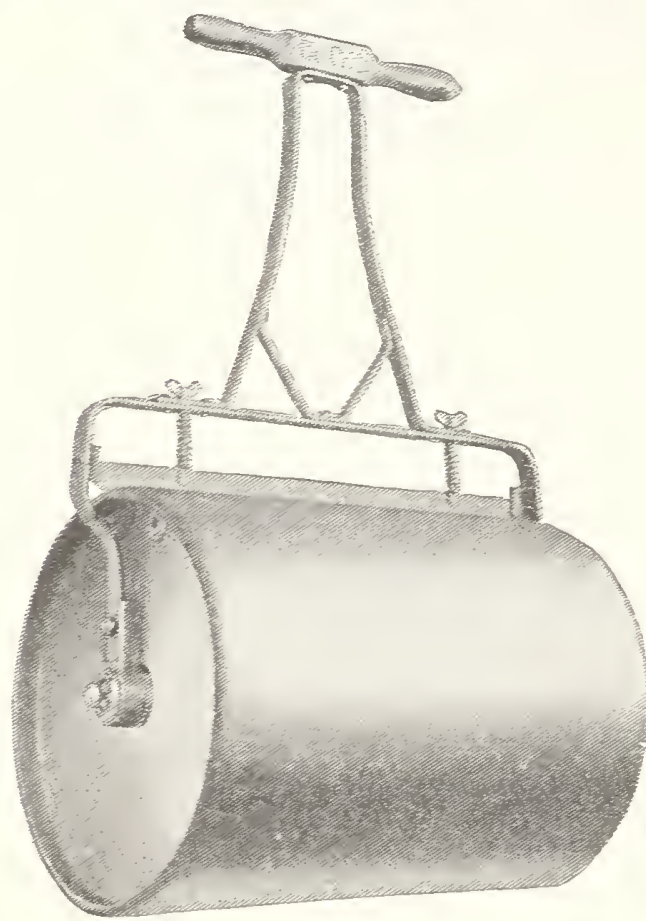

WATER BALLAST ROLLER FOR LAWNS

With a Water Ballast Roller, one can secure any weight desired by simply removing a cap and filling it with as much water or sand as may be required. When filled with sand they weigh $50 \%$ more than with water.

The "WB" type is fitted with a steel scraper, which is adjustable and can also be used to hold the handle in place when not in use.

No. Diameter Length Wgt. Filled Price

1014 in. 24 in. $250 \mathrm{lbs}$. $\$ 18.50$

2018 in. 24 in. 330 lbs. 22.25

3024 in. 24 in. 440 lbs. 25.75

4024 in. 32 in. 590 lbs. 28.00
GRASS SOD and CEMENT TAMPERS

Useful for tamping down sod and uneren spots on lawns, tennis courts and golf grounds. Made of iron, with heavy wooden handle.

Square Pattern. Size 6 in. Weight 12 lbs. Each \$2.25. Size 8 in. Weight 17 lbs. Each \$2.75.

BAKER'S HORSE LAWN SHOE

It is made of a steel plate turned up at the toe to protect the turf, with two riveted prongs that fit the horseshoe in front and a clamp that sets up to the heel. In ordering please send size of horseshoe from toe to heel, or a tracing of the shoe to insure a good fit. Per set, $\$ 10.00$.

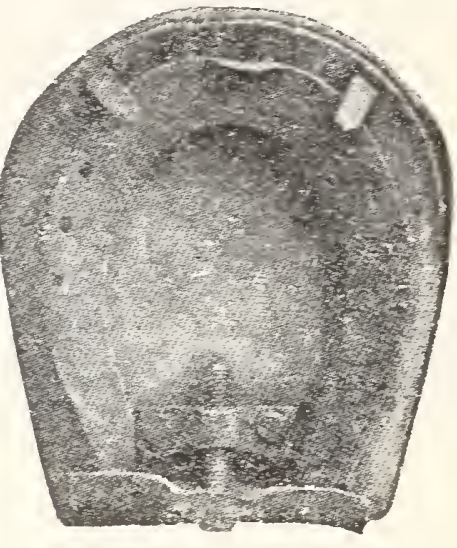

\section{LEATHER HORSE BOOTS}

Wade with double thick riveted soles and straps to go around the hoof. In ordering send outline of horse's shoe. Per set of four, \$18.00.

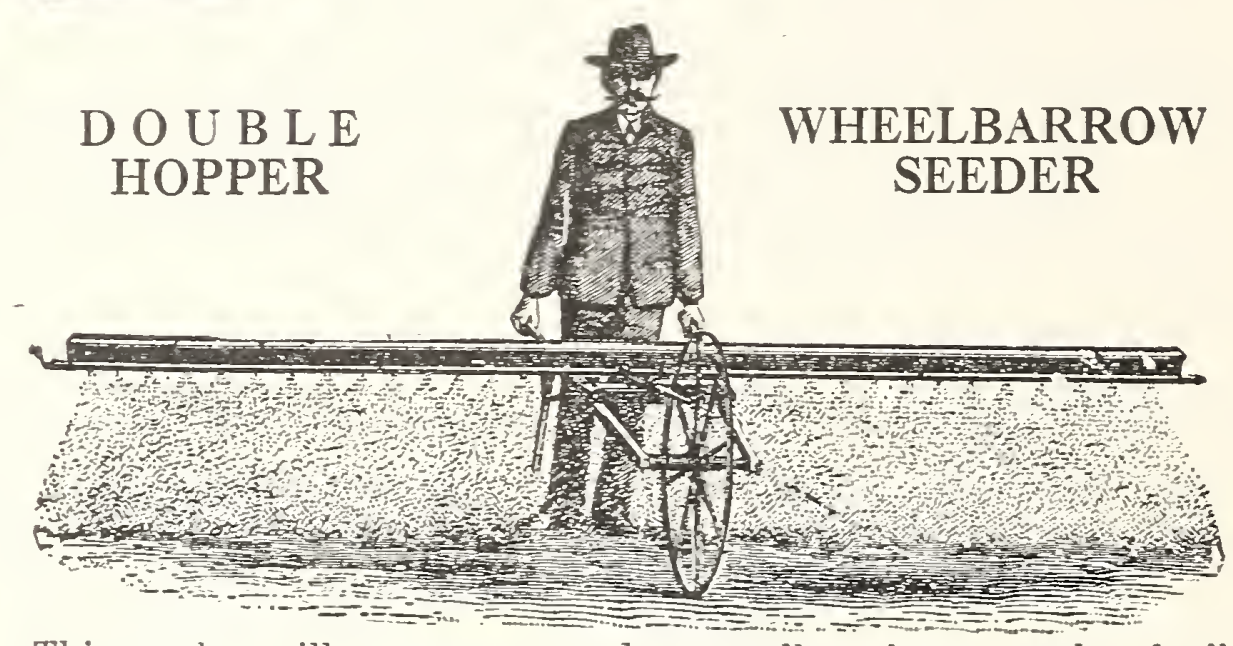

This seeder will sow grass seeds as well as heary seeds of all kinds. It can be regulated to sow any quantity per acre the whole length (14 feet) of the hopper and it does not clog up. Full directions with each seeder. No. 9. Price $\$ 20.00$.

\section{HAND FERTILIZER SOWER}

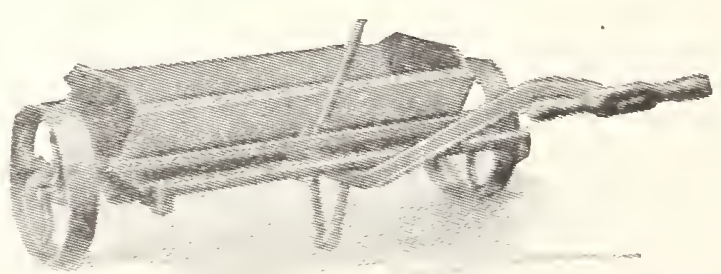

The Hand Sower is small, light, easily operated in close quarters, conveniently drawn by one man and well balanced, fills a need on the smaller place that no other fertilizer distributor can reach. Particularly in top dressing lawns and putting greens on golf courses is the Stevens Hand Sower a veritable necessity. The Hand Sower carries a wood hopper 34 in. long and with capacity of $11 / 2$ bushels. The weight without load is only 85 lbs. Great care has been exercised in its construction to provide for easy balance when loaded. One man easily handles it. Price $\$ 30.00$.

\section{POST-HOLE DIGGER}

The blades are 9 in. long and the handles $5 \mathrm{ft}$. long. Price

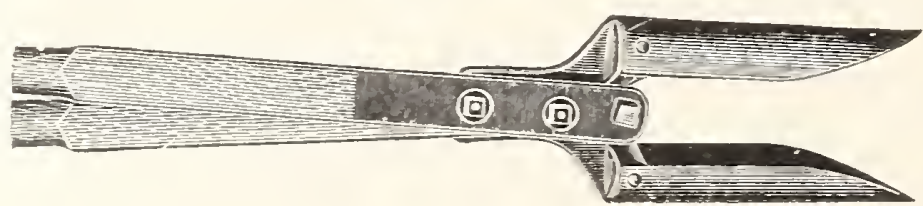




150 WEST 23rd ST., NEW YORK

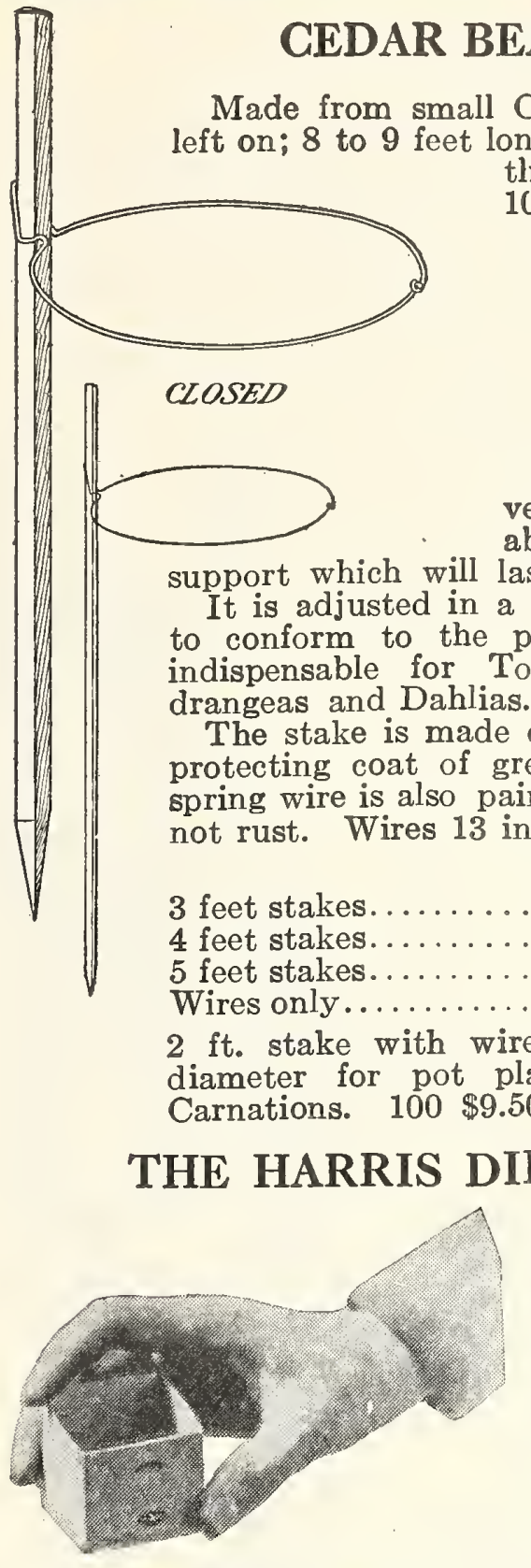
Dahlias.
FAN TRELLIS

Very popular for train.. ing pot plants for windows or conservatories.

Height Width Each

18 in. 6 in .....\$0.40

24 in. $\quad 10$ in..... . 60

30 in. $\quad 13$ in..... .80

36 in. 16 in..... 1.40

All painted dark green.

The "Adjusto" is a very simple, unbreakable, practical and cheap

pill last a lifetime. Tomatoes, Roses, Hyprotecting coat of green paint; the heavy . ameter. Each Doz. .$\$ 0.20 \quad \$ 2.25$ $\begin{array}{ccc}\ldots & .25 & 2.75 \\ \ldots & .25 & 3\end{array}$

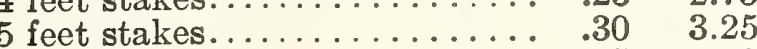
列 diameter for pot plants and

Carnations. $100 \$ 9.50 \ldots \ldots \ldots . .12$

1.25

an idea cut worm an ideal cut worm guard when placed around the plant in the garden.

1001000

No. $13 / 4$ B, size $13 / 4 \times 13 / 4$, depth $21 / 2$-in . . . . \$0.50 $\$ 3.50$

No. 2 B, size $2 \times 2$, depth $21 / 2$ in ........ .604 .00

No. $3 \quad B$, size $3 \times 3$, depth 3 in..........70 5.00

No. $4 \quad$ B, size $4 \times 4$, depth 3 in...........75 5.50

\section{SOD PERFORATOR}

Used for renovating bad spots in lawns, terraces, etc. In perforating the ground it permits the seeds to enter the soil and germinate quickly. Size 12 in.x 12 in. with handle. Each $\$ 4.50$.
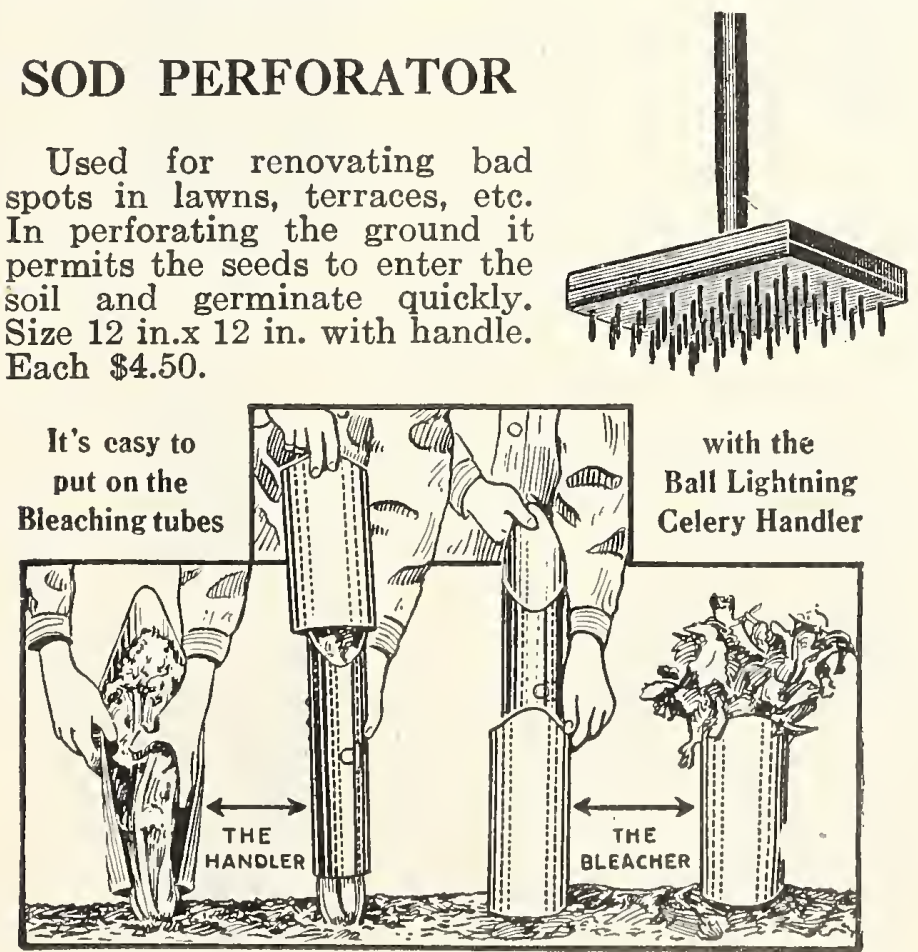
used for sharpening lawn

\section{TOMATO STAKES}

Made with Cypress, 1 inch square, 5 feet long, pointed at end. Doz. $\$ 2.50$, $100 \$ 16.00$.

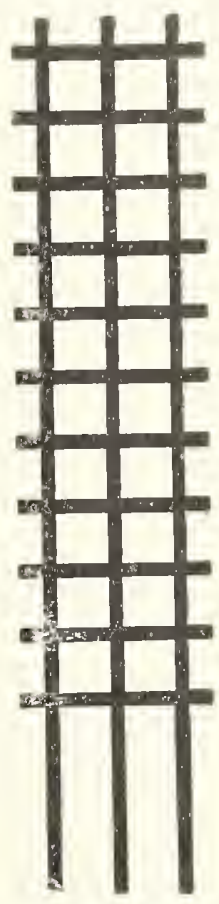

\section{LATTICE} TRELLIS

A substantial plant support for use around doors and windows for plants and vines. Made with three upright supports. Painted green. $8 \mathrm{ft}$. high, 18 in. wide. Each $\$ 4.00$.

\section{VERANDA}

\section{TRELLIS}

Adapted for outdoor use for climbing vines and Roses. Painted green. 8 ft. high, 18 in. wide. Each $\$ 4.00$.

\section{LAWN MOWER SHARPENING GOMPOUND}

This is a grinding paste mowers. It is applied to the blades and by rotating them backward and forward on the bottom knife it sharpens them in a very few minutes without taking the machine apart. Full directions with each can. Can $60 \mathrm{c}$.

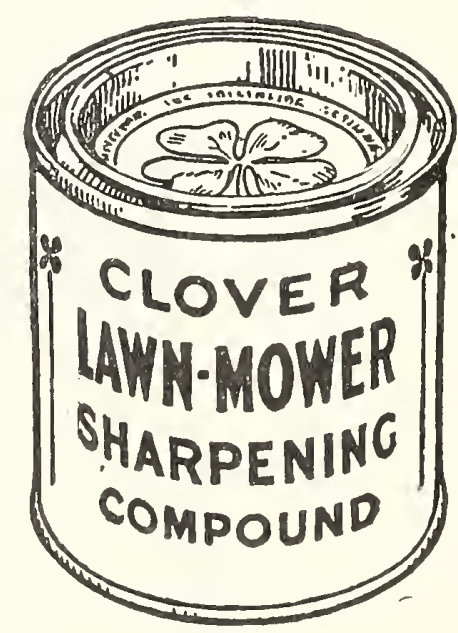

\section{GELERY BLEACHERS}

The home grower and private gardener will find this an ideal system of bleaching Celery-handy, neat and just the thing to bleach a few stalks every few days as wanted.

It only takes a week or ten days after putting on these bleachers when your Celery will be a beautiful white, and all ready for the table. No banking with soil, no hunting up boards, and it produces better results on early Celery. The same bleachers can be used over and over again the same season.

Price of Bleachers, $61 / 2 \times 13$ in., 60c. per doz., $\$ 4.50$ per $100, \$ 40.00$ per 1000 .

\section{GELERY HANDLER}

For putting on bleachers. Each $\$ 1.50$. 


\section{AUTO-SPRAY PUMPS}

No other style of sprayer will do such a variety of work, and do it so well. We recommend it for trees, shrubs and vines, greenhouses, poultry houses, hospitals and stables for disinfectants, for sheep and cattle dip and cattle fly oils.

It may be used where any bucket or knapsack Sprayer can be used, and with much more satisfaction. Even those who have commercial orchards and large power Sprayers need the "Auto-Sprayer" No. 1 for small work.

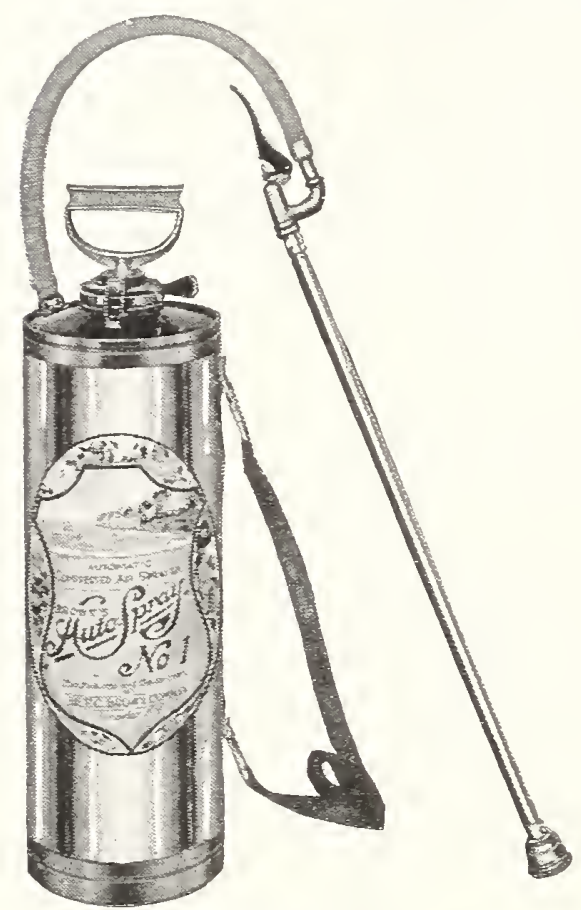

Au to Spray No. 1

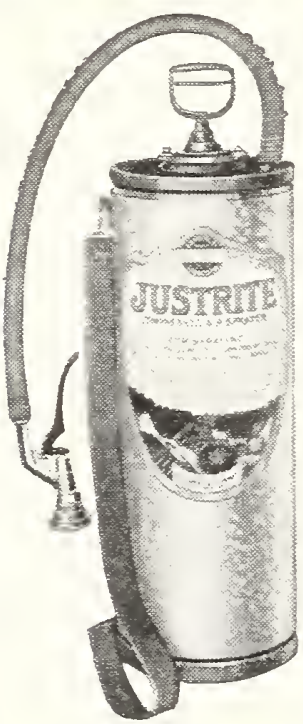

Justrite Sprayer

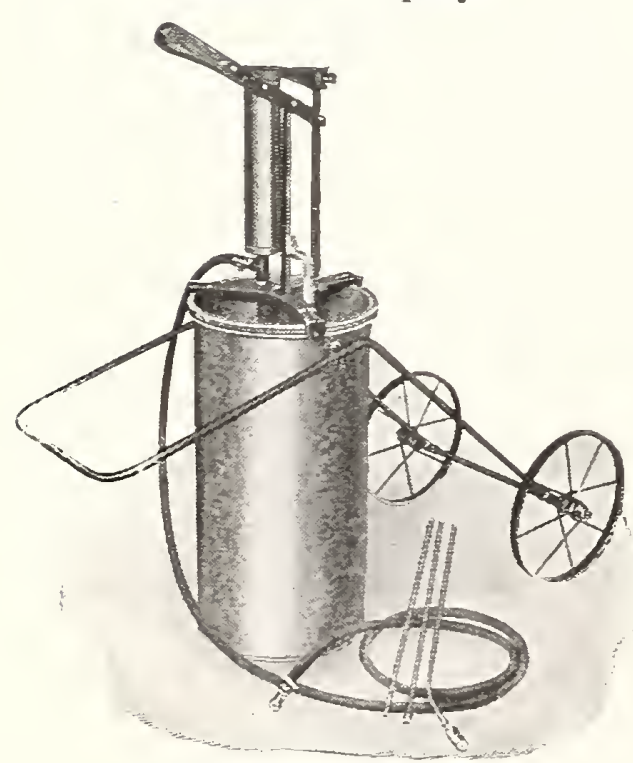

Paragon Sprayer No. 3
No. 1 B. Brass tank, with "Auto-Pop" nozzle. Capacity $3 \frac{1}{2}$ gals.............\$9.25

No.9 D. Galvanized tank, with "Auto-Pop" nozzle.......................6.25

No. 9 B. Brass tank, with "Auto-Pop" Nozzle, $31 / 2$ gals. Screw locking device...... 9.25

No.9 D. Galvanized tank with "Auto-Pop" nozzle.......................6. 6.25

No. 100 B. Brass tank with "Auto-Pop" nozzle. Capacity 5 gals................10.50

No. 100 D. Galvanized tank, with "AutoPop" nozzle........................ 7.00

"Auto-Pop" nozzle with hose and connections. 2.00

"Auto-Pop" nozzle....... . . . . . . . . . 1.50 Extension pipe, brass, $2 \mathrm{ft}$. lengths, each... .60 Elbow extension, solid brass............ 35 Brass strainer................... 1.50 Set of soft parts for No. 1........... . .25 Two row attachment, 1 nozzle.......... 1.50 Auto-Spray, No. 50 B. Similar to No. 9, with a capacity of $2 \frac{1}{2}$ gals. only.......... 8.00

\section{JUSTRITE SPRAYER}

A very handy sprayer for small work around the garden and whitewashing. Tank 17 in. by $61 / 4$ in. Capacity 2 gals. and automatic nozzle. Galvanized tank. Each $\$ 5.00$.

\section{BANNER NO. 22 SPRAYER}

This sprayer is adapted for all spraying purposes, whitewashing and disinfecting. Tank 21 in. by $71 / 2$ in., capacity about 4 gals. Automatic nozzle for three different sprays. No. 22 Brass tank, $\$ 9 . j 0$.

\section{PARAGON NO. 3 SPRAYER}

For spraying trees, vegetables, whitewashing or water paints.

Mounted on a strong metal truck and can easily be wheeled to any desirable place. All liquid passes through the automatic, self-cleaning strainer before entering the pump, and cannot clog the nozzle when spraying.

Equipment: $10 \mathrm{ft}$. Special Spray Hose, $71 / 2 \mathrm{ft}$. Extension Pipe, one Mist Nozzle, one Steel Cap, one Straight Spray. Any additional length of hose can be furnished at a reasonable extra charge. Capacity, 12 gallons, galvanized tank. Price, $\$ 25.00$. Without truck, $\$ 21.50$.

\section{PARAGON NO. 4 SPRAYER}

Adapted for fruit or garden spraying. Barrel holds 28 gals., mounted on strong 30 -in. iron wheels.

Equipment: $20 \mathrm{ft}$. Spray Hose, $10 \mathrm{ft}$. Extension Pipe, 1 Srray Nozzle and 1 Straight Spray. Complete, $\$ 39.50$.

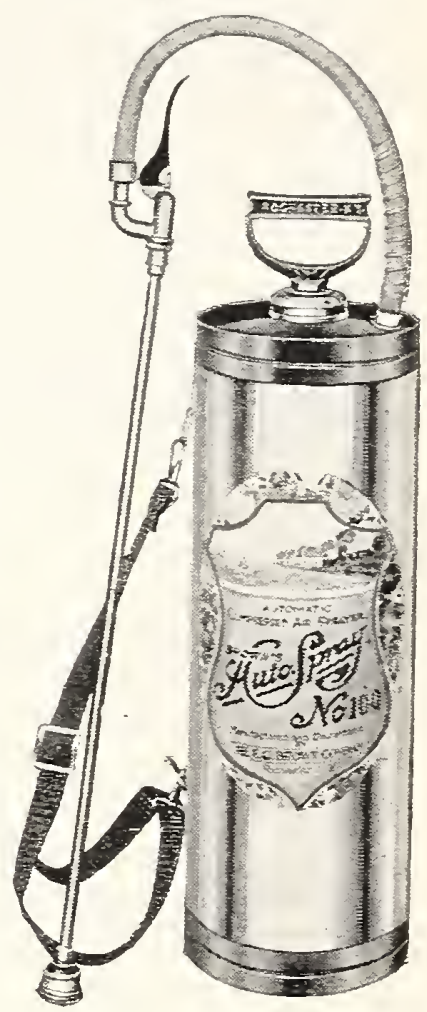

Auto Spray No. 100

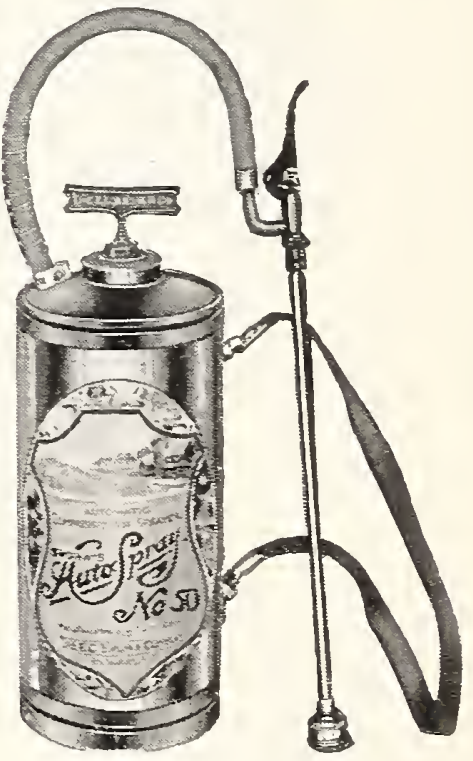

Au to Spray No. 50

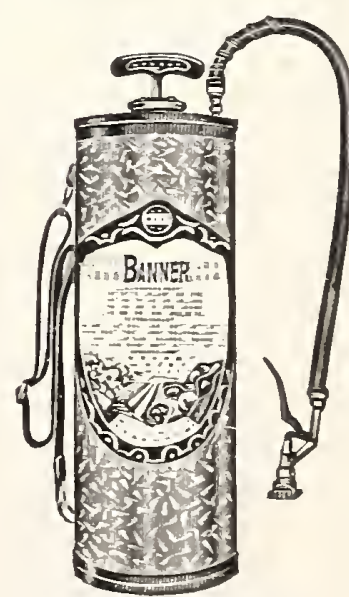

Banner Sprayer 


\section{"POMONA" BARREL SPRAY PUMP}

Very Powerful and Large Capacity-All Working Parts Bronze The best orchard barrel Sprayer. It is unusually powerful and of large capacity, fully capable of supplying four leads of hose and eight nozzles. There is nothing about the Sprayer to get out of order, and with ordinary care it will last a lifetime.

Pump, with Agitator and Hose Coupling. .$\$ 22.00$

Outfit C. Pump with Agitator, one lead $15 \mathrm{ft}$. , Discharge Hose. and Mistry Jr. Nozzle...

Outfit D. Pump with Agitator, two leads, $15 \mathrm{ft}$. each, Hose and two Mistry Jr., Spray Nozzles..

Barrel furnished for above and mounting..... 28.25

11.00

Bamboo Extension. $10 \mathrm{ft}$. long. A brass tube inserted in a bamboo rod. Fitted with brass stop-cock..................................... 6.00 Iron Pipe Extension. \& ft. long. Fitted with stop-cock............. 3.50 Barrel Cart. For mounting the above Sprayers. Wheels with 3 in tires, without barrel.

16.00
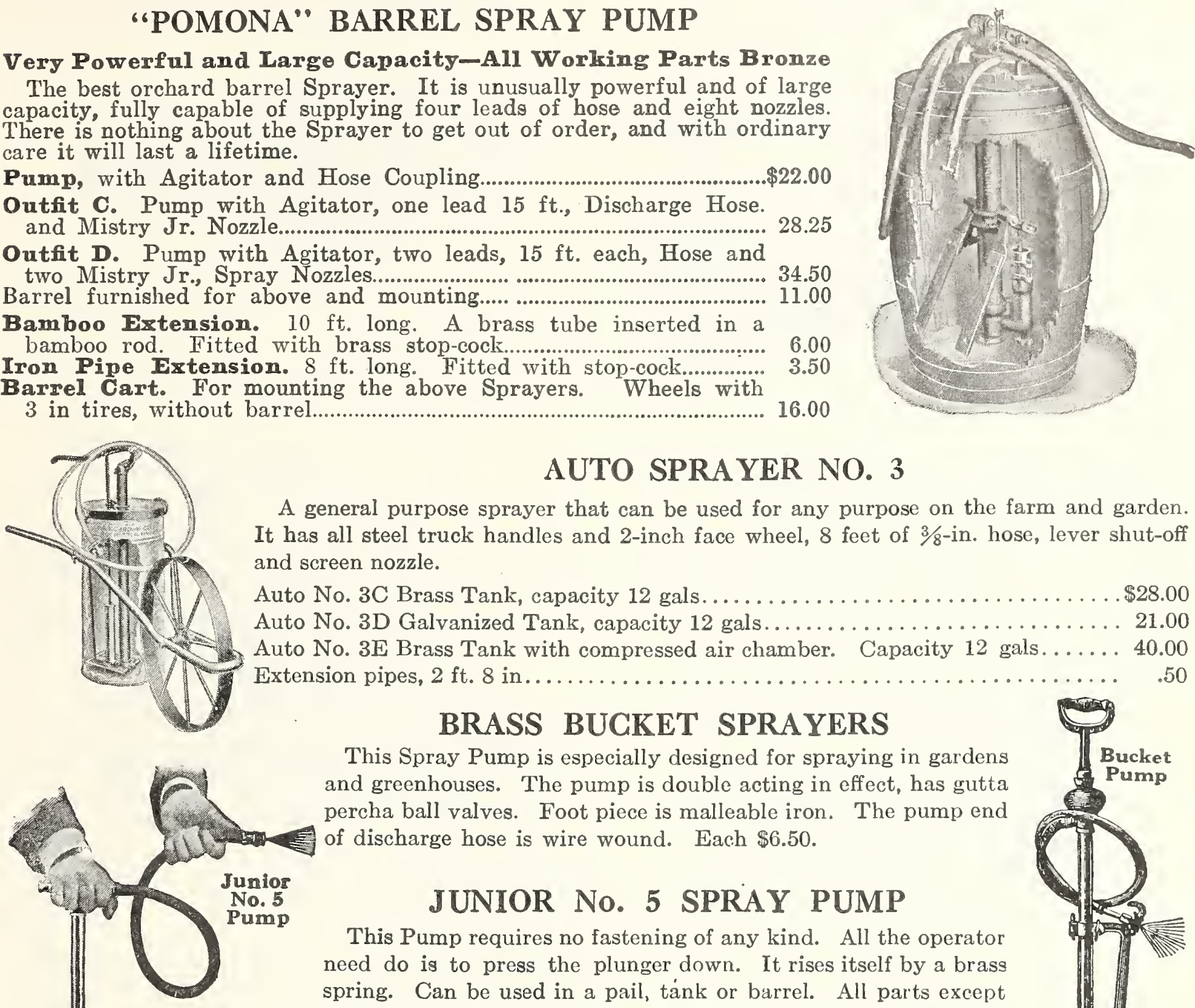

AUTO SPRAYER NO.

A general purpose sprayer that can be used for any purpose on the farm and garden. It has all steel truck handles and 2 -inch face wheel, 8 feet of $3 / 8$-in. hose, lever shut-off and screen nozzle.

Auto No. 3C Brass Tank, capacity 12 gals........................ \$28.00

Auto No. 3D Galvanized Tank, capacity 12 gals...................... 21.00

Auto No. 3E Brass Tank with compressed air chamber. Capacity 12 gals..... 40.00

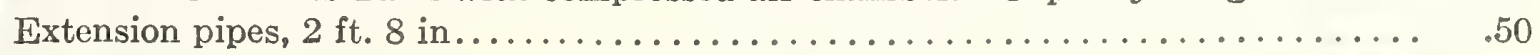

\section{BRASS BUGKET SPRAYERS}

This Spray Pump is especially designed for spraying in gardens and greenhouses. The pump is double acting in effect, has gutta percha ball valves. Foot piece is malleable iron. The pump end of discharge hose is wire wound. Each $\$ 6.50$.

\section{JUNIOR No. 5 SPRAY PUMP}

This Pump requires no fastening of any kind. All the operator need do is to press the plunger down. It rises itself by a brass spring. Can be used in a pail, tánk or barrel. All parts except handle and hose are solid brass. Complete with hose and nozzles as shown in cut, each $\$ 3.50$.

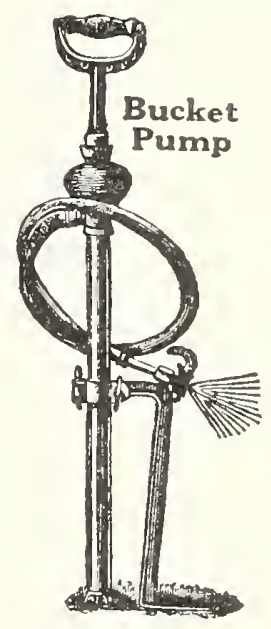

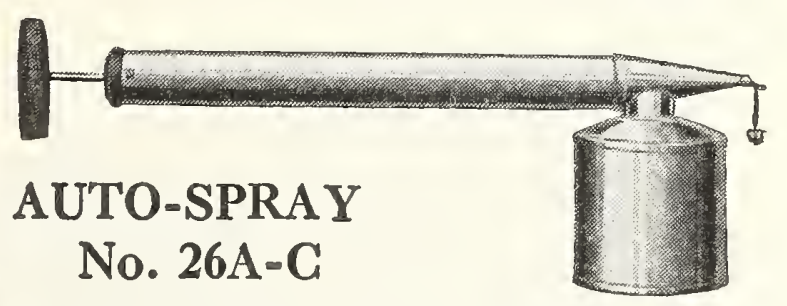

The Auto Spray No. 26 operates continuously on both the up and down stroke and throws a fine misty spray. Two spray caps, one straight and one at an angle for under the leaves. Capacity, 1 quart, 26A tin, $\$ 1.00 ; 26 \mathrm{C}$ brass, $\$ 1.25$.

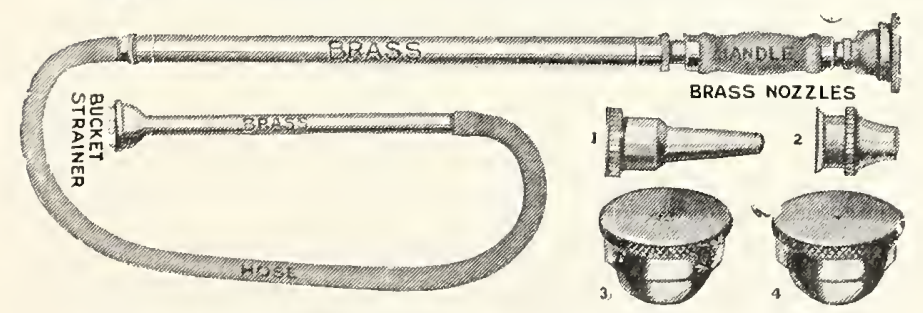

No. 45 STURDY SPRAY PUMP

The sturdy is made with all brass parts, it may be used in pail or can. Four nozzles for all kinds of spraying. Easily operated by one man. Each \$4.50. Extension rods, 24 inches. Each $60 \mathrm{cts}$.

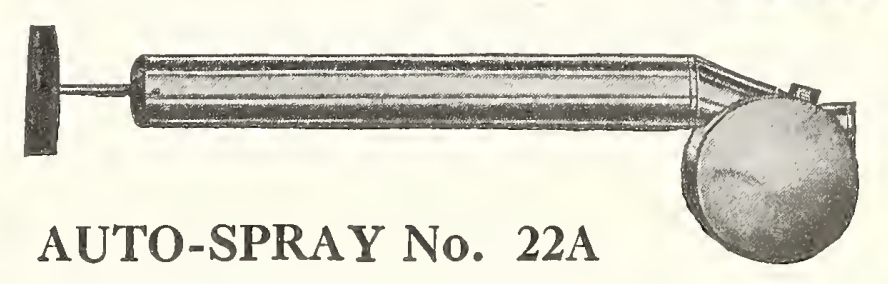

A single acting hand atomizer. Made from good heavy material. Capacity 1 qt. Pump cylinder, 14 inches by $1 \frac{3}{4}$ inches. Length 22 inches. Each $50 \mathrm{c}$.

\section{GOMPRESSED AIR SPRAYERS}
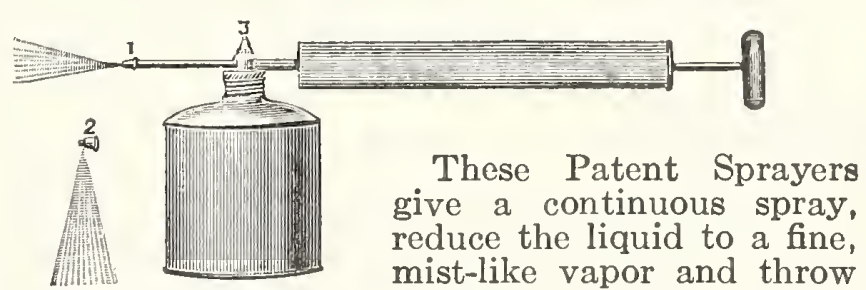
it with great force, so that it is driven into the smallest ${ }^{*}$ cracks and crevices. By means of the universal nozzle the spray can be thrown on the underside of the leaves of plants and shrubs.

No. 1. Galvanized reservoir............\$1.75

No. 2. Brass pump and reservoir........... 2.25

No. 3. Tin pump and reservoir........... 1.50 


\section{SPEEDEX GOMPRESSED AIR SPRAYER}

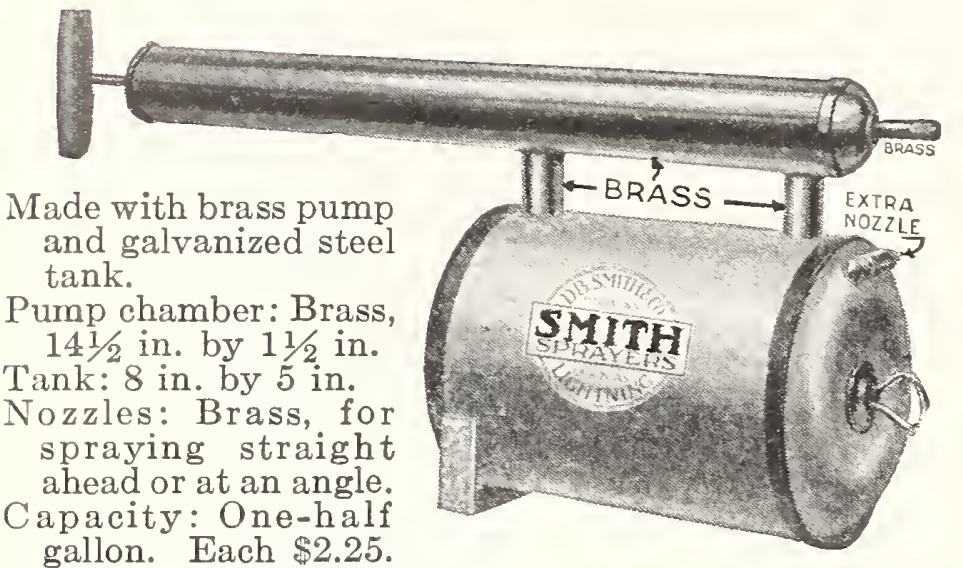

THE MEYER'S POWER SPRAY GUN

MYERS SPRAYGUN

LONG DISTANCE SPRAY

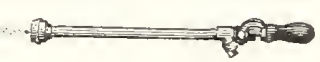

This gun utilizes the entire capacity of any power spray pump and does away with all bamboo extensions, nozzles and fittings. It can be adjusted to make a long or short distance spray and is fitted for $3 / 4$-inch hose coupling and $1 / 4$-inch pipe. Each $\$ 7.00$.

DUSTER BROWN POWDER GUN

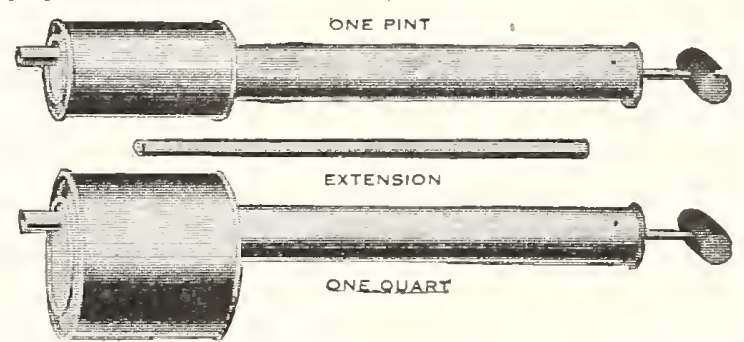

Especially adapted for use in applying insect powders. Length over all, 17 in., with extension 12 in. long.

No. 2 B, pint size, $\$ 1.00$; No. 2 C, quart size, $\$ 1.25$.

\section{DOUBLE BARREL DUST GUN}

Will dust all kinds of insecticides; has large dust chamber which is easily filled. Length, $131 / 2$ inches. Each 60c.

\section{HUDSON GHEMICAL SPRAYER}

The Hudson $160 \mathrm{G}$ is designed for oil sprays. It has a 11/2-gallon tank with automatic nozzle which controls the compressed air chamber. Nozzle is brass and easily removed for cleaning. Each $\$ 5.00$.

\section{RUSTIC BIRD HOUSES}

The Rustic Bird Houses are made with Rustic Cedar and are very ornamental and attractive to all birds.

No. 1 Log Cabin, one-family house, $10 \mathrm{in.} \mathrm{wide,} 10 \mathrm{in}$. high...\$2.50 and No. 2 Log Cabin, two-family house, $10 \mathrm{in.} \mathrm{wide,} 12 \mathrm{in.} \mathrm{high,} 14 \mathrm{in}$. deep. . No. 3 Log Cabin, two-family house, 14 in. wide, $12 \mathrm{in.} \mathrm{high,} 17 \mathrm{in}$, deep . No. 4 Log Cabin, two-family house, 14 in. wide, 17 in. high, 16 in. deep. No. 5 Wren House, four-family house, 14 in. wide, 18 in. high, 19 in. deep No. 6 Hexagonal, one-family house, 12 in. wide, 14 in. high, 19 in. deep. No. 7 Twelve-room Martin House, 24 in. wide, 22 in. high............

\section{DU PONT SEMESAN}

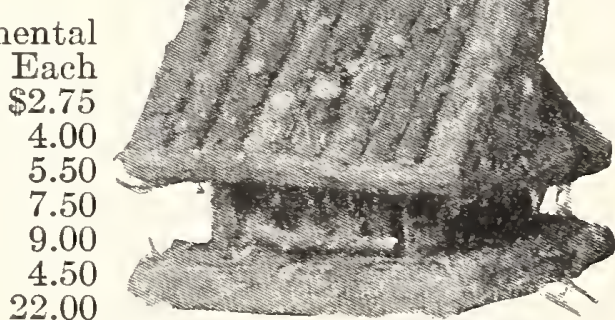

Bird House, No. 4 Log Cabin
(0IIPOND

SEMESAN A Mercuric Disinfectens ONe PaiND RET

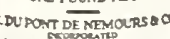
use of this remarkable mecuric compound, either in dust or liquid form, not only provides disease control, but accelerates seed germination, invigorates seedling growth, insures sturdier stands and produces larger, more beautiful flowers, foliage and vegetable crops.

Semesan will control such disease organisms as "damping-off" of seedlings, stem rot of Carnations and root rot of Violets, which are borne in the greenhouse, coldframe and seed bed soils. When choice tubers or bulbs have been cut accidentally or in separation, Semesan will protect them from storage molds or rots. It is being increasingly used for the disinfection of cuttings, graftings, tools and general equipment used in agricultural operations.

Descriptive booklets upon request.

Prices: 2 oz. 60c., 4 oz. $\$ 1.00,8$ oz. $\$ 1.60,1$ lb. $\$ 2.75,5$ lbs. $\$ 13.00$. 
GARDENER'S HARROW

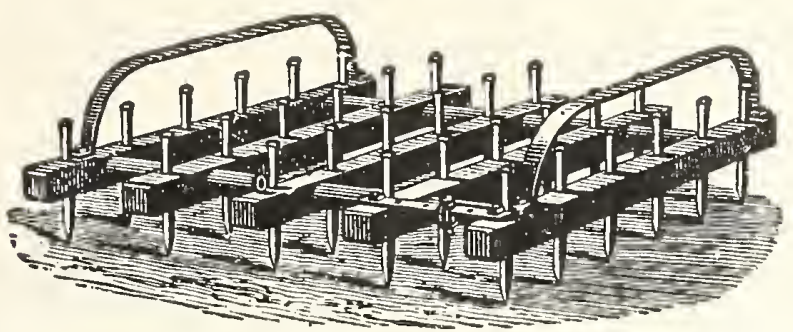

Designed for one horse, convenient to handle and get around garden plots, etc.

25 teeth with runners................\$13.00

30 teeth with runners.............. 14.00

\section{THE HOPPEN GRINDSTONE}

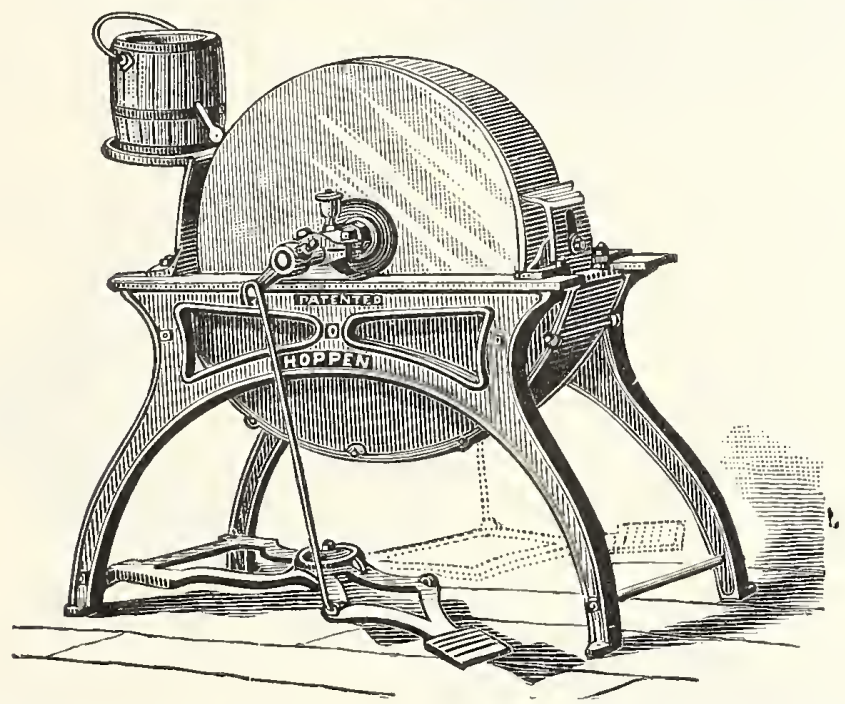

The frame is all iron and is very rigid. Every private estate should have one of these grindstones on hand.

No. 0 Stone, $24 \times 21 / 2$ in., with handle, treadle,

bucket and shield pan.................\$41.00

No. 1, Stone, $24 \times 3$ in., with handle, treadle,

bucket and shield pan..............43:00 F. O. B. Belleville, N. J.

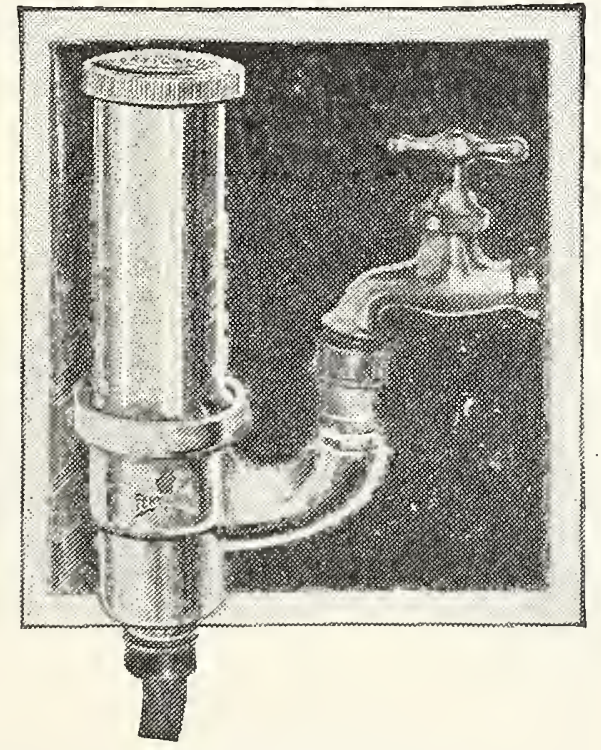

FERTILATOR

The Fertilator is attached to the faucet in watering lawn, gardens or greenhouse. The water passing through dissolves the Fert-O-Stick at the base evenly, giving a uniform strength at all times.

Galvanized Fertilator, with 3 Fert-O-Sticks, each $\$ 5.00$. Fert-O-Sticks, $1 / 2$ doz. in box. Per box $\$ 2.25$.
ONE-HORSE GARDEN PLOW

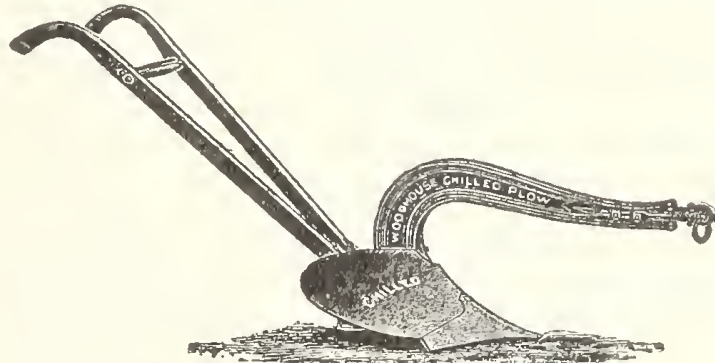

No. 6 iron beam, wood handles; cuts a 3- to 6-inch deep furrow and 7 to 10 inches wide. Weight $65 \mathrm{lbs}$. No. 6. Price, with extra point, $\$ 12.00$; with wheel, $\$ 2.00$ extra.

\section{OLIVER GHILLED PLOWS}

These are acknowledged to be the best general purpose plows in the world.

No. B-C-N, one-horse, light; wood or steel beam.$\$ 13.50$ No. $10 \mathrm{~N}$, one-horse, heavy; wood or steel beam. 17.00

Add for wheel on one-horse plows, $\$ 2.00$. Add for jointer on one-horse wood beam plows, $\$ 3.60$; steel beam plows, $\$ 4.00$.

\section{PORTABLE WOOD HURDLES}

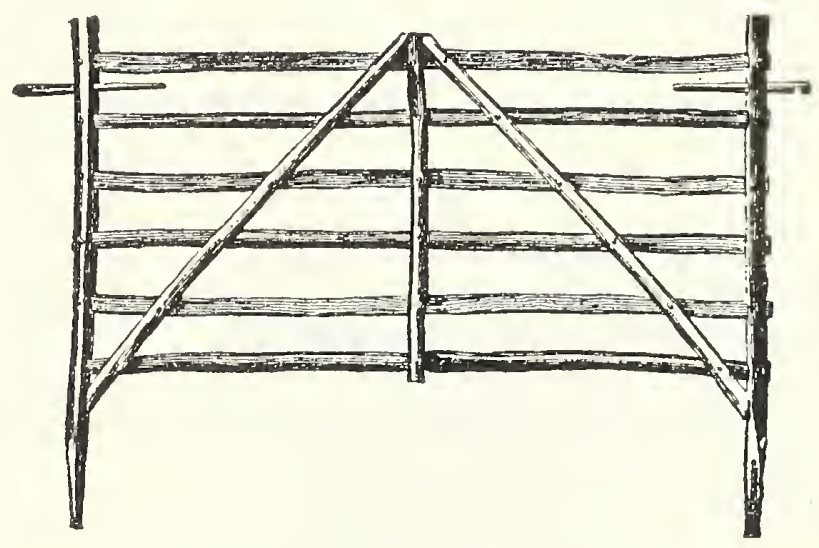

They are suitable for inclosing and dividing lots or plots to suit any requirement on a gentleman's country seat, or for farmers' use in general. Made with split chestnut. They measure $8 \mathrm{ft} .3 \mathrm{in}$. in length.

With 4 bars, suitable for horse and cows, per 100 $\$ 210.00$.

With 5 bars, suitable for sheep, per $100 \$ 220.00$.

4-bar Hurdle Gate, $10 \mathrm{ft}$. long, each $\$ 5.75$.

5-bar Hurdle Gate, $10 \mathrm{ft}$. long, each \$6.25.

Prices subject to change. F.O.B. Dutchess Co., N. Y

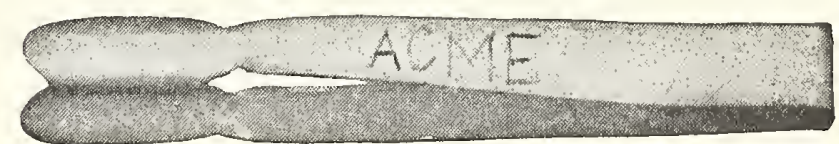

\section{ACME SEEDLING PICKER}

A very handy tool for transplanting seedlings and small plants. A great labor and time-saving device. Each 25c.

\section{SANITAS PRODUCTS}

SANITAS ANIMAL SOFT SOAP. For use on all animals. Qt. can $\$ 1.25$.

SANITAS "INSECTOL." For chicken mites, etc. Stainless non-inflammable and odorless. Gal. can $\$ 2.25,5$ gals. $\$ 10.00$.

SANITAS "SIXCO." A coal tar disinfectant for outbuildings, stables, chicken houses, etc. Gal. can $\$ 2.25,5$ gals. $\$ 10.00$. 


\section{CALIFORNIA SPRINKLER}

This is the most popular Sprinkler on the market. It has four brass arms and is mounted on a sled, so that it can be easily dragged over the lawn without turning off the water. Price $\$ 2.50$.

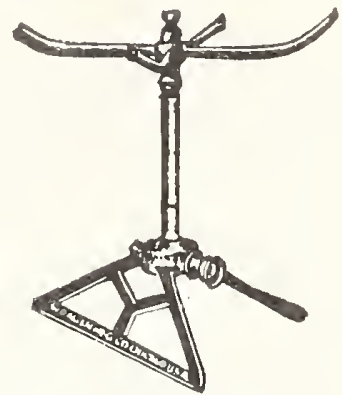

\section{THE TU-WAY SPRINKLER}

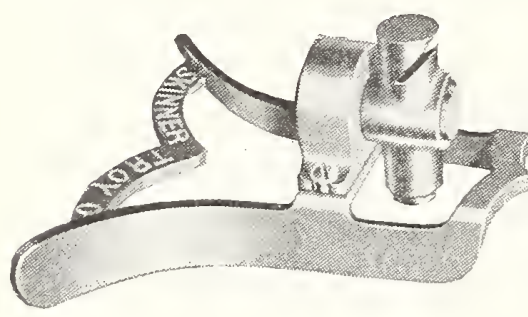

Can be used as a circle sprinkler or by giving the nozzle a half turn you have a sprinkler for a half circle to use for borders without wetting the sidewalk. Each $\$ 1.00$.

\section{“WATER WITGH' SPRINKLER}

This Sprinkler works more satisfactorily with a low pressure of water than any other.

No. 4, with stand, $\$ 1.50$.

\section{RAIN KING SPRINKLER}

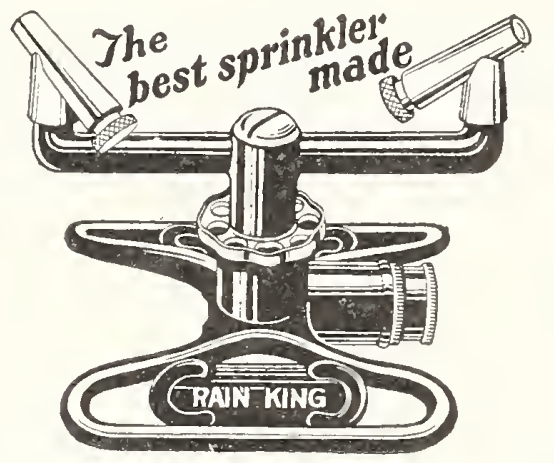

The Rain King is a real innovation in the sprinkler line, and radically different from any other sprinkler ever made. A most wonderful variety of uses. Circular or stationary spray, fine or coarse, fast or slow. large lawn, small lawn, trees, shrubs, flower beds, takes care of them all. Small, compact, easily handled. Simple adjustments. For Putting Greens it is excellent. Each $\$ 3.50$.

\section{THE “SKINNER" LAWN MIST SPRINKLER}

For lawns, vegetables or flowers this Sprinkler throws the finest mist that can be used out of doors. Mounted on two wheels and a caster. Length 15 feet, five-spray clusters, 36 inches apart. Total 15 nozzles. Each $\$ 14.00$, f.o.b. Troy, O

\section{PEACOCK SECTIONAL SPRINKLER}

Made to cover large areas in lengths of $121 / 2$ feet. Fivespray clusters, 36 inches between. Total 40 nozzles. Each section mounted on a wheel truck at one end. $\$ 18.00$ per section, f.o.b. Troy, O.

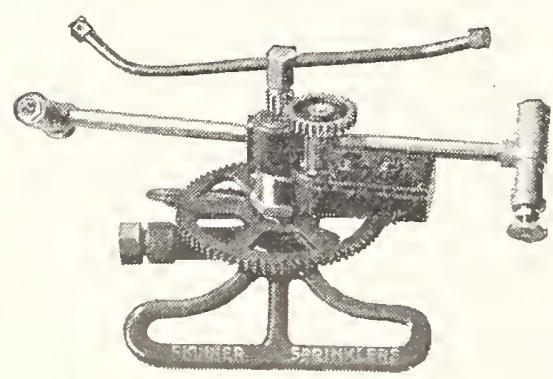

\section{ROTO RAIN SPRINKLER}

A sprinkler made to water large areas. It stands only nine inches high, made in heavy brass, and gears run in water. The large nozzles travel slowly and the inner arms faster. Each $\$ 16.00$. 


\section{MOR-RAIN SPRINKLER}

As a general, all-round sprinkler, a sprinkler that comes nearer to meeting all requirements for the average size lawn than any other sprinkler made, the Mor-Rain is without question the ideal.

It waters both full and half circles. To change from a complete circle to a half circle, just give the nozzle head a halfturn, and the job is done.

It will throw fine drops of water uniformly over a $50 \mathrm{ft}$. circle. But you can regulate the area by opening or closing your faucet. The head and arms are made of brass. The base is of iron and weighs 3 lbs., so that it cannot easily be upset. Attractively painted.

Height 8 inches. And like all Skinner sprinklers, Mor-Rain is fully guaranteed. Each $\$ 3.00$.
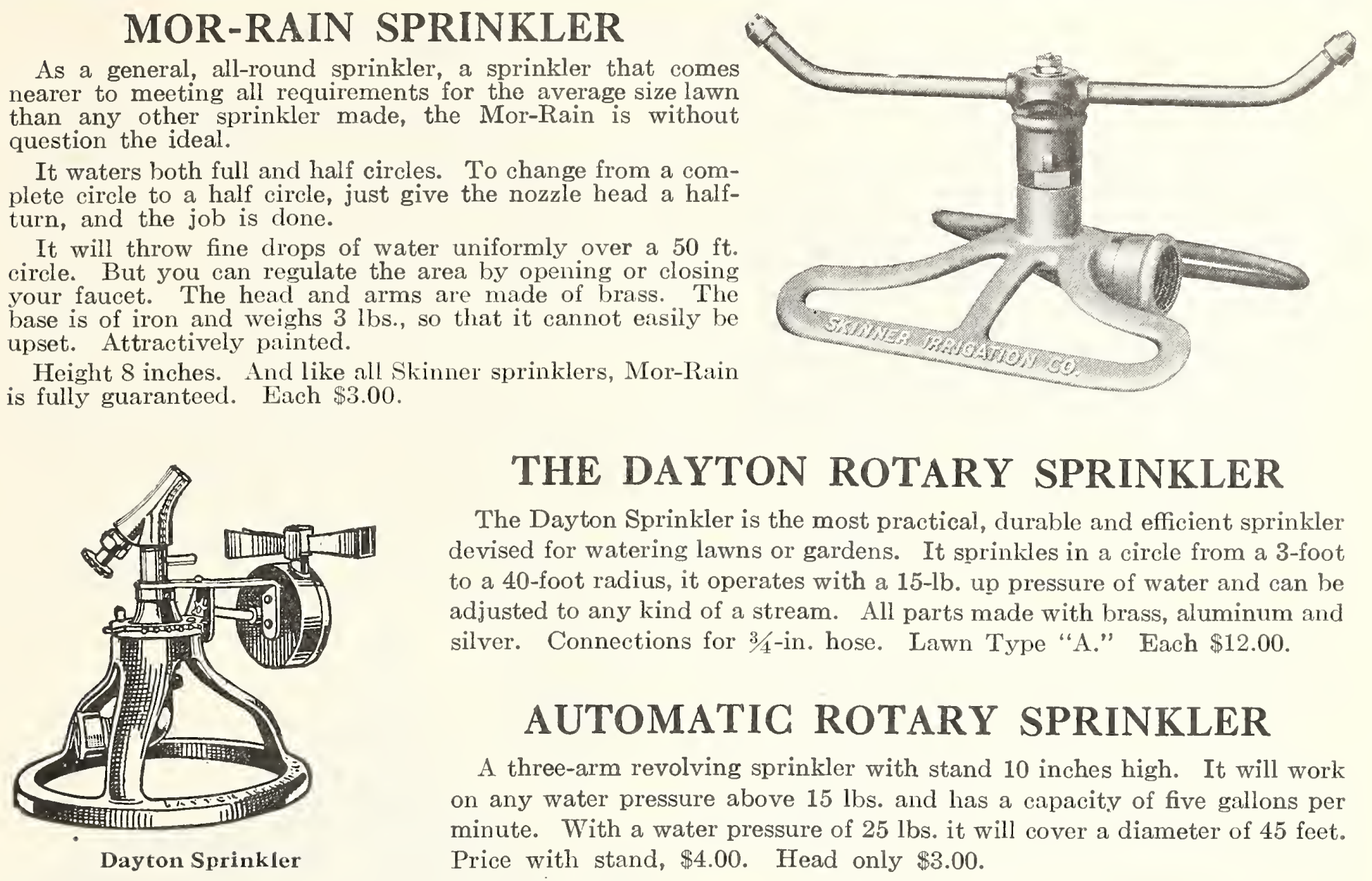

WATER FAN LAWN SPRINKLERS

Model No. 6 Water Fan. An oscilating sprinkler 18 inches long, with eleven diverging outlet tubes, mounted on a rigid galvanized frame. With a pressure of $30 \mathrm{lbs}$. it will cover an area $15 \times 50$ feet. All gears are enclosed to protect them and provide for soft grease lubrication. Each $\$ 15.00$.

Model No. 8 is similar to No. 6, only that it has fifteen outlets, and with a water pressure of $35 \mathrm{lbs}$. will cover an area of $24 \times 50$ feet and is 22 inches long. Each $\$ 18.00$.

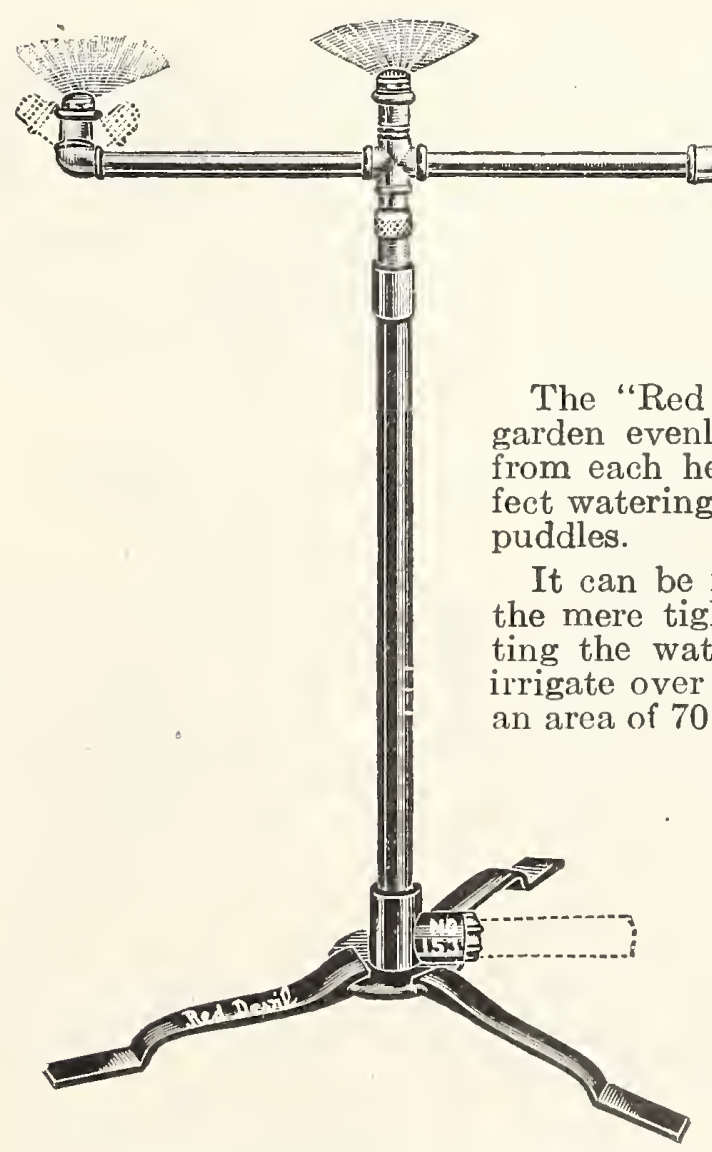

Red Devil Lawn Sprinkler

The Dayton Sprinkler is the most practical, durable and efficient sprinkler devised for watering lawns or gardens. It sprinkles in a circle from a 3-foot to a 40 -foot radius, it operates with a 15 -lb. up pressure of water and can be

\section{AUTOMATIG ROTARY SPRINKLER}

A three-arm revolving sprinkler with stand 10 inches high. It will work on any water pressure above $15 \mathrm{lbs}$. and has a capacity of five gallons per minute. With a water pressure of $25 \mathrm{lbs}$. it will cover a diameter of 45 feet. Price with stand, $\$ 4.00$. Head only $\$ 3.00$.

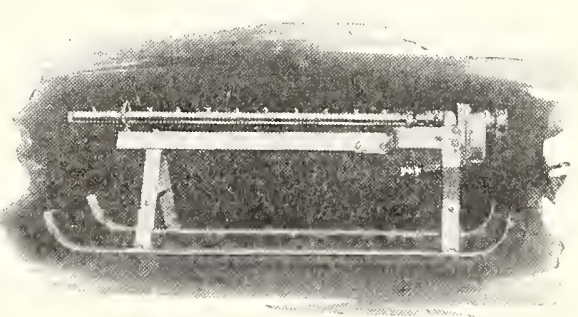

\section{RAINMAKER LAWN SPRINKLER}

This sprinkler is made on the turbine principle, the water coming from the nozzle strikes the turbine paddle on the wheel causing it to revolve. As the turbine wheel revolves it travels around the circular base carrying the jet around about eight times per minute. With a pressure of $40 \mathrm{lbs}$. it will cover a space of 300 sq. yds. Each $\$ 25.00$.

\section{RED DEVIL LAWN SPRINKLER} "Renly without waste of water. It sprays perfectly, throwing seven streams each head that break into a mist-like cloud. This assures perect watering and causes the water to penetrate instead of laying in

the reve at any speed, or made stationary by ing the water heads at different angles will cause the atomizer to irrigate over a large or small area. When set correctly it will cover an area of 70 feet. Red Devil, No. 151. Each $\$ 12.00$.

\section{GIANT RAIN KING LAWN SPRINKLER}

This Sprinkler is adjustable to height as well as distance, direction and volume of water. It plays like a gorgeous spiral fountain in any circle up to 90 feet. Easily locked so it won't revolve, or will throw water in 1, 2, 3 or 4 directions. Each nozzle works independently, throwing solid stream or any desired spray. It stands 4 feet high and has 20-inch arms. Price $\$ 14.00$.

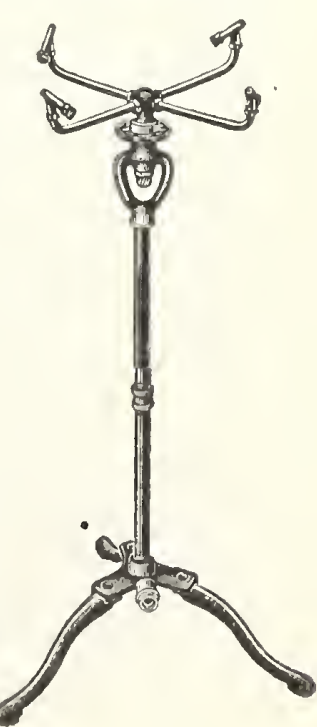




\section{BUCKEYE INCUBATORS AND BROODERS}

All the Buckeye Incubators are hot water heating system and guaranteed to do everything they claim.

\section{BUCKEYE INCUBATORS}

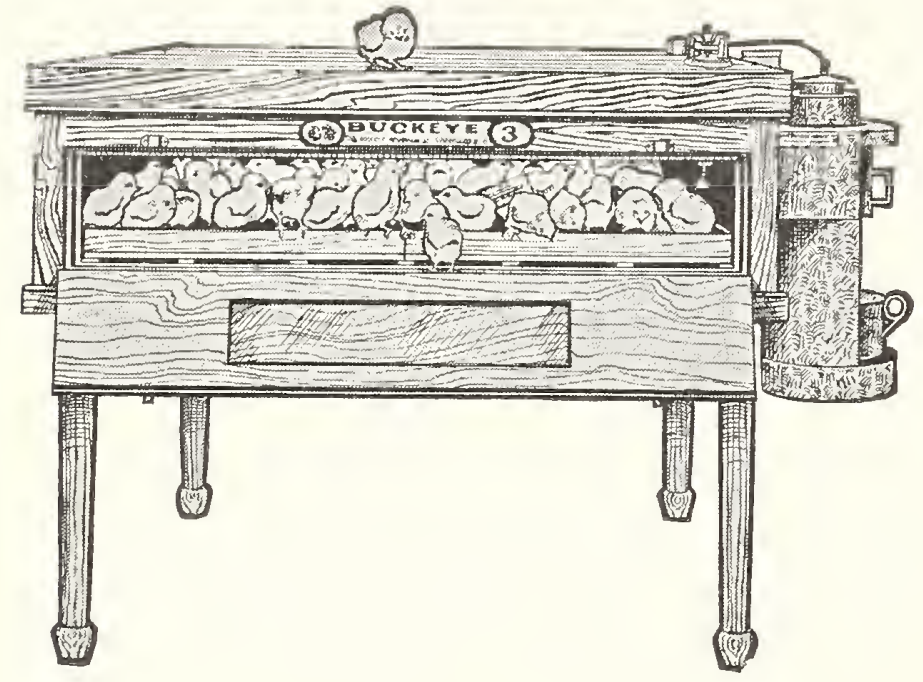

No. 14, Style E. Capacity, 65 eggs......\$16.50

No. 16, Style E. Capacity, 120 eggs.......... . 27.50

No. 17, Style E. Capacity, 210 eggs......... 36.75

No. 1, Standard. Capacity, 120 eggs.... 37.50

No. 2, Standard. Capacity, 175 eggs... . . . . 44.50

No. 3, Standard. Capacity, 250 eggs... . . . . 57.75

No. 4, Standard. Capacity, 350 eggs.... . . . 68.00

No. 5, Standard. Capacity, 600 eggs......... 107.00

\section{BUCKEYE BROODERS}

No. 18. Coal Burner. Galvanized hover, 42 inches. Capacity, any number up to $500, \$ 21.50$.

No. 19. Coal Burner. Galvanized hover, 52 inches. Capacity, any number up to $1000, \$ 26.50$.

No. 27 Blue Flame Brooder. Capacity up to 200 chicks. $\$ 17.50$.

No. 28. Blue Frame Brooder. Capacity up to 350 chicks, $\$ 20.00$.

Descriptive catalog of the above mailed on request.

\section{THE BLUE HEN COAL BURNING COLONY BROODER}

The Blue Hen is designed right and built right. It is easy to operate and requires but very little attention because of its sensitive automatic regulation. It has extra large coal capacity which enables it to hold the fire from 12 to 15 hours. The cast iron heater is powerful. It heats quickly and holds a steady fire because of its large grate area.

No. 44. Capacity, 500 chicks; diameter of hover, 48 in.; coal capacity, 25 lbs. Price $\$ 21.00$.

No. 45. Capacity, 1000 chicks; diameter of hover, 56 in.; coal capacity, 35 lbs. Price, $\$ 26.00$.

F. O. B. Lancaster, Pa.

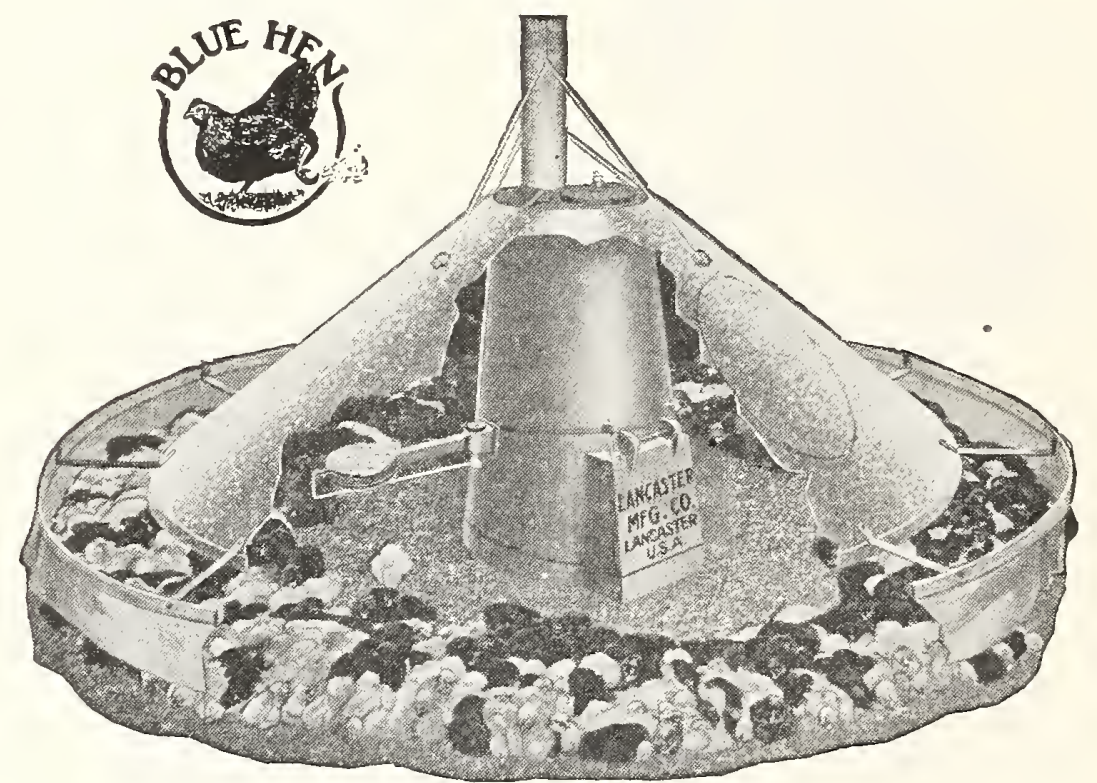

\section{GONKEY'S}

\section{POULTRY REMEDIES}

Ask for "Conkey's Poultry Book." Free with all purchases.

Canker and Bronchitis Remedy.........50c.

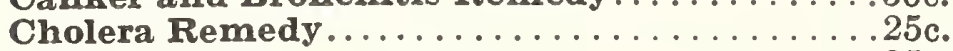

Gape Remedy....................25c.

Head Lice Ointment. ............

Healing Salve.................... 25c.

Healing Powder..................25c.

Lice Fix. . . . . . . . . . . . . . .

Lice Liquid ....... Qt. $60 \mathrm{c} ., 2$ qts. $90 \mathrm{c}$. , gal. $\$ 1.50$.

Lice Powder. .....................25c.

Limber Neck Remedy................60 .

Noxicide Dip and Disinfectant......... gal. $\$ 2.00$.

Poultry Worm Remedy...............25c.

Roup Pills......................... and 60c.

Roup Remedy..............30c., 60c., $\$ 1.20$.

Scaly Leg Remedy....................25c.

Sorehead Remedy...................25c.

Sulphur Candles. Each.................

White Diarrhoea Remedy..............30c.

\section{POULTRY SUNDRIES}

Egg Preserver. Water glass. One quart with water for 15 doz. eggs. Qt. 50c., gal. \$1.25.

Egg Testers. Each 50c.

Nest Eggs, China. 3 for 10c., doz. 35c.

Poultry Punches. Moe's Clip and Punch. Each 30c.

Poultry Shears. Nickel plated, \$4.50.

Thermometers. Brooder. Each \$1.00. Incubator. "Tycos." Each $\$ 1.00$

Hygrometer. An indicator to show the moisture conditions in the incubator. Each $\$ 1.75$.

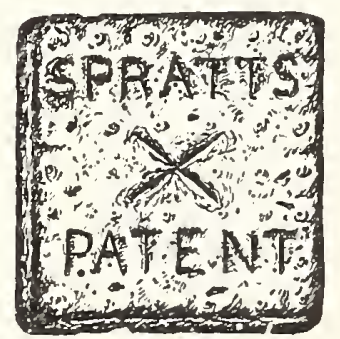

\section{"SPRATT"S" MEAT "FIBRINE"}

Vegetable Dog Cakes. The standard dog food. Used at the leading kennels and dog shows throughout the world. A staple and constant food for all breeds of dogs. Per lb. 20c., 10 lbs. $\$ 1.50,100$ lbs. $\$ 14.00$.

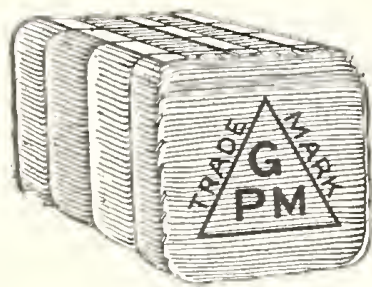

\section{PEAT MOSS. Torf Mull}

Granulated Peat Moss should be used liberally about the garden or greenhouse, for pot plants, window boxes and growing bulbs, etc. It is also useful for mulching perennial beds, lawns, Roses, etc., and mixing with sandy or clayey soils.

Small bale, enough to cover 16 square $\mathrm{ft} .1$ inch deep...................\$1.50

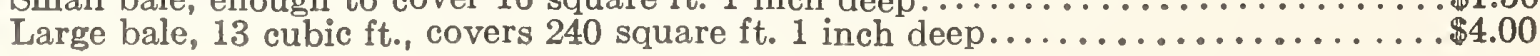




\section{POULTRY SUPPLIES}

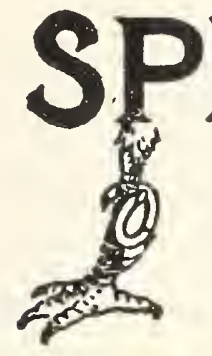

IR-O LEG. BAANDS

Black, White, Blue, Pink

Amber and Ruby

Made with celluloid in three sizes. 12 for 20c., 25 for $30 \mathrm{c} ., 50$ for $50 \mathrm{c}$., 100 for $90 \mathrm{c}$.

State what breed of chicken they are required for when ordering.

\section{POULTRY IILLING KNIVES}

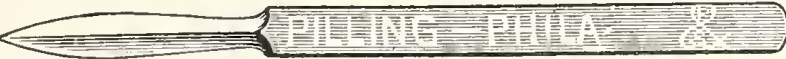

Made with finely tempered steel, with nickel handle. Each 65c.

\section{GAPE WORM EXTRACTOR}

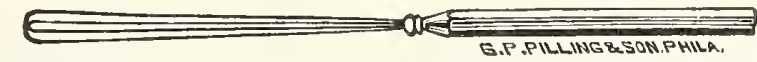

Full directions with each instrument. Each 30c.

\section{POULTRY CATCHING NET}

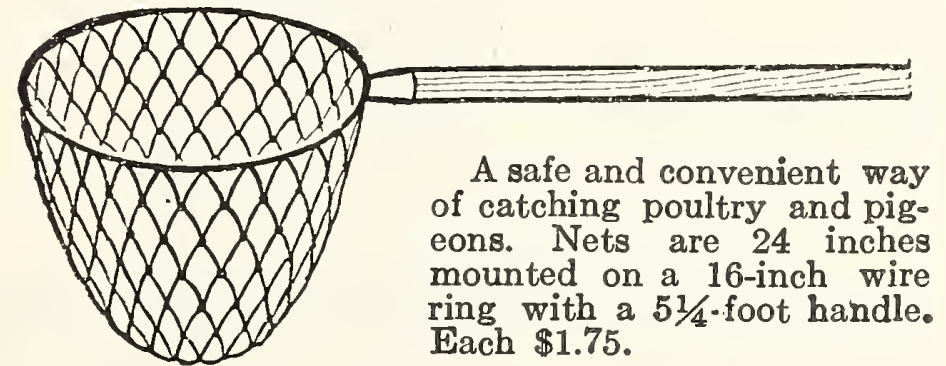

\section{GRINDING MILI}

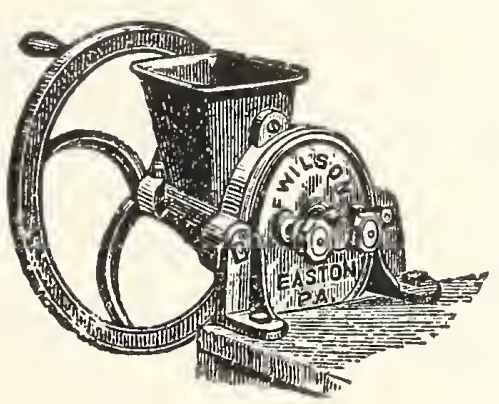

This machine will grind dry bones, shells or grain, either fine or coarse. It will make excellent grit out of old crockery, melted glass, etc. Hand wheel 22 in. Hopper $21 / 2 \times 31 / 4 \times 4$ in. Weight 33 lbs. To bolt on table or bench.

No. $1, \$ 5.00$

\section{COLLINS OAT SPROUTER}

The Collins Oat Sprouter is made in units, eight separate pans of galvanized steel. The pans are $11 \times 15$ in. and fit on top of each other. The pans are perforated to furnish the right drainage to insure sprout ing of all the fertile grain.

Place beside furnace or in warm room and you have a continuous supply of green feed. With eight pans, 11 by 15 in., each $\$ 4.00$. With five ans, 11 by 15 in., $\$ 3.00$.

\section{FARMER'S \\ CAPONIZING \\ SETS}

Complete with full instructions for any one to use. $\$ 4.00$.

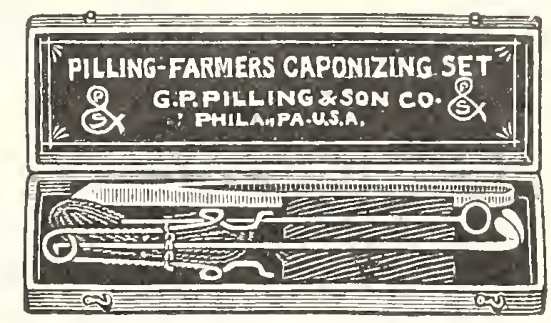

\section{"RAT CORN"}

A safe and sure exterminator of rats and mice. This is not a poison and can be used without fear when other animals are around. No smell from the dead rats is detected, as the bodies dry up after death. Sizes 25c., 50c. and $\$ 1.00$.

\section{"HOLDZEM"}

An adhesive especially prepared for catching rats and mice. Easy to apply. Spread the paste on a board $1 / 8$-inch thick. No chance for them to get away if they touch the paste; no dying between walls. Safe, non-poisonous and effective. One-pound cans, $\$ 2.25$ each.

\section{"THERMO" FOUNTAIN}

This fountain is built to meet the need for a fount that will stay open with reasonable care in Winter, without the aid of any fuel. It is Thermo built and depends on the heat stored in the water in the reservoir chamber, hence in cold weather use hot water. 1 gal. $\$ 2.25$, 2 gals. $\$ 2.75$.
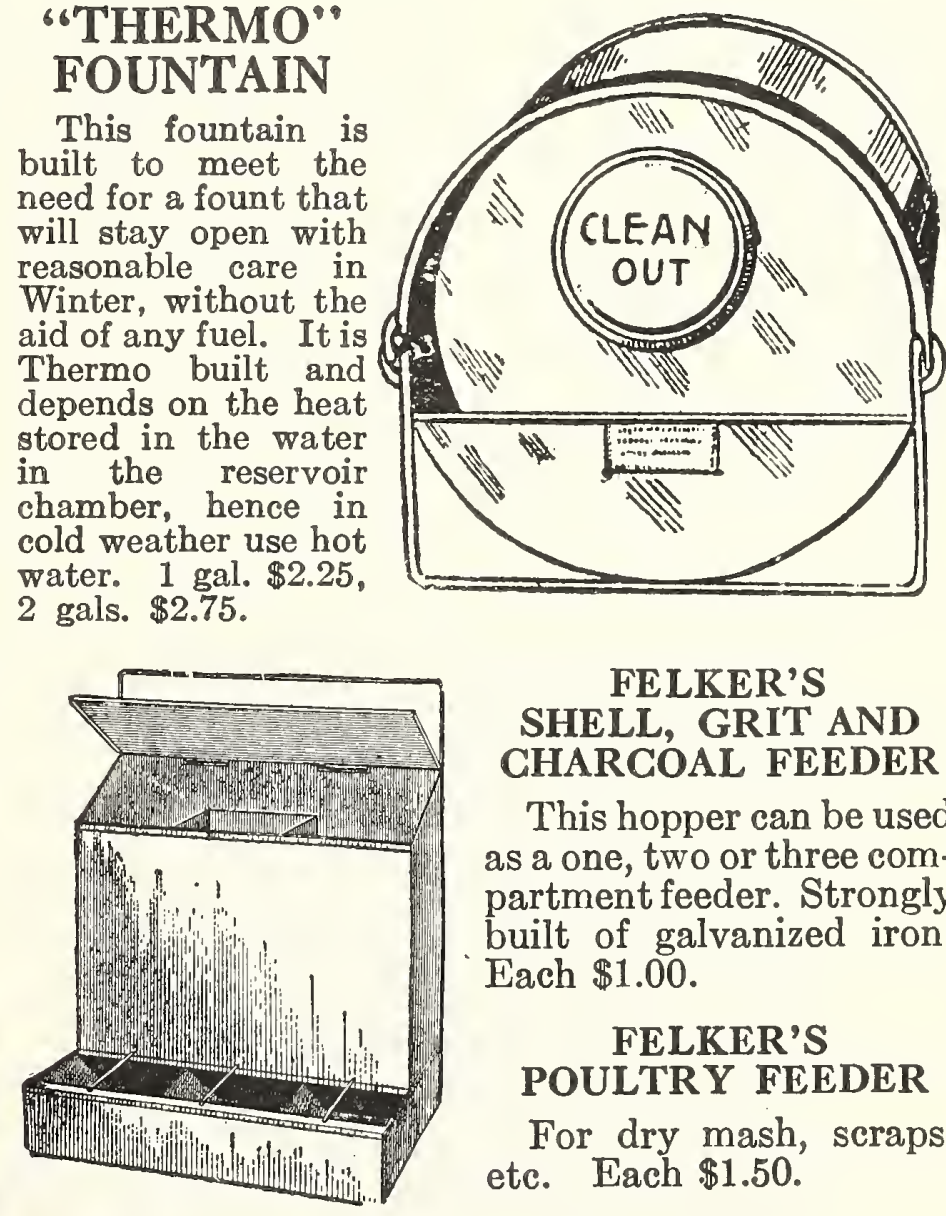

LKER'S SHELL, GRIT AND CHARCOAL FEEDER

This hopper can be used as a one, two or three compartment feeder. Strongly built of galvanized iron. Each \$1.00.

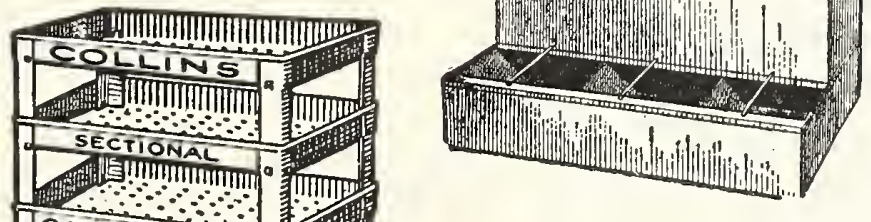

\section{FELKER'S POULTRY FEEDER}

For dry mash, scraps, etc. Each $\$ 1.50$.

\section{THE JUNIOR CHICK FEEDER}

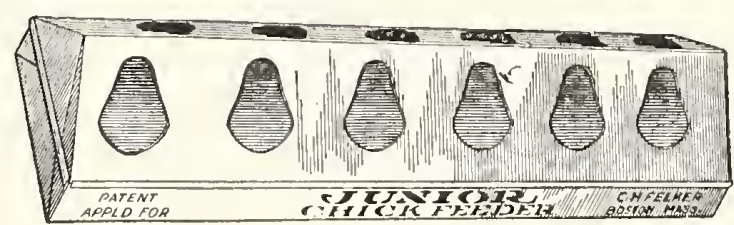

iIt is practical and sanitary. Will not waste feed. For feeding dry mash, grain, sour milk or water to small chicks. 12 inches long, each 35c.; 20 inches long, e ach 50c. 


\section{POULTRY FOUNTAINS AND FEEDERS}

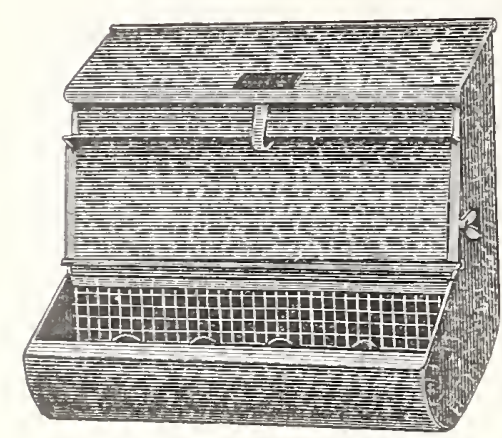

KENTUCO GHICK FEEDER

This feeder is designed so that the feed will run out easily and keep just enough before the chicks without clogging or letting them throw it out and waste it. Size 5 in. long by 6 in. high No. 31. Each 50c.

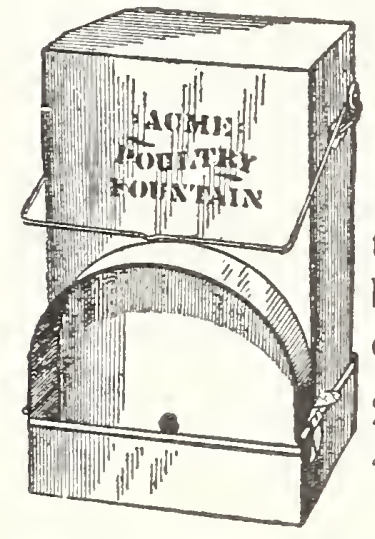

\section{SANITARY DROP BOTTOM FOUNTAIN}

A distinct improvement over the one-piece fountain. The bottom is hinged to open and can be easily cleaned.

2-quart size $\$ 1.25$.

4 quart size $\$ 1.75$.

\section{GARLAND FLOWER GUARD}

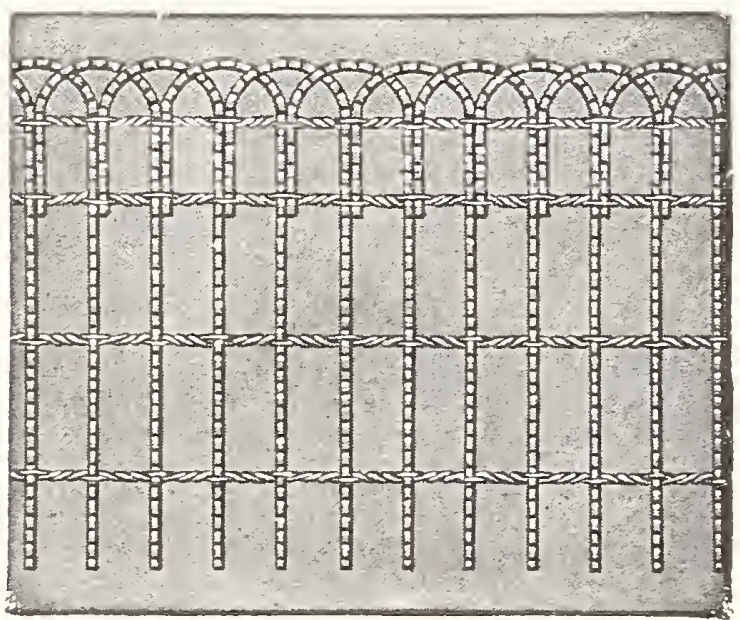

The Garland Flower Guard forms an excellent protection to flower beds. The ends of pickets, extending below the lowest cable, are pushed in the ground and answer the purpose of posts.

Cables No. 12 wire. Pickets No. 9 wire, spaced $21 / 4$ inches apart.

Made with steel wire and galvanized after weaving.

16 inches wide, per linear foot

22 inches wide, per linear foot.

$\$ 0.18$

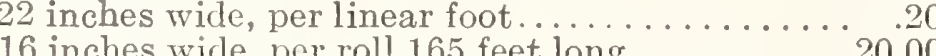

22 inches, per roll 165 feet long.................. 21.50
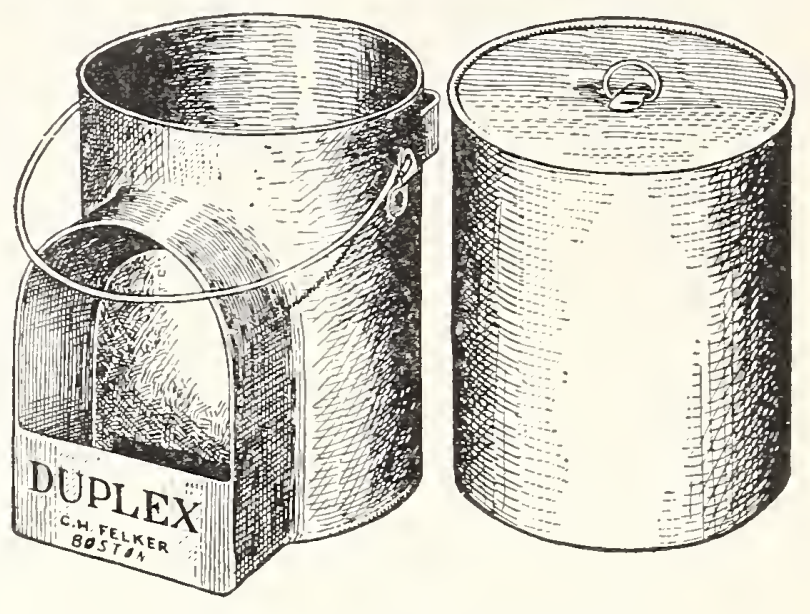

\section{DUPLEX FOUNTAIN}

The latest and most practical sanitary fountain on the market. This is a double fount and keeps the water clean and pure. Easy to fill and care for. Each, 4-qt. \$1.15, 8-qt. \$1.40.
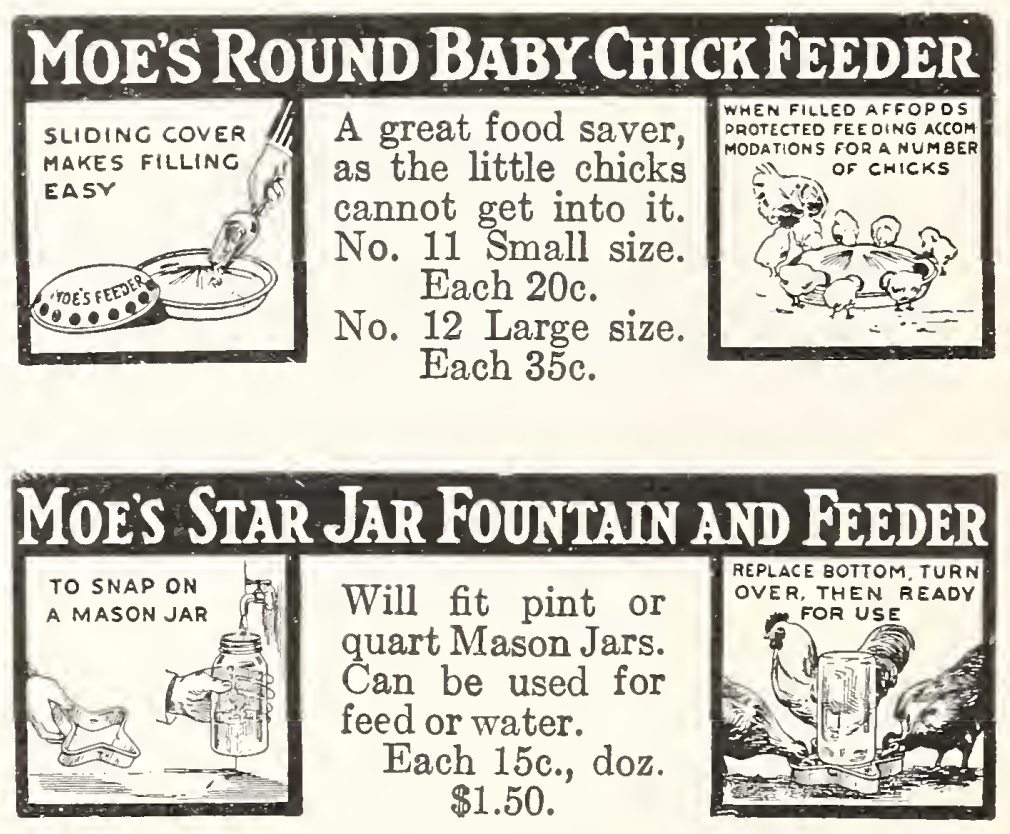

THE "ALL-RITE" FOUNTAIN

Fits any Mason Jar and has hanger to hang up out of dirt or litter. Each 25c.

\section{FERGUSON'S COMBINATION SPRAYER AND SYRINGE}

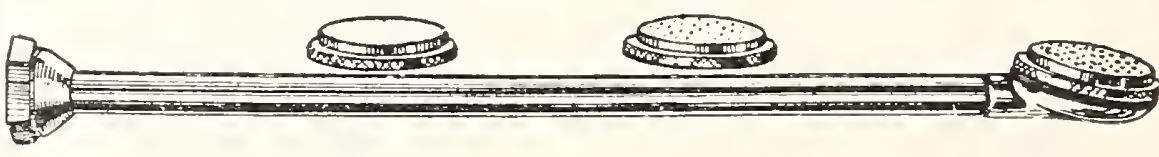

Three roses-fine, medium and coarse. Recom. mended for syringing under the foliage of plants where force is needed to keep down red spider, etc. Made of brass and screwed on the end of any $3 / 4$ inch hose, $\$ 8.00$.

\section{SOILTEX SOIL TESTER}

A handy pocket outfit, containing enough material for 75 to 100 tests. Complete with color chart and lime tables. It determines accurately the degree of acidity of any soil and tells exactly how much lime should be applied. Complete outfit, $\$ 1.00$. 


\section{EGG BOXES AND GRATES}

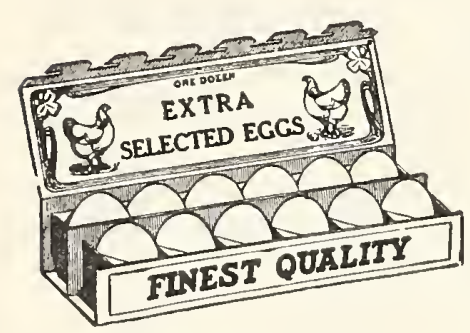

\section{SELF-LOCKING EGG BOXES}

Made with best quality card board. Ventilated and self-locking. 25 for 60 c., 100 for $\$ 2.00 .1000$ for $\$ 18.00$.

\section{FOLDING PAPER \\ EGG BOXES}

Convenient for carrying a dozen eggs to local customers. Doz. 20 c., 50 for 60 c., 100 $\$ 1.00,1000 \$ 9.00$.

\section{EGG GASE} FILLERS

Full cushion fillers for cases of eggs. Regulation $2 \times 6$ style. 50 for $85 \mathrm{c}$, $100 \$ 1.60$, $1000 \$ 15.00$.

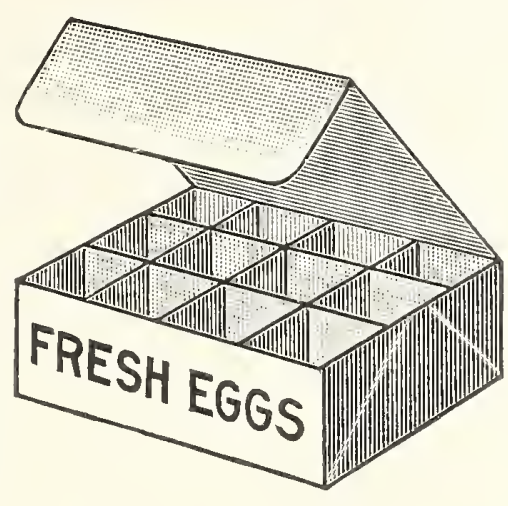

SURETY GUSHION WOODEN EGG GRATES

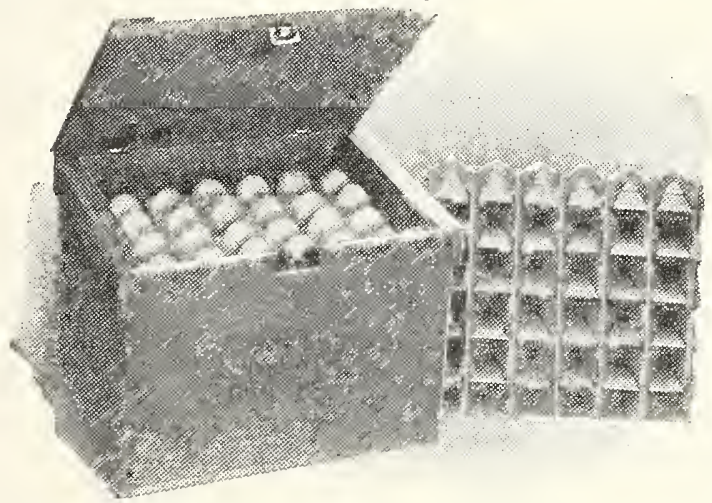

Easier and quicker to pack than ordinary egg crates. The trays are inverted one above the other which hold the eggs from coming in contact with each other. Two-doz. size, each \$1.50; 4-doz. size $\$ 1.80 ; 6$-doz. size $\$ 2.10 ; 8$-doz. size $\$ 2.40 ; 10$-doz. size $\$ 2.60 ; 15$-doz. size $\$ 3.25$.

Extra Filler Sets, 12-egg size, doz. $\$ 1.50,100 \$ 8.00$, 24-egg size, doz. $\$ 2.00,100 \$ 12.00$.

When ordering extra fillers, kindly state what size egg crate they are wanted for.

\section{GELERY BLEAGHING PAPER}

A patented, flexible, odorless, waterproof material similar in appearance to patent roofing. It completely excludes the light, keeps the stalks clean because no dirt touches them. The strips are easily applied and a great saving of cost and labor over using boards or dirt.

The rolls of bleachers are placed over the holders with a roll on each side of the row, and as they are unrolled the wire arches are placed over the rows to keep the bleaching paper in place.

The rolls are 100 feet long and 12 inches wide. Price per roll, including 25 wire arches 42 inches long, $\$ 5.00$; roll handlers, $\$ 1.50$ each.
Buy eggs by mail from your country friends shipped in aluminized METAL EGG GRATES

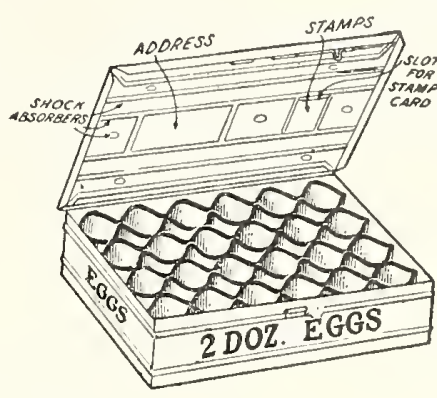

Indestructible; pays for itself in a few shipments; lasts for years; makes interchangeable shipping easy. Buy yours now and realize more money for your eggs. Your friends want them.

The Metal Edge Filler is a wonder. A new invention and cannot be beat for safely carrying eggs by mail. Light in weight but strong.

Reversible address cards are placed over eggs, address visible through opening in lid. Names of shipper and receiver are placed on each side of this card.

Write us about Butter-Egg Crates.

Prices Prices

3-dozen size......\$1.50 $\quad \begin{aligned} & \text { 6-dozen size...... } \$ 2.50 \\ & \text { 9-dozen size..... } 3.25\end{aligned}$

4 -dozen size...... 2.00 12-dozen size.... 4.00

Add postage for $3 \mathrm{lbs}$. to the price for each 150 miles if wanted by mail.

\section{SURETY GUSHION EGG BOX}
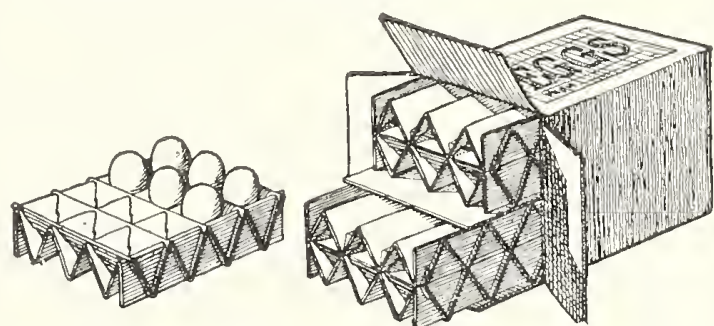

A simple and safe box for delivery of eggs by Parcels Post. Simple in construction, easily assembled, and the most scientifically constructed egg carrier on the market.

Doz. size........each 20c., doz. $\$ 2.00,100 \$ 15.00$ 2 doz. size........each 30 c., doz. $\$ 3.00,100 \$ 18.00$

Extra Filler Sets, 1-doz. size, each 15c., doz. $\$ 1.50$, $\$ 10.00$.

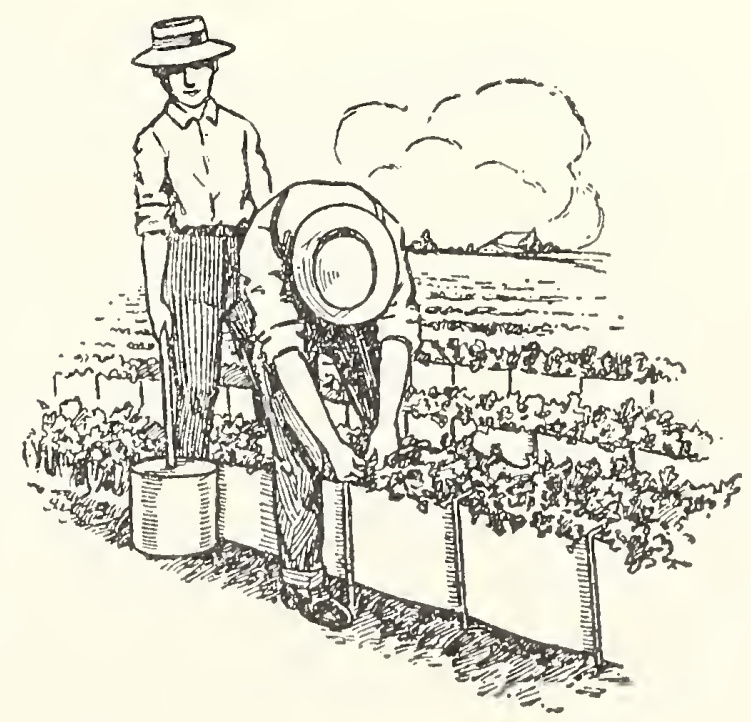


SEIECIED DRYKIINED CYPRESS "THE WOOD EVERLASTING"

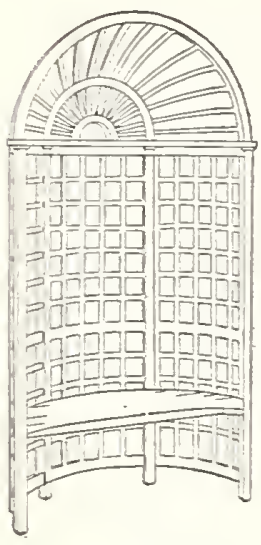

825

COZY CORNER

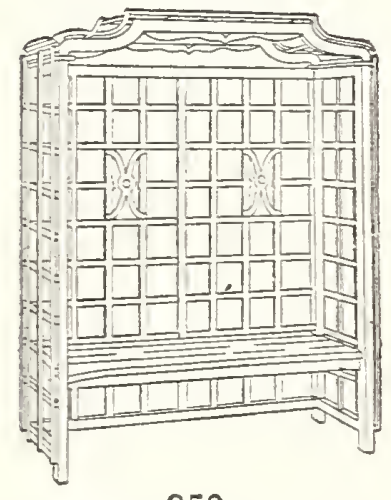

850

JOSEPHINE ARBOR

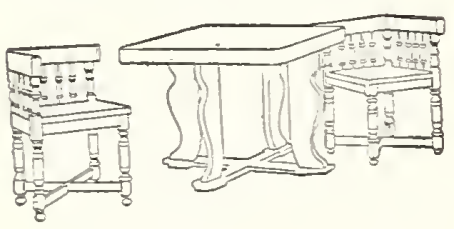

775

TABLE SET

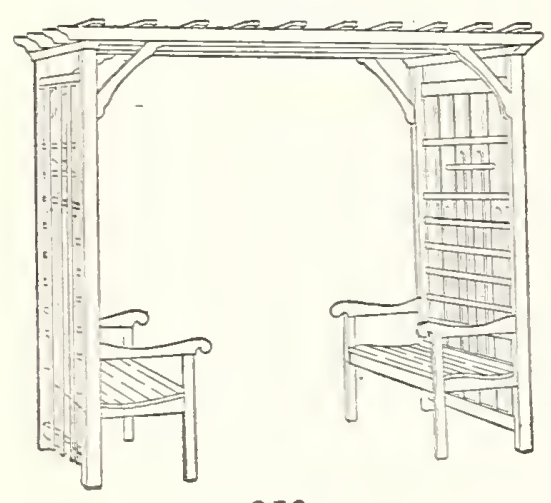

950

PERGOLA

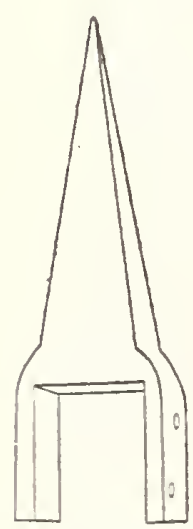

ANCHOR

BOOT

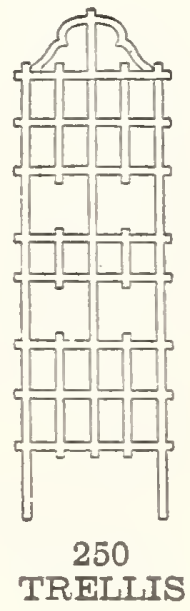

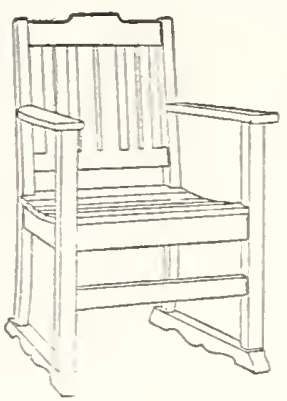

975

CHAIR

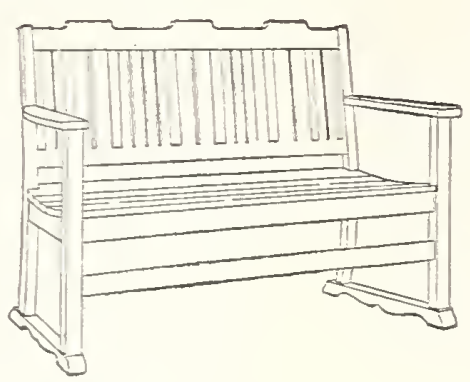

985

SETTEE

Width Height Depth

No.

$825 \mathrm{Coz}$

Corner $5^{\prime} 2^{\prime \prime} 6^{\prime} 8^{\prime \prime} 2^{\prime}$

975 Chair 2' 2'9" I' I $^{\prime \prime}$

985 Settee $\quad 5^{\prime} 2^{\prime \prime} 2^{\prime} 9^{\prime \prime}$ I'$^{\prime \prime \prime}$

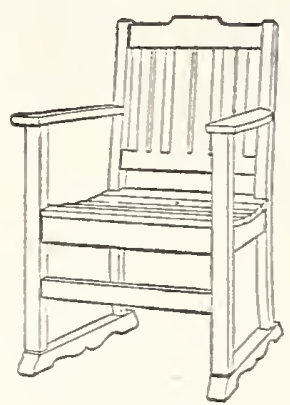

975

CHAIR

Price

$\$ 95.00$

1 2.75

23.00

725 Arbor

$$
5^{\prime} 6^{\prime \prime} 7^{\prime} 3^{\prime \prime} \quad 3^{\prime} 8^{\prime \prime}\left(4^{\prime} \text { path } 45.00\right.
$$

850 Josephine

$$
\text { Arbor } 4^{\prime} 2^{\prime \prime} 7^{\prime} 8^{\prime \prime} 2^{\prime} \quad 91.00
$$

750 Rose

$$
\text { Gate } \quad 5^{\prime} 6^{\prime \prime} 7^{\prime} 3^{\prime \prime} \quad 3^{\prime} 8^{\prime \prime} \quad 60.00
$$

775 Table Set (table and four chairs nested) $40^{\prime \prime} \times 40^{\prime \prime}$

109.00

950 Pergola $7^{\prime} 6^{\prime \prime} 7^{\prime} 3^{\prime \prime} 4^{\prime}$

925 Bower 6 6 6 $6^{\prime \prime} 7^{\prime \prime} 4^{\prime} 8^{\prime \prime}$

700 Arbor

Pergola $7^{\prime} 6^{\prime \prime} 7^{\prime} 3^{\prime \prime} 4^{\prime}$

250 Trellis $\quad 2^{\prime} 4^{\prime \prime} 8^{\prime}$

200 Trellis $\quad 2^{\prime} 8^{\prime \prime} 8^{\prime}$

68.00

$51 . \infty 0$

95.00

8.00

I0.00

900 Grecian

$$
\text { Bench 4' 191/2" 24" }
$$

41.00

500 Table $\quad 3^{6 \prime \prime} 30^{\prime \prime}$

28.00

All pieces are painted with three coats of best quality weather resisting out-of-door enamel. They can also be furnished unpainted at reduction of fifteen per cent $(1 ; \%)$ from above prices.

Each piece is shipped completely assembled, well crated, ready for installation. Anchor Boots furnished with Nos. $700,725,750$ and 950 .

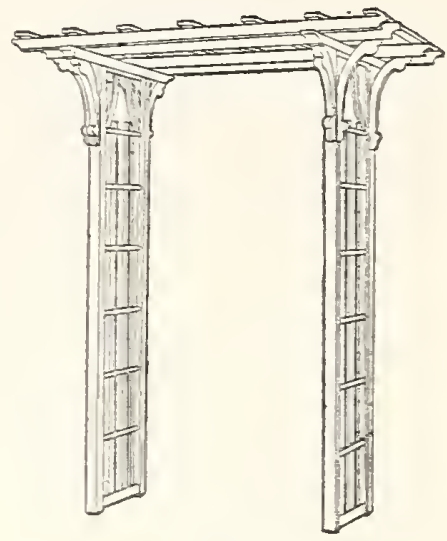

725

ARBOR

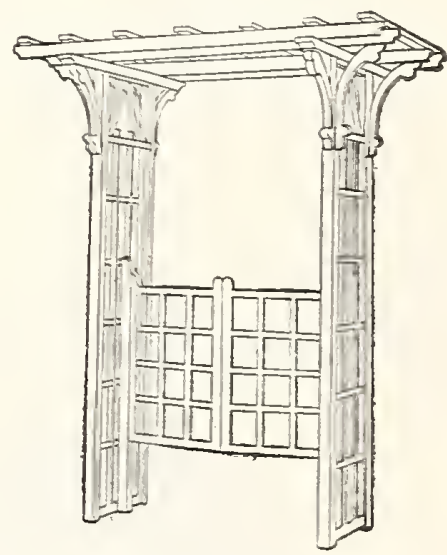

750

ROSEGATE

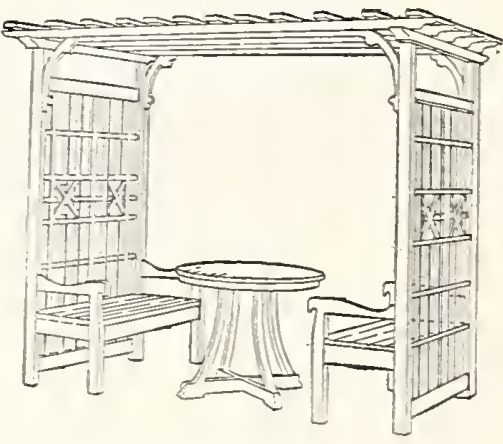

700

ARBOR PERGOLA WITH 500 TABLE

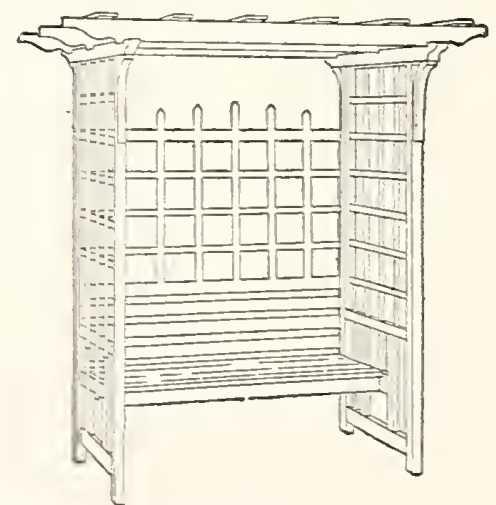

925

BOWER

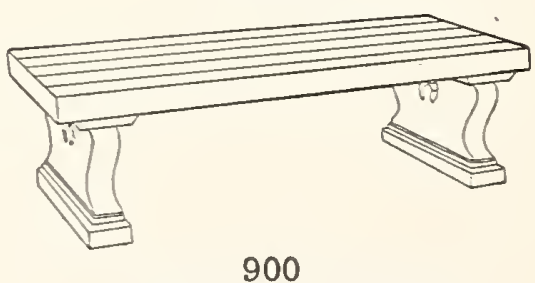

GRECIAN BENCH

Descriptive Catalogue on request. 


150 WEST $23 \mathrm{rd} \mathrm{ST.,NEW} \mathrm{YORK} 107$

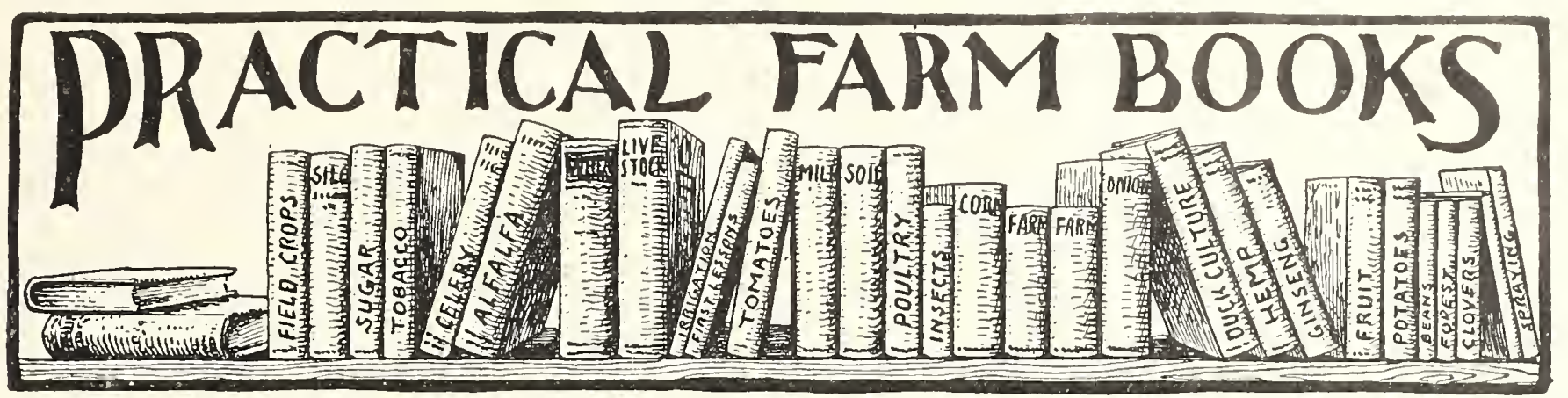

A mine of information in each book. Here is a list of standard books written by practical men in language that can easily be understood. Sound, snappy and full of meat. No matter whether you are a beginner or an old hand at the business, you can learn something from these volumes.

\section{FRUITS, FLOWERS, GARDENING, ETC.}

Annuals, A Little Book of. A. C. Hottes..... $\$ 1.50$ American Apple Orchard. F. A. Waugh...... 1.75 Asparagus. F. M. Hexamer.............. 1.00 A Woman's Hardy Garden. H. R. Ely...... . 2.00 Bulbs and Tuberous-rooted Plants....... 2.00 Bulb Growing. C. L. Thayer............. 1.25 Bush Fruit Production. R. A. Van Meter.... 1.25 Cabbage, Cauliflower and Allied Vegetables.

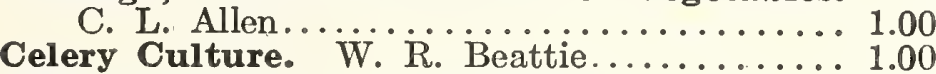
Chrysanthemum. A. Herrington.......... 1.00 Climbing Plants, Little Book of. A. C. Hottes. 1.50 Commercial Floriculture. Fritz Bahr...... 5.00 Culinary Herbs. M. G. Kains............ 1.10 Cyclopedia of Farm Animals. Bailey....... 7.50 Cyclopedia of Farm Crops. Bailey.......... 7.50 Cyclopedia of Horticulture. L. H. Bailey. In three volumes; new edition..........25.00 Dahlia Culture. Waite.................... 1.50 Dahlia Production. R. H. Patch.................... 1.25 Fertilizers and Crops. Dr. Van Slyke........ 3.00 Floriculture, Practical. P. Henderson......... 2.00 Flowers, How to Grow Them. Rexford..... .50

Fruits, American. S. Fraser............... 4.75

Fruit Diseases, Manual of. Hessler and Whitzer. 3.00 Fruit Growing, Beginner's Guide to. F. A. Waugh.

Fruits and Vegetables under Glass. $W$. Turner 5.00 Fruit Trees, Dwarf. F. A. Waugh........... 1.00 Garden Guide, The Amateur Gardeners Handbook.....

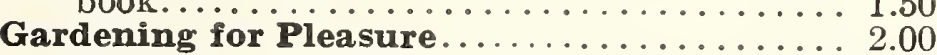

Gardening for Profit. P. Henderson......... 2.00

Gladiolus, The. A. C. Beal ............... . 1.25

Grape Culture. A. S. Fuller.................. 2.00

Greenhouses, Their Construction and Equipment. Wright................. 2.00

Greenhouse Management. $\quad \dot{L}$. $\mathrm{R}$. Taft.......... 2.25

Hardy Shrubs. F. A. Waugh............. 1.25

Hedges and Windbreaks. E. P. Powell...... 1.00

Home Floriculture. E. E. Rexford......... 1.75
Home Vegetable Garden. A. Kruhm..... \$1.50

Injurious Insects. W. C. O'Kane........... 3.25

Iris, The. J. C. Wister................. 1.25

Landscape Gardening, Practical. R. Cridland. 2.50

Landscape Gardening. F. A. Waugh........ 2.00

Lilies, Hardy Garden. H. S. Adams. . . . . . . 1.25

Manual of Gardening. L. H. Bailey ........ 3.25

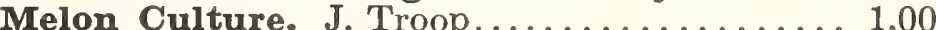

Milady's House Plants. F. E. Palmer........ 1.00

Mushroom Culture. Duggar........... 2.00

Mushrooms, How to Grow Them. Falconer.. 1.60

New Onion Culture. T. Greiner........... 1.00

Old Time Gardens. A. M. Earle........... 2.50

Peas and Pea Culture. G. G. Sevey.... 1.00

Plant Propagation and Nursery Practice.

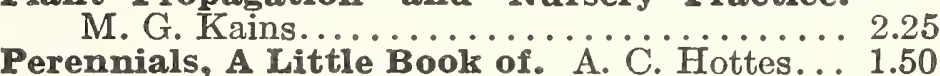

Plant Culture. G. W. Oliver and Hottes..... 3.50

Potato, The. S. Fraser.................. 1.00

Principles of Flower Arrangement. E. A. White $\ldots 2.50$

Pruning, Principles and Practice of. "Kains. 2.50

Pruning Manual. L. H. Bailey............. 2.50

Rose Culture, Commercial. E Holmes .... 2.00

Roses and Their Culture. S. C. Hubbard... 1.25

Roses for All Climates. Thomas........... 3.00

Rock Gardens. E. H. Jenkins............... 3.00

Standardized Plant Names. 546 pages...... 6.00

Strawberry, The. S. Fraser............. 1.25

Sweet Corn Culture. A. E. Wilkinson....... 1.00

Sweet Potato Culture. J. Fitz.............. 1.00

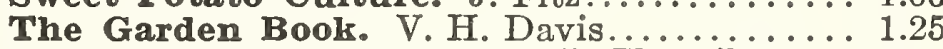

The Cultivated Evergreens. L. H. Bailey...... 5.00

Tomato Production. Paul Work........... 1.25

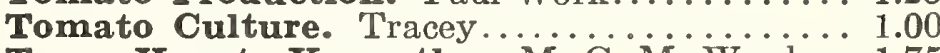

Trees, How to Know the. M. $\ddot{\mathrm{C}}$. $\dot{\mathrm{M}}$. Weed... 1.75

Tree Wounds and Diseases. A. D. Webster.. 2.50

Vegetable Forcing. Watts............. 2.50

Vegetable Gardening. R. L. Watts.......... 2.50

Violet Culture. Coon.................. 1.75

Water Gardening. Peter Bisset............. 5.00

Wild Flower Families. C. W. Weed.............. 1.50

\section{FARM, POULTRY AND ANIMALS}

Alfalfa, Book of. F. D. Coburn.........\$\$.00 Bee Keeping. L. C. Root................ 1.75 Bookkeeping for Farmers. Atkeson......... . .35 Butter Making. C. A. Publow ............. 1.00 Canary Birds. D. L. Burkett............. .60 Corn, The Study of. V. M. Shoesmith...... 1.00 Crops and Methods for Soil Improvement.

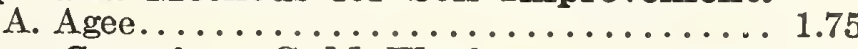

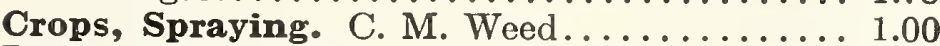
Ducks and Geese. Lamon and Slocum........ 2.00 Farm Dairying. C. Larsen............... 2.00 Farm and Garden Rule Book. L. H. Bailey. 3.00 Farmer's Cyclopedia of Agriculture. E. V.

Wilcox and C. B. Smith............ 4.50 Fertilizers and Crops. L. L. Van Slyke....... 3.50 Insects and Insecticides. H. M. Weed....... 1.75
Living from Eggs and Poultry. H. W. Brown. $\$ 1.40$ Milk and Its Products. H. H. Wing........ 2.50 Modern Methods of Testing Milk and Milk Products. L. L. Van Slyke.............. Poultry Breeding and Management. Jas. Dryden........................ 2.00

Poultry Diseases. E. J. Wortley............... 1.25 Poultry, Feeds and Feeding. Lamon \& Lee.. 1.75 Poultry Architecture. G. B. Fiske......... 1.00 Right Use of Lime in Soil Improvement.

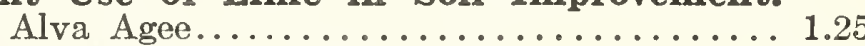

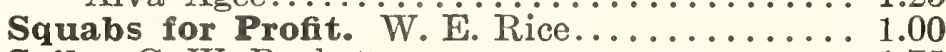

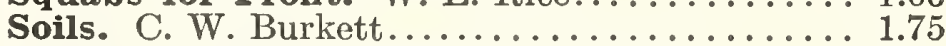
Turkey Raising. Lamon and Slocum......... 1.75 Weeds of the Farm and Garden. L. H. Pammel 2.00 Young Farmer: Some Things He Should Know. F. Hunt.................. 2.00

Prices of books are subject to change.

We shall be pleased to supply any books not listed above at advertised prices. 


\section{INSECTICIDES}

ANSECT (Rose Bug Killer). Highly effective when used on Rose Bugs, many hard-bodied insects, Red Spider, Mealy Bug, and other garden pests. Use one part in thirty to fifty parts of water. IVill not discolor the foliage of plants or affect the flowers. A thorough spraying is essential. $4 \mathrm{oz} .30 \mathrm{c}$, pint $\$ 1.00$, gal $\$ 6.00$.

APHINE. Has no equal for the destruction of green, black or white fly, thrips, red spider, mealy bug, caterpillars, scale and other insects and blights. Use one part to forty parts of water. 1/4 pt. 25c., $1 / 2$ pt. 40 c., 1 pt. 65 c., qt. $\$ 1.00$, gal. $\$ 3.00$.

ANT DESTROYER. A non-poisonous powder. Will destroy or drive away black ants. $1 / 4 \mathrm{lb} .25 \mathrm{c} ., 1 / 2 \mathrm{lb}$. $40 \mathrm{c}, \mathrm{lb} .75 \mathrm{c}$.

ANT GELATIN, "Marvel." An effective remedy for destroying ants. Tin 50c.

ARsenate OF LEAD, Paste, Key Brand. For caterpillars, chewing insects, fruit flies and codling moth. Contains $151 / 2$ per cent Arsenic Oxide. Mixes easily in water and will not burn foliage. Dilute $1 \mathrm{lb}$. to 20 gals. water. L b. $40 \mathrm{c}$., 5 lbs. $\$ 1.75,10$ lbs. $\$ 3.00,25$ lbs. $\$ 6.00$, 50 lbs. $\$ 10.00,100$ lbs. $\$ 18.00$.

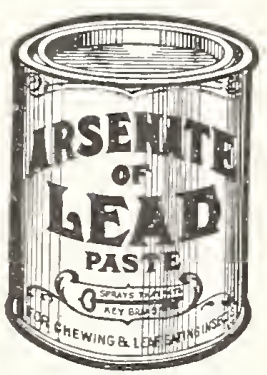

ARSENATE OF LEAD, Powdered, Key Brand. Better than Paris Green and does not burn foliage. Can be used either wet or dry for dusting. With water use $1 \mathrm{lb}$. to 15 or 25 gals. Lb. $45 \mathrm{c} ., 5 \mathrm{lbs}$. $\$ 2.00,10$ lbs. $\$ 3.50,25$ lbs. $\$ 8.00,100$ lbs. $\$ 24.00$.

AXFIXO. A nicotine preparation for thrips on Dahlias and other plants. 5 -lb can $\$ 3.00$.

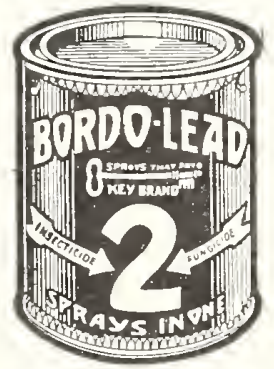

BORDO-LEAD, Paste, Key Brand. Insecticide and fungicide. Two sprays in one. A mixture of Arsennate of Lead and Bordeaux Mixture. Splendid for Potatoes, Apples, Pears and vegetables. $1 \mathrm{lb}$. makes $31 / 2$ gallons ready to apply. Lb. 35c., 5 lbs. $\$ 1.75,10$ lbs. $\$ 3.00$, 25 lbs. $\$ 6.00,50$ lbs. $\$ 11.00,100$ lbs. $\$ 20.00$.

BORDEAUX MIXTURE, Paste, Key Brand. 7 per cent copper. For blight, mildew, rust and fungus diseases. $1 \mathrm{lb}$. to 3 gals. of water, 5 lbs. $\$ 1.75,10$ lbs. $\$ 3.00,25$ lbs. $\$ 6.00,50$ lbs. $\$ 10.00$.

BORDEAUX MIXTURE, Powder, Key Brand. 12 per cent copper. Used same as Bordeaux Mixture, also for dusting dry. For spraying use $1 \mathrm{lb}$. to $8 \mathrm{gals}$. water. Lb. 35 c., 5 lbs. $\$ 1.50,10$ lbs. $\$ 2.75,25$ lbs. $\$ 6.00$.

BUG DEATH. Is extensively used for Cabbage and Tomato worms, Potato and Cucumber bugs. Lb. $25 \mathrm{c}, 3$ lbs. $60 \mathrm{c}$., 5 lbs. $90 \mathrm{c} ., 121 / 2$ lbs. $\$ 1.75$.

CATTLE COMFORT. Protects cattle, dogs, etc., from flies and other insects. Gal. \$2.50.

CARBOLA. A disinfecting germ-killing white paint. Used instead of whitewash for stables, chicken coops, dairies, cellars, etc. 10 lbs. make 10 gals. 5 lbs. $75 \mathrm{c} ., 50$ lbs. $\$ 5.50$.

COCOTINE. A non-poisonous contact insecticide to kill aphides and plant lice. $3 \mathrm{oz}$. can $25 \mathrm{c}$.

COPPER SOLUTION. For mildew, Pear and Apple scab, rust on Carnations and Violets. Gal. \$4.00.

CUT WORM KILLER. This is a coarse powder for sprinkling near the plants to be protected. It is harmless to birds or chickens. $1 \mathrm{lb}$. is sufficient for 175 plants or $100 \mathrm{ft}$. of drill. Lb. $50 \mathrm{c} ., 5$ lbs. $\$ 2.00$, 25 lbs. $\$ 7.00$.
CYANOGAS, G Grade Fumigant (Calcium Cyanide). For fumigating greenhouses, mushroom beds and soils. 1 lb. $60 \mathrm{c} ., 5$ lbs. $\$ 2.50$.

CYANOGAS, Grade A Dust. Used destroying aphis, white fly and other insects, also exterminating moles, rats, ants, etc. $1 \mathrm{lb} .60 \mathrm{c} ., 5 \mathrm{lbs} . \$ 2.50$ 25 lbs. $\$ 8.50,100$ lbs. $\$ 25.00$.

FORMALDEHYDE. A useful fungi-

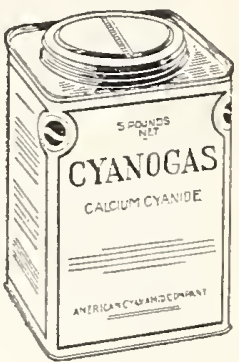
cide for Potato scab, rosette in Lettuce, Onion smut and fungus in soil. For Potatoes, use $1 \mathrm{lb}$. to 30 gals. of water and soak the tubers about $1 \frac{1}{2}$ hours before planting. Lb. bottle $40 \mathrm{c}$.

FUNGINE. An infallible remedy for mildew and other fungus diseases. Pt. 65 c., qt. $\$ 1.00$, gal. $\$ 3.00$.

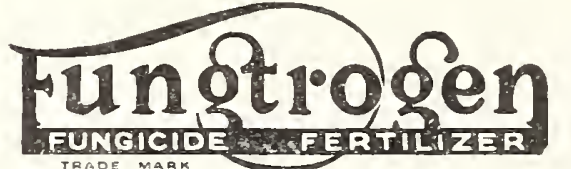

A complete spray for mildew and black spot on Roses. It will not disfigure the leaves or petals. Pint $\$ 1.25$, qt. $\$ 2.00$, gal. $\$ 6.00$.

GRAPE DUST. For prevention of mildew on Roses, Grapes, Gooseberries, etc. 5-lb. pkg. 90c., $10 \mathrm{lbs}$ $\$ 1.75,100-1 b$. keg $\$ 16.00$.

HELLEBORE POWDER. For rose slugs, currant worms, etc. Dust on with gun or bellows while the foliage is moist. $1 / 2 \mathrm{lb}, 30 \mathrm{c} ., \mathrm{lb}, 55 \mathrm{c} ., 5 \mathrm{lbs}$. $\$ 2.50$.

IMP SPRAY SOAP. Effective against green fly, aphis, red spider and thrips. Mix with 12 parts of water for spraying. Gal. $\$ 3.00$.

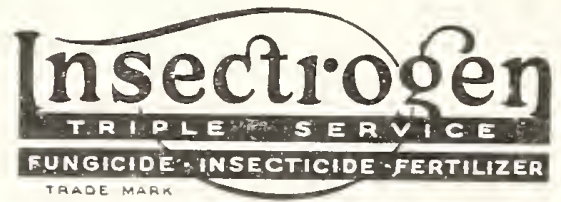

A complete spray, fungicide and fertilizer combined. Use for all leaf eating insects, red spider and mildew. Pint $\$ 1.75$, qt. $\$ 2.75$, gal. $\$ 8.00$.

KEY-CIDE POWDER. A combined insecticide and fungicide. Kills bugs and prevents blight, rot, mildew and fungus. Can be used for wet spraying or dusting for fruits, vegetables and flowers. 1 lb. makes 7 gals. liquid. $1 / 2$ lb. $25 \mathrm{c} ., 1 \mathrm{~b} .45 \mathrm{c} ., 5$ lbs. $\$ 2.00$ 10 lbs. $\$ 3.50$.

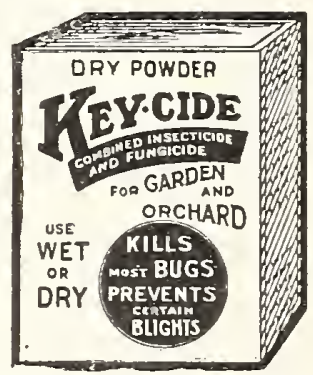

KEROSENE MISCIBLE OIL, Key Brand. Valuable against all soft-bodied insects. Contains 80 per cent Kerosene. Qt. 75 c., gal. $\$ 2.00,5$ gals. $\$ 7.50,50$ gals. $\$ 15.00$.

LEMON OIL. For destroying mealy bugs, scale, thrips, red spider, etc. Qt. $\$ 1.00$, gal. $\$ 3.25$.

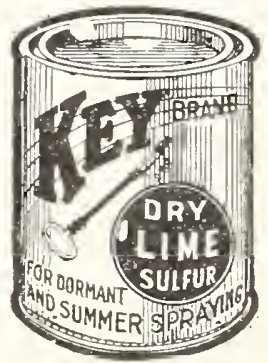

LIME SULPHUR, Dry. Used for all scale insects as a dormant spray. Has all the effectiveness of Liquid Lime Sulphur, and is much easier to handle. $1 \mathrm{lb}$. makes from 4 to 10 gallons. Lb. 35 c., 5 lbs. $\$ 1.60,10 \mathrm{lbs}$. $\$ 3.00,25$ lbs. $\$ 6.00,100$ lbs. $\$ 18.00$.

LIME SULPHUR, Liquid. For spraying fruit trees, etc. 5 gals. $\$ 4.50,30$ gals. $\$ 13.00$, barrel, 50 gals. $\$ 18.00$. 


\section{INSEGTICIDES-Continued}

LOTOL. A complete, concentrated contact remedy in jelly form. Used for all kinds of plant lice and all sap sucking insects. Use one teaspoonful to one gallon of water. 1-oz. tube $35 \mathrm{c} ., 3-\mathrm{oz}$, tube $75 \mathrm{c}$.

MAG-O-TITE. For control of root maggot on Cabbage, Radish and other root crops. $1 \mathrm{lb} .50 \mathrm{c} ., 5 \mathrm{lb}$. $\$ 1.50,25$ lbs. $\$ 5.00,50$ lbs. $\$ 9.00$.

MELROSINE. The general contact insecticide that kills rose bugs and other insects. Dilute with 20 to 25 parts of water. Pleasant and harmless to use; guaranteed effective when used according to directions on can. Pt. $\$ 1.00$, gal. $\$ 6.00$.

NICO-FUME LIQUID. For spraying or fumigating. Does not stain or injure the blooms. Lb. $\$ 2.25,4$ lbs. $\$ 8.00,8$ lbs. $\$ 15.00$.

NICO-FUME PAPER. Extra strong tobacco paper for burning. 144 sheets $\$ 5.50,288$ sheets $\$ 10.00$.

NICO-FUME POWDER. A specially prepared tobacco powder fumigant to destroy aphis, thrips, etc., in greenhouses. 5 -lb. can $\$ 4.75,10$-lb. can $\$ 8.50$.

NICOTINE SULPHATE "Black Leaf 40." For aphis, thrips, etc., 1-oz. bottle 35c., 1/2 lb. $\$ 1.50,2$ lbs. $\$ 4.50,10$ lbs. $\$ 15.00$.

PARA-DICHLORO-BENZINE. Krystal Gas. The best remedy for Peach tree borers. 1-lb. tin 75c., 5 lbs. $\$ 3.00$.

PARIS GREEN. For potato bugs, etc. 1/4 lb. 15c., $1 / 2$ lb. 30c., lb. 50c., 5 lbs. $\$ 2.25$.

PYROX. Bowker's Paste. Kills all leaf-eating insects and prevents blights and fungous troubles, without injury to fruit or foliage. Sticks like paint and rain don't wash it off. Lb. 50c., 5 lbs. $\$ 2.00$, 10 lbs. $\$ 3.50,25$ lbs. $\$ 7.50,50$ lbs. $\$ 12.00,100$ lbs. $\$ 22.00$.

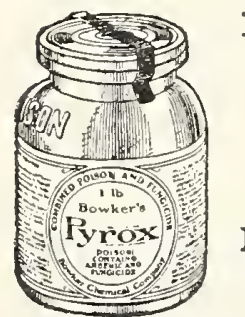

PYROX, Powdered. A dry form of Pyrox that is more convenient to handle. Can be used for dusting or mixed with water as a spray. It will keep indefinitely in containers. $1 \mathrm{lb}$. 65c., 5 lbs. $\$ 2.75,25$ lbs. $\$ 12.00$.

RADIO BLIGHT SOAP. For blight, smut, red spider and fungoid diseases, use $1 \mathrm{lb}$. to 5 gals. water. Lb. $\$ 1.25$.

SCALE DESTROYER, TARGET

(Soluble Oil). Dormant spray for San José, and Oyster Shell Scale. Most effective for Leaf Roller. Spray for tree infesting scale and most soft bodied sucking insects. Qt. 60c., gal. $\$ 1.60$, 5 gals. $\$ 6.50$, 30 gals. $\$ 26.00,50$ gals. $\$ 38.00$.

SCALECIDE. For San José scale and spraying all kinds of trees. Qt. 75c. 1-gal. can $\$ 1.75,5$ gals. $\$ 6.50,10$
gals. $\$ 11.00,30$ gals. $\$ 27.00,50$ gals. $\$ 38.00$.

SLUG SHOT. Destroys all insects injurious to house and garden plants, vegetables and fruits of all kinds. 1-lb. cartons 20c., 5-lb. pkg. 60c., 10 lbs. $\$ 1.20$, keg of 125 lbs. $\$ 13.00$.
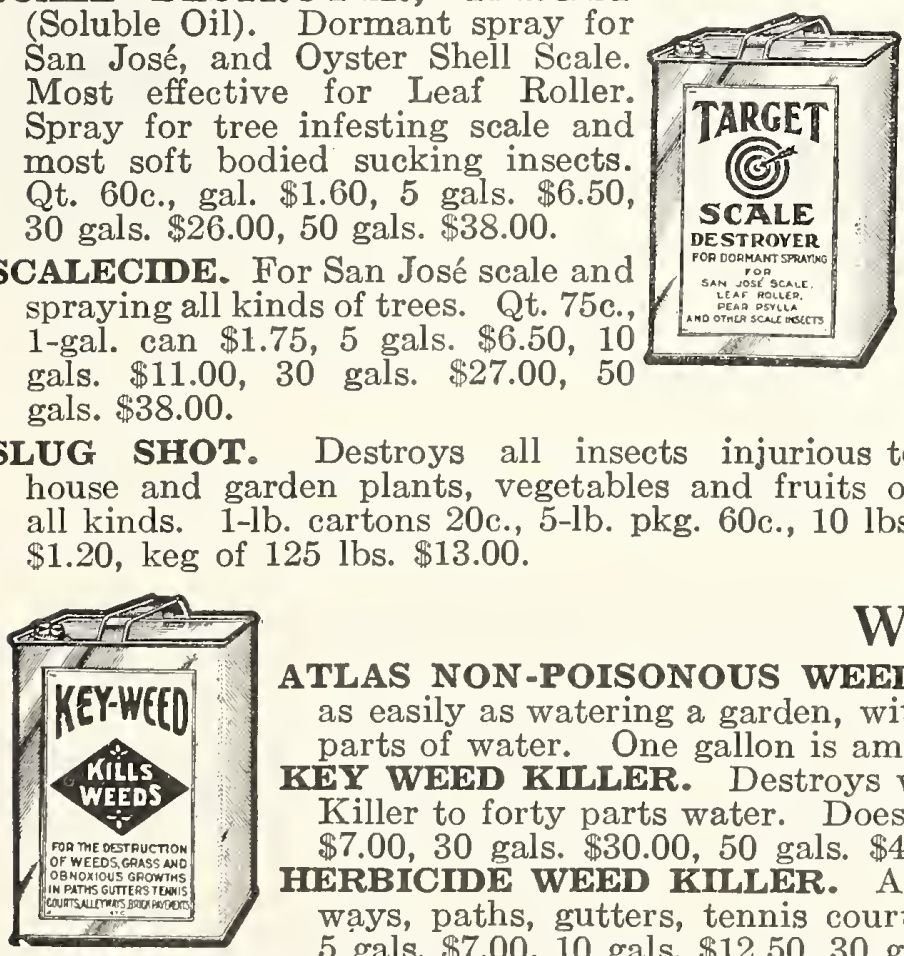

\section{WEED KILLERS}

ATLAS NON-POISONOUS WEED KILLER. Will exterminate all undesirable vegetation as easily as watering a garden, without endangering human or animal life. Dilute with 20 parts of water. One gallon is ample for 500 square feet. Qt. $75 \mathrm{c}$. gal. $\$ 2.00,5$ gals. $\$ 8.00$ KEY WEED KILLER. Destroys weeds in paths, roads and gutters. Dilute one part Weed Killer to forty parts water. Does not discolor cement or stone. Qt. $60 \mathrm{c}$., gal. $\$ 1.75,5$ gals. $\$ 7.00,30$ gals. $\$ 30.00,50$ gals. $\$ 45.00$

HERBICIDE WEED KILLER. A liquid preparation for the killing of every kind on roadways, paths, gutters, tennis courts. One gal. makes 40 gals. liquid. Qt. 60c., gal. \$1.75, 5 gals. $\$ 7.00,10$ gals. $\$ 12.50,30$ gals. $\$ 30.00,50$ gals. $\$ 45.00$.

WILSON'S WEED KILLER. Kills all plant growth. It is a clean odorless highly concentrated liquid. When diluted with water-one part Weed Killer to 40 or 50 parts of water, it is a sure death to all weeds. 5 gals. $\$ 8.00,10$ gals. $\$ 15.00,25$-gal. drum $\$ 30.00$, 50-gal. drum $\$ 50.00$.

The prices quoted in this catalogue are subject to change without notice. 


\section{F E R T I L I E R S}

\section{BONE MEAT}

This bone meal is made from the best quality of bone and finely pulverized. Valuable for top dressing lawns, Roses, flowers and vegetables. Apply about 1000 lbs. per acre or 5 lbs. to 100 sq. ft. $5 \mathrm{lbs}$. $50 \mathrm{c}$., 10 lbs. 75 c., 50 lbs. $\$ 2.50,100$ lbs. $\$ 4.50,200$ lbs. $\$ 8.00$, ton $\$ 65.00$.

\section{BONE, COARSE}

A coarse grade, well adapted for Grape vine and Rose borders. 100 lbs. $\$ 5.00$, ton $\$ 70.00$.

\section{BLOOD AND BONE}

It is of value for garden crops, fruit trees, Grape vines, etc. For garden crops, drill in 300 to $500 \mathrm{lbs}$. per acre. 100 lbs. $\$ 5.50$.

\section{BON ARBOR}

This plant food has a wonderful effect on plant life. It is good for flowering plants of all kinds, vegetables, fruits and shade trees, lawn, etc. 5-lb. pkg. $\$ 2.50,50$ lbs. $\$ 18.00$.

\section{CARNATION FOOD}

This Carnation food is not a chemical stimulant, but an evenly balanced ration to produce a natural growth, vitality and productireness. 100-lb. bag $\$ 6.00$.

\section{CATTLE MANURE (SHREDDED)}

A natural fertilizer for garden crops and lawns. 100 lbs. $\$ 4.00$, ton $\$ 60.00$.

\section{CHARCOAL}

Useful for sweetening sour soils or mixing with potting soil. Coarse or fine. 100 lbs. \$5.50. Very coarse, per bag, $\$ 5.00$.

\section{CLAY'S FERTHIZER}

Highly recommended by leading horticulturists in the cultivation of flowers, fruits and vegetables for exhibition, etc. 56 lbs. $\$ 7.50,112$ lbs. $\$ 14.00$.

\section{DRIED BLOOD}

For top dressing, mixing with the soil and applying in liquid form, it is one of the best and safest nitrogenous fertilizers. $100 \mathrm{lbs} . \$ 8.00$

\section{FERTOBAC}

This is a Tobacco fertilizer for lawns and gardens. 100 lbs. $\$ 2.50$, ton $\$ 45.00$.

\section{FLORANTD}

An organic nitrogen fertilizer for flowers, fruits, regetables or lawns. 1/2-1b. tin 50c., 50-lb. bag $\$ 12.00$.

\section{FERTILIS TABLETS}

A concentrated fertilizer in tablet form, easy to use, clean and odorless. 100 tablets $25 \mathrm{c}$., 1000 tablets $\$ 2.00$.

\section{FOUR SEASONS FERTIUIZER}

For flower gardens, shrubbery, trees, vegetables, fruits and lawns. Easy to apply and no unpleasant odor. 8 lbs. 50c., 25 lbs. $\$ 1.50,50$ lbs. $\$ 2.50,100$ lbs. $\$ 4.00$, ton $\$ 60.00$.

\section{HUMUS}

Valuable for all garden purposes, including lawn and greenhouse plants. $100-1 \mathrm{~b}$. bag $\$ 2.00,500 \mathrm{lbs}$. in bags $\$ 7.00$, ton in bags $\$ 25.00$, f.o.b. Warbasse, N. J.

\section{LIME, HYDRATED}

For correcting acids in soils use $8 \mathrm{lbs}$. for $30 \mathrm{sq}$. $\mathrm{ft}$. of ground. 5 lbs. $25 \mathrm{c} ., 10 \mathrm{lbs} .35 \mathrm{c} ., 25 \mathrm{lbs} .60 \mathrm{c} ., 100 \mathrm{lbs}$. $\$ 2.00$, ton $\$ 30.00$.

\section{LIMESTONE, GROUND}

A very finely screened ground Limestone. Useful for sour soils and to correct improper conditions of the soil. Ton $\$ 9.00$, f. o. b. West Stockbridge, Mass.

\section{NITRATE OF SODA}

It is valuable for grain, Corn, Beets, Potatoes, grasses, Peas, Beans, Clover, etc. Being extremely soluble it should not be applied until the plants are above ground. 1 lb. 15c., 5 lbs. 60c., 10 lbs. \$1.00, 50 lbs. $\$ 3.50,100$ lbs. $\$ 6.00$.

\section{POTASH MARL}

A valuable plant food for vegetable crops, flowers and lawns. It is odorless and clean to handle. For lawns use $200 \mathrm{lbs}$. to 1000 square feet. It contains 7 per cent potash. 100 lbs. $\$ 2.50$, f.o.b. New York City; 500 Ibs. \$10.00, ton \$35..00, f.o.b. Marlton, N. J.

\section{PULVERIZED SHEEP MANURE}

A rich, pure and natural manure. Excellent as a top dressing for lawns, and mixing with the soil for greenhouse plants-one part manure and six parts soil. 5 -lb. pkg. 45cc., 10 lbs. 75 c., 50 lbs. \$2.25, 100 lbs. $\$ 4.00$, ton $\$ 60.00$.

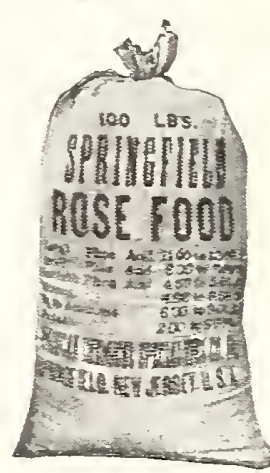

ROSE FOOD (SPRINGFIELD)

Contains just what is needed for the Rose. It is a properly balanced, organic Rose food and entirely takes the place of bone meal, sheep manure or tankage. It stimulates the vitality of the plant and produces a larger crop of more perfect blooms. 10 lbs. $\$ 1.00,25-\mathrm{lb}$. bag $\$ 2.00,100-\mathrm{lb}$. bag $\$ 6.00$.

\section{SALT, AGRICULTURAI}

Used for top dressing Asparagus beds, etc. 100 lbs. $\$ 2.00,200$ lbs. $\$ 3.75$.

\section{SMITH'S CHRYSANTHEMUM MANURE}

For Mums, Roses, Carnations. Sweet Peas and other greenhouse plants. 50-lb. bags \$5.50.

\section{SOOT, IMPORTED SCOTCH}

A fertilizer for stimulating growth and giving a rich, dark foliage; also an excellent remedy against slugs, grubs and cutworms. Bag of $100 \mathrm{lbs}$. \$7.00.

\section{STADLER'S SUPERIOR PLANT}

Feed your plants new life and beauty with Stadler's SUPERIOR Plant Food. Universal in its year'round use. Use it on potted ferns or plants, Roses, hardy shrubs, trees and lawn. Just dissolve a teaspoonful in the watering pot every time you sprinkle the garden. Clean and odorless. 25̌c., 50c. and $\$ 1.00$ cans.

\section{STIM-U-PLANT}

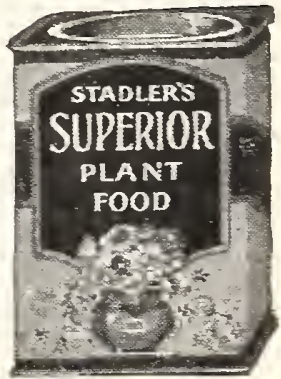

A plant food in tablet form for fertilizing all kinds of growing plants in the home or garden. Tablets should be used in the soil or dissolved in water and applied to the soil. 30 tablets $25 \mathrm{c} ., 100$ tablets $75 \mathrm{c}$. , 1000 for $\$ 3.50$

\section{THOMSON'S TOP DRESSING MANURE}

A special top dressing of unusual merit. 28 lbs. $\$ 4.50,56$ lbs. $\$ 8.00,112$ lbs. $\$ 15.50$.

\section{THOMSON'S VINE AND PLANT MANURE}

A well-known English fertilizer. 56 lbs. \$6.50, 112 lbs. $\$ 12.00$.

\section{VIGORO (Swift's)}

A specially prepared plant food for lawns, flowers, shrubbery and trees. Vigoro has no unpleasant odor and can be conveniently applied at any time. $100 \mathrm{lbs}$ $\$ 5.50$

\section{WOOD ASHES}

For lawns, gardens and fruits, hardwood ashes are unequaled; one to two tons per acre. $100 \mathrm{lbs} . \$ 2.50$, ton $\$ 45.00$. 


\section{AMERICAN AGRIGULTURAL GHEMICAL CO. FERTILIZERS}

\section{TIP-TOP FERTILIZER}

Suitable for Potatoes, root crops and garden truck. Ammonia, 5 per cent; available phosphoric acid, 8 per cent; potash, 6 per cent. 100 lbs. $\$ 3.50$, ton $\$ 55.00$.

\section{HILL AND DRILL FERTILIZER}

A mixed fertilizer for using in hills and drills and sowing broadcast for farm and truck crops. Ammonia, 4 per cent; available phosphoric acid, 8 per cent; potash, 7 per cent. 100 lbs. $\$ 3.00$, ton $\$ 50.00$.

STOCKBRIDGE RELIABLE (Market Garden)

A general fertilizer for farm and garden crops and Potatoes. Ammonia, 4 per cent; available phosphoric acid, 8 per cent; potash, 4 per cent. 100 lbs. $\$ 3.00$, ton $\$ 50.00$.

\section{MURIATE OF POTASH}

For Potatoes, Corn, grain, etc. Analysis, 48 per cent K 20.100 lbs. $\$ 5.00,200$ lbs. $\$ 9.50$.

\section{SQUARE BRAND FERTILIZER}

Suitable for Corn, garden crops, small fruits, etc. Ammonia, 2 per cent; available phosphoric acid, 8 per cent; potash, 5 per cent. 100 lbs. $\$ 2.50$, ton $\$ 40.00$.

\section{BASIC LIME PHOSPHATE}

Used for lawns and gardens. Available phosphoric acid, 13 per cent; lime, 30 per cent. 167 -lb. bags $\$ 2.75$, ton $\$ 28.00$.

\section{ACID PHOSPHATE}

Also for mixing with other fertilizers to increase the phosphoric acid content. For farm crops, 16 per cent available phosphoric acid. 200 lbs. $\$ 2.50$, ton $\$ 20.00$

\section{SULPHATE OF AMMONIA}

Used for top dressing crops. Ammonia, 24 per cent; nitrogen, 16 per cent. 100 lbs. $\$ 7.00,200$ lbs. $\$ 12.00$.

All the above fertilizers are offered, f. o. b. factory at Carteret, N. J.

\section{"ADCO" ARTIFICLAL MANURE}

A simple preparation for making stable manure from garden refuse, grass clippings, weeds, leaves, vegetable tops, etc. It contains nothing injurious to health or animal life, is odorless and weed free.

Refuse can be piled in a heap or pit and with "Adco" added to the refuse causing the bacteria to rot and make manure. Fifty pounds of Adco makes a ton of well rotted manure.

Adco, in 25-lb. bags, enough for 12 wheelbarrows of waste or $1 / 2$ ton of manure. Each $\$ 2.00$. Adco, in 150-lb. bags, enough to make 3 tons manure. Each $\$ 10.50$, f. o. b. Warners, N. J.

\section{FERTOBAC. Tobacco Fertilizer}

Fertobac is a double action product-a natural fertilizer and a positive insecticide. It sweetens the soil, controls the worms, green fly, thrips, aphis, Strawberry beetle, cutworms, and all soft-bodied insects. It contains 3 to 4 per cent ammonia, 3 to 5 per cent potash, $1 / 2$ per cent phosphoric acid, and 1 to $11 / 2$ per cent nicotine. 100 -lb. bags $\$ 2.50$, ton $\$ 45.00$, f.o.b. Lancaster, Pa.

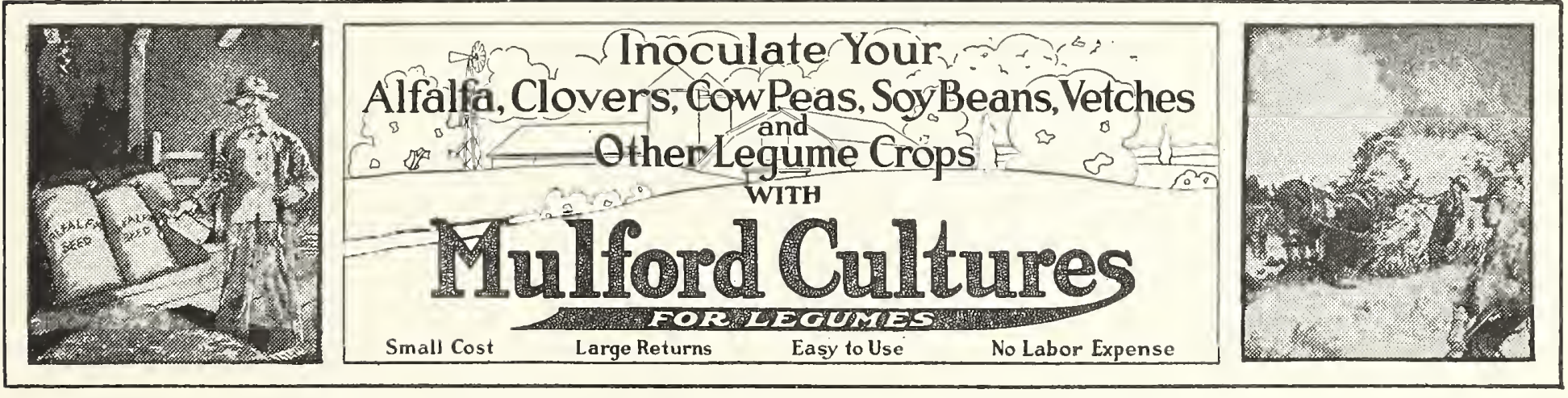

Mulford Cultures contain pure, tested strains of active, vigorous nitrogen-fixing bacteria for inoculating seeds of legumes or soil.

Mulford Cultures are "different" and should not be confused with other brands.

Legumes offer the best known means of maintaining soil fertility and rejuvenating overcropped and wornout fields. They add both humus and nitrogen to your soil and thus increase your yield of wheat, cotton, corn and other non-legume crops.

The U. S. Dept. of Agriculture and many State Agricultural Experiment Stations recommend inoculation of legumes with nitrogen-fixing bacteria to induce a prompt "catch" and increase your yield.

Mulford Cultures are prepared for:

$\begin{array}{lllll}\text { Alfalfa Lucerne } & \text { Red Clover } & \text { Cow Peas } & \text { Vetch } & \text { Garden Peas } \\ \text { Crimson Clover } & \text { Alsike Clover } & \text { Soy Beans } & \text { Velvet Beans } & \text { Garden Beans } \\ \text { Sweet Clover } & \text { Bur Clover } & \text { Peanuts } & \text { Sweet Peas } & \text { Lima Beans }\end{array}$

Sweet

Alsike Clover

Soy Bean

Sweet Peas

rden Bean

Always specify on your order what crop you want to inoculate, as there is a different strain of bacteria for each legume.

Garden Size for Peas, Beans, Lima Beans and Sweet Peas, 35c.

For Large Seeds, Soy Beans, Cow Peas, etc. 1 bus. size 60c., 2 bus. size $\$ 1.00,5$ bus. size $\$ 2.25,20$ bus. size, $\$ 8.00$.

For small seeds, Alfalfa, Clovers, etc., $1 / 2$ bus. size 60 c., 1 bus. size $\$ 1.00,21 / 2$ bus. size, $\$ 2.25,10$ bus. size $\$ 8.00$. 


\section{INDEX}

\begin{tabular}{|c|c|c|}
\hline $\begin{array}{l}\text { Page } \\
.111\end{array}$ & $\begin{array}{l}\text { Page } \\
\ldots .95\end{array}$ & $\begin{array}{r}\text { Page } \\
94,95\end{array}$ \\
\hline Achimenes. & $\begin{array}{l}\text { Dirt Bands... } \\
\text { Dog Biscuits. . }\end{array}$ & $\begin{array}{l}\text { Lawn Rollers ... } \\
\text { Lawn Seeders... }\end{array}$ \\
\hline Agapanthus........50 & Egg Boxes.... & Lawn Sprinklers. .100-101 \\
\hline Amaryllis... & Farm Seeds. . & Lawn Sweepers........94 \\
\hline ntirrhinum. & Ferguson's Sprayer... 104 & Lawn Trimmer. . \\
\hline Aquatic Plants... & Ferns....... & Leg Bands. \\
\hline Asparagus Buncher...76 & Fertilizers...106, 110, 111 & Lily Bulbs. \\
\hline Bamboo Canes........76 & Fertilizer Distributor...94 & Lily of the Valley.. \\
\hline Bamboo Rake.... & Fertiliator .........999 & Lycoris.... \\
\hline Barley......... & Fertobac... & Madeira Vine. . \\
\hline Baskets...... & Flower Guard. & Mats, ${ }^{,}$Hotbed. \\
\hline Bean Poles..........95 & Flower Pots... & Millet......... \\
\hline Bedding Plants... & Flower Seeds, $1-2,28-49$ & Montbretias. \\
\hline Begonias...... 50, 57-58 & Fumigating Materials & Mills, Grinding. . \\
\hline Bird Houses. . . . . . & 108,109 & Mulford Cultures. \\
\hline Bird Seeds..... . . . & Fumigators.........77 & Novelties....... \\
\hline Bone Mills..... & Garden Tractor... & Oat Sprouter.... \\
\hline Books.......... & Gladiolus..... & Oats. \\
\hline Boots, Rubber. & Glass Cloth & Oxalis. \\
\hline oxes, Flower. & Gloxinias & Palms. \\
\hline Brooders.... . . & Grass Edgers. . & Peas, Field. \\
\hline room Corn. & Grasses............23-25 & Peat Moss. \\
\hline oms ..... & Greenhouse Plants.... .58 & Planet, Jr., Tools . 88,89 \\
\hline ckwheat. . . . . . 26 & dstones... & Plant Protectors...... 85 \\
\hline Bulbs..........50, 56 & Hand Cart... & Plant Supports... \\
\hline ums. & $\begin{aligned} .99 \\
87\end{aligned}$ & Plows...... \\
\hline $\begin{array}{l}.50 \\
.51\end{array}$ & $\begin{array}{l}\text { Hedge Trir } \\
\text { Herbs.... }\end{array}$ & Post Hole Digger... \\
\hline Can & Horse Boots. & Potatoes.... \\
\hline 4 & Hose, Garden. & Pot Covers....... \\
\hline 58 & Hose Reels & Poultry Feeders... \\
\hline ation Si & Hotbed Sash. & Poultry Founts...... 104 \\
\hline Toaf and Rarn & $\mathrm{Hu}$ & Poultry Net.......... 103 \\
\hline Cele & $\mathrm{H}$ & Poultry Supplies. \\
\hline & Hyacinthus. & Powder Duster. 76,7998 \\
\hline nther & 102 & ing $\mathrm{Sh}$ \\
\hline Clover: & Insecticides..106, 108, 109 & ing snears.....80, 81 \\
\hline Corn $\mathrm{H}$ & Japanese. & Pumps, Spray.. 96-97-98 \\
\hline Cor & Is & Rakes. $\quad 80$ \\
\hline $\mathrm{Cc}$ & Kniv & Rape... \\
\hline $\mathrm{Cr}$ & Labels. & Rat Killer....... \\
\hline$\ldots \ldots \ldots \ldots$ & Lawn Mor & Refuse Burner. \\
\hline & Lawn Mower Sharp- & Rollers..........87, 94 \\
\hline & ener.........883 & Roses.... .4, 66, 67, \\
\hline
\end{tabular}

\section{NURSERY INDEX}

\begin{tabular}{|c|c|}
\hline Page & Page \\
\hline Acer...............73 & Clethra............69 \\
\hline Almond...........699 & Climbers.........667 \\
\hline Althæa............669 & 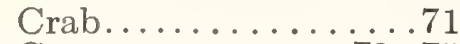 \\
\hline Akebia..........667 & Currants........72, 75 \\
\hline Amelanchier.........69 & Cydonia...........70 \\
\hline Ampelopsis.........67 & Daphne........ \\
\hline Amygdalus.........699 & Delphiniums.....4,61 \\
\hline Anemones..........4 4 & Deutzia...........70 \\
\hline Apples............74 & Dogwood..........69 \\
\hline Ash.............. & Elæagnus...........70 \\
\hline Asters............. 3 & Elder............71 \\
\hline Azalea..........4, 69 & Elm......... \\
\hline Barberry......3, 69, 74 & Euonymus.........70 \\
\hline Beech............73 & Evergreens..........72 \\
\hline Benzoin... . . . . . . . .669 & Forsythia.......... \\
\hline ula...........73 & Fraxinus..........73 \\
\hline ch............ & Fruits........74, 75 \\
\hline Blackberries........75 & Ginkgo Tree..........73 \\
\hline Boxwood..........72 & Golden Bells........70 \\
\hline Buddleia..........69 & Gooseberries........75 \\
\hline aing Bush.......70 & Grapes............ \\
\hline Calycanthus........ & Halesia... \\
\hline pa....... & Herbs and Roots...... 22 \\
\hline$\ldots \ldots \ldots 79$ & Honeysuckle......67, 71 \\
\hline$\ldots \ldots \ldots 74$ & Horse Chestnut. . . . . .73 \\
\hline nut... & Hydrangea........ \\
\hline anthus.......6 & Hypericum........70 \\
\hline rsanthemums.....5 & Ivy $\ldots \ldots \ldots \ldots \ldots$ \\
\hline Clematis....... & hine. \\
\hline
\end{tabular}

Page

Rustic Baskets........86

.

Sanitas............999

Sash, Hotbed. . . . . . . .80

Saucers, Pot.... 76, 77

Seeders...... 85, 88, 94

Seed Pricker..........99

Semesan........27,98

Shading, Greenhouse...80

Shears, Pruning... .80, 81

Sod Perforator. .......95

Sod Tampers..........94

Soil Tester............104

Sorghum ............27

Spot Market.........89

Sprayers...96-97-98, 104

Sprinklers.......100, 101

Stakes, Plant...... 79, 97

Sudan Grass.... . . . . . . 27

Sweepers, Lawn ...... 94

Sweet Peas....... 47, 48

Thermometers.......81

Tigridias ...........53

Tomato Stakes........95

Tomato Supports.....95

Tractors............93

Tree Pruner......... 80

Trellis............95

Truck and Barrel.....84

Tuberoses...........53

Tubs, Plant..........85

Vases, Flower. ..... 84

Vegetable Plants......22

Vegetable Seeds....3, 5-23

Vetches...........27

Violets............58

Watering Pots........82

Weed Killers......... 109

Weeders............82

Wheelbarrows ..........82

Wheelbarrow Racks... 84

Wheat............27

Window Boxes.......884

Zephyranthes........53 


\section{8}

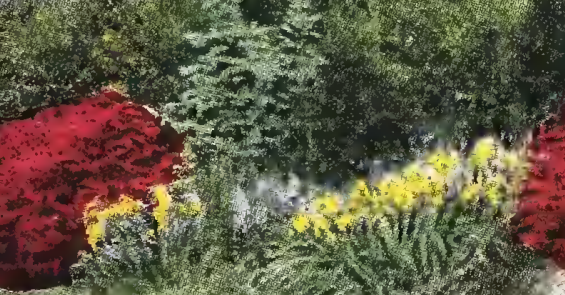

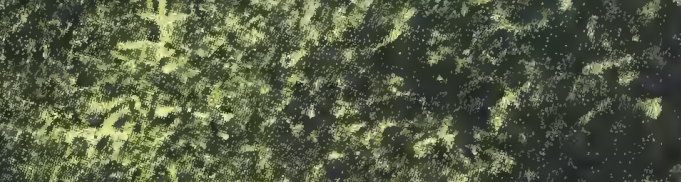

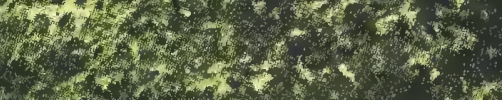

.

$20,40,0$
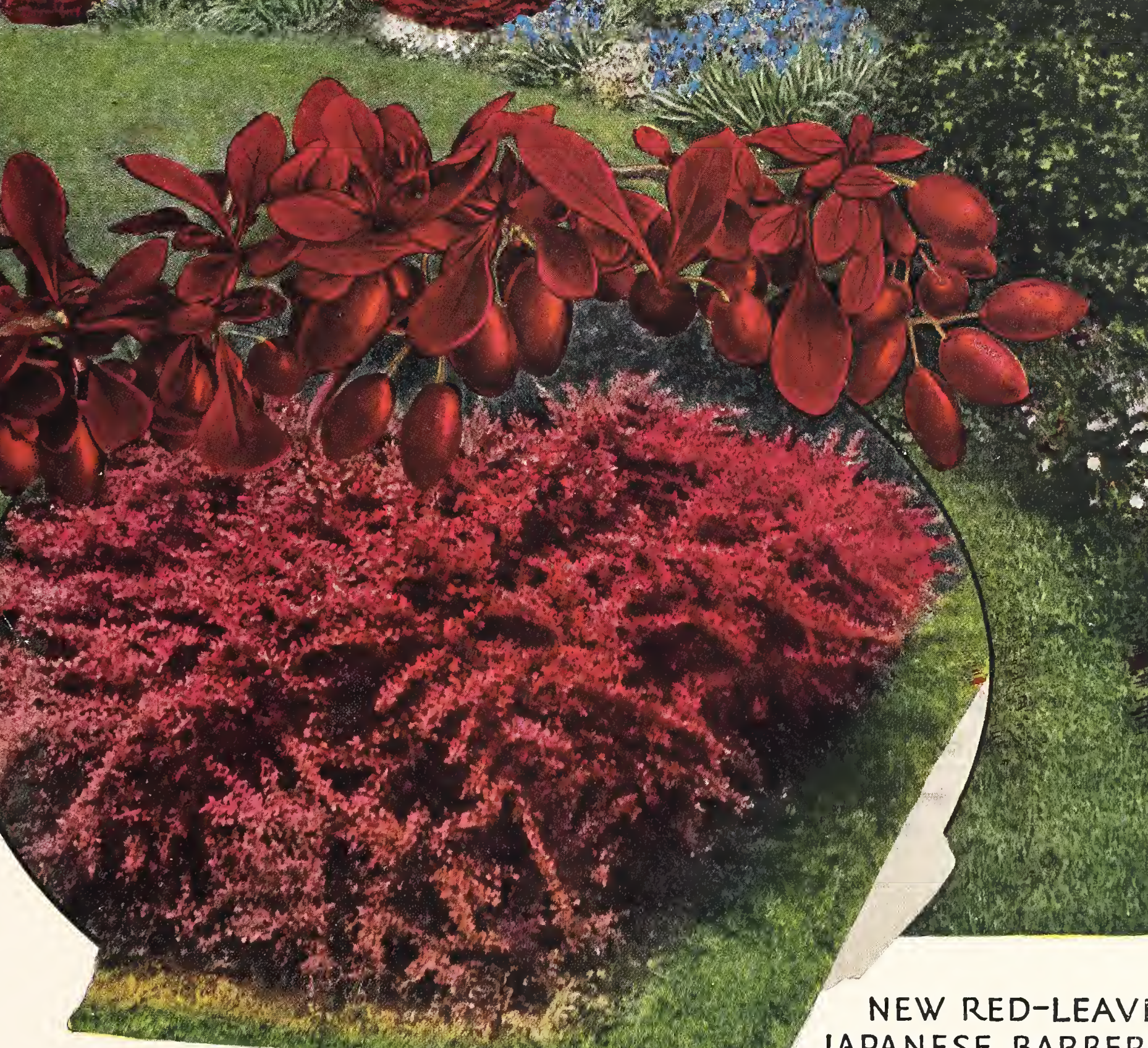

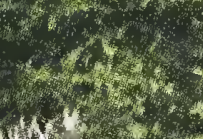

$3+2,4$ 


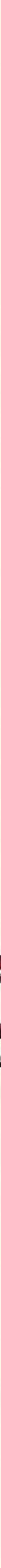

T IS only once in a lifetime that a really worth-while, outstanding novelty in hardy

00 shrubs is introduced, and in this new Barberry we have such a plant.
It is similar in all respects to the green-leaved Japanese Barberry which is so popular for mixing in the shrubbery border, as single specimens, or for planting in clumps on the lawn, as well as for foundation plantings and for hedges, but the foliage of this new variety is of a rich, Iustrous, bronzy red, similar to the richest red-leaved Japanese Maples. However, unlike these and other colored shrubs in which the coloring fades or disappears entirely as the season advances, this new Barberry becomes more brilliant and gorgeous throughout the summer, and in the fall its foliage changes to vivid orange, scarlet, and red shades, more brilliant and more effective than in the ordinary Japanese Barberry. In this coloring it is unequaled by any other shrub and is followed by the same brilliant scarlet berries common to the type, which remain on the plant the entire winter.

AII that is required to develop its brilliant coloring at all seasons is that it be planted in full exposure to the sun.

I-year plants $75 \mathrm{cts}$. each, I 3 for $\$ 7 . \quad 2$-year plants $\$ I .25$ each, Io for \$II. 3-year-old specimen plants $\$ 2.50$ each, Io for $\$ 20$ 
Vegetable Seeds for Planting in Hotbeds in March

BEANS

BEETS

EARLY CABBAGE

EARLY CARROT

CAULIFLOWER

CELERY

EGGPLANT

ENDIVE

KOHL-RABI

LEEK

LETTUCE

ONION

PARSLEY

PEPPER

RADISH

TOMATO

\section{Seed Sowing and Planting Table for Vegetables for Home Gardeners in New York and Vicinity}

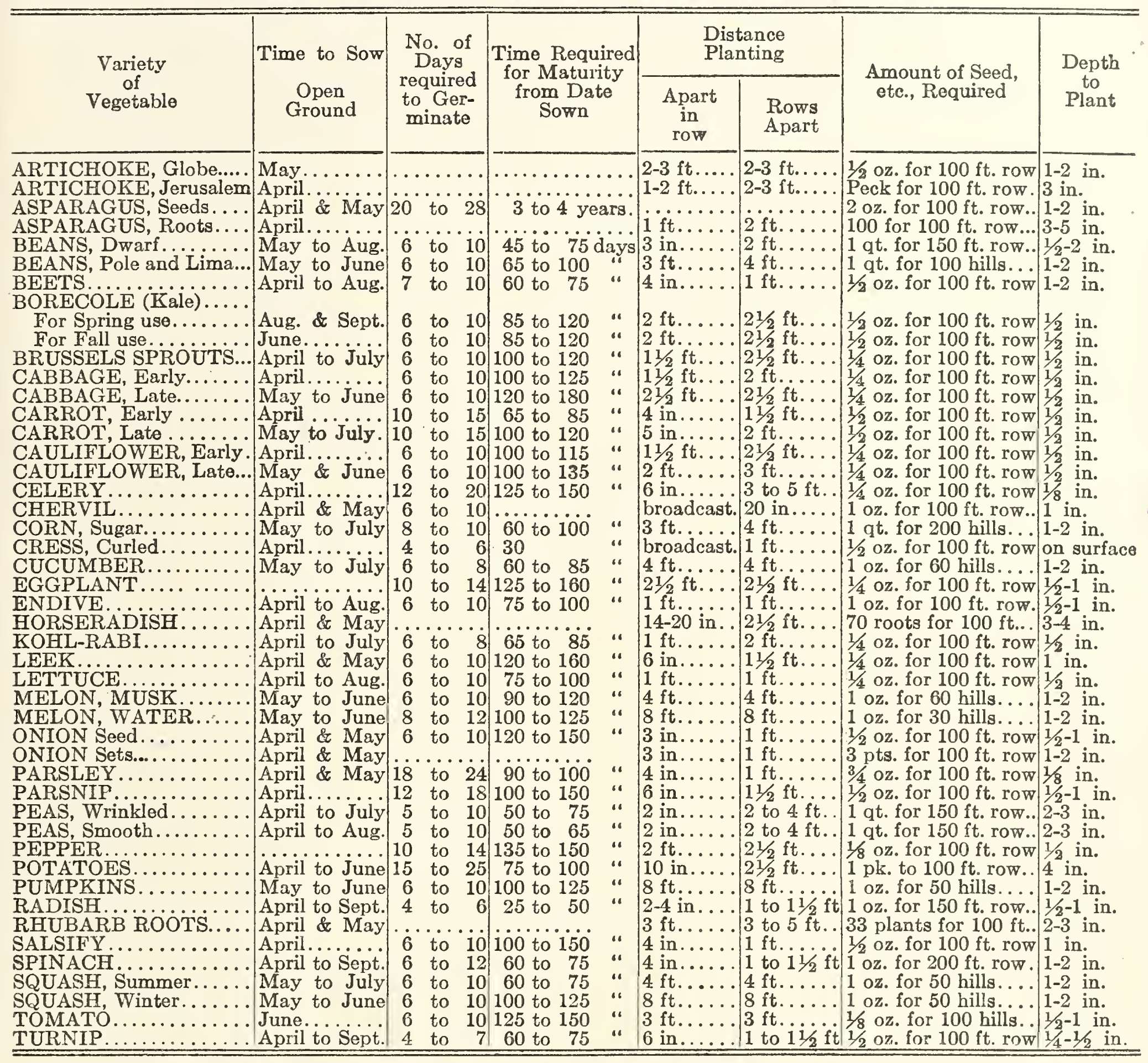

\section{Insecticides to Use for Insects and Fungous Diseases}

Insects that suck the juices from Plants and Foliage. In powder form, use Slug Shot, Hellebore or Tobacco

Dust. In liquid form for spraying, use Aphine, Black Leaf 40, Kerosene Miscible Oil, Lemon Oil or Whale Oil Soap. Insects that eat the Plants or Foliage. In powder form use Slug Shot, or Arsenate of Lead Powder. In liquid form use Ansecto, Aphine, Arsenate of Lead, Paris Green, or Whale Oil Soap.

Scale on Hard Wood Trees. Spray with Scale Killer, Scalecide, Lime Sulphur or Wilson's Plant Spray.

Fungous Diseases. Spray with Bordeaux, Fungine or Pyrox. Dust with Bordeaux or Grape Dust.

Underground Insects. Cut Worm Killer, Tobacco Dust or Vermine.

\section{QUANTITIES OF FIRTLIZER TO USE}

Bone Meal. 5 lbs. to 100 sq. ft.; $1 / 2$ to 1 ton per acre.

Blood and Bone (Tankage). 300 to $500 \mathrm{lbs}$. per acre.

Lime, Hydrated. For lawn, 100 lbs. to 400 sq. $\mathrm{ft}$., 1 ton per acre on light soils; 2 tons per acre on heavy soils.

Nitrate of Soda. $1 \mathrm{oz}$. to 2 gals. water; 100 to $200 \mathrm{lbs}$. per acre.

Sheep IManure. 1 lb. to 5 gals. of water, 500 to 600 lbs. per acre. 


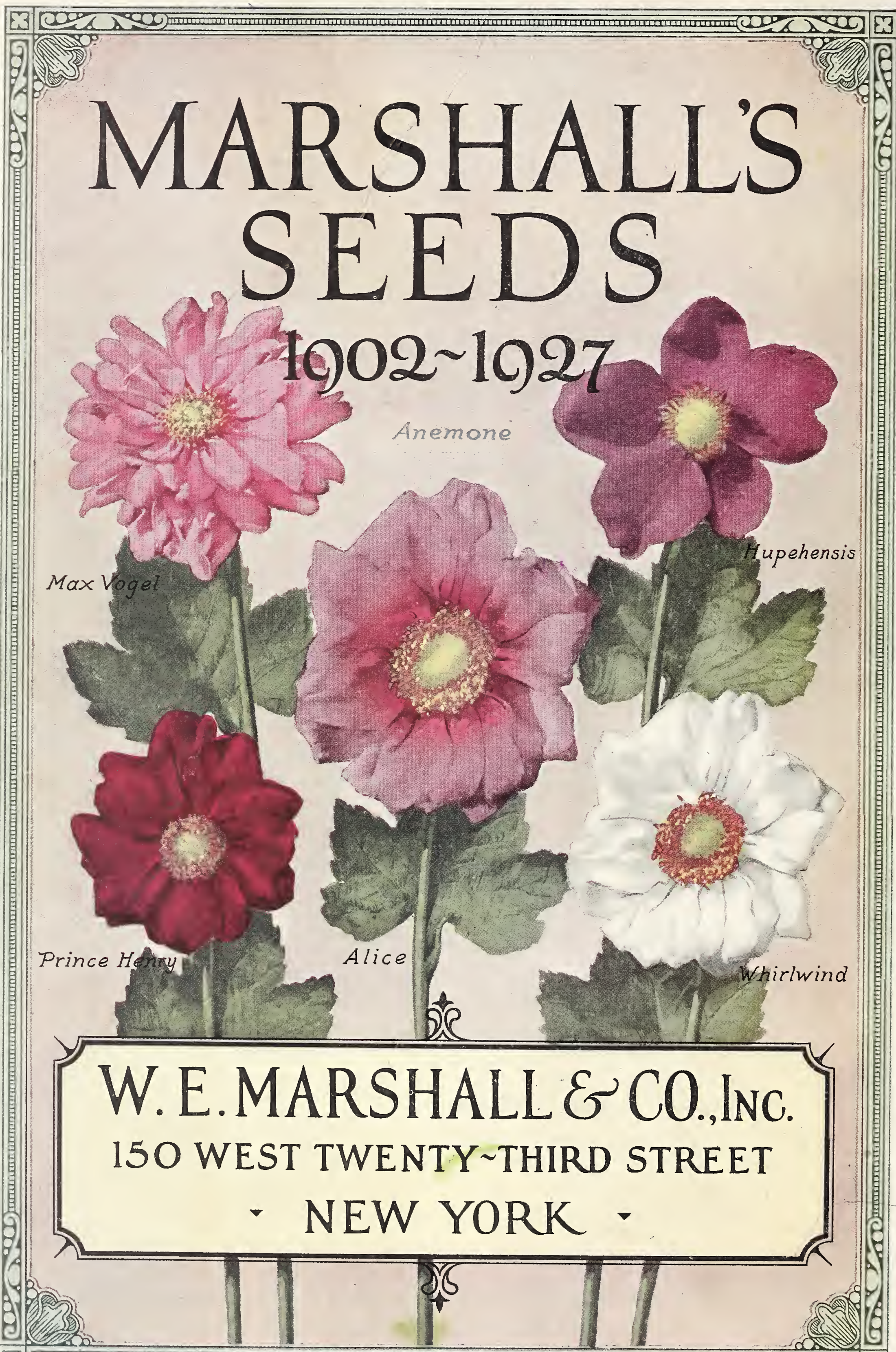

